Historic, Archive Document

Do not assume content reflects current scientific knowledge, policies, or practices. 



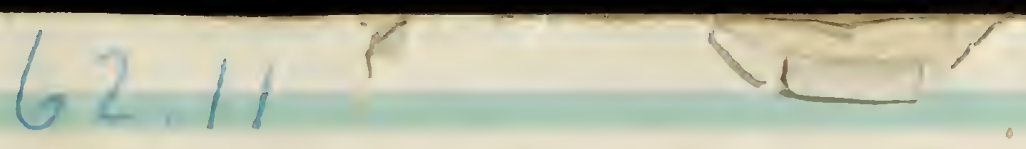

\section{IF YOU WANT TO KNOW ANYTHING}
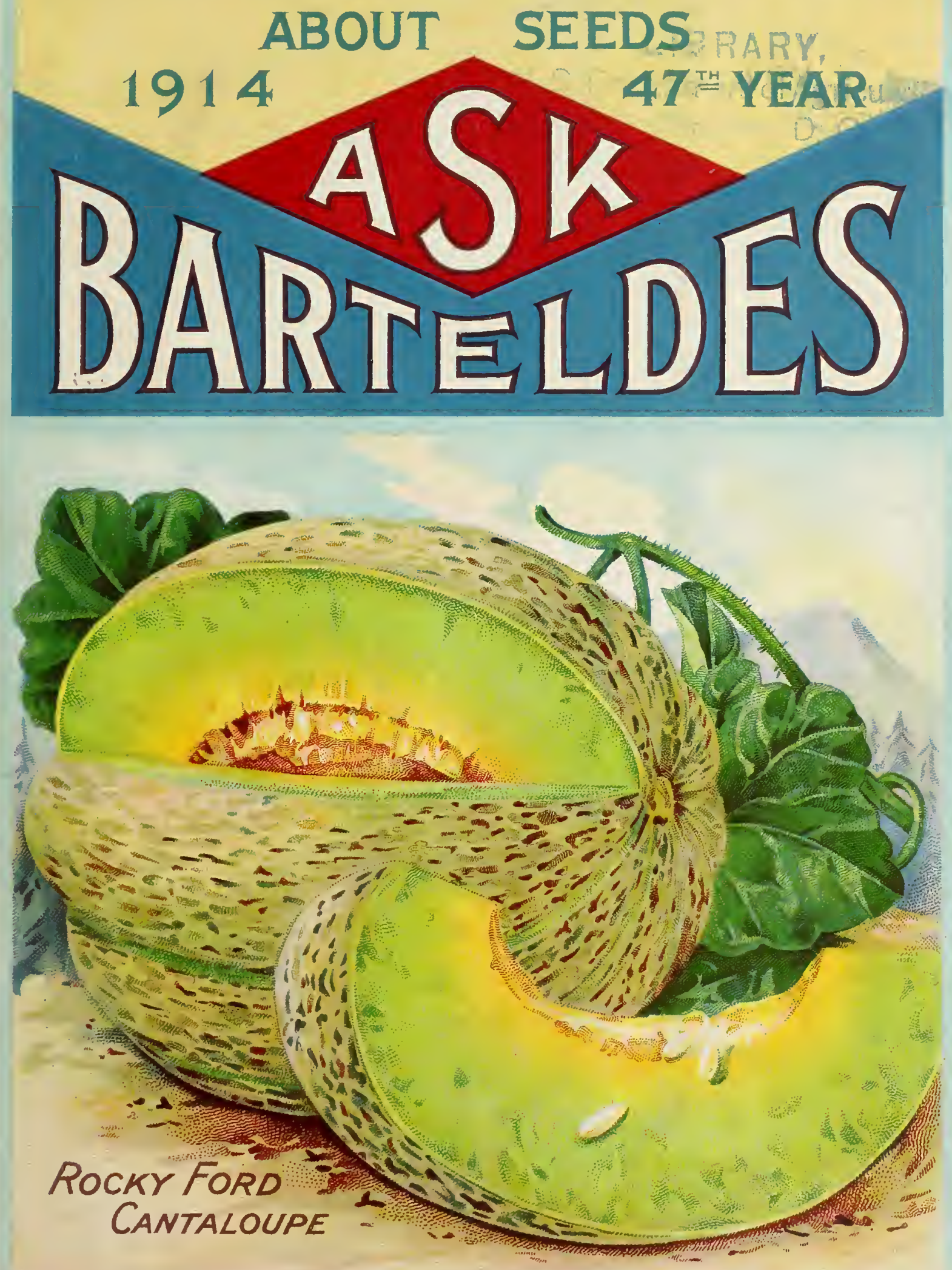


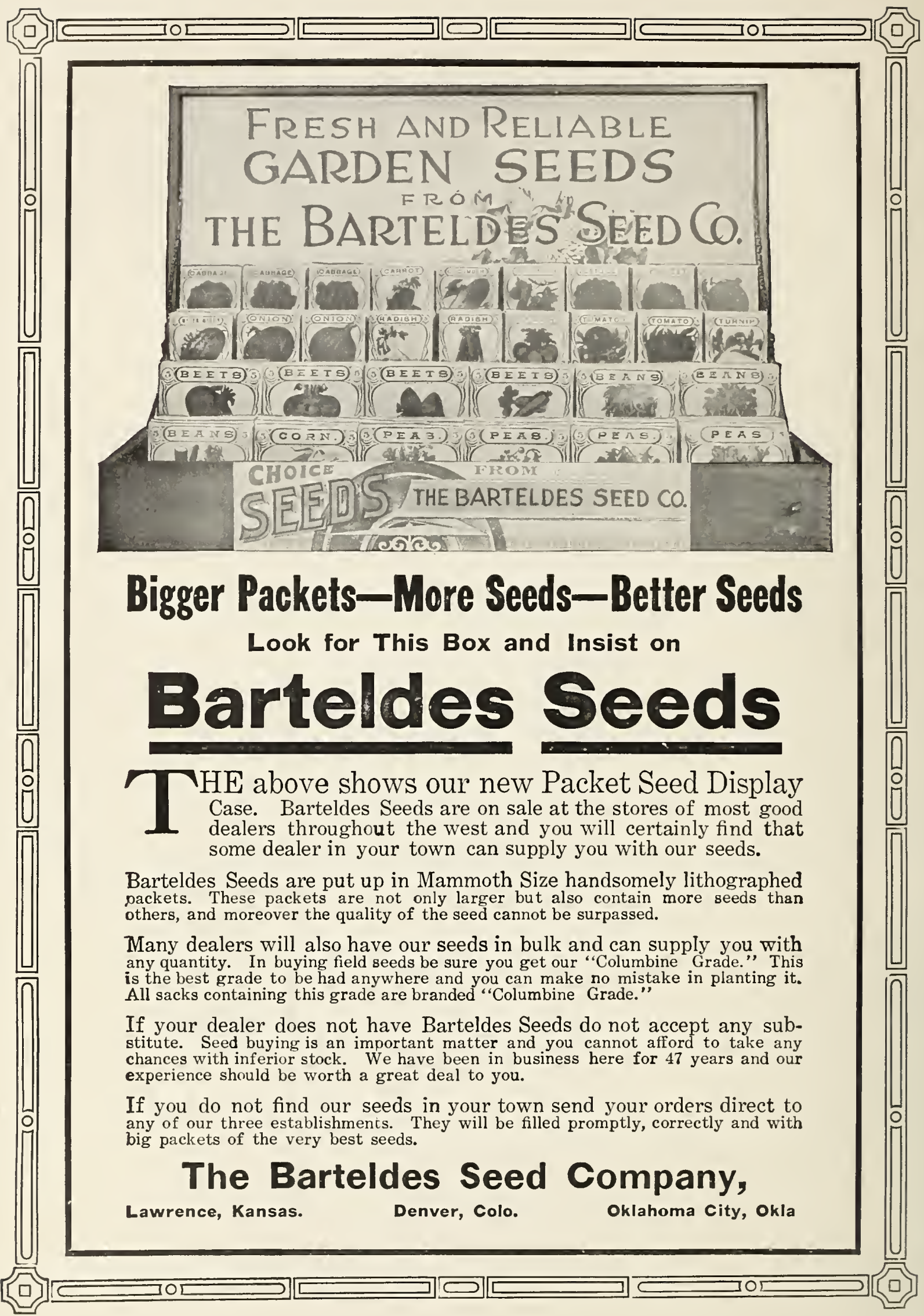


NO GOODS SENT C. O. D.

SEND MONEY WITH ALL ORDERS

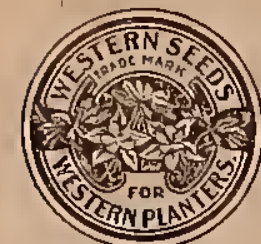

THE BARTELDES SEED CO.

Order No.

DENVER, COLORADO

ORDER SHEET

State whether goods are to be shipped by Freight, Express or Mail

Date

Your Name

(Write verg plain)

Post Office State

Street and No.

County

P. 0. Box

R. F. D. No.

Express or Freight Office

Express Co. or Railroad
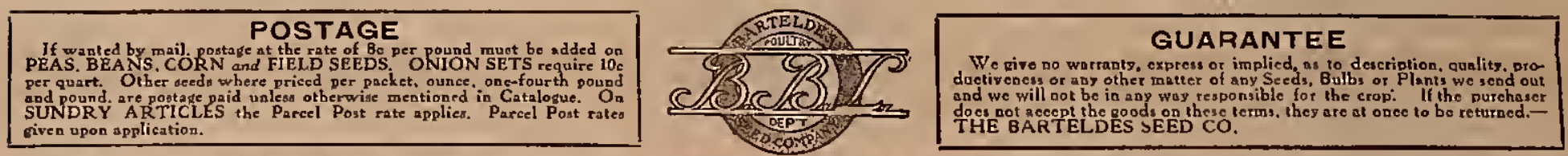

FOR BARTELDES' BEST LINE OF POULTRY SUPPLIES SEE PAGE 104 OF THE GENERAL CATALOGUE

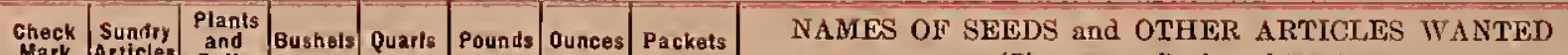

\begin{tabular}{c|c|c|c|c|c|c|c|} 
Gheck & $\begin{array}{c}\text { Sunfiry } \\
\text { Marticles }\end{array}$ & $\begin{array}{c}\text { Plants } \\
\text { and } \\
\text { Bulbs }\end{array}$ & Bushels & Quarls & Pounds & Ounces & Packets \\
\hline
\end{tabular}

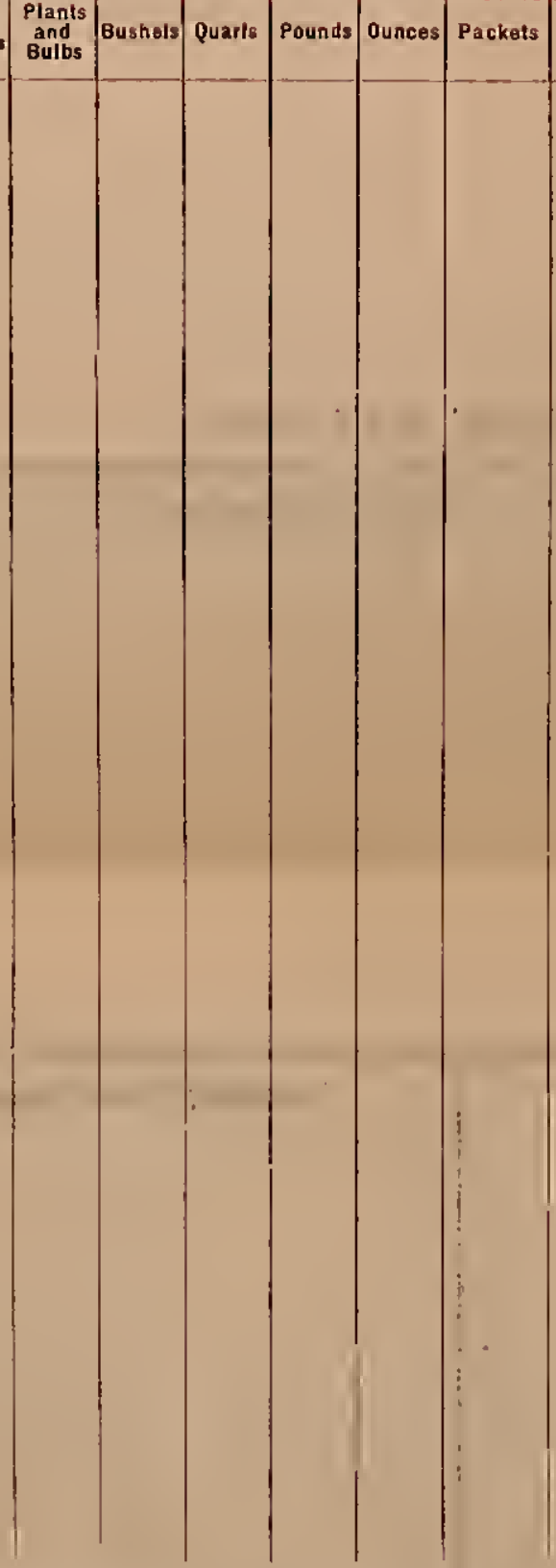

(Please use one linc for eneh item.)

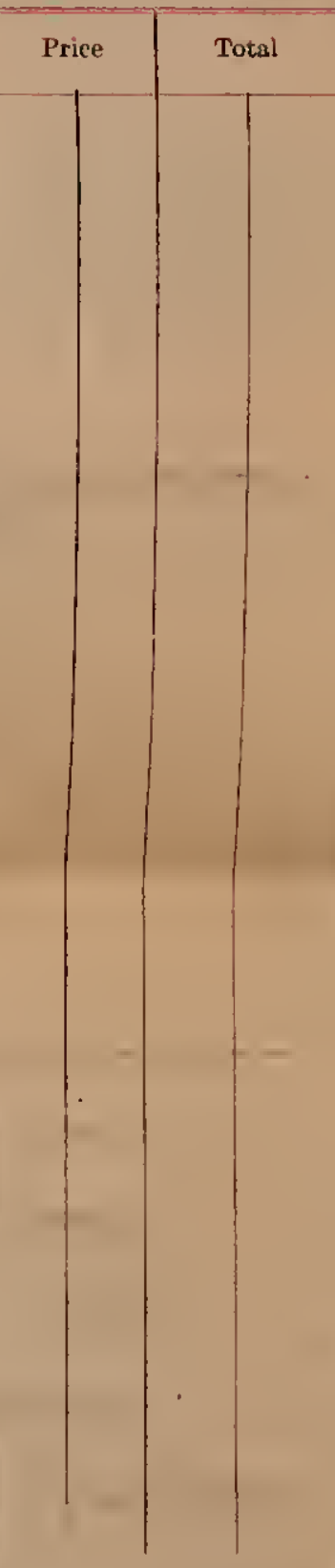

Do You Grow for Market or Home Use?

If you have anything to write to us with this order please write it on a separate sheet.

If in need of more order sheets and self-addressed envelopes ask for them and they will be mailed to you free. 

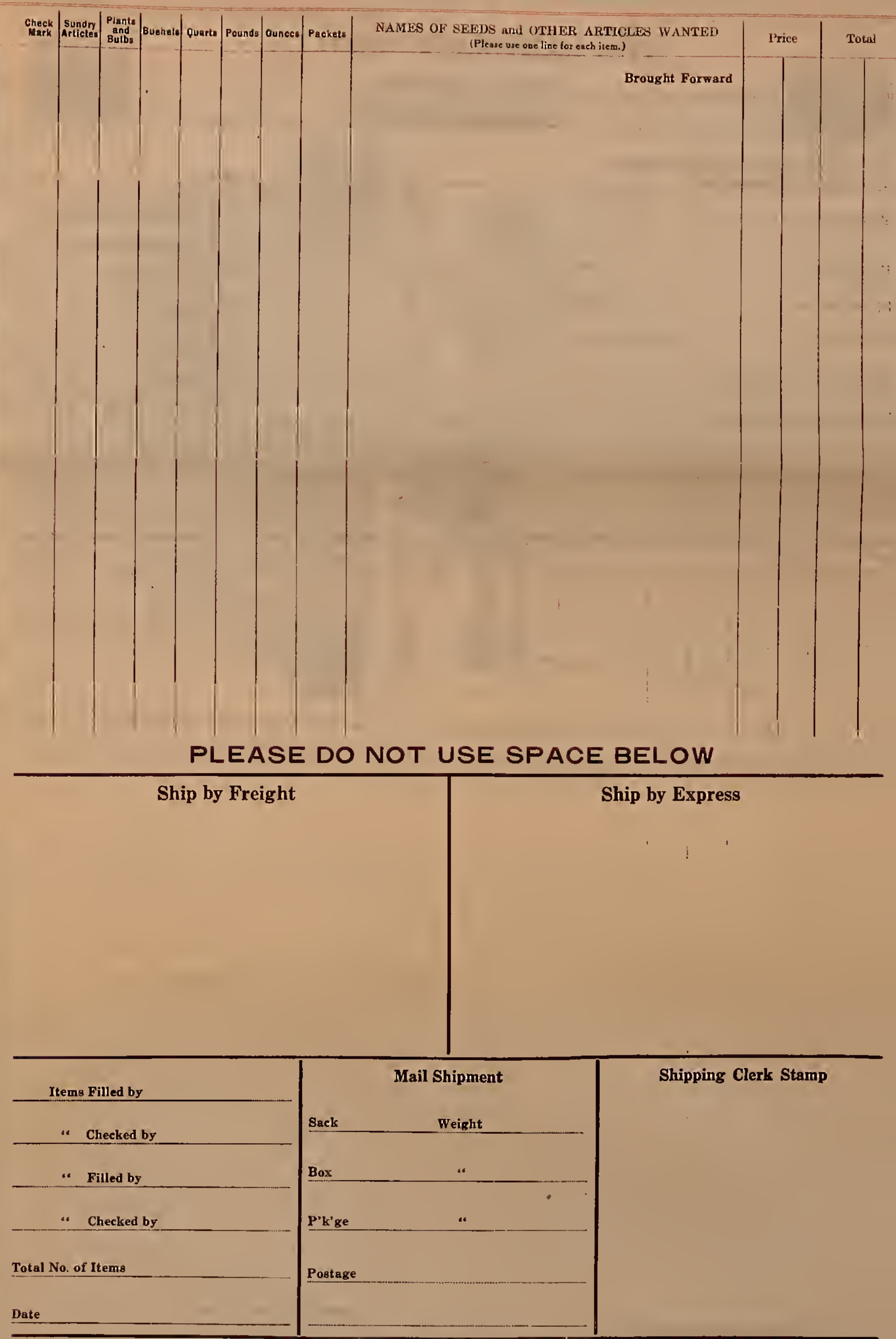

If you want any select balbs for fall planting either indoors or outdoors ask for our "Fall Bulb Catalogue," sent free to any address in September or Uctober. 


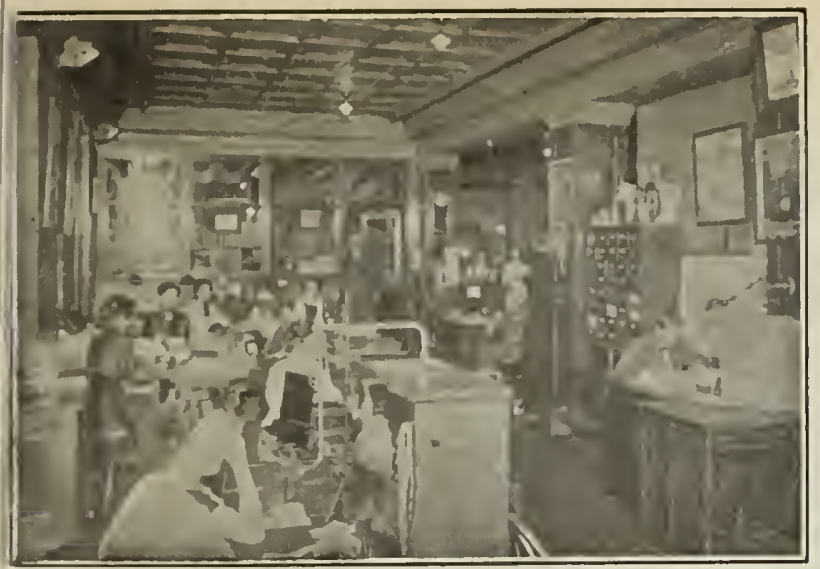

OUIR GW:NEIR.M, OFFICE.

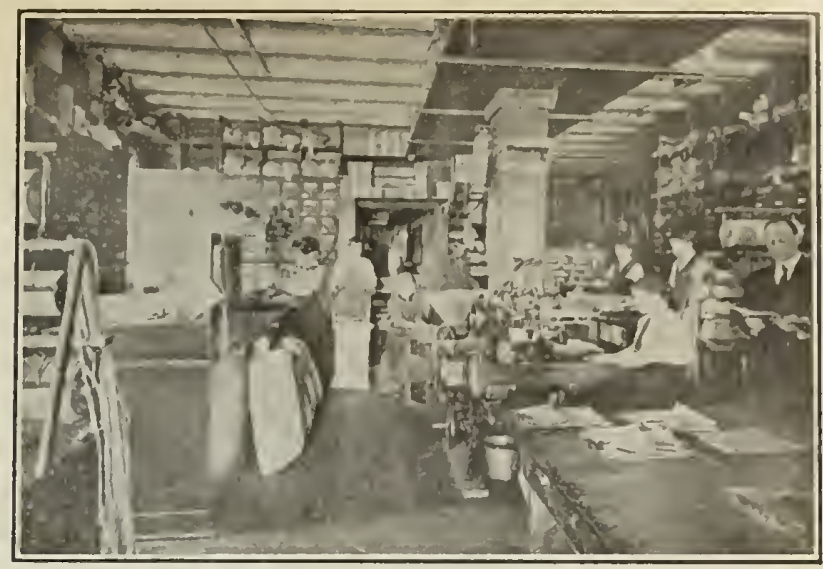

THE PACKING ROOM,

\section{Notice to Customers---Read Carefully}

\section{Terms of Sale}

No goods sent C. O. D. Please accompany youl order with remittance in full by draft, money order or cash in regisered letter. We take $2 \mathrm{c}$ postage stamps in moderate amounts.

\section{Order Early}

We earnestly solocit our friends to send their orders to us early-at once-before the rush is on. No matter how small or large your order it will receive our careful attention.

Use the order sheet and our self-addressed envelope, and ask for more when you want them.

If roods do not arrive promptly after receiving our notice that goods have been shipped, please write us

\section{Goods by Mail}

All Garden, Flower and Tree Seeds, also certain Bulbs and Plants, are sent by mail or express without further cost, except Beans, Corn, Peas. Onion Sets, Grain, Grass and Field Seeds. Plants and other articles which require postage from $j$ to 12 , cents per pound added to remittance, when wanted by mail. Read carefully about postage, etc., under each departrient in this catalogue.

If pastage allowed is more than aetual eost of shipping goods-on aceount of the new pareel post law-ive will either refund the difference, if amount is large enough, or will add seeds to make up the amount sent.

\section{Goods by Express or Freight}

When ordering to be shipped at your expense goods priced "prepaid" you may deduct $8 \mathrm{c}$ per pound flom prices. Often we send by express prepaid, instead of mail, goods priced prepaid. If not convenient for you to receive by express be sure to mention when ordering.

Whenever our notification card says "Prepaid," you are to pay nothing. Write us at once if a charge is added.

\section{ERRATA}

First line under Premium Packets should

read: Customers sending orders for seeds in pack-

ets and ounces not included in collection.

\section{LIST OF PREMIUMS}

\section{Premium Packets}

Customers' selection of one of the following books: nces not included in collections

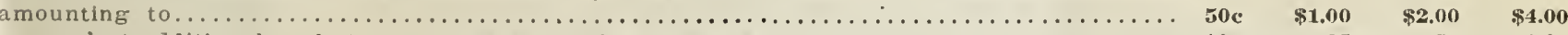
may select additional packets or ounces amounting to, extra.................... $10 \mathrm{c}$

Positively, the above offer is for seeds in packets and ounces only. Not in bulk, or other goods, and discount cannot be used as postage.

We give to an enstomers on orders for mixed quantities of GARDEN AND FLOWEL SELDS, positively free, choice of followlug:

Orders Amounting to $\$ 2.00$ or Over

llok, Iractleal Sugkestions for Vegetable Culture, written by a practical man and prepared explessly for the vegetablo gardener.

\section{Orders Amounting to $\$ 5.00$ or Over}

Customers" selection one of the following books:

Vegetahle cinrdenlng. Prop. Green's latest edition; 115 illustrations:

The Poultry Manual, revised edition; 144 pages.

Spraylug Crops; Why, When and How. By Prof. Weed.

Anparagus. Its culture for home use and market.

Honfe Pants and How to Sueceed With Them. Profusely illustrated. Just what the ladies want.

Amatenr Frult Growing. A rellable guide for beginners, also helpful to the experienced.

The Barteldes Farm fiulde. Fvery denartment of farm life eovered in detail ly experts.

Be sure to mention about premiums when ordering, otherwise we are to conclude you do not want them.

We do not give premiums, presents or extras with orders or part order for Bulbs, Grass, Clover, Grain or Field Seeds, Implements, Poultry Supplies, Fertilizers, Bee Supplies and other Sundry Articles.

Market Gardeners, Nurserymen and Florists should ask for special catalogue issued expressly for their use.

\section{ADDRESS ALL ORDERS \\ THE BARTELDES SEED COMPANY}




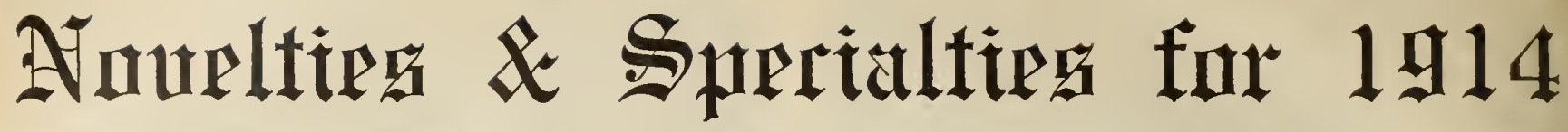

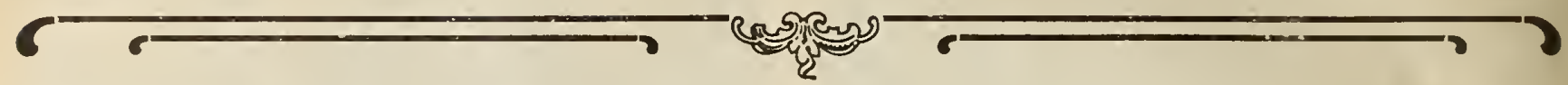

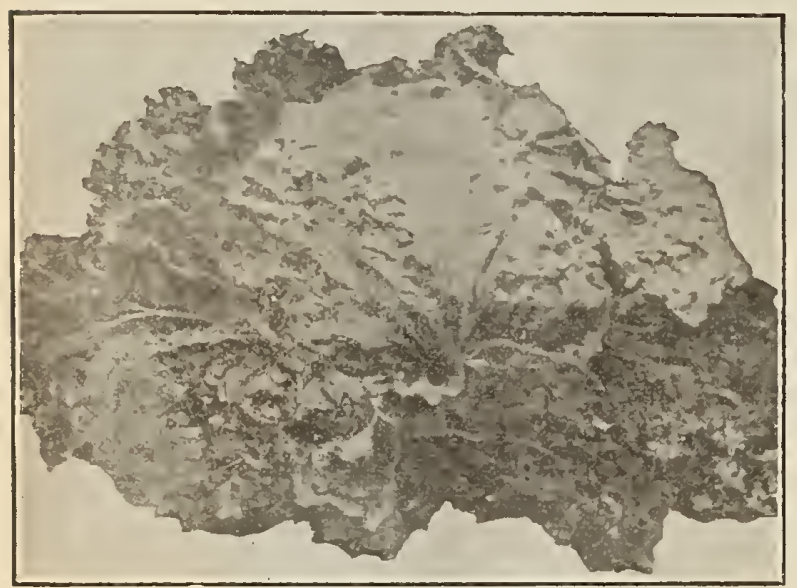

Los Ingeles Lettuce.

\section{LOS ANGELES LETTUCE.}

One of the best rarieties for main crop. When the few outside leaves are stripped off, there remains a shapely head as hard and large as a small cabbage with interior yellowish white, crisp and tender.

Pkt., 5e; oz., 15e; 1/4 lb., 50c; lb., \$1.50.

\section{PENCIL POD BLACK WAX BEAN.}

Plant grows about 15 inches high, very productive with pods straight 6 to 7 inches long, light golden yellow in color, round, meaty and deeply saddlebacked; flesh brittle, solid and stringless; flavor very fine.

Pkt., 5e; 1/2 lb., 15e; lb., 20c.

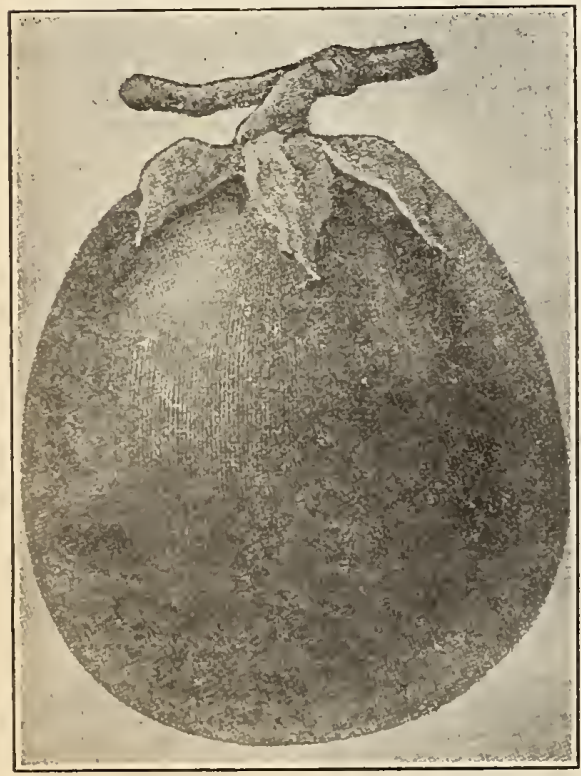

BInck Beatuty Lgr Plant.

\section{BLACK BEAUTY EGG PLANT.}

The earliest large fruited variety. The fruits set freely and derelop quickly so the entire erop can be harvested before frost. They are large, thick and of a rich lustrous purplish black. The calyx is entirely free from spines or thorns.

Plit., 10c; 1/2 oz., 25e; oz., 40c; 1/4 lb., \$1.15.

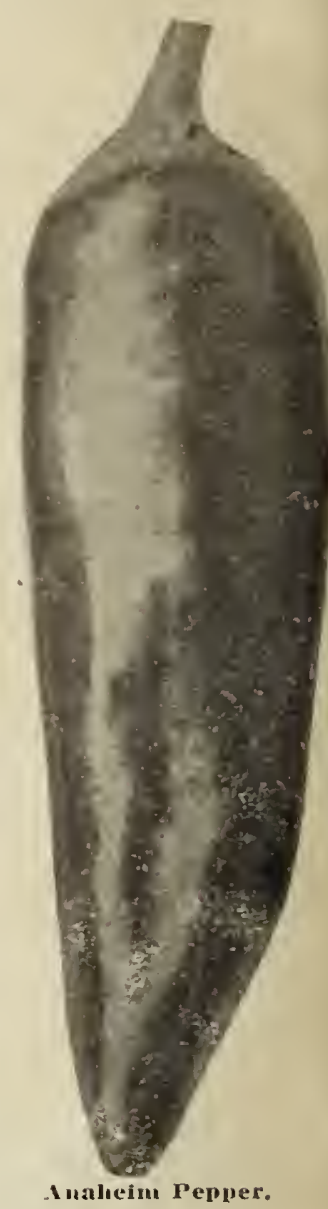

\section{ANAHEIM PEPPER.}

Plants are very vigorous and produce fruits 6 to 8 inches long, tapering from $1 \frac{1}{2}$ to 2 inches in diameter at top to almost a point. When dried they are a brilliant scarlet and are still more pungent than the Black Mexican Chili Pepper.

Pkt., 5c; 1:2 oz., 15c; oz., 25c; 1/4 lb., 75c. 


\section{Cabbage-Copenhagen Market}

This is the finest large round-headed medium early cabbage; the heads maturing all at the same time. They average about 10 pounds eaeh; are very solid with small core and of fine quality. Sowed in March, they are ready for market the latter part of August, in our trial ground, and are about as early as Charleston Wakefield, but will give a mueh heavier yield per aere. 'It is short stemmed, with small saueer-shaped light green leaves, always tightly folded, and ean, therefore, be planted very elose.

Pkt., 10c; 1/2 oz., 40c; 1 oz., 75e; 1/4 lb., $\$ 2.50$.
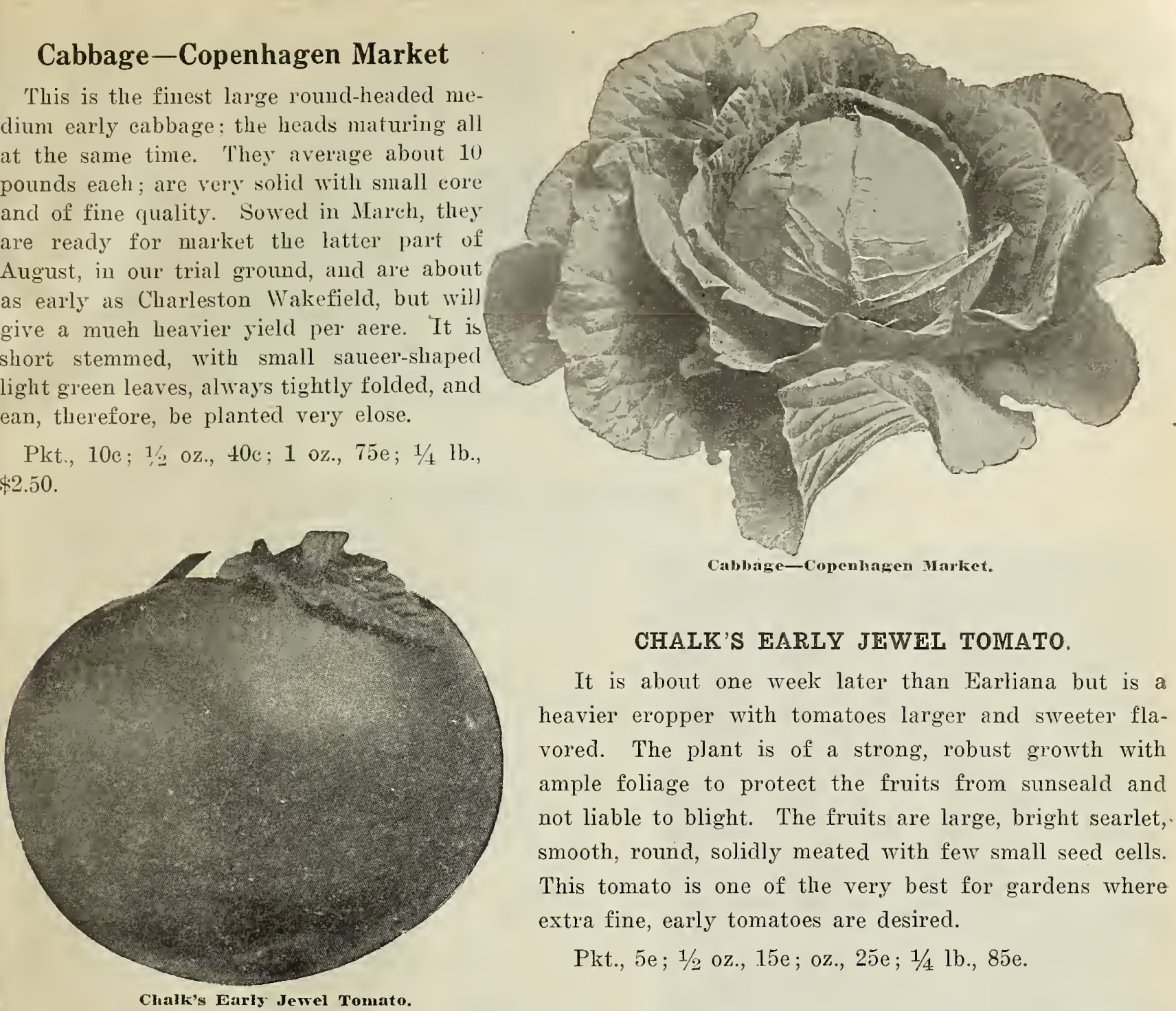

CHALK'S EARLY JEWEL TOMATO.

It is about one week later than Earliana but is a heavier eropper with tomatoes larger and sweeter flavored. The plant is of a strong, robust growth with ample foliage to protect the fruits from sunseald and not liable to blight. The fruits are large, bright searlet, smooth, round, solidly meated with few small seed cells. This tomato is one of the very best for gardens where extra fine, early tomatoes are desired.

Pkt., 5e; 1/2 oz., 15e; oz., 25e; 1/4 lb., 85e.

\section{Dimorphotheca Aurantiaca}

\section{The African Golden Orange Daisy.}

This is an extremely showy annual of easy culture and is a beautiful flower. The hardy plant has a branehing habit, growing 10 to 12 inches in height, and is an exceedingly profuse bloomer. The marguerite-like blossoms, about $2 \frac{1}{2}$ inehes in diameter, are of a rich, glossy orange gold color.

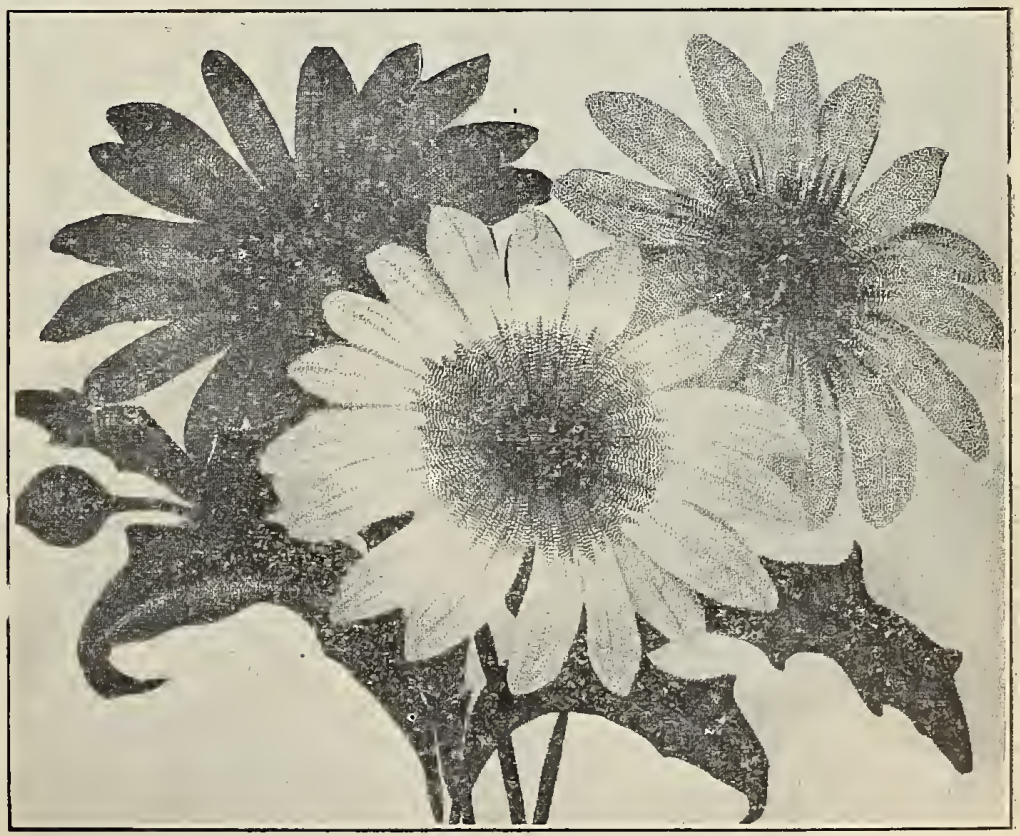

Pkt., 10e. 


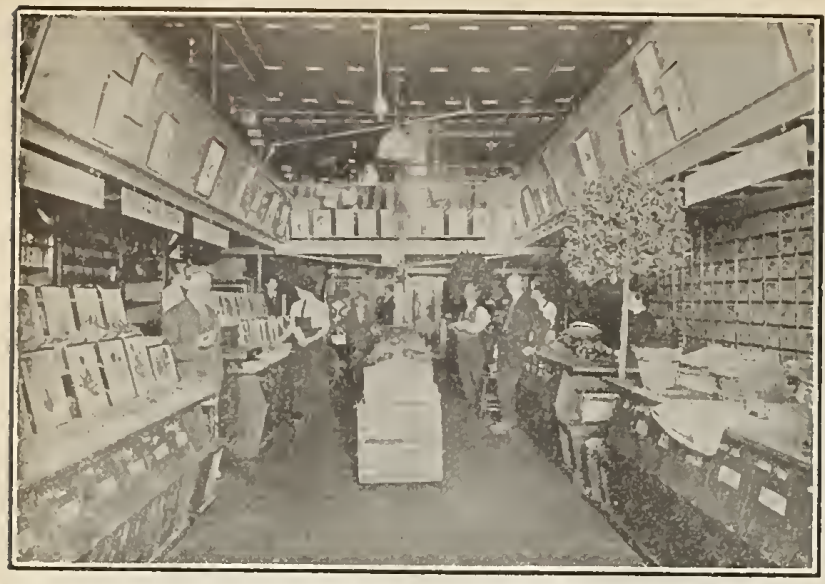

RETAIL STORE.

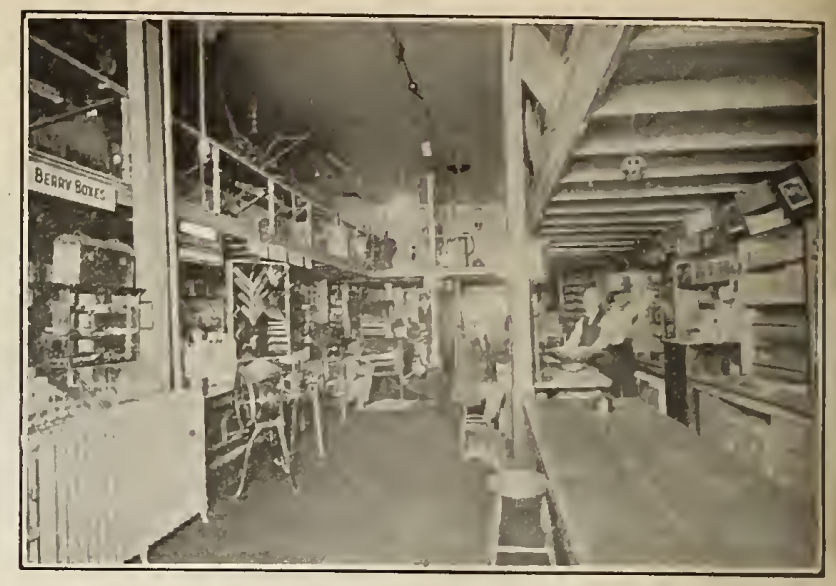

POULTRY DEPARTMENT.

\section{Climbing American Beauty Rose \\ NEW}

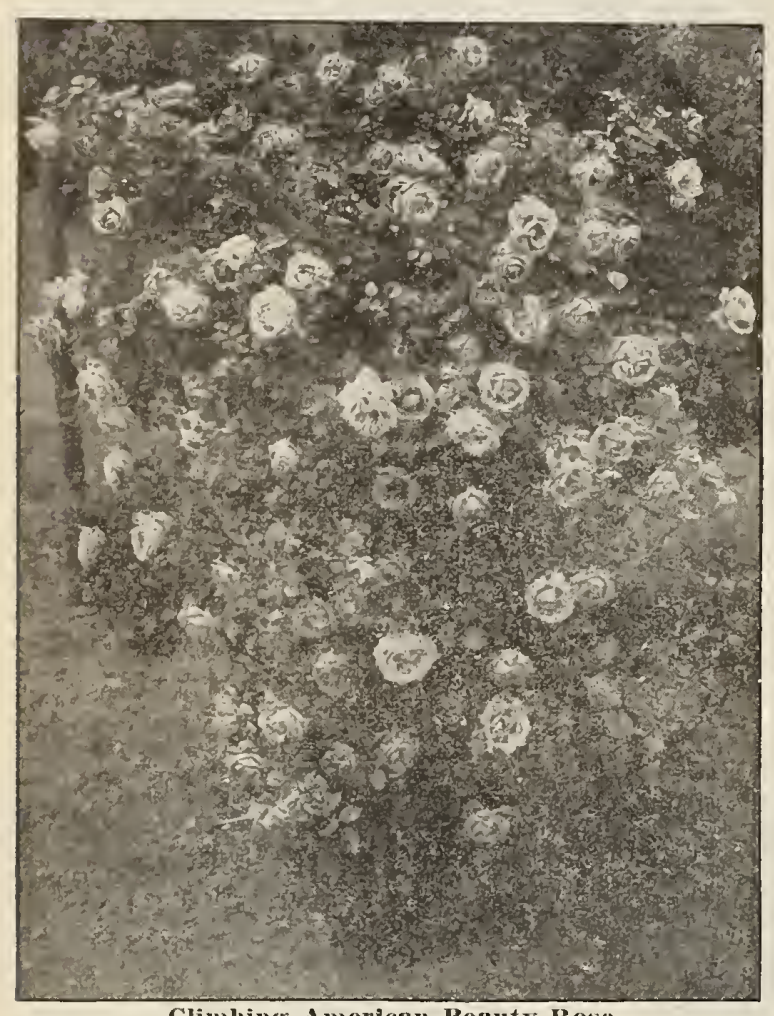

Climbing American Beauty Rose.

The Climbing American Beauty is the result of a cross between an unnamed seedling and the grand old American Beauty, thereby producing an Ameriean Beauty rose of the same eolor, size and fragranee as its parent, with the addition of beautiful, lasting foliage and better blooming quality. One plant of this new rose will produce twenty times as many blooms in June as the old American Beauty, besides blooming oceasionally during the summer. The roses grow on single stems, measure three to four inches in diameter, and have an exquisite fragrance. While the old American Beauty is rarely satisfactory planted in the open ground, this new rose has proved perfeetly hardy, stands heat and drought well, and the foliage is green and beautiful until the snow falls. It can be trained to trellises and porehes, grown in bush form, and is unequaled as a pillar rose. Our plants are not budded, but grown on their own root. Price, each, $75 \mathrm{c}$, postpaid.

\section{Feterita}

This new variety of Durha, introduced from the Sudan, produces stalks of medium size, bearing 10 to 12 leaves and a large upright head, well filled with pure white or bluish white seeds. The grain is larger than that of Milo and softer than Kaffir. Its feeding value is equal to either Milo or Kaffir. It is about 25 days earlier than Kaffir and yields considerably more. Eighty bushels per acre was reported last year. It should be planted about 2 weeks later than Indian Corn as it is more liable to rot in the ground. Sow in hills 40 to 44 inches apart each way and cover 1 to 2 inehes deep. When sown in hills 3 to 5 lbs. will sow one acre; if sown for fodder, with a grain drill, it takes about $75 \mathrm{lbs}$. per acre.

$\mathrm{Lb}, 15 \mathrm{e} ; 5 \mathrm{lbs}$., 50e. If wanted in quantity ask for price. 


\section{Standard Vegetable Seeds}

We wll furulwh Garden Scels, at the prices ln the following list, postpaid, execpt leavy secis, sich as beans, l"eas, Corn, Onion sels and Ficld seeds. For these It wll be necessary to ald to the remittance 8 eents per lb. to cover postage. Half 1b. sold at 1b. rate, except Beans, leas, Corn and Field sechs.

\section{Artichoke}

CULTUIE. Sow in April in rich soil, and transplant the following spring to permanent beds in hills three feet apart and two feet between the plants. Green Artichoke gives a partial crop the first season if the plants are started in hot beds in February and March. The beds will remain in bearing for years. Protect in winter by a covering of leaves or coarse manure.

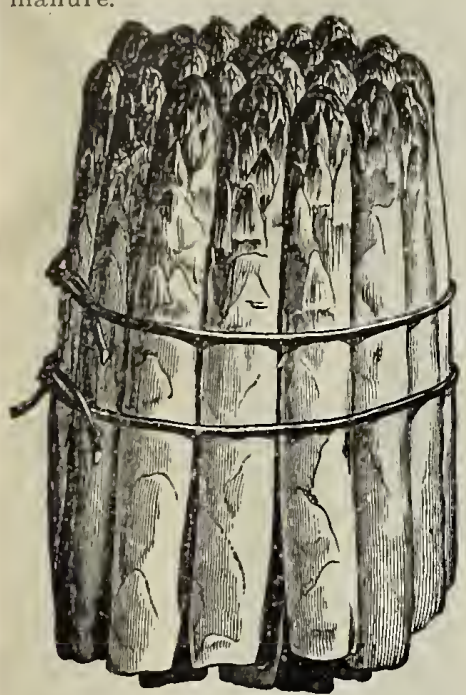

LARG EGREEN GLOBE. Produces large, globular heads; scales green shading to purple; best for general use,
Pkt., 5e; oz., 35e; 1/1 1b., \$1.00.

JWIRUSALEM. Tubers in season, $10 \mathrm{c}$ per $1 \mathrm{~b}$. For full description and prices in quantities see Field and Farm Seed Department. Pamphlet about Jerusalem Artichokes sent free.

\section{Asparagus}

CULTURE. The seed should be sown in March or April just as soon as the ground can be worked, in good, rich mellow soil, in drills one foot apart, then covered from $1 / 2$ to $3 / 4$ inch deep. The following spring the young plants should be set in their permanent places. The soil for them should be made as rich as possible, bearing in mind that the beds are to bear many years, and that it is easier to work in a good supply of manure before the plants are set than after. Dig a trench two feet deep, mix plenty manure with the top soil and fill the trench $1 \frac{1 / 2}{2}$ feet; they lay the plants being careful to spread the roots, from $11 \%$ to 2 feet apart, and then fill up the trench. The carences should the from 2 to 4 feet apart. trenches should be from to depart in which case it takes about 4,000 panto apart, in which case it takes about 4,000 plants to well drained soils; they come sooner and send out more shoots than if planted in stiff heavy soils. One ounce will produce about 600 plants, and it takes about 11,000 plants to cover one acre, if planted 2 feet each way.

For full direction, how to grow asparagus, get our Asparagus book, by Hexamer. Price, 50c.

\section{EARLY ARGENTEUIL.}

It is the earliest big asparagus grown, stalks weighing 3 to 4 ounces. The head is green and slightly pointed and the scales are very closely set. Being a vigorous grower, it is not trobuled very much with rust.

Pkt., 5c; oz., 10c; 1/4 1b., 30c; lb., 90c

PALMETTO.

It is of very large size, even and regular in growth and appearance. It is very early, immensely productive and of the best quality.

Pkt., 5c; oz., 10c; 1/a 1b., 25e; 1b., 75c.

CONOVER'S COLOSSAL.

The standard variety; of large size, tender and of excellent quality.

Pkt., 5c; oz., 10c; 1/4 lb., 20c; 1b., 60c.

\section{COLUMBIA MAMMOTH WHITE.}

An entirely new and magnificent variety, which is sure to be in great demand, because it furnishes white shoots which stay white as long as fit for use without earthing up or any other artificial blanching, and because it can be absolutely depended on to give 80 to 90 per cent white plants from seed.

Pkt., 5e; oz., 10c; 1/4 1b., 25e; 1b., 75c.

Roots of above varieties, 20e per dozen, $\$ 1.00$ per 100 , by express. Prices for larger quantities on application.

\section{BEANS}

Add 8c per $1 b$. for postage.

CULTURE. Plant in drills about 2 inches deep and from 18 inches to 2 feet apart, according to the richness of the soil-the poorer the soil, the closer they can be planted; the plants should be about three inches apart. A succession of sowings can be made from the first week in May until in August. One pound to 100 feet of drill; 60 to 80 pounds to an acre.

\section{Dwarf or Bush---Green Podded Varieties}

\section{BARTELDES' STRINGLESS.}

This new bean, which has originated in our own growing ground, and has been carefully cultivated, is the earliest of all stringless varieties, being 8 to 10 days earlier than any other variety. Plant is small, bushy, very erect, compact and very prolific. Pods are about $41 / 2$ inches long, straight, bright green, oval round through cross section, and containing 5 to 6 yellowish seeds of good quality.

Pkt., 5e; 1/2 lb., 15e; 1b., 25c; 2 lbs., $40 \mathrm{c}$.

\section{EARLY YELLOW SIX WEEKS.}

An early snap short variety, producing edible pods 40 days after germination. Very bushy, erect. Pods long, flat, straight.

Pkt., 5e; 1/2 lb., 10c; lb., 15e; 2 lbs., 25e; 10 lbs., \$1.15.

\section{BURPEE'S STRINGLESS.}

Extra early, round, fleshy pods; very brittle, almost entirely stringless, rust proof, vigorous, productive and, without doubt, the best green podded beans known.

Pkt., 5e; 1/2 lb., 15e; 1b., 26e; 2 lbs., 35e; 10 lbs., \$1.25.

\section{FULL MEASURE.}

This new, round, green-podded bush bean is the result of a cross between Yosemite Mammoth Wax and Refugee. It is entirely stringless and of excellent quality. The pods are 5 to 6 inches long, round, firm, but tender and remain fit for use many days after

Pkt., 5e; 1/2 1b., 15e; lb., 20c; 2 lbs., 35c; 10 lbs., $\$ 1.50$.

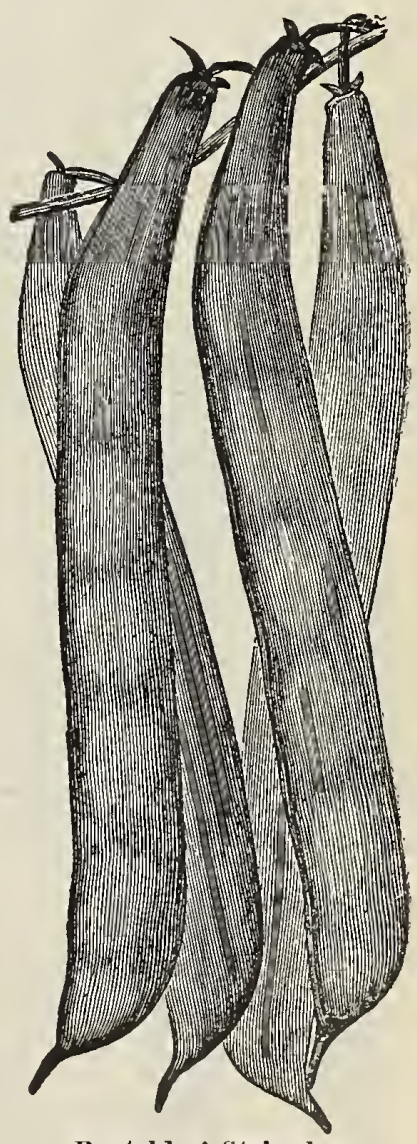

Barteldes' Stringless.

\section{GIANT STRINGLESS VALENTINE.}

Resembles the Valentine, though the round pods average one-third larger and usually are stringless. Is fully a week Rlier than the Improved Valentine.

Pkt., 5e; 1/2 1b., 15e; 1b., 20c; 2 lbs., 35c; 10 lbs., \$1.25.

Matures in forty days after germination; pods round, and fine in flavor. Habit of growth, vigorous.

Pkt., 5c; 1/2 lb., 10c; ib., 15c; 2 lhs., 25c; 10 lbs., \$1.15. 


\section{BEANS-Continued.}

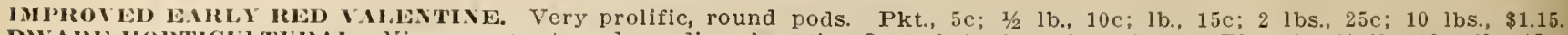

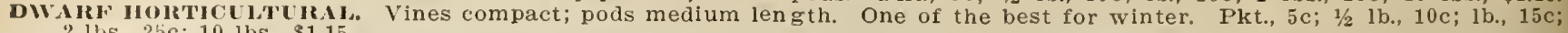

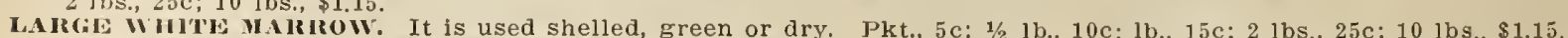

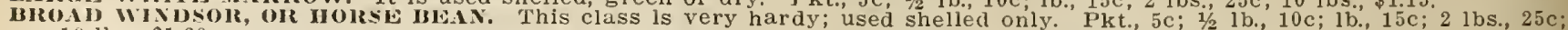
CAlHoril CiEAM BUTrelk. White, very large round seed; growth 24 to 30 inches in height, and of branching habit.

The best for winter use. Pkt., $5 \mathrm{c}$; $1 / 2$ lb., 10c; $1 \mathrm{~b} ., 15 \mathrm{c} ; 2$ lbs., $25 \mathrm{c} ; 10 \mathrm{lbs}$., $\$ 1.20$.

\section{Dwarf or Bush---Yellow Podded Varieties ROUND PODDED KIDNEY WAX.}

Under ordinary culture, this new variety will yield twice as many pods as Wardwell's, while their absolute stringlessness and fine delicate flavor make it by far the most desirakle Wax Bean yet introduced. The plants are of erect, bush habit. reachins 18 to 20 inches in height and are almost blight proof. The fleshy pods are about six to seven inches long and threeeighths of an inch thick; the color is a rich lemon-yellow, a color that will catch the eye, je; 1/2 ll., 15e; lb., 20e; 2 lbs., 35e; 10 lbs., \$1.50.

WARDWELL'S KIDNEY WAX.

We consider this variety one of the best wax beans. It is earlier than the Golden Wax; pods very large; long, tender, stringless and of a fine light golden color. It grows taller than Golden Wax and out-yields it by far. We recommend it highly, both for private and market garden.

Pkt., 5e; 1/2 1b., 15e; lb., 20e; 2 lbs., 35e; 10 lbs., $\$ 1.50$.

\section{IMPROVED GOLDEN WAX.}

The pods are large, long, half round, brittle and entirely stringless, and of a beautiful rich golden color. As a snap bean it excels every other variety in tenderness and rich buttery flavor, while as a shell bean for winter use it has few or no superiors. It is very prolific, of dwarf, compact growth.

Pkt., 5e; 1/2 lb., 15e; 1b., 20c; 2 lbs., 35e; 10 lbs., \$1.50.

\section{NEW STRINGLESS WHITE WAX.}

The pods are 5 to 6 inches long, rather flat in shape, but fleshy, juicy, of a good flavor, bright lemon color and entirely stringless at all stages. They are an enormous cropper and, being white seeded, are equally good for snap or winter bean.

Pkt., 5e; 1/2 1b., 15e; 1b., 20e; 2 lbs., 35e; 10 lbs., \$1.50.

DAVIS' WHITE WAX. Immensely productive, bearing large, handsome,

straight and almost stringless pods five to six inches in length. Pkt. straight and almost stringless pods five to six

REFUGE WAX. Similar to Green Refugee, but yellow pods. Pkt., 5c; DWARE BLACK WAX. Known as Butter Beans. Pkt., 5c; 1/2 1b., 15c; 1b., $20 \mathrm{c} ; 2$ lbs., $35 \mathrm{c} ; 10$ ibs., $\$ 1.25$.

ChALLENGE DWARF BLACK WaX. Extra early. Pkt., 5c; 1/2 1b., 15c; CURRIES' RUST-PROOF BLACK WAX. Hardy and productive; round pods. Pkt., 5c; $1 / 2$ lb., 15c; 1 b., $20 \mathrm{c}$; 2 lbs., 35c; 10 lbs., $\$ 1.25$.

FLAGEOLET WAX. An early wax variety; long pods. Pkt., $5 \mathrm{c}$; 1/2 1b., 15c; FLAGEOLET $1 \mathrm{~b}$., $20 \mathrm{c} ; 2$ bs., $35 \mathrm{c} ; 10 \mathrm{lbs}, \$ 1.25$.

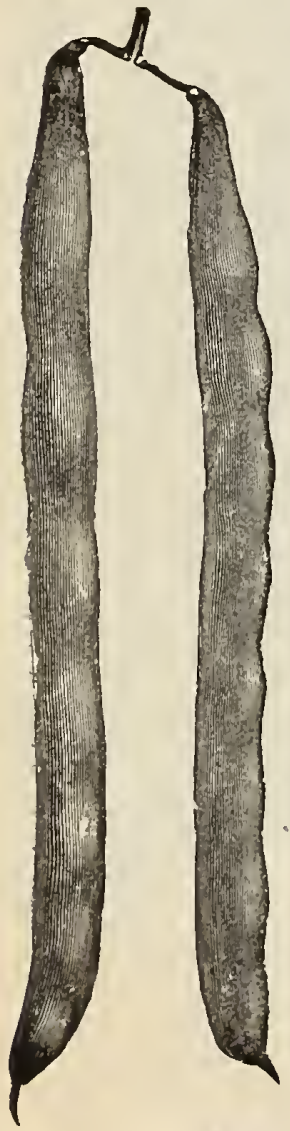

\section{Bean---Pole or Running}

Pole Beans mature very well in Colorado. They should be more extensively grown, as they can be planted with corn, which will furnish the support to

BURGER's STRINGLES. This new pole bean is very early and a continuous bearer. The rich, dark green pods grow in clusters; they are 6 to 8 inches long, so meaty and so deeply saddle-backed that the width is greater than the thickness from back to front Widh is greater than the thickness from back le fleshy and entirely stringless. The dry beans are $1 / 2$ inch long, and of the purest white color. On account of long, and of the purest white color. On account of

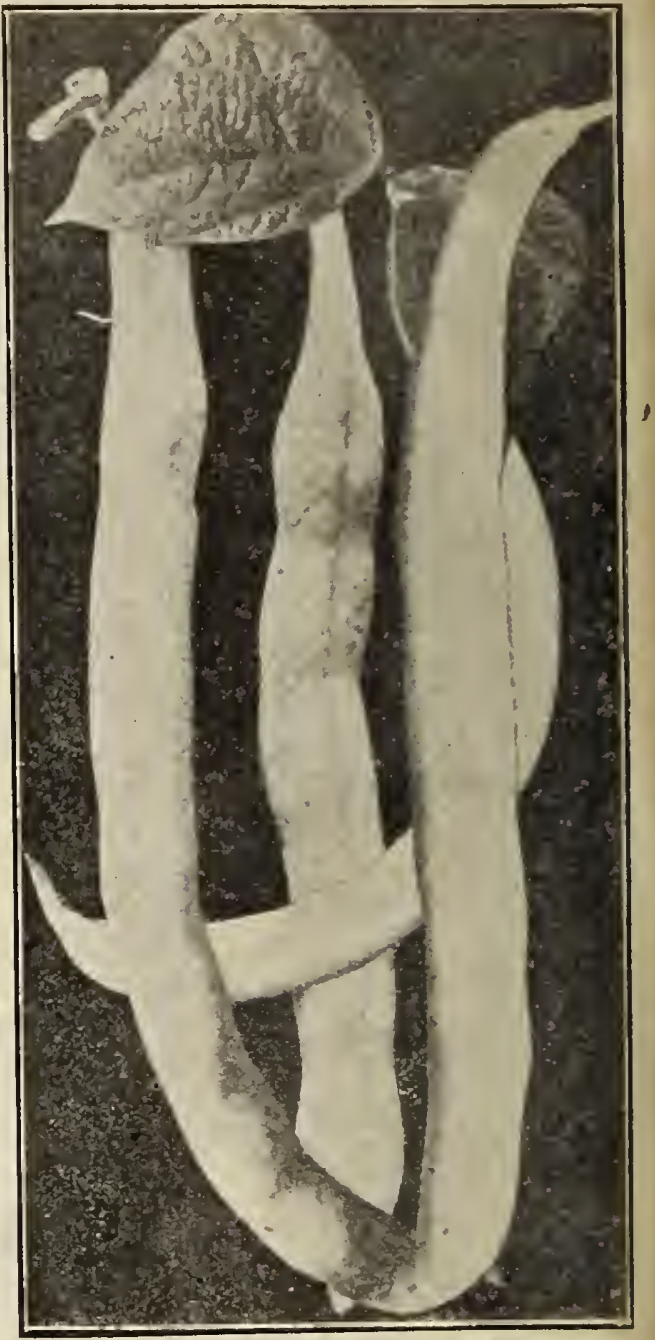

Lound Podded Kidney Wax. Pkt., 5e; $1 / 2$ lb., 15e; 1b., 20e; 2 lbs., 35e; 10 lbs., $\$ 1.50$.

\section{LAZY WIFE.}

This sort is popular in many localities. As its name indicates, a handful of choice, stringless pods at a single grab. The pods are broad, thick, very fleshy and entirely stringless, and possess a rich, buttery flavor

I’kt., 5e; $1 / 2$ 1b., 15e; 1b., 20c; 2 lbs., $35 \mathrm{e}$; 10 Ibs., \$1.25.

\section{EARLY GOLDEN CLUSTER WAX.}

The Early Golden Cluster begins to bear in July, and continues until frost; pods are six-to eight inches lone flavor is most delicious. It can be used shelled or as a string bean.

Pkt., 5e; 1/2 lb., 15e; 1b., 20e; 2 lbs., 35e; 10 lbs., $\$ 1.25$.

\section{KENTUCKY WONDER.}

Vine vigorous, climbing well and very productive, bearing its pods in large clusters; pods green, very irregular and spongy as the beans ripen.

Pkt., 5e; 1/2 lb., 15e; lb., 20e; 2 lbs., 35e; 10 lbs., \$1.25.

LARGE WHITE LIMA OR BUTTER. Rich and finest flavor, and one of the best of pole beans. Pkt., 5c; 1/2 lb., 15c;1b., 20c; 2 lbs., 35c; 10 lbs., $\$ 1.25$.

CAROLINA. A small variety of Lima, more vigorous in growth, earlier in season and more prolific in pods. Pkt., $5 \mathrm{c} ; 1 / 2$ lb., $15 \mathrm{c} ; 1 \mathrm{~b} ., 20 \mathrm{c} ; 2$ lbs., $35 \mathrm{c} ; 10$ lbs., $\$ 1.25$.

DUTCII CASE KNIFE. Pods long, green and flat; can be either snapped or shelled. Pkt., 5c; 1/2 lb., $15 \mathrm{c} ; \mathrm{lb}, 20 \mathrm{c} ; 2$ lbs, $35 \mathrm{c} ; 10 \mathrm{lbs}, \$ 1.25$

HOH'TCULTURAL OR SPECKLED CRANBERRY. A showy bean, maturing in 80 days. Pods red; valued either as a snap or for shelling. Pkt., 5c; $1 / 21 \mathrm{~b} ., 15 \mathrm{c} ; 1 \mathrm{~b} ., 20 \mathrm{c} ; 2 \mathrm{bs}$., $35 \mathrm{c} ; 10 \mathrm{lbs} ., \$ 1.25$.

CU'T SHOR'T or CORY HILL. An old variety, very popular for planting among corn; pods short, round and tender; beans nearly oblong. Pkt., 5c; 1/2 1b., 15c; lb., 20c; $21 \mathrm{bs} ., 35 \mathrm{c} ; 10$ lbs., $\$ 1.25$.

WHITE CREASE BACK. Seeds small, qval, very white and hard, but are of very superior quality Burger's stringless. baked. Round pods. Pkt., 5c; 1/2 1b., 15c; 1 b., $20 \mathrm{c}$; 2 lbs., $35 \mathrm{c}$; 10 lbs., $\$ 1.25$. 


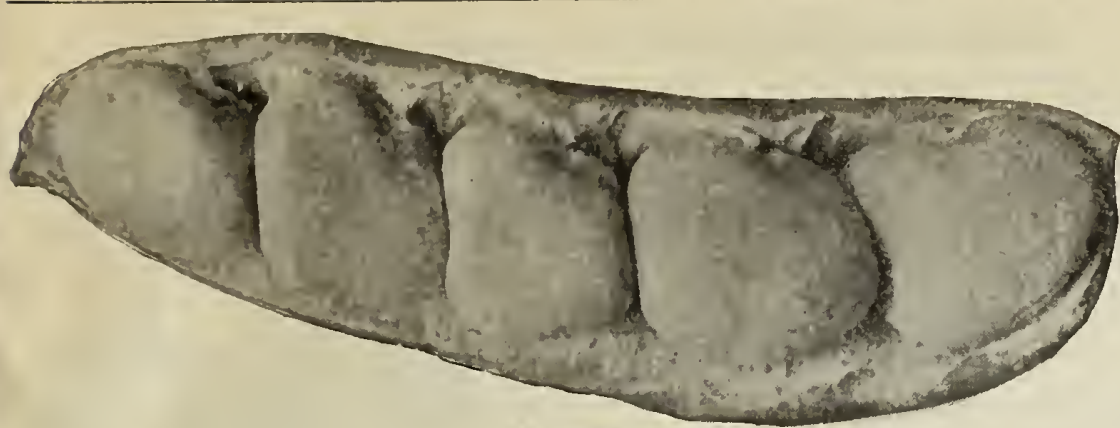

Large Lima.
BURPEE'S BUSH LIMA.

It is the true bush form of the old Large Lima Pole Beans. It grows vigorously to a height of 18 to 20 inches, forming a circular bush two to two and a half feet in diameter, yielding from 50 to 100 fine pods similar to Large White Lima which are grown on poles. Pkt., 5e; 1/2 lb., 15e; 1b., 20e; 2 lbs., 35e; 10 1bs., \$1.35.

HENDERSON'S BUSH LIMA.

The New Bush. Lima grows without the aid of stakes or poles, is compact, bush form, from 15 to 18 inches high, and produces enormous crops of delicious Lima Beans. The New Bush Lima is at least two weeks earlier than any of the climbing Limas.

Pkt., 5e; 1/2 lb., 15e; lb., 20c; 2 lbs., 35e; 10 lbs., $\$ 1.35$.

\section{Flowering Beans}

Very desirable for trellis, or to cover old fences, etc. While the green seeds are edible, the attractiveness is the profuse blossoms. Prices: Pkt., 5c; 1/2 1b., 15c; lb., 25c;2 1bs., $40 \mathrm{c}$.

WHITE RUNNER. A pure white flower.

TRI-COLOR RUNNER. Pink and white in the same blossom.

\section{BEETS---For Table Use}

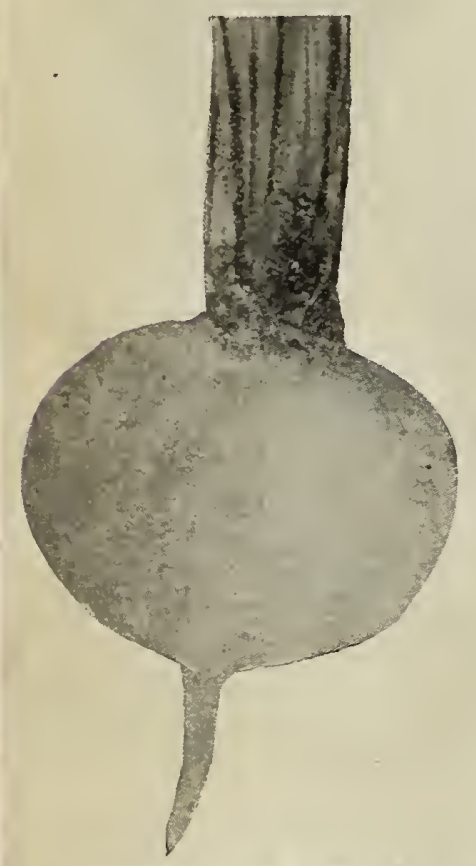

Barieldes' Hlood Turuip.

CULTURE. Beets require a deep, rich, mellow soil, and may be sown from early spring to commencement of summer. Drop about 1 inch deep, in drills 12 to 18 inches apart. One ounce to 100 feet of drill; 6 to 8 pounds to an acre.

\section{CRIMSON MODEL BEET.}

This is indeed a model variety and will be highly appreciated both for forcing or growing outside. It is extremely smooth and symmetrical in shape and of a fine rich blood-red color. It makes a rapid growth, matures early, is almost round in shape and in quality is most excellent, being sweet, tender and free from coarseness. The tops are small, making it a fine variety for forcing in hot bed.

Pkt., 5e; oz., 10e; 1/4 lb., 35e; 1b., \$1.00.

\section{EXTRA EARLY EGYPTIAN.}

An extra early turnip-shaped variety; has small top and grows quickly. The flesh is in alternate rings of white and deep red.

Pkt., 5e; oz., 10e; 1/4 1b., 25e; 1b., 90e.

\section{ECLIPSE.}

It is nearly as early as Egyptian and much more desirable, owing to its globe shape, great smoothness and regularity, having a small top; very sweet, fine, and dark blood great smoothness and regularity, having
color.
Pkt., 5e; oz., 10e; 1/1 lb., 2te; lb., 90e.

\section{THE LENTZ.}

It is as early as the Egyptian, flesh very tender and sweet at all times, whether old or young; very productive, good keeper, and will produce a crop in six weeks from the time of planting the seed.

Pkt., 5e; ox., 10e; $1 / 4$ lb., 25e; $1 \mathrm{~b} ., \$ 1.00$.

\section{BARTELDES' BLOOD TURNIP.}

An improved strain of Early Blood Turnip; very good for forcing, early sowings or main crop. It cooks sweet and crisp.

Pkt., 5e; oz., 10e; 1/4 1b., 35e; lb., \$1.15.

\section{EARLY BLOOD TURNIP.}

Here we have the old standby, the turnip beet, with its dark red color, well known to so many home-

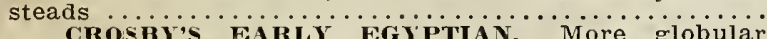
CROSBY'S EARLY EGTPTIAN. More globular DETRotT DARK RED. Extremely popular for

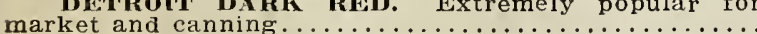
GDnoNo's Blood TuRvip. Very eariy, of handsome round shape ..................... HALF LONG BEET. Yields more than the turnip-

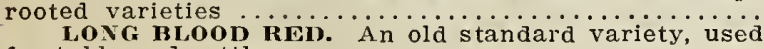

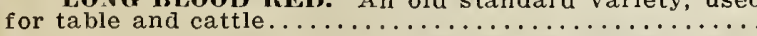

\begin{tabular}{rrrr} 
Plkt. & Oz., & 1/4 1 lb. & \multicolumn{1}{c}{ Lb. } \\
$\$ .05$ & $\$ .10$ & $\$ .25$ & $\$ .90$ \\
.05 & .10 & .25 & .90 \\
.05 & .10 & .25 & .90 \\
.05 & .10 & .25 & .90 \\
.05 & .10 & .25 & .90 \\
.05 & .10 & .25 & .90
\end{tabular}

SWISS CHARD OR SILVER BEET.

$A$ distinct vegetable and much superior to the common beets for greens. If sown at the same time, it will be fit to use before them. Later the plants form broad, flat, beautifully white and wax-like stems to the leaves, which are very delicious cooked as beets

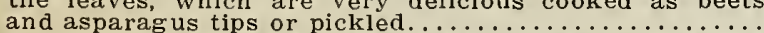
FoliAge BeErs. A species of Chard in various

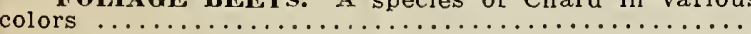

$\begin{array}{llll}.05 & .10 & .35 & 1.00 \\ .05 & .10 & .35 & 1.15\end{array}$

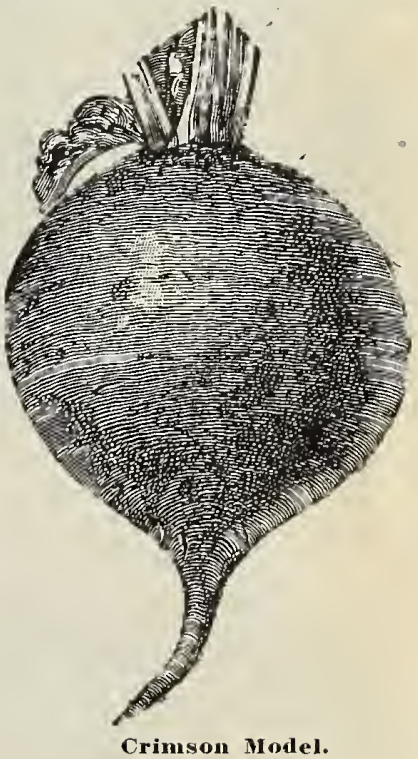

This is a little booklet issued with the intention of helping the Western Seed Planters to secure a fine garden. It tells you in a concise way how to cultivate and take good care of your vegetables, flowers, bulbs, plants and small fruits. It is sent free for the asking with each order. 


\section{MANGEL WURZEL AND SUGAR BEET FOR STOCK FEEDING}

If not prepaid, lb., 40e; :3 llis., \$1.10; 5 lbs., \$1.75.

CUl'LlE. They require a soil plowed deeper and the drills further apart than garden beets. Sow in April or

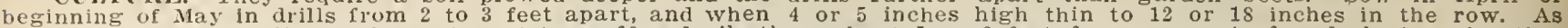

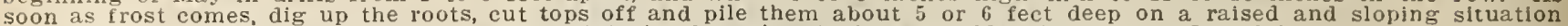

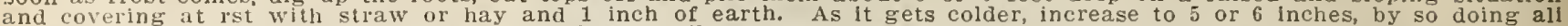
danger of heating is obviated and the roots keep until next summer. Four or five pounds to one acre

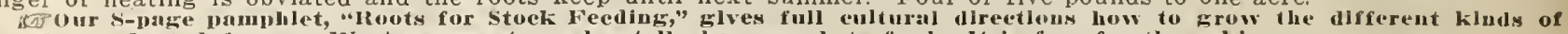
roots best adapted for our western country; also tells how minch to feed. It is free for the asking.

GOLDEN TANKARD MANGEL WURZEL.

This is undoubtedly one of the most profitable varieties to grow for stock, as it s an enormous cropper, and said to be one of the most nutritious Mlangels in cultivation. Color bright yellow.

0\%, 5e; 1/4 1b., 15e; 1 b., 50e; postpaid.

MAMMOTH LONG RED MANGEL WURZEL.

This is a particularly fine Mangel, growing from one-half to two-thirds aborc the round The roots anormous size, smooth and regular in shape.

Oz., 5e; 1/1 1b., 15e; 1b., 50e; postpaid.

\section{RED GLOBE MANGEL WURZEL.}

A large variety of excellent quality, productive and a good keeper; color, light red; flesh white; better adapted to shallow soil than the long varieties.

Ox., 5e; 1/3 1b., 15e; 1b., 50e; postpaid.

YELLOW GLOBE MANGEL WURZEL.

More delicate than the long red; more easily pulled.

Oz., 5e; 1/2 1b., 15e; lb., 50e; postpaid.

GIANT FEEDING SUGAR BEET OR HALF SUGAR MANGEL WURZEL.

This new Sugar Beet gives nearly as large a yield of easily grown and harvested roots as a crop of Mangels, besides being much more succulent than the ordinary Sugar Beet. It grows well above the ground and is easily pulled. Under same cultivation will ield twice more than regular Sugar Beets.

oz., 5e; $1 / 1$ lb., 15e; 1l., soe; postpaid.

\section{RED TOP SUGAR BEET.}

It unites capacity for a large yield with an exceedingly rich flesh, making it the best for rats rather large, growing slightly above the surface; white, washed with red at top; flesh fine grained and very sweet. Oz., 5e; 1/4 lb., 15e; lb., 50e; postpaid.

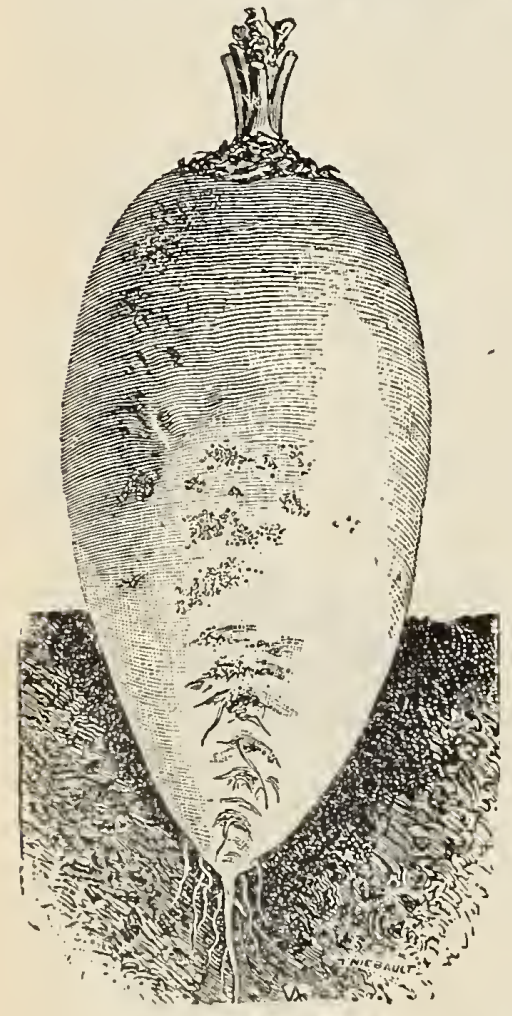

Giant Fecdlng Sugar.

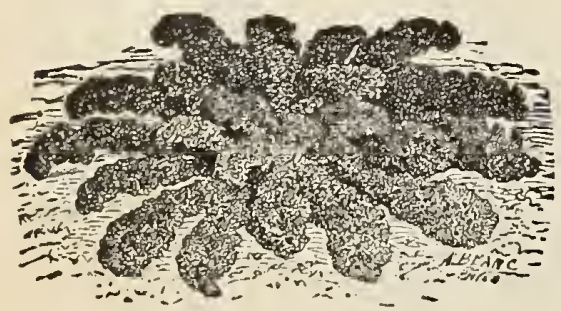

Kale-Dwref German.

\section{SILESIAN SUGAR.}

This is the old well-known form of Sugar Beet long raised in this country for feeding

Oz., 5e; 1/2 lb., 15e; lb., 50e; postpaiil.

\section{LANE'S IMPERIAL SUGAR.}

This beet will yield almost as much in bulk as the best mangels, and contains a large percentage of sugar. The roots are smooth groad at the shoulder and gradually taper to the base. They grow with a considerable portion above the soil and are easily harvested. Light green foliage, smooth whitish green skin and crisp, snowwhite flesh. Highly recommended by Agricultural Stations as a stock-feeding beet.

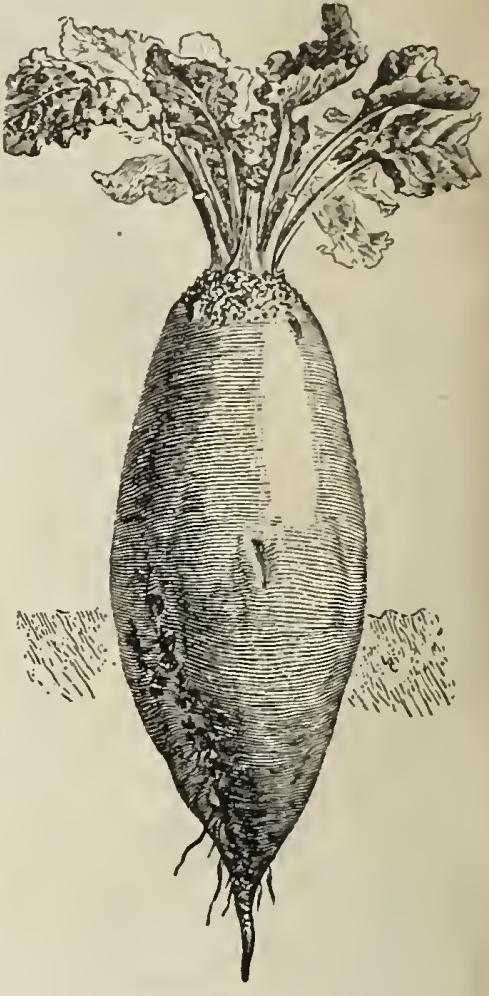

Golden Taukard.
VILMORIN'S IMPROVED SUGAR.

A variety out of which much sugar has been made; skin cream color; flesh white; an average of 15 tons per acre can be produced.

Oz., 5e; $1 / 4$ lb., $15 \mathrm{c} ; 1 \mathrm{~b}$., 50c; postpaid.

WHITE KLEIN WANZLEBEN SUGAR.

This variety has proved to be a very valuable sort, not only in foreign countries, but as well in Colorado and other sections of this country, where it has been thoroughly tested. It has a rather long, slender root, very rich in sugar, and grows deeply sunk in the hround and it is claimed to yield under average conditions about 16 tons to the acre, containing 15 to 16 per cent of sugar.

Oz., 5e; 1/4 lb., 15e; lb., 50c; postpaid.

\section{Borecole or Kale}

\section{DWARF GREEN GERMAN}

Sow in the spring for "sprouts" or "greens." Hardy, prolific, flavor similar to cabbage: desirable in every garden.

Pkt., 5e; oz., 10e; 1/1 ll., 30e.

DWARF PURPLE GERMAN.

A variety of the preceding, and identical with it, except in color, which is eautiful purple, $1 / 4$ lb., 40c.

TALL GREEN CURLED OR SCOTCH.

This is one of the most popular varieties. It is very hardy, and is much improved by frost. Two feet high.

Pkt., 5e; oz., 10e; 1/4 1b., 40e.

\section{Broccoli}

CULTURE. Sow early in spring, transplant and cultivate the same as cabbage. The Broccoli is a species of cauliflower, but more hardy and coarser grained; does best in a cool, moist climate. They will produce heads in October and Novmer and should any plant not be forward enough for use before frost let them be removed to a light cellar where they will head during the winter.

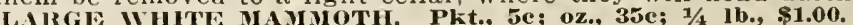

PURP'LE CAPE. PKt., 5e; oz., 35e; $1 / 4 \mathrm{lb.,} \$ 1.00$.

\section{Brussels Sprouts}

CITURI. Cultivated for the small heads that grow in considerable numbers from the main stem. It is a delicacy much esteemed by some. Sow in seed bed middle of spring: transplant and manage as winter cabbage.

Pkt., 5e; oz., 25e; 1/4 1b., 75e. 


\section{CABBAGE}

CULTURE. For early cabbages sow the seed in a hot bed, in March or April, covering the seed from $1 / 4$ to $1 / 2$ inch deep and, when bif enough; transplant to another bed. As soon as the ground is in good condition, transplant outside, in rows 2 feet apart and 15 to 18 inches in the row. The soil should be mellow, rich and well drained. For late crop the seed can be sowed in a cold frame, or even in the open ground, and then transplant in rows 3 feet one way and 2 feet the other, so as to be able to work with a horse and cultivator. One ounce of saltpeter dissolved in 3 gallons of water sprinkled over the cabbages or cauliflowers will destroy the green worm. The liquid, being clear does not color the caulifower or cabbage heads. Fine air-slacked lime or tobacco dust, sifted on the young plants, as soon as the fleas appear on the ground,

One ounce will produce about 2,000 plants. About 16,000 early or $\$, 000$ late cabbages plant one acre

How to Grow Cabbage and Caulifower, by Lupton. Price, 30 , postpaid.

\section{Extra Early Varieties--Pointed Head}

\section{EXTRA EARLY EXPRESS.}

Produces fair sized heads in 80 to 85 days from time of sowing seed. Does not form as large head as the "Etampes," but is several days earlier.

l'kt., Je; az., 20e; $1 / 2$ lib., 60e; lb., \$1.80.

EXTRA EARLY ETAMPES.

One of the earliest cabbages, producing well formed conical heads, remarkably large for so early a ripener. Whoever plants it will be amazed in its early maturity.

l'kt., äl; nx., 201te; $1 / 1$ lb., G0e; lb., \$1.80.

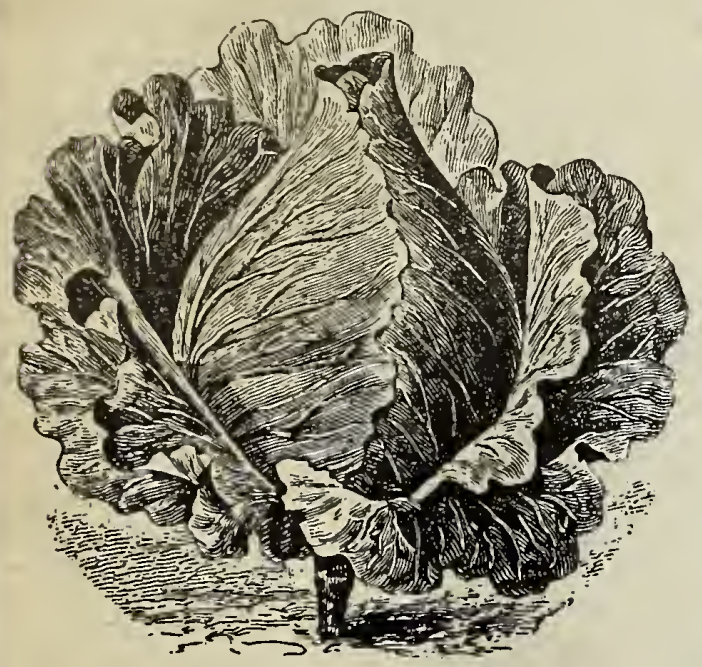

Sure Header Winnigstadt.

\section{Early Varieties--Round Head}

THE GLORY.

The earliest large, solid, round head. The plants are somewhat pale green and make very outside leaves.

Pkt., 10e; oz., 25e; 1/4 1b., 75c; 1b., \$2.25.

\section{EARLY SPRING.}

Its great value lies in its being the earliest flat cabbage, a type much preferred over the heads by many. The heads have few outside leaves and these are small and grow so close to the head that they can be planted very close together.

Pkt., 5e; oz., 20c; 1/4 lb., 60e; lb., \$1.75.

\section{ALL-HEAD EARLY.}

It is among the earliest of the large cabbages. It is fully one-third larger than the Early Summer. The deep, flat heads are remarkably solid and uniform in color as well as in shape and size. It is very tender and of fine quality.

Pkt., 5e; oz., 20c; 1/4 lb., 60e; 1b., \$1.75.

\section{EARLY SUMMER.}

This variety is about five days later than the W'akefield, but being fully double the size it may be classed as one of the best Large Early Cabbages in weight it is about equal to most of the late varieties, and its short outer leaves enable it to be planted nearly as close as the Wakefield.

Pkt., 5c; oz., 20c; 1/4 1b., 60c; lb., \$1.75.

\section{EARLY DWARF FLAT DUTCH.}

Has succeeded admirably on account of its ability to resist heat; it never flaws under the severest sun and produces very fine large heads after the earliest sorts have disappeared. We recamend it highly.

Pkt., 5c; oz., 20e; 1/4 Ib., 60c; 1b., \$1.75.

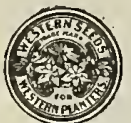

BARTELDES' SURE HEADER WINNIGSTADT.

A strain of the well known Winnigstadt Cabbage, but improved by scveral years' selection of the earliest, hardiest and best formed heads, used for seed raising. Plants are almost sure headers, having produced 98 heads out of 100 plants set. It does well in any soil, but if planted in a rich soil will produce one of the largest heads among pointed
head varieties. It is good for early planting or for winter use, its keeping qualities being equal to Danish Ballhead. We recommend it strongly. Plit., 5e; oz., 25e; $1 / 4$ lb., 65e; lb., \$2.00.

\section{TRUE JERSEY WAKEFIELD.}

This is an admirable sort, suited to the family and market garden. The heads begin to mature in the latter end of June to the first of July, and may be cut in succession for several weeks. Our seed is true Long Island grown.

Plkt., 5c; o\%., 2ac; 1/4 lb., 65e; lb., \$2.00.

EARLY YORK.

One of the earliest varieties; not recommended for summer use.

Pkt., 5e; oz., 15e; 1/4 1b., 50e; Ib., \$1.50.

\section{EARLY WINNIGSTADT.}

A well-known and very popular early variety; in season very close to the Wakefield; heads large, decidedly conical; leaves bright, glossy green; heads solid and hard, even in summer. This is a very sure heading variety, valuable not only for early use, but also for winter cabbage.

Pkt., 5c; oz., 20c; 1/4 1b., 50c; lb., \$1.60.

PE.TSAI OR CHINESE CABBAGE.

This is a valuable addition to the family garden. It is a delicious vegetable, the flavor being a blending of cabbage and turnip. The leaves are long and bleach readily; the plant has a beautiful appearance, but does not make a solid head. Plant 2 feet apart each way in good, rich soil.

Pkt., 10c; o\%., 75c; $1 / 4$ 1b., $\$ 2.50$.

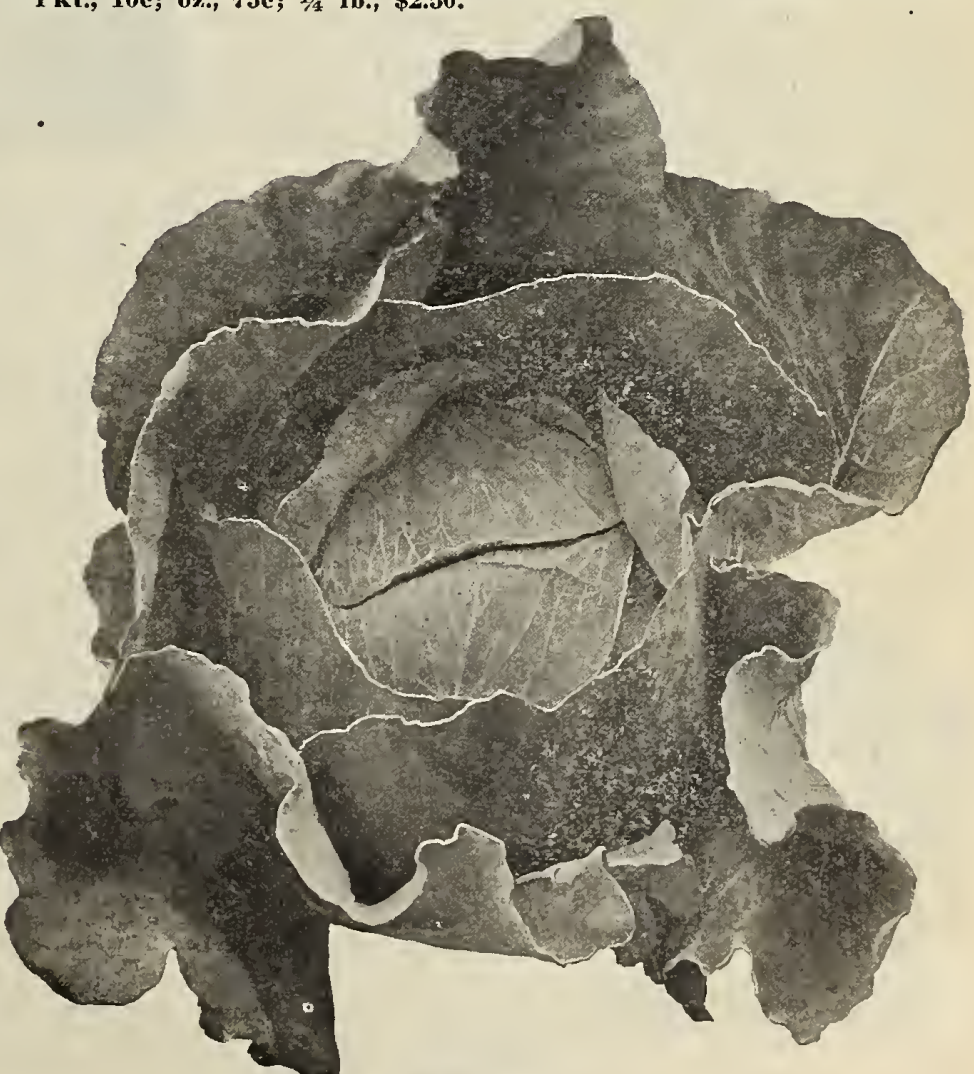

The Glory 


\section{CABBAGE--Medium Early and Late Varieties}

ALL SEASONS.

One of the earliest of the second early sorts. Heads very large, round, often nearly spherical, but usually somewhat

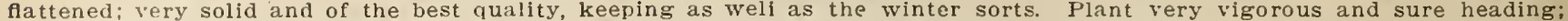
leaves lar.ge and smooth. Remarkable for its ability to stand the hot sun and dry weather.

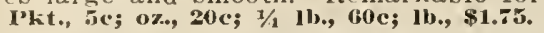

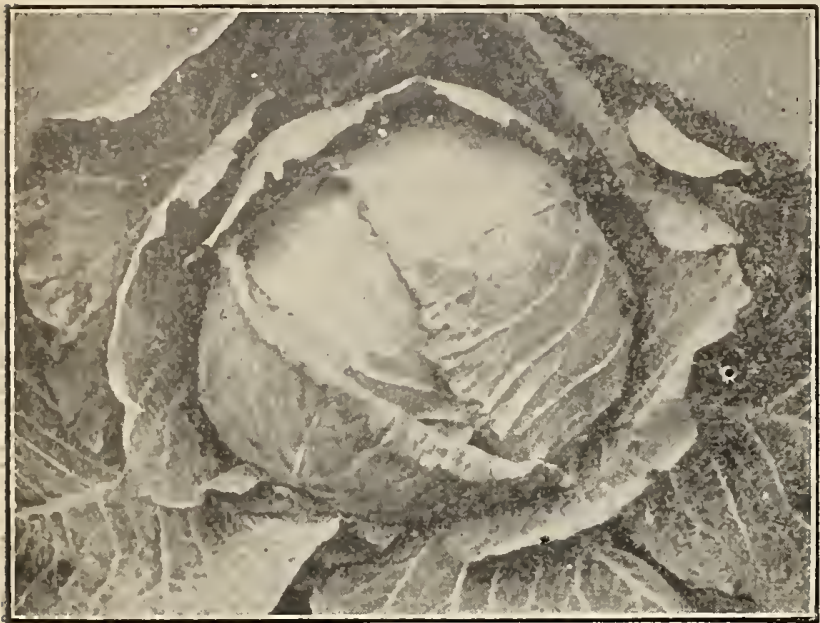

Barteldes' Select Danish Ballhead.

DANISH BALLHEAD OR HOLLANDER CABBAGE.

This variety, known as Ballhead, has been selected and brought to perfection for more than 50 years by Danish gardeners, who grow it almost exclusively for winter use. Bears shipping well, and keeps far into the spring. Heads round as a ball, extremely solid and fine grained, excellent cooking qualities. Our largest cabbage growers have had best returns from the Hollander. Takes full season to make matured the Hollander. Takes full season to make matured be fooled into buying so-called Hollander at low prices. We have both long and short stemmed varieties. When ordering juantity state which is wanted.

Pkt., 5c; oz., 25c; $1 / 4$ lb., $75 c$; 1 b., \$2.50.

\section{PREMIUM LATE FLAT DUTCH.}

As a variety for winter it has no superior. Heads large, bluish green, round, solid, broad and flat on top, and of ten tinted with reddish brown after being touched with frost; they open white and crisp, are tender and well flavored. It is a fall and winter variety, and one of the very best to keep. With a good cultivation, on moist, rich ground, 95 in 100 will head up hard and fine.

Plkt., 5c; oz., 25c; 1/4 lb., 60c; $1 \mathrm{~b} ., \$ 1.75$.

DRUMHEAD SAVOY. An excellent

Pkt., 5c; oz., 20c; 1/4 ib., 65e; lb., \$2.00.

MAMMOTH ROCK RED. This is by far the best, largest and surest heading red cabbage

Pkt., 5c; oz., 20c; $1 / 4$ lb., 65c; $1 \mathrm{b.}, \$ 2.00$.

CHICORY.

LARGE ROOTED. A hardy plant, introduced from and much used in Europe as a substitute for coffee. In the fall the roots require to be taken up and cut into small pieces and put where they will dry, requiring the same treatment used for drying apples. When required for use, it should be roasted and ground like coffee. Requires similar treatment to carrots.

Pkt., 5c; oz., 15c; 1/4 lb., 40c; 1b., \$1.20.

IVITLOOF. An easy growing crisp winter salad, which can be raised in every home and is known as French Endive. The roots are crown out-doors and planted in earth, in a dark, cool roots are grown out-doors and planted in earth, in a

Plit., 10c; oz., 25e; 1/: lb., 60c; 1b., \$2.00. CHIVES.

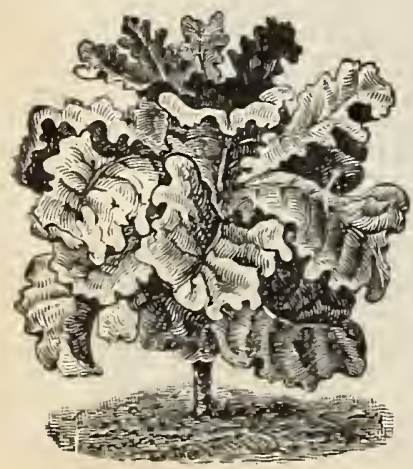

The Chives are small and not very important members of the onion tribe, but quite hardy everywhere. The leaves are slender and appear very early in the spring, and may be shorn often during the season. They are propagated by divisions of the root. The Chives make the very best border for beds in the vegetable garden and are not only ornamental, bearing pink flowers and a mass of green leaves, but equal to the onion for flowers and a mass of green

Plkt., 5c: $1 / 2$ oz., 40c; oz., 70c.

Foots, $25 \mathrm{c}$ per bunch, postpaid CORN SALAD.

BROAD LEAVED. Used as a small salad throughout the winter and spring. Sow thickly in drills; cover slightly first of autumn and sprinkle with straw on the approach of severe winter, or sow in a cold frame,

Pkt., 5c; oz., 10c; 1/4 lb., 25c; 1b., 85c.

\section{COLLARDS}

GEORGIA SOUTHERN OR CREOLE. This is the variety so extensively used in the South, where it furnishes an abundance of food for both man and beast. Forms a large, loose, open head. or a mass of leaves on a tall stem. Freezing improves the quality.

Pkt., 5c; oz., 10c; $1 / 4$ 1b., 30c; 1b., \$1.00.

Collards. 


\section{CAULIFLOWER}

CULTURE. The same as for cabbage, except that extra manure and plenty water will pay with cauliflower. If the soil be dry, water frequently, and if the plants could have a heavy mulch of hay or straw it would keep the soil moist, and the plants would not suffer from a drouth. The early kinds should be strong enough to plant out not later than May 1st: the late kinds may be planted out same time as caboge. To destroy the Cauliflower Magrot it is recommended to take one ounce of sulphuret of potassium and dissolve it in one gallon of water. Heat the liquid to about 100 degrees, take a large spoon, or something that will hold the one-hundredth part of a gallon, and pour the liquid against the stalk of the plant just above the ground

One ounce produces 1,500 plants; 15,000 plants will cover one acre.

We grow large quantities of Caulifower and Cabbuge PInnts, usually ready through May and June. See back part of catalogue.

For full directions how to grow Cauliflower for profit get our book on Cabbage and Caulifiower, by Lupton, 30e postpaid.

\section{EARLY DANISH SNOWBALL}

(Our Special Strain.)

The plants are very dwarf. The outer leaves are erect. The inner ones lap over the head so as to completely shade from the sun. It is a valuable market variety for early and late.

Pkt., 15e; 1/1 oz., 75e; oz., \$2.25; 1/4 1b., \$7.00.

\section{BARTELDES LATE SNOWBALL OR DRY WEATHER.}

This splendid Cauliflower, introduced by us in 1907 to Western Planters has Samples weighing 8 and 11 pounds have been brought to us with the statement that they average 7 pounds in large fields planted with this stock. We feel satisfied that it answers the purpose we have been seeking; that is, to furnish a Cauliflower well adapted to our Western country, for use in summer. Is about 2 weeks later than Danish Snowball. It has a larger head, solid, white and very fine grained. The leaves are large and have a tendency to fold over the head to protect it from the scorching sun of our summer months. It also stands the drouth bettel than any other Cauliflower grown.

Pkt., 15e; 1/4 oz., 75e; ox., \$2.25; 1/4 Ib., \$7.00.

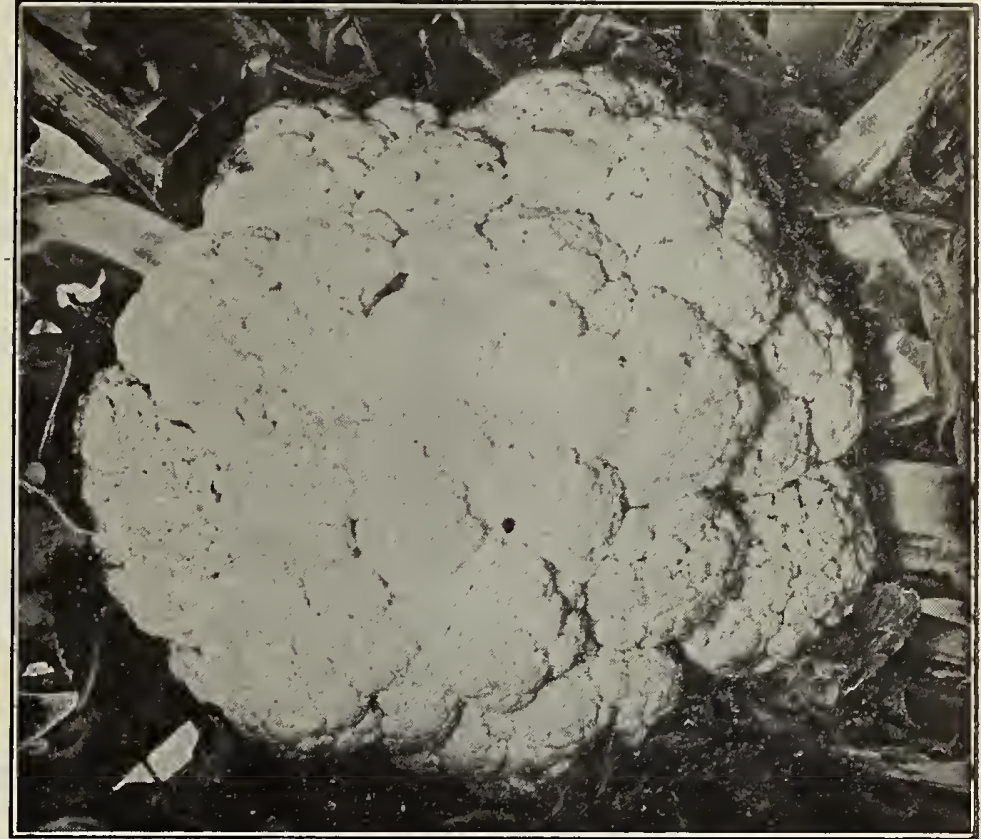

Barteldes' Dry Weather Cauliflower.

EXTRA EARLY DWARF ERFURT-Selected.

This is the choicest selected stain of the popular Erfurt type, and is remarkable for its extreme reliability in heading. Plants very dwarf, with solid, pure white heads of superior quality. Planted in rich soil early in the spring, heads 8 to 10 inches in diameter, can be marketed in July.

Pkt., 15e; 1/4 oz., 75e; oz., \$2.25; 1/4 Ib., \$7.00.

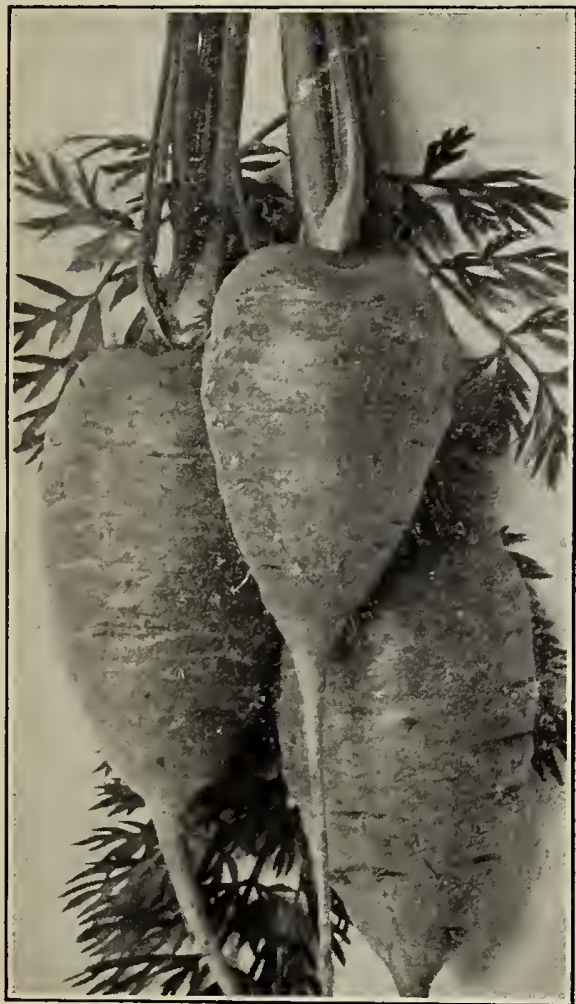

Early Scarlet Horn.
EARLY PARIS, A most excellent French variety, and the popular early sort in the Paris
markets. Heads large, white, compact and solid, of excellent flavor, tender and delicious. Leaves large, stalk short. Being so early, it must always be a favorite.

VEITCH'S AUTUMN GIANT.

A distinct and valuable late variety. Heads very large, white, firm and compact, and remain for a long time fit for use. The plants should be started and transplanted early in the season to insure their full development.

Pkt., 5e; 1/4 ox., 25c; ox., 80e; $1 / 4$ Ib., \$2.25.

\section{CARROT}

CULTURE. The carrot, like other root crops, delights in a sandy loam deeply tilled. For early crops, sow in spring as soon as the working order; for late crops they may be sown any time ground is in good June. Sow in rows, about 15 inches apart, thinning out to 3 inches between plants. Do not cover more than $1 / 2$ inch deep. One ounce to 150 feet of drill: plants. Do not cover
3 pounds to an acre.

\section{EXTRA EARLY SHORT FORCING.}

An excellent forcing variety; very tender and fine flavor; small growth Pkt., 5e; oz., 15e; 1/4 Ib., 35e; lb., \$1.20.

\section{EARLY SCARLET HORN.}

A very early variety. Recommended for the market and family garden. Texture fine, and delicate in flavor. $\$ 1.10$.

\section{OX HEART OR GUERANDE.}

This new French carrot is one of the most valuable of all recent introductions, either for family use or market. It is an intermediate between the Ialf Long and Horn varieties, attaining a diameter of 3 or 4 inches at the neck and of most beautiful shape and rich orange color. It is of extra fine quality and very productive.

Pkt., 5e; oz., 10c; 1/4 1b., 30e; Ib., \$1.10.

DANVERS HALF LONG.

Admirable in color, fixed in habit, a wonderful producer the best of alb for the stock breeder, and valuable to the market gardener. With this variety the planter secures the largest return to the acre with the least difficulty of arvesting.

Pkt., 5e; oz., 10e; 1/4 lb., 30e; Ib., \$1.10. 


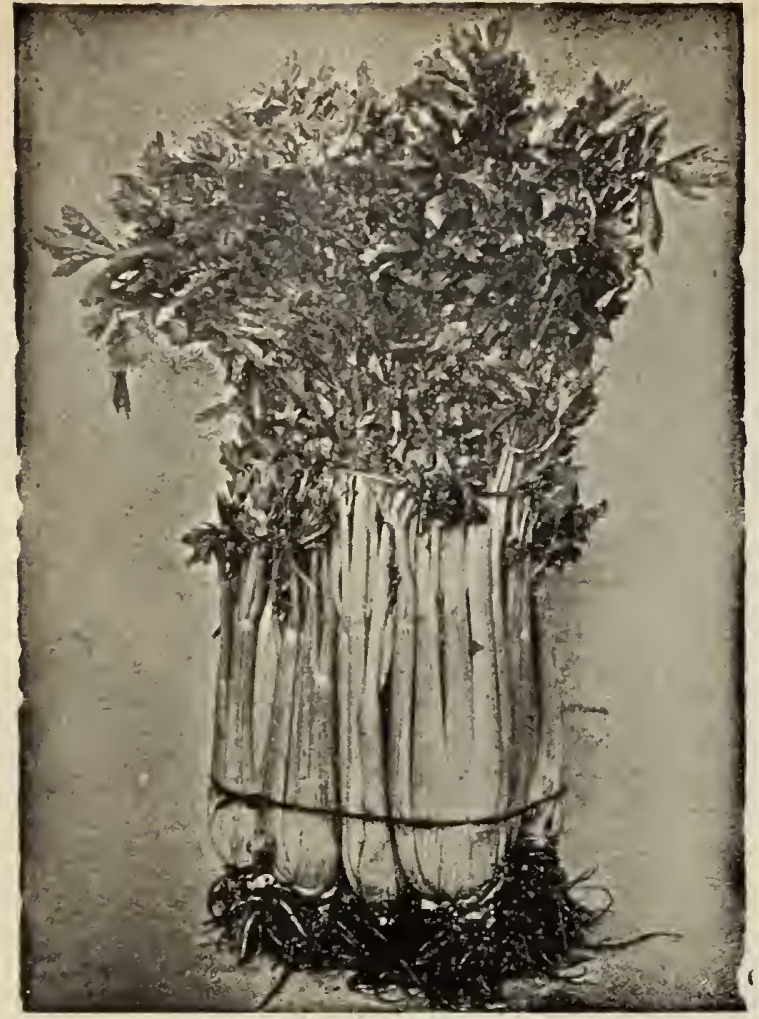

Barteldes' Golden Self-Branching.
CARROT-Continued.

CHANTENAY.

One of the most perfect and uniform in shape, smooth, heavy yielder, and of fine table qualities. It grows 5 or 6 inches long: is fine in texture and easlly dug; the flesh is of a beautiful deep orange olor, tender and of excellent flavor.

l'kt, 5e; ox., 10e; 1/4 lb., 30e; Ib., \$1.10.

\section{HALF LONG SCARLET NANTES.}

Top medium, finely divided; roots medium, cylindrical, smooth, bright orange; flesh orange, becoming yellow in center, but with no distinct core; finest quality.

Pkt., 5e; oz., 10e; $1 / 1$ lb., 30e; lb., \$1.10.

\section{LONG ORANGE.}

The old stand-by, both for table use and for stock feeding for late summer and winter. Fed to milk cows it increases the flow of rich milk and imparts to the butter in winter a fresh flavor, and golden color.

Pkt., 5e; oz., 10c; 1/4 Ib., 30c; lb., \$1.10.

\section{LARGE WHITE BELGIAN.}

Grows one-third out of the ground. Root pure white, green above ground, with small top. It will grow to a very large size on light, rich soil, and is very easily gathered. Flesh rather coarse: raised exclusively for stock.

Pkt., 5e; oz., 10c; 1/4 1b., 25e; 1b., 90c.

\section{LARGE YELLOW BELGIAN.}

Same as above, except in color.

\section{GIANT AUSTRALIAN.}

This is the largest yellow carrot in cultivation, some specimens weighing 12 to 15 pounds, and an average yield is from 30 to 40 tons to an acre.

Pkt., 5e; 0z., 10e; $1 / 4$ lb., 30e; lb., \$1.00.

\section{CELERY}

CULTURE. For early celery the seed is sown in February or March, in hot-bed, in drills 4 to 6 inches apart, and covered about $1 / 4$ of an inch deep. When fairly out of seed leaf, they are transplanted in another bed, or can be thinned out to 2 or 3 inches in the row and left girowing till needed to plant outside. In April they are planted in the field, in rows, 2 to 4 feet apart, and set 6 inches in the row. In planting press the ground around the plants. but be careful not to let the earth get into the heart. The soil should be made very rich and the plants will have to be earthed up three or four times during their growth. The summer varieties, such as Golden Self-Blanching and White Plume, do not need any more care to bleach, but the winter varieties need to be banked up. Celery needs more water than other garden crops, and, if allowed to suffer from want of water, is liable to get soft. For winter use, sow the seed outside in latter part of April or beginning of May, in beds, and transplant, to the field, in July. The rows should be 2 feet apart, if the roots are to be dug out, and put in trenches to bleach or four feet apart if wanted to bleach on the same spot where growns. When cold weather sets in, dig a trench in a high and well drained place one foot wide and of a spot where growns. When cold weather sets in, dig your plants closely in it and cover gradually with straw or hay and earth as the weather gets colder. The top of the your plants closely in it and cover gradually with straw or hay and earth, as the weather gets colder ${ }^{2}$ The top of the
trench should be sloping to allow water to run off. One ounce produces 4,000 plants and it takes about 42,000 plants to set trench should be sloping to allow wate

CELERY PLANTS ready in June and July. See plant list.

Get "Celery for I'rofit," by T. Greiner, price 20c postpaid, or "Celery Culture," by Bentty, eloth, price soc postpald. BARTELDES' GOLDEN SELF-BLANCHING.

IN SEALED PACKAGES-Seed crop almost a fallure. The plant is of a beautiful appearance, of close habit and compact growth, and straight, vigorous
stalks. The ribs are perfectly solid, crisp, brittle, and
flavor, surpassed by no other variety, while it has the of delicate flavor, surpassed by no other variety, while it has the deciding merit of being self-blaching to a very remarkable de-
gree. Our stock of this variety is selected with special care in gree. Our stock of this variety is selected with special care in
France. It is the strain for market gardeners, also for family
garden.

Pkt., 5e; 1/2 oz., 55e; oz., \$1.00; 1/4 lb., \$3.50.

WHITE PIUML. This celery is valued because, naturally, the stalks and portions of the inner leaves and heart are white, by simply tying up the stalks and drawing up the soil with the hoe, the work of blanching is completed. It is ornamental, tender, crisp, of good flavor, and very early.

Pkt., se; Oz., 25e; 1/4 Ib., 70c; Ib., \$2.25. leaved variety. It blanches very quickly after earthing up, when it is of a beautiful yellow-white color, very solid and crisp, and of a nutty flavor, which is not equalled by any other sort. The

Under high culture this variety will give the best satisfaction.

BOSTON MARKET. It forms a cluster of heads instead of a single one.

HAIF DWARF. When blanched it is of a yellowish-white. making it very ornamental.

Ikt., 5e; Oz., 15e; $1 / 1$ lb., 50e; lb., $\$ 1.50$,
GOIDEX Histinct variety.

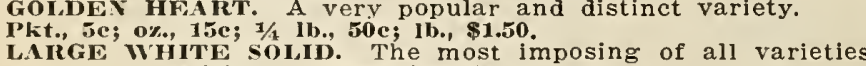

though not as delicious as dwarf sorts.
Pkt., 5e; ox., 15e; 1/1 lb., 50e; lb., \$1.50. CELERIAC OR TURNIP ROOTED.

Grown exclusively for its roots, which are turnip shaped, very smooth, tender and marrow-like. The roots are cooked and sliced. used with vinegar they make an excellent salad. They are used

for seasoning meats and to flavor soups.

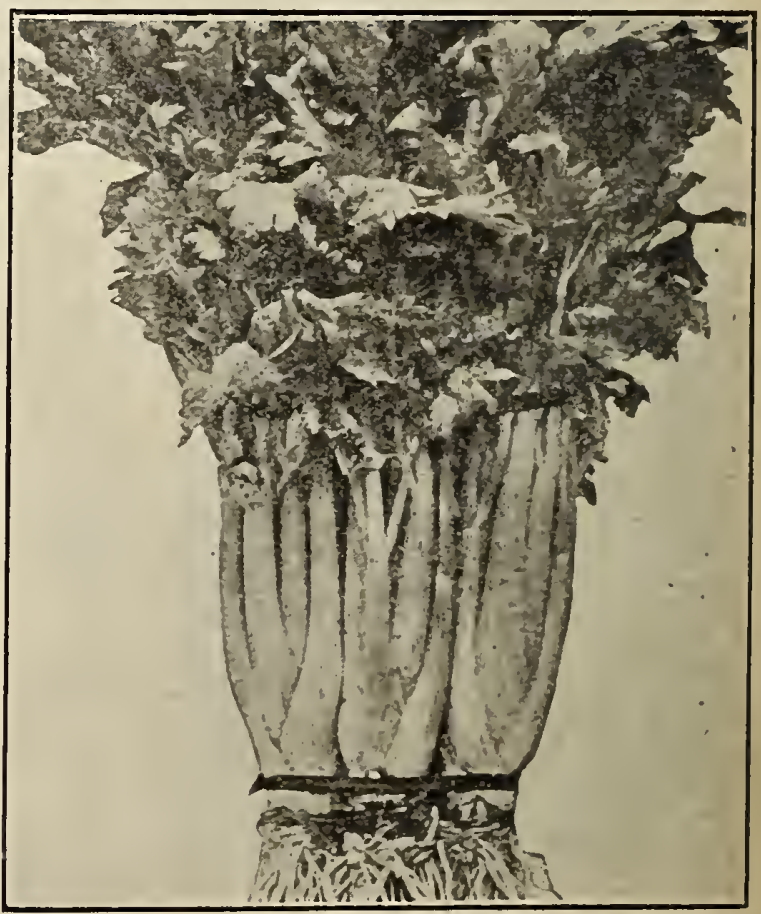

Glant Paseal. 


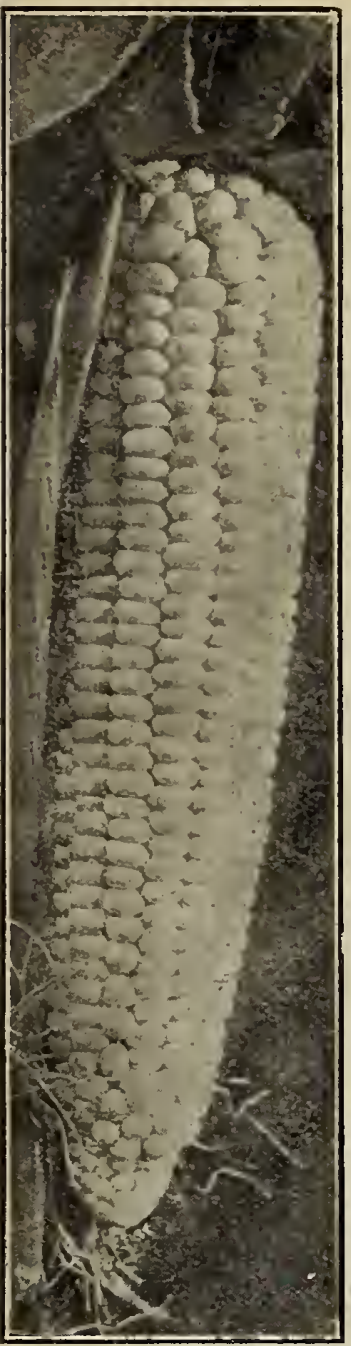

Early Evergreen.

\section{CRESS}

GARDEN CURLED or PEPPERGRASS. Used as a small salad. Sow very thickly in shallow drills, on a smooth surface, at short intervals throughout the season.

Pkt., 5e; oz., 10e; 1/4 1b., 15e; 1b., 50e.

TRUE WATER CRFSS. Is quite distinct from the Garden Cress, and only thrives when its roots and stems are submerged in water. It is one of the most delicious of small salads and clatable place can be found.

Pkt., 5e; oz., 30e; $1 / 1 / 1$ lb., \$1.00.

\section{SWEET CORN}

CULTURE. All varieties of sweet corn may be either sown in rows, $4 \frac{1 / 2}{2}$ feet apart, and the seeds planted about eight inches in the row, or planted in hills at a distance of three or four feet each way, according to the variety grown or the richness of the soil in which it is planted. s weet Corn should not be planted deeper than one inch and a half, as it is liable to rot in the
glound. Hoe often, drawing the earth against the stems, and break off the side shoots. One pound to 300 hills. Ten pounds to an acre. Twelve to twenty pounds if planted in drills.

\section{GOLDEN BANTAM.}

This new Sweet Corn is described as the tenderest, sweetest and best Sweet Corn in existence. Its attractive yellow color being another good feature added to its many good qualities, makes it an easy seller on the market. The stalks are vigorous and strong grow about 1 feet hich and produce 3 to 4 fine eight-rowed ears 6 to 8 inches long. on account of its firm texture it can be planted early.

Pkt., Je; $1 / 2$ 1b., 15e; 1b., 20c; 2 lbs., 35c; 10 lbs., \$1.20.

HOWLING IOB. One of the earliest large varieties, being only 4 to 5 days later than White Cob Cory. The ears are 7 to 9 inche long, 12 and 14 -rowed. It generally produces 2 fine ears to a stalk. Pkt., 5e; 1/2 lb., 10c; lb., 15e; 10 lbs., \$1.00.

PEFP O'DAY. Is not only one of the earliest Sweet Corn, but is very sweet and immensely productive, stalks producing from 210 large size ears and being dwarf, about 4 feet in height, admits a close planting.

Plit., 5e; 1/2 1b., 10e; 1b., 15e; 2 lbs., 25e; 10 lbs., \$1.00.

WHITG COR CORY. It is strictly an early kind for market and home use; ears about 7 inches long with milky white kernels, sweet. tender and delicious.

Pkt., 5e; 1/2 lb., 10e; lb., 15e; 2 lbs., 25e; 10 lbs., \$1.00.

MAMMOTH WHITE CORY. The largest and best extra early Sweet Corn. The ears are 12-rowed and very much larger than White Cob Coly. No other Sweet Corn will find ready sale in a market which is supplied with this splendid variety.

Pkt., 5e; 1/2 1b., 10e; 1b., 15e; 2 lbs., 25e; 10 lbs., \$1.00.

EARLY EVERGREEN. This corn has all the good qualities of its parent, "Stowell's Evergreen," but matures earlier. Stalks grow flom 6 to 7 feet high.

Pkt., 5e; 1/2 1b., 10e; 1b., 15e; 2 lbs., 25e; 10 lbs., $\$ 1.00$.

EARI,Y MINNESOTA. This is among the earliest of the sugar varieties, and is much esteemed not only because it matures early. but for its excellent qualities as well. Ears rather small, long and pointed.

Pkt., 5e; 1/2 lb., 10c; lb., 15c: 2 lbs., 25c; 10 lbs., \$1.00.

COUNTRY GENTLEMAN. The ears are not only of good size, but are produced in great abundance, frequently bearing four good ears, while the average is three to a stalk. The cob is very small, giving great depth to the kernels, which are of pearly whiteness.

Plkt., Je; 1/2 lbs., 10e; lb., 15e; 2 lbs., 25c; 10 lbs., \$1.15.

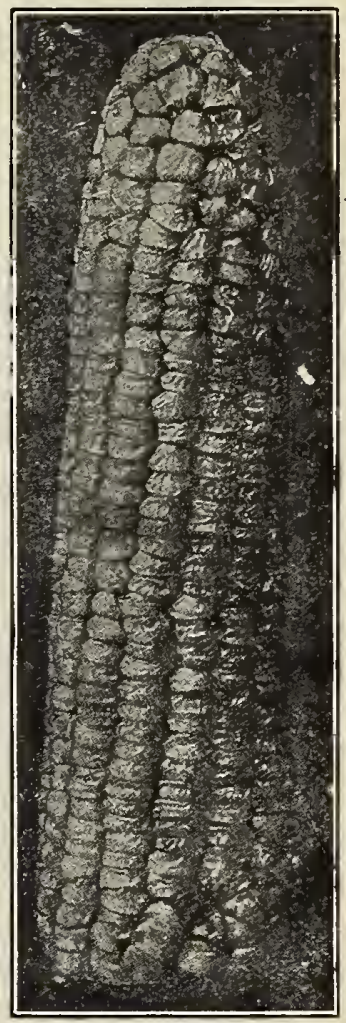

Howling Mob.

PERRY'S HYBRID. A very fine medium early variety, and with ears containing 12 to 14 rows of kernels, well filled to the end. $1 / 2,00$

PKt., 5e; 1/2 lb., 10e; 1b., 15e; 2 lbs, 25e; 10 Ibs., \$1.00. canners and market gardeners for late use. It is very productive, the ears are of large size, grains deep, exceptionally tender and sugary, and remains for a long time in an edible condition.

Pkt., 5e; 1/2 lb., 10c; lb., 15e; 2 lbs., 25e; 10 lbs., $\$ 1.00$.

EXTRA EARIY ADAMS. The earliest corn for table use; not a sugar corn.

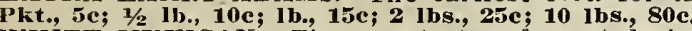

WHITE MHXICAN. The sweetest and most desirable for early family use.

BLACK MEXICAN. Similar to above, except in color of seed.

CROSBY'S CARLY. Most excellent variety and remarkably early.

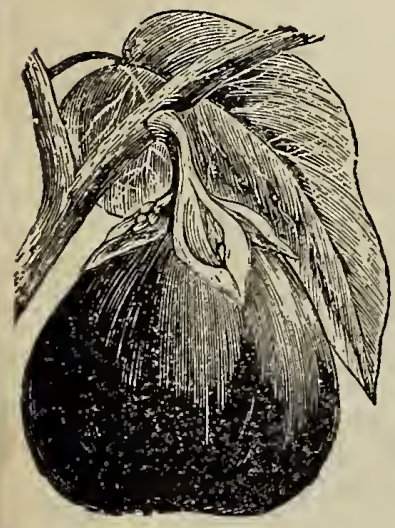

New York Improved.

EGYPTIAN SUGAR. It is of vigorous habit, late, good for canning.

FOR FIELD CORN SEE FIELD AND FARU SEED DEPARTHENT-PAGE 62.

\section{EGG PLANT}

CULTURE. Sow in hot-beds, very early in the spring; thin them out as soon as big enough to be handled to 3 or 4 inches each way, and transplant to 2 or 3 feet apart in very rich, warm ground. Do not plant them outside till nights are real warm, as the least frost will, if it does not kill them, check the growth, and it will take 2 or 3 weeks before they get over it. Hoe often and hill up gradually till they blossom. One ounce to 1,500 plants.

EARLY LONG PURPLE.

This is the earliest variety; very hardy and productive; fruit long and of superior quality. Pkt., 5e; 1/4 oz,, 10c; oz., 25e; lb., 75c.

NEW YORK IMPROVED-LARGE, PURPLE SPINELESS.

This variety has about superseded all others both for market and home garden; a favorite in Colorado. Our stock is extra selected direct from the best growers in New Jersey.

Pkt., 5e; 1/4 oz., 15e; oz., 35e; 1/4 1b., \$1.15.

BLACK BEAUTY.

This is the earliest large fruited variety. The fruits set freely and develop quickly so the entire crop can be harvested before frost.

Pkt., 10e; oz., 20e; oz., 45e; $1 / 4$ lb., $\$ 1.25$ 
CUI.TURE. Drop in hills 4 to 6 feet apart, as soon as the weather becomes settled and warm. Scatter 8 or 10 seeds

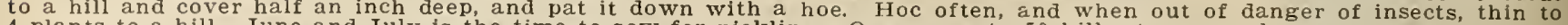
4 plants to a hill. June and July is the time to sow for pickling. One ounce to 50 hills; two pounds to an acre.

\section{Barteldes' Extra Select White Spine Cucumber}

An early white spine cucumber of handsome, very dark green color, and of excellent quality for slicing; vines hardy and productive. The fruit grows from six to eight inches in length and very uniform in size and shape. Its dark green colcr is less affected by the sun than most other kinds and is retained much longer. Its splendid color, uniform size and shape make it very popular as a shipping variety as well as for home use.

I'kt., 5e; oz., 15e; 1/4 lb., 35e; 1b., \$1.15.

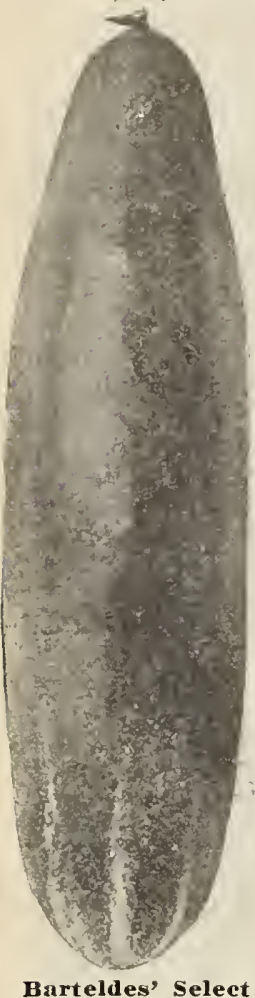

White Spine.

ARLINGTON WHITE SPINE.

the "money maker" among cucumbers being the earliest and most productive. Rich green color throughout its entire length and very straight.

Pkt., 5e; oz., 10c; 1/1 lb., 30c; 1b., \$1.00.

\section{EXTRA LONG WHITE SPINE.}

A selected strain of the White Spine. It is very uniform in size and exceedingly early, at the same time makes long growth-10 to 12 inches. The va riety for forcing and early market.

Pkt., 5e; oz., 10c; 1/1 1b., 30c; 1b., \$1.00.

\section{EARLY WHITE SPINE.}

Vines vigorous, fruiting early and abundantly; fruit uniformly straight and handsome, dark green, with a few white spines; flesh tender and of excellent flavor.

l'kt., 5e; oz., 10e; $1 / 1$ ib., 30c; 1b., $\$ 1.00$.

DAVIS PERFECT.

One of the best cucumbers grown, both for forcing and outdoors. The plants are so vigorous that they resist the cucumber disease so common among the forcing varieties. The fruit is slim and symmetrical in shape, from 9 to 10 inches long, and of a dark, glossy, grcen color.

Pkt., כe; oz., 10e; 1/4 lb., 30e; 1b., \$1.00.

EARLY FRAME.

Of early growth and vigorous, fruit medium size and straight. It is popular for both table use and pickling. 5kt., 5e; oz., 10c; 1/4 lb., 30c; lb., \$1.00.

\section{EARLY RUSSIAN.}

One of the earliest in cultivation, resembles the Early Frame, but is smaller and shorter, being only 4 inches long.

Pkt., 5e; oz., 10c; 1/1 lb., 30c; 1b., \$1.00.

BOSTON PICKLING.

A distinct variety which has obtained a great degree of popularity in Boston market as a pickle. Medium long; a great producer.

Pkt., 5e; oz., 10c; 1/4 lb., 30c; 1b., \$1.00,

\section{KLONDIKE.}

This is a medium early choice strain of the white spine type with dark green skin. Fruits are large, averaging eight inches, uniform in size and attractive in appearance.

Pkt., 5e; ozø, 10e; $1 / 4$ lb., 30e; lbo, $\$ 1.00$

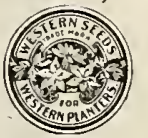

\section{BARTELDES' SELECT PICKLE.}

An improved strain of Boston Pickling; being more symmetrical in shape, holding longer its green color, and immensely productive. It is the pickle needed for factories and home use.

Pkt., 5c; oz., 10c; 1/4 1b., 30c; 1b., \$1.00.

EARLY CLUSTER.

A very popular early cucumber, producing its fruit in clusters near the root of the plant. Its usual length is about 5 inches; skin prickly; flesh white, seedy, tender and well flavored.

Pkt., 5e; oz., 10e; $1 / 4$ lb., 30e; lb., \$1.00.

IMPROVED LONG GREEN.

Unquestionably this is the most popular general purpose cucumber in the West. When matured is 9 to 12 inches long, very solid and crisp, and retains its dark green color until nearly ripe. One of the best for small pickles if pickled young.

Pkt., 5c; oz., 10c; 1/4 1b., 30c; 1b., \$1.00.

SHOR'T PRoLIFIC PICKLING. A very short variety of the "Frame" type, abundant bearer. highly recommended for pickles, for which it is used extensively in New York state.

Pkt., 5c; oz., 10e; 1/4 1b., 30c; 1b., \$1.00.

PARISIAN PICKLE. A decidedly distinct variety, most suited for making French pickles.

Pkt., 5e; oz., 15e; $1 / 4$ 1b., 35e; $1 \mathrm{b.}, \$ 1.25$.

CHICAGO OR WESTERFIELD PICKLING. Very popular with Chicago market gardeners.

Pkt., 5e; oz., 10e; $1 / 4$ lb., 30c; $1 \mathrm{~b} ., \$ 1.00$.

COOI AND CRISP. One of the earliest and most prolific of all pickling cucumbers.

Pkt., 5c; oz., 10e; 1/4 lb., 30e; 1b., \$1.00.

NEW EVERBEARING. It is of smali size, very early enormously productive.

Pkt., se; oz., 10e; $1 / 4$ lb., 30c; $1 \mathrm{~b}$. , $\$ 1.00$.

WEST INDIA GHERKIN. Very small, length from 2 to 3 inches.

Pkt., 5e; oz., 20e; $1 / 1 / 1 \mathrm{lb} ., 50 \mathrm{c} ; 1 \mathrm{~b} ., \$ 1.50$.

JAPANESE CIIMBING. It quickly climbs on poles or trellises. Good for eating and pickling.

Pkt., 5e; oz., 15e; $1 / 4$ lb., 35c; lb., \$1.25.

\section{ENDIVE}

CULTURE. It is the same as lettuce. In order to bleach the green varieties gather all the leaves together and tie them up for a few days. It furnishes an appetizing salad for the fall and winter months.

GREEN CURI,ED. Leaves finely cut or laciniated; bleaches very readily. Pkt., 5e; oz., 15e; 1/4 lb., 40e; 1b., \$1.25.

BROAD LEAVED BA'TAVRAN. A large summer variety; very productive and one of the best.

Pkt., Je; oz., 15e; 1/4 lb., 40c; lb., \$1.25.

WHITE CURLED. Does not need blanching. Finely cut and curled leaves, almost white. Pkt., 5c; ox., 15e; 1/1 1b., 40c; 1b., \$1.25.

\section{GARLIC}

The Garlic is the most pungent of all the onion family. It is much used in the south of Europe. The root or bulb is composed of many small bulbs called "cloves," which are planted in the spring 6 to 8 inches apart, and in August the bulbs are ready to gather.

Bulbs, lb., 30e; 3 lbs. for 80e; postpaid.

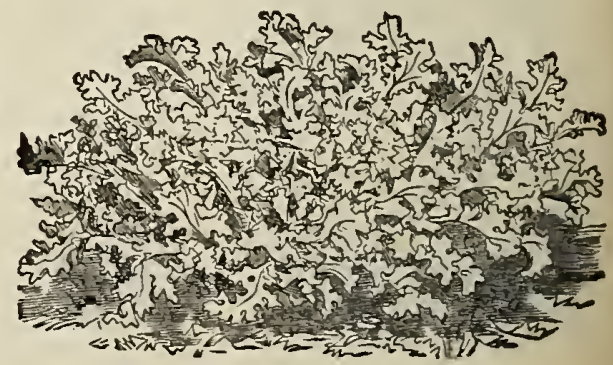

Endlve-Green Curled. 


\section{Kohl-Rabi or Turnip Rooted Cabbage}

CULTURE. Sow in the spring in rows 18 Inches apart; afterwards thin to 8 to 10 inches in the row. The edible part is a turnip-shaped in the row. The edible part is a turnip-shaped When used for the table this should be cut when quite small, as it is then very tender and deliquite small, as it is then very tender and delicate, but if allowed to reach its full size it becomes tough
2,000 plants.

EARLY WHITE VIENNA. The earliest and best for forcing; very tender; excellent for table use.

Pkt., 5e; oz., 20e; 1/4 lb., 60e.

EARIY PURPLE VIENNA. Same as above, only differs in color.

I'kt., 5e; oz., 20e; $1 / 41 \mathrm{lb.,} 60 \mathrm{c}$.

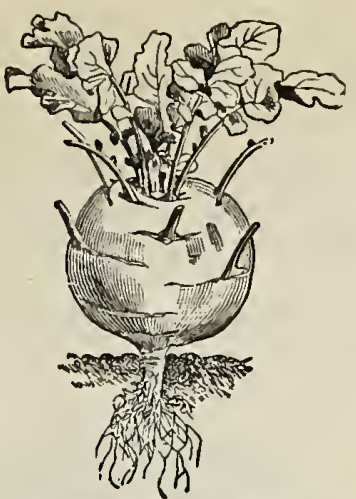

Vienna Kohl-Rabl.

\section{LEEK}

CULTURE. A hardy species of onion, sown in drills or broadcast. When 6 inches high transplant into rows a foot apart, setting the plants 4 or 5 inches deep and about 6 inches apart in the row. Used mostly in soups and stews. One ounce to 2,000 plants,

\section{LARGE LONDON OR SCOTCH FLAG.}

This Leek, besides being valuable for soups and salads, when blanched makes an excellent dish if sliced and cooked like green peas.

Pkt., 5e; oz., 15e; 1/4 lb., 45e; lb., \$1.40.

\section{LETTUCE}

\section{HORSE RADISH}

Horse Radish produces no seed, but is grown from pieces of the root.

CULTURE. Mark off rows $2 \frac{1 / 2}{2}$ feet apart in rich, moist, well prepared ground, and set the pieces of root 18 inches apart in rows, vertically, the small end down. Cultivate thoroughly until the tops cover the ground, when their shade will keep down the weeds.

Small roots, 15e per dozen; 75e per 100, prepald. If by mall, add $10 \mathrm{c}$ per dozen; 25e per 100. If wanted in quantity, ask for special prlces.

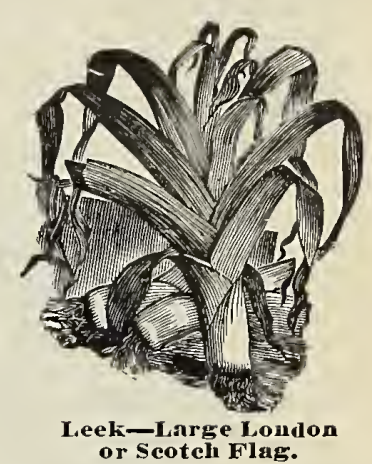

CULTURE. The early sowing may be made under glass, in January or February, keeping the plants thin and admitting plenty of air, every fine day. For a succession, outside, sow every two weeks, as soon as the ground is open, in drills one foot apart, covering the seed about one-quarter of an inch deep and thinning out to 6 or 8 inches in the row. For a cut salad sow thicker and do not thin out. They do best in a rich and moist soil. One ounce to 3,000 plants.

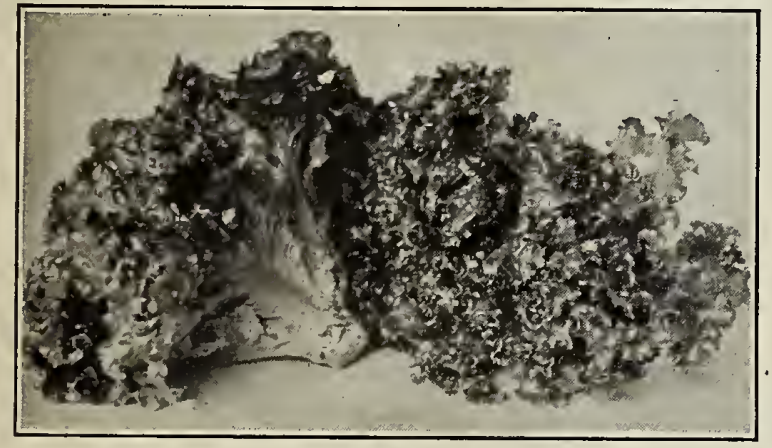

Grand Rapids.

\section{Curled or Loose Leaved Varieties}

\section{BLACK SEEDED SIMPSON.}

The leaves of this variety are very large and form a compact mass rather than a distinct head. Good for forcing or growing outside.

Pkt., 5e; oz., 10c; 1/4 1b., 25e; 1b., 80c.

\section{EARLY PRIZE HEAD.}

It forms a large, loose head and remains tender and crisp throughout the season; is slow, to go to seed, and of superior flavor. The leaves are very large, crimped, bright green tinged with brownish red on edge.

Pkt., 5c; oz., 10c; 1/4 1b., 25c; 1b., 80c.

\section{GRAND RAPIDS.}

As a lettuce for greenhouse forcing, this variety undoubtedly stands at the head of the list, being of quick growth, little liable to rot, and standing for some days after being fit to cut. The plant is upright and forms a loose head or cluster of large, yellowish-green leaves, slightly crimped and blistered and rather thin. It will stand shipping long distances better than most sorts.

Pkt., 5c; oz., 10c; 1/4 lb., 25e; 1b., 80c.

\section{EARLY CURLED SIMPSON.} tion.

One of the best early sorts for market or family use; recommended for general cultivaPkt., 5e; oz., 10e; 1/4 1b., 25e; 1b., 80c.

\section{EARLY CURLED SILESIAN.}

The old favorite; of dwarf, compact habit, and quick growth; crisp, golden leaves with finely curled edges.

Pkt., 5e; oz., 10e; 1/4 lb., 25e; lb., 80c.

\section{PARIS WHITE COS.}

The Cos lettuces are distinct from the preceding sorts, in having long, narrow, spoonshaped leaves, which usually fold into loose, sugar-loaf shaped heads, which blanch better by having the outer leaves drawn about them and tied. On account of their exceeding crispness, tenderness and delicate flavor, they are becoming more and more popular in this country.

Pkt., 5c; ox., 10c; 1/4 lb., 30c; 1b., \$1.00.

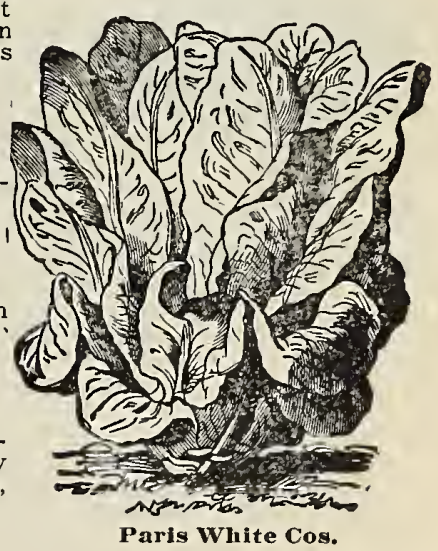

We shall be pleased to mail any of your frlends, who garden, for either pleasure or profit, any of our catalogs. Send us names and addresses, telling us whether to send this Seed Catalog, Bulb List, or Market Gardener's Price List. Your friends will certainly he obliged so this seed reliable Seed House-The Barteldes Seed Co. 


\section{Cabbage or Heading Varieties}

\section{BARTELDES' "FRENCH FORCING."}

It is very early and sufficiently curly to be attractive, yet makes a reasonably solid head with scarcely any outside leaves. Its solid, upright shape allows of close planting, and less likely of rotting on lower leaves.

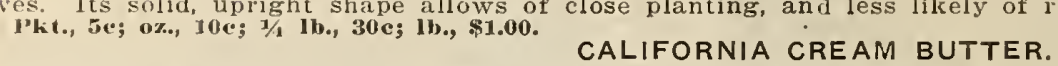

Heads large, round, and of a beautiful appearance. The outer leaves are medium grecn, marked with small brown spots; inner leaves of a rich cream color. Medium early, and makes a good sort for summer use. Quality very good; rich buttery flavor.

EARLY OHIO-SELECTED.

An excellent Head Lettuce for forcing or outdoors. The leaves are light green, blistered, very crisp and tender and of delicious flavor.

Pkt., כe; ox., 10e; $1 / 2$ lb., 30e; 1b., $\$ 1.00$.

\section{Barteldes' Denver Market}

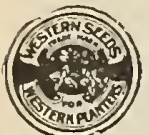

It is an early variety of Head Lettuce, either for forcing or open solid heads of a good solid heads of a good very slow to seed. The leaves are beautifully blistered, very crisp, tender and of excellent flavor. By these blistered leaves it distinguishes itnow grown. Buy from us and get the true stock. yoc.

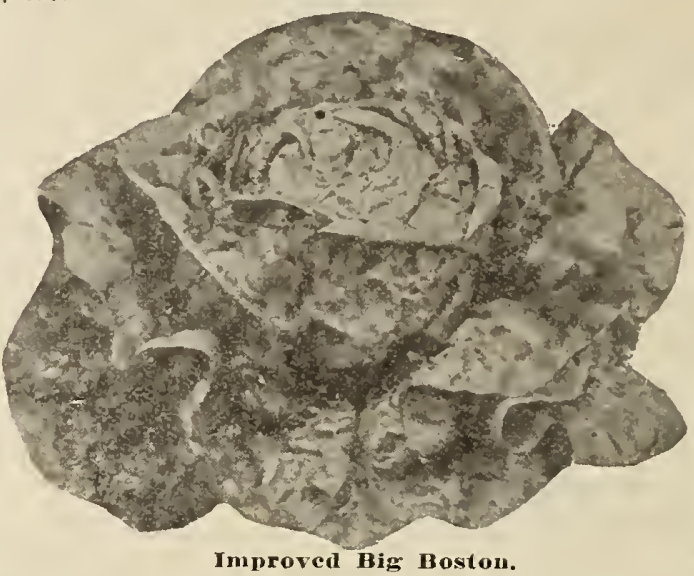

DENVER MARKET FORCING.

A stock selected expressly for growing under glass.

Pkt., 5e; ox., 10e; $1 / 4$ lb., 30c; 1b., $\$ 1.00$.

EARLY TENNIS BALL.

One of the best varieties of head or cabbage lettuce for growing under glass.

Pkt., 5e; o\%., 10e; x/4 1b., 30e; lb., \$1.00.

EARLY CABBAGE, OR DUTCH BUTTER-HEAD.

Gnc of the best for forcing and also for summer use.

Pkt., 5c; oz., 10e; 1/2 1b., 25e; $1 \mathrm{~b} ., 80 \mathrm{c}$.

HANSON.

The heads are of very large size, deliciously sweet, tender and crisp.

Pkt., 5e; oz., 10c; 1/4 1b., 25e; lb., 80c.

\section{MUSHROOM SPAWN}

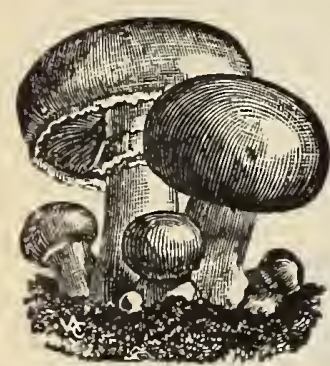

Mushroons.

CULTURI. Mushrooms can be grown any place where the proper temperature, which is from 50 to 63 degrees Fahrenheit, can be maintained, and is moist enough, without being very damp or dripping with water. If the temperature is below 50 or above 63 degrees, it is not safe to try to raise them. Cellars, caves, abandoned mines, and even old sheds may be used. In growing mushrooms, the beds should be made of stable manure, which has been fermented. Obtain fresh horse manure with some of the litter which has been well trampled down, and pile in heaps about 3 feet deep when well pressed down with the fork, and wet it thoroughly. In 5 or 6 days it should be turned over, mixing the cold and hot manure. In another week a second turning will be necessary, and, if dry, water again. If well pressed down and merely moist. there will be no danger of sour fermentation. The compost will be ready to use in 2 or 3 weeks, there will be no danger of sour fermentation. The compost will be ready to use in 2 or 3 weeks,
according to weather. When water cannot be squeezed out from the damp manure, it is in the according to weather. When water cannot be squeezed out from the damp manure, it is in the
right condition to be mixed with one-fourth of good loam. Make your beds about 4 feet wide, right condition to be mixed with one-fourth of good loam. Make your beds about 4 feet wide,
18 to 20 inches deep and of any length desired. Press down the manure with a fork and let the beds stand for about a week before spawning, as they are too hot Cut a brick into 12 pieces. insert them from 1 to 2 inches deep and 8 to 10 inches apart each way. Do not sprinkle unless very dry, as too much water will retard germination. In two weeks examine the beds and, if the spawn is running (which can be known by white thread-like fibres seen in the manure) it is ready to be cased. Casing consists in applying a layer of pure white sand or sandy loam, from 1 to $11 / 2$ inches deep, on the surface of the bed. This loam should be carefully screened. Mushrooms should appear in 5 to 10 weeks after spawnon the surface of the bed. This loam should be carefully screened. Mushrooms should appear in 5 to 10 weeks after spawning and a good bed will bear from 3 to 4 months. In picking mushrooms twist them from the soil and fill the holes left with fresh loam. Sprinkle with luke warm water, when real dry, and after mushrooms have been gathered. The main
causes of failure are: (1) spawning at a too high temperature; (2) the use of too much water; (3) unfavorable temperature during the growing season.

For fuller information, get our book, "Mushroom Culture aud Pure Culture Spawn." Price, 35c postpaid.

PURE CUITURE SPAWN. 1 brick by mail, 40c; 5 lbs. by express, not prepaid, $80 \mathrm{c} ; 10$ lbs. by express, not prepaid, $\$ 1.50$.

Ask for our leaflet on Pure Culture Spawn, free for asking.

\section{MUSTARD}

GIANT CURLED OR CHINESE.

Highly esteemed for salads, particularly in the South. The leaves are twice the size

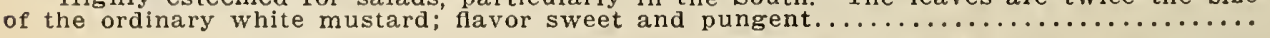
OSTRICH PLUME.

The leaves are long, ruffled and curved as gracefully as an ostrich plume. Is especially

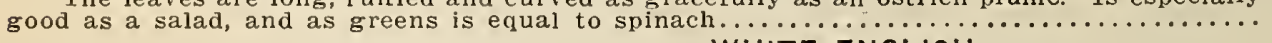
WHITE ENGLISH.

The leaves are light green, mild and tender when young, seed light yellow........ BROWN OR BLACK.

The common small seeded variety.

$\begin{array}{llll}\text { Pkt. } & \text { Oz. } & 1 / 41 b . & \text { Lb. } \\ \$ .05 & \$ .10 & \$ .25 & \$ .75\end{array}$

$\begin{array}{cccc}.05 & .10 & .25 & .75 \\ .05 & .10 & .15 & .40 \\ .05 & .10 & .15 & .40\end{array}$




\section{MUSK MELON}

CULTURE. The soil for musk melons must be light, rich and sandy; if grown on a heavy soil the quality will be poor and they will not be so early. When there is no more danger or frost, drop 8 to 10 seeds in hills, 6 feet apart each way, covering about $\%$ inch deep. As soon as plants commence to run, thin out to 3 best plants in a hill and cultivate till the vines cover the whole ground. If slow to fruit, pinch off the ends of the growing shoots. Ash or air-slacked 60 hills, and sifted on the young plants while the

it takes 2 to 3 pounds to one acre. 25: Much of the melon seed offered throughout the country is the product of immature and deforme

ing in the "How to Grow Melons for Market." Price, 20c, postpaid.

\section{GREEN FLESH VARIETIES}

\section{THE ROCKY FORD CANTALOUPE.}

It is one of the Netted Gem type, oval in shape, averaging from $4 \frac{1 / 2}{2}$ to 5 inches in length, of a delicious favor, very fine and smooth grained flesh of a light green color throughout when ripe. It takes its name from the district from which it has been, for the past several years, so extensively grown, Rocky Ford, Colorado, and from which point these melons are shipped by the carload to nearly every station in the United States, till the name of Rocky Ford has bec ome a synonym for excellence in cantaloupes. The seed we offer is our own growing at Rocky Ford,

\section{l'kt., 5c: oz., 10c; 1/4 lb., 25c; 1b., 90c; 4 lbs., \$3.00.}

Barteldes' Select Strain Rocky Ford Cantaloupe

An improved strain growing more vigorously, ripening more evenly and yielding more than the common strain. A good acquisition among n.

\section{ROCKY FORD RUST RESISTING} CANTALOUPE.

This new strain of Cantaloupe (Imoroved Pollock's Strain) is the product of several years' careful selection from the strongest and most vigorously growing plants. It is not quite as early as Barteldes" seleet Rocky Ford, but will yield more.

In comparing the vines and fruits of the common strain with this new strain we found that the melons, hidden under a healthy growth of vines, were larger more solidly netted with thick, firm flesh and small seed cavity thick, plety filled with the hills, where leaves were very few, the tured, the flesh watery and thin and tured, the flesh

Pkt., 5e; oz., 20e; $1 / 4$ 1b., 45e; 1b., \$1.50 4 11)ศ., \$5.50.

\section{EXTRA EARLY CITRON.}

Earlier than any other cantaloupe large and showy and of fine flavor. This variety will be found profitable by all gardeners, and desirable also in the private garden till others come into condition.

Pkt., 5e; oz., 10c; 1/4 1b., 25c; 1b., 90c; 4 lbs., \$3.00.

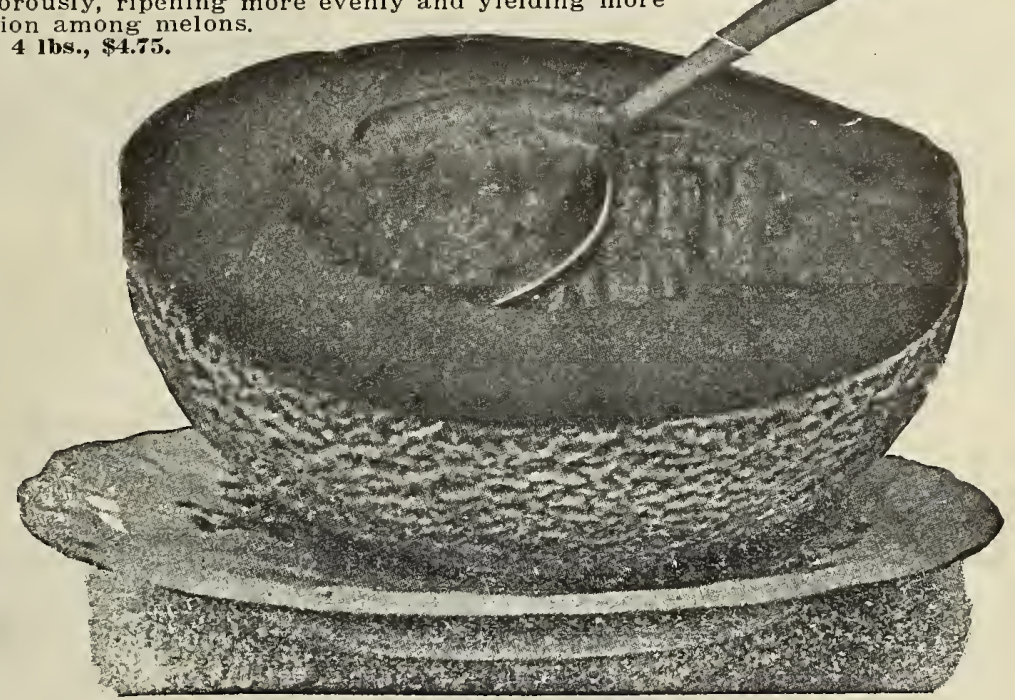

\section{"Barteldes' Select Strain Rock Ford.}

EXTRA EARLY HACKENSACK.

By careful selection and improvement carried on for some years, this strain has been so developed that it produces melons with all the good qualities of the well known Hackensack Melon, but at least ten days earlier Pkt., 5e; oz., 10c; 1/4 1b., 25e; lb., 90c; 4 lbs., \$3.00.

\section{NETTED GEM.}

This has become one of the most popular of small or basket melons. The fruit is oval, slightly ribbed, densely covered with coarse netting. Flesh thick, green, very sweet, and highlv flavored. We offer an exceptionally fine stock of this sort Pkt., 5c; oz., 10c; 1/4 1b., 25c; 1b., 90c; 4 1bs., \$3.00.

\section{NETTED NUTMEG.}

We consider this one of the best varieties in cultivation for family use. Vines vigorous, hardy, productive: fruit round, slightly flattened at both ends, ribbed, covered with coarse netting; flesh very thick, green and of the highest flavor.

\section{Pkt., 5c; oz., 10c; 1/4 1b., 25e; 1b., 90c; 4 lbs., \$3.00.}

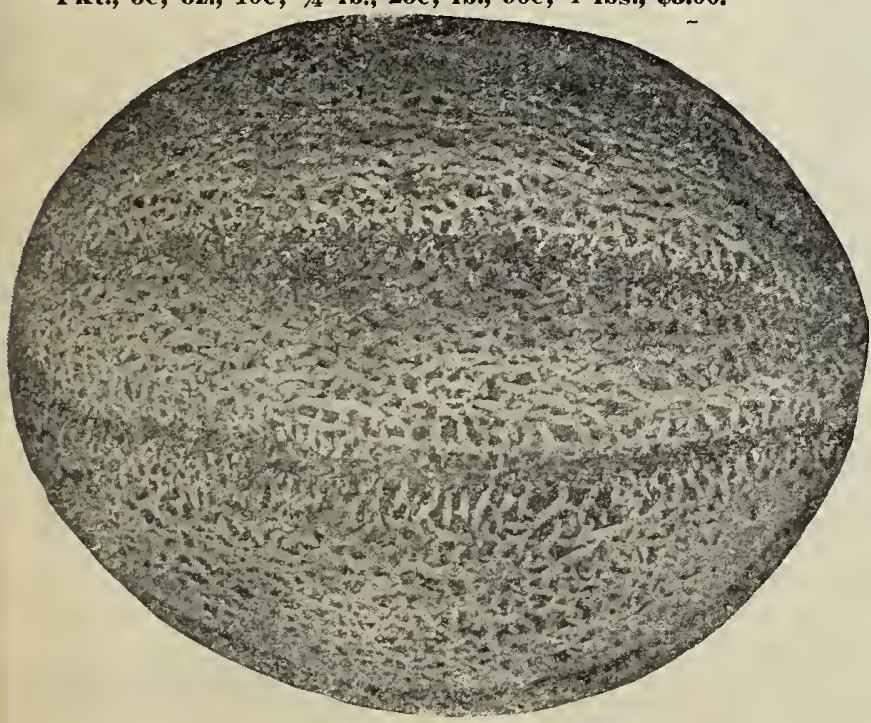

Burrell's Gem.
THE HACKENSACK.

The most popular variety of musk melon grown for market by gardeners in the vicinity of New York. It ends; it is of most delicate flavor, and wonderfully productive

Pkt., 5e; oz., 10c; 1/1 lb., 25e; lb., 90c; 4 lbs., \$3.00.

\section{MONTREAL MARKET.}

This fruit is nearly round, flattened at the ends, deeply and very regularly ribbed; skin green, deeply netted; flesh remarkably thick; light green, melting, and of a delicious flavor. They are very regular in shape, and uniformly grow to a very large size.

Pkt., 5e; oz., 10c; 1/4 lb., 25c; lb., 90c; 4 lbs., \$3.00.

\section{CASSABA OR LARGE PERSIAN}

Long oval shaped; skin very thin and delicate; flesh extremely tender, rich, sweet and juicy.

Pkt., ธe; oz., 10c; 1/4 1b., 25e; 1b., 90c; 4 lbs., \$3.00.

\section{KHIVA OR WINTER MUSK MELON.}

Musk melon for Christmas dinner. Yes, a delicious, sweet musk melon is a rare treat. You can have such and from your own garden, if you plant KHIVA. It is the most delicately flavored winter-keeping melon we have ever eaten. The flesh is white and very thick, 2 or 3 inchs deep. The skin is firm, with a grayish gireen color, slightly mottled. Is of egg-shape, and weighs 12 to 30 bs. Not real delicions until in November and later. They keep nicely until in January.

pkt., 5c; oz., 20c; $1 / 4$ lb., 75e; ib., \$2.75. 


\section{MUSK MELON--Yellow Flesh Varieties \\ BURRELL'S GEM.}

This is another Colorado product and, like the Rocky Ford Cantaloupe, one that we can be proud or. It has a tough, thin rind, well arched ribs covered with a closely laced and interlaced gray netting. Shape is quite elongated, the diameter from stem to blossom end being one-third more than from top to bottom. Meat reddish orange, very thick, fine grained and spicy; vines vigorous; average weight, $2 \frac{1 / 4}{4} \mathrm{Ibs}$, and, notwithstanding its thin rind is an ideal shipping melon.

Pkt., 5e; oz., 10e; 1/4 1b., 30e; 1b., \$1.00.

\section{EMERALD GEM.}

Is of medium size; skin, while ribbed, is perfectly smooth and of a deep emerald green color. The flesh is thick and of a suffuse salmon color, and ripens to the green rind. It is so very juicy and rich that it almost drops to pieces when dipped out with a spoon. The favor is very sweet and luscious. The vines are hardy and very prolific, and the melons mature extremely early.

Pkt., 5e; oz., 10e; $1 / 4$ lb., 30e; lb., \$1.00.

\section{DEFENDER.}

One of the best yellow fleshed sorts. Fruits medium size and oval in shape.

Plet, 5e; oz., 10e; 1/4 1b., 30e; 1b., \$1.00.

\section{PAUL ROSE.}

A cross of Osage and Netted Gem, among the best of the salmon or red-fleshed sorts. Flesh unusually thick, firm and delicious; well netted and fine for market.

Pkt., 5e; oz., 10e; 1/1 1b., 30e; 1b., \$1.00.

\section{BANANA.}

An entirely distinct variety, bearing longer, slender banana-like fruit. Skin creamy white and entirely free from netting. Flesh deep salmon color, thick and of good quality.

Pkt., 5e; oz., 10c; 1/1 1b., 35c; lb., \$1.10.

OSAGE.

The great popularity which this melon has attained is due mainly to its peculiar luscious, spicy flavor, and its perfect shipping qualities. The skin is very thin, of a dark green color, and slightly netted. The flesh is of a salmon color, remarkably sweet, extremely thick and delicious to the rind. It is also very productive.

Pkt., 5e; oz., 10e; 1/4 1b., 25e; 1b., 90c.

PEÁCH MELON OR GARDEN LEMON.

The fruit is about the size of a large peach, oval shaped, and of a bright orange yellow color somewhat russetted. When it first ripens it is quite hard, and has very little flavor, but they soon become mellow, not sweet, and have a rich flavor. For sweet pickles, pies or preserving, they are superb.

Pkt., 5e; oz., 15e; 1/: lb., 40c; lb., \$1.25.

\section{WATER MELON}

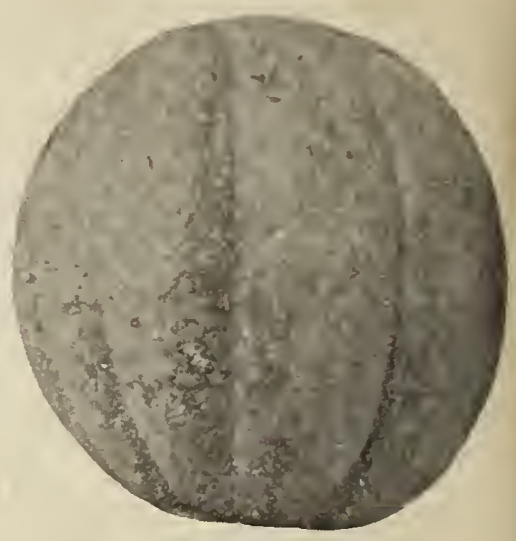

Defender.

CULTURE. This is the same as for musk melon, except that they should be planted from 8 to 10 feet apart. One ounce for 30 hills; 3 to 4 pounds to an acre.

are Fifteen cents per pound may be dedueted when five pounds or more of one variety of Melon is ordered, not prepaid. Be sure to ask for prices if you inteud purchasing Melon Seeds in large quantity.

\section{COLE'S EARLY.}

This is an extra early melon, maturing fully a week or more in advance of any other variety. Melons are oval in form, handsomely striped with light and dark green, small, but of good quality and desirable for raising where seasons are short. Pkt., 5e; oz., 10e; 1/1 1b., $20 \mathrm{e}$; 1b., 75e.

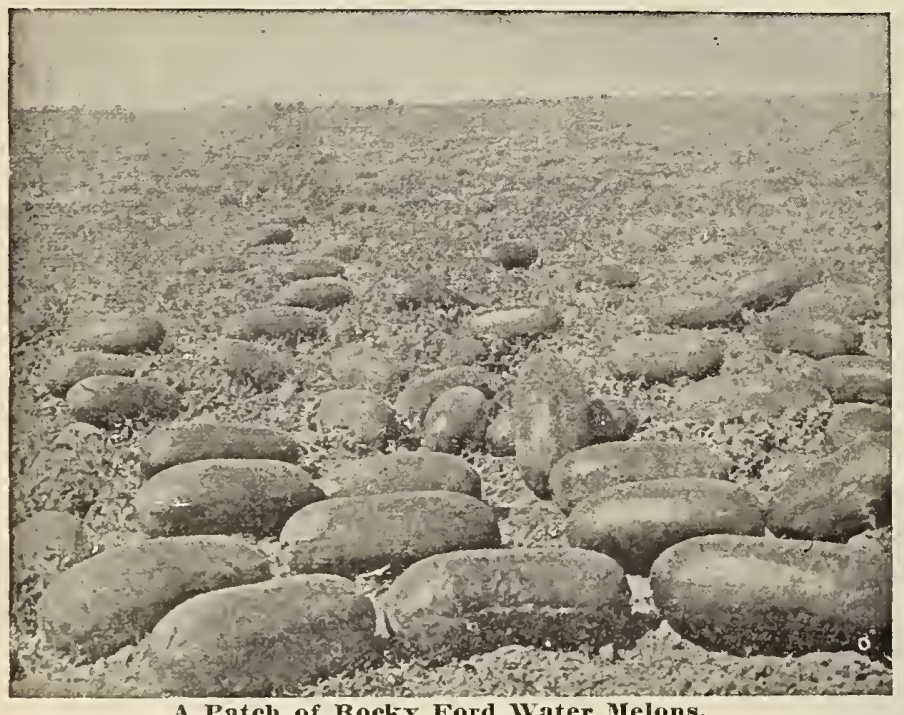

A Pateh of Rocky Ford Water Melons.

\section{PHINNEY'S EARLY.}

A veary early variety; medium and uniform size. The skin is smooth, with uniform, narrow, white mottled and dark green stripes. Flesh light red or pink, very sweet and delicious.

Pkt., 5c; oz., 10e; 1/4 lb., 20c; lb., 70c.

ICE CREAM, OR PEERLESS.

An early delicious melon for home use or home market. It has too thin a rind for shipping. Few, if any, melons surpass this for quality and productiveness. Flesh bright scarlet, solid to center, melting and delicious. Pkt., Je; oz., 10c; $1 / 2$ 1b., 20c; 1b., 70c.

\section{CHILEAN.}

A very brittle, thin skinned variety, of the highest merits for home garden. It is slightly oblong; the skin is deep green, striped with still deeper green; the flesh is bright red, juicy and very sweet. It grows to a large size and we recommend it very highly, especially for the southern states.

Pkt., 5e; oz., 10c; 1/4 lb., 25e; lb., 90c.

KLECKLEY'S SWEET, (Monte Cristo Sweet.)

Large oblong melon, 20 inches in diameter, somewhat tapering at the ends. The skin is dark green, flesh bright scarlet, ripening close to the skin; seeds white, lying close to the rind, leaving a large solid heart which does not crack open when ripe. The scarlet flesh is sweet and sugary. The melon is better for home use than for shipping.

Pkt., 5e; oz., 10e; 1/4 lb., 30e; Ib., \$1.00.

\section{Rocky Ford--Barteldes' Select}

This melon is considered one of the best for this climate. The skin is dark green, flesh-bright scarlet, ripening close to the skin, the rind being only about one-half inch in thickness. Seeds white, lying close to the rind leaving a large solid heart which does not crack open when ripe. The scarlet flesh is sweet and sugary and of such texture that it leaves no strings of pulp whatever in eating. It is the best table melon today.

Plit., 5e; oz., 15e; 1/4 lb., 45e; lb., \$1.40.

\section{ROCKY FORD.}

Ordinnry Strain. Saved from average good specimens.

Pkt., 5e; oz., 10e; 1/4 1b., 30e; 1b., 90c.

Produces melons 18 to 24 inches long and 10 to 12 inches in diameter and weighing 50 to 60 lbs. The deep red flesh is of excellent flavor; the heart is large but without core. It has a thin rind, but very tough, making it an excellent shipper.

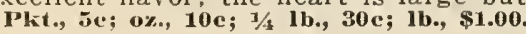


WATERMELON-Continued.

SWEET-HEART.

A new melon of excellent quality. Vine vigorous, and productive, ripening its fruit early. Fruit large, oval very heavy, uniformly mottled, light and dark green. Rind thin, but firm. Flesh bright red, firm, solid, very tender, melting and sweet. Fruit remains in condition for use longer than any other sort. Ilkt., 5e; oz., 10e; 1/4 lb., 25e; ib., 70e. CUBAN QUEEN.

A large and solid variety, rind very thin and strong, skin striped with dark and light green. Vines strong, healthy and of vigorous growth; very heavy cropper, flesh bright red, tender and melting, luscious, crisp and very sugary. It is an excellent keeper, and bears transit well.

\section{BLACK DIAMOND́.}

A cross between Kolb's Gem and Hoosier King. Its prominent point of merit is its extreme size. MIelons rveighing 75 to oval.

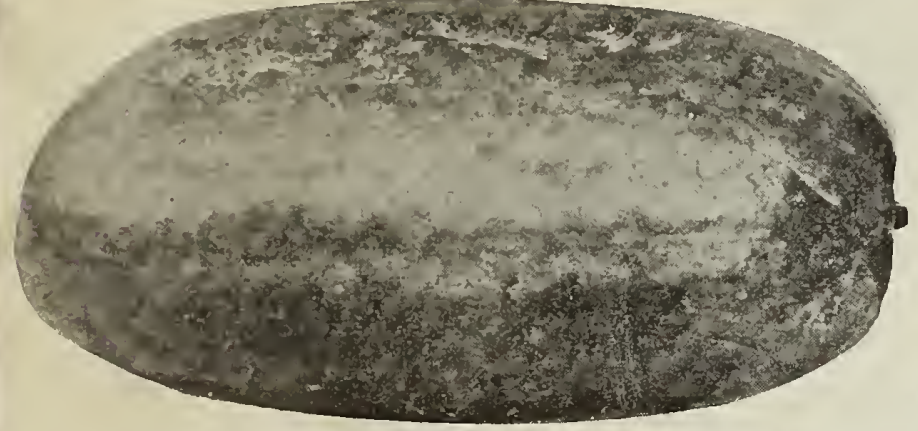

Florida Favorite. Pkt., 5e; oz., 10e; $1 / 4$ lb., 25e; lb., 70e.

MCIVER'S WONDERFUL SUGAR.

Oblong in shape, attains great size and weight, the rind showing broad stripes of light and dark green; flesh rosy pink, solid and stringless from rind to core. Crisp and delicious.

Plet., Jैe; oz., 10c; 1/4 lb., 25e; 1b., 70c.

\section{FLORIDA FAVORITE.}

Oblong in shape, growing to a very large size; rind darl with light green stripes; flesh light crimson, crisp and deliciously sweet.

Pkt., 5e; oz., 10e; 1/4 lb., 25e; 1b., 70c.

GYPSY OR RATTLESNAKE.

One of the largest water melons, long, smooth, distinctly striped with light mottled and wavy, dark green, regular stripes. Flesh bright scarlet and very sugary. Thin skinned, but bears varriage well.

SEMINOLE.

It is extra early, enormously productive, extra large and of most delicious flavor. It is of two distinct colors, gray The oray color predominates, about one-fourth of the melons being of the light green color. Melons of both colors are found on the same vine.

TRIUMPH.

Triumph is a cross between the Duke Jones and Kolb's Gem, having the handsome dark green color of the former, and the fine shipping qualities of the latter, but infinitely superior in flavor, and grows much larger than either, having known to attain a weight of over 100 pounds.

KOLB'S GEM.

Vines of medium size, but remarkably vigorous and healthy, Fruit of the largest size, round or slightly oval, marked with irregular mottled stripes of dark and very light green. Flesh bright red extending to within half an inch of the rind; always solid, very firm, a little coarse, but sweet and tender. An excellent keeper and very good for shipping.

Plit., 5e; oz., 10e; $1 / 4$ lb., 25e; lb., 70e.

KENTUCKY WONDER. In shape it is oblong; skin dark green, marbled in stripes of light green.

Pkt., Je; oz., 10e; 1/4 1b., 25e; lb., 70c.

BLACK SPANISH. Round, very dark green, with scarlet flesh and black seeds; early.

Pkt., 5e; oz., 10e; 1/4 lb., 25e; 1b., 70 .

MIAINIOTH IRONCLAD. This variety is one of the largest melons grown.

Pkt., 5c; oz., 10c; 1/4 1b., 25e; 1b., $70 \mathrm{c}$.

ICING OR ICE RIND. Fruit of medium size, nearly round.

Pkt., 5c; oz., 10c; $1 / 4$ 1b., 25e;

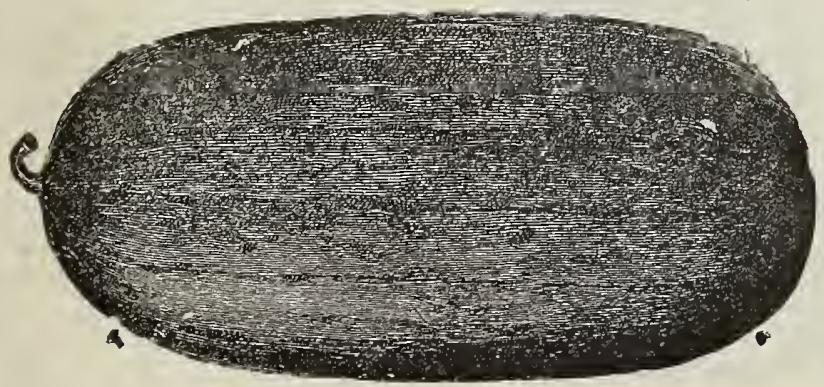

Halbert Honey.

JONES' JUMBO. Rind green with light stripes.

Pkt., 5e; oz., 10c; 1/4 lb., 25e 1b., 70c.

PRIDE OF GEORGIA. One f the best table varieties. Pkt., 5e; oz., 10e; 1/4 lb., 25e; $1 \mathrm{~b} ., 70 \mathrm{c}$.

MOUNTAIN SWEET Size large, flavor good, rind thin, dark in color. Plkt., 5e; oz., 10e; 1/4 lb., 25e;
lb., 70e. ICEBERG. Similar to Kolb's Gem, but darker.

Pkt., 5e; oz., 10e; 1/4 lb., 25e; lb., 70e. DIXIE. A cross between
Kolb's Gem and Mountain Pkt., 5e; oz., 10e; 1/4 lb., 25e lb., 70c.

KANSAS STOCK OR COLORADO PRESERVING MELON. It is immensely productive. The melons grow to a large size, some of them weighing as high as 60 or 70 pounds. The flesh is firm and solid with only very few seeds. The melons will keep all winter and can be fed to stock the same as turnips and beets. They grow on most any kind of soil stand dry seasons very well and seem adapted to most climates. Pkt., 5e; oz., 10e; 1/4 lb., 25e; lb., soc.

HALBERT HONEY.

shell, pink flesh, seeds black. The most luscious, han and valuable winter melon in the world. It is very hardy and does well in any soil which grows melons. The melon Pkt., 5e; oz., 20c; 1/4 lb., 60c; lb., \$1.75.

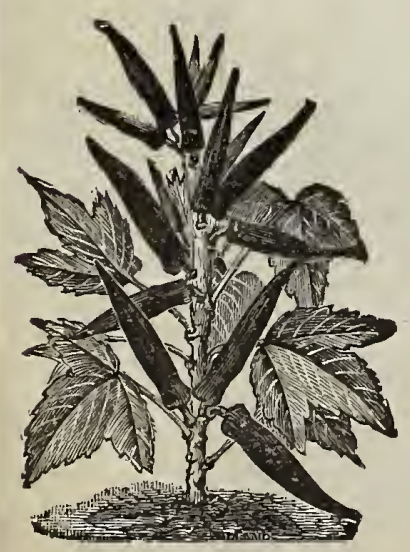

Okra-Dwarf.

This new Melon has all the good qualities of Kleckley sweet, and has fruits more even and regular in outline, with a darker, richer colored skin. Vines are very vigorous and set fruits very freely-four and five large melons are frequently seen clustered closely together. It is one of the earliest melons grown, and averages 18 to 20 inches long.

Plkt., 5c; oz., 10c; 1/4 1b., 30c; 1b., \$1.00.

This melon is used for preserving; rind is striped and marbled with light green; flesh white and solid. Pkt., 5e; oz., 10e; $1 / 4$ lb., 30c; lb., 90e.

\section{OKRA OR GUMBO}

CULTURE. Sow late in the spring, after the ground has become warm, in drills 3 feet apart, and, when plants are 3 inches high, thin out from 10 to 12 inches. They should be well manured. They also can be started in a hot bed and transplanted afterwards. The young green seed pods of this plant are used in soups, or stewed, and served like asparagus. The young pods can also be dried for winter use. One ounce will plant 80 hills.

\section{WHITE VELVET.}

It is very distinct in appearance, and unlike other varieties, the pods are not ridged, but are perfectly round and smooth, of superior flavor and tenderness. The plants atively dwarf and of compact branching growth; the pods are of extra large size and duced in great abundance. Pkt., 5e; ox.., 10e; 1/1b., 20e; 1b., 60e.

Early, long podded and productive.

inches long and usually eight ridged.

\section{DWARF.}

TALL.

Pkt, 5e; oz, 10e; 1/4 lb., 20e; 1b., 50c. 


\section{NASTURTIUM}

The seeds, while young and succulent, are pickled and used as capers. The plants are also highly ornamental; the tall variety makes an excellent screen or coverlng for unsightly places in the garden. Do not sow untli the ground ls warm.

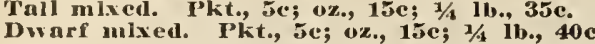

\section{ONION}

We make a specialty of onlon seed, and handle it extensively We grow a large portion of our seeds ourselves and have

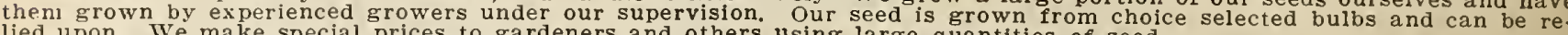
lied upon. We make special prices to gardeners and others using large quantities of seed.

5 lb. lots onlon Seed, not prepald, 15e less per pound.

10 Ih. lots Oulon seed, not prepald, 20e less per pound.

CULTUIR. Onions thrive best in a rather deep, rich, loamy soil, and unlike most vegetables, succeed well when cul-

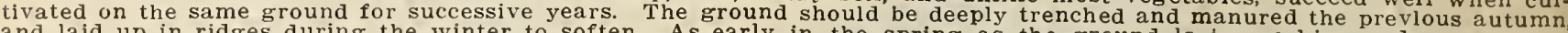

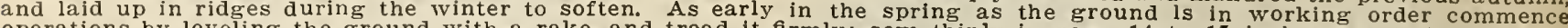

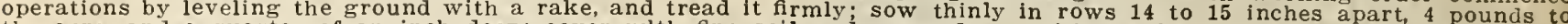
the acre, and a quarter of an inch deep; cover wlth fine soll and press down with the back of a spade or light roller. When the young plants are strong enough, thin gradually, so that they stand 3 or 4 inches apart. Keep the surfall

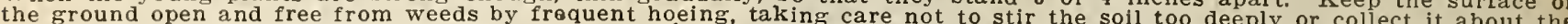

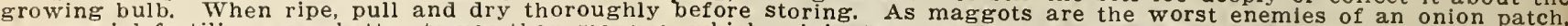
commercial fertilizers are better to use than manure, which originates magrots Our Vegetable Grower is just the patch, See price in back part of this catalog. One ounce of seed to

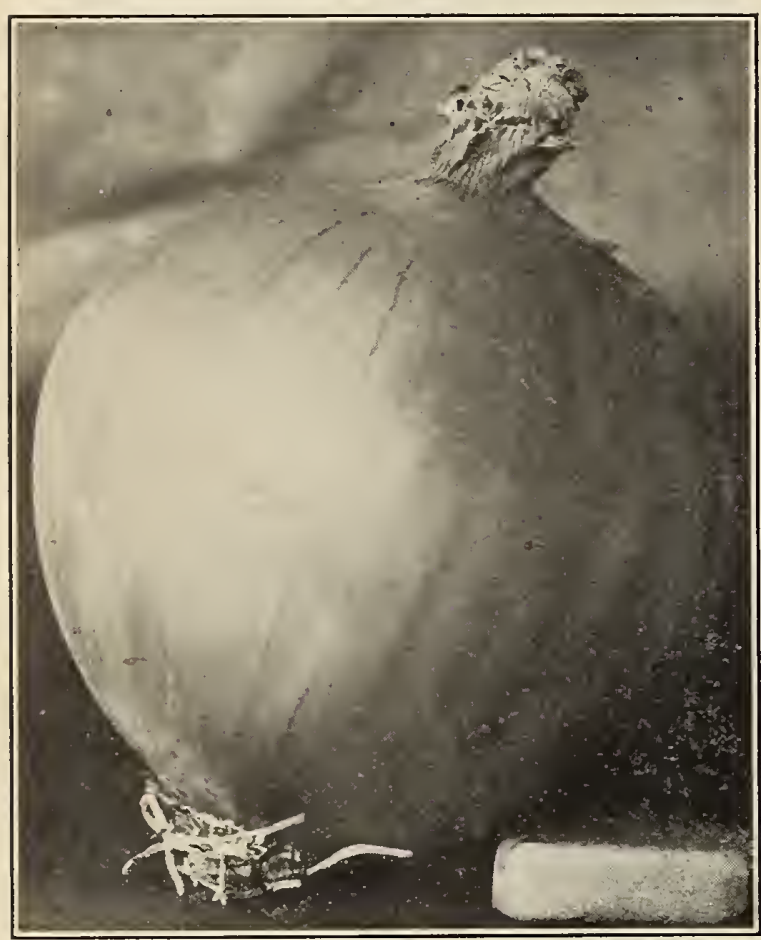

150 feet of drill; 4 to 5 pounds to an acre.

Book, "Onlons for Profit," by Greiner, postpald, 30c.

\section{YELLOW VARIETIES}

YELLOW GLOBE DANVERS.

A very excellent variety of globular shape; flesh white and mild flavor, skin brownish yellow. It is very productive and a good keeper

Pkt., 5c; oz., 15c; 1/4 1b., 40c; 1b., \$1.25.

\section{Select Colorado Grown Yellow Danvers}

Grown from selected bulbs expressly for us in

Larimer county. Is acclimated and gives best results. Pkt., 5e; ; $0 ., 20 e ; 1 / 111$., 50e; 11 ., \$1.60.

SOUTHPORT YELLOW GLOBE.

Of the same general character and quality as the Southport

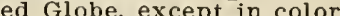

Pkt., 5̇c; oz., 15e; 1/4 lib., 40c; 1b., \$1.25.

\section{OREGON YELLOW DANVERS.}

It is a cross between the flat and the globe, one of the best keepers for our western climate.

Pkt., 5e; oz., 15e; $1 / 4$ lb., 40e; lb., \$1.25.

YELLOW FLAT"DANVERS.

Same as above, except in shape and a little earlier to mature.

I'kt., 5e; oz., 15e; 1/4 11., 40e; lb. \$1.15.

This new handsome variety is a splendid type of the celebrated Spanish fancy onions, which are annually imported in to the United States from spain. The onions grown here quite rival the imported ones in great beauty and enormous size, weighing in many cases from 3 to $33 / 4$ pounds each. The outside skin is of a rich yellow color, while the flesh is white, sweet and mild.

P'kt., 5e; oz., 15e; $1 / 1$ lb., 40e; lb., $\$ 1.25$.

\section{GIGANTIC GIBRALTAR.}

The handsome large bulbs are nearly globular in shape. Thin skin of light straw color, flesh white, tender and mild. The ripened bulbs are very similar to those of Prizetaker, but will make large bulbs when grown in the south. The leaves are deep green with a glossy surface and withstands dry weather and the attack of insects better than any other onion grown.

Giant Gibraltar.

BROWN AUSTRALIAN.

It is of medium size, wonderfully hard and solid and most attractive for market, both as to form and appearance. They are extremely early in ripening. It has the reputation of keeping the from its firmness and indencitely and was the reputation of keeping hardness that it will keep in good condition skin is a clear amber brown.

plit., 5e; oz., 15e; 1/1 lb., 35e; lb., \$1.00.

\section{RED VARIETIES}

SELECT COLORADO GROWN RED GLOBE.

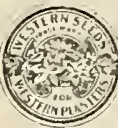

Grown for us and under our Super-

isor's care from selected bulbs in Larimer county. Is well acclim l'kt., 5e; 0z., 20e; 1/4 1b., 50c; $1 \mathrm{~b}$. \$1.(is.

LARGE RED WETHERSFIELD.

Large deep red. thick, nearly round, fine grained, pleasant flavored and prod

l'kt, EXTRA EARLY RED FLAT. This valiety ripens about 10 days earlier than
the large Wethersfield and is rather smaller in size, but close grained and heavy. GIANT COLOMBO.

This nerv Onion from Teneriffe is the giant of the fimily. They average 2 to 4 pounds, under proper culture: straw or light brown color; arc very mild and the very best for stuffing. On account of their flavor they are used very much Pkt.. 10e: 1/2 0z., 85e; 0\%., 60e; $1 / 41$ 1b., \$2.00; 1b. 8.000 .
Pkt., 5c; 0z., 25e; 1/4 lb., 65c; 1b., \$2.25.

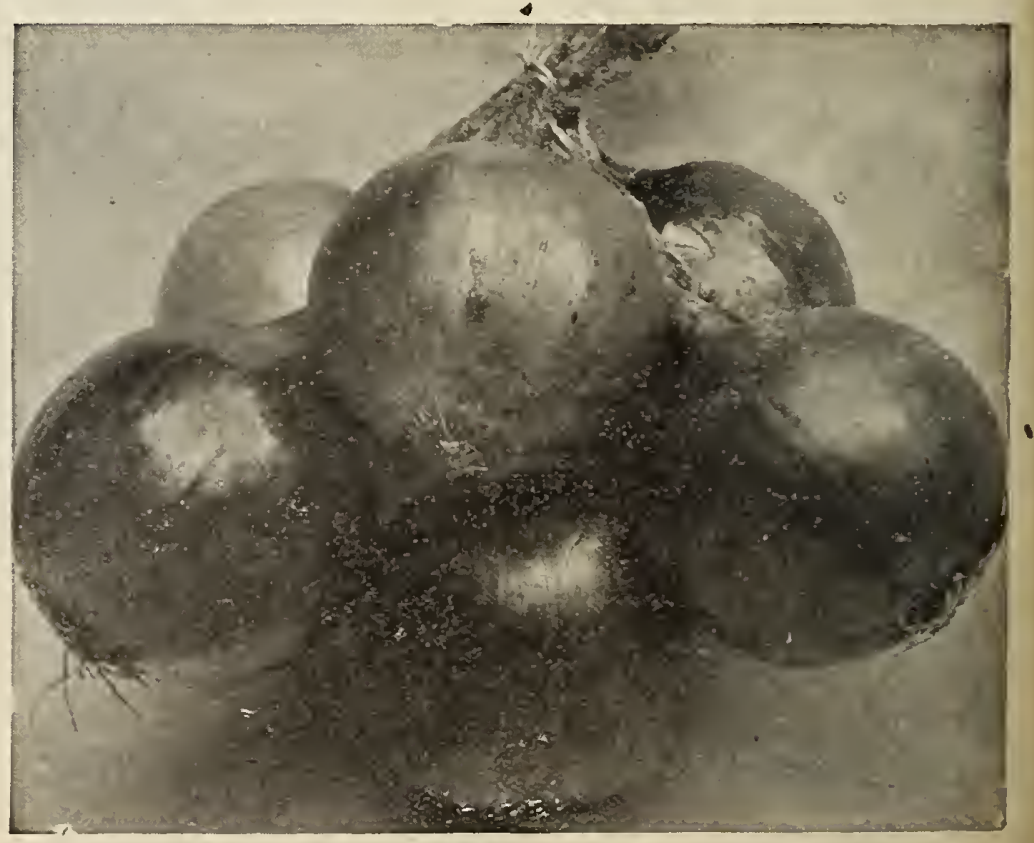

Select Colorado Grow u Red dilohe. 
ONION-RED VARIETIES-Continued.

SOUTHPORT RED GLOBE.

A large globe-shaped onion, with small neck, rich red color, a splendid keeper and of extra tine quality. It matures a few days later than the Red Wethersfield.

I'kt., 5e; oz., 15e; 1/1 Ib., 40c; 1b., \$1.25. RED BERMUDA-Imported Seed.

The bulbs of this variety are similar in form and early ripening to the White Bermuda: very flat and of a light pink

color. The flesh is white, slightly suffused with pink. Teneriffe grown seed.
Pkt., 5e; oz., 25e; $1 / 3$ Ib., 75e; lb., \$2.50.

\section{EXTRA EARLY BARLETTA.}

(True French Stock.)-Is fully two or three weeks earlier than the Early White Queen, which heretofore has been the earliest variety in cultivation. They are of pure paper white color, very mild and delicate in diameter and three-fourths of an inch in thickness.

Pkt., 5c; oz., 2ve; 1/4 lb., 55e; lb., $\$ 1.75$.

\section{EARLY WHITE QUEEN.}

Succeeds well everywhere. The bulbs are small, flat, beautifully white and of excellent beavor, but the principal recommenation is the marvelous rapidity of its growth. Sown in February it will diameter onions 1 or 2 inches in diameter early in summer. Sown in June they will be ready to pull late in the autumn, will keep sound for one year, retaining to the last their most exquisite flavor. $\$ 1.75$

\section{WHITE BERMUDA-Imported seed.}

This valuable onion is especially adapted to the southern states and is the most profitable of all varieties of onions for the grower. Ease of cultivation, large size, mildness of flavor render it most valuable of all other types. The White Bermuda is a sport from the original Red Bermuda, has not yet become firmlly fixed in habit, therefore, the grower will often find "off color" onions among his crop. Pkt., 5c; oz., 25e; 1/4 1b., 75e; 1b., \$2.75.

\section{EL PASO.}

A new variety from Mexico. It grows there to a diameter of 6 inches, weighing two-thirds of a pound; flavor very mild. Our seed of this variety comes direct from Mexico, bought from growers. Skin of the onion generally white, but sometimes mixed with red and yellow. Pkt., 5e; oz., 25e; 1/11b., 75e; 1b., \$2.50.

\section{ONION SETS}

Prices given are subject to market fluctuations. When you want large quantities ask for market priees. Thirty-two pownds constitit

RED BOTTOM. Produced by sowing thickly the seed. They mature under this method when about half an inch through.

Qt., 20e; $1 / 4$ bu., \$1.00; bu., \$3.50.

YEILOW BOTYOM. Identical with the preceding, except in color

Qt., 20c; 1/4 b11., \$1.00; bu., \$3.50

WHITE Bo'Tros. They do not keep as well as the red or yellow, but produce beautiful white onions early in the eason.

Qt., 25c; 1/4 bu., \$1.35; bu., \$4.00.

SILLLor's. Used extensively in Germany. Valuable for an eally crop. 'They grow in clusters, very productive, of very mild and sweet flavor.

Qt., 25e; $1 / 4$ bu., $\$ 1.40$; bu., $\$ 4.75$.

TOP OR BUT'TON. Produces no seed, but instead a number of small bulbs or onions about the size of an acorn. on the top of the stalk. The little bulbs are used instead of seed, and will produce a large onion, maturing much earlier

\section{PARSLEY}

CULTURE. Parsley succeeds best in rich, mellow soil. As the seeds germinate very slowly, 3 or 4 weeks elapse sometimes before it makes its appearance. It should be sown early in spring, previously soaking the seeds for a few hours in tepid water. Sow thickly in rows a foot apart and half an inch deep. One ounce to 150 feet of drill.

$$
\text { NEW EME RALD. }
$$

The plants are of dwarf, compact growth; the leaves are of a handsome, bright green color, very finely crimped and curled; of most ornamental appearance; commands highest price in Denver markets.

Pkt., 5e; ox., 10e; $1 / 4$ ib., 25e; 1b., 75e

\section{CHAMPION MOSS OR TRIPLE CURLED.}

The leaves are finely cut and curled and of a dark green color. Fxtra fine for garnishing and culinary purposes.

Pkt., 5e; or., 10e: $1 / 4$ lb., 20e; ib.. 60e. TURNIP.ROOTED OR HAMBURG.

The root is the edible portion and represents a small parsnip iz: shape and color. Flesh white and flavored like celeriac. Foliage same as plain parsley.

Pkt., 5e; oz., 10e; 1/4 1b., 20c; 1b., 60e.

than from seed. The large onion produces the top onion, and the little top onion produces the larger onion.

Qt., 25e; $1 / 4$ bu., \$1.35; bu., \$4.00.

WHITE MULTIPLIER ONION SETS. These are of a pure white color, enormously productive, flequently producing as many as 20 bulbs in a single cluster from a single bulb planted, of excellent quality and size for bunching green or can be ripened for use as pickling onions, and for this latter purpose can be grown much more economically than from seed. Their most important quality is extreme earliness, being ready for market from 3 to 4 weeks ahead of other onion sets.

Po'TA'T ONION. Produces a quantity of young bulbs on the parent root, which should be planted early in spring ered one inch deep. They should be earthed up like potatoes

as they continue to grow.

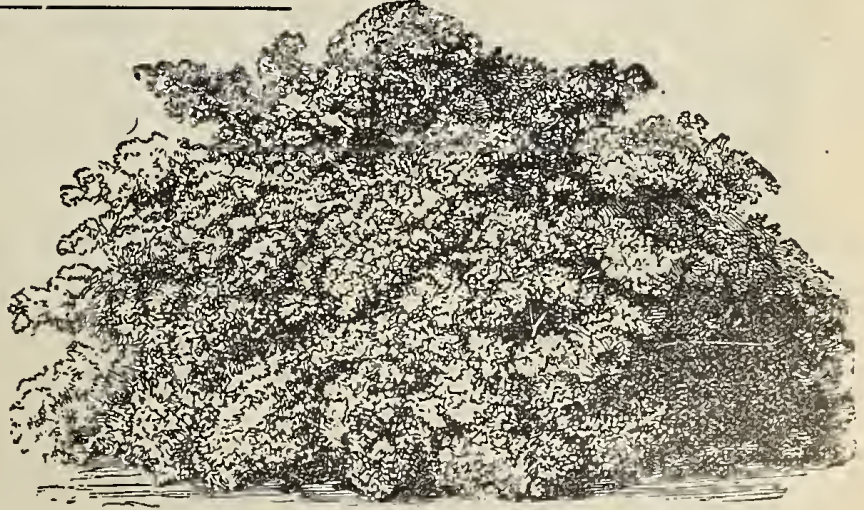

Parsley-Champion Moss. 


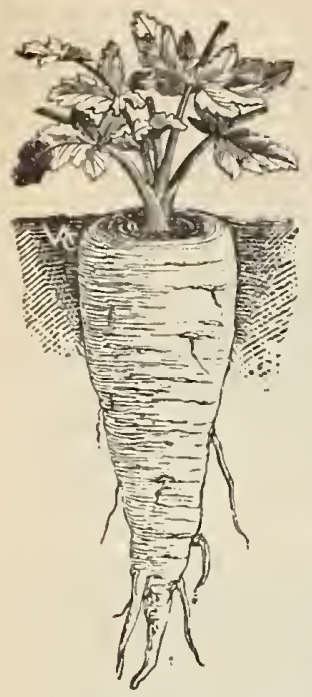

Hollow Crowned.

\section{PARSNIP}

CULTURE. They do best in deep, rich, sandy soil, but will make good roots on any soil which is deep and mellow and moderately rich. As the seed is sometimes slow to germinate, lt should 作 quent cultivation, and thin the plants 6 or 8 to the foot. As they are improved by frost a part of the crop should be left in the ground for spring use. One ounce will sow 150 feet of drill; 5 pounds one acre.

\section{SUGAR OR HOLLOW CROWNED.}

The best for table use; a vegetable of merit, easily raised, and of great productiveness.

l'kt., 5e; 0z., 10e; $1 / 1$ lb., 20c; 1b., 50c. GUERNSEY

Roots comparatively short, ending somewhat abruptly with a small tap root; grows with a cavity on the top or crown of the root.

\section{MAGNUM BONUM.}

A very fine and greatly improved strain of the Hollow Crown, which we can recommend to all

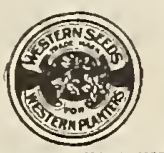
marketmen as a money maker. The rcots smooth, not so long as those of the standard sort, somewhat thicker in diameter and much more easily pulled. A very heavy cropper. l'kt., 5e; $0 \%, 10 \mathrm{c} ; \mathrm{x} / \mathrm{s}$ 1b., $20 \mathrm{c} ; 1 \mathrm{b.g}, 60 \mathrm{c}$.

\section{PEAS}

Peas do best in a sandy soil, not too rich, or they will run up to vines. The smooth kinds can be sown as soon as the ground can be worked, but the wrinkled varieties should not be planted till it is warmer or they will rot. Sow in single or double rows from $11 / 2$ to 3 feet apart, dropping a pea every inch, and covering from 2 to 3 inches deep. For a succession, sow every 10 days up to July. Pea seeds are, som years, full of small holes, caused by an insect called Pea TVeevil. The holes will not prevent the seeds from growing, as the germ is not destroyed. one pound to 50 feet of drill; 90 to 120 pounds to an acre.

When ordering Peas to be forwarded by mail be sure to add postage at the rate of $8 \mathrm{c}$ per pound. Isk for prices on larger quantities.

\section{EARLY SORTS}

\section{ALASKA.}

A variety of remarkable earliness and hardiness. It is a good yielder and produces pods of good size and dark green color, which are well filled with round, smooth peas of splendid flavor. Height, 2 feet. The color of the dried pea is clean off the crop.

Pkt., 5c; 1/, lli., 15c: 1b., 20c; 2 lbs., 35c. FIRST AND BEST.

This is a reliable early cropper of the hardy smooth-seed variety. Not quite as early as Alaska. Height, $2 \frac{1}{2}$ feet.

Pkt., Je; 1/3 1b., 15e; 1b., 20c; 2 lbs., 35e. *PROSPERITY, ÓR GRADÜS.

This remarkable Pea is not only large and of the best quality, but it quite as early as the small, round, extra early. It is hardy and may be planted as soon as the ground is fit to work be planted as soon as the ground is feas. The in the spring, along wen color and measure 4 pods are of bright green color, and measure 4 inches or more in length, being as large as a Telephone and equally well filled with luscious Peas-8 to 10 in a pod; vine growing about 30 inches high. The Peas are of first-class table quality and retain their color and attractive appearance after cooking. Height, $21 / 4$ feet.

Pkt., 5e; 1/2 1b., 15e; 1b., 25e; 2 lbs., 45c. UNIQUE.

Dwarf, hardy, prolific, first early variety of great merit; pods in pairs long pointed, dark green and well filled with peas of fine flavor. One of the best smooth seeded varieties for extra early sowing.

Pkt., 5e; 1/2 1b., 15e; 1b., 25e; 2 lbs., $45 c$.

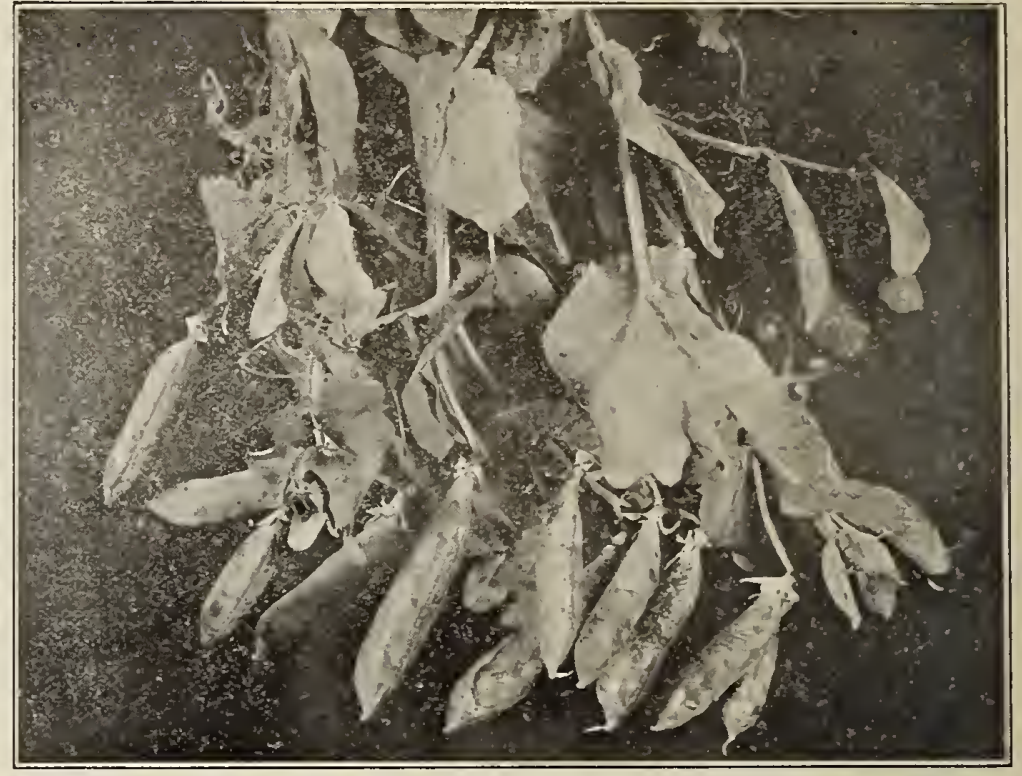

TOM THUMB.
Nott's Excelsior.

Vine bushy, growing to a height of 10 inches, foliage heavy; productive; ready to use in 35 days after sprouting. Height, 10 inches.

*NOTT'S EXCELSIOR.

Robust and vigorous in growth, inclined to throw out laterals from the base of the stock, producing in profusion long

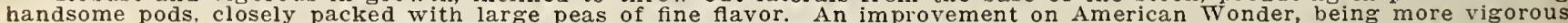
and prolific with larger pods and more peas. Height, 12 inches.

Pkt., 5c; $1 / 2$ lb., 15e; 1b., 20c; 2 lbs., 35e.

*AMERICAN WONDER.

The vine grows 8 to 10 inches high, and is very prolific in pods of striking form and size. In maturity it is among the earliest of the green wrinkled sorts, ripening in about 50 days from germination. Height, 10 inches.

Pkt., 5e; 1/2 1b., 15e; 1b., 20c; 2 lbs., 35e.

*MCCLEAN'S LITTLE GEM.

A good standard sort; early, productive and of good flavor, growing from 18 to 20 inches high.

Pkt., 5e; 1/2 1b., 15e; lb., 20e; 2 1bs., 35e.

*PREMIUM GEM.

An improvement on the Little Gem, being larger and more productive; early in maturing; very luscious in flavor; highly recommended; try it Height, $11 / 2$ feet.

Pkt., 5e; 1/2 ib., 15e; lb., $20 \mathrm{e} ; 2$ lbs., 35e

\section{MEDIUM EARLY SORTS}

\section{*DWARF TELEPHONE.}

Grows from 20 to 24 inches high; the vines are very vigorous, of a branching habit. and bear for a long time a great

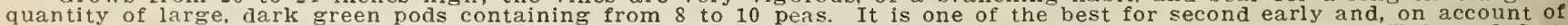

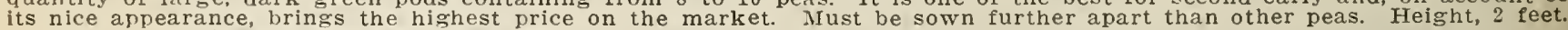
Pkt., Je; 1/2 llo., 15e; 1b., 25e; 2 llss., $40 c$.

\section{*DWARF CHAMPION.}

In this we have the type of Champion of England Peas, with all the good qualities of its parent. It grows $21 / 2$ feet high

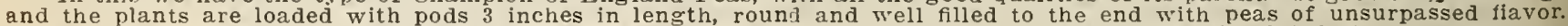
It bears the longest of any peas, being in that respect as good as Champion of England. Height, $21 / 2$ feet.

l'kt., 5e; $1 / 2$ lb., 15e; li., 25e; 2 lbs., 40e. 


\section{*TELEPHONE}

This variety is one of the finest branching, tall, wrinkled marrows yet introduced. It is immensely productive, of the finest quality and excellent sugary flavor; vine very strong, averaging 18 to 20 pods per stalk; the pods are of large size and closely packed with 6 or 8 large, delicious peas. Height, $4 \frac{1 / 2}{2}$ feet.

l'kt 5 e; $1 / 21 \mathrm{~b}, 15 \mathrm{~s} ; 1 \mathrm{~b}, 20 \mathrm{c} ; 2$ lbu, 350

Plot, 5e; 1/2 lb., 15e; lb., 20e; 2 lbs., 35c. midale crop; one of the best peas ever sent out Height, 2 feet

Pkt., 5e; $1 / 2$ lb., 15e; lb., 20e; 2 lbs., 35e.

TVRBL RING. For a continuance or excelied. Height, $21 / 2$ feet.

Pkt, 5c; 1/2 lb., 15e; 1b., 20e; 2 lbs., 35e. from 18 inches to 2 feet high and beal's grand pods, well filled with large and well flavored peas from top to bottom of the haulm. Height, $1 \frac{1 / 2}{2}$ feet.

Pkt, 5e; $1 / 2$ lb., Me; lb., 20e; IDA., 35e. medium height, giving the greatest number of pods of any on our list. Height, 2 feet.

Pkt., 5e; 1/2 lb., 15e; ll., 20e; 2 lbs, 35e. Premium Gem but stronger in habit. Height, 3 feet.

Pkt., 5e; $1 / 2$ 1b., 15e; 1b., 20e; 2 lbs., 35e.

GRAY SUGAR. Edible Pods. The most desirable of all edible pod eas. The pods are flat and crooked, and contain 5 to 6 peas. Height, $1 \frac{1}{2}$ feet

Plet. 5e; 1/2 1b., 15e; Hb., 25e; 2 lbs., 40e.

Pkt., 5e; 1/21b., 15e; Hb., 25e; 2 lbs., 40e. which it resembles in strength of vine and general habit; wrinkled and very sugary; requires sticking; ripens for table use in 70 days after germination. Height, 5 feet

Pkt., 5e; 1/3 ll., 15e; lb., 20e; 2 lbs., 35e.

WHYT MIAROWFAT. A strong, productive variety, requiring much space; not recommended for garden purposes, unless brushwood can be obtained. Height, '4 feet.

Fkt., 5c; 1/: lb., 10e; 1lb., 15e; 2 lbs., $25 e$.

BLACK EYE MARROWTAT. Very similar to the White Marrowfat, except the black eye in the seed. Height, $3 \frac{1 / 2}{2}$ feet.

Pkt., 5e; $1 / 2$ lb., 10é; lb., 15e; 2 lbs., $25 e$.

\section{PEPPER}

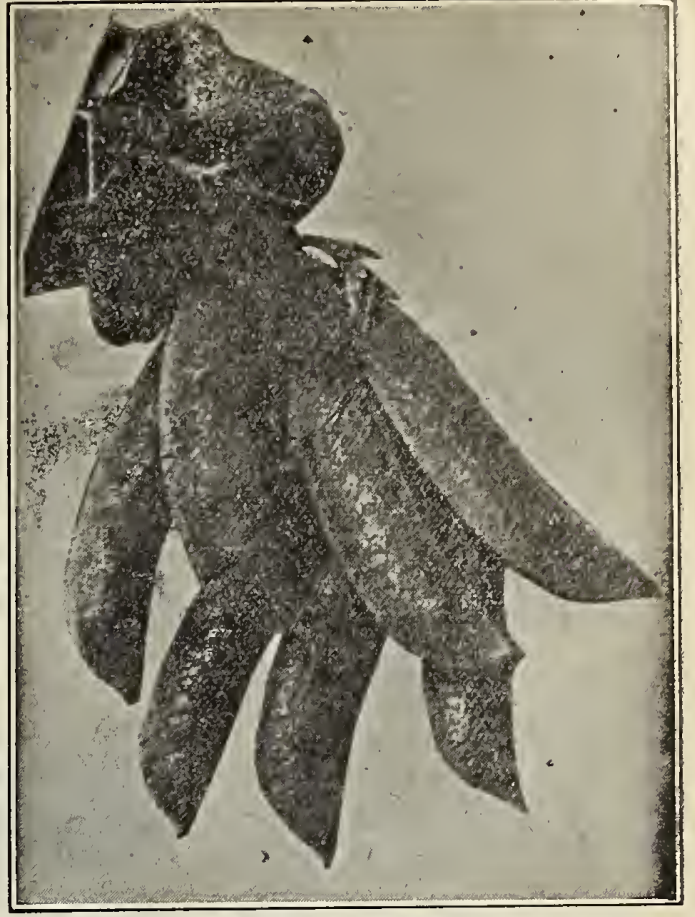

Cliampion of England.

CULTURE. Pepper should be started in a hot-bed, in February or March, and not planted outside till the ground is warm and there is no danger of frost. Set the plants in rows 2 feet apart and 18 inches in the row. Hoe often and keep the weeds down. One ounce produces about 1,500 plants.

\section{LARGE SWEET SPANISH.}

(Bell shaped.) A very large sort, of square form, mild, thick and suitable for filling with cabbage, etc., and for a mixed pickle; less pungent than most other sorts; notwithstanding its size it is one of the earliest varieties.

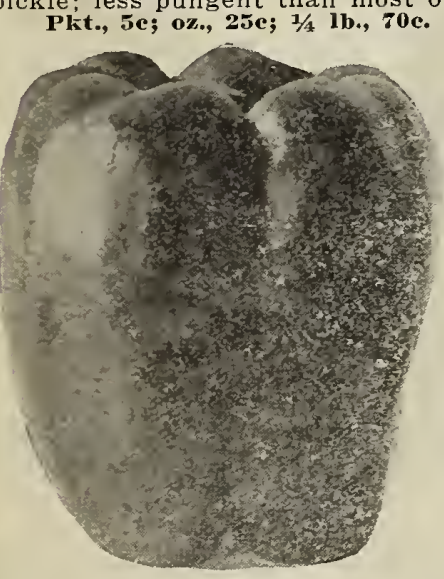

Ruby King.

\section{CHINESE GIANT.}

One of the very best and largest Mango Peppers ever introduced. Its mammoth size splendid shape, beautiful rich glossy-red color and mild flavor all lead us to recommend splendid shape, beautiful rich glossy-red color and mild favor, all lead us to recommend are produced throughout the season, and ripen almost as early as the well known Ruby

King.
Pkt., 10c; oz., 40c; 1/4 lb., \$1.20.

PROCOPP'S GIANT.

This variety may be justly called the Goliah of the pepper family. They grow uniformly of a very large size. They are of a brilliant scarlet color, flesh fully $1 / 2$ inch in thickness. In flavor they are just hot enough to be pleasant to the taste.

Pkt., 5e; oz., 25e; $1 / 4$ 1b., 70e.

\section{RUBY KING.}

Fruits are 6 to 7 inches long by about 4 inches through, of a bright red color. They are remarkably mild and pleasant in flavor, and can be sliced and eaten with vinegar like tomatoes. One of the best for making mangoes.

Pkt., 5e; oz., 25e; 1/4 lb., 70e.

\section{MONSTROUS MAMMOTH.}

Of cylindrical form, 6 inches long by $2 \frac{1}{2}$ inches in diameter. When ripe the fruit is of a beautiful coral red, sweet and thick fiesh.

Pkt., 5e; oz., 25e; 1/4 1b., 70e.

\section{NEW NEAPOLITAN.}

This new pepper is decidedly the earliest of all large mild peppers. The plants are of a spreading, open branched growth, two and one-half feet in height when full grown but begin to form fruit when only a few inches in height. They average four to four and a half inches in circumference at the stem end, and four to four and a half inches long. They are thick meated and as sweet as an apple.

Pkt., 5e; oz., 30c; $1 / 4$ lb., 80c.

\section{GOLDEN DAWN.}

In shape it resembles the popular Bell or Bull Nose pepper. It is of a most beautiful golden yellow color, making a very handsome appearance, both in growth and upon the table.

Pkt., 5e; oz., 25e; 1/1 1b., 70c.

\section{CELESTIAL.}

It is not only a useful pepper, but one of the most beautiful plants in existence. The plant begins to set in peppers early in the season, and continues until frost, branching freely and bearing profusely. The peppers up to the time they are full grown are ing preely and beario profusely. Pkt., 5e; oz., 25e; $1 / 4$ lb., 70c.

\section{LONG RED CAYENNE.}

Fruit brilliant coral red; conical, from 2 to 3 inches in length, from $3 / 4$ to 1 inch in diameter; very pungent.

Pkt., se; оz., 25e; $1 / 1$ 1b., 70e.

RED CHILI. (True Mexico Grown Seed.)

This is slightly larger in growth than the Red Cayenne, with larger fruits, three inches in length and an inch in diameter. Bright red, very hot and fiery. Ripens early Makes the famous Mexican Chili.

Pkt., 5e; oz., 25e; $1 / 4$ lb., 70e.

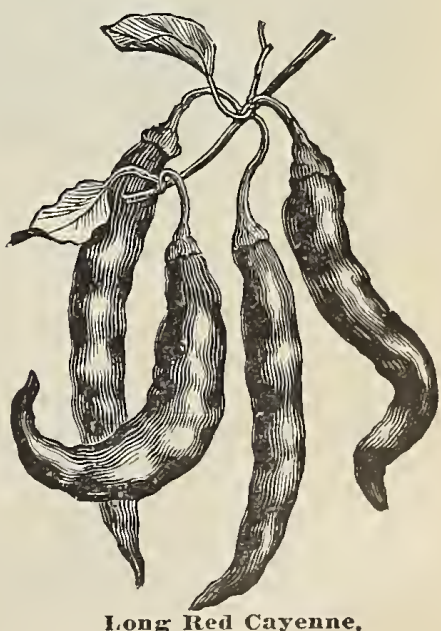

Long Red Cayenne, 


\section{POTATOES}

CU1TU1RE. Potatoes can be grown in any soil, provided it is well drained, but, if grown on sandy, rich soll, they will be of better quality than if planted on clay soils. Sod land is most excellent for this crop. The seed should always be under the sod and not on top of it. It is best to put the manure on one year before the potatoes are to be planted, and in no case raw stable manure should be used, as it is llable to give the scab. In cutting potatoes for planting, do not cut the pieces too small and be sure to have 1 to 3 eyes on them, according to the kind. The constant use of very small tubers should be avoided, or they are likely to run out. The sets should be planted from 3 to 4 inches deep, according to the time of planting, in rows 3 feet apart and 16 to 18 inches in the rows. They should be cultivated 2 or 3 times before they are six inches high, to keep down the weeds. It is not a good plan to hill up potatoes and it should not be done unless they are pushing out of the ground. If planted $1 \frac{1 / 2}{2}$ feet by 3 feet there wil be about 9,700 hills on one acre, and it will take between 600 and 700 pounds, according to the size of the sets, to plant it. At 3 by 3 feet one-half the quantity is needed.

l'rices, 1 lb., 10e; 2 lbs., $15 e ; 4$ lbs., $25 \mathrm{c}$.

1f wanted by mail, add be per pound to pay postage. We use extra packing for mail whlpments.

When large lots are wanted write for prices, stating varieties and quantities desired. When ordering, please state whether or not we shall substitute any other varieties, in case varieties wanted are exhausted.

All our seed potatoes are grown by experienced men who make a specialty of potatoes for seed. You can depend upon our stock.

"Potatoes for Profit," a book giving full directions how to grow them; price, 20 cents.

EARLY PINK OHIO.

The standard among early varieties. Oblong shape, pink skin, shallow eyes. Can be marketed before fully matured.

\section{EARLY WHITE OHIO.}

There is a great demand in many markets for a white potato and in this we have the genuine early Ohio identical with the old the improved color.

\section{EARLY SIX WEEKS.}

The earliest variety for this Western country. It is a good cropper, oblong in shape and has shallow eyes.

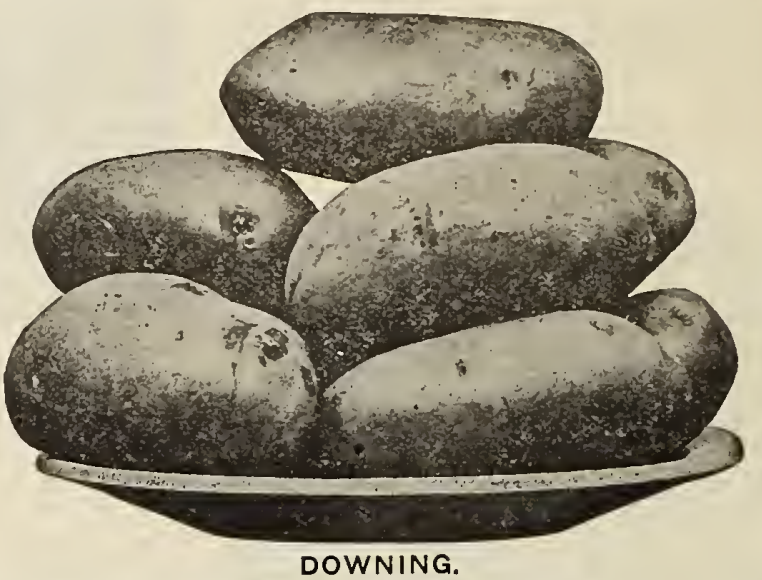

RUSSET, OR NETTED BURBANK.

Since Introduced Han Been Named Netted Gen.

A real acruisition against scab. vines very robust; tubers medium long, smooth, with shallow eves and netted skin, flesh very white and floury; they bake white and foury; they bake quickly. They are absolutely scab proof even if planted in infected soil. They generally set 8 to 10 large tubers to each plant and require a rich soil to produce their usual heavy tonnage. They mature for main crop and are giant cropper. Grown around Carbondale and much liked. In south Idaho they produce the heaviest crop.

WHITE BURBANK.

Similar to the Russett Except in Coior.

One of the best for main crop; is about 10 days later than Early White Ohio. It is a white potato, kidney shaped, smooth skin, with shallow eyes, and a heavy
be planted further apart than other varieties.

RURAL NEW YORKER.

This is a large, white potato, a fine cropper and of the best quality. They grow to a large size, smooth, oblong, inclining to round and rather flattened, very solid, good keepers, and the vigorous growth of the plant enables them to withstand disease to a remarkable extent.

PEACHBLOW, Or Improvtd Red McClure.

Moderate and uniform in size with eyes nearly flush with the surface, dry and tough skinner. When either boiled or baked is dry, mealy and of very good flavor.

MAMMOTH PEARL.

One of the best for main crop. White skinned, shallow eyes, white flesh, late but of good quality.

ROSE SEEDLING.

This is the potato that is famous about Greeley, and is now known in nearly all potato markets as "Colorado Red," "Greeley Seedling," etc. It is our standard for general crop. Our stock is selected for purity.

\section{SWEET POTATOES}

CULTURE. Sweet potatoes should be started in a hot-bed. When the ground is warm and danger of frost past the shoots are lifted carefully and planted in rows 4 feet apart and 2 feet in the row. They need considerable care till well started, but afterwards will grow easily. They should be cultivated quite often, moving the vines to prevent them from rooting at the joints. They must be harvested before frost. One bushel of seed will produce 1,800 to 2,000 sprouts.

To insure prompt filling of orders for Sweet Potatoes, they must be engaged ahead. Standard weight of Sweet Potatoes, 50 pounds per bushel; 125 pounds net per barrel.

Busers wll piease note that owlng to the tenderness of Sweet Potatocs, we do not guarantee the safe arrival of Sweet Potato Seed or Plants; however, we use all preeaution possible in packing and time of shipplng. Sweet Potatoes shouid not be mailed. \$1.50.

YELLOW NANSEMOND. Standard variety for main crop. The best for short season localities. Ten lbs., 75e; 23 lbs.,

YELLOW JERSEY. Similar to the preceding, only shorter and thicker in size. Ten lbs., 75e; 25 lbs., \$1.50.

\section{Sweet Potato Plants}

Ready say 15 untll in July.

If wanted by mail, postage should be added; $15 \mathrm{c}$ for $50 ; 25 \mathrm{c}$ for 100 plants. Will make a special rate on large 10 ts. risk.

We posltively will not aceept orders for long distance sinipping of Sweet Potato Seed or Plants, exceptlng at purchaser's

\begin{tabular}{|c|c|c|c|c|c|}
\hline Yellow & Nansemond & $\begin{array}{c}\text { Per } \\
50 \\
50 \ldots \ldots c\end{array}$ & $\begin{array}{l}\text { Per } \\
100 \\
40 \mathrm{c}\end{array}$ & $\begin{array}{l}\text { Per } \\
1,000 \\
\$ 3.50\end{array}$ & Yellow Jersey \\
\hline
\end{tabular}

We have fertilzers espeelaliy suited to potato euiture. Ask for particuiars. Humplrey's Concave Potato Knife Is Just the thlng to eut potato sets witi; 30e, 3 for $75 e$, postpaid. 


\section{PUMPKIN}

CURTURE. Pumpkins are now principally cultivated for agricultural purposes. They are usually planted in fields of corn or potatoes, but may be profitably raised in fields by themselves. Sow first of May, in hills 8 feet apart. One ounce to 30 hills; 4 pounds to an acre.

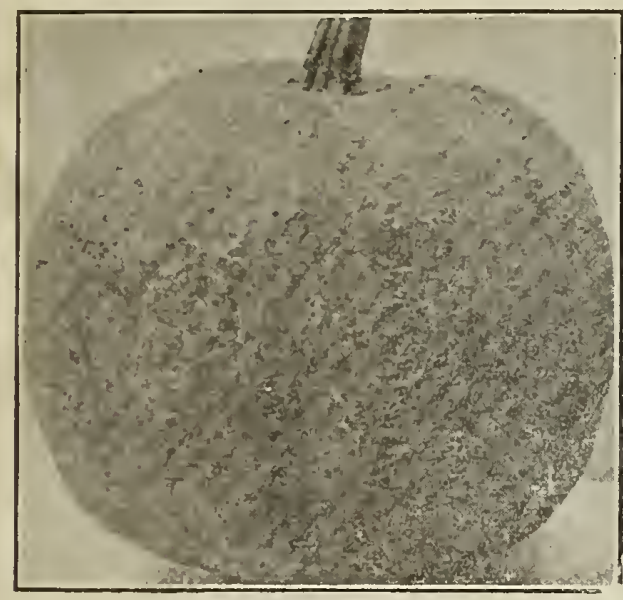

Sugar or Pie.

\section{LARGE CHEESE.}

A popular variety in the South. Fruit flattened, the diameter being 2 or 3 times more than the length. Skin mottled light green and yellow, changing to rich cream color as it matures; flesh tender and of excellent quality.

Plit., 5e; oz., 10e; x/4 1b., 20e; lb., 65e.

COMMON FIELD.

The well-known old Connecticut variety. Grows well among corn; ies in shape. Excellent dairy stock food.

Plkt., 5e; o\%., 10e; $1 / 1$ 1b., 15e; 1b., 40c.

\section{MAMMOTH TOURS.}

A French variety, which grows to an immense size, often weighing over 100 pounds. Fruit is either long or round, but generally flattened at both ends; skin pale green marked with deeper bands and marbling.

Pkt., 5c; 0x., 15c; 1/4 lb., 30e; lb., \$1.00.

\section{KING OF MAMMOTHS.}

The flesh and skin are of a bright golden yellow color. Flesh fine grained and of excellent quality. Notwithstanding its enormous size, it is one of the very best pie pumpkins ever grown, and a splendid keeper. This enormous variety has been grown to weigh over 200 pounds.

Pkt., 5e; oz., 15e; $1 / 4$ 1b., 30c; 1b., $\$ 1.00$.

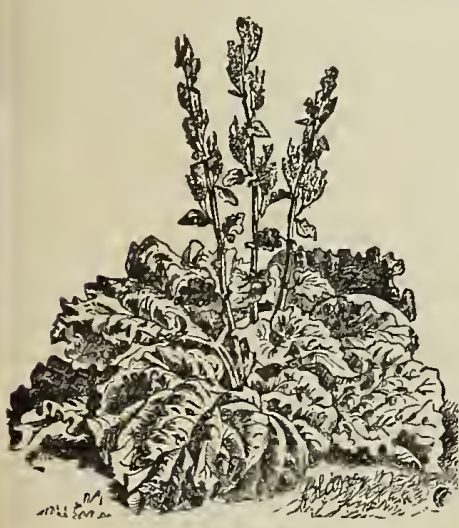

Rhubarb.

\section{RHUBARB}

CULTURE. Rhubarb succeeds best in deep, somewhat retentive soil. The richer its condition and the deeper it is stirred, the better. Sow in drills an inch deep and thin out the plants to 12 inches apart. The following spring inches apart. The following spring transplant into place; set the plants will produce from 400 to 500 plants. will produce from 400 to 500 plants. Morse; price, $50 \mathrm{c}$.

UIN NA EUS, Very early and tender.

Plkt., 5e; oz., 15e; 1/1 1b., 35e; 1b., \$1.25.

VICTORI. Very large, later than Linnaeus.

Pkt., 5e; oz., 15e; $1 / 4$ lh., 35e; lb., $\$ 1.25$.

RHUBARB ROO'TS. Above two varieties, 2 for 25 ; 5 for 50c; 12 for $\$ 1.00$, prepaid if not prepaid, soe per dozen; $\$ 3.00$ per 100.

AUSTRALAN CRMMSON WINTER RHUBARB. Recently offered to the public by Luther Burbank. It can be grown in winter indoors. Every lover of this succulent. plant should give this variety a trial. Seed packet, $5 \mathrm{c}$; roots, $15 \mathrm{c}$ each. prepaid.

King of Mammoths.
CUSHAW, OR CROOKNECK.

A French variety, liked by many. Has yellow flesh, solid and sweet. 65e.

Pkt., 5e; oz., 10c; $1 / 1$ 1b., 20e; 1b.,

\section{KENTUCKY FIELD.}

A large round variety, produced in abundance. Has thick meat of fine quality. Very suitable for canners use.

Pkt., 5c; oz., 10c; 1/4 lb., 15c; 1b., $40 \mathrm{c}$

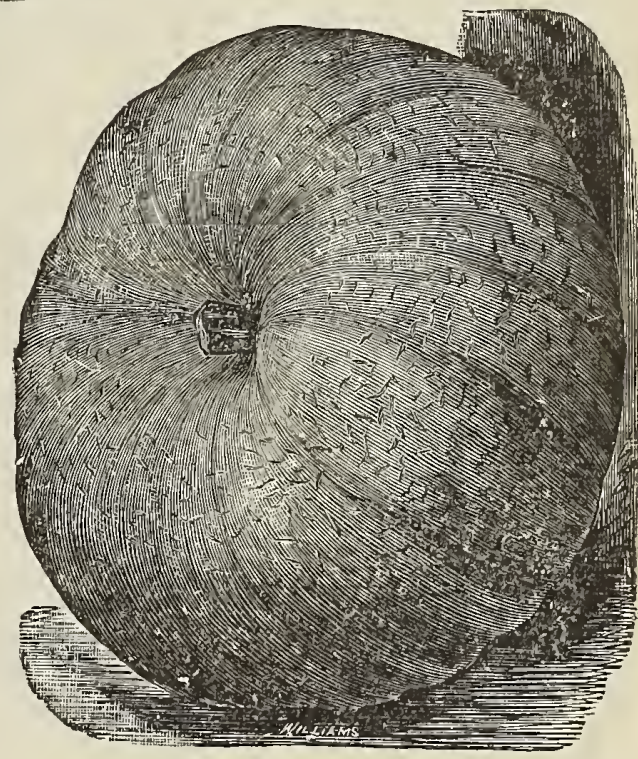

The Barteldes Seed Co.

Iliff, Colo., Oct. 1, 1913. Dear Sirs:

I am inclosing one dollar for which please send me 3 Paper White Narcissi and the rest of dollar worth in Tulips, suitable for outdoor planting. The Garden Seeds I got from you this spring did fine. I took pictures of some of the vegetables and expect to order again this winter, so please send me catalog when ready, and oblige.

MRS, I, R. COLLARD. 


\section{RADISH}

CUITUIE. Sow as early in the spring as the ground can be worked. and every two weeks throughout the season, for

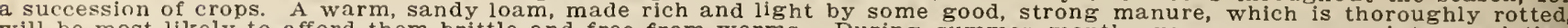

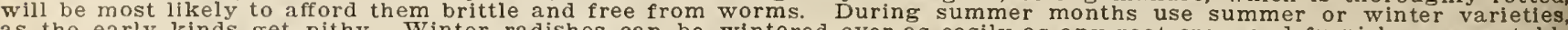

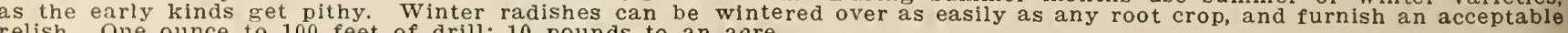
relish. One ounce to 100 feet of drill; 10 pounds to an acre.

Five-pound lots of one variety, $15 \mathrm{e}$ less per pound, not prepaid.

\section{BARTELDES WESTERN SEEDS \\ ARE BEST ADAPTED TO THIS WESTERN COUNTRY}

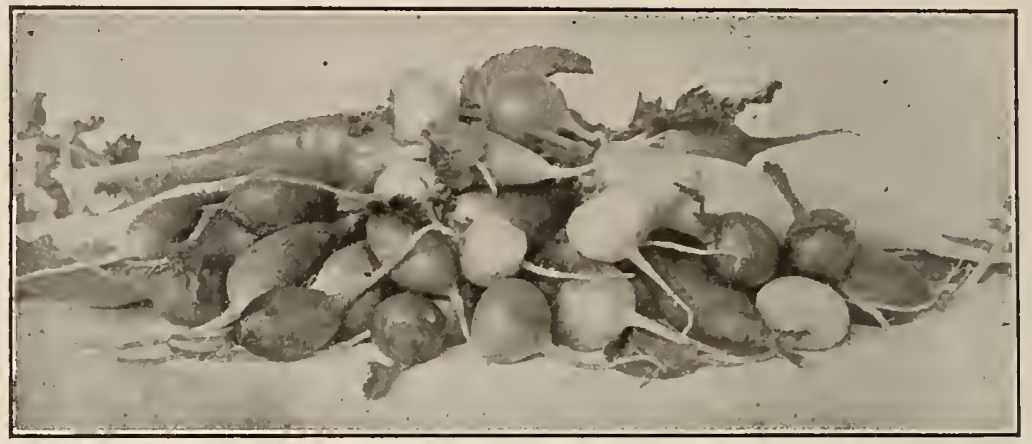

SEEDS, BULBS

AND PLANTS DO NOT TAKE PARCEL POST RATE, BUT A SPECIAL RATE APPLIES

\section{NON-PLUS-ULTRA.}

By far the smallest topped and earliest forcing radish in cultivation Roots small round deep rich red with very crisp, tender, white flesh. This is the very best variety for forcing, as it will mature in 18 to 21 days, and the tops are so small that a large number can be grown in a single bed.

Pkt., 5e; Oz., 10e; 1/4 1b., 25e; 1b., 75e.

\section{CRIMSON GIANT.}

This new radish is an entirely new type and differs radically from all the varieties hitherto in cultivation, in-sofar as its roots attain more than double the size of those of other forcing varieties, without getting pithy or hollow. other forcing varieties, without getting pithy or hollow. ference and over an ounce in weight, their pure white flesh remaining firm, crisp and mildest of flavor. It is equally well adapted to outside culture.

Pkt., כe; oz., 10c; 1/2 1b., 25e; 1b., 75c.

\section{EARLY SCARLET GLOBE.}

This variety makes roots fit to pull as early as NonPlus-Ultra but they are much larger when full size and for this reason are very popular in some markets. Roots round or slightly olive shaped; color rich, deep scarlet; flesh white or slightly

Pkt., 5e; oz., 10e; 1/1 1b., 20e; 1b., 65e.

\section{EARLY SCARLET TURNIP-WHITE TIPPED.}

A beautiful variety; deep scarlet with white tip. It is vory ornarnental for table use, and is very popular as a market variety. It is of the same size and shape as the scarlet turnip variety.

Pkt., 5e; oz., 10e; 1/4 1b., 20c; lb., 60c.

\section{FRENCH BREAKFAST.}

A medium sized radish, olive shaped, with small top, of quick growth, very crisp and tender; of a beautiful scarlet color except near the root, which is pure white.

Pkt., 5e; oz., 10c; 1/4 lb., 20c; lb., 60c.

\section{Long Varieties}

\section{BARTELDES GLASS.}

It is a long radish of light pink color, white tipped, of uniform size. The flesh is transparent white, always crisp and brittle even if grown to a large size, and mild flavored. It was named "Glass Radish" on account of the fine transparency of the flesh.

Plet, 5c; 0z., 10c; 1/4 1b., 25c; 1b., 75c.

\section{EARLY LONG SCARLET SHORT TOP.}

This is undoubtedly the best standard variety for private garden and market use. It grows 6 or 7 inches long, half out of the ground. It is very brittle and crisp and of quick growth. Color, bright scarlet; small top, tapers regularly to the root, and is uniformly straight and smooth.

Plkt., 5e; oz., 10e; 1/1 lb., 20e; 1b., 60e.

\section{CINCINNATI MARKET.}

An improved Long Scarlet Short Top, the roots being more perfect in shape and excellent for forcing.

Pkt., 5e; oz., 10e; $1 / 4$ lb., 20c; 1b., 65c.

\section{LONG BRIGHTEST SCARLET.}

Extra early, the roots being fit for use about 25 days after sowing; very bright color; quite unique, being the most fiery scarlet in any kind of radishes. It is very slightly tipped with white, and the flesh is crisp and tender.

Plkt., 5e; oz., 10e; 1/2 1b., 20e; 1b., 60e.

\section{WOOD'S EARLY FRAME.}

A sub-variety of the Long Scarlet, not quite so long, and a little thicker; of brilliant scarlet color, mild, brittle; of fine flavor, and the most suitable for forcing and early market garden.

Plit., 5e; 0\%, 10c; 1/2 1b., 20c; 1b., 60c.

\section{CHARTIER.}

Color, scarlet at top, shading to pink at center and white at tip. It is very crisp, tender and of mild flavor.

Pkt., 5e; 0\%, 10e; $1 / 1$ 1b., 20c; 1b., 60e. 


\section{RADISH-Continued.}

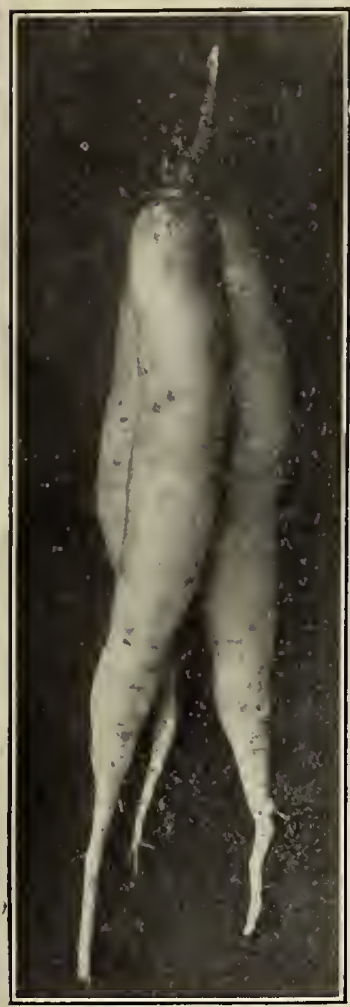

rctcle.

ROUND BLACK SPANISH.

Roots round, sometimes top-shaped, three to four inches in diameter. Skin black, flesh white and pungent. A favorit winter radish in this Western country.

Pkt., 5e; 0z. 10e; 1/4 lb., 25e; 1b., 70c.

\section{LONG BLACK SPANISH.}

This variety is sown the last of summer for fall and winter use. Grows to a large fize; oblong shape; quite solid. If stored in pits, or packed away in sand, it will keep until spring.

Pkt., 5e; oz. 10e; 1/4 1b., 25e; 1b., 70c.

SAKURAJIMA, OR JAPANESE RADISH.

This mammoth winter radish attalns a length of two feet and a diameter of one foot and more. It is a white variety of mild and more. It is a white variety of like turnips pickled in in it can be cooked like turnips, pickled in brine, or sliced and eaten raw like other winter radishes. Its leaves make a very pleasing new green, cooked the sarne as kale or dandelion. The seed must not be sowed before July or it will run up to seed and will make no root is ready for the table early in autumn and keeps in a cool cellar all through winter.

Pkt., 10c; o\%., 20c; 1/4 lb., 60c; lb., \$1.75.

\section{WHITE ICICLE.}

wre white. Very early; much the earliest and finest long
ly as Long Scarlet Short Top, with less foliage, rendering 作 they are fully as large as those of the Long Brightest Scarlet. The Icicle is, perhaps, superior to the finest,long red. Roots pure snowy white, 4 inches in length and $1 / 2$ an inch in diameter; l'kt., 5e; oz., 10e; $1 / 1$ lb., 20e; 1b., 65e.

\section{LONG WHITE VIENNA.}

hite radishes in cultivation. It is most beautiful in shape: nesh are pure snow whit

\section{WHITE DELICIOUS.}

er use than the White Vienna. The roots are thicker and the esh is even more solid. It does not grow so quickly, but will stand longer in good condition. The roots are of a pure paper whiteness, half long in form, gradually tapering at the lower end.

\section{WHITE STRASSBURG.} Thm, brittle, tender, and possesses the most desirable character of retaining its crispevere heat and grows very quickly.

\section{GIANT WHITE STUTTGART.}

large, top-shaped, and of quick growth. In 5 to 8 weeks after being sown it will proarge roots. Notwithstanding its large size, the quality is always the very finest, firm, pkithy not pithy

YELLOW SUMMER TURNIP.

fall sort; best to stand the heat; can be sown late; is a general rite with market gardeners; large, oblong, russet color.

Pkt., 5e; oz., 10e; 1/4 lb., 20c; lb., 70c.

\section{Winter Varieties}

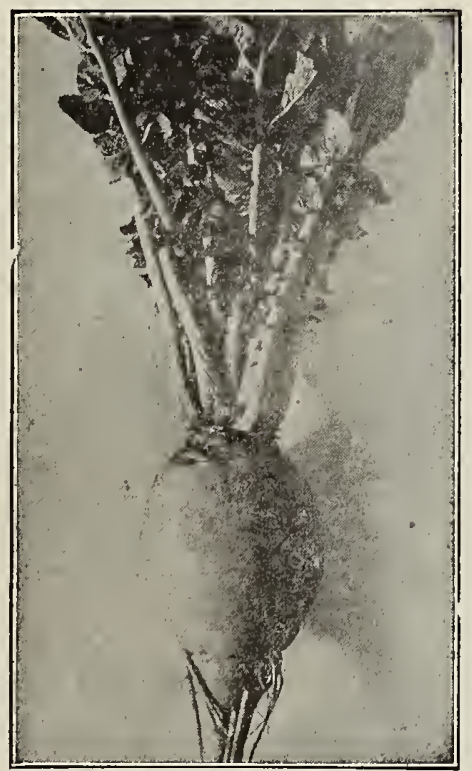

Japanese Winter Radish.

CHINA ROSE-COLORED.

It is of a half-long shape, pink color flesh solid. It has not that strong flavor peculiar to the Black Spanish and keeps equally well. It should be sown during August.

Pkt., 5e; oz. 10e; 1/4 1b., 25e; 1b., 70c.

CHINESE WHITE, OR "CELESTIAL."

This is the large white radish, cultivated extensively by the Chinese gardeners about San Francisco. It keeps well into the winter, and is usually crisp and not strong. Our seed is direct from California Pkt., 5e; ox., 10c; $1 / 4$ lb., 25c; lb., 80e.

CALIFORNIA WHITE MAMMOTH.

A giant whitefleshed fall radish. It grows from 8 to 12 inches in length a n d a b o u t $2 \frac{1}{2}$ inches in diaming solid, tender and of very good flavor, which is maintained many weeks after gathering.

Pkt., sc; oz., 10c: 1/4 1b., 25c; 1b., 70c.

\section{SALSIFY OR OYSTER PLANT}

CU1.'URE. The Oyster Plant succeeds best in light, well enriched, mellow soil, which, previous to sowing the seeds, should be stirred to the depth of 18 inches. Sow early in the spring, in drills 15 inches apart; cover the seeds with fine soil 1 inch deep. One ounce for 60 feet of drill; 7 pounds to one acre.

\section{MAMMOTH SANDWICH ISLAND.}

This new Salsify, recently introduced from the Sandwich Islands, grows fully double the size of the common variety, and is superior in quality. It is pure white in color, and is invaluable to market gardeners.

Pkt., 5e; oz., 15c; 1/4 1b., 40c; lb., \$1.25.

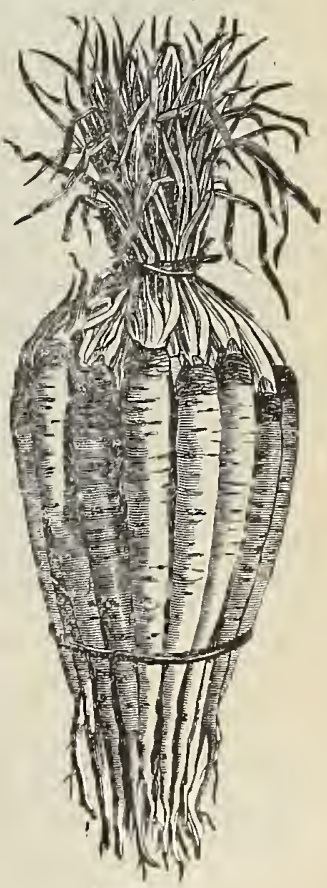

Salsify. 


\section{SPINACH}

CUI'ICLE. It is one of the most easily managed of all vegetables, requiring but llttle culture. The maln crop is sown in scptember, and it is sometimes covered with straw in exposed places durlng winter, which plevents it flom being cut witl the frost. For summer use it may be sown at intervals of 2 or 3 weeks from Malch to August. Spinach is best developed, most tendel and succulent when grown in rich soll. One ounce to 100 feet of drill; 10 to 12 pounds to an acre. Flve lbs. or nore of one variety, not prepald, nt 15e less per

ROUND SUMMER.

This variety is generally preferred for early spring sowing, and is ponular wlth the market gardeners. Leaves lare, thick and fleshy. Not quite so hardy as the prickly, but stands winter well.

Pkt., כ̌e; 0\%., 10e; $3 / 1$ 1b., 15c; 1b., 35e VICTORIA.

The foliage is heavy, the broad, dark leaves being of the true Savoy appearance, and are of the finest quality, bu the features that make it of special value, both for market and family gardens, is that it is in prime conother varieties of spinach have run to seed.

Pkt., 5e; oz., 10e; 1/1 1b., 15e; 1b., 35c.

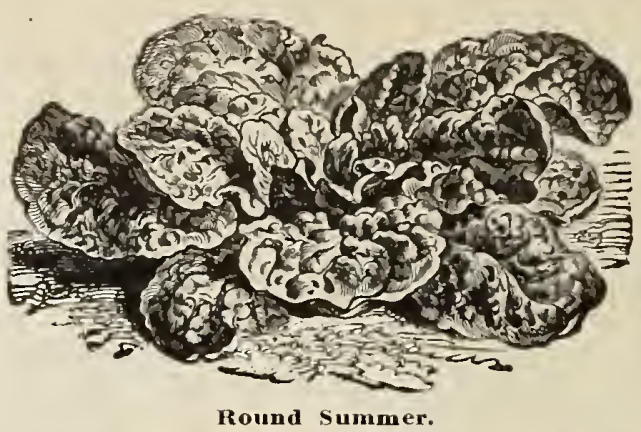

ARGE ROUND THICK LEAF VIROFLAY.

\section{LONG STANDING.}

An improved strain of excellent merit, having all the good qualities of the ordinary sorts; what renders it especially desirable is the fact that it is much later in going to seed than any other variety.

Pkt., 5e; oz., 10c; 1/s 1b., 15e; Ib., 35e.

\section{PRICKLY WINTER.}

The hardiest variety, and will withstand the severest weather, with only alight protection of leaves or straty. The seed is prickly; leaves triangular. oblong, or arrorv-shaped. It is the best for fall sowing, which in this latitude is made about the first of September.

Pkt., 5e; oz., 10c; 1/1 1b., 15c; lb., 35e.

A variety with very large, thick leaves, making it especially desirable where bulk is desired,

Pkt., 5c; 0z., 10e; 1/4 lb., 15c; 1b., 35c.

\section{AMERICAN CURLED SAVOY LEAVED.}

A inost valuable variety. In appearance the leaf is wrinkled in the same way peculiar to Savoy Cabbage, from whence the name. It produces nearly twice the bulk of crop as the ordinary sort, is fully as hardy, and in all respects equal.

Plet., 5e; oz., 10e; 1/4 1b., 15e; 1b., 35c.

NEW ZEALAND.

This is different from the ordinary type of spinach, being of a branching habit, producing large, thick leaves, which

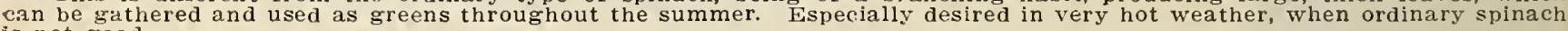
is not good.

Pkt., 5e; 0z., 10c; 1/4 1b., 30c; 1b., $\$ 1.00$.

\section{SQUASH}

CULTUIRE. Solv about the middle of spring, in hills, the early sorts about 4 feet apart, and the late varieties 6 to 8

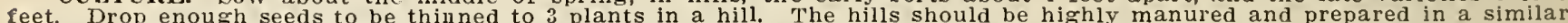

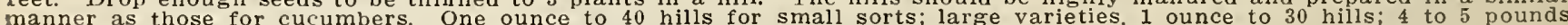
to an acie.

Five pounds or more of one variety, not prepaid, at $15 \mathrm{c}$ less per pound.

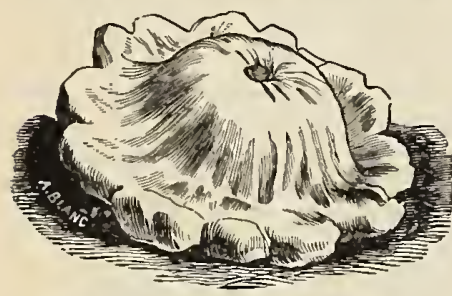

White Buslt or Patty Pau.

EARLY WHITE BUSH.

The earliest to mature; very productive; light cream colored.

Plit., 5c; 0\%., 10c; $1 / 1$ lb., 25e; ll., 75c.

MAMMOTH WHITE BUSH.

The fruit is a beautiful clear waxy-like and is much larger than the above variety. Plit., 5e; oz., 10e; 1/1 1b., 25e; 1b., 75c.

GOLDEN SUMMER CROOKNECK.

A small crooked-necked, summer squash skin bright yellow covered with warty increscences Very early productive and of excellent flavor.

Pkt., 5e; oz., 10c; 1/4 1b., 25e; 1b., 75c.

MAMMOTH SUMMER CROOKNECK.

It is the best summer squash, and for these reasons: It is twice as large as the ordinary summer Crookneck, far more warty and several days earlier.

Plet., 5e; or., 10c; 1/1 1b., 25e; 1b., S0c.

\section{PROFILIC MARROW}

Is remarkably productive and very early, being about 12 days ahead of the Boston Marrow. Its color is most attractive-a brilliant orange red; quality excellent; a good keeper.

Plet, Je; oz., 10c; $1 / 4$ lb., :30c; 1 b., 90c.

\section{BOSTON MARROW.}

Oval in form; color of skin bright orange, flesh yellow: very desirablc for late autumn and winter use

Pkt., Je; oz., 10e; 1/4 1b., 30e; 1b., 90e.

\section{VEGETABLE MARROW.}

A favorite English sort; early, skin greenish-white, flesh white, soft and of rich flavor; quite distinct from other sorts.

Pkt., 5e; oz., 10e; 1/t lb., 30c; lb., \$1.00. •

\section{FORDHOOK}

One of the hardiest, flesh thick, small seed cavity, and a good keeper.

1'kt., 5e; oz., 10e; x/4 1b., 30c; 1b., 90c.

\section{DELICIOUS.}

One of the best squash for table use, combining finemess and compactness of grain, dryness and exceeding richness of flavol. It is an excellent fall and winter variety though it does not acquire its best quality until winter. The fruits usually weigh from 6 to $10 \mathrm{lbs}$. The rind is uniformly green; the flesh dark orange and very thick.

I'kt., 5e; oz., 10e; 1/4 1b., 30c; 1b., \$1.00.

\section{ESSEX HYBRID.}

An improved American Turban, having the color, shape and superior qualities of the Turban, with the dry and hard shell of the Hubbard.

1'lkt., 5e; oz., 10e; $1 / 4$ 1b., 30e; 1b., 90e.

SIBLEY'S.

One of the best for shipping owing to the hardness of the shell. Flesh is solid and thick, a bright orange color and of choice quality.

Pkt., 5c; oz., 10c; 1/4 1b., 30e; lb., \$1.00.

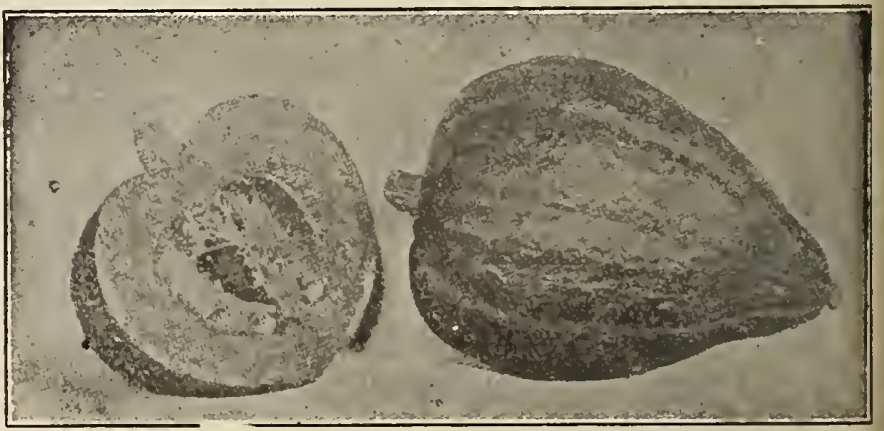

Dellelous. 

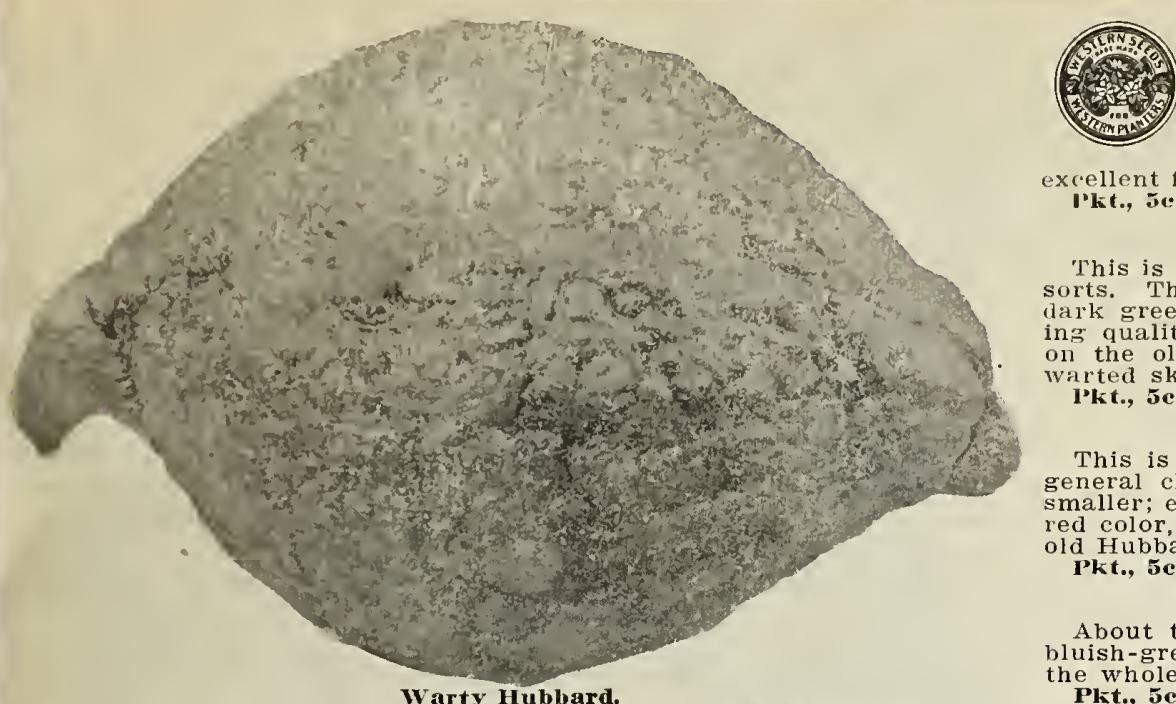

HUBBARD.

The best table squash yet known ood specimens being about equa to the sweet potato. It has a har shell, and with some care will keep three months later than the Marrows; flesh fine grained, dry and of excellent flavor.

let., 5c:; 0z., 10e; $1 / 3$ lb., 30e; Ib., \$1.00.

\section{WARTY HUBBARD.}

This is one of the best in quality of all winter sorts The flesh is dry and sweet Shell very talk oreen and hard, which insures long keeping qualities. It is considered an improvement on the old type of Hubbard, on account of its varted skin.

l'kt., 5e; oz., 10e; 1/1 1b., 30c; 1b., \$1.00.

\section{GOLDEN HUBBARD.}

This is a very distinct sort of the shape and general character of the Hubbard, but a little smaller; earlier to mature, and of a rich orangered color, instead of the dark olive-green of the old Hubbard.

Pkt., 5e; oz., 10e; 1/4 lb., 30e; Ib., \$1.00.

\section{MARBLEHEAD.}

About the size of the Hubbard, with shell of bluish-green, and bright orange flesh. Requires the whole season to mature.

Pkt., 5e; oz., 10e; $1 / 1$ lb., 30c; lb., \$1.00.

Size, enormous, often weighing 100 to 200 pounds; very profitable for stock feeding, especially where root crops are rown extensively; remarkably productive.

Pkt., 5e; oz., 10e; 1/4 1b., 30e; 1b., \$1.00.

\section{TOBACCO}

CULTURE. Tobacco, in this part of the country, should be started in hot-bed in March, and treated the same as tomato.

HAVANA. Pure Cuban-grown seed. When grown in this country commands a high price as cigar stock. Pkt., 5e; oz., 30e; $1 / 1$ lb., \$1.00.

MISSOURI BROAD LEAF. A well known standard sort, valuable for cigar wrappers. Pkt., 5e; oz., 25c; 1/4 Ib., 75c. CONNECICUT SEEU LEAF. Best adapted to the climate of the middlc and Northern states, as it is more hardy and endures the cold better than the tender varieties grown in the South. Pkt., 5c; oz., 25e; 1/4 lb., 75c.

White BURLEY. A variety largely grown for the manufacture of Fine Cut and Plug. Pkt., 5e; oz., 50c; 1/4 Ib., \$1.50.

\section{TOMATO}

CULTURE. The seed should be sown in March, in a hot-bed or greenhouse, or they may be sown in a box and kep

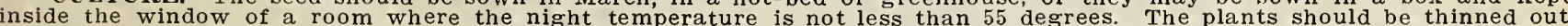

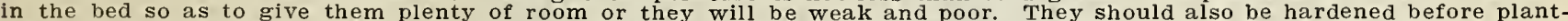

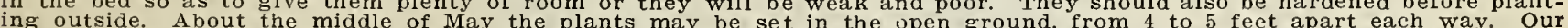

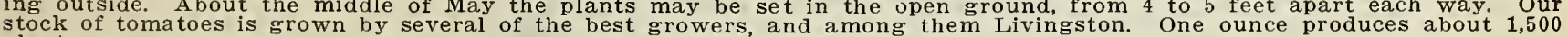
stants.

CHALI'́, EARLY JEWEL. SEe Novelties.

EARLIANA.

Produces fruit earlier than any other variety. The quality is good, of large uniform size, red color. It is very solid being a shy seeder. Every gardener will make good profit on early tomatoes when raising Farliana.

\section{JUNE PINK.}

This new Tomato resembles Earliana, except in color which is a fine pink color. It is the earliest pink tomato grown, and is from $21 / 2$ inches to 3 inches in diameter. The vines are very robust, almost blight proof, and very heavy bearers, being the first on the market, and lasts till frost

Pkt., 5e; 0z., 25e; 1/4 Ib., 75c; lb., \$2.25.

\section{EXTRA EARLY RED.}

An old favorite and much in dcmand for private gardens where early small size tomatoes are wanted.

Plit., 5e; oz., 20e; 1/4 Ib., 60c; lb., \$2.00.

\section{DWARF CHAMPION.}

Its close, upright growth enables it to be planted much nearer together than any of the other sorts, and the yield. therefore, is accordingly much greater. In productiveness it is unsurpassed. It is also very early; is medium sized and attractive in appearance; the skin is tough and the flesh solid and of fine quality.

Plkt., 5e; oz., 25e; 1/4 Ib., 75e; 1b., \$2.25.

\section{NEW CORELESS}

A large main crop, bright red variety which may soon take the place of all other tomatoes now used for canning and catsup making. It is immensely productive, clusters of four to seven fruits are produced at six to eight inches apart along the stem when plants are trained to stakes. All of the fruits are of a marketable size, almost round in shape, with rlepression at the stem almost eliminated. The seed cells are surrounded by bright red, heavy, meaty and delicious flesh. It is a very frm fruit and one of the best for long distance shipping.

Pkt., 10c; 1/2 oz., 20c; oz., 30c; 1/1 lb., \$1.00; Ib., \$3.50.

\section{THE TRUCKER'S FAVORITE TOMATO.}

Its fine, smooth, uniformly shaped fruits command the highest market prices. The fruits are thick meated and very solid; the meat is of the finest flavor, making the tomatoes equally good for slicing and for cooking purposes. The vines are of strong growth, not subject to rust or blight, and bear enormous crops iill frost

Pkt., 5e; oz., 25e; 1/4 1b., 75e; Ib., \$2.25.

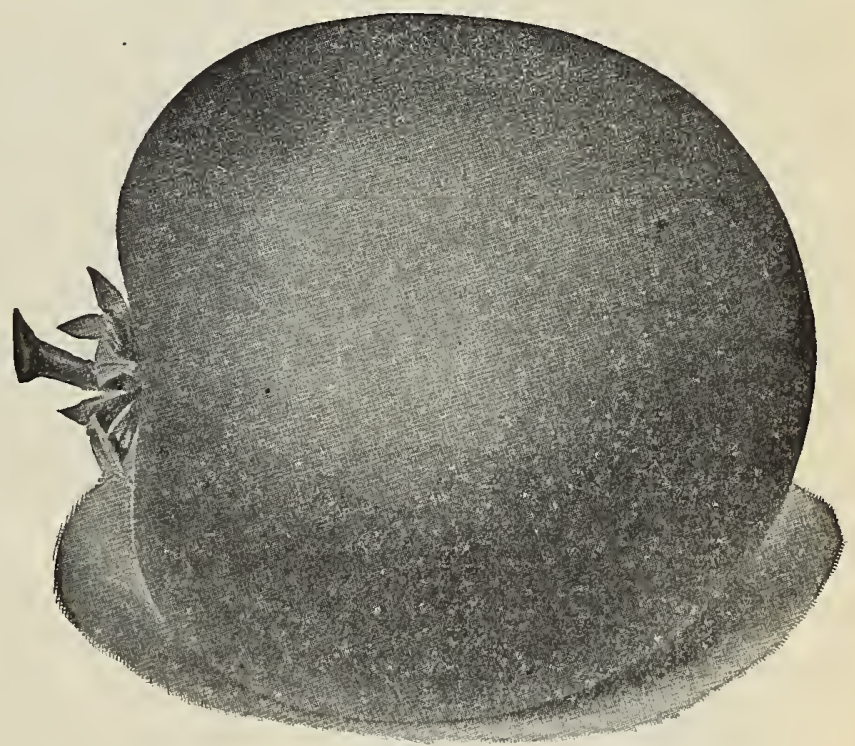

New Coreless.

KANSAS STANDARD.

The "Kansas Standard" belongs to the potato-leaved class; is of rapid, vigorous growth, with strong, heavy stalks which stand up well unless, which is often the case, they are pulled down by over abundant fruit. It begins they are pulled down by over abundant fruit. It begins blooming when only 6 or 7 inches high, attains a height of and is produced in clusters of 4 to 5 tomatoes.

Pkt., 5e; oz., 30c; 1/4 lb., 90c; Ib., \$3.00. 
BEAUTY.

The color is a very glossy crimson, with a slight tinge of purple. $1 \mathrm{t}$ grows in clusters of 4 or 5 large fruits, retaining its size very late in the season. It is very productive and will yield more pounds of fruit to the acre than most other kinds. It ripens early and evenly, and is perfect

Pkt., 5e; oz., 20e; 1/1/1b., 60e; lb., \$2.00.

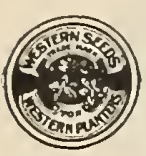

\section{BARTELDES SELECTED STRAIN BEAUTY.}

Grown especially for us, and under our personal care, from specimens selected and improved. It is the smoothest and best of the large purple sorts. Nothing better and more worthy to carry our trade mark.
l'kt., 5e; ox. 25e; 1/1/ 1b., 75e; 1b., \$2.25.

\section{HONOR BRIGHT.}

The foliage is yellowish green, and the first fruit as it ripens turns first white, then yellow, and when fully ripe is a bright red. The fruit ripens slowly and seems to ripen up exceptionally well after picking, so that the fruit can be picked when white, packed and shipped, and after 5 to 10 days will be found solid and ripened to a rich, bright red.

Pkt., 5e; oz. 25e; 1/4 1b., 75e; lb., \$2.25.

\section{ATLANTIC PRIZE.}

This is one of the largest, smoothest, best flavored and brightest colored extra early tomato.

Pkt., 5e; oz., 20e; 1/4 1b., 60e; 1b., \$2.00.

BARTELDES SELECTED STRAIN STONE. Grown by the same grower who grows Barteldes' Selected Strain Beauty, with same care, and bearing also our trade mark. It ripens for main crops; is very large, and bright scarlet color: very smooth, ripening evenly to the stem fleshed as the name indicates; is an excellent shipper; quality the very best; fine for canning; a good keeper, not subject to rot.

Pkt., 5c; oz. 25e: 1/2 1b., 75c; 1b., \$2.25.

\section{NEW MATCHLESS TOMATO.}

The vines are of strong, vigorous growth, well set with fruit. The fruits are free from core, of a rich cardinal red color, and are not liable to crack from wet weather; are of very large size, which is maintained throughout the season until killed by frost. The skin is remarkably tough and solid, and ripe specimens picked from the vines will keep in good condition for several weeks.

Pkt., 5e; oz., 20e; $1 / 1$ 1b., 60e; $1 \mathrm{~b}$. , $\$ 2.00$.

TROPHY. An improved sort for either private use or market garden.................. ROYAL RED. It is a first-class main crop variety for the shipper, market and private

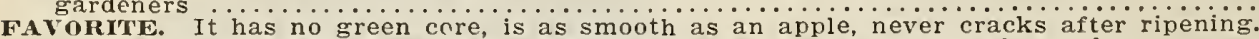
It is a brilliant dark glossy-red color, ripening all over and through evenly........ ACME. A tomato of superior quality; size, meâium; color, maroon or reddish with sligh

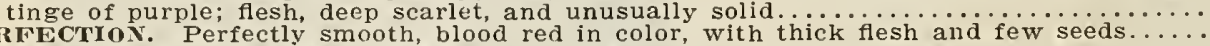

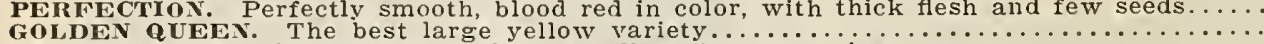

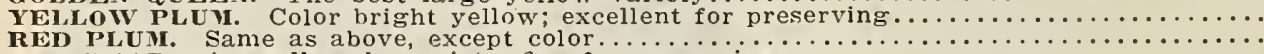

RED PEAR. A small early variety, fine for preserving.

YELIOIV PEAR Same as above, except color.......

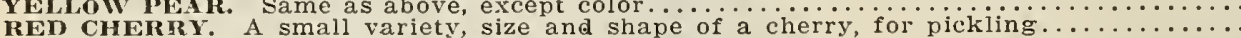

YELlOW CHERIR Same as above except color .

HUSK TOMATO, oR YELLOW GROUND CIERRY. This is liked by many for preserves and

\section{Aromatic, Medicinal and Pot Herbs}

Every Kitehen Garden Should Have a Few of These Useful Herbs.

\begin{tabular}{|c|c|c|c|}
\hline $\begin{array}{l}\text { Pkt. } \\
\text {.05 }\end{array}$ & $\begin{array}{l}\mathrm{Oz} \\
\mathbf{\$} . \mathbf{2 0}\end{array}$ & $\begin{array}{l}1 / 4 \mathrm{lb} . \\
\$ .60\end{array}$ & $\begin{array}{l}\text { Lb. } \\
\mathbf{\$ 2 . 0 0}\end{array}$ \\
\hline .05 & .20 & .60 & 2.00 \\
\hline .05 & .20 & .60 & 2.00 \\
\hline .05 & .20 & .60 & 2.00 \\
\hline .05 & .20 & (0). & 2.00 \\
\hline .05 & .25 & .75 & 2.25 \\
\hline .05 & .25 & .75 & \\
\hline .05 & .25 & .75 & \\
\hline .05 & .25 & .75 & \\
\hline . & .25 & .75 & \\
\hline .05 & .25 & .75 & \\
\hline .05 & .25 & .75 & $\ldots$. \\
\hline .05 & .25 & .25 & \\
\hline
\end{tabular}

Pkt. Oz.

Anise. An annual, cultivated for its seeds and its leaves, which have a fragrant, agreeable scent, and a pleasant taste..................... se 10e Balm. A hardy perennial of aromatic taste and a
greateful fragrant smell................... Borage. Annual; in Germany the leaves the cut and used for cucumber salad............... 5e 15e

Caraway. The seeds are used or flavoring....... 5e 10e

Catnip or Catmint. A great favorite among medicinal herbs ......................... 5e $\mathbf{3 5 c}$

Cliervll. Annual; used for soups and salads...... 5e $15 \mathbf{e}$ Coriander. Annual; its tender leaves are sometimes used for soups and salads................. 5e 10e

Dandelion. Perennial; cultivated or spring greens; an excellent tonic..................... 5c $\mathbf{2 5 c}$

DIll. Annual; it is cultivated for its seeds which are used medicinally and for flavoring pickles.. 5e
Hop. The popular variety of commierce... Pkt. Oz.

Horehound. Perennial; used as a tonic.......... se $20 \mathrm{c}$

Iyssop. A perennial with aromatic flowers and of pungent flavor ...................... 5e $20 \mathrm{c}$

Lavender. Perennial; eultivated for its fragrant flowers and aromatic leaves................ 5e $15 \mathrm{c}$

Rosemary. Perennial; the tops only are used as a medicine .......................... 5e $40 \mathrm{c}$

Rue. Perennial; a very powerful tonic. It must not be allowed to run to seed................. sc $15 \mathrm{c}$

sage. Perennial: tea made from the leaves is an exrellent means for producing sweat. $1 / 4 \mathrm{~b}$.,

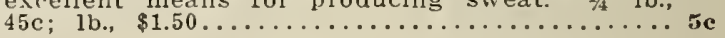
$15 e$

Safron. Annual; the dried flowers are used for medicinal purposes ....................... 


\section{POT HERBS-Continued.}

Pkt. Oz.

Savory. Annual; leaves are used for culinary pur-

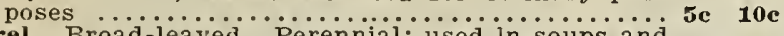

Sorrel. Broad-leaved. Perennial; used in soups and salads and sometimes cooked like spinach

sweet Basil. Annual; the leaves are used for highiy seasoned dishes ..................... 5e 15e

Srrect Fennel. Perennial. Tea made from the seeds is an excellent remedy in case of colic and stomach complaints ...................... 10

\section{TURNIP}

CUJTURE. Turnips do best in highly enriched, light, sandy or gravelly soil; commence sowing earliest varieties in

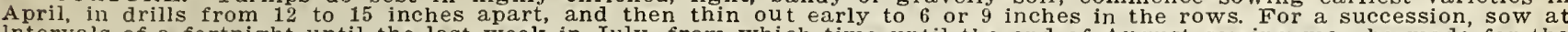

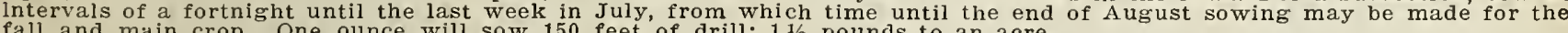
fall and main crop. One ounce will sow 150 feet of drill; $11 / 2$ pounds to an acre.

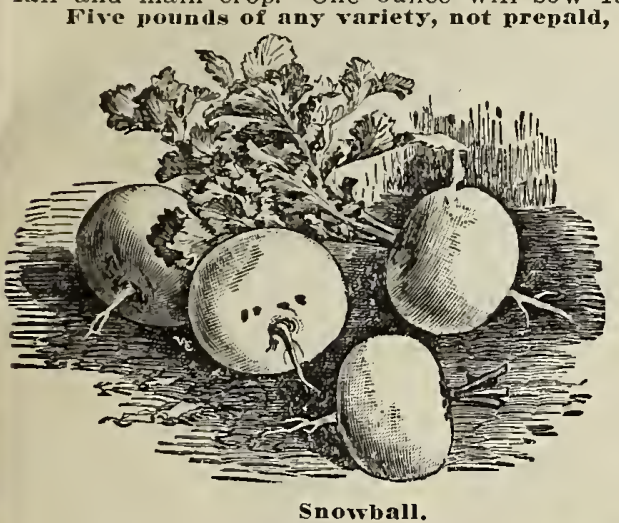

EARLY WHITE EGG

A quick growing egg-shaped, perfectly smooth, pure white va rlety, growing half out of the ground, with small top and rough leaves. Its smooth, white skin and quick growth make it particularly deslrable for market purposes. The flesh is very sweet, firm and mild, never having the rank, strong taste of some varieties.

Pkt., 5e; oz., 10c; 1/4 1b., 20c; 1b., b0c.

\section{EARLY WHITE FLAT DUTCH-} Strap-Leaved.

Thls is a popular early turnip for table use for autumn and early winter, but as they become overripe with age, and in keeping lose somewhat of their succulence, the need to be succeeded by the Pomeranian Globe or Golden Ball.

Pkt., 5e; oz., 10c; $1 / 4$ lb., 20c; 1b.,

PURPLE TOP-Strap-Leaved.

The standard of this part of the country. Superior for early or late planting. Round, flat, good sized, small top with but, good sized, fesh very fine grained flavor good resh very fine grained; flavor good.

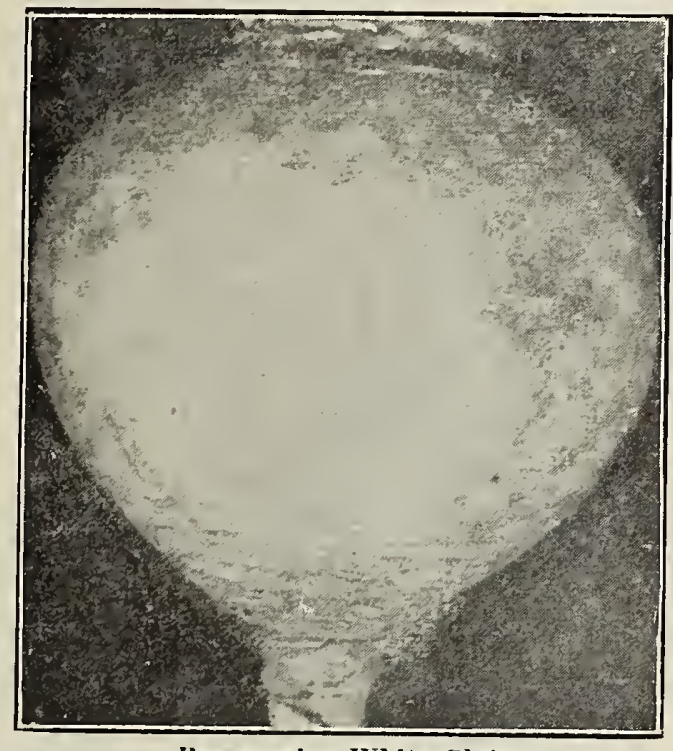

Pomeraniau White Globe.

\section{EXTRA EARLY WHITE MILAN.}

The earliest in cultivation. The bulb is very flat of medium size, quite smooth. It is a nure white, thus making it especially desirable for forcing. Pkt., 5e., oz., 10e; 1/4 lb., 25e; 1b., 75e.

\section{EXTRA EARLY PURPLE TOP MILAN.}

A bright puiple top; leaves few, short and light of color growing very compact, and makes an exceedingly small and neat top. The pure white flesh is of the choicest quality, hard, solid and fine grained. It is an excellent keeper.

Pkt., 5e., o\%., 10c; 1/4 1b., 25c; 1b., 75c.

\section{EARLY SNOWBALL.}

It is medium sized, pure white and early, of excellent quality. In our market it is much admired.

Plet., 5e; ox., 10e; 1/4 lb., 20c; lb., 50c.

\section{AMBER GLOBE-Strap-Leaved.}

One of the best varieties, either for table use of a field crop for stock. Flesh yellow fine grained and sweet; color of skin, vellow with green top. Hardy, keeps well; a good cropper, grows to a very large size.

Plkt., 5e; oz., 10e; y/4 lb., 20e; lb., 50e.

\section{GOLDEN BALL.}

Undoubtedly among the most delicate and sweetest yellow fleshed turnips yet produced. Not of large size, but firm, hard and of most excellent flavor. Pkt., 5c; oz., 10c; $1 / 4$ lb., 20c; 1 b., 50c.

\section{COW HORN.}

This variety is pure white, except a dash of green at the crown, and in

Phape is long like a carrot, and generally crooked, hence its name.
Plkt., 5c; oz., 10e; $1 / 4$ lb., 20e; 1b., 50c.

\section{SWEET GERMAN,}

Flesh white, hard and firm, partaking much of the nature of a rutabaga. Must be sown much earlier than the flat turnips. In the autumn and early Pkt., 5c; oz., 10c; 1/4 lb., 20e; lb., 50c.
Plke an apple by keeping.

\section{YELLOW, PURPLE TOP RUTABAGA.}

Hardy and productive, Hesh yellow, of solid texture sweet and well flavored; shape slightly oblong; terminates abruptly with no side or bottom roots; color deep purple above and bright yellow under the ground: leaves small, light green, with little or no neck; the most perfect in form, the richest in flavor, and the best in every respect.

Pkt., 5e; oz., 10e; 1/4 lb., 20c; 1b., 50c.

\section{LARGE EARLY RED TOP} GLOBE.

Large size, rapid growth, un usually attractive and admired by all. Pkt., 5c; oz., 10c; 1/4 1b., 20c; 1b.

\section{POMERANIAN WHITE GLOBE-} Strap-Leaved.

This is a free-growing, roughleaved sort, useful for both table and stock. It is not quite so rapid in growth as the flat varieties; may be expected to come in as a succession in autumn and is admirable for table use in early winter.

Pkt., 5e; oz., 10e; $1 / 4$ 1b., 20e; lb., soc.

\section{YELLOW ABERDEEN OR SCOTCH YELLOW.}

This is a highly approved cattle turnip, attaining a large size. It is solid, nutritious, a good keeper, and is in every respect reliable. ธoc. 


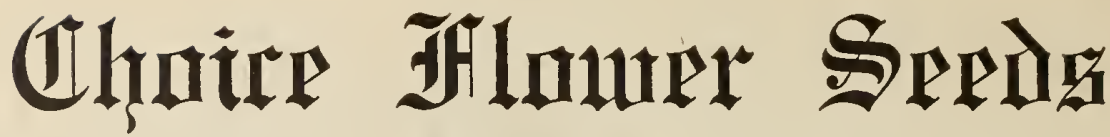

\section{DIRECTIONS FOR PLANTING AND CULTURE PRINTED ON EACH PACKAGE}

\section{All Flower Seeds Sent Prepaid on Receipt of Price}

\section{ABRONIA-Umbellata.}

A handsome trailing plant, with clusters of sweetscented Howers resembling Verbenas in shape, but of smaler vase, color, rose lilac, with white eye. Fine husk from the seed before sowing (as it grows much surer.) Height, 6 inches. Halfhardy annual.

ABUTILON, or Flowering Maple.

Desirable for the conservatory in winter, and effective border plants during summer, producing a profusion of lovely bell-shaped 年, 2 to 6 Finest Mixed.

\section{ACROCLINIUM.}

This beautiful everlasting flower somewhat resembles the Rodanthe, but the flower heads are of larger size. It is largely used for winter bouquets, for which purpose the flowers should be cut before they are fully expanded. Half-hardy annual.

$$
\text { Mixed. Ptk. 5e }
$$

White.

Pkt. 5c

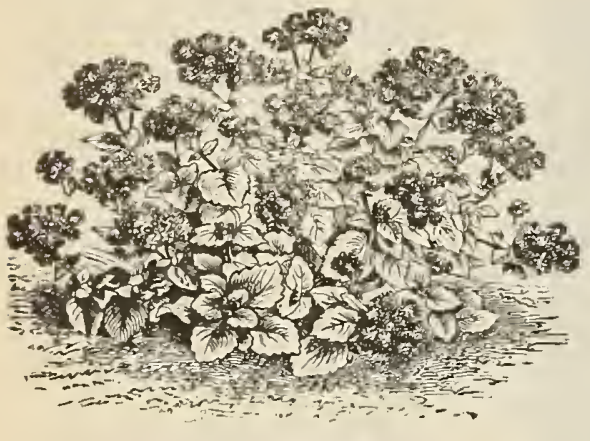

Ageratum.

Dwarf, or Little Gem.

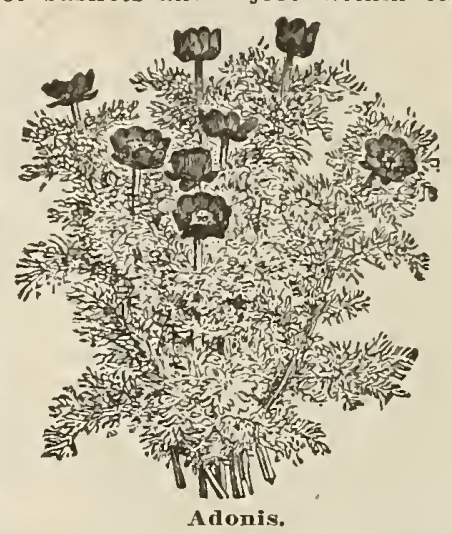

ADLUMIA, or Allegheny Vine.

A most beautiful and graceful climber, thriving in a sheltered situation, and climbing by its tendrils to any obreach. Is sometimes known as Mountain The beautiful pink and white flowers are produced in abundance during the three summer months. It is biennial and thate put ler months. It is biennial, and makes feet. Pkt. 10e

ADONIS-Aestivalis.

Plants with fine and graceful foliage, and brilliant scarlet flowers, remaining a long time in bloom. Grows well in the shade or under trees. Height, 1 foot. Hardy annual.

\section{AGROSTEMMA-Coronaria.}

(Rose Campion.)

Perfectly hardy plants, producing pretty pink-like blossoms on long slender stems. Very useful for putting into bouquets, and
pretty in masses or in beds. About $11 \%$ feet high. Fine mixed. Perennial. A Pkt. $5 \mathrm{c}$ AGERATUM-Mexicanum.

Flowers light blue or lavender; very desirable for bouquets, furnishing a continuous bloom through the summer. Plants flower well in the house in winter, when potter in the fall before frost. Height, 12 inches. Hardy Pkt. 5c

\section{ALONSOA-Myrtifolia.}

An attractive bedding plant with remarkably brilliant scarlet flowers, in bloom from July till frost. Removed to the house, they bloom well during winter. Height, is inches. Half-hardy annual.

Pkt. 5e

\section{ALYSSUM-SWEET.}

A favorite flower for bouquets; white, very fragrant and producing a succession of blooms through the summer and until after severe frosts. Always wanted when a bouquet is made.

Maritiuum. Oz. 20c; Pkt. 5c Saxatile, Flowers brilliant golden yellow completely hiding; pke foliage. Hardy perennial. Height, 1 foot. Pkt. 5c

\section{AMARANTHUS.}

Valuable for its varieties of handsome foliage, whether grown in the conservatory or garden. The colors will be more brilliant if planted in moderately rich soil. Height, 2 to 3 feet. Hardy annual.

'Tri-Color (Joseph's Coat).

Caudatus (Love Lies Bleeding).

Cruentus (Princess Feather).

Phit. 5e Pkt. 5e

\section{AMMOBIUM-Alatum. (Everlasting.)}

A small, white immortelle or everlasting, very useful for cutting when fresh, and drying admirably for winter bouquets; producing a succession of blooms from July till frost. Height, 18 to 24 inches. Hardy annual.

\section{ARMERIA-Maritima (Sea Pink.)}

Pkt. 5e

These handsome plants are well adapted for ornamenting rock work and edging walks. Hardy perennial. Height, 6 inches. Rosy pink. Pkt. Jc

\section{AMPELOPSIS.}

One of the best climbing plants for permanent situations, as it is perfectly hardy, climbing to the sides of whatever it may be grown against by the rootlets it throws out all along the stems. In the autumn the dark-green foliage assumes beautiful tints of orange, crimson, etc. Height, 50 to 100 feet. Hardy perennial.

Quinquefolia (American Woodbine)

Veitchii (Japan or Boston Ivy).

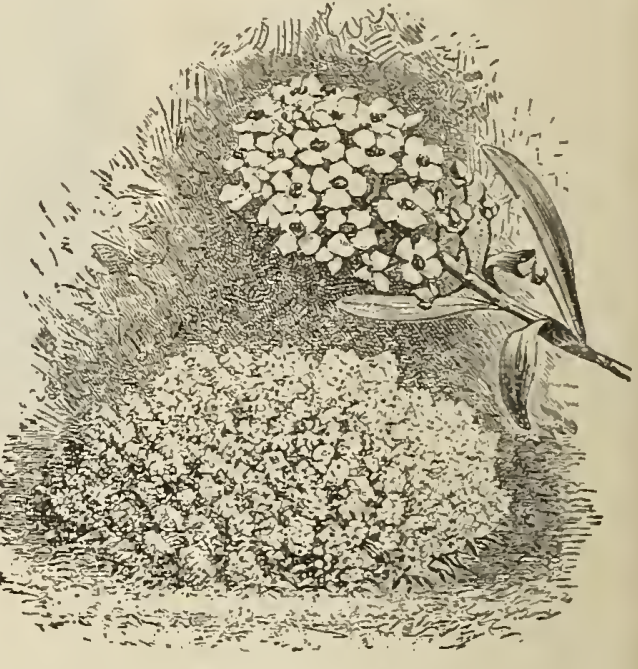

sweet Alyssum.

ASPARAGUS

A very popular house plant, much used for hanging baskets. Perennial. Sprengeri.

Plumosus Nanus. 


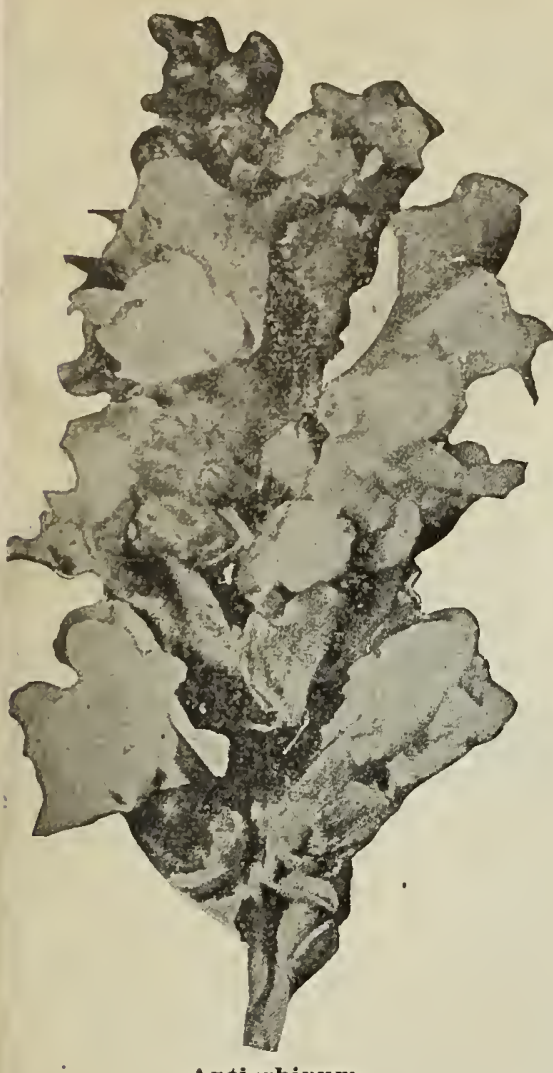

Antirrhiuum.
ANTIRRHINUM-Snapdragon.

One of the most desirable flowers in the catalogue for its variety of colors and succession of blooms, lasting from July until severe frost. The plants should be covered with fine boughs or other light material in November, and they usually survive and bloom finely the second year. Height, 1 foot. Perennial.

Bwarf, mixed colors.

'all, mixed colors.

Pkt. 5e

Plet

coral. New variety growing $21 / 2$ feet high and a profuse bloomer; color, bright red, and white throat.

Pkt. 10 c

AQUILEGIA COERULEA.

True Rocky Mountain Columbine.

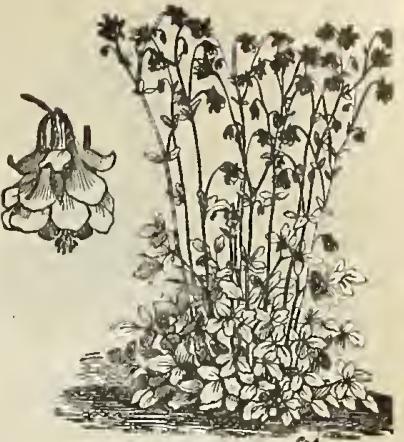

Double Columbine. Colorado's emblematic flower. Needs to be seen to be appreciated. The flower petals lay open more flat than the common Columbine. Color is a light blue, in very high altitudes nearly white. We are headquarters for this seed and furnish the true Aquilegia Coerulea.

Can supply roots at $20 \mathrm{c}$ each, or three for 50e., by mail.

AQUILEGIA-Garden.

Height, from 1 to 3 feet. Hardy perennial.

Mixed Colors. Single and double.

Yellow Pkt. $10 \mathrm{c}$

\section{ASTER}

No family of plants bears such marks of progress as the Aster, and none is more eagerly sought. An almost endless variety; always reliable. For best resuits sow seed early indoors, then transplant to open ground. Our seed can be depended upon for fine bloom.

Queen of the Market. The earliest variety. Colors, white, pink, red, blue or mixed. $1 / 4$ oz., $40 \mathrm{c}$.

Pkt. 10e

Trufraut's Paeony Flowered. Medium tall; deserves a place in every garden. The colors are bright and delicate. White, blue, indigo, rose, red. Pkt. 10e

All colors, mixed, $1 / 4$ oz., $50 \mathrm{c}$

Pkt. $10 \mathrm{e}$

Vietoria. Of the tall varieties, none excels the Victoria. The flowers are large and double, of glóbular shape, ranging in all colors possible. Mixed, $1 / 4$ oz., $50 \mathrm{c}$.

Pkt. 10c

Comet, or Branehing. A handsome and very distinct variety, resembling Japanese Chrysanthemums, Half dwarf.

White Giant, the finest white grown. Pkt. 10e

Mixed, including many colors, $1 / 4$ oz. $60 \mathrm{c}$.

Plet. 10e

Day break. A beautiful Aster, a rare gem among this splendid family; the flowers are round, large and full, of a delicate shell-pink and borne on long stems; the best for bouquets. The plants are very robust and of branching habit.

Pkt. 10e.

Mignon. Similar to the Victoria though the flowers are smaller and the plant more dwarf. Mixed. Pkt. 10e

German Quilled. This is the popular Japanese Needle. Grows 18 to 20 inches high, with 30 to 40 flowers on long stems. Mixed. $1 / 4$ oz., 50c. Pkt. 10e Good Mixed. All varieties. $1 / 4$ oz., $40 \mathrm{c}$

Pkt. 5e

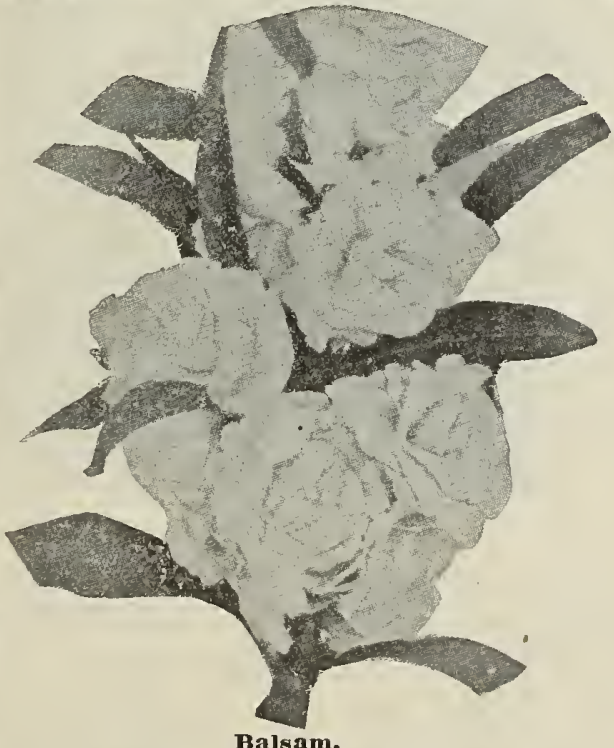

Balsam.

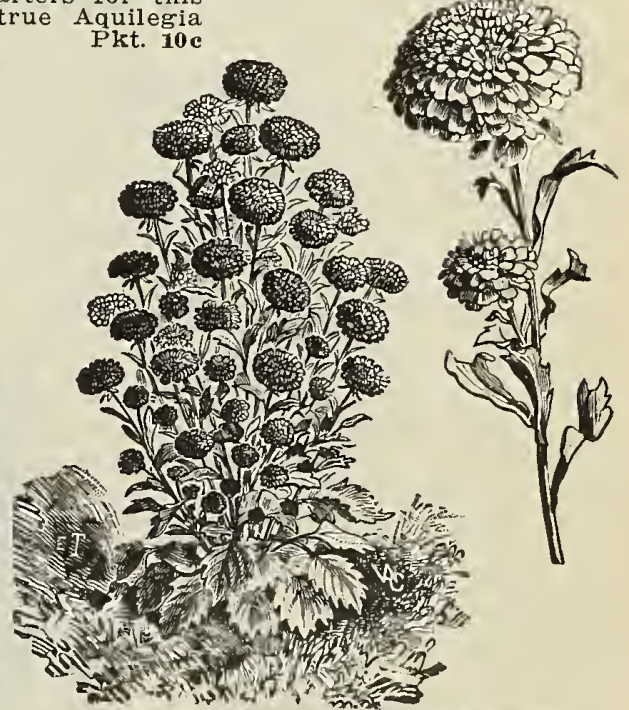

Aster-Trufiaut's Paeony Flowered.
BALSAM,

The Balsam has been so much improved by cultivation as to be scarcely recognized. The blossoms are double, though semi-double and single ones are very certain to appear, and such plants should be removed. Require a rich, deep soil, good culture and plenty of space to grow to perfection. Height, 2 feet. Tender annual.

Double, Mixed. Oz., 35c. Pkt. 5e Double, Camellia, Mixed. Oz., 60c. Pkt. 10e

Double, White Alba Perfecta. Oz., $\$ 1.00$. Pkt. 10e

\section{BEANS-Various Colors.}

Ornamental climbers for porch arrd trellis. Scarlet, White, Tricolor Runuer, each, pkt., $5 \mathrm{c}$; $1 / 4$ 1b., $10 \mathrm{c}$; $1 / 2$ lb., 20c; 1b., 35c, prepaid.

BEGONIA-Tuberous Rooted.

The newer forms of Begonias are among the most brilliantly beautiful of flowering plants. They can be grown from

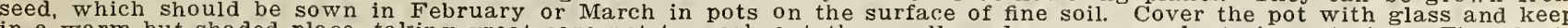

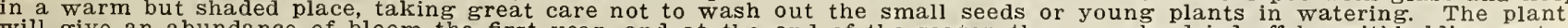

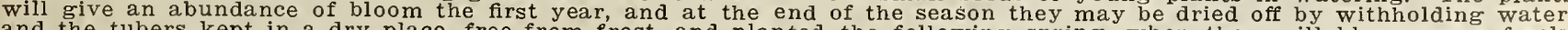

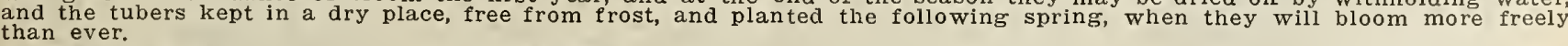

Single. Mixed.

Bulbs. See Bulb List. 


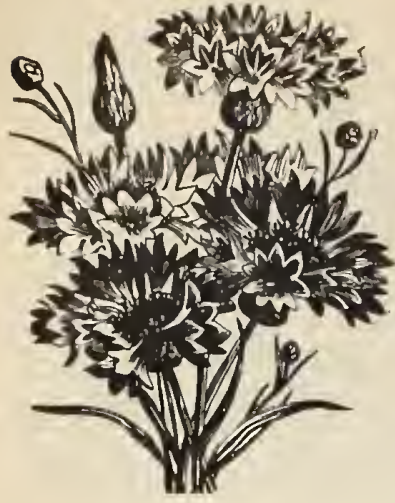

Bachelor's Button.

\section{CALIFORNIA POPPY-Eschscholtzia.}

A flower attractive in follage, bud and blossom. One of the most brlllant flowers grown. plants procumbent, forming dense, bushy masses with a successlon of flowers from July untll after severe frosts. When grown with Dwarf Convolvulus, contrasts finely wlth the dark blue. Height, 1 foot. Half-hardy annual.

California. Mlxed.

Early Douglusil. Early flowering, yellow with golden center.

Mammoth Golden West. Large orange color, shading to yellow at edges Pkt. Ec

Pkt. 5c

BACHELOR'S BUTTON-Centaurea Cyanus.

A showy annual, of easy culture, flowering freely with a great variety of colors, in common garden soil. Height, 2 feet. Pkt. 5c. BILL FLowER. See Campanula.

BIGNONIA RADICANS-Trumpet Vine.

Magnificent, hardy, deciduous climber, with brilliant flowers, deserving a first place as an ornament and effective covering for walls, houses, etc. Hardy perennial. Helght, 20 to 30 feet.
BOS'TON IVY. See Ampelopsis.

\section{BOX WOOD-Buxus Sempervirens.}

A fine small evergreen, with pale green leaves. Can be trained in desired form by shearing; largely used for bordering flower beds. Hardy perennial.

\section{BRACHYCOME-Swanriver Daisy.}

A delicate dwarf growing plant, suitable for growing in grasses, edgings and rustic baskets. The flowers are of various shades of blue and white, with dark and white center, cineraria-like in form, rather bell-shaped. After blooming the petals of the flowers roll up closely.

Mixed colors.

\section{CACALIA-Coccinea (Tassel Flower.)}

A pretty annual, with flowers of bright scarlet, borne in clusters on slender stalks, about a foot in length. They keep in bloom from early summer until aumn furnishing flowers for cutting every day. Height, 1 foot. Pkt. 5c

\section{CALCEOLARIA.}

A favorite and universally admired genus, remarkable for their large, beautifully spotted blossoms produced In almost countless variations of markings. They are grown in pots in the conservatory, greenhouse and garden. Perennial

Hybrida Grandiflora. Flowers of $1 \mathrm{~m}$ mense size; seed saved from fillest specimens. Pkt. 25e

CALLA-Aethiopica.

An old and very desirable plant, either as an acuatic or for ornamentation of the drawing room and conservatory. Thrives in any light, rich soil when plentifully watered. Height, 1 to 2 feet. Half-hardy perennial. Pkt. 10c

For Bulbs, see Bulb List in back part of this catalogue.

CAMPANULA MEDIA-Bell Flower.

A beautiful hardy herbaceous perennial, bearing a great profusion of attractive Bell flowers; doing best in ight, rich soil. Height, 2 to 3 feet. Mixed colors. Looking Glass.

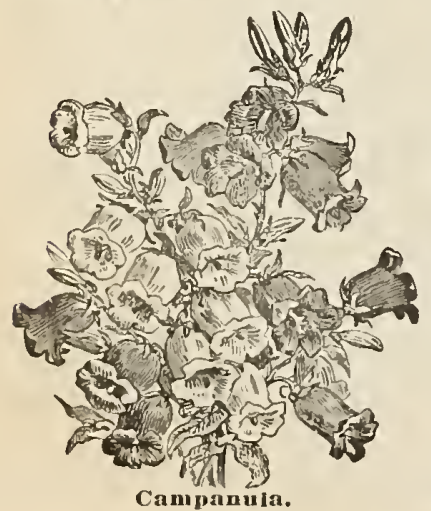

Pkt. 5e

$$
\text { Venus }
$$

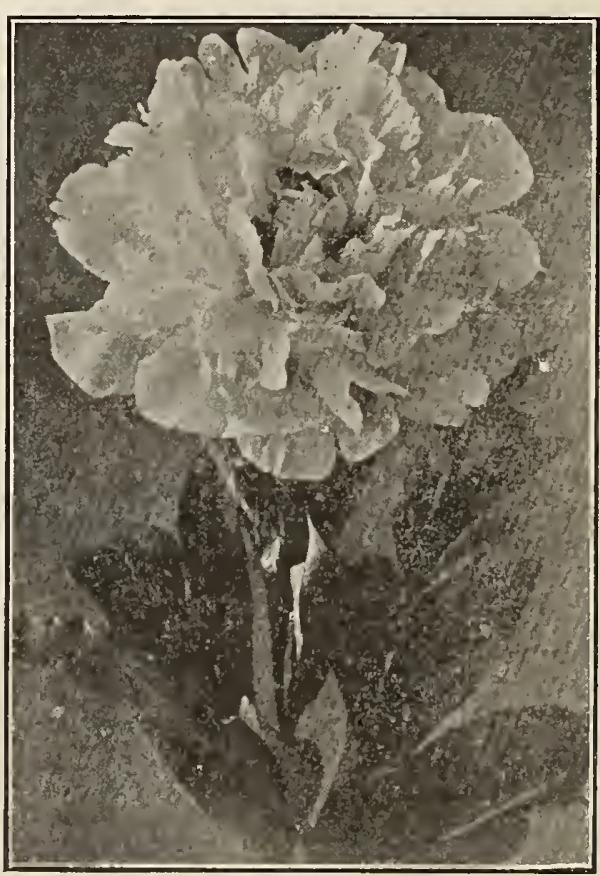

Carnation.

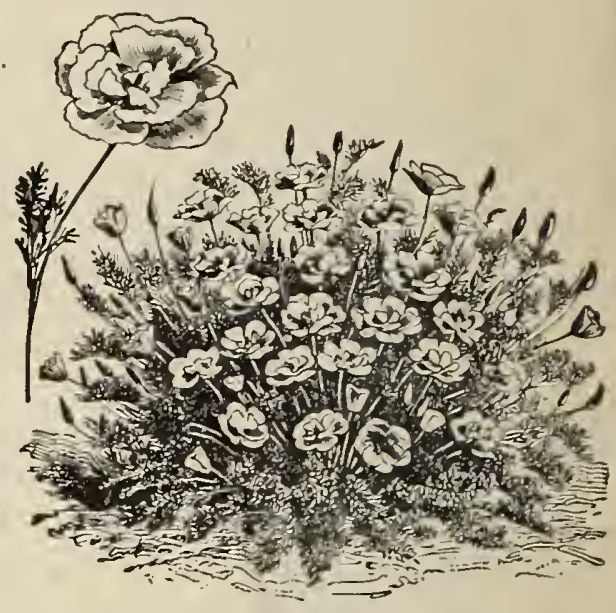

Callornia Poppy.

\section{CALLIOPSIS.}

A very showy border plant, producing flowers in nearly every shado of yellow, orange, crimson, red and brown. If the seed pods are removed as fast as they appear, the plant will remain in bloom much longer. Height, 2 feet. Hardy annual.

Mixed colors.

Pkt. 5e

\section{CALENDULA-Officinalis.}

This splendid variety has large double flowers beautifuly imbricated, resembling in size and form the finest Aster. Each petal, of pale straw color, is regularly marked with a stripe of bright, deep orange. Blooms profusely with a succession of flowers from July till frost. It is one of the best annuals for a garden display. Height, 18 inches. Pkt. $\mathbf{6 c}$

\section{CARNATION.}

This beautiful and well-known plant produces finer flowers when grown from seed than when grown from cuttings taken from old plants. Our seed will produce a fine variety of colors, with flowers of good size and substance. Height, 18 inches. Half-hardy perennial.

German. Mixed colors.

Pkt. 10e

Maranerite. These are deservedly the most popular Carnations with the amateur, as they begin flowering four months from time of sowing. The strain offered is of extra of large, double, beautifully fringed, highly-scented flowers. vixed Colors.

Grenadin. Pink and white, mixed.

Pkt. xoe CARNATION PLANTS.

Campanuia.
Pkt. $15 \mathrm{c}$ Ready in April.
Seedings of various colors furuished. See page 56.

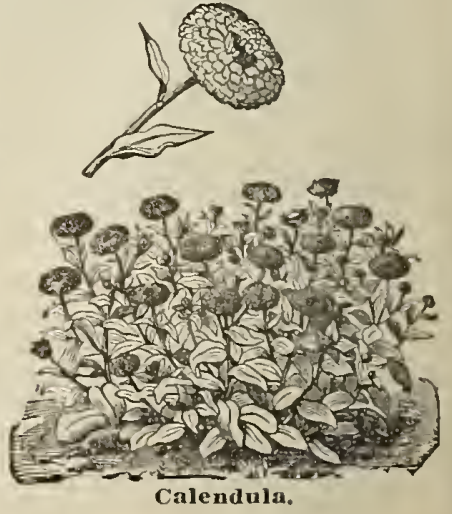




\section{CANARY-BIRD FLOWER-Tropaeolum Canariensis.}

One of the best climbing plants, with graceful foliage of a delicate shade of green, with small yellow flowers, which, when half expanded, have a fanciful resemblance in shape of canary bilds. Height, $S$ feet. Half-hardy annual.

\section{CANDYTUFT,}

Candytuft is desirable for bouquets, especially the white, for its form, fragrance and profusion of bloom. Height, 1 foot. Hardy annual.

vixed Colors. Oz., $15 \mathrm{c}$

White Rocket. Oz., $20 \mathrm{c}$.

Wwarf, Tom Thumb. Oz., $20 \mathrm{c}$.

Empress. Oz., $25 \mathrm{c}$.

Plkt. 5e Pkt. 5e Pkt. 5e Pkt. 10c

\section{CATCHFLY-Silene Armeria.}

A showy, free flowering plant, with bright, dense heads of flowers, growing well in common garden soil. Adapted for border, circular beds and ribbons. Height, 18 inches. Hardy annual.

Pkt. 5c

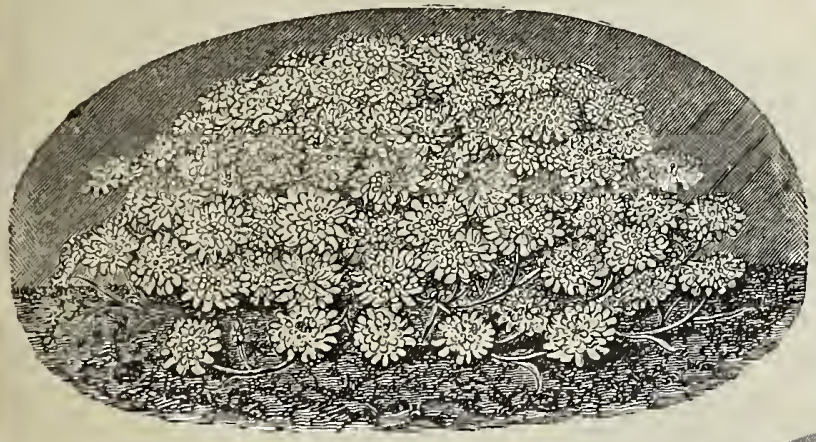

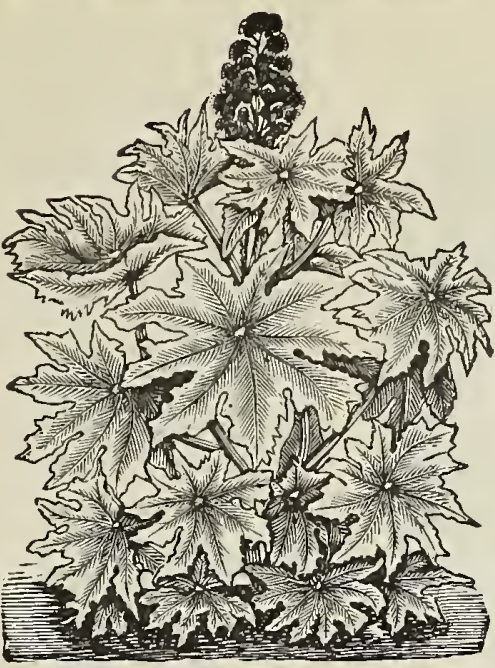

Castor Beans.

CASTOR BEANSRicinus.

A luxuriant, expansive foliage plant of tropical appearance, that should have a place in every garden affording the requisite space. The stalks of the plant are of a brownish red; the leaves are very large, palmate, and strikingly elegant. Height, 6 to 10 feet. Tender annual.

Sanguineus. Large, red. Oz., $15 \mathrm{c}$.

Pkt. 5e

Zanzibariensis. New Zanzibar, a giant, a largeleaved variety. Oz., $20 \mathrm{c}$.

Pkt. 5e

\section{CANNA.}

Stately plants, with foliage of elegant growth, presenting a Juxuriant and tropical appearance, and much employed in ornamental planting; when planted in clumps of 4 or 5 contrasting colors are very cffective. Height, 3 to 6 feet. The seeds should be cut at one of the ends about 1-16 inch and then soaked in warm water for 24 hours. Tender perennial.

$\begin{array}{ll}\text { Mixed Colors. } & \text { Pkt. 5c } \\ \text { Madame Crozy varieties. Mixed colors. } & \text { Pkt. 5c }\end{array}$

For Bulbs, see BuIb List in back part of this catalogue.

\section{CLARKIA-Pulchella.}

The Clarkia is held in great estimation in Europe, and especially in England, where it is as common as the Candytuft. The flowers are very pretty and of many colors, double and single. As the plant is apt to suffer in our hot, dry summers, it is better to sow the seed in a partly shaded situation.
Hardy annual. Height, $1 \frac{1 / 2}{2}$ feet.

Candytuft-Tom Thumb.

PERENNIAL CHRYSANTHEMUM.

Maximum. (Ox-eyed-Daisy.) A freelooming, hardy perennial, 2 feet high, blooming, hardy perennial, feet high, erss, which are well adapted for cuterss, which are well adapted for cut-
ting, lasting over a week in water.

Frutescens. (Marguerite or Paris Daisy.) This variety, under the name of Marguerite, has attained great popularity among florists. The pretty starshaped white flowers are freely produced and the plant will grow under almost any circumstances. grow pkt. 10c

Perennial Japanese. For la te a utumn blooming in the house, after the frost has destroyed all the bright colors in the garden, there is no flower to take the place of this finely shaped, double flower produced in profusion. Height, 18 inches. Double, mixed colors.

Pkt. 15c Plants of Perenmial Chrysanthemum
ean be Furnished in all Colors. Ask for Prices.

\section{CENTAUREA GYMNOCARPA.}

Fine cut silvery foliage. Pkt. 5c

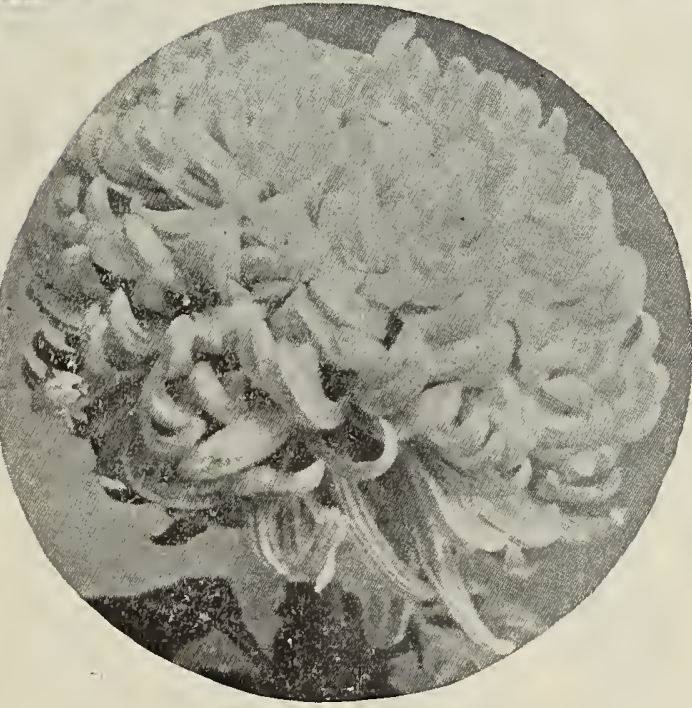

EARLY ANNUAL CHRYSANTHEMUM. The glorious and showy autumn-blooming chrysanthemums, which are now so much admired and cultivated, have their relatives among the summer annuals, which are plants can be raised by sowing the seed early in the house or frame, and planting them out when the weather is favorable, or the seeds can be orable, or the seeds can be sown where the plants are to
stand. Mixed.

CENTAUREA IMPERIALIS.

The finest of all Sweet Sultan family, as a cut flower.

Mixed colors. Pkt. 10e

CENTAUREA MOSCHATA. See Sweet Sultan.

\section{CENTAUREA CANDIDIS.} SIMA-Dusty Miller.

Magnificent efoliage plants of silver white and grey foliage, indispensable for borders and edges. Half-hardy peren nial. Height, 1 foot. Pkt. $10 c$

\section{CENTAUREA MARGUERITE-White.}

A sweet-scented Centaurea about as large as a medium-sized Carnation. It is a sport from Centaurea Odorata, and the plants are about 18 inches high. The flowers are beautifully laciniated and produced on long stems; their lasting quality after being cut is remarkable. The bcauty of this easily cultivated annual is certain to excite admiration.

CHRISTMAS PEPPER.

A beautiful pot plant of easy culture; very ornamental.

Pkt. 10e CINERARIA-Hybrida Grandiflora.

Very attractive and much admircd greenhouse plant; perennial; height, 1 to 2 feet.

CINERARIA-Maritima Candidissima.

White-leaved; used for bedding, vases, etc. Height, 1 foot.

Pkt. 25e

\section{CLEMATIS.}

Well known and universally admired climbers, some of the varieties being remarkable for the beauty and fragrance of their blossoms. Nice for covering arbors, verandas, etc., as they cling readily to almost any object. Most of the kinds are hardy, herbaceous perennials, but some little protection in northern latitudes through winter is advised. Will do well in any garden soil. Height, 15 feet. A fine mixture of varieties. Pkt. 10e

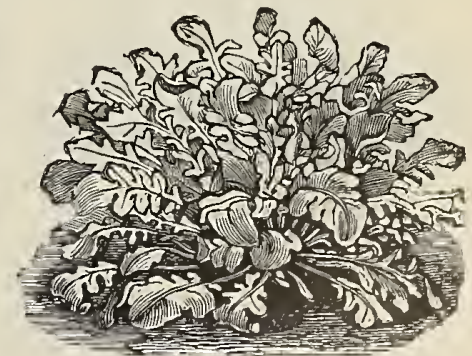

Centaurea-Dusty Miller. 
THE BARTELDES SEED CO., DENVER, COLO.

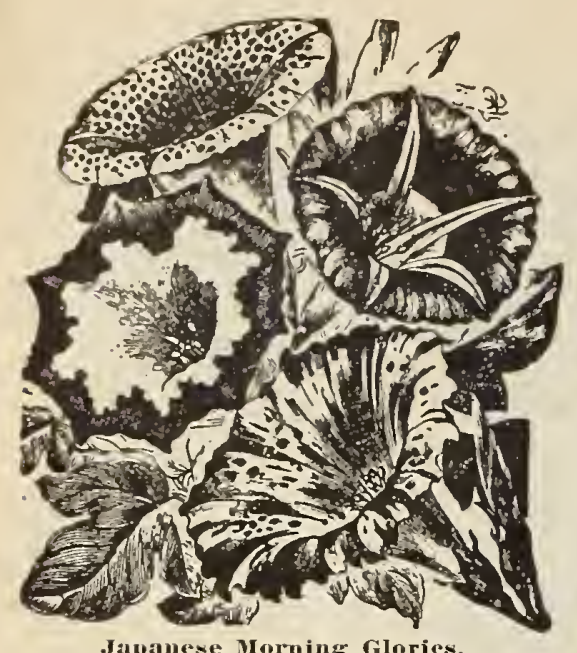

Japamese Morning Glories.

DOUBLE MORNING GLORY

The variety of colors is almost limitless, running from the darkest reds and purples through all shades of blue, and pink to snow-white. Flowers are streaked, mottled, striped, marbled and bordered in wonderful double and some are so much fringed as to have the appearance of a double flower. Colors.

Pkt. 10e

\section{COSMOS.}

Are unquestionably very handsome flowers, and there is but one objection to their giving general satisfaction, and that is their late flowering habit. The plants require a very long time to develop, and that brings their flowering season late in the fall. This objection will not be found in our in the open ground in the beginning of May will produce blooming plants in August and they will continue to fower late in the fall. We know of no single flower that is as handsome as the Cosmos, while for keeping qualities when cut they are unexelled.

$\begin{array}{ll}\text { Eearly Flowering. Mixed. } & \text { Pkt. Je } \\ \text { Iellow. } & \text { Pkt. Jc } \\ \text { Crimson. } & \text { Pkt. Je } \\ \text { white. } & \text { Pkt. Je } \\ \text { Pinl. } & \end{array}$

white.

Pink.

Pkt. 5e

Gialuts of California. Mixed. Pkt. 5e
CLEOME, or SPIDER PLANT.

Better known in the West as "Pocky Mrountain Bee Plant." It is the emblem flower of the Colorado state Bee Keepers' Assoclation. Has a very attractlve

flower in shades of pink and crimson on tall branching plants. A splendid honey
plant. Oz., 20c.

ChIHING BLACK-NYED susax. See Thunbergla.

COBAEA-Scandens.

A splendid climbing plant with large purple bell-shaped flowers and elegant tendrils: when well established grows very rapidly, with numerous branches. Height, 15 to 20 feet. Tender perennial. Pkt.10c

\section{CONVOLVULUS MAJOR--Tall Morning Glory.}

"Ihis well-known annual is one of the most popular climbers. Of rapid growth, soon covering a fence or trellis with the abundant foliage and bright flowers. A great variety of colors and shades. Helght, 15 feet. Hardy annual.
Mixed colors. Oz., $15 \mathrm{c}$ : $1 / 4$ lb., $35 \mathrm{c}$.

\section{CONVOLVULUS MINOR-Dwarf Morning Glory.}

A trailing procumbent plant with flowers of rich shades of blue, in some specimens rivaling the Pansy in richness of color, finely shaded with yellow and white. In bloom from July till after severe flosts. Height, 10 inches. Half-
hardy annual.

\section{IMPERIAL JAPANESE MORNING GLORY.}

The flowers are of immense size and of strong colors. Soak seed before planting. Mixed colors. Oz., $25 \mathrm{c}$.

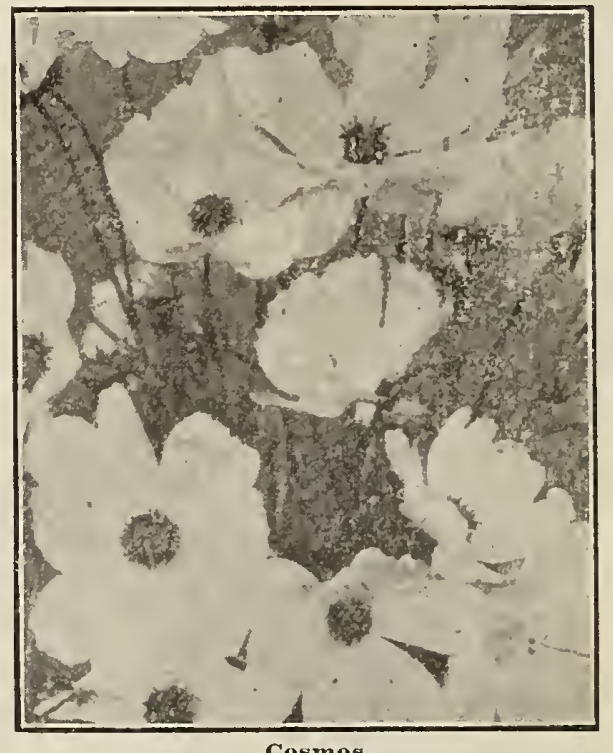

FANCY JAPANESE MORNING GLORY-Fringed.

The perfection of Morning Glorles. Immense flowers, often as big as a saucer. The colors, shadings and markings of the flowers are llmitless. The foliage is luxuriant, distinct and varied, green, silvery and yellow. The robust vines attain a height of 30 to 40 feet in one season. Soak the seed in luke warm water for a few hours before planting.

Hixed Colors.

Pkt. $10 c$

MIXED CLIMBERS.

In this we have included all the popular quick-growing climbing annuals, such as Ipomoes, Nasturtiums, Sweet Peas, Japanese Hop, Cypress Vines, ete. Just the thing for covering old fences, arbors, etc. $1 / 2$ oz., Corx LACuRYuA. See Job's Tears. COLEUS-New Hybrids.

Probably there is no other kind of foliage plant so well known and unifoliage plant so well known and unione of the most beautiful of our variegated perennial foliage plants for the greenhouse or garden decoration, ribbon-beds, etc., of rapid growth and easy culture. Tender perennial. Height, 1 to 2 feet. Pkt. 250 ColduBINE. See Aquilegla. Valley.

COREOPSIS LANCEOLATA.

Flowers large, single, golden yellow. For generosity of blooms there is nothing to compare with it, and it will bear cutting from better than any other plant; at the same time it is always graceful. Perennial. It can be grown freely from seed, and does well when treated as an annual.

CORN FLOWLR ASTER. See Stokesía.

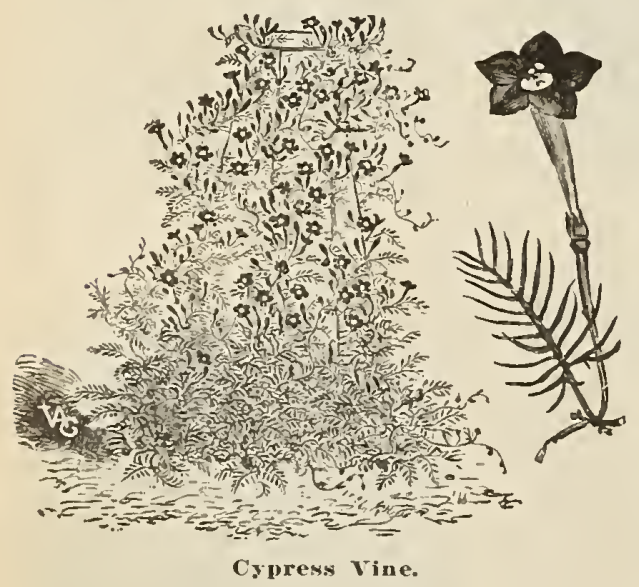

COXCOMB-Celosia Cristata.

A highly ornamental plant, producing crested heads of flowers, somewhat l'esembling a cock's comb. There are many colors and shapes, but the scarlet and crimson are the most brilliant Dwar. Mixed colors. Pkt. 10c Feathered. Mixed. Pkt. 10c CYCLAMEN.

Well-known and universally admired tuberous rooted plants. producing exceedingly handsome perennial, One foot high. Persicum, mixed, of great Gity and many colors. Pkt. 15e Gisanteum, mixed, characterprofuse bloom; each flower is profuse bloom; each flower is from 2 to $2 \frac{1}{2}$ inches long. Very
choice.

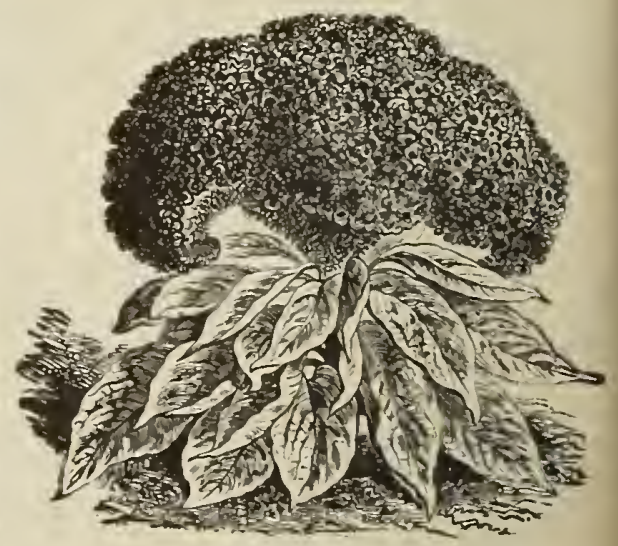

Coxcoub.

CYPRESS VINE-Ipomoea Quamoclit.

One of the most beautiful climbers; fine, delicate cut foliage, dotted with small, scarlet, star-shaped flowers. For ering pillars, trellis work, etc., it is not surpassed for grace and beauty. Height, 8 feet. Tender annual. vixed colors. 


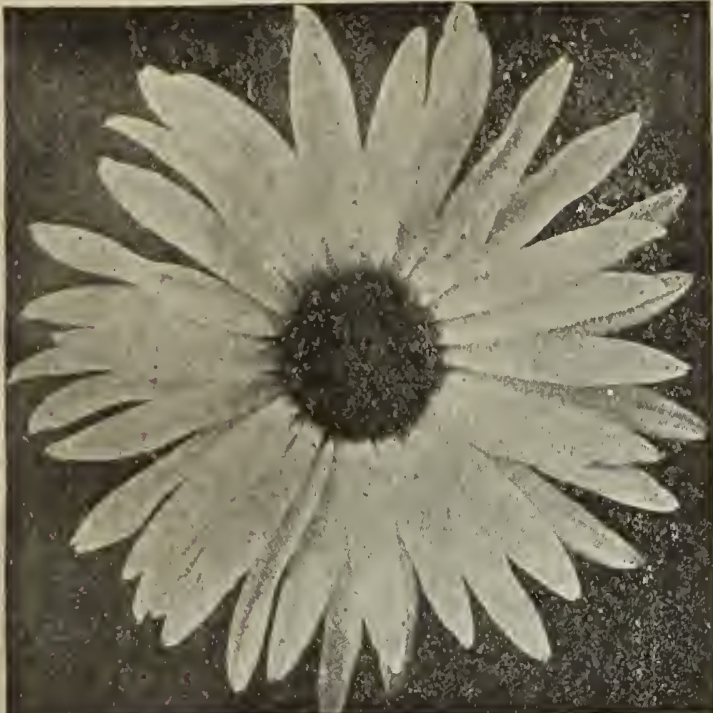

Shasta Daisy.

\section{Dahlia--Hornsveld's Giant Hybrids Mixed}

This new variety will be found one of our best cut flowers for summer use. It has magnificent long stemmed, single and semi-double flowers, of immense size and in a great variety of colors. It will bloom freely the first year from seed, but for best results should be started in a box in the house in February and set outdoors when weather is
warm.

\section{DELPHINIUM-Perennial Larkspur.}

A very attractive hardy plant for corners of yard, also center of flower beds.

single, mixed.

Double, mixed.

Pkt. 10e

Pkt, 15e

DIANTHUS. See Pinks and Sweet William.

DIGITALIS-Fox Glove.

Showy and useful plant for the border; flower's borne in tall spikes, bell or thimble shaped, of all borne in tall spikes, bell or thimble shaped, of all colors; new plants nay be obtained by dividing the
roots. Height, 2 feet. Hardy biennial. Mixed colors

EsCHSCHOI.TZIA. See California Poppy.

\section{EVERLASTING FLOWERS.}

Iixed. This consists of all the popular Everlastings.

\section{FEVERFEW-Matricaria.}

A free-flowering, half-hardy perennial plant growing 18 inches in height. Seed sown early in the spring in the open ground will produce flowers by iall. The plant throws up numerous stems, terminating in clusters of very double, pure stems, flowers, three-quarters of an inch in diameter. These are desirable for cut flowers. Plants bloom freely when grown in pots in a cool room. Pkt. 10e

FLAX-Searlet. See Linum.

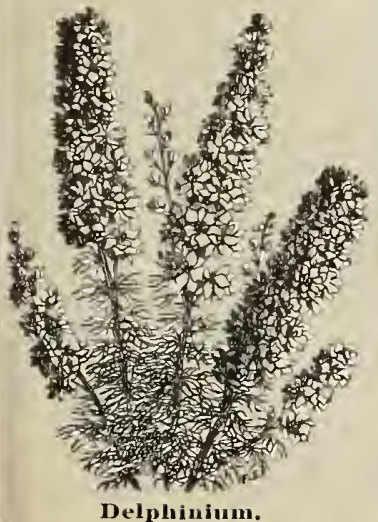

Delphininu.

Mixed, oz., $15 \mathrm{c}$.

\section{DAISY--Bellis Perennis}

Charming little plants for edging and borders. The flowers are quilled and flat-petaled, with white, pink, red and variegated. Not all will come double from the seed, and the single ones should be pulled out. Ifciglit, six inches. Tender perennial.

Dowble, mixed.

Lonsfellow, double, pink.

Pkt. 10c

snowball, double, white.

Pkt. 10e

Pkt, 10e

\section{SHASTA DAISY--Burbanks}

Alaska, pure white.

California, pale yellow color turning to white.

Pkt. 10e

Pkt. 10e

vestralia, flowers semi-double, creamy color.

Pkt, 10e

Mixel.

Pkt. 10e

OX-EYED DAISY. See Chrysanthemum Maximum.

PIRIS DAISY. See Chrysanthemum Frutescens.

\section{Dahlia}

This exceedingly beautiful genus comprises an almost endless number of varieties, all more or less showy in the flower garden in the late summer, when most other flowers have faded. They are all of easy cultivation, growing freely in most any soil, from seed sown in the spring. If sowed early in the house and transplanted in June in the spring. If sowed early in the house and transplanted in June

Finest double mixed.

Pkt. $10 \mathrm{c}$

Finest single, mixed.

Pkt. 10e

For Dahlia Bulbs, see back part of this catalogue.

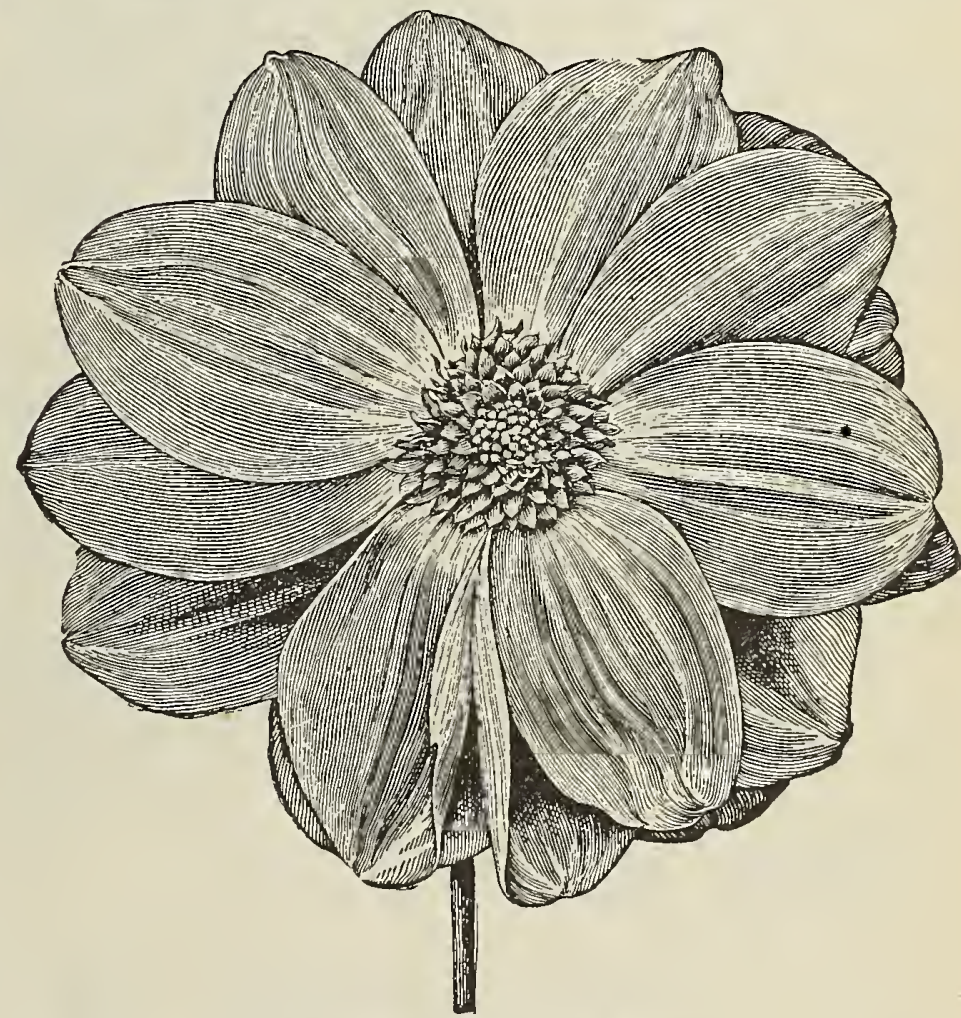

Dahlia-Hornsveld's Giant Hybrids.

FORGET-ME-NOT-Myosotis Alpestris.

This beautiful little flower is too well known to require description or recommendation. The delicate biue flowers appear all summer. Height, 6 inches. Hardy perennial. Pkt. 10e

\section{FUCHSIA.}

The varieties of Fuchsias are now numbered by hundreds, and some are exceedingly beautiful. They are as easily grown from seed as cuttings, and from seed many improved varieties are obtained. Height, 1 to 3 feet.

Double and single, mixed.

Pkt. 25c

\section{FOUR O'CLOCK-Marvel of Peru.}

A handsome plant, making an attractive display of its many colored flowers from the middle of July till frost. The blossoms are marbled and spotted in the most diversified manner, the same plant producing different colors; some branches will grow flowers of a single color only, while others will have stripes. The leading colors are red, white and yellow, with stripes and variegations of all three. Height, 2 feet. Hardy annual. 


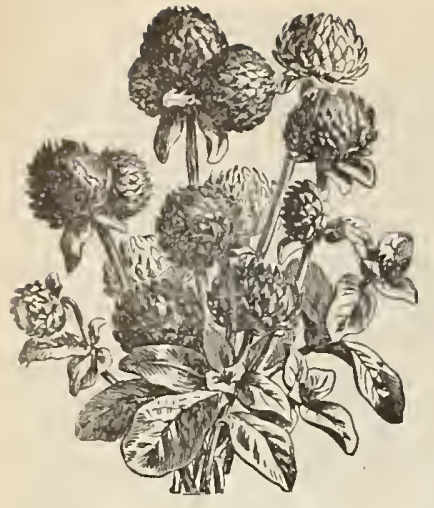

Globe Amaranth.

GLOXINIA-Hybrida.

Greenhouse perennial plants, producing rich and beautifully colored flowers. They deserve extensive cultivation.

Mixed.

Pkt. 25e

\section{GODETIA.}

A beautiful plant of neat, dwarf, compact habit, with a profusion of rich carmine flowers, produced in a succession of blooms from August till frost. Height, 1 foot. Hardy annual.

Mixed.

Pkt. 5c

\section{GOURDS}

A great variety of curiously formed and marked fruits: the vines are of rapid growth and with luxuriant foliage; adapted for covering screens, arbors, etc. Height, 10 to 20 feet. Tender annual.

\section{Dish Cloth or Luffa.}

A rapid climber, having long, green fruit, the inside of which is a fibrous mass, which, when the shell and seeds are removed, make an excellent substitute for a bath sponge. Oz., 30c.

\section{Japanese Nest Egg.} Oz., $25 \mathrm{c}$

White, egg-shaped, does not crack and is not injured by heat or cold

\section{Dipper or Siphon.}

Useful for dippers. Oz., 25c

Pkt. 5e

\section{Sugar Trough.}

Have thick, tough shells; very durable. Oz., $20 \mathrm{c}$. Hereules' Club. The longest gourd grown. Oz., $25 \mathrm{c}$.

Mock orange. Golden yellow. Oz., $25 \mathrm{c}$.

All Kinds, Mixed. $1 / 2 \mathrm{oz}, 15 \mathrm{c} ; \mathrm{oz} ., 25 \mathrm{c}$.

\section{HELICHRYSUM.}

One of the best of the immortelles; good shape, size and a variety of desirable colorsyellow, sulphur, cream, white, pink, rose, red and crimson. Retain their natural shape very perfectly when dried. In bloom from July till destroyed by frosts. Height, 18 inches Hardy annual. Mixed.

HeLIANTHUS. See Double Sunflower.

\section{HELIOTROPE.}

A well known popular greenhouse plant, fine for bedding, vases or baskets and exquisite for pot culture in winter. Flowers purple, borne in trusses, and exceedingly fragrant. Height, 1 foot. Half-hardy perennial.
Pkt. 10c
Pkt. 5c Pkt. 5e Pkt. 5e

\section{GERANIUM-Zonale.}

Pkt. 5c

(

tter known and more universally admired than any other The constant succession and durability of blooms till frost comes, the brilncy of the scarlet and other colors, and the exquisite markings of the leaves of some of very desirable for pot culture or bedding. No garden seems

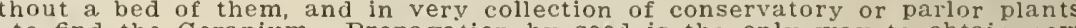

\section{GILIA.}

Pkt. 15c

from Pkt. 5c

GAILLARDIA,

A showy annual, with brownish-red flowers, bordered with yellow and white, blooming strongly through the season, and until aiter heavy frosts. Height, 18 inches.

Single, mixed colors.

Pkt. 5e

Grandiflora. Large flowered. Perennial; very fine mixed.

Pkt. 10c

GLYCINE SINENSIS. See Wistaria.

\section{GYPSOPHILA}

Small, fragrant flowers, borne on long feathery stems. No flower adds more of light and grace to a bouquet than this, and when once grown will be found indispensable. In bloom through the summer from the first of July till frost. Although not belonging to the immortelle class, the flowers dry finely and are very desirable for winter bouquets. Height, 1 foot.

Elegans-Angel's Breath. Delicate pink. Pkt. 5e Paniculata-Bahy's Breath. Pure white per-
ennial.

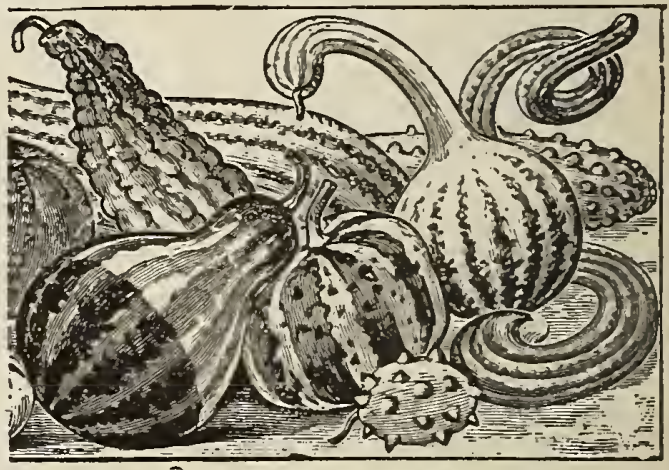

\section{HOLLYHOCK}

A great variety of brilliant colors, combining richness and delicacy in a remarkable degree; flowers large and densely double, remaining a long time in bloom. Is one of the best and most ornamental of the perennials. Height, 5 feet.

Prize, double, mixed. Pkt. 10c

Separate Colors, double, white, pink, yellow, maroon, red, each Pkt. 10c

Hollyhock Allegheny.

This is a species that will bloom the flrst year if started in the house in March and transplanted in May. The petals are fringed and the flowers of different colors. Pkt. 10c

\section{Hollyhock Annual.}

Will bloom in August or beginning of September if sown in April. Flowers are single, semi-double and double. Mlxed colors.

Pkt. 10c

OUR FAIL CATALOGUE OF BULBS.-At the end of September we issue a complete catalogue of Bulbs. Thls includes Daffodils, Tulips, Hyacinths and those other gorgeous flowering bulbous plants. We plan to send this to all of our customers. A request will bring you a copy gladly. 


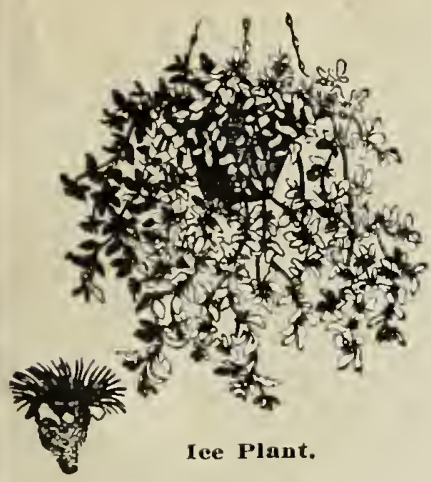

IVY-Hedera.

For a climbing plant in the garden to do duty as a creen for an old well or building, or to adorn either when new, it is a well known and favorite plant. For indoor winter decoration Ivy is unequaled, as it can be trained in any desired form, and will bear any amount of hardship and bad usage. Height, 30 to 60 feet. Perennial.

JAPANESE HOP-Humulus Japonicus.

A rapid growing, perfectly hardy, annual climber of the hop family, of the easiest culture and indispensable for covering unsightly objects, or verandas, trellises, etc. Sows itself after the first year. Variegated leaves.

JOB'S TEARS-Coix Lachryma.

Curious ornamental grass from East India, with broad corn-like leaves and seeds of light slate color, wonderfully lustrous. Valuable for the formation of winter bouquets in connection with everlasting howers, and Strings of handsome beads are formed 1 rom the seeds. Pkt. 5e

\section{HIBISCUS-Africanus.}

Pkt. 5e HYACINTH BEAN-Dolichos Lablab.

Splendid climber, with abundant clustered spikes of purple and white flowers, which
followed by exceedingly ornamental seed-pods. It is of rapid growth and often runs

\section{ICE PLANT-Mesembryanthemum Crystallinum.}

Pkt. oc

Dwarf plant of procumbent or trailing habit, finely adapted for vases, rock work, etc. surface of the foliage is covered with panicles resembling crystals of ice glistenin

INSECT POWDER PLANT. See Pyrethrum.

Pkt.

KOCHIA SCOPARIA-Mexican Burning Bush.

An ornamental, quick-growing annual, forming a symmetrical bush covnual, forming a symmetrical bush covers. The plant dies soon after bloomers. The plant dies soon after bloom-
ing.

KUDZU VINE-Jack-and-the-BeanStalk Vine.

The most remarkable rapid growing hardy perennial. Starts into growth slowly, but after a few weeks time grows almost beyond belief. Nothing its equal for porches, arbors, old trees,
etc.

\section{LANTANA-French Hybrids.}

Rapid growing plants; the flowers are borne in Verbena-like heads, embracing every shade of pink, purple, orange and white. Half-hardy nial. Height, 3 feet. Mixed. Pkt. 10c

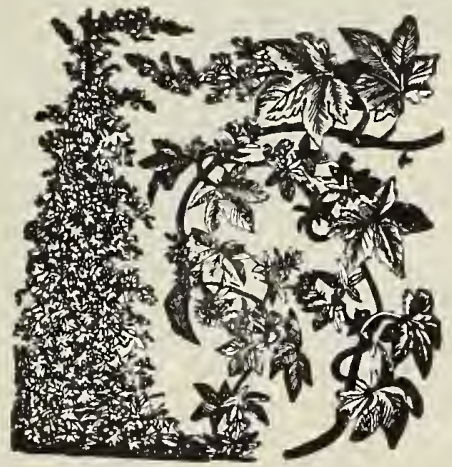

Japanese Hop.

\section{LARKSPUR-DeIphinium.}

A fine variety of colorsshades of blue, red and others, striped and mottled. The flow. ers are produced in splkes, which are continually pushing out from the main stem and branches, furnishing an abundance of bloom through the season. When grown in vases makes a fine display, Height, 2 feet. Hardy annual.

Double tall mixed. Pkt. Ge Double dwarf mixed. Pkt. 5e

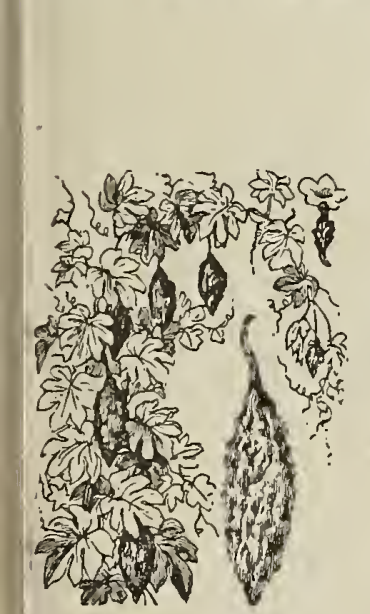

Momordiea.

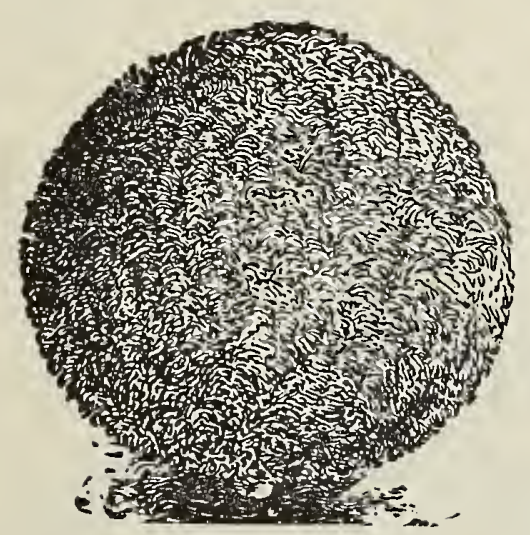

Mexican Burning Bush.

LINUM. Grandiflora Rubrum-Scarlet Flax.

Distinguished for its brilliant colored flowers, which are deep crimson with black center saucer shaped, and very conspicuous in bed and border. The foliage of the plant is slender and delicate, and the flowers produce very little seed. Height, 11/4 feet. Hardy annual.

LOVE-IN-A-MIST. See Nigella.

LILY OF THE VALLEY-Convallaria Majalis.

The Lily of the Valley is a sweet little plant, thriving in common soll. It will do well in any shady situation where fe wother plants will thrive; can be multiplied by dividing roots or by be multiplied by dividing roots or by
seed. Hardy perennial. Height, 1 foot Pkt. 10e

For LILY PIPS, see page 50.

LOBELIA-Crystal Palace.

An elegant and useful class of plants of dwarf, compact growth, bearing a profusion of delicate blue flowers. In bloom through the summer and autumn. Make a neat and effective edging for Geraniums and ornamental leaved plants; pretty for baskets and vases and piazza decorations. Height,
P inches. Haif-hardy annual.

MARGUERTE. See Chrysanthemum.

\section{MAURANDYA.}

This vine is one of the best for window garden and almost equal to Smilax in delicate beauty. It is very hardy, blooms profusely and is very easily grown from seed and roots readily from cuttings.

MAIEVEL OF PERU, See Four O'clock.

\section{MIMULUS.}

These flowers are remarkable for their rich and beautiful markings and spots; well adapted for vases, pots and baskets, and also for open culture

in the garden. Height, 1 foot. Half-hardy perennial.

Tigrinus. Monkey Flower.

Pkt. 10c MOMORDICA CHARANTIA-BaIsam Pear.

Very curious climbing plant with ornamental foliage; fruit golden yellow, warted, and when ripe opens, showing the seed and its brilliant carmine interior. Annual. Height, 10 feet. Pkt. 5c

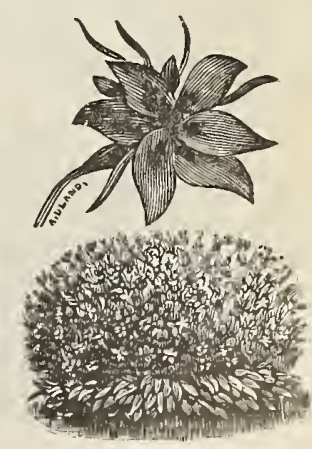

Lobelia, 


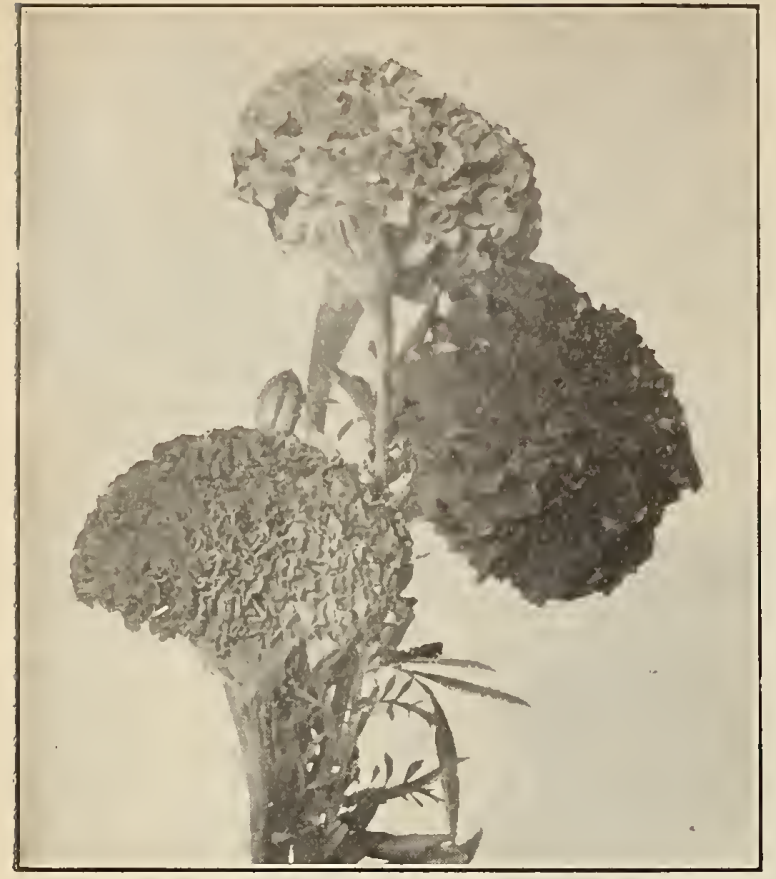

Marigold.

MARIGOLD.

A showy plant of compact, symmetrical growth, handsome foljage and a profusion of flowers of brilliant shades of yellow, finely variegated and striped with dark rich colors of maroon, and brown. Filowers are about an inch in diameter, full double to center, and cover the plant profucely. Height, I foot. Half-hardy annual.

French, Double Dwarf.

Pkt. 5e

Ifrlean, Donble 'Tall.

Plkt. 5e

\section{MIGNONETTE--Reseda}

one of the best known and most popular flowers, indispensable for the garden; is suitable to almost any location and soil, furmishing its ragrant hlossons continuously through the summer and until after severe frosts. Height, I foot. Hardy annual.

Grandiflor:. Sweet, large flowering. Oz, $15 \mathrm{c}$ 'Pkt. 5e Golden Rucen. Golden yellow. Oz, 40c. Pkt. se Gisut White. Pyramidal, tall growing. Oz, 40c. Pkt. Jc Giant Maehet. This is the popular strain used by florists. Pkt. 10e

Moss IRosE. See Portulaca.

MINOSA IPUDICA. See Sensitive Plant.

MOURNING BRIDEScabiosa.

One of the best flowers for bouquets; plants of dwarf habit and compact; the flowers borne on long, wiry stems. A great variety of colors from white riety of colors from white most black. In bloom from most black. In bloom from August till after severe
frosts. Height, 18 inches. Hardy annual.

Dwarf, double, mixed.

Pkt. 10c

\section{MOON FLOWER-Ipomoea Noctiflora Mexicana.}

The true Moon Flower is the most vigorous of all the summer climbers; a single plant can easily be made to cover, by August 15, a trellis 30 to 50 feet high and 6 feet broad, with a dense mass of leaves, studded every night or cloudy day with hundreds of beautiful white and wax-like flowers 4 to 6 inches in diameter. Height, 30 to 50 feet. Tender annual.

IORNING GLORY. See Convolvulus.

MYosotis. See Forget-Me-Not. short and stout. The greatest beauty is the brilliancy of its beauty is the brilliancy of its carmine-red flowers, which are produced in the greatest profuthe day. The fragrance is not so the day. The fragrance is not so Affinis, but is deliciously sweet. plants of the tobacco family, which are noted for freedom and fragrance of their bloom. Halfhardy annual, 3 feet high. Flowhardy annual, 3 feet high. Flowlong, tubular corollas, and are of exquisite fragrance. Deserves a exquisite fragrance. Deserves a
place in every garden. Plkt. 10*
NICOTIANA SANDERAE. The shape of the flower resembles that of the Nicotiana

NICOTIANA AFFINIS.

A handsome genus of garden
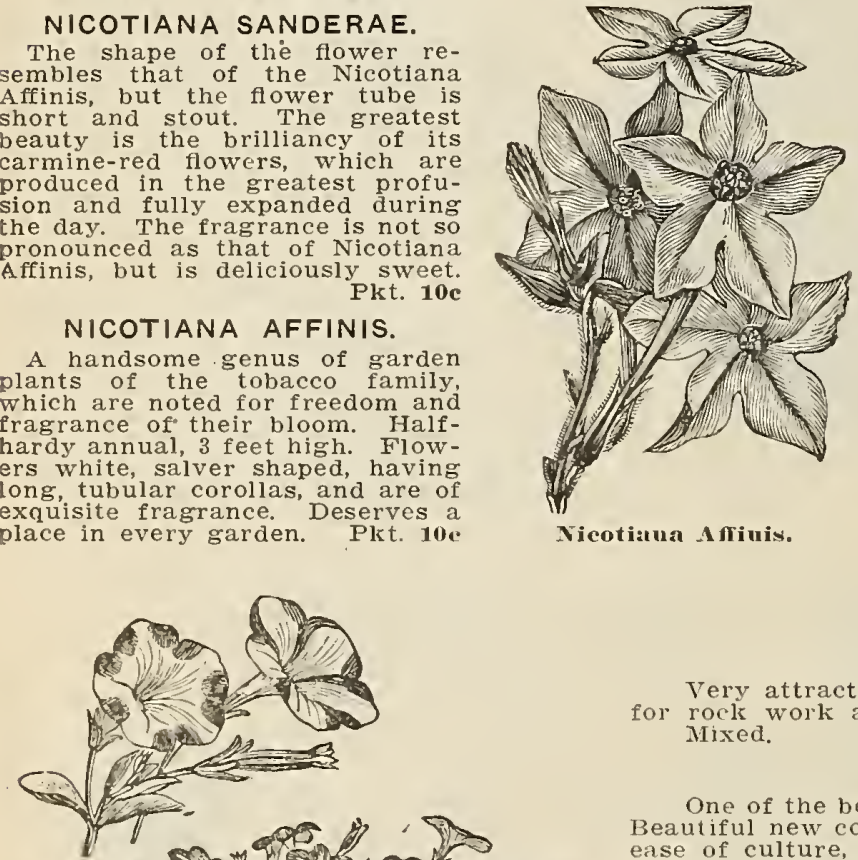

Nicotiana Amius. Mixed. Pkt. 10e

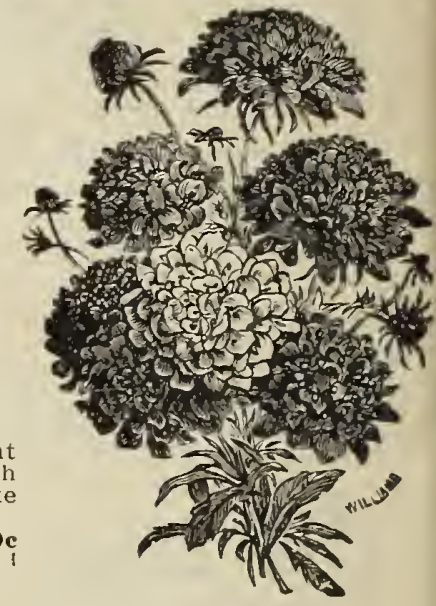

Mourning Brlde.
NEMOPHILA.

This popular plant is to he found in almost every garden, and has secured a place in the heart of all lover's of flowers. Of dwarf, spreading habit, it is well adapted to border or pot culture. The flowers are exquisitely colored. blotched and spotted; they are quite apt to sport in an endless rariety of shades from black and blue to lighter colors. Height, 6 inches. Hardy annual.

Mixed colors.

NIGELLA-Love-in-a-Mist.

Pkt. 5c

A showy annual with fine cut foliage and curiously formed double flowers of light blue color. The form and color render it very desirable for bouquets. Height, 1 foot.

Double, mixed colors.

Pkt. 5c ORNAMENTAL GRASSES.

Ornamental grasses are very useful for cutting. when fresh for summer bouquets, and also dry well for working with everlasting flowers for winter bouquets This assortment includes the most delicate and gracefui varieties.

Stipa Pennata or Featler Grass. Pkt. sc

Lasurus Ovatus. Pkt. 5c

Gruerinm or Pampas Grass. Forms elegant plumes.

All Kinds. Hixed.

Pkt. 5e

OXALIS.

Very attractive and beautiful plants, with richly colored flowers, suitable r reck ark and rustic baskets. Half-hardy perennial. Height, 6 inches.

Pkt. 10c

\section{PETUNIA.}

One of the best flowers for a splendid display throughout the entire season. Beautiful new colors, striped and marked in the most diversified manner. The ease of culture, profuse and continuous blooms, adaption for different styles of growth-indoors and in the garden-render the Petunia one of the most valuable of the annuals and entitled to a generous share of the space in every garden. In bloom from the first of July to October. Half-hardy perennial. Donble llixed. Saved from choice double fowers, always some come ingle. Giants of California. Produce immense large single blossoms. Pkt. 15c Striped and blotelied. Single mixed.

Pkt. 50

\section{PASSIFLORA-Passion Flower.}

A most interesting and well known order of climbers, bearing singularly beautiful flowers. They are the pride of South America and West Indies, where the woods are filled with the species, which climb about from tree to tree bearing flowers of striking beauty.

Passitlora coerulea.

Pkt. $10 \mathrm{c}$ 


\section{TALL NASTURTIUMS}

This well-known annual is one of the best for trellis and arbor decorations: flowers of a great variety of rich colors, striped and spotted with different shades. Is excellent for vases and baskets; excellent for vases and baskets; beds withoui trellis support; probeds withoui trellis support; prodrom the first of July until frost. Height, 6 to 10 feet.

leinemanl. Silky bronze chocolate. Oz., $15 \mathrm{c}$. Pkt. 5e. Coceiueum. Bright orange scar-
let. Oz., $15 \mathrm{c}$. selillingi. Bright yellow, maroon blotches. Oz., $15 \mathrm{c}$. Pkt, 5e. Pearl. Cream white. Oz.,

15c. regelianum, Brownish violet. Oz, 15c. Oz., 15c. Hemisphaericum, Straw color Straw color,
rosy blotched, fine. Oz., 15c. Pkt. 5e King Tlieodore. Crimson, dark leaved. Oz., 15c. Crimson, dark leaved. Oz., $15 \mathrm{c}$.

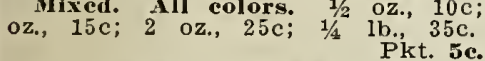

NEW FRENCH NASTURTIUM, "CHAMELEON."

This new Nasturtium is a most remarkable advance in this brilliant family. We find that in richness and variety of colors it surpasses any other strain, and is also unique in bearing flowers of quite distinct coloring on one aud the same plant-some clear, deep crimson, others blotched on light ground, and others beautifully mottled. We furnish both Tall and Dwarf separately. Oz., 20c. Pkt. 5e.

\section{MADAM GUNTHER'S HYBRIDS.}

A grand strain of tall growing Nasturtium, containing many colors not found in any other mixture. Oz., 15c. Pkt. 5c.

\section{DWARF NASTURTIUMS}

A bed of Dwarf Nasturtiums is very desirable for borders along walk ways, etc. They are in cons tant bloom. Grow about one foot

Brilinnt. A handsome scarlet. Oz., $15 \mathrm{c}$., ruing. A blue tinted red. Oz., 15c., Creamy white. Pkt. Jc. King Theodore. Maroon. Maroon. Oz., Lady Bird. Orange yellow, red spots. Oz., 15c. Pkt. 5c. dark leaved. Oz. 15c Purpureum. Crimson. Oz. yixed Colors. $1 / 2$ oz. Pkt. 5e. $15 \mathrm{c} ; 2$ oz. 25c.1/4 Ib., 40c., $15 \mathrm{c} ; 2$ oz., $25 \mathrm{c} ; 1 / 4$ lb., $40 \mathrm{c}$. Pkt. 5c. $15 \mathrm{c}$. NASTURTIUMS VARIEGATED LEAVES.

The foliage of these new Nasturtiums is strikingly beautiful, rendering the plants very ornamental, even when not in bloom. Some of the leaves are $1 / 2$ to $2 / 3$ white and yellow others are mostly green but blotched and striped with yellow and white, and others are mostly pure yellow with stripes of green. When in bloom Tall, mixed colors. Pkt., 10e; oz., 25e.

Tnarf, mixed colors. Pkt., 10e; oz., 30c.

\section{LOBBIANUM NASTURTIUM.}

These constitute, without doubt, some of the finest of our annual climbers; they are as easily grown as the common Tall Nasturtium, which they far surpass in rem able brilliancy of their flowers, and also in height of vines

Mauy Colors. Mixed. $1 / 2$ oz., $10 \mathrm{c} ; 0 z ., 15 \mathrm{c}$.

Pkt. 5e.

\section{NEW IVY LEAVED CLIMBING NASTURTIUM.}

This is the most distint and showy variety, differing from all other Nasturtiums in both foliage and flower. The plants are of strong running growth; the leaves, are deep rich green, veined with silvery white, closely resembling
in form and veining those of the hardy English Ivy. Oz., 20c.

Six packets of any varieties of Nasturtiums except Variegated Leaved for 20 ; 12 for $40 c$. Five $1-0 z$. pockages for 50c.

\section{PANSIES}

Next to the Rose there is no other plant which enjoys such universal popularity as the Pansy. It is a favorite with

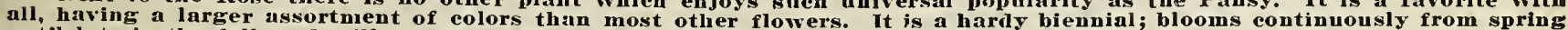
until late in the fall, and will, if slightly covered, bring fine results the second sear.

No garden, hovever small it may be, should be vithout a bed of Pansies.

\section{Trimardeau.}

Very large flowered variety. An entirely distinct and beautiful race with flowers of the richest and most varied shades of color. Plants of vigorous, compact growth The flowers, which possess unusual substance and consistency, are each marked with three large blotches or spots. with three large blotches or spots. White. With dark center. Pkt. 10e.
Black. King of Blacks. Yellow. A clear yellow. Pkt. 10c. Blue. Azure blue. Pkt. 10c. Purple. Deep royal purple. Pkt. 10c. Bronxe. A golden bronze. Pkt. 10c. Lord Beaconsfield. Lavender and purple. Pkt. 10e. Mixed. All colors. Pkt. 10e. One packet of each of the seven varieties for $50 \mathrm{c}$.

Bugnot's Very Large Stained, Mixed. A species extra large, five blotches; plants vigorous, with short stalks bearing well above the foliage; flowers of fine form and substance. Extra ers of fine form and substance. Extra
fine.

\section{Cassiers' New Giant Odier.}

Extra large flowers of the showy and popular odier type, being all three or five-spotted on backgrounds of rich glowing colors in many distinct shades.
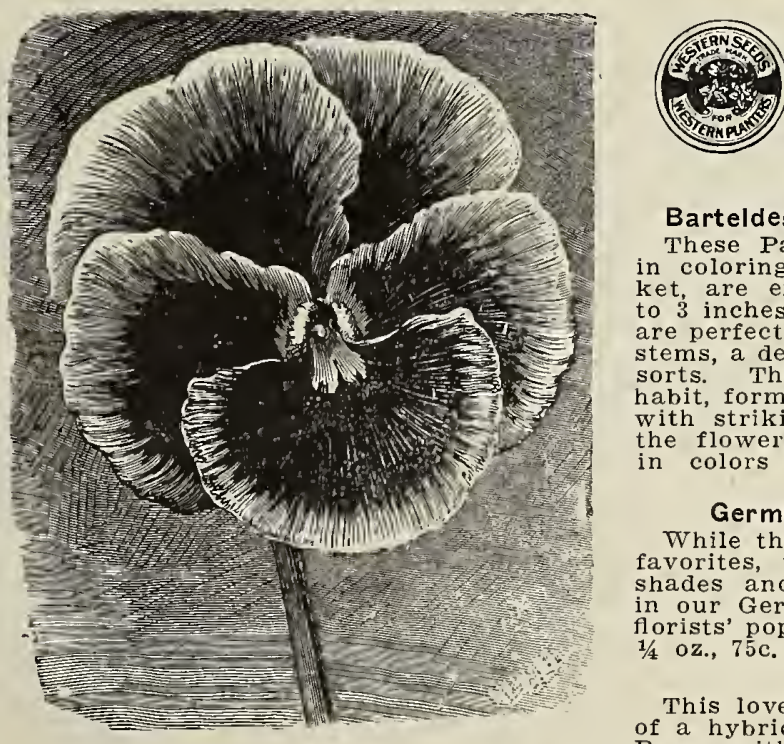

Barteldes' Giant Market Pansies.

A mixture of the very best grown in different parts of the world. Not and fine colorings.

Pkt. 20 e.

Barteldes' Triumph of the Giants.

These Pansies, though not as rich in coloring as Barteldes Giant Market, are extra large, measuring $25 / 8$ to 3 inches in diameter. The flowers are perfectly round and borne on long sorts. The plants are compact in habit, forming perfectly round bushes with strikingly pretty foliage, while the flowers are brilliant and varied in colors and abudantly produced.

German Imperial Mixture.

While the oiant flowered are great favorites, they do not carry all the shades and colors which are found in our German Mixture. This is the florists' popular strain. Mixed.

Sweet-Scented.

This lovely new class is the result of a hybridization or crossing of the Pansy with the Sweet Violet, retainGood Mixed.

Consisting of many popular colors of ordinary strains. Pkt. 5e. ing the delightful violet perfume, with Pansy blossoms of good substance and in many colors. They include pure striped, blotched. feathered, etc. orange and lavender, also 


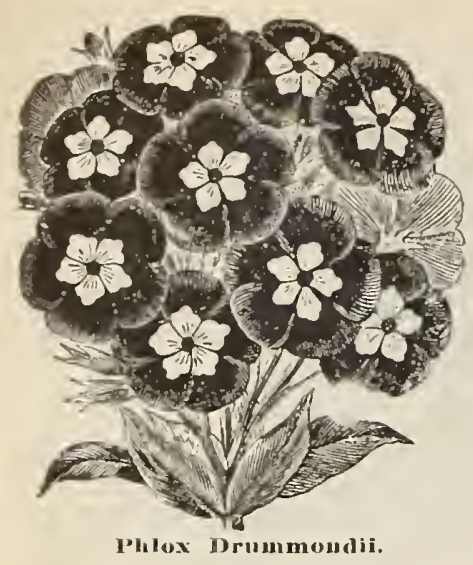

POPPY

SINGLE AND DOUBLE, MIXED.

A grand collection of the amnual varieties. Oz., $20 \mathrm{c}$. Pkt. se.

\section{FAIRY.}

The flowers are perfectly double, of large size and magnificent form. In colors the grand, large flowers are of pure white, glowing scarlet, light lilac, scarlet with white and black, rose and deep maroon. Annual. Mixed. Pkt. 5e.

\section{THE SHIRLEY.}

They are similar in every way to the Wild Scarlet Field Poppy of England and the Continent, but the range of colors is so varied that scarcely two will be found alike. Annual. Pkt. 5e.

\section{ICELAND-Perennial.}

The delicate, fragrant flowers are exceedingly beautiful, and with their long stems are well suited for cutting. The plants are perfectly hardy, easily cultivated, and the lovely white, yellow and orance-red flowers are in bloom flom early summer until fall. Hardy peremial, blooming the first year from

Pkt. 10e.

\section{PHLOX DRUMMONDII}

No flower excels this in all the qualities that make a and profusc bloom, being one of the last to succumb to he frost of late October. It is excellent for bouquets. 11 combine to place it in the list of the best half dozen vers for garden decoration. Height, 18 inches.

P’hlox Drummondii. Mixed. Oz., 60c.

Flalox Drummondll, Grandiflora. Large wering, mixed. Oz., $80 \mathrm{c}$.

Plılox Mlua. White. Oz., $\$ 1.00$

Perenuial Phlox. Mixed.

Plılox. Star of Quedlinglurg. Star-shaped ver, Mixed.

\section{PICOTEE.}

Very much like Carnation, as fine and more delicate its coloring; perennial; height, 18 inches. German, mixed.

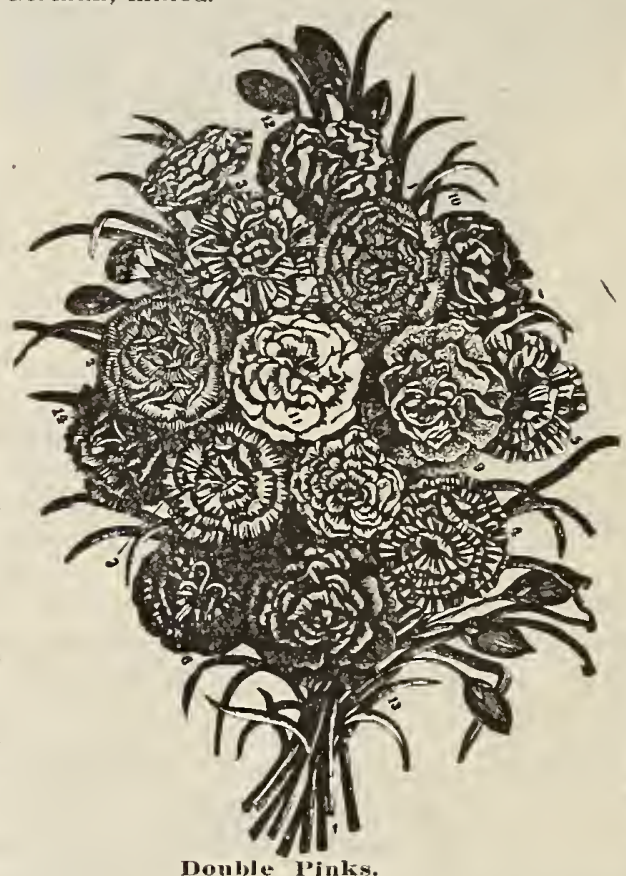

Pkt. 10e

\section{PINKS--Dianthus}

Splendid large flowers of the richest and most brilliant colors and markings: constantly in bloom from July till after severe frosts; the first and also the second year. No flower excels this genus for a brilliant show of colors through the summer. Height, 1 foot. HEDDEWIGII-Double.

Mixed. Oz., $\$ 1.00$ Pkt. se HEDDEWIGII-Single.

Mixed. Oz. $75 \mathrm{C}$ Pkt. 5e. ALBUS FLORE PLENO.

Double white. Pkt. 5e. PLUMARIUS.

Perpetual. or June Pink. Pkt. 5e. CHINENSIS-Double China.

Mixed. 1/4 oz. 15c: oz. 35c. Pkt. 5e. LACINIATÜS-single Fringed.

Mixed. 1/4 oz., 25c: oz., 75c. Pkt 5e. IMPERIALIS-Double.

PORTULACA-Rose MOSS. There are scarcely any flowers in cultivation that make such a dazzling display of beauty as a bed of many hued, brilliant colored Portulacas. They are in bloom from about the first of July until killed by frost in autumn. Plant in open ground after it has become warm, in light soil, and in a dry situation. If the beds have a full exposure to the sun the ground will be covered with plants and the effect beautiful. Tendler annual. Heisht, nche

Donble. Mixed. single. Mixed.

NEW ORIENTAL HYBRID-Perennial Poppy.

For brilliancy of colors there is nothing to equal these Oriental Poppies. The flowers are of enormous size, often measuring over six inches in diameter. One of their most valuable qualities is that they are perfectly hardy perennials, living through winters with but little protection and increasing in size and beauty from year to year. Pkt. 10e.

\section{PRIMROSE-Primula.}

These are, perhaps, the most desirable of all houseblooming plants. They are in almost constant bloom all winter, and if the plants be transferred to the border they will hloom nearly all summer. Though perennial, new plants flower more freely, and seed should be sown every year. Give them a long time for growth before flowering, and do not force the young plants, but simply protect them from frost and damp, cutting winds. Height, 1 foot.

obronica.

siucusis. Mixed.

Pkt, 10c.

PYRETHRUM-Insect Powder Plant.

lfoscum. Flowers 2 inches in diameter, carmine with yellow center.

Pkt. 10e.

The dried and powdered flowers of the Pyrethrum Roseum, is certain death to Plant Lice, Flies, Cabbage Worms and nearly every form of insect life. It is harmless to man, but when diluted with ten times its bulk of flour, kills Cabbage Worms and other insects. Height, 1 foot.

Aureum. This is the beautiful bedding plant witl golden leaves, called "Golden Feather:" Pkt. 10c.

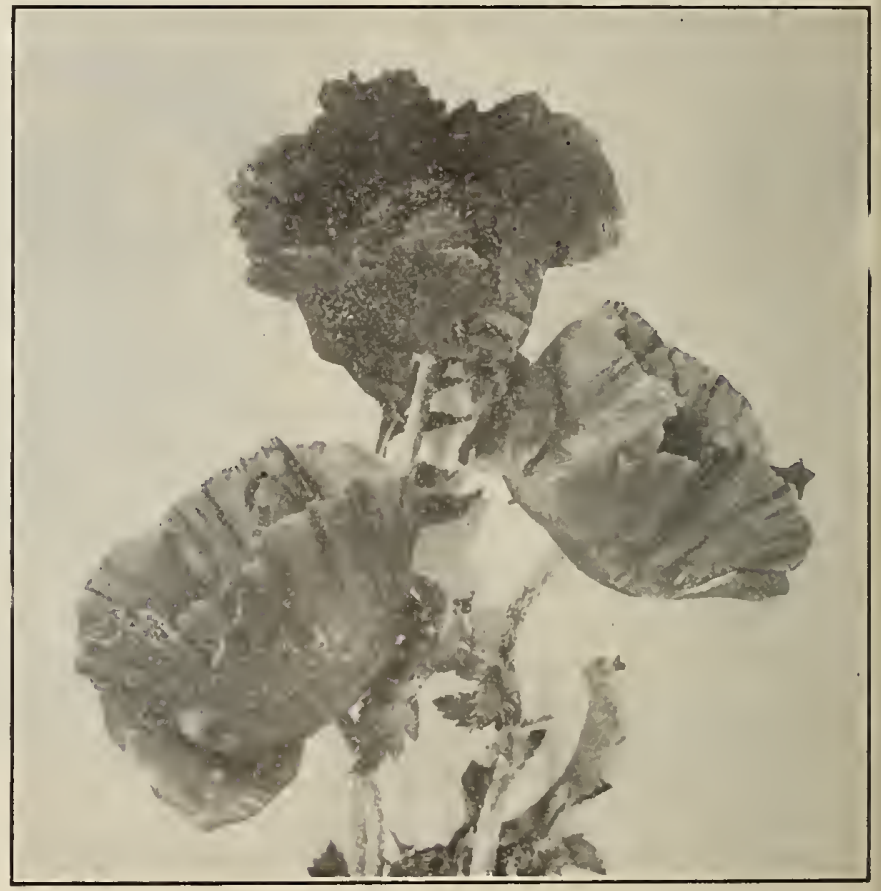




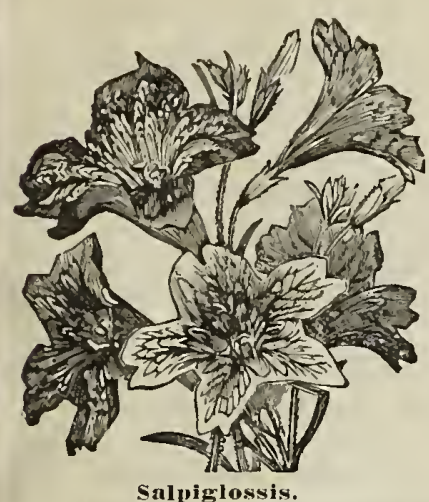

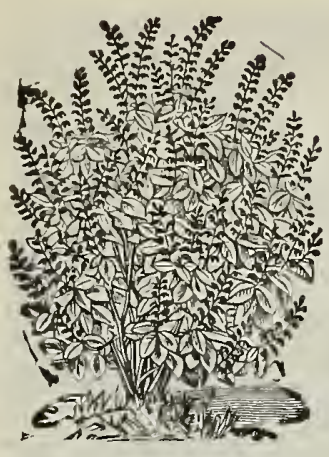

Salvia.

ROSE, NEW DWARF-Rosa Multiflora.

Height, 20 inches. They commence blooming when about 3 inches high; like annuals, they germinate, flower and produce seed within a year. Blooming is continuous thioughout the summer, but is naturally more abundant the second season. The flowers are single, semi-double and double in almost equal proportions, and present almost all the variations of color found in other roses. A young plant raised from seed sown January 15 expanded its first flowers 3 months later.

RAGGLD SAILOR. See Centaurea.

IRESTDA ODORATA. See Mignonette.

RICINUS. See Castor Bean.

ROSE CAMPION. See Agrostemma.

\section{SALPIGLOSSIS.}

A beautiful annual that deserves to be more widely known; when once grown in the garden will be one of the first to be chosen for the next year. Flowers of the richest colors-blue, crimson, yellow, purple, scarlet, etc., with texSplendid for bouquets. Height, 2 feet. Mixed colors. Pkt. 5c.

\section{SALVIA-Coccinea.}

The Salvia or Scarlet Flowering Sage is a very ornamental plant, flowering in spikes, and continues in bloom in the open ground till frost, when the plants can be removed to the greenhouse and they will continue in bloom a long to the greenhouse and they will continue in bloom a long time. This variety is of the dwarf habit, and the spikes of flowers $31^{\circ}$ not so large as some of the greenhouse sorts.
Height, $1 \frac{1}{2}$ feet. Tender annual. SCABIOSA. See Mourning Bride.

\section{SCHIZANTHUS.}

This annual should be more widely cultivated. Flower different shades of blue curiously cut and delicately spotted laced with crimson, white, yellow, etc. Adapted for garden
and indoor culture. Hxcellent for bouquets. Height, 18 and indoor culture. Excellent for bouquets. Height, 18 inches.

Mixed Colors.

Pkt. 5e.

SEÑSITIVE PLANT-Mimosa Pudica.

A curious plant, manifesting sensation to the touch of any object that jars or stirs the leaves or branches; the stalks immediately drooping or folding together, as if possessed of life and an over-supply of nerves, affording a source of amusement for the little and large folks. Height, 1 foot. Tender annual.

SILENE. See Catchfly.

\section{SMILAX.}

No climbing plant in cultivation surpasses this for graceful beauty of its foliage In cut flowers and for wreathes, etc. it is indispensable to florists. Its hard texture enables it to keep several hard texture enables it to keep several Nothing is finer for clothing statuettes. Nothing is finer for clothing statuettes,
vases, etc. Height, 10 feet. Tender perennial. Oz., $50 \mathrm{c}$.

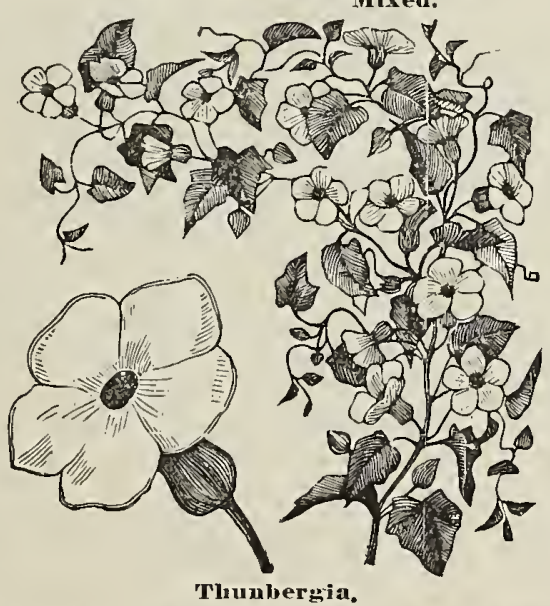

THUNBERGIA. Alatum-Climbing Black-Eyed Susan.

A trailing or climbing plant with flowers of various shades of vellow and white, having a dark center or eye. Finely adapted for vases or hanging baskets, for piazza decorations. Height, 4 feet. Mixed.

TROPAEOLUM CANARIENSIS. See Canary Bird flower.

VENUS' LOOKING GLASS-Campanula Speculum.

A small genus of hardy annuals with purplish-lilac flowers varying to rose-colored and white. They grow rapidly and are in bloom the whole summer.
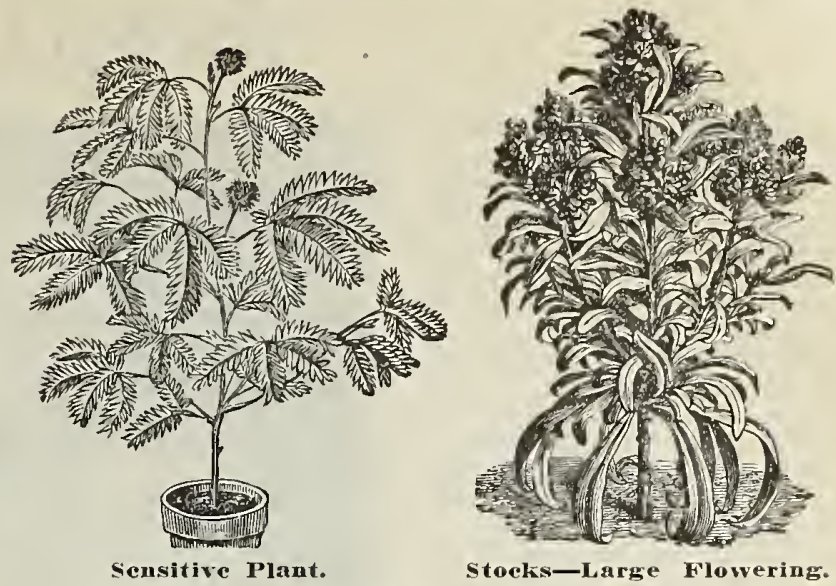

STOCKS-Ten Weeks.

Plants grow about one foot high, making a compact bush, covered with splendid spikes of blooms from July till
frost. This seed is our own importation from the most celebrated German grower of this flower, saved only from the selected plants, and will produce the largest proportion possible to obtain of large double flowers, in the most 1 foot.

German Dwarf Double, Mixed. $1 / 4$ oz., 60c. Pkt. 10c. Separate Colors. White, blue, crimson, purple, yellow.

The Brompton Stock cannot endure our winter, but if plants are grown in the open ground during the summer, in autumn they can be removed to the house, where they annual. Height, 1 foot.

Mixed.

Pkt. 10c. Pkt. 10a

The improved varieties of this popular flowers are very beautiful and should find a place in every garden. A great variety of rich colors, eyed and variegated with other shades, forming large trusses of blooms, remaining a long tims in blossom. A bed of Sweet Williams is very attractive the flowers une and first of July, at a time when but few other single. Mixed.

Plet.

SWAN RIVER DAISY. See Brachýcomb.

SWEET SULTAN-Centaurea Moschata.

A handsome annual with fragrant flowers, borne on long slender stems. Their fragrance and habit of growth adapt them linely for

Pkt. ธc. STOKESIA CYANEA.

'The Cornflower or Stokes' Aster.

This is one of the most charming and beautiful native hardy plants. The plant grows from 18 to 24 inches high, bearing freely, from early June until frost, its bossoms, each measuring from 4 to 5 inches across. Pkt. 10c.

\section{SUNFLOWER}

Fleliantleus. Globosus Pistulosus. An exceedingly double variety, adapted by stately growth for a back-ground to the lawn, or a screen to hide unsightly aces. It is also raised as an absorbent of miasma in damp or ill-drained situations, thus preventing fevers, The flowers are quite attractive. Hardy annual. Pkt. 5e. Iammoth Russian. Oz., 10c. Pkt. 5e. 


\section{SWEET PEAS} Peas delight in a soil inclined beauty is a gross feeder, a good should be mixed with the ground. Fall is the best season to prepare the soil. A good many failures have been made by manuring in the spring, for the reason that all pea vines like a moist ground, and the heat originated by the manure, combined with the heat from the sun, is too much for the young vines, which turn yellow and die. The best season to sow the seed is as soon in the spring as the ground can be rank growth, but few flowers. Dig a trench 1 foot deep by 16 or 18 inches wide and $\mathrm{mix}$ in it six inches of top soil with old manure. In this plant your seeds in 2 rows and drop one pea every inch or two; then cover with two inches of soil, gradually filling the trench as they grow. One side has to be a little lower to allow surplus water to drain off. Flowers must be picked off every day if you want them to bloom all through the summer. Bone dust and nitrate of soda will hasten the time of flowering.
GLNEIRAL CULTURE. Sweet to be clayey and, as the little supply of well rotted manure worked. Late sowing produces

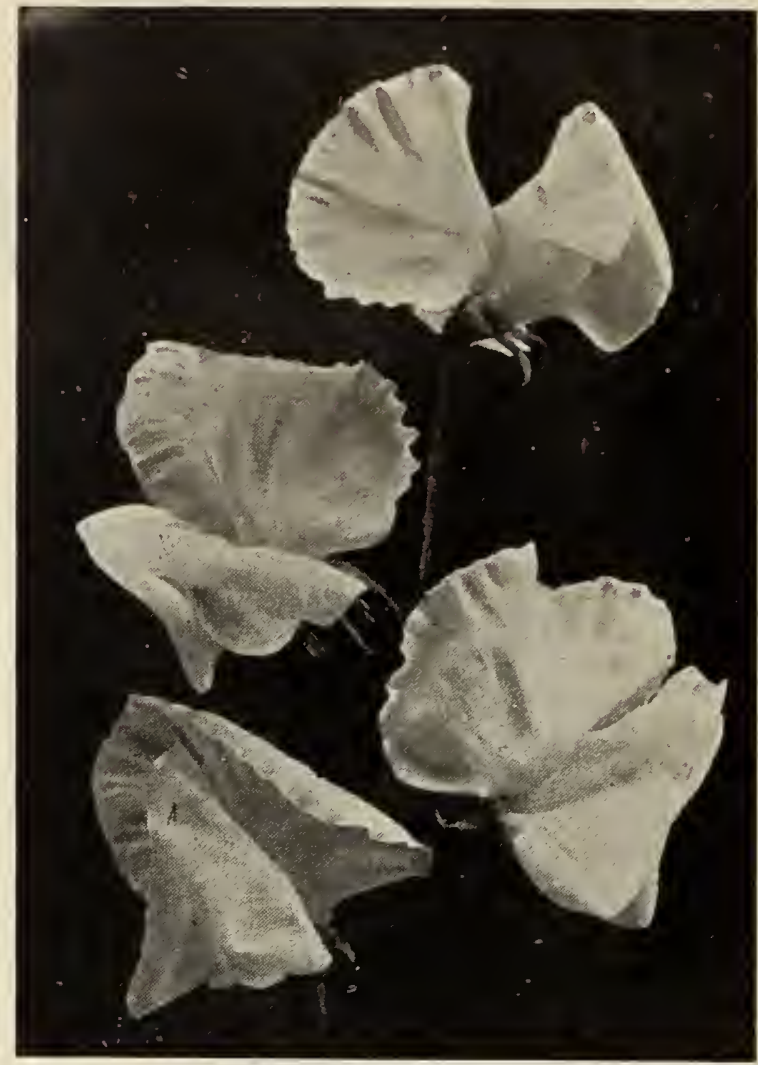

\section{Orchid Flowered Varieties}

This new type of Sweet Peas is appropriately deveribed as "truly sigantic." The fiowers are not only of enormoum size but the outer edges of the standard and wings are beautifully crumbled and waved, anl ure loosely and gracefully , on long, stif stems. Piants are heulthy and vigorous and produce these long stemmed flowers in abundanee.

Countess spencer-A clear pink which deepens at outer edges. Pkt. 5c; $1 / 2$ oz., 15c; oz., $25 \mathrm{c}$

Countess Speneer Hybrids. Strong and vigorous growers in various colors. Pkt. 5c; $1 / 2$ oz., $15 \mathrm{c}$; Oz., $25 \mathrm{c}$.

White spencer. The white flowers are extremely large and beautiful. The bold standard is crinkled and fluted and its wavy leaves are so folded that the keel is almost hidden. The flowers are borne three and four to the stem and are uniformly well placed. Pkt. 5c:

1/2 oz., $15 \mathrm{c}$ : Oz., $25 \mathrm{c}$.

Black Knight Spencer. The flowers are very dark color and beautifully waved and crinkled, both standard and wings. The stems are thick and long and carry well either three or four fine blos-

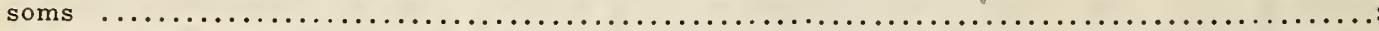

Captain of the Blues Spencer. The flowers are of immense size and always well waved and crinkled. The standard is purplish maroon, the wings bluish purple, showing veins of rosy purple......

Blanehe Ferry speneer. This is the favorite pink and white orchid flowered variety. Pale rose stand-

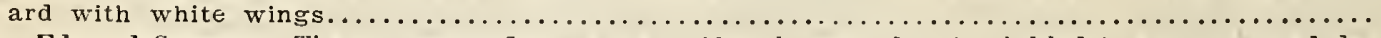

Klng Fdward Speneer. The enormous flowers are uniformly waved and crinkled to a pronounced degree. The unusually large drooping wings-one and three-eighths inches wide-make the flower appear truly gigantic. The color is dark red and is the nearest approach in color to the popular

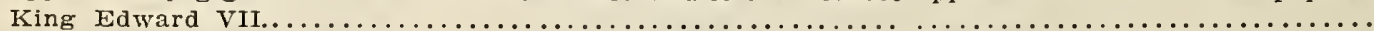

Gaiety Spencer. A fine flower striped with rosy magenta, usually three flowers on a stem. This is a

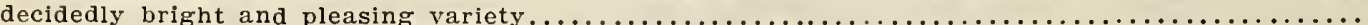

Mrs. Routzaln speneer. It is of immense size, wavy edges, and its long stout stems bear uniformly four blossoms. The color is a beautiful blending of soft straw color, tinted with blush pink and

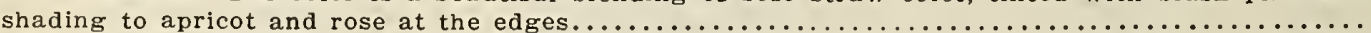

Prineess Alice speneer. A lovely shade of lavender, strong, vigorous grower, three and four flowers

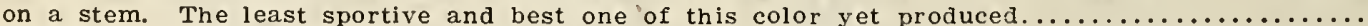

Princess Katherine speneer. A grand black seeded white of this lovely type, of unusual vigorous growth, three and four flowers on a stem; wavy standard measuring two inches across........

Prinirose spencer. The flowers are well placed, three to four on strong, thick stems. The color is a pronounced primrose or creamy yellow throughout both standard and wings. It is equal in richness of color to The Hon. Mrs. E. Kenyon, which it outranks both in form and size........

Queen Vletoria speneer. Flowers very large and waved. The background is deep primrose flushed

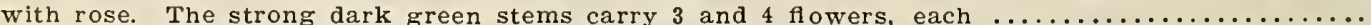

Geo. Herbert speneer. The extra large bright rosy-carmine flowers are generally borne 4 on a stem

Flora Norton spencer. The flowers though not extra large a re very wavy, bright blue with tint of

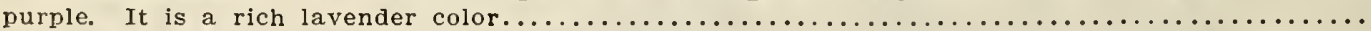

otlello speneer. Flowers very deep maroon, very large and wavy with drooping wings. It is a

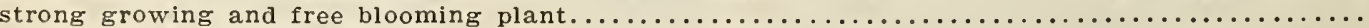

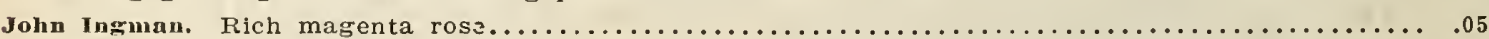

Helen Lewis. Intense rich crimson orange. The flowers are truly of a gigantic size...........05

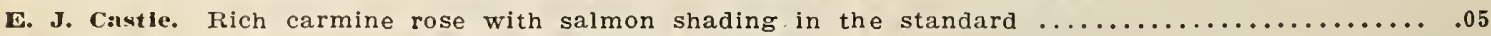

Norn Unwin. This charming variety takes its place easily in the front rank of pure white, the

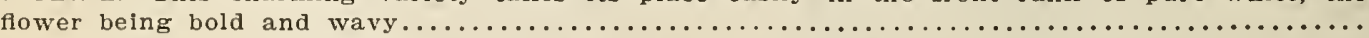

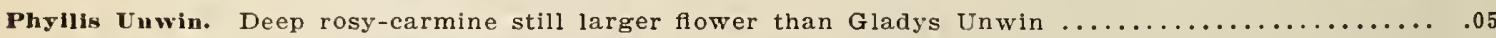

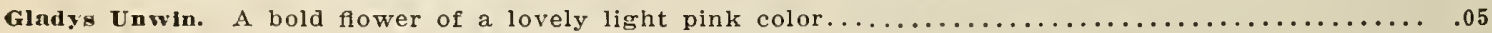

Irs. Alfred Watkins. Flowers beautifully formed and widel $y$ spreading of a clear pink color...... .05

$\begin{array}{rrr}.05 & \$ .20 & \$ .30 \\ .05 & .20 & .30 \\ .05 & .20 & .30\end{array}$




\section{SWEET PEAS--STANDARD VARIETIES}

PRICES: 5e per preket; 6 packets for 25e. 10e per ounce; $1 / 4$ 1b., 35e; 1 lb., $\$ 1.10$. Postprid. varletles marked (*) are consldered best of thelr class.

WHITE.

Emily Henderson. A persistent bloomer.

- Bianche Burvec. A splendid pure white variety.

Sadle Burpce. Hooded form

Montblanc. Earliest and best for forcing.

* Dorothy Eckford. The largest and best flower.

SCARLET.

- KIne Edvard vix. The best of all red shades; large, bright scarlet.

Saloplan. Very bright scarlet with large flower.

Mars, A large and well formed flower.

* Queen Alexandra. Bright scarlet, medium large flowers, holding its color well. Semi hooded form.

\section{PINK.}

Lady Marle Currle. Fine orange pink, of intense color, splendid for cutting.

-Jamet Scott. Soft pink, large hooded flowers.

MIss Wilmott. Large orange pink flowers, strong and vigorous.

Katherine Tracy. A soft but brilliant pink.

Lorcly. A delicate-shell tinged with yellow, often 4 flowers on a stem.

Apple Blosson. Bright rose and pink.

Prlma Donna. A lovely shade of soft pink, very vigorous, usually 4 blossoms to a stem.

Modesty. White with a tint of pink on the edges.

Lady Penzanee. An attractive orange pink with a medium hooded blossom.

Henry Eckford. Almost a clear orange, medium large; open form. It is liable to burn in the sun and should be protected for finest blossoms.

\section{MAROON}

- othello. Deep maroon and of a rich velvety effect.

Black Knight. Very deep maroon, an improvement on Boreatton.

* Mldnight. Deep violet maroon selfcolored. One of the very darkest, almost black; hooded form.

\section{YELLOW.}

-Hon. Mrs. E. Kenyon. A fine, large, clear primrose.

Mrs. Eekford. Beautiful shade of light primrose. Very vigorous grower.

Queen Vletoria. Light primrose self colored, good size flower; hooded form; black seeded and a strong grower.
PINK AND WHITE.

Earicent of All. This is the standar among florists, as it has no riva for forcing.

Early Blanche Ferry. A good bloomer.

ROSE.

Prince of Waies. Deep rose, beautifully, hooded, an improved Her Majesty.

Her Majesty. Large hooded flowers

* Lord Roseberry. Bright magenta rose with veins of deeper shade large size and hooded form.

VARIEGATED AND STRIPED.

*Helen Picree. Blue mottled on pure white.

America. Scarlet, striped on white Large open flowers.

Gray Friar. Watered purple on white ground.

* Maid of Honor. Flowers white shaded at top with lilac and lavender; hooded form.

LAVENDER AND LIGHT BLUE.

New Countess. Delicate lavender.

*Lady Gisel Hnnilton. Very large flower with long stems, standard lavender, wings azure blue.

* Mrs. Geo. Higginson, Jr. A clear azure blue.

*Iottie Eckfort. Silvery white shaded with lavender.

Dorothy Tenuant. Rosy purple, large size.

* Romolo Piazrani. Improved Dorothy Tennant. A fine large variety.

\section{BLUE AND PURPLE.}

Captaln of the Blues. Bright purple hue.

Countess of Cadogan. Flowers open a purple, but soon change to a lilac and then to a blue.

* Navy Blue. The large flowers are of a rich violet purple with the effects of a dark navy blue.

* Florg vorton. Bright clear blue with tint of purple; open form.

SWEET PEA SEED INOCULATED WITH NITROGEN CULTURE, Named varieties: White, plnk, blue, yellow, variegated, maroon, scarlet, lavender - and mixed. 1 oz. pkg., 20c; 4 oz. pkg., 60e; 5 pkgs. of 1 oz. different colors, $80 \mathrm{c}$.

\section{SWEET PEAS IN MIXTURES}

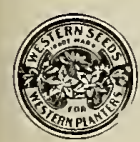

Our "COLUMBINE" Grade (Mixed) mix in all our choice varieties. Oz., 10c; $1 / 4$ lb., 35c; 1b., $\$ 1.10$. an ounce at least. Oz., 10c; 1/t/ 1b., 35c. Pkt., 5c.

Nothing better in mixture of varieties and should not be compared with ordinary mixtures on the market. We LIGHT CoLORS oNLY. Mixed from named varieties. Oz., 10c; 1/4 1b., 35c. Pkt., 5c.

RED, WHITE AND BrUE MIXTURE. Consists of Salopian, Blanche Burpee and Navy Blue mixture. Try

ECKFORD'S FINE MIXED. Oz., 10c; $1 / 41 \mathrm{~b} ., 30 \mathrm{c} ; 1 \mathrm{~b} ., 90 \mathrm{c}$. Pkt. 5c.

\section{DWARF SWEET PEAS-Cupid.}

Ten inches high. A dwarf variety that is suitable for pot culture, hanging baskets, etc. Blossoms are smaller than ordinary tall varieties. Oz, $10 \mathrm{c}$.

White Cupld. Pure white blossoms.

Pink Cupld. Clear soft pink standard, white wings.

Mlxed Cupld. Contains many colors.

\section{BUSH SWEET PEAS.}

(Mixed.)

A distinct type of bush habit (not dwarf like Cupid) with blossoms much the same as tall varieties but shorter stems. Oz., 10c; 4 oz., $35 \mathrm{c}$.

Pkt. 5c.

\section{DOUBLE SWEET PEAS}

It has been a difficult task by hybridization and selection to change the habit of the Sweet Pea to the double form and much remains to be done. The result at best is really semi-double flowers. The best varieties we have will not produce more than half-doubles, the others remaining of the usual single type. We furnish them mixed. Oz., 10c; $4 \mathrm{oz}$. 35 c.

\section{EVERLASTING PEAS.}

A perennial clinuer, producing a succession of white, rose and purple blossoms in clusters. Suitable for trellises, Oz., $35 \mathrm{c}$.

\section{WALLFLOWER.}

The large, massive spikes of the Wallflower are very conspicuous in beds and borders, and are very useful in making bouquets. They are deliciously fragrant, perfectly double, and combine many shades of color-the orange, double, and combine many shades of color-the orange,
purple and chocolate predominating. Height, 18 inches.
Tender perennial. ender perennial.

Double, Mlxed.

Slngle, Mixed.
Pkt., 10c. Pkt., 10c.
WHITLAVIA-Grandiflora.

An elegant annual, with delicate foliage and drooping clusters of rich, dark blue and white bell shaped flowers. Is fine for baskets and vases; for piazza decorations is one of the best, flourishing best in partly shaded situation. Height, 1 foot. 


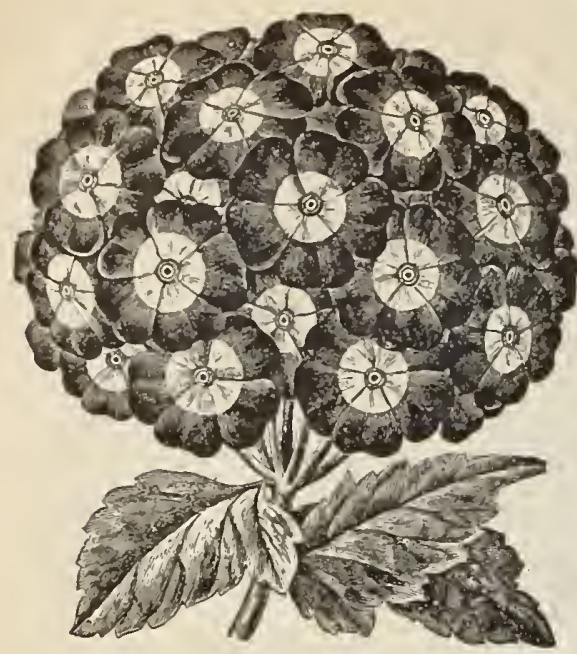

Verbena Mammoth.

\section{VERBENA.}

The most popular bedding plant grown from seed. The fine variety of colors, with stripes and markings of different colors, profuse and long continued bloom and excellence for bouquets, malie them one of the most desirable annuals for general culture. Grown from seeds the flowers are quite fragrant, and blossoms stronger than from cuttings. Tender perennial.

Verbenal IIyhrila. Mixed colors. 1/4 oz., $25 \mathrm{c}$; oz., $75 \mathrm{c}$.

Pkt., 5c.

Mammotl. Mixed. $1 / 4 \mathrm{oz}, 50 \mathrm{c} \ldots \ldots .$. . Pkt., 10c

Separate Colors. White, pink, purple, blue, scarlet striped. Each pkt., 10c.

We furnisls Verbena plants in the spring montlis. See list of plants.

\section{VIOLET-Viola Odorata.}

The violet should not be wanting in any garden, on account of its fragrancc and early appearance. A single flower will perfume a whole room. Succeeds best in a shady, sheltered place, and can be easily increased by dividing the roots. The violet is an emblem of faitlfulness. Hardy perennial. Height, 4 inches.

Pkt., 10e.

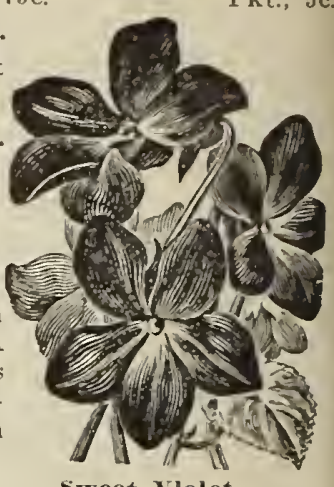

sweet violet.

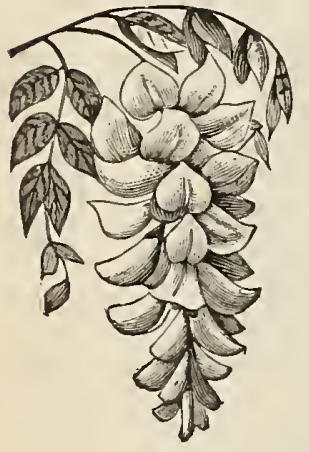

Wistaria.

WILD FLOWER GARDEN, or Mixture of all Kinds of Flower Seeds.

Any one who has planted and cultivated flowers in neatly laid out beds and borders is aware of the labor and constant attention required to produce the desired effect. To those who cannot give this care, "The Wild Flower Garden" presents a substitute which, for its unusual and varied effect, cheapness and the small amount of labor necessary for its construction has no equal. The seeds we offer for the "Wild Flower Garden" are a mixture of over 150 different varieties, and being mixed can be offered at a much less price than when sold in separate packages. No one not having such a bed can form an idea of its beauty, the different seasons of bloom insuring something new almost every day. $1 / 2$ oz., $15 \mathrm{c} ; 1$ oz, $25 \mathrm{c}$.

Large pkt., 10c.

\section{WILD CUCUMBER-Eschinochystis Lobata.}

Ornamental climbing cucumbers with curious fruit, remarkable for its luxuriance and rapidity of growth. Height, 15 feet. Half-hardy annual. Oz., 15c; 1/4 1b., 40c.

Pkt., 5c.

\section{WISTARIA VINES-Glycine Sinensis.}

One of the quickest growing climbers, of fine bright foliage, producing bunches of rose lilac flowers in great abundance during spring. If once started will live for years. Hardy perennial. Height, 20 feet. Pkt., 10e.

\section{XERANTHEMUM.}

A popular flower of the immortelle class. Blooming freely in common soil. Plant is of compact habit, with flowers borne on strong stems. Colors, white, purple, red, and light blue. Hardy annual. Height, 1 foot. Pkt., Ee.

\section{ZINNIA.}

Fine, large flowers of great variety of colors-red, rose, crimson, scarlet, purple, orange, white and yellow-the flowers full double as a Dahlia, and remaining in bloom from July till frost. Make a fine display when grown in rows, the plants forming a dense hedge, covered with blooms. Height, 2 feet. Half-hardy annual.

Double. Mixed.

New Zebra. Striped, resembling a zebra.

Pkt., 5e. Pkt., 10e.

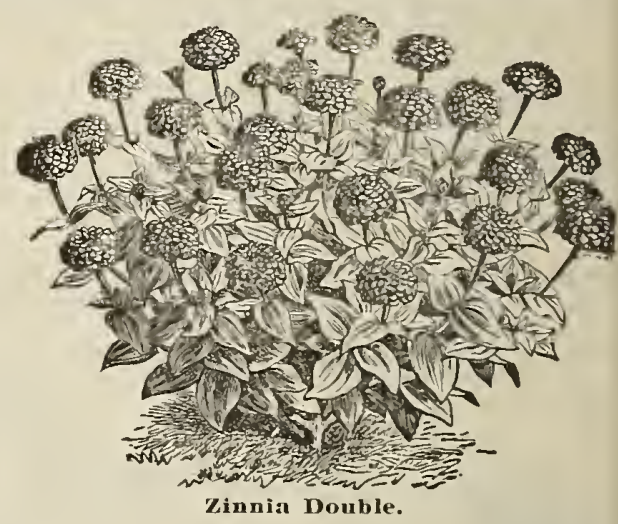

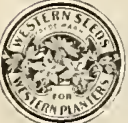

Our Flower Seed Department is fully equipped for efficient service. The stocks we offer are the product of the best European and American specialties. We call particular attention to our Aster, P'ansies, Ploxes and other popular flowers, being in position to meet the requirements of those who take especial pride in their flower garden.

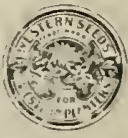

\section{HINTS AND SUGGESTIONS FOR GROWING SUMMER FLOWERING BULBS IN POTS.}

The best soil for growing plants in pots is made by mixing one part ordinary garden soil, one part of turfy matter, or leafmold, with enough sand to make it so friable that it will fall apart readily after squeezing it in the hand. The turfy matter is obtained by cutting of that portion of soil in which the roots are when a piece of sod is turned over. It gives a light spongy soil, rich in vegetable matter.

Every pot more than three inches across should have a layer of coarse gravel, or pieces of broken earthenware, to allow drainage, before filling with soil. Do not repot often when plants are in five or six inch pots; but supply food in the shape of commercial fertilizers.

In repotting any plant, large or small, disturb the roots as little as possible. Slip it out of its old pot, put it into new one and fill in about it with fresh soil. Water well to settle the soil you have added.

If bulbs are started in pots and then plunged into the ground they can bc lifted up before frost and carried in the house where they will continue to bloom for some time.

Certain spccies of bulbous plants will bloom all winter. 


\section{SUMMER FLOWERING BULBS}

Iu plantug leds always begin by outslde row and leave a space between plants and edme of bed of half tie distanee

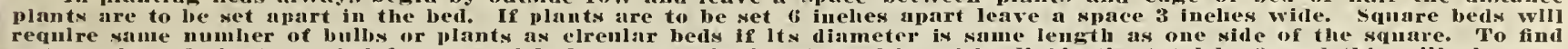

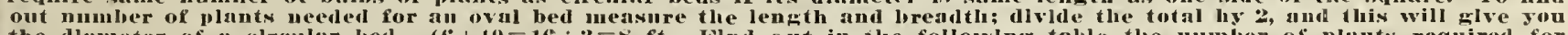

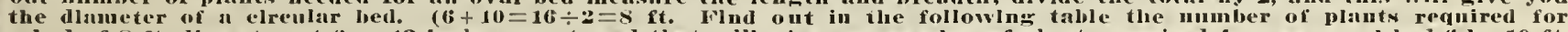

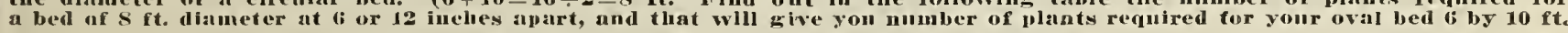

\section{NUMBER OF PLANTS FOR CHCULAR BEDS.}

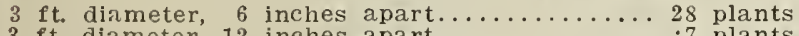
$3 \mathrm{ft}$. diameter, 12 inches apart............ 7 plants
diameter, 12 inches apart.
120 plants
diameter, 12 inches apart
112 plants
00 plants
$10 \mathrm{ft}$. diameter, 6 inches apart.
$10 \mathrm{ft}$. diameter, 12 inches apart
$10 \mathrm{ft}$. diameter, 18 inches apart

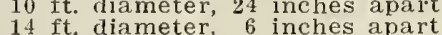

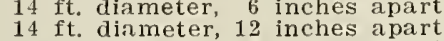
320 plants
$14 \mathrm{ft}$. diameter, 12 inches apart
8 ft. diameter, 6 inches apart.
$14 \mathrm{ft}$. diameter, 24 inches apart.
80
36 plants
20 plants
153 plants
68 plants
39 plants

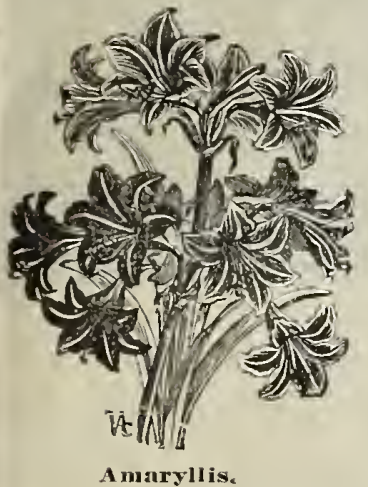

CALADIUMS

Perhaps better known as Elephant's Ear. A very effective plant for outdoor planting where a tropicial appearance is desired. The leaves often attain a length of 3 feet and $11 / 2$ feet wide. With a little care they grow to enormous proportions. Good bulbs, 15c; three for $40 \mathrm{c}$.

\section{CALLA LIILIES.}

This old favorite is always "in style," and a flower that should be in every plant collection. Our bulbs are the true California grown, extra large and vigorous. Order early. We cannot promise to have bulbs in good condition after April 1. Each, 15c; four for $50 \mathrm{c}$.

\section{Cannas}

A ronud bed $z$

The Cannas are among the most beautiful bedding plants. They have long been great favorites, but since the introduction of many new varieties their value has been greatly increasd by adding to the already attractive foliage large flowers of the most brilliant colors, so that they are now indispensable. No plant is better adapted to our climate, and nothing costing so little excels them for masses of beautiful foliage, as well as the abundance of dazzling blooms in many shades. Plant outdoors about the middle of May if werther is warm and settled, setting the plants 18 inches apart each way, and the tallest varieties in center of bed. Do not water too freely until well started, then they should have an abundance.

Priees, 15c eaeh, 2 for $25 \mathrm{e}$; the full colleetion, $\$ 1.20$. Height 3 to 4 feet

Chieago. Light cherry scarlet, green foliage.

Duke Marlborouglt. Rich maroon, green foliage.

Be:teon. It has a truss of medium sized flowers opening at one time making a striking gorgeous effect. Color rich cardinal red; green foliage. Burbank. Orchid flowered, yellow with crimson spots, green foliage West Grove. Moderate large flowers; but large truss of a pure coral pink; green foliage.

Shenandoalı. Large salmon colored flowers, bronze foliage.

Moonliglit. Large number of small flowers in a truss and a creamy white; strong grower; green foliage. Height 5 to 6 feet.

Alphonse Bouvier. Crimson, strong grower, green foliage.

Louisiana. Orchid flowered, often 6 and 7 inches across; color vivid crimson. A strong grower and prolific bloomer; green foliage.

Indiana. Orchid flowered of great size; color velvety fiery orange; green foliage. Height 6 to 7 feet.

Flambeal. Flowers a glowing fiery vermilion orange edged with golden yellow, often measuring 7 inches across; green foliage.

King of Bronzes. Gcorgeous small red flowers; foliage rich red bronze. Unnamed Varieties. Mixed. $10 \mathrm{c}$ each; 3 for $25 \mathrm{c}$; 12 for $80 \mathrm{c}$.

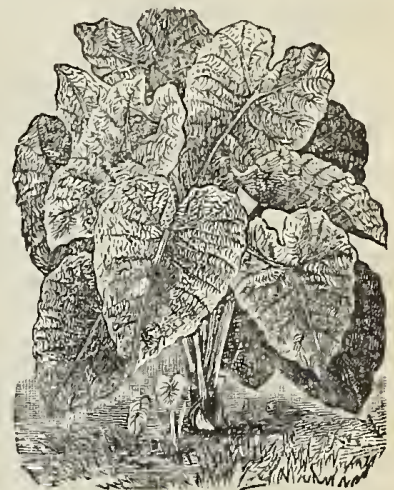

Caladium.

\section{SPOTTED CALLAS.}

Similar in growth to the well known white Calla, except that the foliage is dotted with white spots and the flower is smaller, with

\section{CYCLAMEN.}

A well known and universally admired plant, producing exceedingly handsome flowers. It grows readily, blossoms freely and remains a long time in flower. The soil should be equal parts of turfy loam, leaf mould and sand. Plant in a 5-inch pot well ing lightly till growth begins, then water freely and give plenty of light and air.

The stock of bulbs we offer is grown expressly for critical flower lovers.

Cyelamen Persieum Giganteum. Separate colors, white, red and purple. Each, $15 \mathrm{c}$.

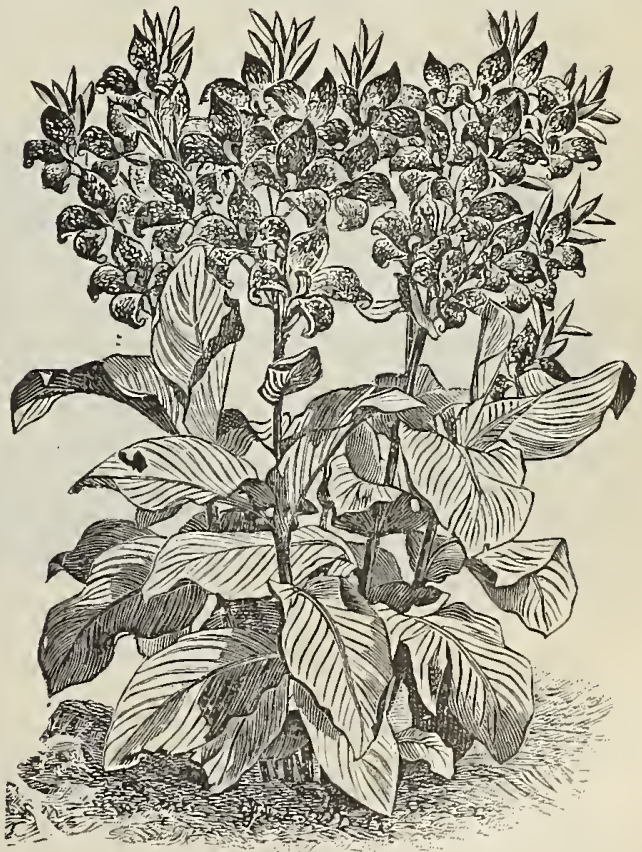

Canuas. 


\section{DAHLIAS}

We make a weelalty of stoek from the famous Whmore Dalia Farm, where there are hundreds of varletles Grown.

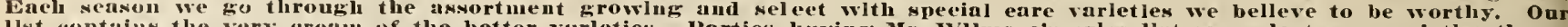

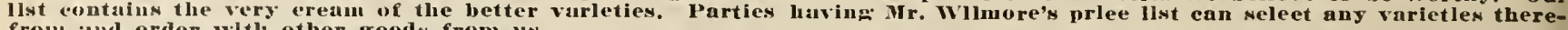

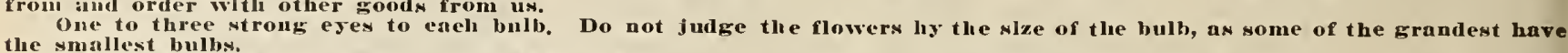

(1) vells at 3.5 eents.

\section{DAHLIAS--DECORATIVE, SHOW AND FANCY VARIETIES}

Prices, $15 \mathrm{c}$ each; $\$ 1.50$ per dozen, except where priced differently. 6 at the dozen rate. WHITE SHADES.

1. I. Chane. Crcamy white streaked with purple, sometimes solid purple. Height, 3 feet.

Bon May. An old Dahlia, but one of the best. White ground, streaked and marbled in a curious manner with bright red. Height, 4 feet. in cultivation. almost round as a ball. Height, 3 feet.

Grand Duke Alexis. An immence white flower, shaded with delicate lavender, on long wiry stem. Height, 4 feet. Price, My Milmay. A very beautiful flower. White oround shaded to pale lilac, very large and full; a free bloomer. Ileight, 3 feet.

Nrs. Linder. This new decorative Dahlia we consider one of oul best. Its color is a beautiful creamy white, shading to blush pink. Of perfect outline. Height, 4 "feet.

Wrs. T. Winters. The grandest of all white Dahlias. Its color is a pure waxy white, which shows no tint or variaticn even in the strongest sunlight. It blooms very freely, producing flowers from 5 to 7 inches in diameter, with beautifully pointcd petals. Another good quality is that it nevcr shows an open center. The plant grows to a height of 4 feet, and is of a rather spreading habit. Price, Each, 20e. for cutting. A Height, 4 feet.

\section{PURPLE, RED AND} MAROON.

Bon Ton. A fine ball shaped flower of a deep garnet red, sometimes tipped and streaked with white. An extra

Fra. Height, 4 feet. Frank Smitl. Rich dark pure white, shaded into pink. pure white, shaded into pink.

Fioral Park Jewel. Rich purple red, tipped and striped with white. Sometimes solid color. Very early and

Grand Morul. Bright scarlet tipped and streaked pure

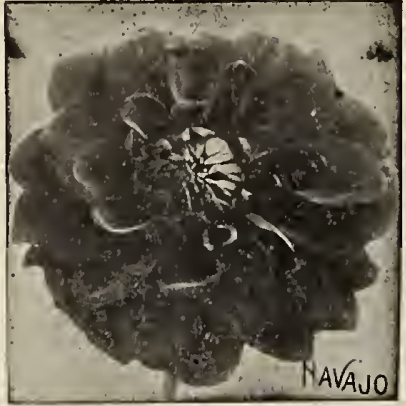
white Height 4 feet

Lynuluurst. 'Scarlet or vermilion. A noble flower. Height 4 feet.

Navajo. See cut. The color is very rich, being a most intense red, with violet shading. Strong and healthy, foliage very dark. Price,
Pioneer. The nearest approach to a black Dahlia of any yet introduced. Height, 3 feet

Purple Gen. Rich royal purple, clear and constant. A first-class flower. Height, 4 feet.

SPECIAL OFFER: One each, above Show and
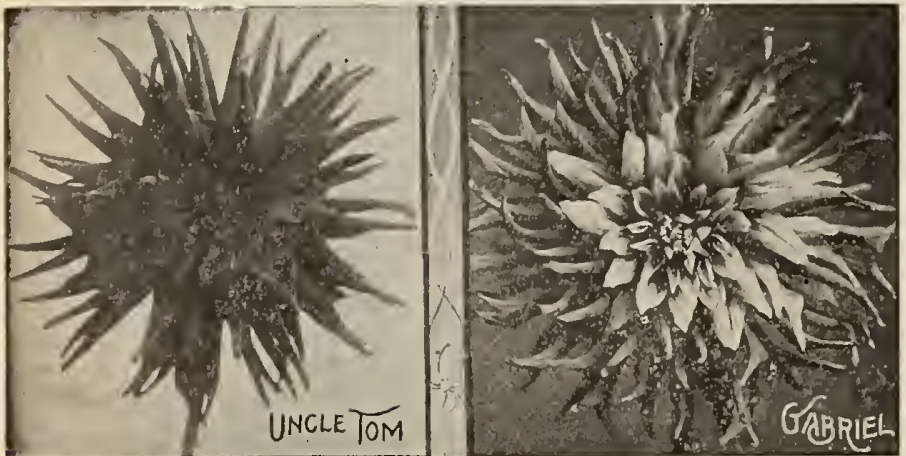

WHITE.

teelsers. A delicate, medium sized flower, borne on long erect slems. Color pure white shading to greenish white at the hase of the petals. Height, 3 feet.
Irs. I'art. Color a delicate creamy white; height, 3 feet. YELLOW.

Mrs. Clas. Turner. Is the finest of all the yellow in the Cactus variety, Extra large, with long, pointed petals and perfect in form. Bright lemon yellow. Height, 4 feet.

Genesta. Rich orange bronze. A fine autumn shade.

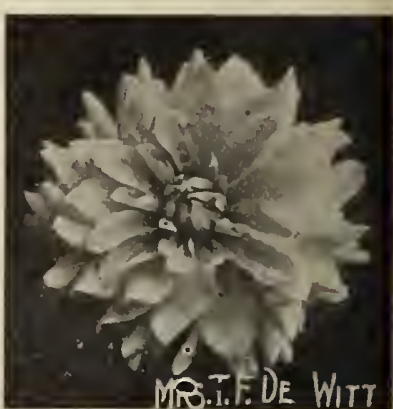

PINK.

A. D. Livonl. Rich pink, finely formed, a very handsome flower. Height, 3 feet.

Annie Moore. A fine variegated flower of medium size. Color, beautiful combination of cherry, pink and white. Height, 3 feet.

Dr. Gatew. This is a lovely shade of shell pink shading to blush at the end of the petals. It has a fine stem, holding its flowcrs well above the foliage. Height. 5 feet.

Dr. Muir. Flowers are large and full. Color, apricot, shaded to orange bronze, Height, 3 feet.

Malam Von Den Dael. See cut. An immense shell pink decorative Dahlia. Stems are exceptionally long and wiry. bringing the large flowers above the follage. Pricc.

Each, 20c.

\section{YELLOW SHADES.}

Golden Treasure. A beautiful burnt orange color. Flower large, well formed and full to the center. Height, 3 feet Kaiser Wilhelm. One of the grandest flowers in cultivation. Of immense size and perfect form. Deep yellow, tipped and shaded with cherry red. Height, 4 feet.

Miss Dodd. Purest yellow. Of exquisite form and color.

markable handsome flower. Height, 3 feet.

Miss Ruth. Lemon yellow, tipped with pure white; Mrss ruth. Lemon yeight, 3 feet.

lirs. Hartong. Very large and exquisite form. Color light fawn, suffused with pink; handsome. Height, 5 feet. Urs. T. Dewitt. See cut 'The large, yellow flowers are perfect both in form and color Price, - Each, 20c The Barou. Bright yellow flowers, sometimes tipped with white. In form they are nearly round. Stems long. An excellent variety for cutting. Height, 4 feet. Price

\section{Varieties -28 bulbs for $\$ 3.50$ prepaid.}

\section{CACTUS DAHLIAS}

Priee, 15e each or $\$ 1.50$ a doz., except wherc prleed differently; 6 at the doz, rate. One eacli, 14 bulbs for $\$ 1,65$, prepaid. PINK.

Countess of Lonsdale. Color, an exquisite shade of rich salmon, with just a suspicion of apricot at the base of the salmon, with jually to the petals. Towards the tips the color deepens gradually to the softcst carmine pink.
Estella. Color, variable ground varying from blush to dark pink, heavily streaked and marked with red, sometimes producing a half of the flower solid red.

Mrs. Alvord. Salmon shaded to primrose, pink petals, and flower finely formed. Height, 3 feet.

ririemlilile. Produces flowers of a delicate flesh pink, shading to white in the center. As a cut flower it is likely to supersede all existing pink sorts. Each, zoe. Zeplivr. A light, feathery form of unique coloring, rosy pink shading to heliotrope. An early and profuse bloomer. Height, 3 feet.

\section{RED AND MAROON.}

Galiricl. See cut. Vcry large and full to the center Color: scarlet to creamy white, often striped scarlet and White Strong tubers. Each, 20c.

Glorlos.. Bright scarlet, long curved petals. One of the best Height, 4 feet.

Mars. Intense scarlet shading to orange at the base of the petals. Height, 3 feet.

Mrs. M. Leslie. It is a fine Cactus. The plant is of spreading habit and the flower very compact, of a deep glowing red.

Unele Tom, See cut. Maroon approaching black; petals, long and narrow, flowers large and full; strong tubers

Helght, 3 feet. 


\section{SINGLE DAHLIA}

I'wentieth Century. A grand single variety, not only valuable as a flowering plant for the garden, but a choice cut flower. It is a rosy crimson, tipped with whlte, and has a white band around the disc. As the season advances they become lighter, until they are almost pure white, suffused with soft pink, not variegated but blended in the most beautlful manner. Price,

Each, 20e.

\section{POMPON OR BOQUET DAHLIAS}

These small, well formed Dahlias are especially desirable for cutting. We name but three colors, but can furnish a full list of colors if desired. Strong tubers, $15 \mathrm{c}$ each; $\$ 1.50$ per doz.

Callerlue. Bright yellow, good form and stem. Height, eet.

Darkness. Very dark maroon, extra fine. Height, 3

DOLlaik Collection. Thlrteen Dahlia Bulbs, no two nlike, our eloice, but not labelled, for \$1.0o. An Immense amount of flowers for the money.

\section{GLADIOLUS}

The most attractive of all summer flowering bulbs, and now that such grcat advancement over the common sorts has

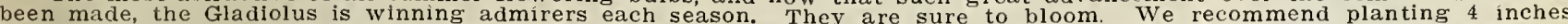

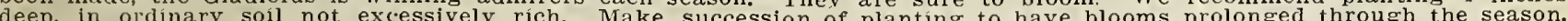
Large bulbs do not always produce the grandest flowers. Medium sized bulbs give best results.

Augusin. Lovely, pure white with blue anthers; strong, straigh

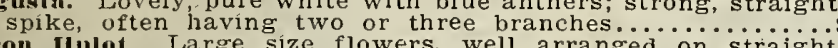
Barou Ilnlot. Large size flowers, well arranged on straight spike; color dark violet, bordering on blue..............

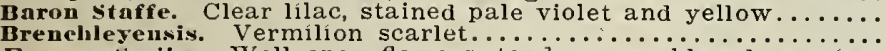
Eugene Seriie. Well open flowers, tender rose, blazed carmineEugen Gll Blas. Eariy flowering plant of dwarf habit flowers salmon-

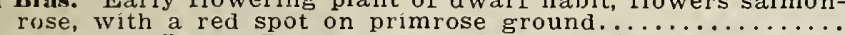
George Panl. Large flowers, deep crimson slightiy stained yel-

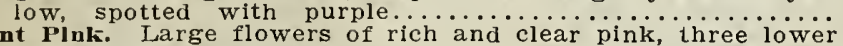
Glunt Pink. Large flowers of rich and clear pink, three lower petals marked with red................. Flowers creamy white, lower petals stained maroon
Klondyke. very desirable as one of the earliest yellow. Pale primrose-yellow with crimson maroon blotch on lower

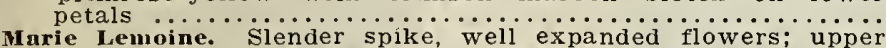
division cream, flushed salmon-lilac; lower division spotted Iay. Jovely purc white flowers, finely flaked bright rosy crimMay. Jovely purc whin fowers, finely llaked bright rosy crim Mephistopheles. Flowers of large size, dark red, stained with

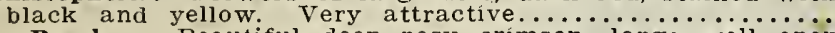
Mrs. Beeeher. Beautiful deep rosy crimson, large well open flowers, with white throat, freely marked................

Prlneeps. This magnificent variety, grown and developed by Dr. Van Fleet, is the largest and most effective and graceful of all Gladioli. It grows from $3 \frac{1 / 2}{2}$ to 4 feet high under ordinary garden conditions; its handsome foliage is a grand setting for the brilliant Amaryllis-like blooms which open more widely than any other variety. The color is rich crimson with intense shadings in the throat and broad white blotches across the lower petals. The flowers range from

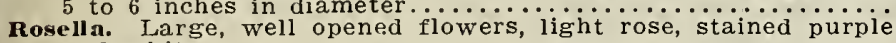

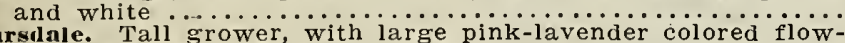
Scarsdale. Tall grower, with large pink-lavender colored llowsnowbank. Fine spike of well formed flowers, pure white, save

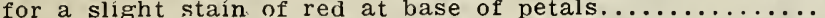
we will sell one dozen mixed varieties at dozen rate, Each

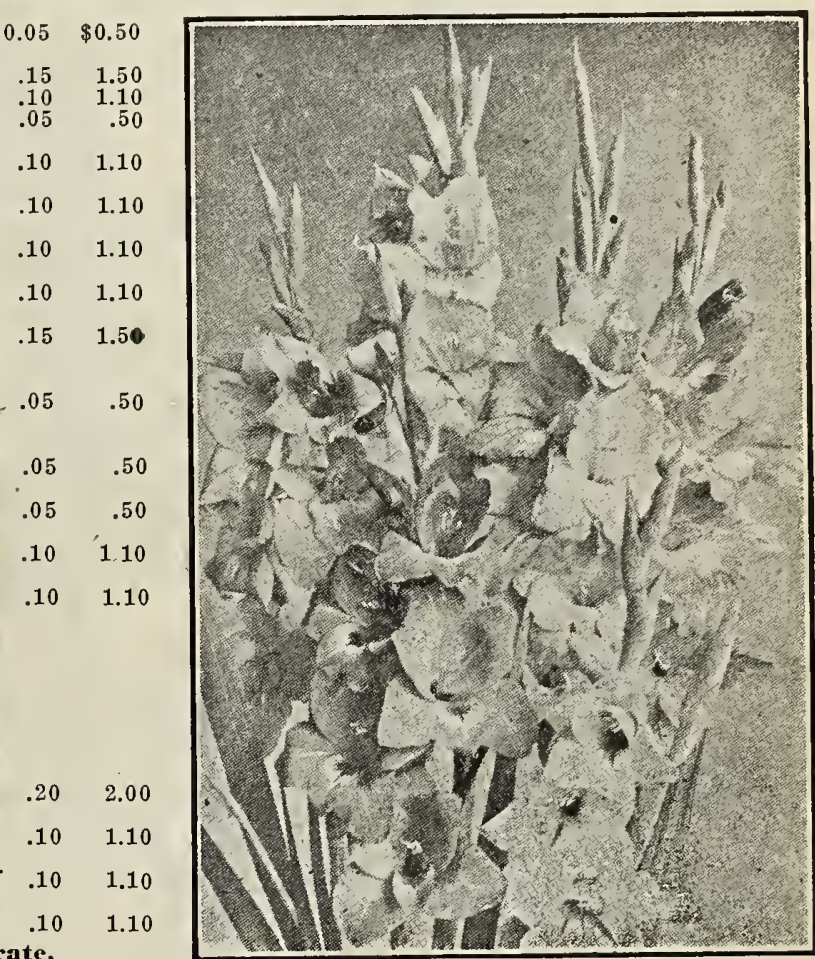

lf prlces per dozen are same.
and

Groff's Struin, Mixed. Our stock of these is from the Gold Medal collection of the Pan-American Exposition. Many flowers measure 5 inches across, from tip to tip of petals. They are surely grand, You should order from this stock If you wish to excel in cultivating Gladioli. All large size bulbs, $10 \mathrm{c}$ each; $75 \mathrm{c}$ per doz. Second size bulbs, $60 \mathrm{c}$ per doz. 100 , not prepaid, for $\$ 3.50$.

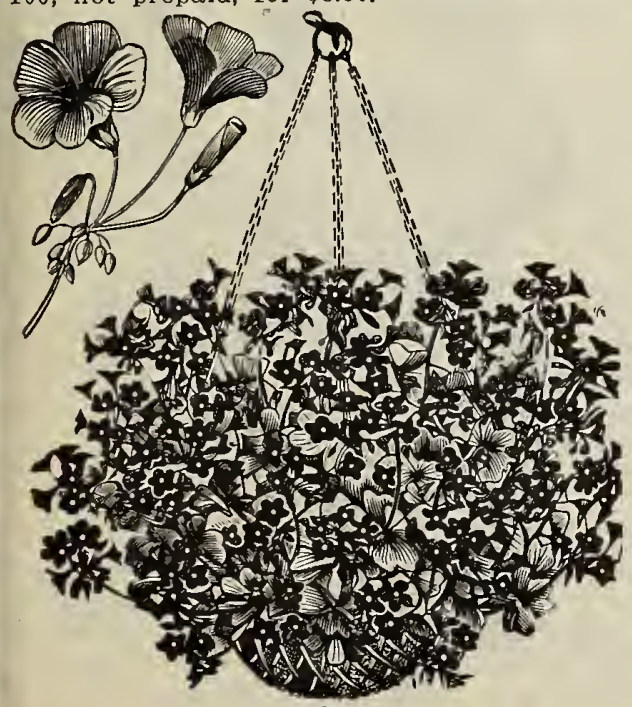

Light Colors Only, Mixed. Eaeh, 5e; 6 for 30e; 12 for 50c, postpald.

High grade Mixture. Made up of many of the finest of the older strains, including some of Lemoine's Seedings. Child's and Burbank's Select. Average good sized bulbs, 4 for $20 \mathrm{c} ;$ doz, for $50 \mathrm{c} ; 100$, not prepaid, for $\$ 2.50$

Good Mixture. Consists of a good assortment of sure to bloom bulbs. Doz., 30c, prepaid; 100 , not prepaid, for $\$ 1.50$.

\section{SUMMER FLOWERING OXALIS.}

Useful for bordering beds, and also for hanging baskets. Dieppi, pure white. Lasandra, rosy pink. Price, either color, dozen, 30c; 25 for 50c, postpaid.

\section{TIGRIDIAS (Tiger, or Shell Flower.)}

These gorgeous summer flowering bulbs look well associated with Gladioli, Lilies and kindred stock; grow about $2 \frac{1 / 2}{2}$ feet high and flower freely throughout the summer. They require the same treatment as Gladioli, and should be lifted in the autumn and dried off in the same way. Mixed colors, 5c each. dozen for $50 \mathrm{c}$, prepaid.

\section{MONTBRETIAS.}

One of the brightest and best of summer flowering bulbs, and one which will be more generally used when its merits become more fully known. Plant in clumps of 6 or 12 bulbs in May or June. They greatly resemble the Gladioli in growth and produce beautiful spikes of star shaped flowers in various shades of orange, yellow and red. Mixed varieties, 3 for $10 \mathrm{c}$; per doz., $30 \mathrm{c}$

When wantlng Hyaelnths, Tulips, Nareissus, ete., in the fall ask for Fall Bulb Oxalls. Prlce List, sent free. 


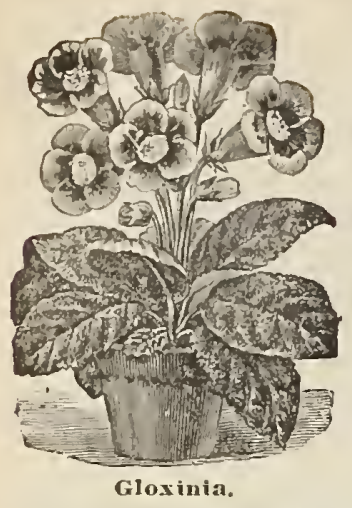

TUBEROSES

One of the most delightifuly fragrant and beautiful of the summer flowering bulbs. By skillful management a succession of flowers may be obtained all the year round. For early flowers they can be started in February or March in the they can be planted at intervals as late as August. For open ground culture plant in May and June in warm location. in May and June in warm location. bulbs each 5c: 12 for 50c; postpaid. Not bulbs, each $5 \mathrm{c} ; 12$ for $50 \mathrm{c}$; postpaid. Not
prepaid, 12 for $40 \mathrm{c}$. Second size bulbs, $30 \mathrm{c}$ per doz., postpaid; not prepaid, $25 \mathrm{c}$.

Bulb Collection Offer No. 30 Priee, Postpaid, 30 Cents. 1 Lilium Auratum.

2 Montbretias.

1 Tigridia.

2 Gladioli.

Bulb Collection Offer No. 50

one each of the following postpaid, for 50e.

1 Spotted Calla.

1 Named Canna.

1 Begonia, double. 1 Amaryllis Formosissima.

1 Begonia, single.

\section{Gloxinias}

\section{Hardy Perennial Herbaceous Plants and Roots}

No flower garden is complete without an assortment of the hardy plants that usually require very little care. They can often be tucked away in corners and odd places to come up each season with the opening of spring.

The priees named inelude postage except where noted. If we are privileged to ship by express at your expense we ean usually supply mueh larger and stronger roots for the saue priee.

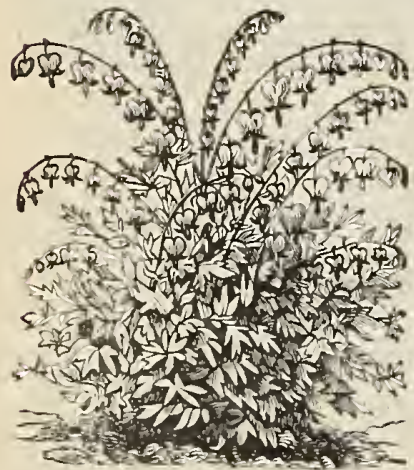

Bleeding Heart.

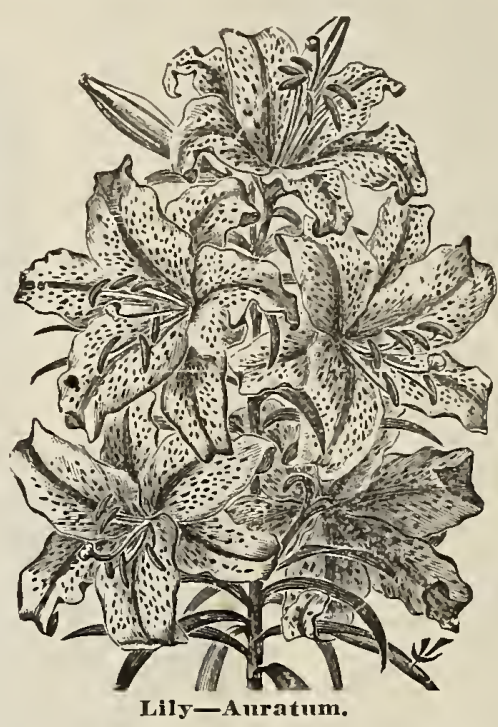
tily. Pure white Each, 20c; dozén for $\$ 1.75$.

Auratuu. The true golden-banded Lily Japan-see cut. This Lily is perfectly be in $\$ 2.00$.

Speeiosum Rubruu. A beautiful Japan ariety, with six broad white petals, with

Speciosum Album. The white petals have green bands through the center. Each, Speeiosum Melpomene. Flowers pinkish crimson, frosted white petals curved and widely bordered. Each, 15c; dozen, $\$ 1.50$.

Tigrinum Flore Pleno. The old fashioned Double Tiger Lily. Much admired for its stately habit, bearing immense clusters of blossoms of orange red, spotted with $\$ 1.25$.

Lily of the Valley. A bed or clump of these in a shady corner will thrive and pips for $20 \mathrm{c}$; 12 for $30 \mathrm{c} ; 100$ for $\$ 2.25$

ACHILLEA.

The Pearl. Pure double white flowers, useful for cutting. Each, $15 \mathrm{c} ; 3$ for $40 \mathrm{c}$. ANTHEMIS OR PARIS DAISY.

Large white flowers; free bloomer. $15 \mathrm{c}$ each; 3 for $40 \mathrm{c}$. ASTILBA JAPONICA.

A species of Spirea, with dark green cut leaves and feathery white flowers. Each, $20 \mathrm{c}$ not prepaid. AQUILEGIA COERULEA-The True Rocky Mountain Columbine.

The true beauty of this flower is appreciated when seen wild in the mountains of Colorado. We make a specialty of collecting roots and furnish lone but the true stock. We ship to all parts of the United States. This flower is embodied in our trade

BLEEDING HEART OR DIELYTRA.

The old favorite, heart shaped flowers, Each, $20 \mathrm{c} ; 3$ for $50 \mathrm{c}$

BURNING BUSH-Lychnis Chalcedonia.

A very showy plant with bright scarlet flowers. Blooms in July. Each, 15c 3 for $40 \mathrm{c}$.

CAMPANULA.

In several varieties, including the Canterbury Bell. Each, $15 \mathrm{c} ; 3$ for $40 \mathrm{c}$ COREOPSIS LANCEOLATA.

Flowers are bright golden yellow. Each, 15c; 3 for $40 \mathrm{c}$. DIANTHUS BARBATUS-Sweet William.

Continues in bloom most all summer. Large, double flowers. Each, 15c; 3 for $40 \mathrm{c}$

DELPHINIUM FORMOSUM.

Perenuial Larkspur.

A very graceful, tall growing plant, with long spikes of bright blue flowers Each, $15 \mathrm{c} ; 3$ for $40 \mathrm{c}$.

A very ornamental plant, growing to about 3 feet high. Each, 15c; 3 for $40 \mathrm{c}$

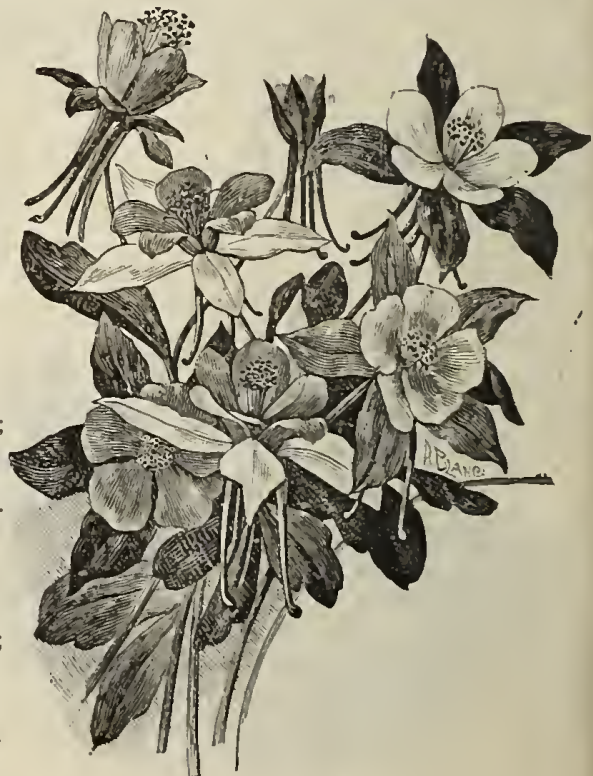

Columbine. 


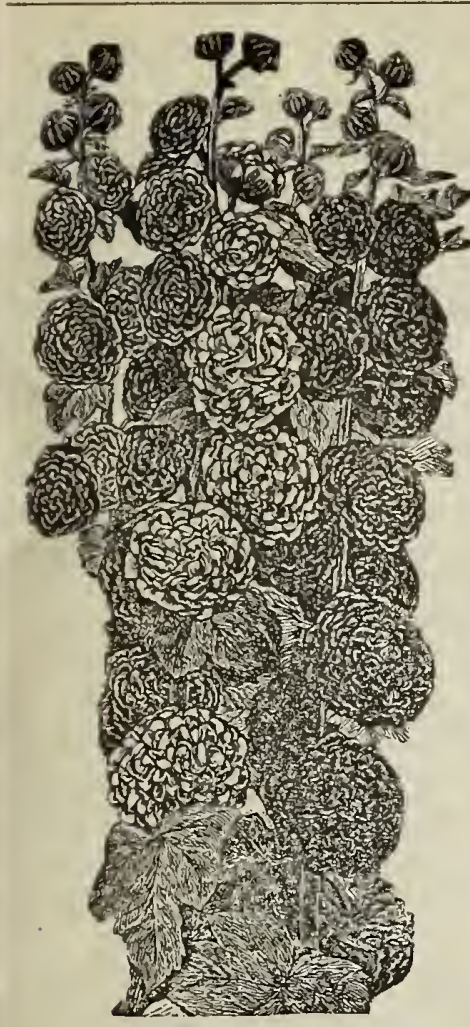

Hollyhocks.
JAPANESE IRIS-Iris Kaempferi.

A splendid hardy plant of easy culture, which delights in constant cool, moist soil. It succeeds splendidly by the side of a stream, lake, pond or in a swamp. It has the richest colors of the family and can be compared to orchids. It commences blooming about the middle of June and continues for 5 to 6 weeks. Many of the flowers measure 8 to 10 inches in diameter. Mixed varieties, each, $25 \mathrm{c}$; dozen, $\$ 2.50$.

GYPSOPHILA PANICULATA-Baby's Breath,

Small white flowers, very useful for bouquets. Each, 15c; 3 for $40 \mathrm{c}$.

HELIANTHUS MULTIFLOROUS PLENUS-Dahlia Sunflowers.

Loaded with yellow flowers. Makes excellent cut flowers. Each, 15c; 3 for $40 \mathrm{c}$ HELIANTHUS MAXIMILLIANAE.

Yellow, long graceful sprays. Fine for cut flowers; blooms in September; height, feet. Each, $15 c$ for $40 \mathrm{C}$

\section{SHASTA DAISIES-Burbank's New Varieties.}

There are now a few more varieties of this celebrated favorite, which are quite superior to the older form of Shasta Daisies. IVe mention a few of the best that produce flowers twice the size of the old form, with extra long stems,

Alaska, Westralia, California. Each, $20 \mathrm{c} ; 6$ for $\$ 1.00$.

\section{FUNKIA OR DAY LILY.}

White Day Lily-Funkia Alba. Has milky white flowers, 3 to 4 inches long. In very cold localities refuires some protection through the winter. Each, 15e.llow Day Lily. Produces large, fragrant yellow flowers, during July and August. Each, 15c.

\section{GAILLARDIA GRANDIFLORA.}

Has a mass of blooms the entire season. Flowers are dark red-brown, with petals of orange or crimson. Price, $15 \mathrm{c} ; 3$ for $40 \mathrm{c}$.

\section{HOLLYHOCKS.}

The handsome double flower of the improved varieties of this flower makes it a great favorite.
Our stock is grown by a man who makes a specialty of bulbs and shrubs. We have in stock double white, salmon, pink, yellow, red and maroon. One year old roots. Each, 10c; doz., \$1.00.

MAMMOTH ALLEGHENY HOLLYHOCKS.

This entirely new Hollyhock is quite distinct from the older varieties. Flowers beautifully fringed. Mixed colors. 10c each; doz., $\$ 1.00$.

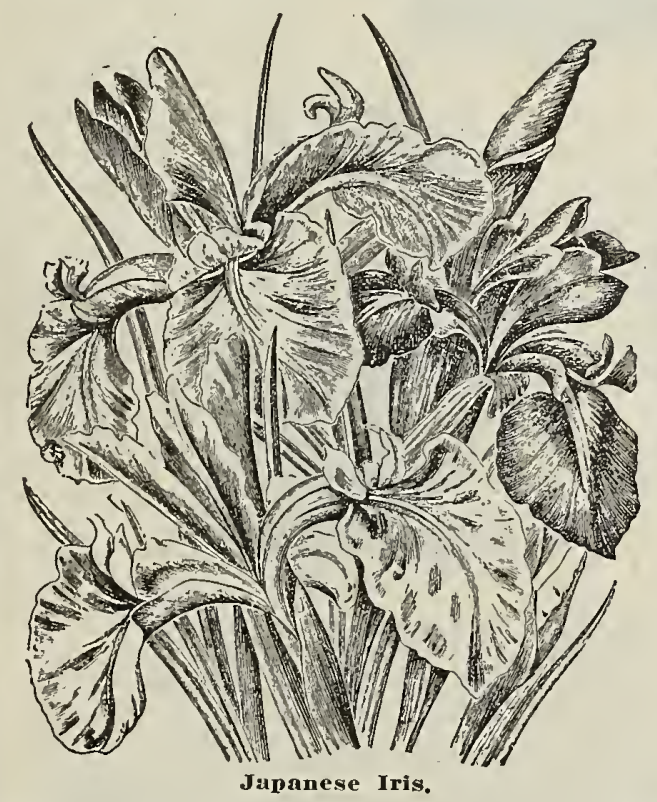

IRIS GERMANICA-FIag, Fleur de Lis.

This is one of the most desirable summer flowering plants. They bloom in June and July and because of the great lange of color are also known as "Rainbow Flower." Each, 15c; 3 for $40 \mathrm{c} ; 12$ for $\$ 1.25$.

\section{Named Varieties.}

Canary Bird. Light canary yellow. Celeste. Bright blue.

Conspicua. Maroon and yellow.

Florentina Alba. White tipped pale lilac.

Honorabilis. Yellow and crimson.

Flavescens. Tuight primrose yellow; very large and free flowering.

Irs. H. Darvin. Satiny white veined crimson.

Delieata. Standard light blue; droop. ing petals white, edged lavender.

Queen of May. Soft rosy lilac, almost pink; free bloomer.

\section{SIBERIAN IRIS.}

Blue. This is a flower of remarkable hardiness and vigor and one of the best for cut flowers.

\section{EARLY FLOWERING HARDY PHLOX.}

These we consider the most desirable of all hardy perennials.

These we consider the most desirable of all hardy perennials.
Flowering abundantly from July until late in the autumn. These new French varieties are of a dwarf growth, seldom attaining a height of over 12 to 18 inches. The immense flower heads often measure from 7 to 9 inches across, with flowers as large as a silver dollar, and comprise all shades of color, vermilion to white. They delight in sunny location and rich soil bur are by no means particular. We can supply these in ten different colors-white are by purple, lavender, deep lilac, pale pink with red diferent colors- white, pink, red, scarlet, salmon pink. $15 \mathrm{c}$ each; 3 for $40 \mathrm{c}$; set of ten different colors, $\$ 1.00$ postpaid.
On orders for Hardy PhIox amounting to $\$ 2.50$ and over we will give as preminm Manual on Cultivation of the Phlox. Price 25e.

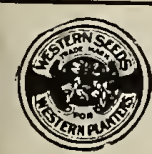

Our BAR'TELDES CUITURAL GUIDE is a booklet giving concise dircetions how to grow nice vegetables and flowers; also small fruits and flowering shrubs It is sent free with orders for the asking.

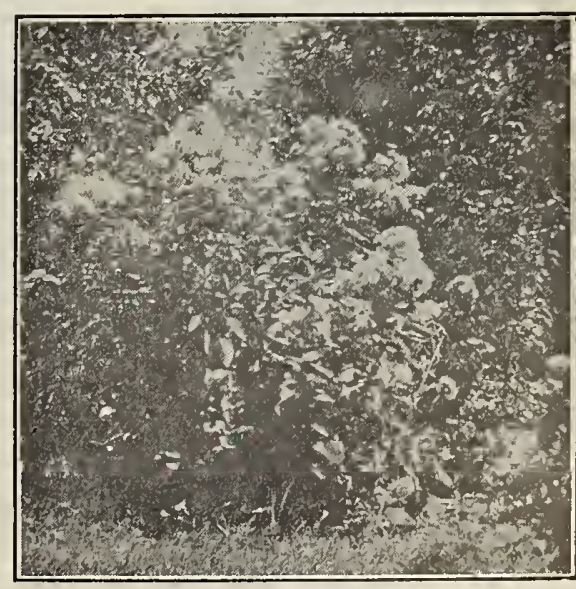

Hardy Phlox. 


\section{PAEONIES}

This grand old Favorite is today one of the most popular flowers. The Japanese have always held them in esteem and have brought to use an endless variety of colors and forms of bloom. The plant is perfectly hardy and increases rapidly. The flowers come early and are very seldom attacked by disease. An assortment should be in every garden. Our roots are extra large.

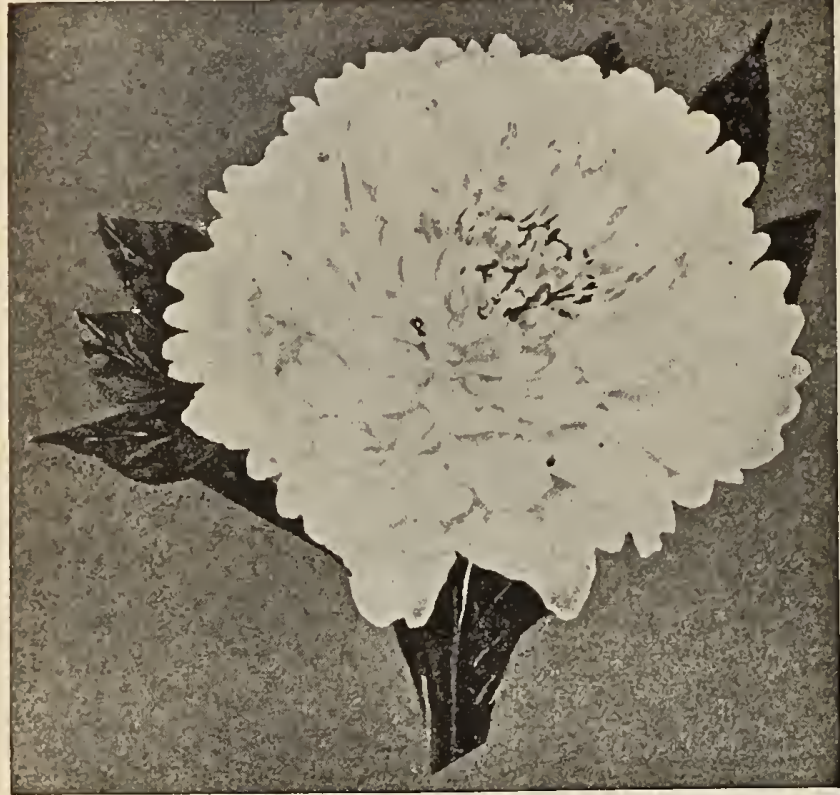

Pacony-Nestiva Maxima.

RUDBECKIA OR GOLDEN GLOW.

This is decidedly one of the brightest and most showy among the hardy plants, and one of the easiest culture possible, commencing to bloom in July and continuing until killed by frost. The plant is compact, growing from 4 to 7 feet high, producing numerous stems, which are laden with double goldenyellow flowers, in size and general shape resembling a Cactus Dahlia. Excellent for cut flowers, lasting well when cut. Each,

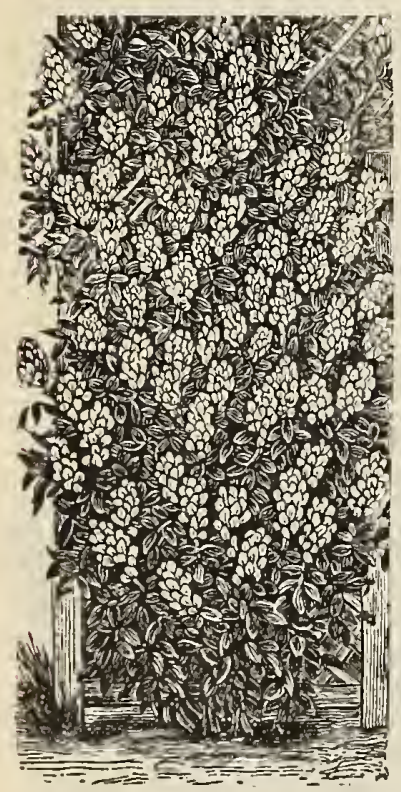
$15 \mathrm{c} ; 3$ for $40 \mathrm{c}$.

Apios Tubcrosa.

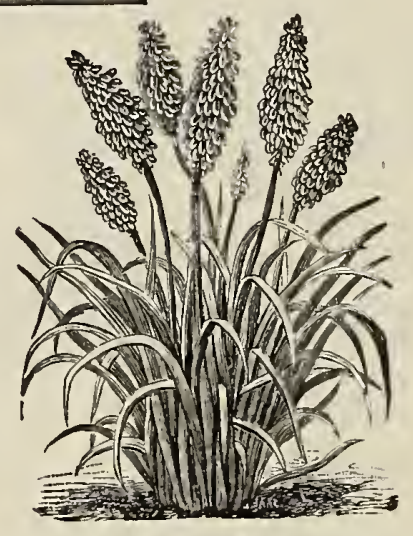

Tritoma.

HARDY CLIMBING PLANTS

FOR PORCHES, TRELLIS, ETC. AMPELOPSIS VEITCHII-Boston ivy.

The handsomest vine possible for trailing to walls, buildings, etc. Is usually hardy; however, some protection is necessary. Two-year-old plants by express, 25c: small plants by mail, $25 \mathrm{c} ; 3$ for $50 \mathrm{c}$, postpaid.

APIOS foliage and blossoms similar to ordinar Wias foliage and blossoms similar to perfectly hardy. Each, $5 \mathrm{c} ; 12$ for $40 \mathrm{c}$, postpaid. BIGNONIA-TRUMPET VINE.

An old-fashioned hardy climber, bearing trumpet shaped crimson orange flowers. Large roots, $35 \mathrm{c}$ each, by express, not prepaid.

\section{CLEMATIS}

and delights in a heavy, rich soil and a sunny position. Dig the soil deep and plant so that the crown of the roots will be 3 inches below the surface of the soil, water freely, especially in dry times; give plants a good top dressing of well rotted inanure late in the fall, and in the spring spade well and carefully into the soil and you will be well repaid. The varieties we have are those best adapted to our climate.

\section{POPPY HARDY ORIENTAL.}

Large and flaming flowers of orange-scar-

\section{PYRETHRUM ROSEUM.}

Very attractive pink colored flowers, Each, TRITOMA-Torch Lily or Red-hot Poker.

Pfitzerl. The freest flowering variety in ultivation, with heads or blooms over 12 inches long of a rich orange-scarlet, shading to salmony-rose at edges, producing a grand masses or beds. Each, $25 \mathrm{c}$.

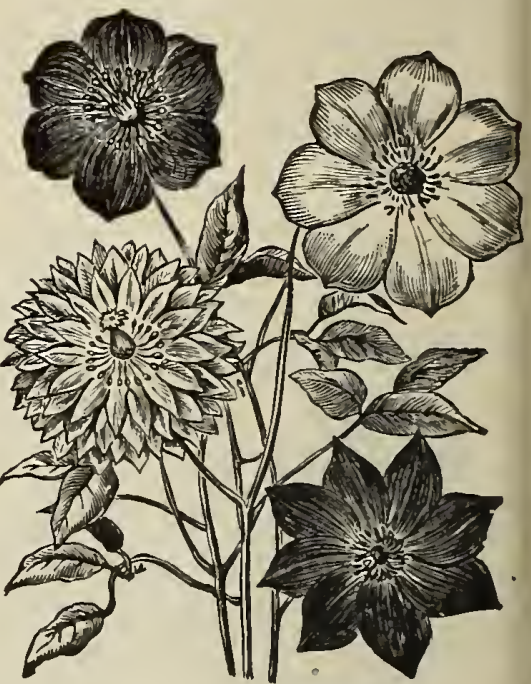

Group of 4 clematis.
Jackmanii. Has rich, large, deep purple flowers, so much armired by all. Healthy two-year-old roots. Post-
paid.

Mme. Eluard Andrc. A new bright red. Large flowering and as free bloomer as Jackmanii. With slight protec

tion it will withstand the winters in Colorado. Postpaid.

SPECrA CLEyATIS OFFEIR: You pay the expressage. 4 to 6 inches in diameter and pure white. Very hardy Paniculata. The flowers are of medium size, pure white, borne in jmmense sheets. Very fragrant. Hardy and of quick growth. This has different style blossoms from the above kinds. The small white flowers are very attractive. In bloom latter part of August and through September. Postpaid. Eduard Andre, red, for $\$ 1.15$. 


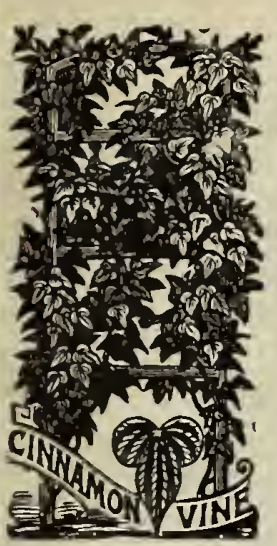

\section{HARDY CLIMBING PLANTS-Continued}

\section{CINNAMON VINE.}

This beautiful climber possesses the rare quality of emitting from its flowers the delightful odor of cinnamon and is appropriately called the Cinnamon Vine. Perfectly hardy, the stem dying down every autumn, but growing again so rapidly as to completely cover any trellis or arbor early in the season. With its beautiful heartshaped leaves and clusters of delicate white flowers, and delicious cinnamon odor, is a most desirable climber. We furnish the large tuber's, postpaid, for 10c; 3 for 25 c. Second size,.2 for $15 \mathrm{c}$; dozen for $60 \mathrm{c}$.

\section{HONEYSUCKLE.}

Searlet Trumpet or Coral. Very strong, rapid grower with red flowers. Large two-year-old roots, $35 \mathrm{c}$, by express, not prepaid.

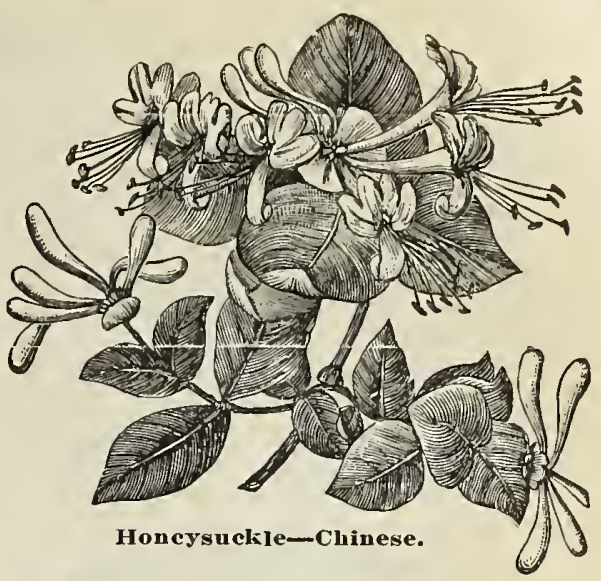

HONEYSUCKLE HALLEANA-Chinese.

Grows vigorously, with yellowish white fragrant flowers, Large two-year-old roots, 35c, by express, not prepaid.

\section{MADEIRA VINE.}

While it grows most anywhere, it does best in a warm, sunny location. Has a small white flower. Foliage of waxy appearance. Madeira tubers are not hardy, though they are excellent climbers, thus we place them on this list. Strong tubers, 2 for $10 \mathrm{c}$; doz., $40 \mathrm{c}$, postpaid.

\begin{tabular}{|c|c|c|c|}
\hline$\underset{\mathbf{2}}{\mathbf{3}}$ & $\begin{array}{l}\text { BULB COLLECTION } \\
\text { Apios Tuberosn, } \\
\text { Cinnamon Vines, }\end{array}$ & N No. 25. & $\begin{array}{l}\text { Climbing Plants } \\
3 \text { Madeira Vines, } \\
\text { all by mail for } 25 .\end{array}$ \\
\hline
\end{tabular}

JAPAN BEAN OR KUDZU VINE.

The most rapid growing perennial vine in cultivation, attaining, once after being established, a height of 50 feet or more in one season. Its foliage is large and furnishes dense shade; It bears small racemes of rosy-purple peashaped blossoms towards the end of August. A splendid glant for covering permanently verandas, dead trees, etc. WOODBINE.

An exceedingly popular vine for porches, arbors, etc. Is very hardy, clings readily. Each, $20 \mathrm{c}$; 3 for $50 \mathrm{c}$; doz.,
$\$ 1.50$, postpaid.

\section{WISTARIA.}

A great climber, with dense clusters of beautiful flowers. Puiple, large roots, $35 \mathrm{c}$ by express, not prepaid. White, large roots, $50 \mathrm{c}$, by express, not prepaid.

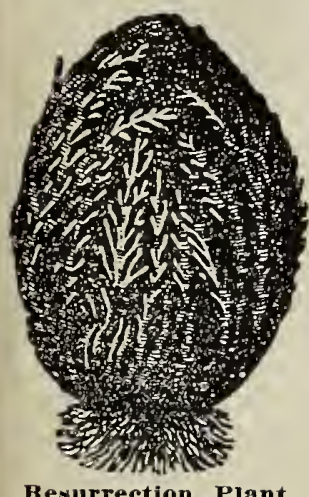

Resurrection Plant Colled Up.
JAPANESE FERN BALL。

Fern roots woven outside and around a ball of moss These roots will produce beautiful sprays of fern from eyes at nearly every inch of their length, then the whole surface is covered.

Directions for Starting. Soak the ball in tepid water from 30 to 40 minutes and hang up. Repeat every other day till well started and after sprinkle when needed. The temperature of a common living room is just right. They can be dried up at any time, put away and started up again by soaking as before. Each, $60 \mathrm{c}$; 3 for $\$ 1.50$, postpaid.

\section{RESURRECTION PLANTS.}

A truly marvelous plant. When you receive it from us it is a shrunken ball of coiled up leaflets; but when immersed in tepid water one fond-like tip unfolds slowly outward, then another and another until flattened into a plant like shape, and transformed into a lovely rosette of beautiful velvet green, fern-like moss, both odd and marvelous. Can be resurrected at will, time and again, indefinitely, by being allowed to curl up and become dry each time, after having been fully opened by water. Large plants, $10 \mathrm{c}$ each; 3 for $25 \mathrm{c}$; small plants, $5 \mathrm{c}$ each; 6 for $25 \mathrm{c}$. All prepaid.

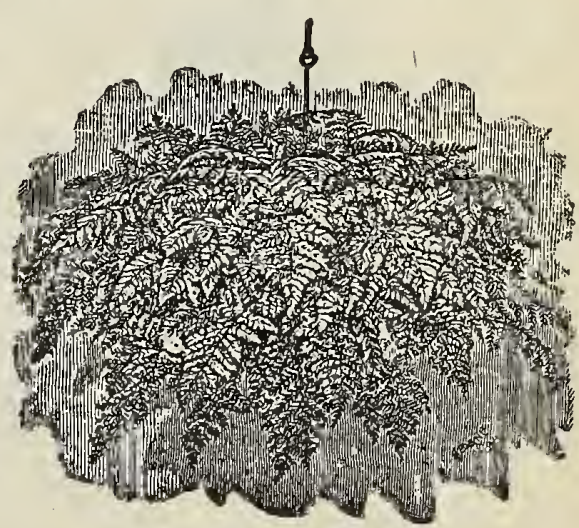

Japunese Fern.

\section{HEDGE PLANTS}

\section{BARBERRY-Purple.}

These are the best plants for hedges, and are very hardy. The foliage and fruit are violet colored, rich looking and very effective $15 \mathrm{c}$ By express only, not prepaid.

SWEET BRIAR-English Wild Rose.

Very rapid grower. The tolir ge is very fragrant, also the flowers This makes a superb hedge, especially when in full bloom. It can be trimmed like other hedges. $35 \mathrm{c}$ each, by express, not prepaid. Dozen, $\$ 3.00$.

Persons contemplating planting large areas of hedgc, or desiring estimates for quantity planting, will do

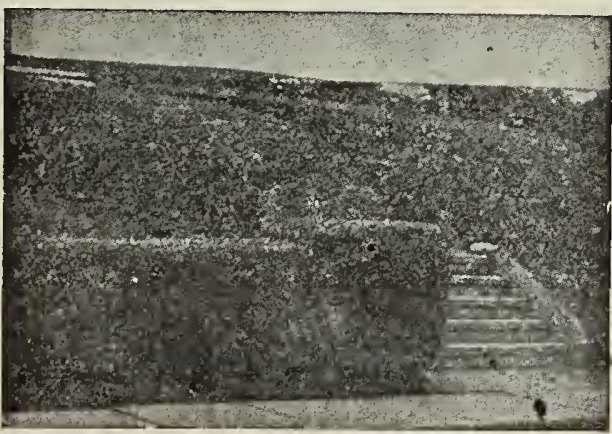

A Hedge of Privet.

\section{COLORADO GROWN HARDY PRIVET.}

Similar to California Privet, but more vigorous and standing our severe winter. Good plants, not pre$\$ 9.00$.

\section{CALIFORNIA PRIVET.}

This plant is coming rapidly to the front, and if properly handled will make the finest hedoe imaginable They are not quite hardy in mountain districts. They should be planted 8 inches apart and in a double row inches apart, and in a double row press only, not prepaid, $10 \mathrm{c}$ each, per dozen, $\$ 1.00 ;$ per $100, \$ 7.00$.

REMEMBER: WE give premium Packets with orlers for seeds in packets and ounces.

GET YOUR NEIGlBORS to conbine their orders with yours, save on transportation, also help your friends in getting reliable seeds.

Our trademark, "Columbine," put on any package from our stores, means that its contents is the best that money can buy. 


\section{HARDY SHRUBS}

\section{Should be Sent by Express}

This stock is all nursery glown and two years old, thus rather too large to be mailed. If must le shippel by mall, add co to 30 cach for packing and postage. Each specimen will be properly labelled and yacked for shipping. Plants reach to in a better coudition when shipped by express.

ALMOND, DOUBLE FLOWERING. The first shrub in the spring to bloom, even young plants being entirely covered with little pink rosettes, before any foliMarcli if you want them to bloom the first year. Blossoms in May. Price for strong plants, either pink or white, $35 \mathrm{c}$ each.

AZALEA PONTICA.

Colors, white, pink, led. This hardy variety produces flowers before foliage and is very suitable for the lawn. Blooms and is very suitable for the

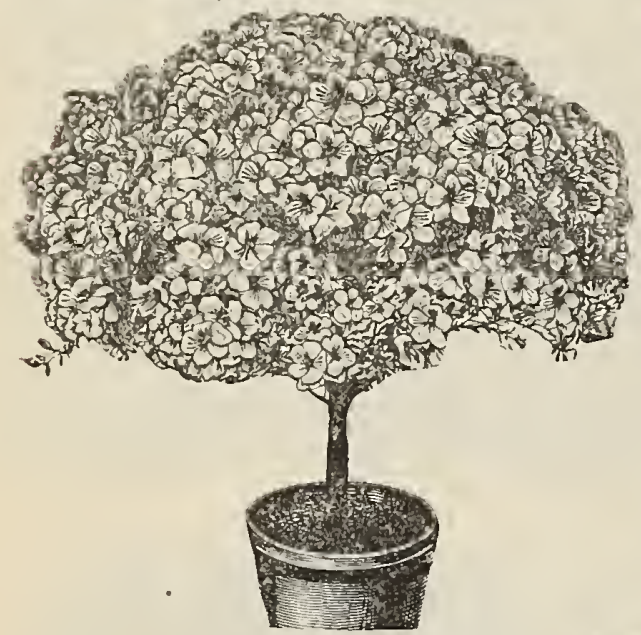

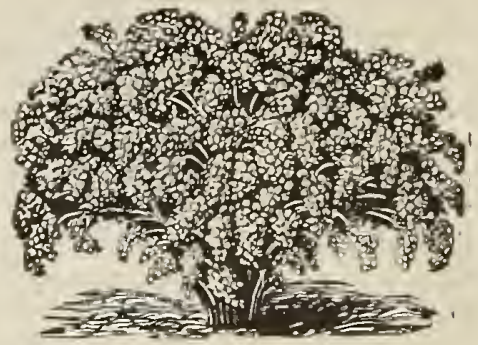

Bridal Wreath.

\section{BLUE SPRUCE}

Rocky Mountain grown. The best Evergieen for lawn. 20 to 24 inches high, $\$ 1.50 ; 2$ to 3 feet, $\$ 2.00$ each, by express only.

BRIDAL WREATH-Spirea Van Houttii.

The most beautiful of all spireas. In the spring it is a perfect fountain of white flowers; it is admiled by all who see it. istrong two-year-old plants. Blooms in May and June. $35 \mathrm{c}$ each
CALYCANTHUS FLORIDUS-Strawberry Shrub.

A well known shrub with double chocolate colored flowers, with decided strawberry scent. Good sized plants. Blooms in June. $35 \mathrm{c}$ each. ENGLISH HAWTHORN-Crataegus.

We have the double flowering variety, which is superior to the old single form. Nice strong plants, $50 \mathrm{c}$ each. HIBISCUS-Rose of Sharon.

Has large, double flowers, pink or white with maroon center. Blooms in August. Each, 35c. HONEYSUCKLE TARTARIAN.

(Upright.) Forms a fine bush with creamy white flowers. Blooms in July, and red berries appear in August. Each, $35 \mathrm{c}$

HYDRANGEA PANICULATA GRANDIFLORA.

A most beautiful shrub with immense panicles of blooms. white fading to a light pink. The most popular shrub we have. Blooms in August. Strong root, $35 \mathrm{c}$ each. Extra large,

GOLDEN LEAVED ELDER-Sambucus Aurea.

Very striking in appearance and a very robust grower. Blooms in July. Each, 35c. Azalea.

JAPAN QUINCE OR FIRE BUSHPyrus Japonicus.

A very showy and popular shrub. Large, bright, scarlet flowers, and may be called a scarlet apple blossom. Blooms in May. Each, $35 \mathrm{c}$.

\section{MOCK ORANGE-Philadelphus Coronarius.}

Sometimes called Jessamine. Free flowering, pure white. Has a Jessamine fragrance. Blooms in June. Large twoyear -old stock. 35c each.

\section{JAPAN SNOWBALL-Virburnum Plicatum.}

This Japanese variety is a close relation to our own Snowball; it is perfectly hardy and forms a nice shaped shrub from 6 to 8 feet high, It is shrub from 6 with fowers during the month of June: flowers resemble our old Snowball, but are rather flat than old Snowball, but are rather flat
round. Strong plants, $40 \mathrm{c}$ each.

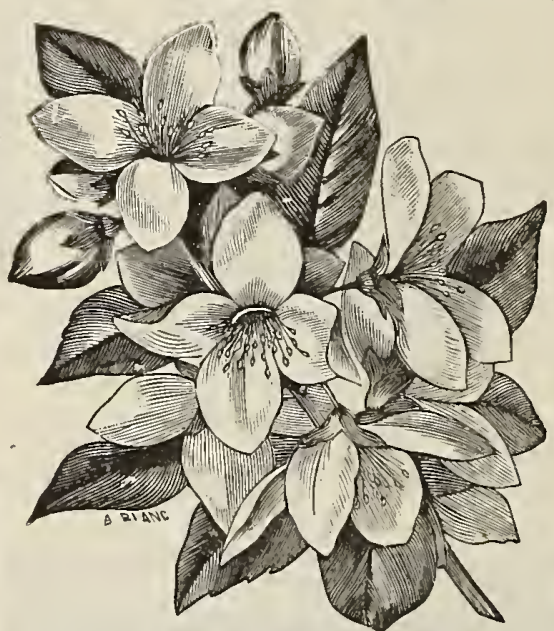

lock Orange.
LILAC.

Grows freely in any soil. We have the pure white and purple colored. Blooms in May. Each, 30c; 2 for $50 \mathrm{c}$. PERSIAN.

This splendid variety has smaller foliage and brightel colored flowers than the common variety. It does not grow so tall and blooms three or four weeks later. We have both purple and white. Each, $50 \mathrm{c}$.

\section{SNOWBALL}

A shrub that needs no introduction. Our stock is choice two-year-old roots. Blooms in June. Each, $35 \mathrm{c}$.

This is a dwarf and very compact glowing variety not over 2 feet, different from any other spirea; covered all summer with bright crimson flowers, and perfectly hardy. Fine plants. Each, $35 \mathrm{c}$.

Strong, slender growing, irregular shrubs, with feather foliage of a most striking pea green, and small, delicate flowers, borne on gracefully bending
branches. These pink fowers are very attractive during July and August. branches.
Price, $35 \mathrm{c}$.

The Barteldes Seed Co.

Gentlemen: The plants ordered from you came all right on the $24 \mathrm{th}$. I am very well pleased with them and thank you
promptness in filling the order. The plants ordered from you came all right on the $24 \mathrm{th}$. I am very well pleased with them and thank you
promptness in filling the order.
MRS. J. M. PERCY.

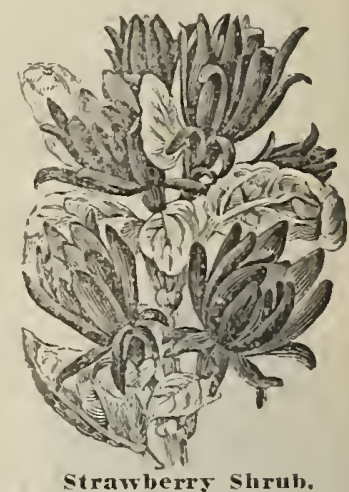

NEW DOUBLE-FLOWERED LILAC.

Decidedly one of the most beautiful of all shrubs, especially adapted for the lawn. The flowers are perfectly double and very fragrant. Being a late bloomer, it is especially adapted to this country, thus not likely to suffer from late frosts, which so often catch the early single varieties. Blooms in June. Each, $50 \mathrm{c}$.

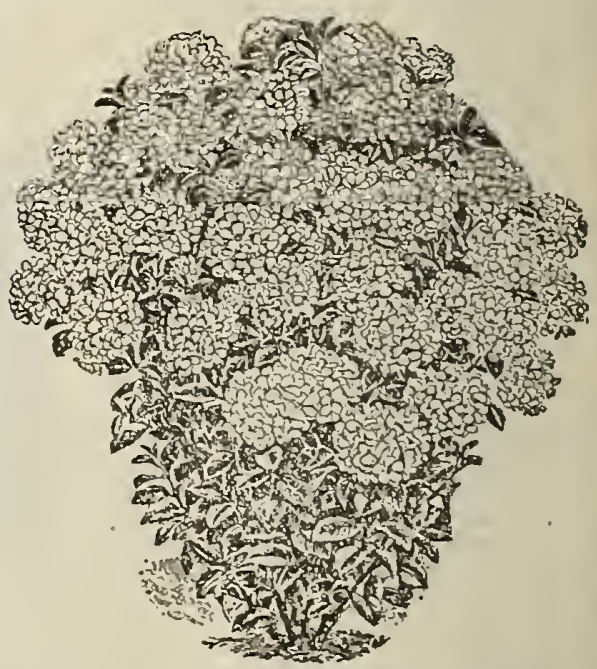

Japan Snowball.

Sioux City, Iowa. 


\section{BARTELDES SELECT ROSES}

BEST ADAP'TED TO OUIR IVESTERN COUNTIRY.

CUITURE. The Rose, rightly called the Queen of Flowers, beins a very heavy fonder, should be planted in soil made as rich is possible, and not too wet. Before planting incorporate in the soil, when digging the hole, a shovelful of well rotted manure and set your plant about one inch deeper than originally planted, spreading the roots and pressing the glound firmly around them. Plant the bedding kinds about $1 \frac{1}{2}$ feet apart, while the climbers are set from 3 to 4 feet apart. The best time to plant them is in April and May. During the summer the ground must be cultivated to keep it free fiom weeds and to prevent it from baking. In the fall, after the leaves have fallen off, the plants should be trimmed back to one-half of the season's growih, tied together and dirt heaped around them. A good dressing of old manure or bone meal will insure a big yield of flowers the next year. To prevent and destroy the rose chafer and rose slug, sprinkle the bushes as soon as leaves are forming and once a week after with a solution of one ounce Paris Green to 100 gallons of tobacco dust is scattered on and under the leaves. The plants should be sprinkled thoroughly before applying powdered insecticides.

CAIS TO GIVE ON RECEIVING PLAN'TS: As our plants are big, strong, two-year-old, they should be trimmed back to one-third of the length of the main branches, removing all the side shoots (they do llot bloom), and if they have been on the way 3 or 4 days, put in a bucket of water for a few hours, unless they are shipped in a growing state and dirt around the roots. We do not trim plants much, unless asked to do so, as most people expect large bushes and they look better untrimmed, but if you want your roses to grow, and we are very anxious that they should, yon must trim them be-

fore or riglit after planting. Three or four eyes to a branch are sufficient.
We have had many flattering testimonials in regard to size and varieties of Roses we have sent out, and we have secured for this season the cream of our growers' stocks. These Roses are too large to inail satisfactorily. If illey must be sent by unal, add $15 e$ each for extra packing and postage.

\section{Hardy Roses for Out Door Planting}

These are by far the most satisfactory Roses for our Western country. They are distinguished for their vigorous growth and large, perfect fowers. We recommend them for permanent beds. We furnish two-year-old field-grown plants, which are kept dormant in our storage cellar and should not be taken out until time for planting.

Price for all the two-sear-old stock, 35e each; dozen, \$3.0o, purehaser paying expressage. If they must be sent by mail, add $15 c$ each for extra packing and postage.

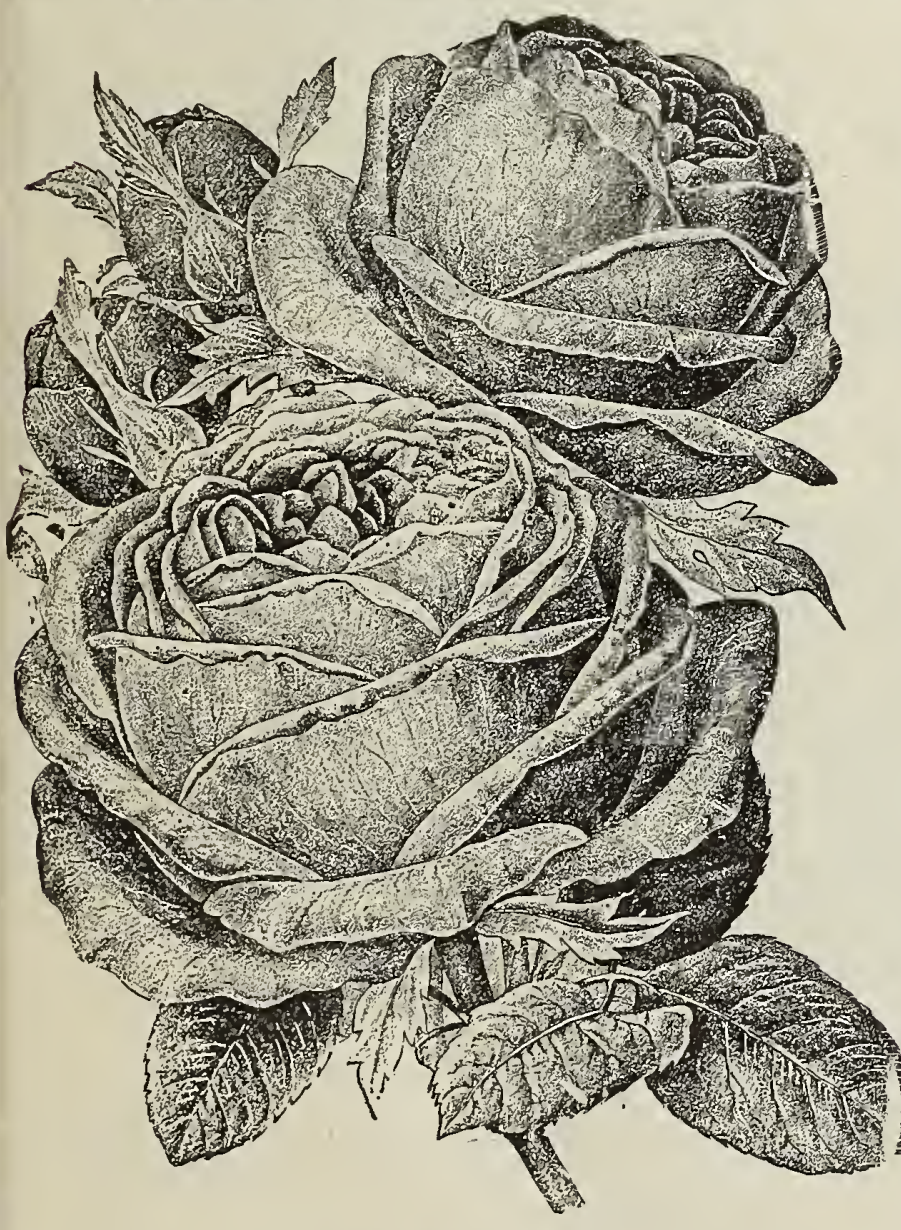

MOSS ROSES.

These are still favorable where an assortment uf Roses are cultivated. Large plants, 35e each; $\$ 3.00$ per dozen.

BLANCHE MOREAU, Pure white flowers in clusters, large, full and sweet; finely mossed.

CRESTED Moss. Rose color, beautifully crested.
WHITE.

COQUETTE DRS BLANCHES. Pure white, with beautiful shell-shaped petals. Especially suitable for cemetery planting

FRAU KARL DRUSCHKI. A pure paper white, large sized and free flowering. The bloom is perfect in form and borne on a long stem. MADAM PLAN'IIER. One of the best for cemeter planting with its large clusters of pure white flowers. MARGARET DICKSON. A grand white, one of the EVERGREEN GEM (Viclnuriana) Memorial Rose. Creamy white with the rich fragrance of Sweet Briar roses.

PINK.

CAPT. CHRIS'TY. Flesh pink flowers, large and full.

CLIO. Flowers are perfect in form; color, delicate satin blush, free blooming and strong, healthy grower. is appreciated by all lovers of Roses. This is the most perfect of Roses. A delicate pink. Half hardy, needs a ittle covering through the winter.

MAGNA CHARTA. Beautiful bright pink, suffused with carmine; strong grower. grower and a free bloomer.

ENGLISH SWEET BRIAR. The well-known English sweet-scented Rose suitable for fancy hedges.

STEETHEART (Vichuriaua) Memorial Rose. A beautiful shade of rosy pink, produced freely, and sweetscented.

\section{LIGHT RED.}

AMLRICAN MFAU'TY. The largest and sweetest of all hardy Roses. Immense in size, rich in color and fragrance; rosy carmine.

ANNA DE DIESBACH. Clear, bright carmine; very large and finely shaped; full and fragrant.

\section{RED.}

BARY RAMBLER. This new Rose is a cross between "Crimson Rambler" and "Glory of Polyanthus," retaining the color and extreme hardiness of the former with the free Howering and dwarf habit of the latter. It is perfectly hardy and is covered with bright crimson flowers all through summer. A superb Rose for pot culture.

GENERAL. JACQUEMINOT. Brilliant scarlet crimson; too well known to need description; no garden complete without it. GIENEIRAL WASHINGTON. Red shaded crimson, arge, full and flat. formed fragrant flower

PRINCE CAMILLE DE ROHAN. Very dark velvety crimson, changing to a deep maroon.

\section{YELLOW.}

GLORIE LYONAISE. White, tinted with yellow. The nearest approach of a yellow rose among Hybrid Perpetual Roses.

JOANNE WESSLNHOFF. Flowers medium size; buds long and pointed and of perfect form. Color clear, lus trous vellow. Half hardy; needs a little covering through the winter.

VRLLOW PRRSiAN. Hardy semi-double yellow flowers, strong grower.

Ten good and strong two-year-old plants, comprising all shades and colors, bush and climbing varieties, our own selection. By express, not prepaid, \$2.25. 


\section{HARDY CLIMBING ROSES}

Desirable for covering trellises, walls or porches, as they succeed under all circumstances. Perfectly hardy, bloom ing in clusters of medium-sized double and semi-double flowers profusely throughout the season. Price for two-year-old fielu-grown plants by express, 35e eaeh; \$3.00 per dozen. If they must be sent by mall, add $15 \mathrm{c}$ each for extra packing and
postage.

NEW CLIMBING AMERICAN BEA UTY. See Novelties.

THE CRISON RAMBLER remains at the head of the climbing roses. It is a vigorous grower, making shoots 10 to 15 feet in a singie season, and when in bloom commands admiration by the gorgeous display of its brilliant crimson clusters of blossoms, each cluster a bouquet in itself. The blooms remain on the plant for a great length of time without losing YELIOW RAMLIS perfectly hardy in all parts of the West.

flows WII'SE IRMMLER. Semi-double flowers lasting a long time on the plants.

SIPCIAI, COLLEC'TION OF RAMBLERS. One each, crimson, white, yellor, with a colored picture. Price, 90e. The steel blue flowers appear in large clusters and are semi-double and a glossy green foliage and a few prickly thorns. the blue flowers make the plant particularly attractive.

LAD GAY. A desirable new rariety of viorous growth. The flowers tinted white. The effect of a plant in full bloom with the combination of the soft white flowers, cherry-pink buds and the deep green foliage is charming.

DowoTiY PEIKINS. This grand climbing rose resembles very much the Crimson Rambler, but flowers are more B ÁTIOR E

PRAIRIE QUEEN. A favorite. A bright red changing to deep pink.

\section{GREENHOUSE ROSES}

We can furnish the following Roses from $21 / 2$-inch pots direct from the greenhouse. They are good, strong, growing plants, and must not be compared with cheap Roses sold in collection lots. Price, 15e eaeli: 2 for 25e; dozen, \$1.25. If by
mąil, add $5 \mathrm{c}$ each, or $40 \mathrm{c}$ a dozen, for postage.

A MERICAN BEAUTY. The most popular Rose grown; color, rosy carmine.

BABY RAMBLER. Large clusters of crimson flowers;

HRIDESMLID. A pink Tea Rose; very fine for cut

flowers. sized and free bloomer.

GifuSS AN TEPLITZ. Dark, rich crimson, changing to a bright velvety red.

LA FRANCE. The most perfect Rose; color, a delicate

MIBERTY. A fine crimson scarlet; free bloomer.

MAUAM A. CHATENAY. Flowers of good size, very double; color, rosy carmine, shaded salmon.

PERLE DES JARDINS. A rich shade of yellow; perfect form and Tea fragrance.

IKICHMIOND. A rich crimson scarlet, with long stems, which does not "blue" with age, blooming as freely as the best monthly rose.

THE BRIDE. A pure white Rose of large size and of dclicious Tea fragrance.

WHITE BABY RAMBLER. Large clusters of white pink; very fragrant.

\section{Summer Bedding Plants}

Ready from April 15 to June 30

\section{From 2-inelh Pot.}

Antirrhinum (Snapdragon), assorted colors..... Each Doz. Antirrhinum (Snapdragon), assorted colors...... $\$ .10 \quad \$ .90$ Asters (Daybreak), best fol bouquets, pink..... $.10 \quad 900$ Carnations, Marguerite, fine summer bloomers... $\quad .10 \quad .90$ Carnations, perpetual blooming, white, pink, red. .10
Cosmos, pink, white, red, yellow................ 90

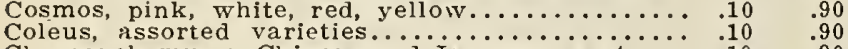
Chrysanthemums, Chinese and Japanese, asst..... $.10 \quad .90$

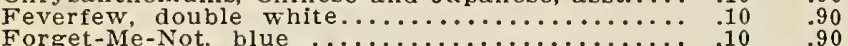
Fuchsia, double, assorted colors..................... Fuchsia, single, assorted colors

Geraniums, double, assorted colors... Geraniums, Lady Washington, assorted colors...

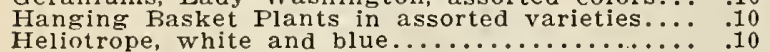

\section{PANSY PLANTS.}

For many years we have made a specialty of offering to our customers a very choice strain of Pansy Plants that are excelled by none for variety of colors and markingsthey are grown from seed costing $\$ 5$ to $\$ 8$ per ounce-positively nothing better. These should always be sent by express. First lots in bloom ready about April 1. Priee, not prepaid, 1 dozen in basket for 50e; 3 baskets for $\$ 1.25 ; 100$ plants not in baskets for \$3.00. Small plants nearly ready to bloom, per dozen, 35e; per 100, \$2.50.
From 2-ineh Pot.

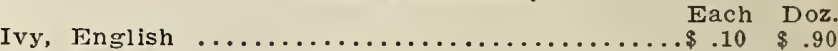

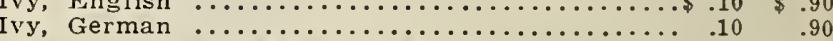

Lobelia, Crystal Palace, (blue)................10 .10

Marguerite, white flower with yellow center.... $\quad .10 \quad .90$

Marguerite, pure yellow.................. .10 .90

Petunia, single, Giants of California, asst. colors. $\quad .10 \quad .90$

Petunia, double fringed, assorted colors............. $\quad .10 \quad .90$

Phlox, Drummondii Grandiflora, assorted colors... $\quad .10 \quad .90$

Pinks, Chinese, double and single, assorted colors $\quad .10 \quad .90$

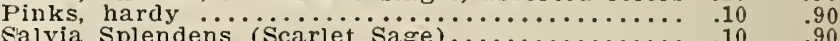

Salvia Splendens (Scarlet Sage)..............10 .90

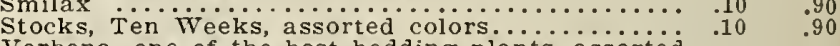

Verbena, one of the best bedding plants, assorted

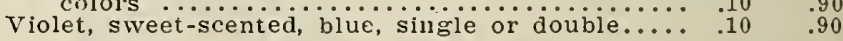

\section{DOUBLE DAISIES.}

Grown exclusively for our trade. Assorted colors, plants in bloom. Can be furnished six in a basket for $40 \mathrm{c}$; two baskets for $75 \mathrm{c}$. All by express; not prepaid.

longfellow. Pink. Three for $25 \mathrm{c}$.

snowball. White. Three for 25c.

\section{BURBANK'S SHASTA DAISIES.}

Alaska. Large white flowers.

California. Creamy color.
viestralia. Flowers semi-double, creamy color.

Each, 20e; 6 for $\mathbf{\$ 1 . 0 0}$, prepaid.

We also furnish, BY EXPRESS ONLY, Deeorative Plants for the Parlor, sueli as:

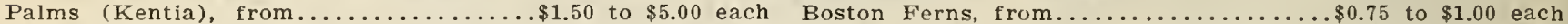

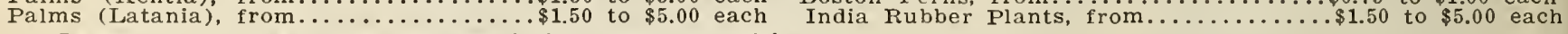

Larger plants of all sizes and descriptions can be furnished on application.

\section{VEGETABLE PLANTS AND ROOTS}

We have increased our facilities in this line and can fill all orders very promptly. These plants are grown from our selected seed and thus you can depend on genuineness of the plants. The men in charge of the work use great care to produce strong, vigorous plants, and pack them properly. These prices do not inelule postage. We do not favor having them sent by mail, as they are sure to damage when confined in a close mail pouch.

If by mail, add Ge per dozen, 30e per 100, for postage.

Fer 12 Per 100 Per 1,000

EARLY CABBAGE. From seed bed. Winnigstadt, Jersey Wakefield; ready May $1 \ldots \ldots \ldots \ldots \ldots \ldots .10 \quad \$ 0.50 \quad \$ 4.00$

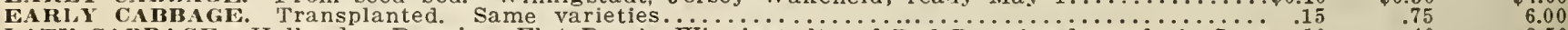
LATE CAIBAGE. Hollander, Prenium Flat Dutch, Winnigstadt and Red Drumhead; ready in June .10

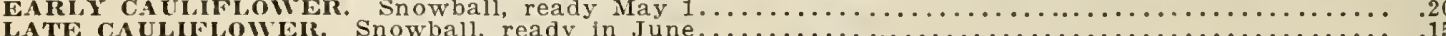

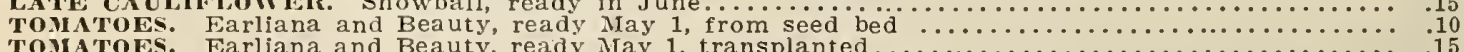

ToMAToES. Earliana and Beauty, ready May 1, transplanted... 


\section{VEGETABLE PLANTS AND ROOTS-Continued.} EGG PIANTS. New York Improved Purple, transplanted, ready June $1 \ldots \ldots \ldots \ldots \ldots \ldots \ldots \ldots \ldots \ldots . . .65$ EGG PLANTS. New York Improved Purple, grown in 3 -inch pots, ready June $1 \ldots \ldots \ldots \ldots \ldots \ldots . .75$

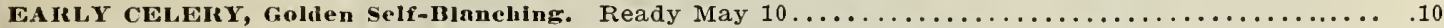

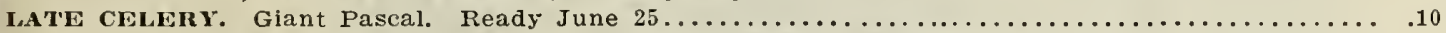

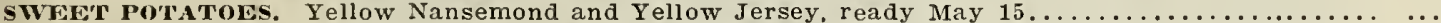
Can quote special prices on large lots Cabbage and Celery in July.

$\$ 1.00-\$ 8.00$

2.00

5.00

.50

.25

.40

4.00

2.00

PARAGUS Roots. Good one-year-old roots. Dozen, $15 \mathrm{c}: 10 \mathrm{~s}, 75 \mathrm{c}$ $\$ 1.00 ; 1,000, \$ 7.00 ;$ if by mail, add $10 \mathrm{c}$ per dozen and $30 \mathrm{c}$ per 100 .

Can supply Conover's Colossal, Palmetto and Columbia Mammoth White.

EARLY ARGENTEUIL. The earliest and largest green asparagus grown. Dozen, $20 \mathrm{c} ; 100 ; \$ 1.00 ; 1,000, \$ 8.00$. If by mail, dozen, $30 \mathrm{c} ; 100, \$ 1.30$.

ARTICHoKes. True White Jerusalem. Pound, $10 \mathrm{c} ; 3$ for $25 \mathrm{c} ; 25$ pounds at $3 \mathrm{c} ; 100$ pounds, $\$ 2.50$. Postage, extra, $8 \mathrm{c}$ per pound.

CHIVES. In bunch, sprouted. Each, 15c; dozen, \$1.25. By mail, 10c each bunch extra.

HORSE-RADISH. Cut 4 to 6 inches long. Dozen, $15 \mathrm{c} ; 100,75 \mathrm{c} ; 1,000, \$ 5.50$. By mail, add $10 \mathrm{c}$ per dozen and $35 \mathrm{c}$ per 100 .

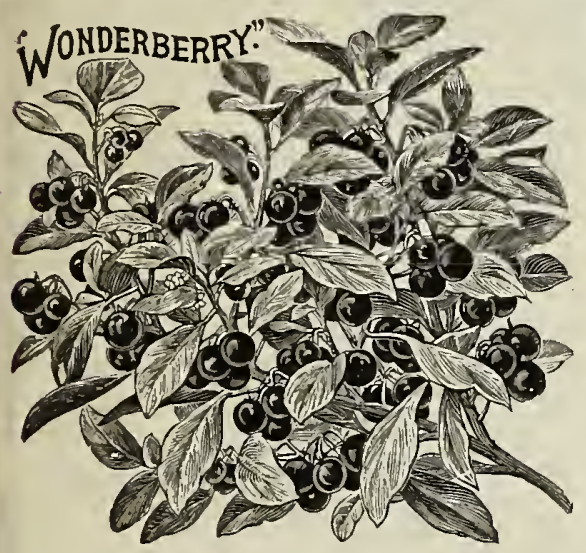

MINT. The true old-fashioned Mint for seasoning. Per clump of roots, 25c; by mail, $35 \mathrm{c}$.

RHUBARB. Large Victoria and Early Linnaeus; cut 1 or 2 eyes to each clump. Dozen, $50 \mathrm{c} ; 100, \$ 3.00 ; 1,000, \$ 20.00$. By mail, 50c per dozen extra.

RHUBARB;, Australian Crimson Winter. Each, $15 \mathrm{c}$; dozen, $\$ 1.00$, postpaid. 100 not prepaid, $\$ 6.00$.

SAGE. One-year clumps. Each, 20c; postage, 5c extra.

TARRAGON. Highly recommended for Tarragon vinegar. Each, 20c; by mail, 5 c extra.

\section{SMALL FRUIT SEEDS}

CURRANT, GOOSEBERRY, RASPBERRY, STRAWBERRY, BLACKBERRY. PKt., 10e; oz., 70c.

New and rare varieties of small fruits are often obtained from planting seed; however, the seed does not produce all plants of the same variety as its parent.

WONDERBERRY. This plant is of very quick growth, ripening fruit in three months from time of seeding, and resembles a tomato plant but of more erect form. The dark purple blueberry-like fruit is produced in great abundance. It is very good for making pies and jellies. It requires same culture as tomato. Pkt., 10e; 1/4 oz., 30e; 1/2 oz., 50e.

\section{SMALL FRUIT PLANTS}

Prices are for plants by express, not prepaid. Plants will reach customers in a better condition if sent by express. We have facilities whereby we can supply from reliable growers the following stock:

\section{CURRANTS.}

La Versalles. Very large red, with long bunches.

Red Cherry. An old favorite. Very vigorous and productive, though bunches are short.

Price, each, 15c; 5 for $65 \mathrm{c}$; dozen, $\$ 1.40$, by express.

If by mail, add $30 \mathrm{c}$ per dozen for postage and extra packing.

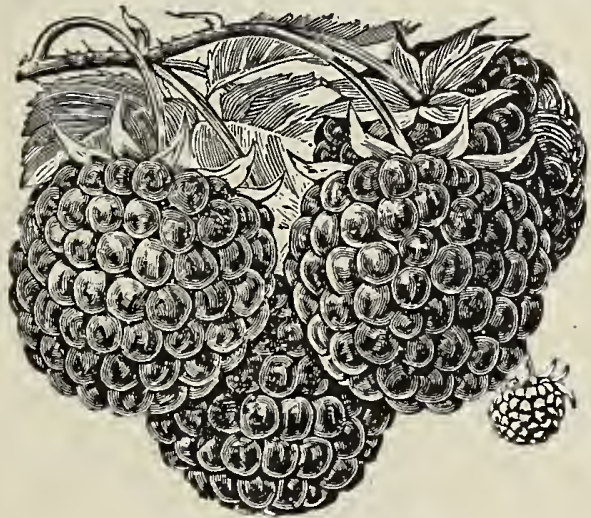

Raspberry-Marlboro.

\section{GOOSEBERRIES.}

Downing. A large handsome pale green. Splendid for both cooking and table use, Houghton. A small, roundish, sweet and tender berry. Enormously productive. Price, each, $15 \mathrm{c}$; dozen, $\$ 1.50$, by express. If by mail, add $30 \mathrm{c}$ per dozen for postage and extra packing.

\section{RASPBERRIES.}

If by mail, add $20 \mathrm{c}$ per dozen for postage and extra packing.

Cuthbert. A remarkably strong, hardy and very large variety. Stands our winters well by covering. Berries are large, rich crimson.

Marlboro. Large size, early, light crimson color; very fine and hardy. An excellent variety for shipping. Price for either, 12 for $50 \mathrm{c} ; \$ 2.50$ per $100 ; \$ 15.00$ per 1,000 , by express.

\section{STRAWBERRIES.}

The following varieties have all perfect flowers and will succeed in any soil that is adapted to ordinary garden crops. They are best adapted to Colorado and the entire West. Jucundas, Captain Jack, Senator Dunlap, Aroma, Shipper's Pride.

Prices for any above varieties, not prepaid. Dozen for $15 \mathrm{c} ; 100$ for $60 \mathrm{c} ; 1,000$ for $\$ 5.00$. If by mail, add $10 \mathrm{c}$ per dozen; $30 \mathrm{c}$ per 100 plants. When by express plants are more satisfactory. Ready in April and May, also September.

When large quandities of any above are wanted, wrlte us in regard to same.

\section{BLACKBERRIES.}

Rathburn. Hardy, wonderfully productive; medium size; sweet and juicy.

Erie. Hardy and very vigorous; free from diseases; early, productive and large.

Price, each, $10 \mathrm{c} ; \$ 1.00$ per dozen; $\$ 5.50$ per 100 , by express.

If by mail, add $20 \mathrm{c}^{\circ}$ per dozen for postage and packing.

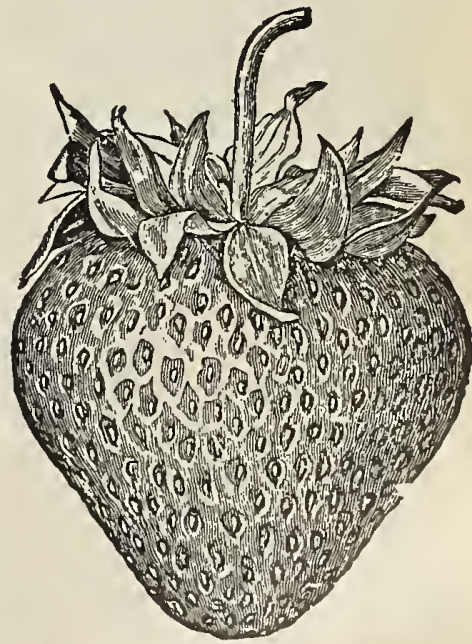

Strawberry-Senator Dunlap. 
WESTERN SEEDS ARE BEST ADAPTED FOR THE

WEST

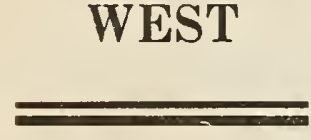

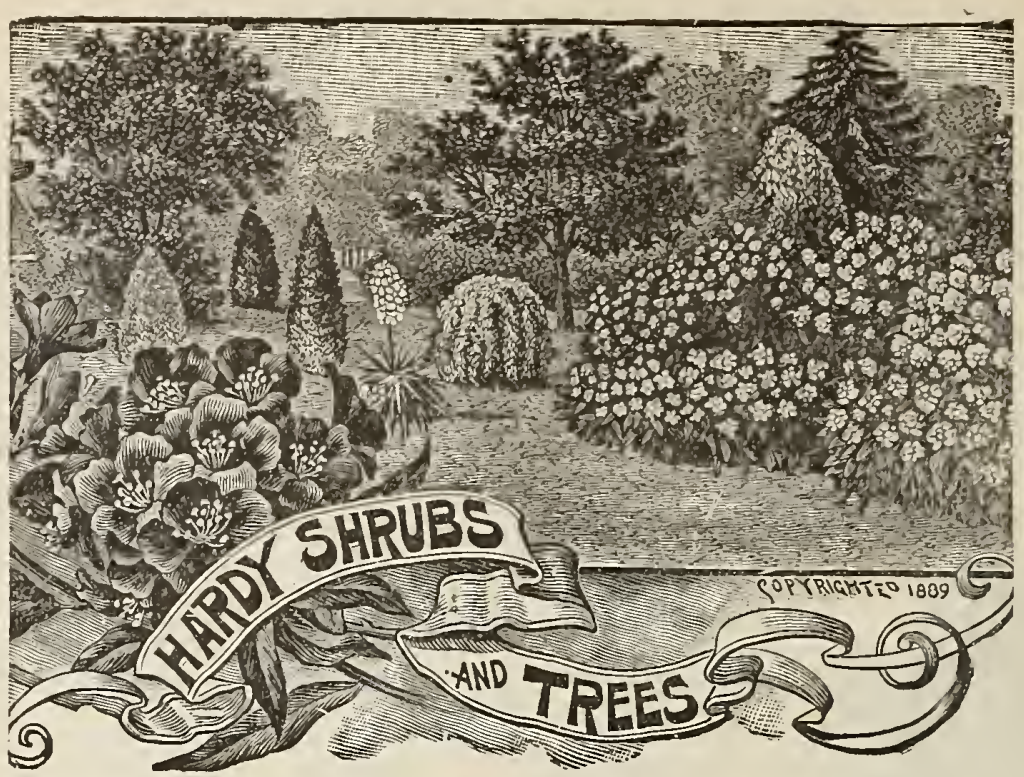

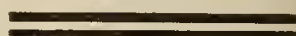

SEEDS

REQUIRE

8 CENTS

PER POUND

FOR

POSTAGE

Priees ly onnee and single pomd inelu
ould write for Nurserymen's Price List.

\section{AILANTHUS, TREE OF HEAVEN.}

Introduced from Japan. It has been quite extensively planted in our Western states, and is noted for its extremely rapid growth. It grows to large size, and its foliage has a
rich tropical appearance. Oz., 10c; $1 / 41 \mathrm{~b}, 20 \mathrm{c} ; 1 \mathrm{~b} \ldots . . .660 \mathrm{c}$

\section{WHITE ASH.}

This is one of the most valuable varieties for forest planting. It is adapted to a wide range of soil and climate. Its growth is extremely rapid, often obtaining a growth of 6 feet in a single season. It is one of the earliest varieties to transplant or grow from seed, requiring no more care or skill than the ordinary crop of white beans or Indian corn skill than the ordinary crop of White beans or Indian corn, With the exception that the seed usually lies dormant the

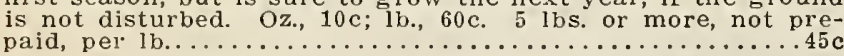

\section{BASSWOOD, OR AMERICAN LINDEN.}

A large tree of rapid growth; wood soft and white: lumber valuable. The foliage is luxuriant and the flowers
produce honey in great abundance. Oz., 15c; $1 \mathrm{~b} \ldots \ldots \ldots \$ 1.00$

\section{BOX ELDER, OR ASH-LEAVED MAPLE.}

A medium-sized tree of extremely rapid growth, not usually attaining a height of over 30 feet. The wood is close

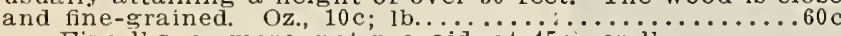
Five lbs, or more, not prepaid, at $45 \mathrm{c}$ per $\mathrm{lb}$.

\section{HARDY CATALPA.}

Its exceedingly rapid growth, its extraordinary success on the Western prairies, the ease and certainty with which it is transplanted, the strong vitality and freedom from disease and insects, the incomparable value of its timber, the most imperishable nature of the wood when used for posts, railroad cross-ties and in other exposed situations the unrivalled beauty of its flowers, all point to the Catalpa as the trec to plant.

Reculir Stoek, oz., $15 \mathrm{c} ; 1 / 1 \mathrm{t}$., $40 \mathrm{c} ; 1 \mathrm{~b} \ldots \ldots \ldots \ldots \ldots 1.25$

Selected stock, oz., 20c; $1 / 4$ lb., $60 \mathrm{c} ; 1 \mathrm{~b} \ldots \ldots \ldots \ldots \ldots \ldots \ldots 2 . . \ldots \ldots$

TEA'S JAPAN HYBRID CATALPA.

A new variety of wonderfully rapid growth, surpassing any othel hardy tree. Most valuable and durable timber very large, handsome foliage and beautiful flowers; magnificently shaped tree. Endures extreme heat or drouth. COTTONWOOD.

A very quick growing tree; will grow anywhere; lumber not very valuable. Oz., $15 \mathrm{c} ; 1 / 4 \mathrm{lb} ., 40 \mathrm{c} ; 1 \mathrm{~b} . . . \ldots \ldots \ldots \ldots . . .1 .00$

\section{WHITE ELM.}

It is the largest of the native Elms, often growing to the height of 80 feet. 'The wood is tough and valuable. It is well worthy of cultivation. both for its wood and orna-

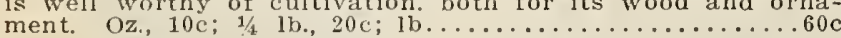

EUCALYPTUS GLOBULUS-BLUE GUM.

Pemarkably quick growing, especially adapted to Southern states. It absorbs malaria and fever germs. Does best when started in seed beds, then transplanted to open ground. Height, 150 feet. Pkt., $10 \mathrm{c} ; 0 \mathrm{z} ., 50 \mathrm{c} ; 1 / 4 \mathrm{~b} ., \$ 1.50 ; 1 \mathrm{~b} . \ldots \ldots 5.00$
EUCALYPTUS TERETICORNIS-GRAY GUM.

$A$ rapid grower and erect. Wood durable and useful for shingles, flooring, street paving blocks, etc., will last for ages. It is also a good honey producer. Height, 200 feet. YELLOW, OR BLACK LOCUST.

This variety is noted for its rapid growth of hard and durable timber. It is hardy and succeeds well in many parts of the country, while in some localities it proves a not already been tested. Oz., 10c; lb. locality where it has HONEY LOCUST.

This is a large and handsome tree; the trunk and branches generally beset with long and formidable spines, on which account it has been employed as a hedge plant The wood is heavy and affords excellent fuel, but is not considered durable as timber. Has done well in our state Wherever planted. Seeds ought to be soaked before plant-

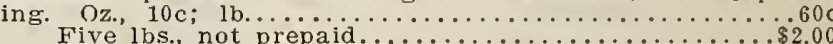
OSAGE ORANGE.

A native of Texas, has been generally introduced over thc country for its extensive employment as a hedge plant It is also known as Bois d'Arc. Proper time to sow is in April or May. Pkt., $5 \mathrm{c}$; oz., 10c; $1 / 41 \mathrm{~b} ., 20 \mathrm{c} ; 1 \mathrm{~b} . \ldots \ldots \ldots \ldots .60 \mathrm{c}$ PAW.PAW.

Too sinall for any value for timber, but makes a fine ornamental tree and is also cultivated for its fruit, which resembles the banana in form and color, and when fully ripe is very delicious. Oz., 10c; $1 / 1,1 \mathrm{~b} \ldots \ldots \ldots \ldots \ldots \ldots \ldots \ldots$

\section{PERSIMMON.}

Tree hardy. Wood very hard and fine-grained. It bears plum-shaped fruit, which is very astringent when green, but plum-shaped fruit, which is very astringent when green, but
edible when fully ripe. Oz., $10 \mathrm{c} ; 1 / 4 \mathrm{lb} . . . \ldots \ldots \ldots \ldots . . . .30 \mathrm{c}$ RUSSIAN MULBERRY.

Said to be the most valuable variety for our climate. The berries are edible. The trees make good fence posts after five y'ears' growth, and also make splendid lumber for cabinet works Pkt., $5 \mathrm{c}$; oz., $25 \mathrm{c}$; $1 / 1 \mathrm{lb} \ldots \ldots \ldots \ldots \ldots \ldots .75 \mathrm{c}$

\section{SUGAR MAPLE.}

It succeeds well in all soils and locations, making a stout, vigorous, rapid growth of hard wood, most valuable for fuel and highly prized for manufacturing purposes. Oz. SOFT, OR SILVER-LEAVED MAPLE.

One of the most beautiful of Maples. The seed ripens in May, and cannot be kept over until fall and retain its vital:ty, hence it should be sown as early as possible after it is taken from the trees. Oz., $10 \mathrm{c} ; 1 \mathrm{~b} \ldots \ldots \ldots \ldots \ldots \ldots . . . . . .35$ Can give prices for quantity in May.

TREE CRANBERRY, OR SNOWBALL.

S Small tree or shrub; is 10 to 12 feet high at maturity. and produces its snowy flowers in large balls or masses in June. Pkt., $5 c ; 0 z . . . . . . . . . .$.

Well-known flowering shrub, highly ornamental. Seedlings usually furnish blossoms of varied colors. Pkt., $5 \mathrm{c}$ 


\section{FRUIT TREE SEEDS}

APPLE.

I'rleen per wingle pound are postpaid.
Apple seeds do not produce the same varieties, but an inferior though hardy stock. Upon the stock thus raised from the seed are grafted or budded the cuttings of such varieties as are desired. The seeds can be planted ill good soll, any time during the winter in the south, or early in the spring in the No spring it must first be frozen, which seed is planted in the spring it must nirst be frozen, which can be done during the winter by placing layers of seed in boxes and covering with sand and exposing them to the cold, freezing weather. After freezing, the seed must not be allowed to become
prived of all moisture.

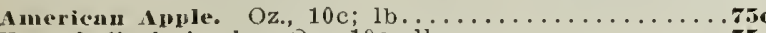

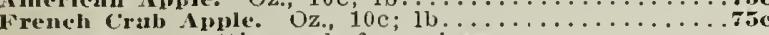

For large quantities, ask for prices.

\section{MAHALEB CHERRY.}

The remarks regarding applcs are applicable to cherries, This variety is considered the best stock upon which to graft

the choicest sorts. Oz., 10c: 1b.................6ec MAZZARD CHERRY.

Another variety used extensively for grafting. Oz., 10c;
Sow the seed thickly in the spring in drills 18 inches apart. The soil should be drep-a rich, moist loam is most suitable. The value of the stock depends largely on a rapid and vigorous growth the QUNCE.

Quinces generally produce the same variety from seed. The stock is used mostly for budding and grafting the pear. The culture from seed is the same as for apple. Oz., 25c; The culture from seed is the same as for apple. Oz., 2500 MYROBOLAN PLUM.

The directions given for apples will apply to plums, except the pits should be planted further apart in the row.

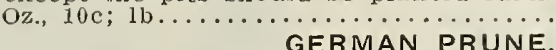

Treated same as preceding. Oz., $10 \mathrm{c} ; 1 \mathrm{~b} \ldots \ldots \ldots \ldots$. .60 PEACH.

Peach stock are raised by planting, the stone, 2 or 3 inches deep, in the fall. If the stones are cracked they are more sure to grow. The after treatment is about the same as for apples. Lb., $20 \mathrm{c} ; 10 \mathrm{lbs}$, not prepaid, $75 \mathrm{c}$.

\section{NUTS}

Priecs per siugle pound are postpaid.

\section{BLACK WALNUT.}

One of the most valuable varieties for timber planting. A very large tree of rapid growth. It delights in rich soil and luxuriates in our prairie loams or timber land clay. Its lumber has a very high market value, and is becoming very scarce. The nuts are a well-known article of commerce. Lb., 20c; 10 lbs., not prepaid, $65 \mathrm{c}$.
HICKORY.

This species becomes a lofty tree, 80 feet high with a diameter sometimes of 2 feet. It furnishes most of the hickory nut of commerce. Lb., $20 \mathrm{c} ; 10 \mathrm{lbs}$., not prepaid, $75 \mathrm{c}$ BUTTERNUTS.

A tree much admired for its timber, and also produces a desirable edibie nut. Lb., $20 \mathrm{c} ; 10$ lbs., not prepaid, $\$ 1.00$

For pruuing trees get a good pair of Pruning shears or a Long Handle Tree Pruner. We lkeep botlh. See our list ln back part of tilis eatalogue.

\section{Rocky Mountain Evergreens}

We make a specialty of collecting from the Rocky Mountain districts. Parties intending to purchase quantities will do well to write us for prices.

ABIES CoNCOLoR-Balsam White Fir. A very handsome tree growing to a good size. Oz., $35 \mathrm{c} ; 1 / 41 \mathrm{~b} ., 90 \mathrm{c} ; 1 \mathrm{~b} ., \$ 3.00$.

ABIES DOUGLASII-Douglas Red Spruce. Rapid growing and ornamental, of pyramidal habit. Oz., $40 \mathrm{c}$; $1 / 4$ lb., $\$ 1.25$; $1 \mathrm{~b} ., \$ 4.00$. PICEA ENGLEMANNII-Englemanns Spruce. Similar to Colorado Blue Spruce,
but grows larger. with needles less rigid and sharp. Oz., 40c; $1 / 4$ b., $\$ 1.30 ; 1 b ., \$ 4.25$.

PICEA, PUNGENS-Colorado Blue spruee. A most desirable conifer, with silvery foliage, for lawns. From selected blue trees only. Oz., 40c; $1 / 41 \mathrm{~b}$., $\$ 1.25 ; 1 \mathrm{~b}$., $\$ 4.00$.

PINUS PoxnerosA-Yellow Pine. Grows to an enormous size, with luxuriant foliage. Oz., $25 \mathrm{c} ; 1 / 41 \mathrm{~b} ., 75 \mathrm{c} ; 1 \mathrm{~b} ., \$ 2.50$.

PINUS FLEXILIS- White Pine. A handsome tree of compact habit and dark green foliage. Wood white, soft and easily worked. Oz., $25 \mathrm{c} ; 1 / 4$ lb., $75 \mathrm{c} ; 1 \mathrm{~b} ., \$ 2.50$.

PINUs Banksiana-Jaek Pine. Gray Pine. This species of pine is the best adapted to sandy soils. It grows more rapidly than most conifers and is a useful small tree for wind-breaks. It is used for fuel and coarse lumber and when
with chemical preservatives makes fair posts or ties. Oz., 50c; $1 / 41$., $\$ 1.50$.

RED CEDAR. Grows in all sections; very valuable timber; a fine ornamental tree. After properly planting out the Red Cedar requires less care and will stand more neglect than any other evergreen. Oz., $10 \mathrm{c} ; 1 / 4 \mathrm{lb}, 30 \mathrm{c} ; 1 \mathrm{~b} ., \$ 1.00$.

JUNIPERUS ARGENTEA-White, or silver Cedar. A native variety of cedar, with silvery foliage. Oz., $20 \mathrm{c} ; 1 / 4 \mathrm{lb} ., 60 \mathrm{c} ; 1 \mathrm{~b} ., \$ 2.00$.

JUNIPERUS MONOSPERMA-Dwarf Trailing Cedar. A very hardy trailing evergreen. Oz., 20c; $1 / 4$ lb., $60 \mathrm{c} ; 1 \mathrm{~b} ., \$ 2.00$.

Ask for onr pamphlet-The Growing of Deciduous Evergreen aud Fruit Trees fro

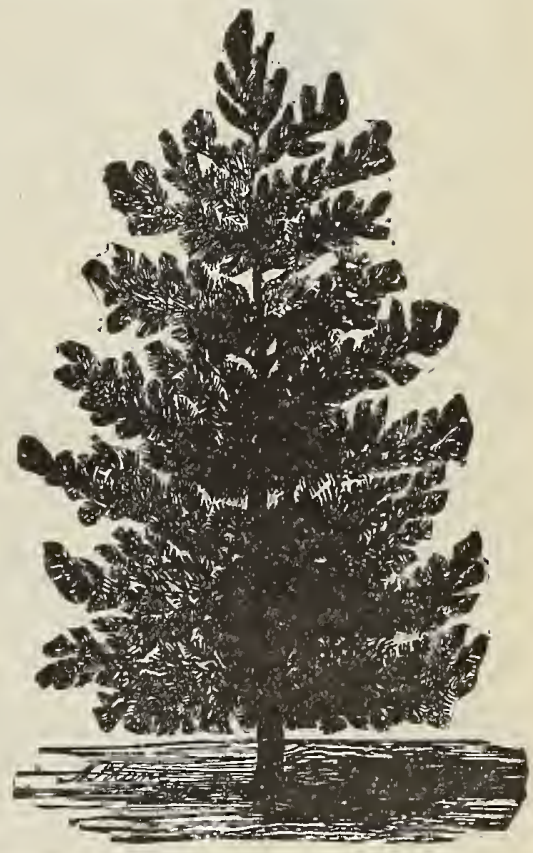

\section{HONEY PLANTS}

\section{CLEOME, OR ROCKY MOUNTAIN BEE PLANT.}

A native of the West. Perfectly hardy. One of the best honey-producing plants. Its blossoms is now the emblematic flower of the State Bee Keepers' Association. It is perfectly hardy, and after once sown will usually self-sow and increase rapidly, Has an attractive flower in shades of pink and crimson. Bees feed heavily on this. Oz., 20c; $1 / 41 \mathrm{~b} ., 45 \mathrm{c}$; lb., $\$ 1.25$, prepaid.

\section{WHITE BOKHARA, OR SWEET CLOVER.}

This is a tall, shrubbery-like plant, growing to the height of 4 to 6 feet, with branches bearing numerous smal white flowers of great fragrance. 10 pounds will sow one acre. Lb., hulled seed, $25 \mathrm{c}$. Ask for free leaflet on Sweet Clover.

our hard earned reputation as honest seedsmen is worth too much that we would offer anything of doubtful character. We have handled seeds for over thirty-five years and expect to do the same for many more years to come. The constant growth of our business is the reward for consclentious service and honest business principles in our dealings with the public. 


\section{FIELD AND FARM SEED DEPARTMENT}

पूर The prices of ail Fleld and Farm Secds are those ruilng January 1, 1914, and are wubject to chunge. As far as

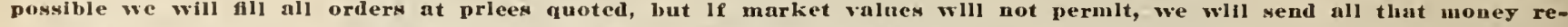
mitted will pay for. Our latest prlee list wlll be sent free for the anklng.

We give special attention to our Grain Seeds, procuring from reliable growers who select for seed. Our process for

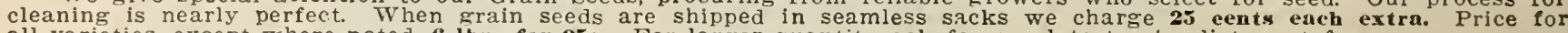
all varieties, except where noted, 6 bs., for 25c. For larger quantity ask for our latest price list, sent free.

If wanted by mail, add postage.

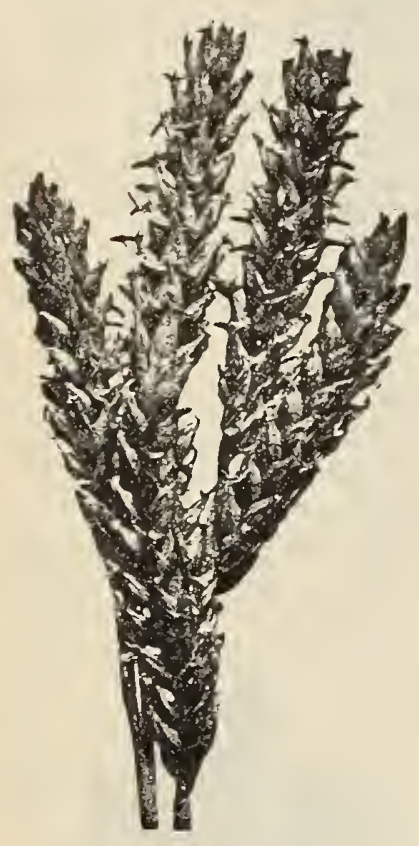

Hulless Barley.

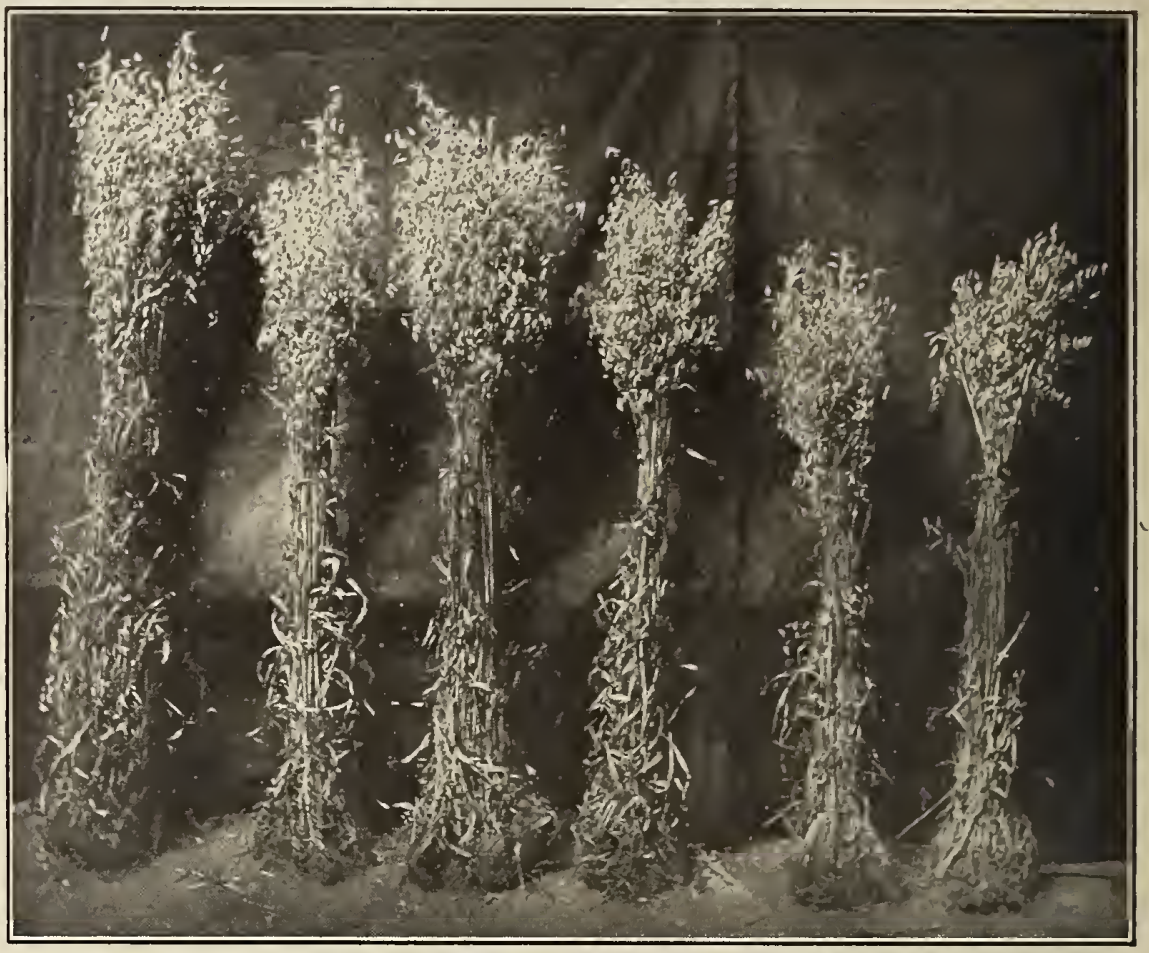

New Market, Swedish Select, Colorado No. 37, 1,000 to 1, Kherson, Red Rust Proof.

\section{BARLEY}

Sow 60 to 90 llis. per nere; on dry land 40 to 50 lbs.

SCOTCH-Both 4 and 6-rowed. This is the staple variety for brewers. It is good for feeding, not having as long

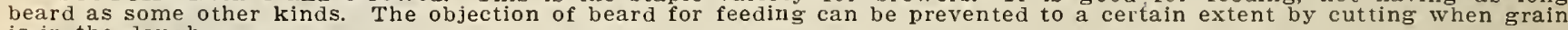
is in the dough.

NAKED, BEAIRDIESS OR WHITE HULIESS. This is decidedly distinct from the malting variety, having no beard

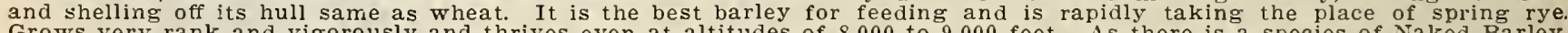

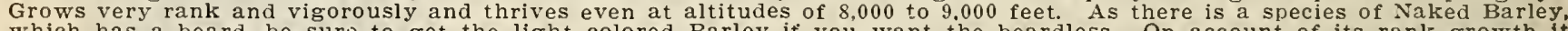

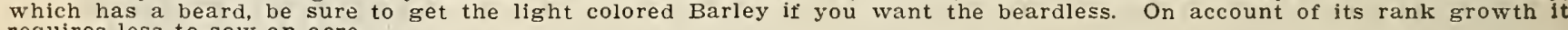
requires less to sow an acre.

CALIFOINIA, OR FEED BARLEY. This is a very hardy kind, producing very large, coarse, bearded heads and an

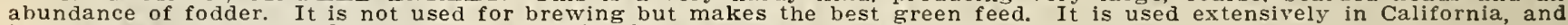
is an excellent grain producer in Colorado. Stockmen are demanding it.

\section{OATS}

No crop gives better results by change of seed than oats. If you have been re-seeding the same strain for several

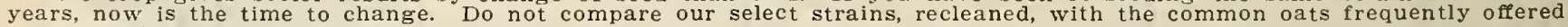
as seed oats

Sowv 50 to 65 lbs, per acre; on dry land 30 to $35 \mathrm{lbs}$

NEW MARKE'T. Is one of the most desirable oats to raise. It grows very erect on large, stiff, nutritious stems, pro-

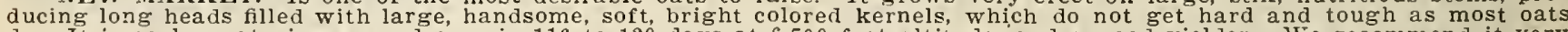

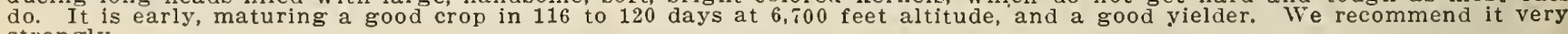
stiongly.

SWEISIH SELECT. A very hardy variety, specially recomntended for the North. Owing to its great root development it withstands drouth very well. The grain is short, plump, white and very heavy, averaging 40 lbs. per bushel.

$\mathbf{1 , 0 0 0} 101$. This is one of the best oats for dry farming. It is medium eally, stands drouth well, and has produced

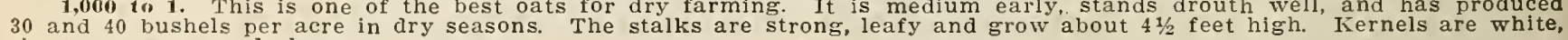
short, numerous and plump.

PEDIGREED COIORADo No. 37. This oat is noted for its large leaf, straw, heavy weight and good quality kernel.

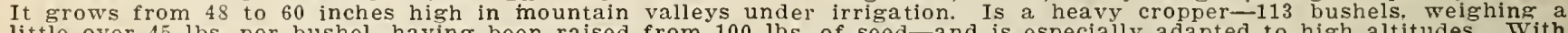

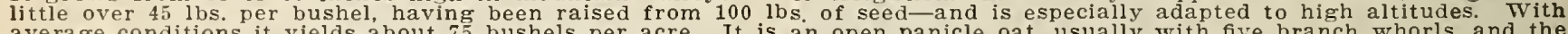

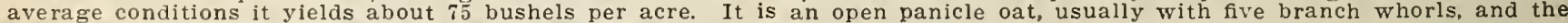
very best milling oat, giving 76 per cent, meat to hull.

Prices, 10-1b. sealed sack, 60c; 25-1b. sealed sack, 90c. Aask for market price on large quantity.

NEW FllERSON. It is one of the earliest oats grown and is sometimes called "90 day oats," as it has ripened crops in

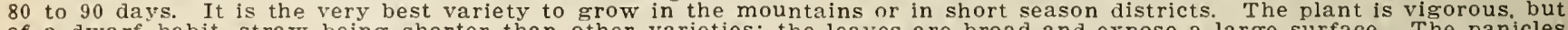

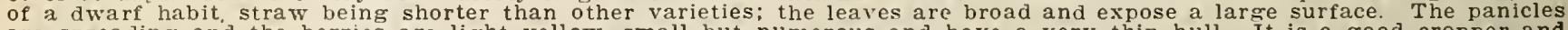

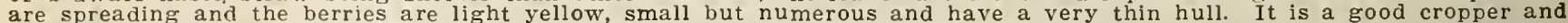
generally weighs well per bushel.

RED RUST PROOF. Not extensively grown, though highly recommended by those who have grown it, and is now

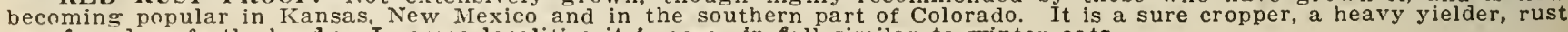
proof, and perfectly hardy. In some localities it is sown in fall similar to winter oats. 


\section{SPRING WHEAT}

Sow 60 to 50 lbs. per aere on irrigated land; 40 to 45 lbs. on dry land.

\section{PEDIGREED REGENERATED DEFIANCE WHEAT}

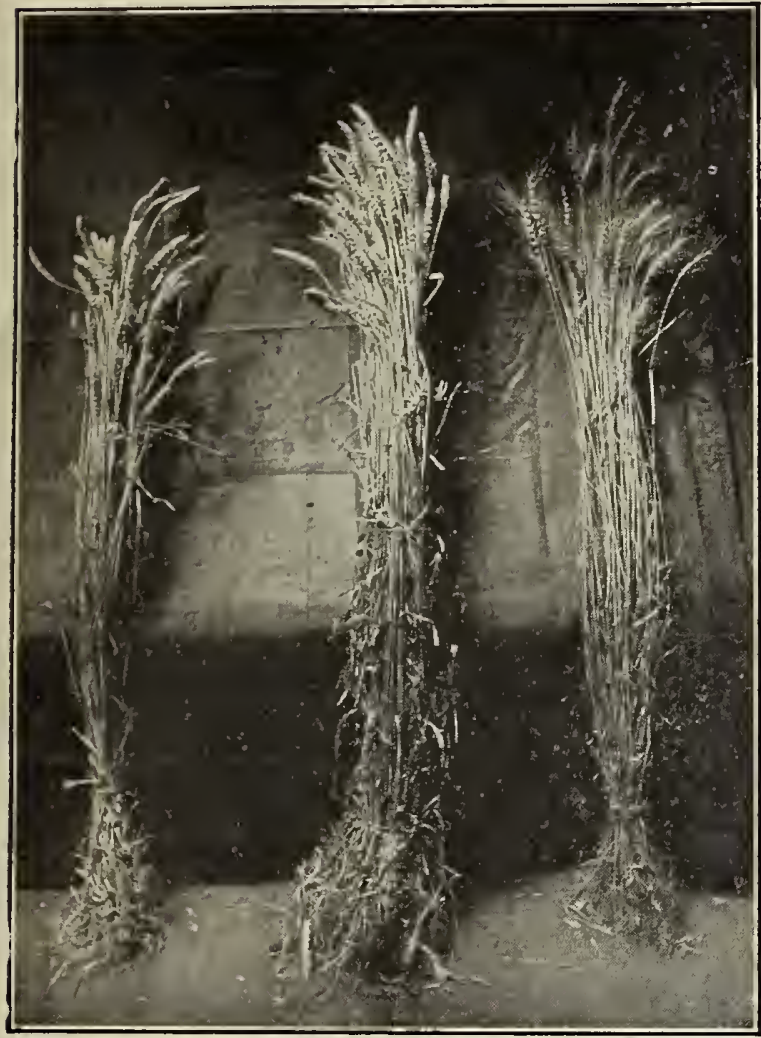

Blue Stem, Regenerated Defiance, Macaroni.

\section{Winter Wheat}

\section{Sow 30 to 35 lbs, on dry land.}

TURKIY RED. This is the best winter variety for this part of the country. It is medium hard bearded and producing long heads. In color it ranges from dark to light red. The grain is large and less liable to shell out than most varieties. It stands drouth and open winters very satisfactorily, and is a heavy yielder.

SILVER IXING. Liked on account of being beardless. It is medium hard, light red, of good weight, heavy cropper and winters very well. Is growing in favor quite rapidly.

\section{Speltz or Emmer}

It makes a good crop with almost any condlion of the soil and climate.

Sow 70 to $80 \mathrm{lbs}$, per acre; on dry land 40 to 45 lbs. It is neither wheat, rye nor barley, and yet it appears to be a combination of these. It is more like wheat than any of the others mentioned. For fat tening cattle, poultry, horses, sheep, pigs, etc., it is claimed to be ahead of other grains, in fact, all kinds of animals seem to thrive on it. Speltz is claimed to be ahead of corn, superior to oats and more profitable than wheat. Yields 80 to 100 bushels of grain and as m'ch as 4 tons of good hay per acre. Excellent for pasture and can be fed in the green state. As green grass hay food it often gives 100 leafy stalks from one seed, which shows its heavy stooling properties. The heads are somewhat similar to two-rowed barley, the spikelets being separated from each other in such a manner that the crop is not eisily injured by the weather. Will grow well and produce enormous crops on land where wheat will not grow.

\section{Improved Winter Emmer}

\section{A NEW GRAIN FOR STOCK FEEDING.}

The original Winter Emmer was introduced fromRussia, by the U. S. Dept. of Agriculture. The Improved is larger, darker in color, heavier in straw and head, is much more hardy, and has larger stooling power than the oliginal type.

It is one of the best drouth and cold resisting winter grains. Many of the heads double the spikelets, giving the appearance of composite wheat; can be grown either by irrigation or by dry farming methods.

Sow at the rate of 1 bushel (40 lbs.), per acre, in September or October, that the grain may come up before freezing weather sets in. If you irrigate, do it before sowing or just before winter sets in. One or two harrowings in $\in$ arly spring will help the grain and it will be ready to harvest late in June or early in July. It should be cut before it gets too ripe and dry.

Price, $20 \mathrm{c}$ per 1b.; 3 lbs. for $50 \mathrm{c}$.

\section{Rye}

Sow 60 to 80 pounds per acre; on dry land 30 to 40 pounds.

SPRING RYE. Is a quick growing crop which will give a good early pasture and later on a good cutting of hay or a grand crop of grain. Please note that in ordering spring rye we offer what is furnished us as spring rye, but make no guarantee for same.

FALL OR WINTER. It is a good crop for early fall or spring pasture, as it keeps green a long time in the fall, and starts growing again as soon as the weather gets a little warm. Does well in any kind of soil. There is always a good market for good fall rye for seeding purposes.

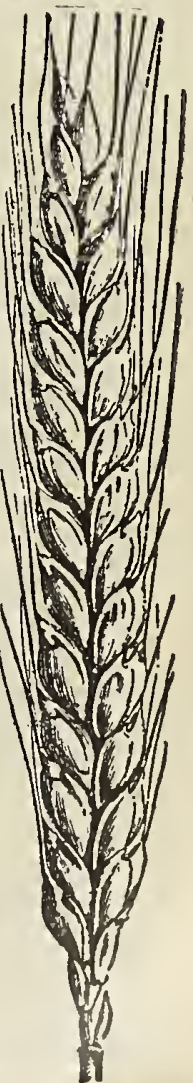

Speltz or Emmer 


\section{SELECTED SEED CORN} pries.

tostate, sc per pound. 8 low, of the small kernel varletles or 10 lbs, of the large varletles, will plant an acre.

\section{AUSTRALIAN WHITE FLINT} (90 Days).

The earliest and surest variety we have for Colorado and the arid lands of the West. It will actually endure more drouth and cold than any other variety known. Grows to a height 12 inches long, usually 8 or 10 rowed, 12 inches long, usually 8 or 10 .
one and two ears to a stalk.

\section{PRIDE OF THE NORTH (90 Days).}

Planted as late as July 4, it has fully matured by October 1. The ears have from 14 to 16 rows, 8 to 10 inches in length, slightly tapering. The kernels are closely set together on the cob, of a light orange color. The stalks usually grow 6 to 8 feet in height, producing one or two good ears.

This is one of the earliest lar early, and not a hard, flinty corn.

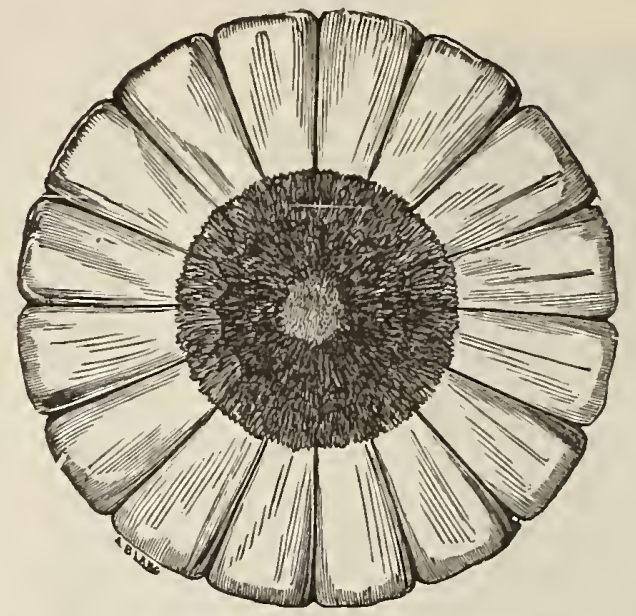

IMPROVED LEAMING (90 Days).

SWADLEY (90 Days).

It is nearly as hardy as White Australian, and fully as early, and firmly convlnced that it is the corn for uplands and woln out solls, where it produces 35 to 50 bushels of where it pcre it stands outh nearly ars per as White Australian. It is much softer kernel, being a pale yellow dent. The ears will average 8 inches lons. 12 to 16 rowed. One-third of the crop will yield two ears on a stalk, maturing in 90 to 100 days. Six pounds of seed wlll plant an acre, 3 feet, 8-inch checkrows. This is the corn for our short season districts. Give it a trial, you will be pleased.

\section{COLORADO YELLOW DENT (90 Days).}

An early Dent variety, ripening with the Flint varieties, and can be grown in almost any locality. Stalks $\operatorname{larg} \theta$ with broad leaves, ear's 8 to 10 inches,
16 rowed, gråin yellow.

yellow Dent corns in cultivation, rinening in 90 to 100 days from planting. It is extra CALICO (90 Days).

The earliest field corn grown. Growth rather short, but stalks are rery leafy. The ear is small and long and grains are peculiar, some being red, blue and white on the same cob. Stands drouth very well.

SQUAW (90 Days).

Fxtremely early and of very dwarf habit; stands drouth as good as White Australian; average length of ears, $71 / 2$ inches; seed of dark purple color and sugary; makes good roasting ears.

\section{CHAMPION WHITE PEARL (100 Days).}

The stock is short and thick. The ear grows low on the stalk, from 10 to 12 inches in length, almost parallel throughout, of medium size, averaging 16 rows of grains. The grains are pure white, very deep, compact and heavy. The cob is small. It makes a superior quality of corn meal.

IOWA SILVER MINE (95 Days).

The stalk grows to a height of 7 or 8 feet, and set the ears about $3 \frac{1}{2}$ to 4 feet from the ground: The ears measure from 10 to 12 inches in length and often weigh $1 \frac{1 / 2}{2}$ pounds. They are very uniform in size and shape, with 16 to 20 straight row's of deep, pure white kernels on a small white cob.

\section{IOWA GOLD MINE (95 Days).}

Similar to above, except in color, which is a bright golden yellow.

HICKORY KING (110 Days).

This new white corn is entirely distinct from all other varieties, having the largest grain with the smallest cob. It yields greater, and is unquestionably the most productive white field corn. Stalks bear two good ears each, and occasionally three. It never has barren stalks, no matter how thin the soil, and both ends of the ear are filled out full.

\section{GOLDEN BEAUTY (110 Days).}

The ears are of perfect shape, with from 10 to 14 straight rows of bright golden yellow grains, remarkable in size, and filled out completely to the extreme end of the cob. The richness nf color and fine quality of grain make it vastly superior for grinding into meal.

\section{BRAZILIAN STOOLING FLOUR.}

This corn stools like wheat, each kernel producing from five to eight stalks, each stalk bearing two or three ears, five to seven inches in circumference, nine to twelve inches in length, color bautiful white. It is the best variety, for ensilage. it yields four times more fodder to the acre than common corn, and more bushels in shelled corn. It contains a much larger quantity of starch than any other corn and, ground and bolted by the same process as wheat, gives a finer flour for bread, biscuits, etc., than that made of wheat flour; also used largely for roasting ears. Four lbs. Will plant one acre.

POP CORN.

WH1TE R1CE. Kernels long, pointed, and resemblin

RUEEN'S GO1,DEN. Yellow seed, pops very laro.

$\begin{array}{rrr}\text { Plit. } & \text { Lb. } & 31 \mathrm{bs} . \\ \$ 0.05 & \$ 0.10 & \$ 0.25\end{array}$

\section{Grass Seed Mixtures}

\section{FOR MEADOWS AND PASTURES.}

It is a well ascertained fact that a thicker and more prolonged growth is produced by a mixture of many sorts of

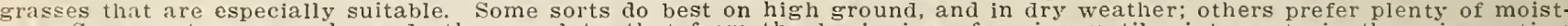
ure some mature so early, and others so late, that from the beginning of spring until winter sets in there is no time when one species or another is not at its best.

In the matter of preparing the soil for pastures, it is necessary to put the ground in the best condition possible to

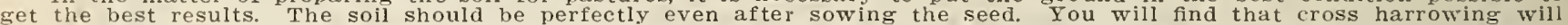

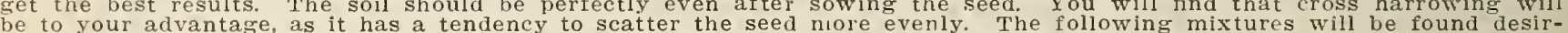
be to your advantage, as it has a tendency to scatter the seed niore evenly. The following mix

For Wei lands use Barteldes Pasture Iixture No. 1. 1 lb. to 10 lbs. at 25c per lb.; $251 \mathrm{bs}$. at $20 \mathrm{c}$ per $1 \mathrm{~b}$.

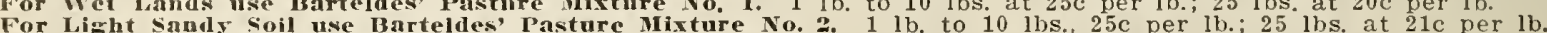

For lrigated Lands use Barteldes Pasture Mixture No. 3. 1 lb. to 10 lbs. at $25 \mathrm{c}$ per lb.; 25 lbs. at $20 \mathrm{c}$ per lb.

Sow liberally of either of above to get best results using 30 to 40 pounds per acre. Ask for prices on large quantities.

The Barteldes Seed Co.

Elmo, Utah.

Dear Sirs:- Will you please send me your latest price list on wheat, oats and potatoes, in quantity, as I want a few

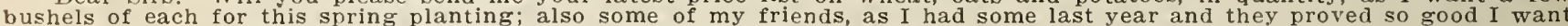
some more. Your seeds have given me good satisfaction for 15 years. As ever, yours truly, 


\section{GRASSES FOR PASTURES}

Postage Se per pound extra.

We have wen in our employ who make a study of grasses adapted to our Western country. Write us about your soll.

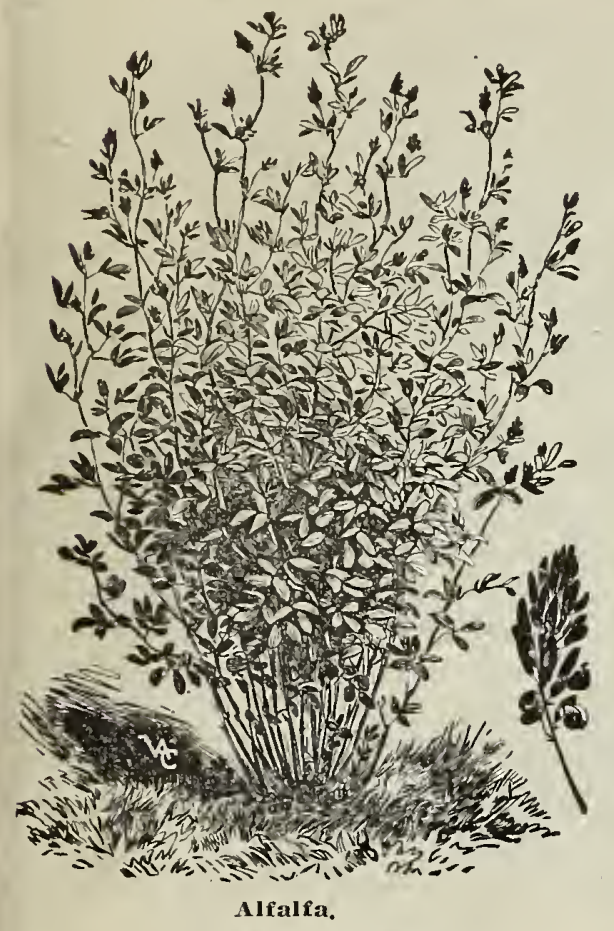

RED CLOVER.

Trifolium Pratense.

Regarded the most important of the whole genus for practical agriculture; valuable not only for forage, but also as a fertlizer for decaying add a large amount of humus to the soil. Makes excellent hay, and can be cut twice a year. Sow 12 to $15 \mathrm{lbs}$. to the acre. Per 1b., 30c.

\section{ALSIKE, OR SWEDISH CLOVER. Trifolium Hybridum.}

Comes from the little province of Alsike in Sweden. One of the hardiest varieties known; is perennial and does not winter kill; stands alike drouth or wet. A great favorite with bee-keepers, as it has flowers having a sweet and agreeable odor and affords excellent for age for bees. Sow 5 to 8 lbs. to the acre.
Per lb., $30 \mathrm{c}$.

\section{MAMMOTH SAPLING, OR PEAVINE CLOVER.}

Being a rank grower makes it most valuable for fertilizing purposes. Forage, flowe and stem much darker than common Red Clover; ripens later than the latter, about the time Timothy, Red Top and other grasses ripen, making thereby a much better quality lbs. to the acre. Per $1 \mathrm{~b}, 30 \mathrm{c}$.

CRIMSON CLOVER. Trifolium Incarnatum. with seed, $25 \mathrm{c}$ each.

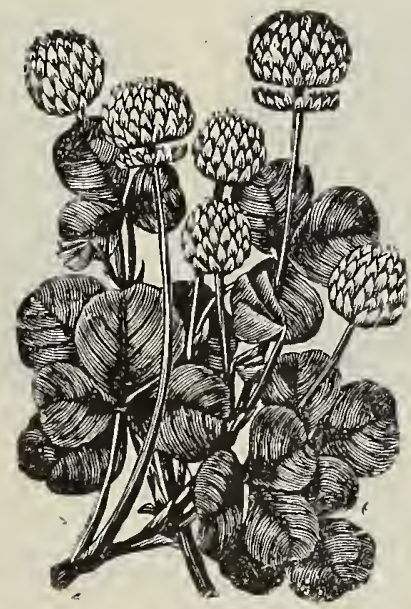

Red Clover.

Particular attention is given to our Grass Seed Department. These seeds are selected with special reference to quality. Every exertion made to furnish Grass and Field seeds, fresh, pure, and rree from noxious and foreign seeds, Our Red Clover, English Blue Grass, Tinothy, Alfalfa, etc, are all recleaned by best machinery, to make them choice.

We cannot print prices of large quantilies, as they are subject to variations, but purchasers may depend on getting them at prices ruling that date. on uricet prices of the day or speeinl prices on large lots cheerfully given on application. Wxuress or freight charices alvays to be paid by the purchaser, except if suficient money is sent to prepay them. Two bushel seamless bags,

\section{ALFALFA CLOVER, OR LUCERNE.}

\section{Medicaso Sativa.}

The most valuable forage plant, is particularly adapted for our Western climate and soil. It requires a deep, mellow soil; newly broken sod does not do so well. It thrives best in a sandy loam, the richer the better, while it has not proved a success on heavy, compact, clay soil. In the dryest and and green as in the spring, as its roots go down from 10 to 30 feet to the moisture of the ground. Although a prodigious yielder, it does not exhaust the soil, but rather improves the ground by the decay of its long roots, and converts it into rich ground, full of vegetable matter. The seed may be sown early in the spring, as soon as the frost is out of the ground, in order to catch the spring rains, as it needs moisture to germinate. In localities where irrigation is used, it can be sown successfully at any time during the summer months. Most of our successful Alfalfa orowers prefer sowing the seed broadcast, while others are more in favor of drilling it in. It is rather difficult to establish the first year, but will, when once started, produce a profitable crop; under favorable circumstances three and even four crops are cut
yearly, aggregating five to seven tons to the acre. Never sow less than 20 pounds of good, clean seed to the acre on irrigated land, as thin sowing produces thick and coarse stalks not relished by stock. On dry land sow from 10 to 12 pounds per acre. If intended to raise Alfalfa for the seed, 12 to 15 pounds is plenty to sow on an acre on irrigated lands, or 3 to

\section{TURKESTAN ALFALFA.}

It is claimed to be more hardy, enduring extreme cold and a wonderful drouth resister. $1 / 4$ lb., 10c; 1b., 25c. For larger quantities ask for price.

\section{WHITE DUTCH CLOVER.}

\section{Trifolium Repense.}

Excellent for pasture, and when mixed with Kentucky Blue Grass makes the finest and most nutritious food for sheep and cows; United States. Sow for pastures 5 to $8 \mathrm{lbs}$.

Fancy. $1 / 4$ lb. pkg., 15c; 1 lb. pkg., $50 \mathrm{c}$.

WHITE BOKHARA, OR SWEET CLOVER, Melilotus Alba.

Tall shrub plant. Grows from 4 to 6 feet high, with branches whose extremities bear abundant small white, extremely fragrant flowers. Splendid for bees. Sown in the spring in drills, 16 inches apart. Ten lbs. will sow one acre. Per lb., 25c.

JAPAN CLOVER. Lespedeza striata.

Low perennial, spreading habit. Stands excessive drouth well; flourishes on poorest soil in the southern states. Sow 15 lbs. per acre. Per lb., 35c.

BUR CLOVER. Medicago maculata.

Is mainly used in southern states and California. It fills in the season when other forage plants have become dried up by the summer heat. It does very well on alkali soils. contain a large proportion of nutritious matter. Sow 15 to 20 lbs. per acre from August ter. Sow 15 to 20 lbs. per
till November. Per lb., $25 \mathrm{c}$.

An annual variety in common use in Italy and south France for feeding green. Also grown largely in this country in Virginia, and we find it does well in our Western states. It is meeting with favor in Texas and adjoining states. Two to four weeks earlier than the Red Clover, and for that reason being more desirable. Immense yielder of fodder. Commences to grow at once after cutting, Sow in the fall in sout roots nearly black; blossoms long and of deep car ESPARSETTE, OR GERMAN CLOVER. Onobrychis sativa.

A leguminous plant with many stems, 2 to 3 feet long, leaves in pairs of oblong leaflets hairy on under side; stalks with spikes of crimson or variegated fiowers, followed by hard, flat pods, toothed and prickly. Perennial, roots hard and woody; flowers in July. Same family as Alfalfa. Adapted to light, chalky, sandy, gravelly soils and barren regions, deficient in rainfall and without irrigation
privileges; will last from 8 to 10 years, according to soil. Sow seed 2 inches deep, and from 30 to 40 lbs. per acre. Price, per 1b., 20c.

ORCHARD GRASS-Dactylis glomerata.

No farmer should be without a small field of Orchard Grass as in many respects it is superior to all other grasses. It stands the drouth, grows well in the shade, does well in wet or poor ground, and weeks before any other, and after grazing ten days' rest is sufficient for another growth. Cows fed on this will produce more and richer milk than on blue grass. It makes a very heavy sod, and when well set remains for many years. It is especially adapted for winter grazing, as it remains green all season. It is well suited to sow mixed with alfalfa, on average of $5 \mathrm{lbs}$. Orchard to $15 \mathrm{lbs}$. Alfalfa seed. Sow 20 to 25 lbs. per acre. Lb., $30 \mathrm{c}$.

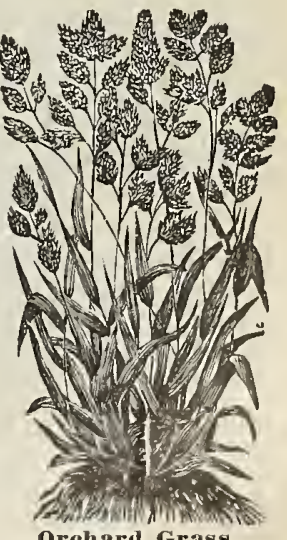




\section{GRASSES FOR PASTURES-Continued}

Postage Sc per pound extra. Ask for latest pricen for laríge quantitien.

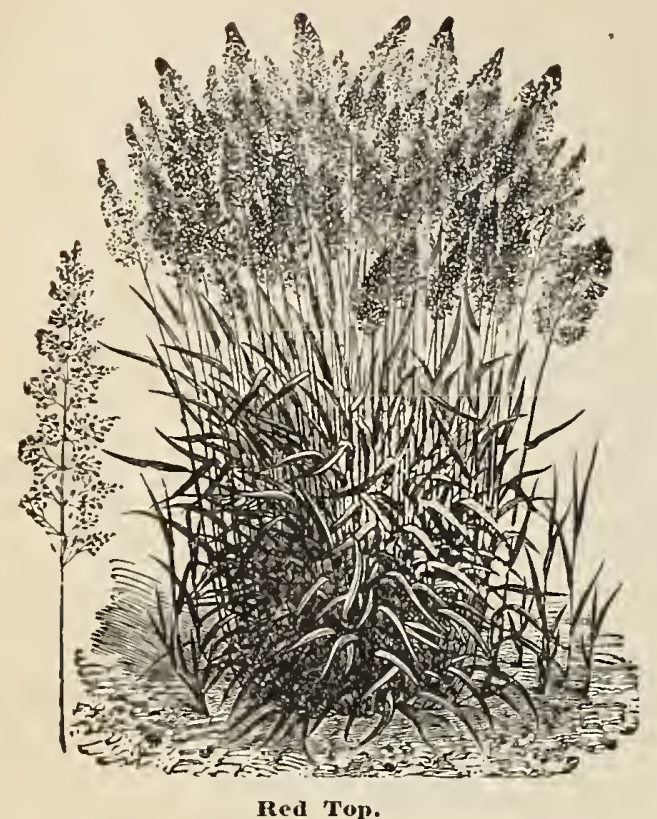

RED TOP-Agrostis vulgaris.

A valuable grass for moist soirs. It is a good permanent grass, standing our climate as well as any other, and consequentiy well adapted to our pastures, in which it should be fed close for if allowed to grow up to seed, the cattle refuse it. On moist, rich soil it will grow 2 feet, and on poor gravelly soil about halt that height. It has been grown successfully even on "alkali" bottom lands, where other grasses falied. We have discontinued handling the chilfy grade of Red Top and now offer only the clean seed. Sow 15 to 20 pounds clean seed to the acre. Lb., $30 \mathrm{c}$.

\section{TIMOTHY-Phleum pratense.}

As a crop for hay, Timothy is probably unsurpassed by any other grass. It is greatly relished by all kinds of stock, especially horses; yields more nutritive matter than most other.grasses or forage plants. Being an early grass, it is well adapted to spring and summer grazing, and if the fall season is favorable it will grow sufficiently
10 to 12 pounds to the acre. Lb., $20 \mathrm{c}$.

TALL MEADOW OAT, OR EVERGREEN GRASS-Avena elatior.

The roots of this grass descend deeply into the sub-soll enabling it to withstand a protracted drouth, and it is green all seasons of the year. Its early growth in spring makes it equal to rye for pasture. It grows quickly after mowing, giving a denser and more succulent aftermath than any of the present popular tame grasses. Sow broadcast 25 to 30 pounds of seed to the acre. Lb., $25 \mathrm{c}$.

\section{JOHNSON GRASS, OR GUINEA GRASS-Sorghum halapense.}

We find this grass winter-kills in the northern states. In the extreme southern part of this state and the southern states it does well. A perennial, a rapid grower, long cane-like roots; the leaf, stalk and panicle of thls grass resembling those of Sorghums. It grows on any land where corn will grow, and like corn, will bear heavy manuring, yielding richly in rich ground. In fact, the richer the land the better the crop. Twenty-five to thirty pounds will sow an acre. Lb., $25 \mathrm{c}$.

\section{CREEPING BENT GRASS-Agrostis stolonifera.}

Especially recommended for lawns in country homes where depending on irrigation. It flourishes where but little moisture. Also good on terraces and sloping ground. Lb., $30 \mathrm{c}$.

PERENNIAL ENGLISH RYE GRASS-Lolium perenne.

While this has long been highly esteemed in Europe and Australia, it has but recently been recognized by our Western ranchers. It is worthy of all the praise given. As a pasture grass it grows quick and withstands drouth reasonably well. For pasture sow in spring 25 to 30 pounds to the acre; for lawns 60 to 70 pound

MEADOW FESCUE, OR ENGLISH BLUE GRASS-Festuca Pratensis.

Especially adapted for permanent

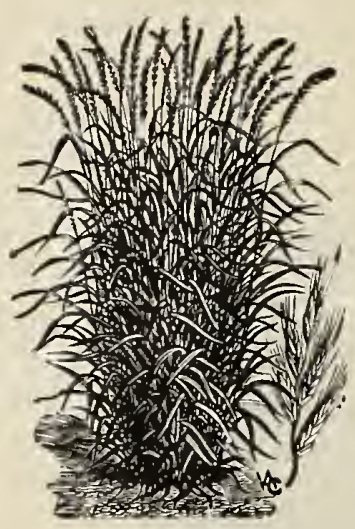

Per. Rye Grass.

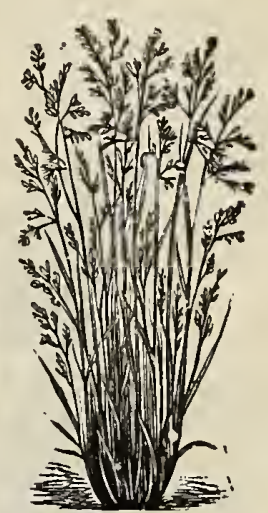

not in tufts like Orchard Grass. Earliest and most nutritious of grasses. Makes good hay and cattle thrive on it, whether in dry or green state. Succeeds even in poor soil and as the roots penetrate deep from 12 to 15 inches, it takes extreme dry weather to affect it. Sow 15 to 20 lbs. per acre. Per 1b., $25 \mathrm{c}$.

\section{BERMUDA GRASS-Cynodon- dactylon.}

This plant has long been naturalized in the Southern states. While it is tender to freezing, it resists dry, hot weather and consequently is a valuable ress to grow over and bind the the most arid and loose lands, and grows luxuriantly in every kind of soll; valuable for pastures, as well as for hay crop; time or sowing, April to June. Used for lawns in the South, as it rins over the ground, forming a dense turf. Sow 3 to 5 pounds per English Blue Grass acre. $1 / 41$ b., $35 \mathrm{c}$; $1 \mathrm{~b}$., $\$ 1.25$.

\section{BROMUS INERMIS, OR HUNGARIAN BROME GRASS.}

This pre-eminent drouth-resisting grass stands at the head of all, and is destined to lead as the most satisfactory and valuable forage grass in all localities where arid solls demand a plant with ability to withstand drouth. Slands intense cold equally well. May be sown in plant with ablilty to withstand drouth. slands intense cold equally well. May be sown autumn with winter wheat, or in early spring. In southern states sow in February or March, preparing lands as for other grasses. Blooms in north in June, and earlier in southern states. For hog pastures a inixture of Bromus Inermis and Alfalfa, where the latter succeeds well, is recommended. For large pastures for cattle a mixture of the following per acre is recommended. nature is to stool out and thus does not show its best until the second season. It seldom produces seed the first year. Aside from Alfalfa, no grass has fulfilled the promises to our Western farmers better than the Bromus Inermis. It meets drouth as well as wet and cold, and for Colorado we know of no grass to equal it. Many of our large ranchers are planting it extensively. Som 20 to 35 lbs. per acre. Lb., $20 \mathrm{c}$.

For particulars ask for special circular.

When sowiug brome Grass in quantity, set the Thempson Wheelbarrow Seeder. See Implement Department.

\section{KENTUCKY BLUE GRASS-Poa pratensis.}

The Great American Grass. The Standard for Lawns. Our "Columbine" Grade is the Purest oltainable. The old standard grass for pasture as well as lawns. Erery farmer knows it and its good qualities. Sow about 25 to 30 pounds to the acre for meadows, for lawns 120 to 150 pounds per acre.

Our Columbine Grade of Blue Grass is put up in sealed packages. Ask for Columbine. 1-lb. pkg., $25 \mathrm{c} ; 3-1 \mathrm{~b}$. pkg., $65 \mathrm{c} ; 6-1 \mathrm{~b}$. sack, $\$ 1.25 ; 10-1 \mathrm{~b}$. sack, $\$ 2.00$.

\section{CANADIAN BLUE GRASS-Poa compressa.}

Produces a fine foliage of dark green color, and is more hardy than Kentucky Blue Grass. It is especially adapted to light, poor, dry soils and makes very satisfactory lawns. It has somewhat a creeping habit and does not need to be clipped as often as Kentucky Blue Grass. 1 lb. $25 \mathrm{c} ; 5$ lbs., $\$ 1.00 ; 10$ lbs., $\$ 2.00$.

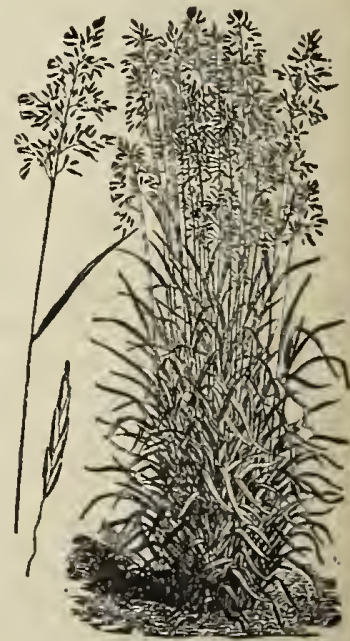

Hungarian Brome Grass. 


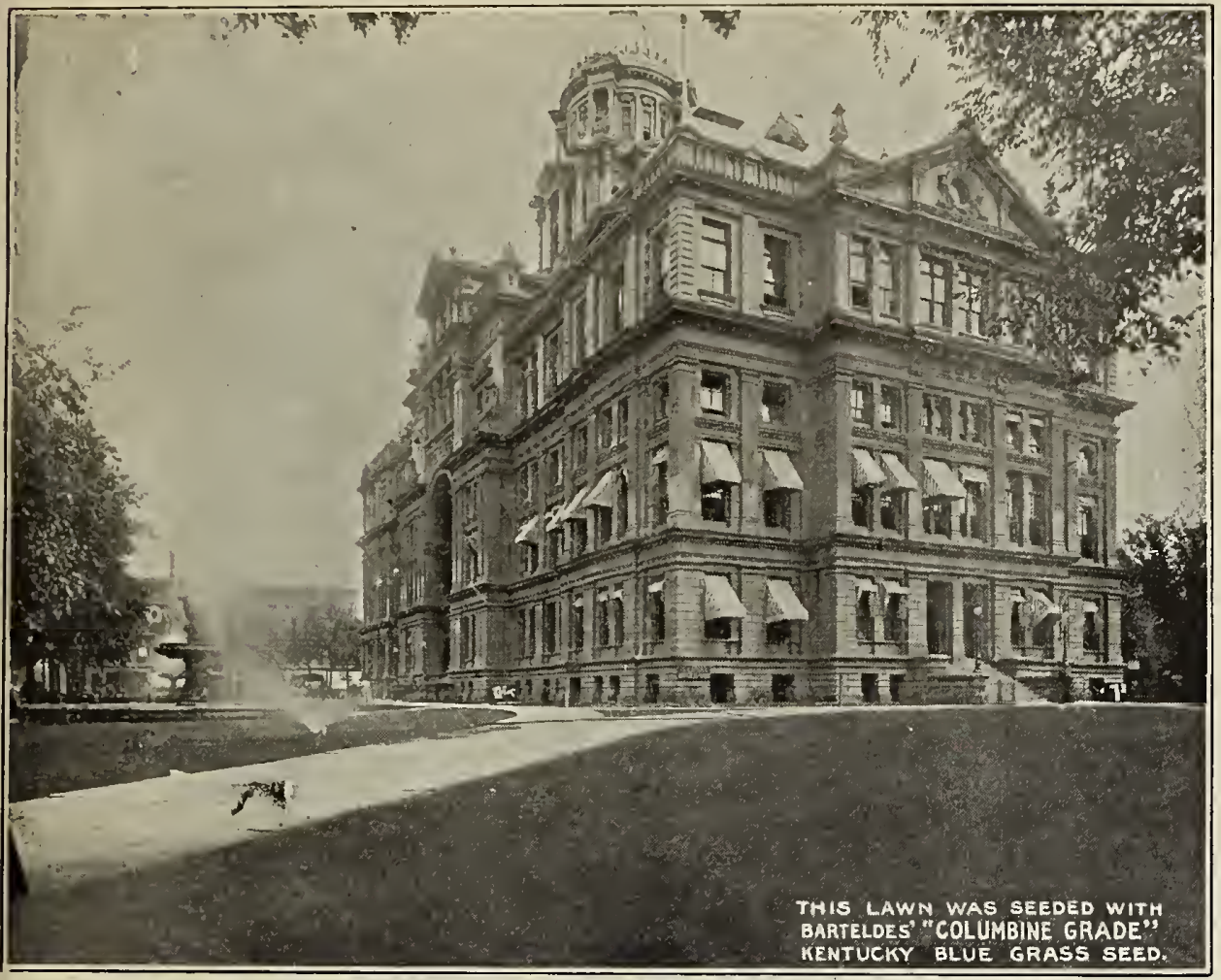

Denver Court House and havn.

\section{HOW TO MAKE A LAWN}

The ground should be dug deeply and thoroughly, then a good conpost of decomposed and finely pulverized manure or rich loam spread over alse to give a sprinkling of bone to give a sprinkling of bone
dust. Use a slanted tooth hardust. Use a slanted tooth harrow and a light or medium roller until the soil is smow the even and harrow again and smooth off with a common garden rake. When the grass has grown 2 or 3 inches in height use the lawn mower. gauged to cut full 1 inch above the ground: repeat the same as often as it grows to that height. The weeds and foul grass can be kept down and destroyed by the repeated mowing. If this is neglected mowing. If this is neglected they will spread and take posconstantly clipped, the leaves and seed stalks are destroyed and the foul vegetation disappears.

As a guide for the proper quantity to order, we may state that one pound of Fancy Mixed Lawn Grass Seed, or "Columbine Grade" Kentucky Blue Grass, is sufficient to thoroughly sow an area of 10 thoroughly sow an area of 10 feet by 20 feet- 200 square mind that in order to produce the best results grass seed for lawns should be sown at least thrice as thickly as sown for hay.

As soon as the grass has become well established a dressing of good lawn Fertilizer is necessary to keep up that beautiful fresh appearance.

\section{THE “DENVER” FANCY MIXED LAWN GRASS SEED.}

We have made the subject of lawns a study for many years and this mixture has been prepared and sold by us in all parts of the country, giving general satisfaction. In making a lawn great care should be taken to use only the very best quality of suitable lawn seed, so as to produce a soft, velvety, evergreen sod.

Put up in sealed packages: 1/4-lb. pkg., 20c; 1-1b. pkg̈, 30c; 3-1b. pkg., 75c; 5-1b. sack, \$1.20; 10-1b. sack, \$2.20.

Lawn Grass Mixture for shady places. Lb., $30 \mathrm{c} ; 3$ lbs., $85 \mathrm{c} ; 5$ lbs., $\$ 1.35 ; 10$ lbs., $\$ 2.50 ; 25-1 b$. sack, $\$ 5.50$.

\section{PLANTS FOR FORAGE AND GRAIN}

\section{MILLET.}

Sow 25 to $40 \mathrm{lbs}$, per acre. Ask for prices on large quantities. Postage 8 cents per pound extra.

\section{NEW SIBERIAN OR RUSSIAN MILLET.}

It is claimed to be the most wonderfuily productive and satisfactory forage plant, possessing in a superior degree all the essential merits of any of the older sorts-exceeding them by far. The claims made are that it is from two to three weeks earlier than the German Millet, is a much heavier cropper, that the hay is much finer, stalks more elastic and growing much taller, that it is rust proof, and chinch bugs do not relish it, and being of stooling habit, requires

\section{JAPA NESE MILLET, or "Billion Dollar Grass."}

Prof. Brooks of the Massachusetts Experiment Station, is quoted. as saying: "At our station it produced 60 bushels of seed, 11,297 pounds of straw, 36,000 pounds of green fodder, 21,000 pounds of hay per acre, being superior to good corn fodder in feeding for milk, and in combination with the soja bean makes a very superior ensilage. Recommended highly for feeding dairy cattle, young stock and sheep, being very rich in nutritious eiements. If sown latter part of April will be ready to cut for hay by middle of July. Attains a height of from 5 to $71 / 2$ feet, according to season." "We cannot recommend it in the far North. Lb., $15 \mathrm{c} ; 10$ lbs., $\$ 1.00$.

\section{MANITOBA, OR HOG MILLET.}

The seed is very rich and thus especially valuable as a hog food. A very much prized peculiarity of this millet is that the seed ripens while the stem is yet green, thus if cut promptly can be threshed for the seed, while the hay after being threshed will make excellent fodder. Lb, 10c; 10 lbs, $50 \mathrm{c}$.

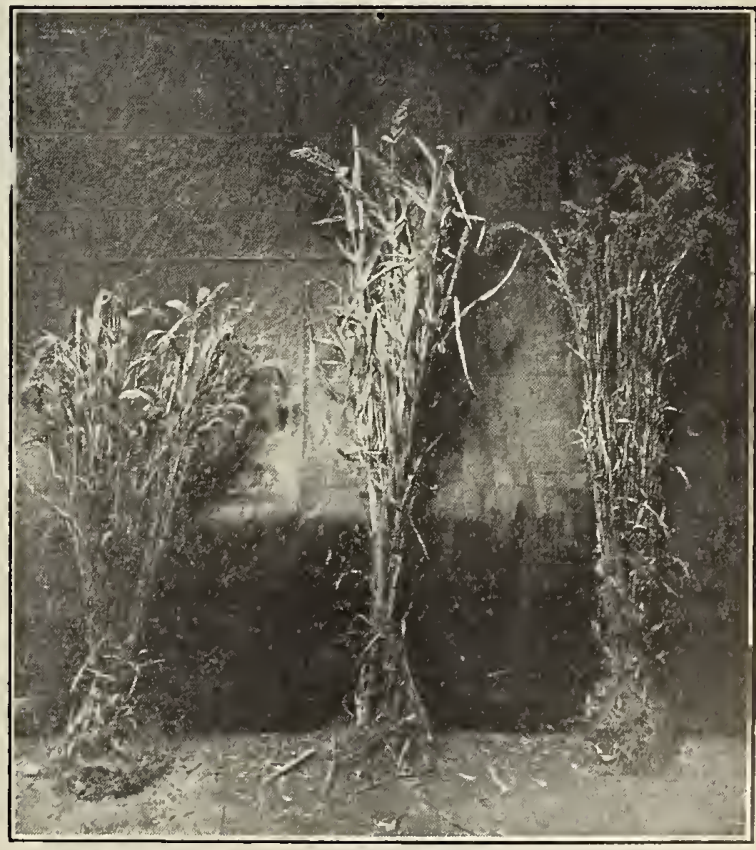




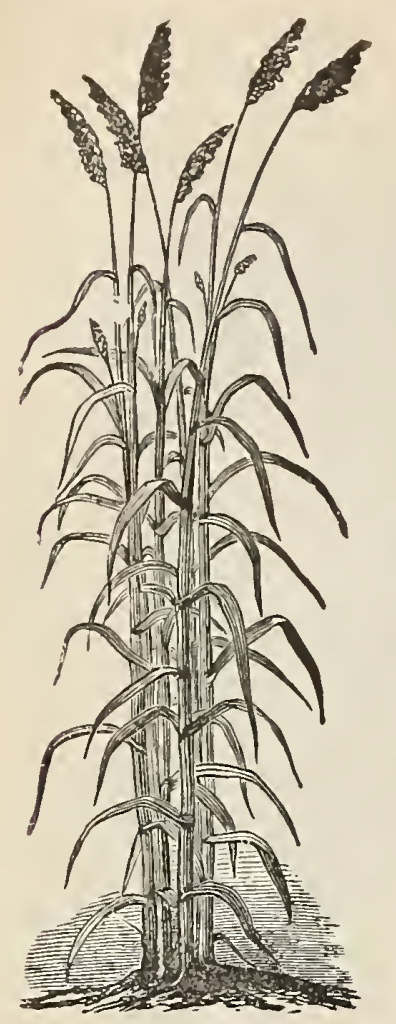

Amber Canc.

\title{
GEIRUAX MHLLET.
}

Few other grasses or forage plants have been able to produce the enormous yield of this plant. It has produced 4 to 5 tons of hay to the acre, and from 70 to 80 bushels of seed. If sown in the spring on newly broken prairie it leaves the grollnd in the finest condition for wheat after harvesting it. Lb., $10 \mathrm{c} ; 10$ lbs., $50 \mathrm{c}$

\section{COLORADO GOLDEN MILLET.}

This is a cross between German and Common Millet with all the good qualities of both parents. It yields a great amount of seed and the hay is fine, juicy, with luxuriant leaves. It is haldier than other millets, being perfectly acclimated to our Western country. Lb., 10c: 10 lbs., $50 \mathrm{c}$

\section{COMBOY MLLET.}

It is an annual grass, with tender, juicy and luxuriant leaves, much relished by all kinds of stock; makes good hay. 1 lb., $10 \mathrm{c}$; 10 lbs., 50

\section{SORGHUM OR EARLY AMBER CANE}

Our seed is for Fodder only; not for Syrup making.

\begin{abstract}
The great fodder crop for dairymen. Dairy farmers say that the Early Amber Cane is the most valuable fodder plant in existence for their use. It is profitably grown anywhere from Manitoba to Mexico, on any good corn ground. It is but little affected by drouth. It is of the very best quality, being sweet, tender and nutritious, and greedily eaten loy cattle, horses and luogs. Dairymen find that the cows will give more and richer milk from its use, and it is claimed that as high as 20 tons of green foddel have been grown per acre. It can be cut several times during the season if not allowed to get too high, and makes good sweet hay. is a profitable crop also to grow for the seed. which is excellent for feeding poultry, and is ery frequently ground and substituted for buckwheat flour. If sown for seed 5 to 6 , pounds will sow one acre. Lb., $10 \mathrm{c}$; 5 lbs., $25 \mathrm{c}$.

\section{CANE SEED FOR FODDER.}

When sown for fodder it should be sown very thickly; 60 lbs, per acre is none too much Cut when the stalk is well filled with sweet sap-don't allow to miture. It will cure nicely and make excellent stock food. Ask for price, stating quantity wanted.

\section{TEXAS SEEDED RIBBON CANE, OR GOOSENECK SORGHUM.}

It is the tallest and largest of the sorghum family, reaching a height of 12 feet with stems over one inch in diameter at the base. It matures from 10 to 120 days. The stalks when cut with the leaves on them make the finest silo for cattle and horses. Lb., $15 \mathrm{c} ; 4$ lbs., $50 \mathrm{c}$.

ORANGE CANE. This variety is well adapted for the Southwest and is about 10 days than Early Amber. Lb, 10c; 5 Ibs., 25c.

RED TOP CANE. Is grown very extensively for fodder. It dos not grow as tall as the other varieties; but makes a large amount of fodder, Lb., 10c; 5 1bs., $25 \mathrm{c}$.

PENCILARIA. Pearl Millet, or Cat Tail Millet.

Immensely Productive. 25 tons per acre.

A native of Central America. It is an annual plant, having long, broad foliage, and, if allowed to develop fully, will attain a height of from 10 to 12 feet, and bear numerous heads from 1 s to 20 inches in length and inch in diameter, completely covered with thousands of seeds, much relished by poultry It is of rapid growth, throwing out from one plant numerous suckers, and if cut as soon as it reaches the height of 2 to 3 feet, it can be mowed from 4 to 6 times, according to latitude, and yields several tons of hay per acre If allowed to grow 6 or 7 feet high, and cut when the flower heads begin to develop, it will yield the heaviest fodder crop per acre of any plant now in cultivation. For feeding it is equal to any fodder, and is relished either green or dry by all kinds of stock. Lb., 15c; 4 lbs., 50c.

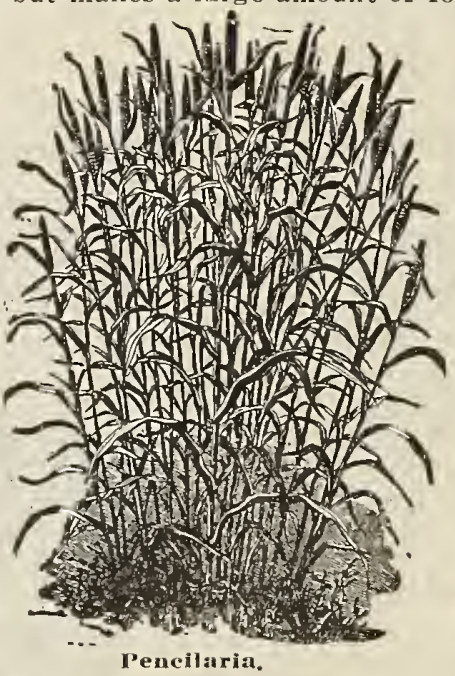

TEOSINTE.

Recommended as the most prolific forage plant yet introduced. 'The stalk, containing much saccharine matter, is very nutritious. It can be cut several times during the season. yielding enormously. One seed will sometimes produce 20 to 60 stalks or shoots, and the warmer the climate the better it yields. Should not be planted until the soil is perfectly warm in the spring. Requires about 4 pounds seed per acre. Plant in drills 3 feet apart, and 2 or 3 seeds every 12 inches in drilt. $1 / 4$ lb., 30c; lb., $\$ 1.00$.

\section{LUPINS.}

When young the plants are good for sheep. Yellow Lupins remain green longer than the white. One of the best plants for soiling. May be sown from April to July, and succeeds well in the poorest of soil. Lb., 10c.

\section{SILVER HULLED BUCKWHEAT.}

An improved sort, much excelling the old common variety, which it has about superseded with us. It blooms longer, matures sooner and yields double the amount per acre. Husk thinner, corners less prominent, and seeds of a beautiful light gray color. Flour made from this variety is pronounced better and more nutritious than others. Thirty to fifty pounds to an acre.
Lb., 10c; 10 lbs., $60 \mathrm{c}$.

\section{JAPANESE BUCKWHEAT.}

A new variety that has been raised here with good results. Early and very productive, with kernels twice the size of any other buckwheat, of a rich, dark brown color and makes a super-ior flour. As it possesses a branching habit only half as much seed is required to plant an acre. ior flour. As it possesses a branching habit onl y half as much
Straw is very stiff and stands up well. Lb., $10 \mathrm{c}: 10 \mathrm{lbs}, 60 \mathrm{c}$.

\section{DWARF ESSEX RAPE-Brassica Napius.}

Main stand-by of the English farmers in raising choice mutton. Perfectly hardy and possesses remarkable fattening properties. Eeasily grown. One acre will pasture 36 head two months, and lambs will make a gain of from 8 to 12 pounds per inonth. Pigs and cattle are also extremely fond of it. A very rank grower and bears heavy manuring and high cultivation. Sow at intervals of several weeks and secure a supply of good feed. Sown in June Rape should be fed in August, though if a first crop be cut about 4 inches from the ground an after growth would be useful later. For breeding flocks a piece should be sown first week in July or later. Does well sown with oats. If soll is rich and clean sow broadcast, otherwise in drits and clltivate same as corn. Poultrymen will do well to grow a small patch to feed green to Does well on alkali ground. Broadcasted it takes 8 to 10 pounds to the acre; in drills, 4 to 5 pounds to the acre. Per $1 \mathrm{~b} . .15 \mathrm{c} ; 10 \mathrm{lbs}$. for $\$ 1.00$.

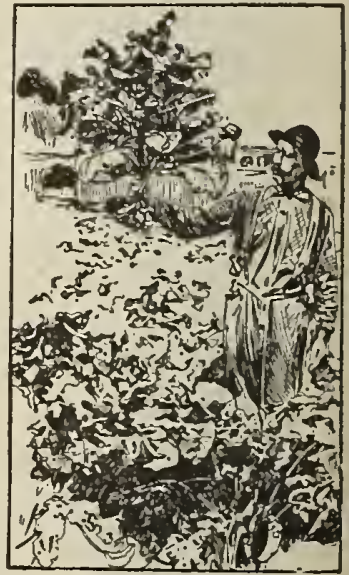

Dwarf Essex IRape. 


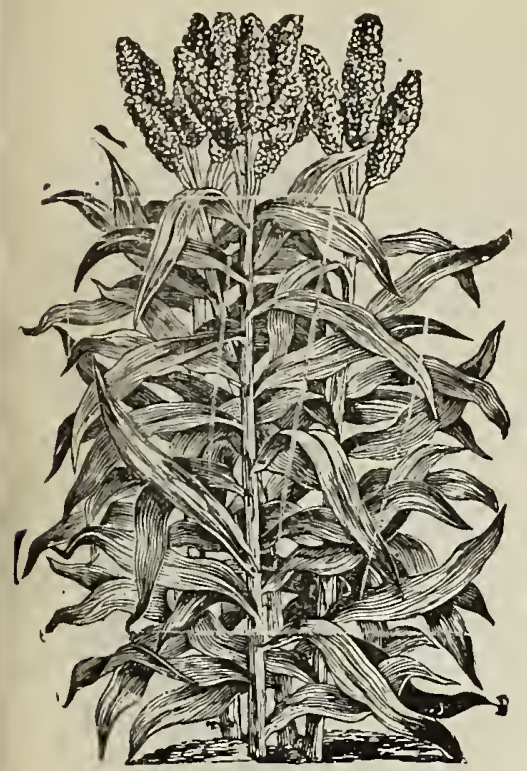

Kafir Corn.

\section{Non-Saccharines}

All of the follownig species of corn bear dry weather well. When common will wholly fail for want of rain at a certain stage, these plants simply stop wait for rain, and then go on and make their full crop. In weight of grain orage they make enormous returns, at a cost less than the cost of gathering that of corn. They will grow on any land where corn will, even on land too poor for corn. As soon as the seed begins to glaze, commence to cut and shock. Make the so heavy that they will go down easily. After well cured stack or house the fodder as you would ordinary corn fodder, or let it stand in the field until wanted for use grain. If it is desirable to separate the feed from the fodder, run the stalks through a threshing machine after removing all but one row of concave teeth. The grain will come out as clean as wheat and the fodder threshed.

\section{FETERITA}

A new non-saccharine from sudan. It is an early maturing drought resisting stghum of considerable value ooth for fodder and grain. it has rather slende juicy and slightly sweet before ripening. Suckers are produced freely when moisture is sufficient. Feterita resembles milo in habit except that the heads are uniformly erect; the seed is larger, softer and chalk white or slightly bluish in color. It differs from Jerusalem corn in having erect heads, black glumes and plumper seed. It is also a little earlier than dwarf milo and yields about the same. It has prodrought. It should be soved in hills 40 to 44 inches apart, and not put in the ground before the ground is warm; about 2 weeks after Indian Corn, as it is still more liable to rot in cold ground. 3 to 5 SHALLU.

A non-saccharine sorghuin from India, known also under the names of California Rice Corn, California Wheat and Egyptian Rice. It is more valuable than Kaffir Corn for grain, as it yields considerably more seed and is quite a drouth resister. The heads grow similar to Broom Corn, forming large heads of round, plump white seeds. Can be popped the same as popcorn and when ground makes an excellent
flour for pancakes. It is more of a grain crop than a forage crop. Sow same as Kaffir Corn. Lb., $10 \mathrm{c} ; 5 \mathrm{lbs}$., $40 \mathrm{c}$.

\section{RED KAFFIR CORN.}

This grolvs taller than the white; the stalks are slenderer, but more juicy and very leafy. The heads are long, slender compact and grow erect; they measure from 1 to 2 feet. The seed is red, smaller than that of the white, and rather hard and brittle. It does well on poor land and matures earlier than the white variety, from 100 to 120 days, and yields much

\section{WHITE KAFFIR CORN.}

It grows from 4 to 5 feet high, making a straight upward growth. It has a stalky stem, with enormous wide leaves. The stalks keep green and are brittle and juicy, not hardening like other varieties of sorghum, making excellent fodder, either green or dried horses. The seed heads form at the top of each stalk, and as soon as these show the grain well the joints next below the top send up shoots which yield the second seed heads. For the grain of seed to the acre. For fodder sow one-half to one bushel, either broadca
or in drills. Lb., 10c; 5 lbs. for $25 \mathrm{c}$.

\section{YELLOW MILO MAIZE.}

Growth is vigorous, stooling from the ground; it sends out shoots from the joints. Seed heads grow to great size,
often weighing $3 / 4$ of a pound, sometimes a full pound after ripe. On account of its branching habit this grain should be planted in rows 4 or 5 feet apart, and 2 to 3 feet in the drill, or 2 plants in a hill, 3 to 5 feet apart. It is one of the surest crops to raise on dry ground, and is mostly grown for its seed, which contains about 80 per cent. of the feeding value of corn. Its stems make better fodder than Jerusalem Corn and Dourha, but not as good as
Kaffir Corn. Lb., 10c; 5 lbs. for $25 \mathrm{c}$.

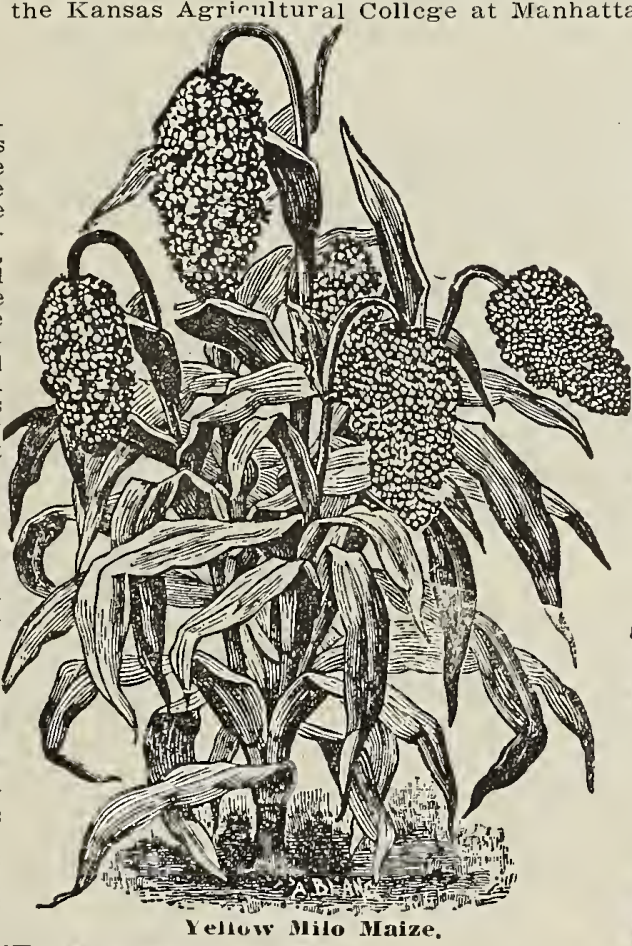

Yellum Uilo Maize.

DWARF STRAIGHT NECK MILO MAIZE.

The advantage of tlie straight neck feature is apparent in gathering, cutting and feeding the heads. It is earlier than the standard variety and its dwarf nature makes it a better drouth resister. The yield is from 60 to 80 bushels per acre. Lb. $10 \mathrm{c} ; 4$ lbs., 25c. DWARF BLACK HULL WHITE KAFFIR CORN.

It is still more a drouth resister than either White or Red Kaffir and is as good yielder. On account of its small height can be harvested with a header. Lb. $10 \mathrm{c}$ 4 lbs., $25 \mathrm{c}$.

\section{BROOM CORN}

Requires soil similar to corn, same cultivation, but should be planted some later in the season. Put ground in prime condition. We think tlat more of our Western farmers should grow Broom Corn for market. It is profitable. Frequently planted in drills $3 \frac{1}{2}$ feet apart, leaving plants 6 inches apart; 10 to $201 b s$. to an acre. IMPROVED EVERGREEN BROOM CORN.

This broom corn grows about 8 to 10 feet high, stands up well and is entirely free from crooked brush. The fibre is long and fine. Its great value is that it will not get red in the field before it is cut, but is strictly a green variety, commending high price. Lb., 10c; 10 lbs., $60 \mathrm{c}$.

JERUSALEM CORN.

It is pronounced one of the best and and grain crops for dry countries Corn, Dourha and Milo Maize. It grows about 3 feet high, makes one large head on main stalk and several smaller heads on side shoots: have seen as high as 8 heads on one stalk. The grain is pure white and nearly flat. Three pounds
will plant one acre. Lb., $10 \mathrm{c} ; 3$ 1bs., $25 \mathrm{c}$.

\section{BROWN DOURHA.}

Similar to the Jerusalem Corn. Grain ame size and shape, but of brown dry weather better than Kaffir Corn and Milo Maize and is a sure cropper every year. Raised more for the grain than for fodder. Yields immensely. Three to five pounds will plant an acre.

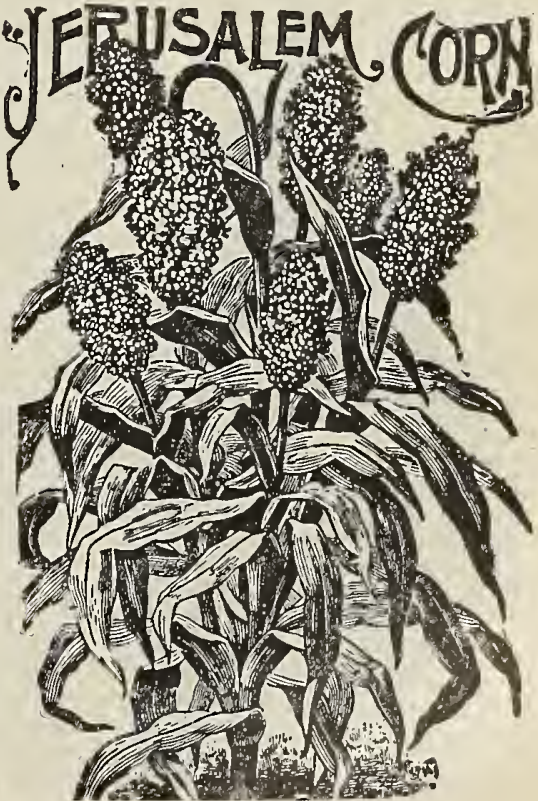


THE OKLAHOMA BROOM CORN.

Origlnated in Oklahoma. Most valuable strain grown there and in the Southwest. Quite distinct from all others in earliness, robust habit and extreme productiveness; brush long and well fibered and is a drouth resister. Averages 5 feet in height. Seed may be let to ripen on brush without injury to latter, removing danger of heating from immature seed in bins. Stalks make excellent fodder if cut at once after brush is pulled. Lb., 10c; 10 lbs., $60 \mathrm{c}$.

\section{SANDVETCH, HAIRY OR WINTER VETCH-Vicia Villosa.}

A forage plant from Europe, highly esteemed there. The Sandretch prospers in the most barren soils, on those too poor to grow the winter tare. Six tons per acre of green forage have been harvested in one cut in poor silicious soils, with second cut for seed or for plowlng under. Sow end of August alone or with a cereal, rye preferred, as this Vetch reaches a height of $3 \frac{1}{2}$ to 5 feet high, and must have a support. Sow 30 to 50 lbs. per acre. If good glowth before winter it may be cut, and again by March 15 . Eaten by all farm stock. Lb., $20 \mathrm{c} ; 6 \mathrm{lbs}$., $\$ 1.00$. SPRING VETCH, OR TARES-Vicia sativa.

Similar in growth to Sandvetch, though for spring sowing only. Lb., $15 \mathrm{c} ; 101 \mathrm{bs}$, $\$ 1.00$. PEANUTS.

The peanut thrives and produces best on a light, sandy, fertile soil with a good clay subsoil. It possesses a long tap-root, which extends deep into the earth, drawing thence the nutriment which is beyond the reach of many of our cultivated crops. The soil should be deep and mellow and well broken up, so as to be ready for planting soon after frosts are over-April is a suitable time. They may be planted in the pod, or shelled, 2 in a hill; it is best to drop about 4 in a hill on the level ground, the rows being laid off $31 / 4$ feet wide, and the hills 2 feet apart; cover them 2 or 3 inches deep. When they come up thin them to 2 in $a$ hill, and if there be any vacancies transplant. It is better to plant them level than in ridges, as they are less liable to suffer from drouth. The plant is an annual, of a trailing habit, with yellow pea-shaped flowers produced in bunches of 5 and will not mature the seeds. They are successfully raised in southern Colorado, where they yield from 50 to 100 bushels per acre.

\section{SPANISH PEANUTS.}

The earliest variety grown; pods are small, but remarkably solid and well filled, and the yield per acre very lare; can be cultivated with the plow. Because of their early habit and easy cultivation it is the best variety to grow for fattening hogs. It is claimed that one acre of peanuts will produce three times as much pork as one acre of best corn. It requires

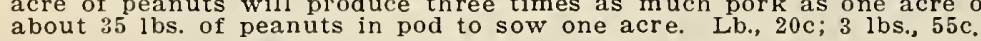

WHITE, OR JUMBO PEANUTS.

Raised mostly for roasting; are not quite as hardy as the Spanish, but nuts are larger. Lb., $20 \mathrm{c} ; 2$ lbs., $35 \mathrm{c}$.

MAMMOTH RUSSIAN SUNFLOWER.

Single neads measure 15 to 22 inches in diameter, and contain an immense amount of seed, which is highly valued by all farmers and poultry breeders who have tried it as an excellent and cheap food for fowls. It is the best egg producing food known for poultry. It can be raised cheaper than corn, and is destined to be an article of great value. Every farmer should plant some of the seed in any waste piece of ground, or alkali ground, any time from early spring up to the middle of July. It is a wonderful improvement on the old native Sunfower, and besides the great value of the seed as poultry and stock food, its leaves make value of the seed as poultry and stock food, its leaves make capital fodder, while its strong, thick stalks can be profit-
ably used as fuel. It produces from 20 to 50 bushels of seed to the acre. Four to five pounds of seed will plant one to the acre. Four to five pounds of seed will plant one
acre. Selected seed, $1 / 4$ lb., 10c; 1b., $25 \mathrm{c}$, postpaid; 5 1bs., not prepaid, 50c. SUNFLOWER SEED FOR FEEDING BIRDS. We have
stock suitable for feeding that we sell at reduced price.
FLAX SEED.

Farmers should not lose sight of the fact that flax can be raised where wheat is raised and where tried has brought better results for amount of labor invested than wheat. Twenty to forty pounds will sow an acre. Lb., $10 \mathrm{c} ; 3$ lbs., $25 \mathrm{c}$.

\section{CANARY SEED.}

As easily grown as wheat. Requires similar culture; 20 to $30 \mathrm{lbs}$. to an acre. We are in the market for the seed Lb., $10 \mathrm{c}$.

\section{HEMP SEED.}

This is a crop that deserves more attention. The seed can be marketed with us. The fibre is in demand in eastern markets. Lb., $10 \mathrm{c}$; 6 ibs., $50 \mathrm{c}$.

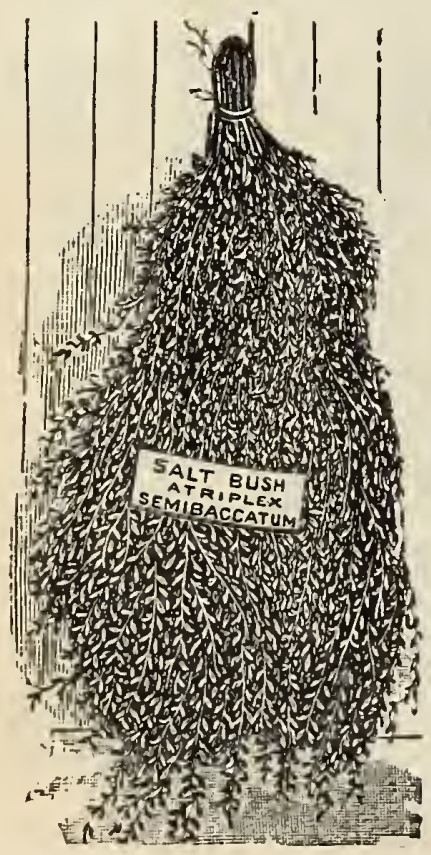

\section{AUSTRALIAN SALT BUSH}

\section{The Forage Plant for Arid and Alkall Soils.}

This new plant comes to us from California, where it has been tested and experimented with to a large extent. Lands that hitherto have laid barren and worthless have been rendered productive and valuable. It can scarcely be conceived that alkali soils, coated with their salts, as covered by snow, can be changed in their appearance or constltuents, yet such is bein

Directions-Sow 1 pound of seed to an acre in the spring before a rain if possible, or irrigate well, on well pulverized soil and cover it lightly (about one-eighth of an inch) with a light harrow or brush, or the plants may be grown in boxes or garden bed, covering the seeds lightly, and planting the seedlings where desired, when from 2 to 3 inches high, 6 or 7 feet apart. If the weather is dry when transplanting, supply a little water to each plant. Oz., 15c; 1/1 lb., 50c; 1b., $\$ 1.00$

\section{WILD RICE-Ziziania Aquatica.}

\section{For Planting in Ponds.}

An annual which sows itself in the fall, about the middle of September, lies dormant all winter, and in the spring commences to sprout as soon as the water gets warm, reaching the r, and in the spring commences to sprout as soon as the water gets warm, reach reaches a height of 7 to 10 feet and ripens late in August or early in september. It should be planted early in the fall, before the seed gets dry, as it is hard to germinate, and before the ice forms, broadcast from a boat, in 1 to 3 feet of water having a mud bottom. It has been successfully planted through the ice in winter and in the spring, but it succeeds best when planted in the fall. If the water is over 4 feet deep, or if it is stagnant, it does not do as well as when the water is moving gently. As an attraction for wild fowl it cannot he equaled, and it is largely used on private shooting grounds to attract water fowls. In large ponds and lakes it purifies the water, affords a refuge for the small fry from the larger fish, as well as furnishing the small fry with plenty of food from the animalculae upon the stalks. It also does well along the shores of marshes, and makes a good hay. In the South two crops can be cut and all cattle are very fond of it. If the seed has to be kept over it must be put under a few lnches of water which, if not frozen, will have to be halloed once in a while $\mathrm{Lb}, 25 \mathrm{c}$

Write for our circular on Wild Rice, free for asking. 


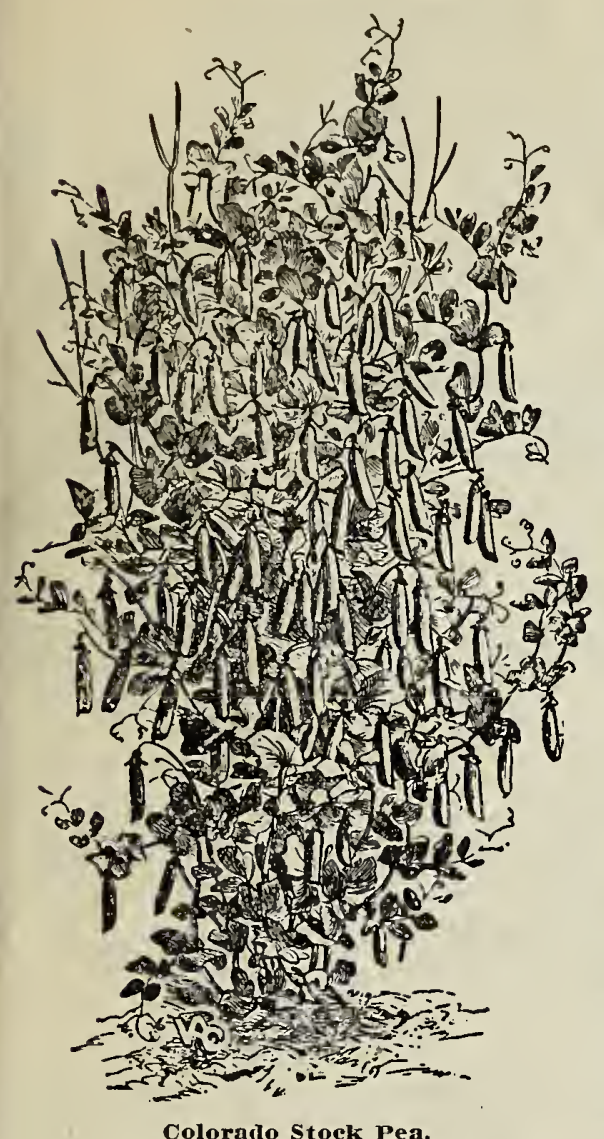

\section{FIELD PEAS}

San Luls Valley is now feeding, winterlng and fattening sheep and stock In greater number and at less cost than anywhere in the entire Unlted States, smply with FIELD I'EAs. San Luis Valley Peas have developed a wonderful and great industry.

\section{SAV LUIS VALLEY S'TOCK PEAS.}

They ean be groven and alo well at all altitude of 9,000 feet.

Tan uly Valley or Colorado stock Pea is a hybrid evidently the Golden Vine intermingled with the Native or Mexican Peas until now the seed has the appearance of a mixed sort and is oll acclimated to hardy, withstanding early frosts and growing until late fall, reaching a length of 4 to 6 feet. The vine continues to blossom as it grows, ripening peas on the ower branches and setting more pods above. The seed averages smaller than garden peas.

Time of Sowing. Being very hardy, the fear of rotting in the ground is not considered. The majority sow in April, although a pea-hay crop can be obtained if sown as late as July. Early sowing is best, giving full season for matured crop.

Quantity to Sowv. When early sowing is made, 40 to $50 \mathrm{lbs}$. of seed per acre makes a crou that covers the ground and produces good tonnage. If late sowing is made, 60 to $\$ 0$ pounds per acre is advisable, as the crop does not ret to matured growth. Thick sowing will aid in choking out weeds.

Harvestimg. If wanted as pea-hay the growth should be at the period Harvesting. If wanted as pea-hay the growth should be at the period and cured like ordinary hay. This makes finest feed for fairy lambs, sheep, hogs and cattle relish this hay. If the peas are desired as dry grain allow crop to mature and handle in shocks, threshing by machine after thoroughly dry. The dry seed can be ground into a meal or fed whole.

The Colorado Stock Pea does not exhaust the soil rapidly like some crops quite the opposite, the nitrogen taken from the air is stored in the ground through the roots. The growing crop can be plowed under when but partly matured-just in the milk-and makes an excellent fertilizer. Orchardists are learning this and consider the crop valuable for this purpose alone.

We advise all stock growers to plant liberally of Field Peas. We have supplied ourselves with seed of the San Luls Valley, recleaned stock, the Wisconsin grown Green Canada Peas, and the northern grown Golden Vlme.

Prices for cach above fluctuate. Lb., 10c; $31 \mathrm{bs}$. for $25 \mathrm{c} ; 10 \mathrm{lbs}$., 60c. Write us when you are ready to buy in large quantity.

\section{WHIP-POOR-WILL COW PEAS}

Pea but more properly belongs to the bean family. It is becoming known in the North, also as a highly valuable fodder and fertilizing crop. It requires a full season to mature. If desired the pods may be harvested for the grain and the plants plowed under to fertilize the soil. The seed or grain is ground and used for cattle feed; the stalk and leaves also make excellent fodder, fed green. Poor, sandy soil may be greatly improved by plowing under a crop of Cow Peas, and thus made into a fertile loam. Plant in a thoroughly pulverized soil. If wanted to plow under for manure, sow with a grain drill in drills a foot apart. If grown for fodder or the seed, plant $31 / 2$ feet apart and cultivate thoroughly. The seed must not be sown until the 10 ibs 80 .

\section{Field Beans}

WHITE NAVY. The standard white bean, of medium size. Plant in drills, so as to cultivate with a horse; 25 to
30 lbs. per acre. Lb., $10 \mathrm{c}$. See market price list for quantity.

MEXICAN BEANS. This is the popular bean with the Mexicans and now is grown extensively throughout Colorado, New Mexico and Arizona. The yield is tremendous. Lb., 10c. See market price list for quantity.

GARLY SOJA BEANS-Coffee Herry, also ealled Soy Beans. Soja Beans are drouth resistant much more so than cow peas, but will not do as well as them on poor ground. The berries ripen in about 3 or 4 months from the time of planting and produce a crop of 20 to 40 bushels to the acre, and are as easily grown as other beans. One bushel of Soja Beans is at least twice as valuable as.corn for feeding pur-

\section{Lentils}

A leguminous annual that flourishes in dry, sandy soil. Easily grown in Colorado. The dry seed is extensively used for soups and forms an importan import article that can be produced in this country to a profit. Lb., 15c; 5
lbs., 60c.

\section{Jerusalem Artichokes}

Hellanthus Tuberosus. A well known vegetable, produced from tubers ike potatoes, which they somewhat resemble. Most valuable food for hog and excellent food for stock. It is claimed they are as good as bran for milch cows. Do best in light, rich soil, but will resist any degree of cold incident to the United States. Plant like potatoes and as early as the of cold incident to in May, Can remain in Yield from 100 to 300 bushels per acre Lb. $10 \mathrm{c}$; 25 ing, $75 \mathrm{c} ; 100$ hos $\$ 2.50$ Yield from 100 to 300 bushels per acre. Lb., 10c; 25
500 lbs., $\$ 11.00$. Ask for free circular on Artichokes.

On account of Jerusalem Artichoke tubers decaying easily we cannot guarantee safe arrival of same and recommend to ship them by express.

Read our book, "Root Crops for Stock," 20 c, by mail. cation.

Ask for our pamphlet, "Root Crops for Stock Fcedlng," sent free on appli-

REMEMBER: We give premlum Packets with orders for seeds in packets and ounces.

GE'T YOUR NEIGHBORS to help your frlends ln getting rellable sceds.

Our trademark, "Columbine," put on any packare, from our stores, means that its contents ls the best that money can buy. 


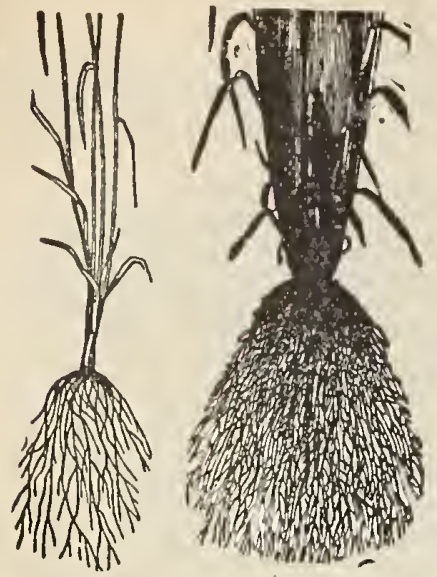

lloot of Houd of grass Grass show- showing the ellect ing need of of using Ibenver

\section{High Grade Fertilizers}

I'rices subject to marked changes. If wanted by mail udd pontage.

These fertilizers contain in a concentrated form food necessary to grow nutritlous farm products in large quantity per acre at lowest possible cost in time, labor and money. They are quick in action. Do not contain weed seeds and are easily applied. TVe have now put 110 for us special brands. If you order by these names you will make no mistake. You will be wise in ordering liberally. creen quisite causes many poor and rusty looking liswns. Do fod. The lack of this one reapt to contain objectionable grass seeds and noxious weed seeds, which you will have to fight for years to come. It cannot be evenly distributed, the result being that one spot is over nourished while the next is starved. All these objections are obviated by using

THE "DENVER" LAWN FERTILIZER.

This is a good article for the price, being made expressly for our trade. (Other makes alled "Denver" are not our forinula.) It contains 3 to $31 / 2$ per cent. ammonia, $\delta$ per cent. available phosphoric acid, and some other lich plant foods, just the materials required to build up strong, vigorous grass shoots and make a luxuriant carpet grass. 'To get a good lawn begin early in the spring, rake over bare places and sow good seed, then apply the Fertilizer of exceptionally high merits. $10 \mathrm{lb}$. pail, $40 \mathrm{c} ; 25 \mathrm{lb}$. sack, $75 \mathrm{c} ; 50 \mathrm{lbs}$. sack, $\$ 1.40$; 100 lb. sack, $\$ 2.50$.

IROSE GROWEIR. Made especially for roses and sweet peas, and without doubt the best fertilizer to use in a flower garden. 10 lbs., $40 \mathrm{c} ; 251 \mathrm{bs}, 75 \mathrm{c} ; 501 \mathrm{bs}$., $\$ 1.40 ; 1001 \mathrm{bs}$., $\$ 2.50$.

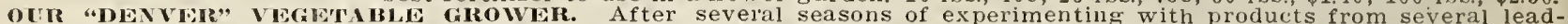

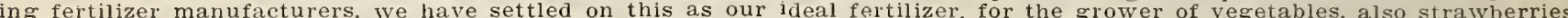

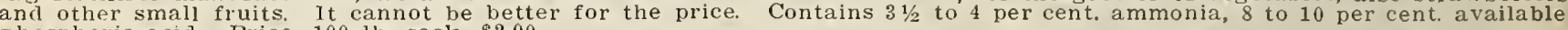

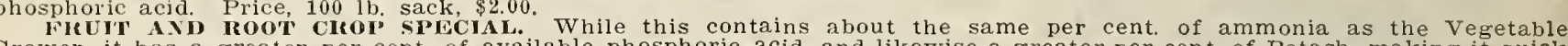

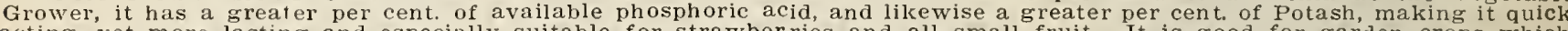

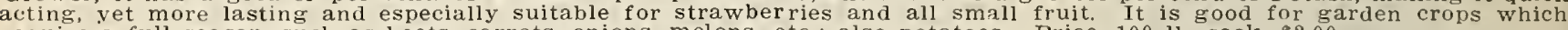
require a full season, such as beets, carrots, onions, melons, etc.; also potatoes. Price, 1001 b. sack, $\$ 2.00$.

SUGAR IIFIT SPECIAL. This is the fertilizer that brings the greatest returns of any. The analysis indicates its

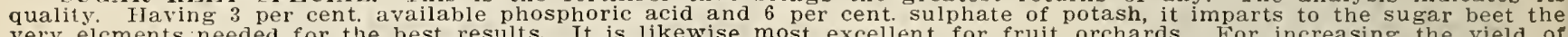

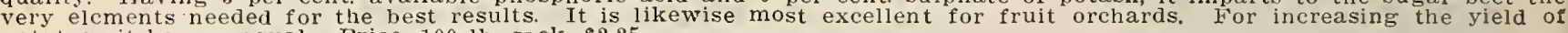
potatoes it has no equal. Price, $100 \mathrm{lb}$. sack, $\$ 2.25$.

I.INE IBONE MIEAL. Decomposes rapidly and yet is available as a good fertilizer through second season after using.

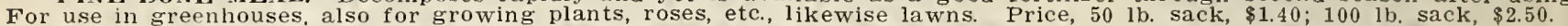

NITR A TE SODA. Being one of the strongest fertilizers known, great care should be exercised in its use. Booklets telling its uses and advantages mailed free Price, $1 \mathrm{~b}, 10 \mathrm{c} ; 3$ lbs, $25 \mathrm{c}^{-10} 1 \mathrm{bs}, 75 \mathrm{c} ; 25,1 \mathrm{bs}, \$ 1.75 \cdot 100,1 \mathrm{bs}, \$ 5.50$.

I.AN PI.STER. An old established fertilizer for grass and grain crops. Price, 100 lb. sack, $\$ 1.00$.

special prices will be given for nuy above ferthimers in 5 sack lots or more.

FARMOGERM-High-Bred Nitrogen-Gathering Bacteria.

Makes Poor Soil Good Soil.

It is now generally understood that the quickest, most economical and most permanent method of adding nitrogen to soil is to plant a leguminous erop of some kind after inoculating the
gathering bacteria.

FARMOGERM is offered for this purpose. It is a pure culture of a High Bred Nitrobottles, and unlike any other preparation of this kind ever offered before, it is all ready for use. Just dilute with water according to directions. 'The carefully selected, active bacteria in Farmogerm insure quicker and larger growth of the crop inoculated, and permanently enrich the soil for
future crops. The theory of inoculation is recognized by authorities as the right solution of the nitrogen fertilizing problem The problem has been to get the right culhave a pamphlet which deals with the subject intelligently and at some length. Let us mail you

FARMOGERM is prepared for the follow ing legumes:

Beans, Vetch Peanuts, den Peas and Sweet Peas.

When ordering be sure and state for what Farmogerm is wanted.

We can supply in GARDEN SIZE a mixed culture for Peas, Beans and Sweet Peas. The U. S. Department of Agriculture says: "In new regions, where Alfalfa, Clover and other leguminous plants have not been cultivated, very few soils have enough of these bacteria in them to be of any practical bacteria in them to be of any pra

The price is $\$ 2.00$ an acre, 10 per cent.

discount on 25 acres.

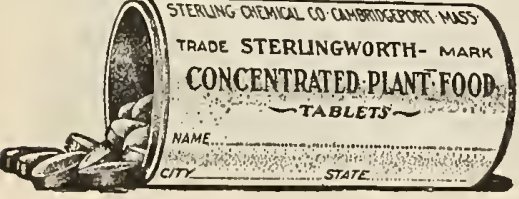
Put up in two sized packages, suitable for
mailing mailing. The large size contains tablets (sufficient
for 35 plants three months.) Price 25c, postpaid. Small or trial size contains 30 tablets (sufficient for 10 plants three months.) Price, $10 \mathrm{c}$, postpaid.

JAPANES PAIM FoOD. Produces a luxuriant fotiage of rich texturc on ferns, palms, rubber plants,

\section{BONORA.}

The recognized fertilizcr of modern times. Used with eminent success by the prominent growers of the country. The actual results strated fully, and are really beyond the expectations of those who have used it. There are many so-called fertilizers on the market. but "Bonora" takes the lead and stands alone in the fertilizer world. Is establishing a reputation for itself second to none. as it never fails to give entire satisfaction. Fol" plant life of every variety it is invalto the early vegetable raiser, as it matures a crop 2 to 3 weeks earlier, greatly improving it in every detail-a thorough test will convince the most skeptical, when instructions are carefully followed, and those are so simple that the most inexperienced grower can carry them out

Has been used on the Capitol Grounds of Washington, D. C., with great success. Trial size, $1 / 1 / 1 \mathrm{~b}$. pkg., making 56 pints solution, 25 c. One lb. size pkg., making 28 gallons solution, $50 \mathrm{c}$

WALKER'S EXCELSIOR PLANT FOOD.

Just what your house plants need. It is odorless and it is safe to use. Dissolves liquid manure. Each package contains full directions. A valuable booklet, "The IVin-

dow Garden," flee with purchases if asked for Price, 5-oz. pkg., enough for 20 plants three

\section{"STERLINGWORTH" PLANT FOOD} TABLETS.

A new, scientific, odorless fertilizer for house plants and vegetables. Contains nitrogen, ammonia, phosphoric acid and potash (nitrog per cent; as ammonia 73 per cent; phosphoric acid, 12 per cent.; potash or oxide, 6 per cent.).

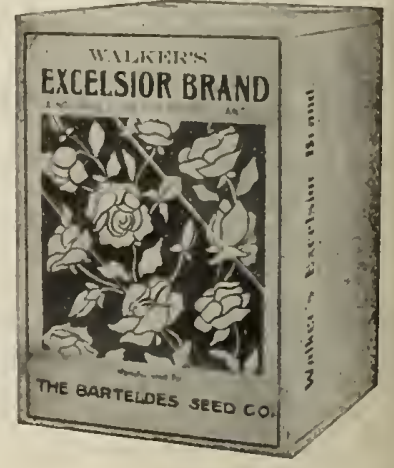




\section{Insecticides}

Poisons eamot be sent by mail.

Prices vubject to Market changes.

Each year proves the importan

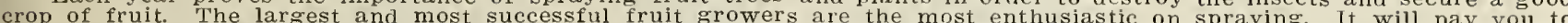

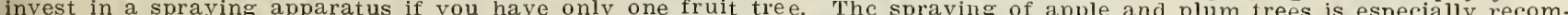
mended. Will furnish table giving formula for making mixtures and directions for application of same on request

ARSENATE OF LEAD.

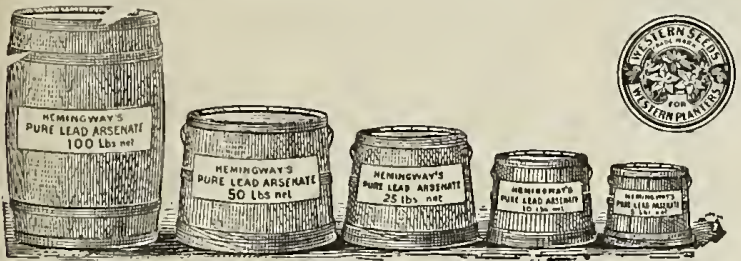

An effective insecticide for leaf-eating insects and par ticularly suitable for very tender foliage, being perfectly safe to apply in any strength without danger of scorching. Will not wash off by ordinary rains. It is now the most popular and successful insecticide used in the popular fruit districts of Colorado. Use $6 \mathrm{lbs}$. to 100 gallons of water. Any of our spray pumps with fine nozzles will apply it. 1 lb. jar, 25c; 5 lb., pail, $\$ 1.00 ; 10$ lb. pail,

Powdered Asenate of Lead. $51 \mathrm{~b}$. can, $\$ 1.50 ; 10 \mathrm{lb}$. pail $\$ 3.00 ; 25$ lb. pail, $\$ 6.75$.

\section{APHINE-Liquid.}

A powerful insecticide which does not affect the most tender plants. Lb. can, $\$ 1.00 ; 1$ gal. can, $\$ 2.50$.

BARTELDES' SMUT COMPOUND-Liquid.

It is put up especially for us after our own formula and is very simple to use. One bottle is sufficient for one ton of grain. Directions on each bottle. Price, 50c.

\section{BORDEAUX MIXTURE-Liquid.}

Concentrated liquid to be diluted before using. Prevents black rot, mildew and rust. Qt. can size, $50 \mathrm{c}$; gal. can, $\$ 1.25$ 5 gal. can, $\$ 5.00$

\section{BLUE VITRIOL-Sulphate Copper.}

in crystals ready to dissolve. $1 \mathrm{lb} ., 15 \mathrm{c} ; 4 \mathrm{lbs}$, for $50 \mathrm{c}$ $9 \mathrm{lbs}$. for $\$ 1.00$. When wanting large quantity ask for prices Copper Sulphate Solution is made by dissolving 1 lb. of Copper Sulphate in 20 gallons of water. CHLOROLEUM-Liquid.

Non-poisonous yet very effective of ridding lawns of ants Drives roaches away. Makes a very satisfactory disinfectant and antiseptic. $6 \mathrm{oz}$, bottle, $25 \mathrm{c}$; pint, $40 \mathrm{c}$; qt., $60 \mathrm{c}$ $1 / 2$ gal., 90c: gal., $\$ 1.50$.

\section{FORMALDEHYDE. "Bartco Brand"-Liquid.}

For the prevention of smut on grains; it is easy to apply. One bottle, diluted with 40 to 50 gallons of water is sufficient to treat thoroughly $30 \mathrm{bu}$, of wheat or barley for sufficient to treat thoroughly 30 bu. of wheat or barley for smut; 40 bu. of

\section{KEROSENE EMULSION-Liquid.}

For plant lice of any kind, cabbage worms, scales, inects on trees, etc. Recommended especially for maple tree scale Ready for use by adding 25 to 50 parts of water to pint of emulsion. Qt., 50c; gal., $\$ 1.25 ; 5$ gal. can, $\$ 5.00$.

\section{INSECT POWDER}

None better Don't be deceived by any low priced article. $1 / 4$ lb., 20c; $1 / 2$ lb., 30c; 1b., $50 \mathrm{c} ; 5$ lb. pkg., $\$ 2.25$.

\section{LEMON OIL COMPOUND-Liquid.}

One of the cheapest, safest and most effective insecticides. Destroys all insects on leaves and roots of plants without injury to flower or foliage, leaving no foreign odor. Dilute with 30 to 50 parts of water. $1 / 2$ pt., $30 \mathrm{c}$; pt., $50 \mathrm{c}$; qt. $85 \mathrm{c}$; $1 / 2$ gal., $\$ 1.40$; gal., $\$ 2.25$.

LIME AND SULPHUR SOLUTION-Liquid.

For San Jose scale. This is one of the best San Jose scale destroyers and the easiest to use. It is a clear, deep cherry liquid free from sediment. It is ready for use just as you get it without boiling and only needs one gallon of solution to be mixed with 12 gallons of clear water. Qt. can, $20 \mathrm{c}$; $1 / 2$ gal, can, $35 \mathrm{c}$; 1 gal. can, $60 \mathrm{c} ; 5$ gal, can, $\$ 2.25$ can, 20c; $1 / 2,00.1$ barrel $\$ 12.50$

Ask for price on large quantities. PURE PARIS GREEN.

Sealed pkgs., $1 / 4$ lb., 15c; $1 / 2$ 1b., $25 \mathrm{c}$ lb., 40c. Large quantity at market price.

Paris Green Solutiom. For small fruits, also for cherries, plums, peaches, apricots, etc., dissolve 4 ozs. Paris Green to 60 gallons of water, add to this 10 lbs. of fresh slacked lime. For apples, pear and all shade trees, 8 ozs. apples, pear and all shade trees, 8 ozs. of Paris Green to 60 gallons water and $15 \mathrm{lbs}$. of linie. The lime is very neces it also makes Paris Green more soluble.

\section{HAMMOND'S SLUG} SHOT-Powder.

Recommended to destroy potato bugs and those on tomato rant worms, cabbage lice and worms, fleas beetles and striper bugs on melons etc.; canker worms etc.; canker worms fruit and ornamental truit and ornamental 1 lb carton trees. $15 \mathrm{c} ; 1 \mathrm{~b}$. $1 \mathrm{~b}$. carton 10 lb. pkg., $90 \mathrm{c} ; 25$
$1 \mathrm{bs} ., \$ 2.00$.

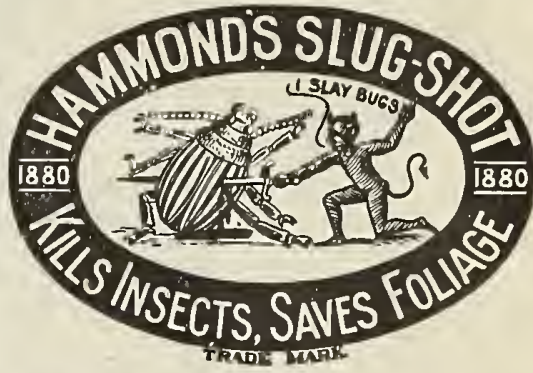

SCALECIDE-Liquid.

A concentrated soluble oil solution which mixes instant $1 y$ with water and stays mixed. Can be diluted at the rate of 1 gal. to 15 or 20 gals. of water, and for many purposes, 1 gal. to 40 or 50 gals. of water. It needs nothing else with it. Is a perfect destroyer of all scale and insect pests, but Wan be applied any time in the year. 1 gt. can, $40 \mathrm{c} ; 1$ gal. can, $\$ 1.00 ; 5$ gal. can, $\$ 4.00$.

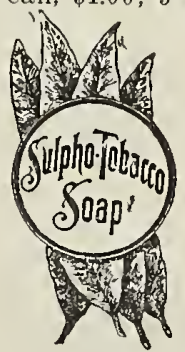

POWDERED SULPHUR.

Lb., 10c; 4 lbs., 30c; 10 lbs., 50c; 25 lbs. $\$ 1.00$. Large quantities at market price.

\section{SULPHO-TOBACCO SOAP.}

This popular insecticide gives excellent satisfaction, and never fails to quickly exterminate all insect life on plants, flowers shrubs, etc. It is cheap, effective, clean an harmless. $3 \mathrm{oz}$. cake makes $1 \frac{1 / 2}{2}$ gallons of prepared solution. $10 \mathrm{c}$, by mail, $13 \mathrm{c} ; 8$ oz cake makes 4 gallons, $20 \mathrm{c}$, by mail, $28 \mathrm{c}$.

\section{TOBACCO DUST.}

To drive off green lice in hotbeds. Lb., 10c; $10 \mathrm{lbs}, 75 \mathrm{c}$ 25 lbs., $\$ 1.50 ; 100$ lbs., $\$ 4.80$

\section{TOBACCO STEMS}

For fumigating. $10 \mathrm{lbs}$. for $40 \mathrm{c} ; 25 \mathrm{lbs}$. for $70 \mathrm{c} ; 100 \mathrm{lbs}$ for $\$ 1.75$.

\section{TOBACCO PRODUCTS}

Tobacco, when correctly applied, is a very effective insecticide.

To-bak-ine, Fumigating Paper. A slow burning paper especially prepared and thoroughly saturated with pure nicotine, making its vapors sure death to aphis, red spider, thrip and all insects infecting greenhouses. It will not injure the most delicate flower. rolls, $\$ 5.25$.

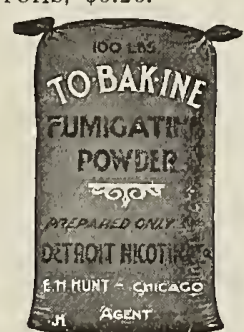

To-bak-ine Li qu i d. A concentrated solution of nicotine, containing definite amount adjusted by chemical assay. Contains no ammonia. May be used as a spray or vaporized. $1 / 2$ pint can, $\$ 1.65 ; 1$ pint can, $\$ 3.0$

To-bak-ine Fumigating

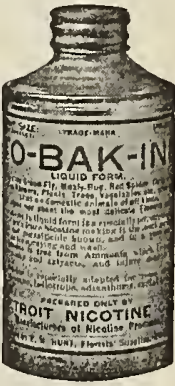
Pownd powder is

superior to tobacco dust, having the ammonia extracted, and positively contain no adulterations. 50

For full information regarding these products ask for booklet, "Words of Wisdom."

WHALE OIL SOAP-(Fish OII).

Used in the greenhouse, nursery and anywhere that insect life exists. Per $1 \mathrm{~b}, 15 \mathrm{c} ; 5 \mathrm{lb}$, box for $60 \mathrm{c} \cdot 50 \mathrm{lb}$. box for $\$ 4.00 ; 100 \mathrm{lb}$ box $\$ 7.50$

Whale oil soan Solution. Dissolve 2 ounces of soap to 1 gallon of water for all small fruit. For large fruit trees, shade trees, etc., use 3 ounces of soap per gallon.

WHITE HELLEBORE-Powder.

For currant worms, ete. A solution of white hellebore to 3 gallons of water is very effective slugs, and not dangerous to apply when fruits are soon ready.
$\$ 1.20$. 


\section{What Crops to Spray and When to Spray}

Never wpray a tree when flowers are open, nor use mlneral poison 4 or 5 weeks before erops are harvested.

APPLE. For canker worm, codling moth and scab, spray Copper Sulphate Solution before buds start. Second spraying, using Bordeaux Mixture and Paris Green just before flowers open. Thild spraying, using same, a week after blossoms have fallen, and once more three or four weeks later.

APRICOT, PEACH AND PEAR. For blight, leaf curl, mildew, codling moth and curculio. Use Copper Sulphate Solution before buds start. A week after blooms have fallen use Bordeaux and Paris Green and repeat three or four weeks after.

BLACKBEIRY AND RASPBERIRY. For rust cut out diseased canes; spray with Copper Sulphate before growth starts. When new canes are one foot high spray with Bordeaux Mixture. Two weeks later use weak Copper Sulphate Solution. When crop is gathered cut off old canes and spray with Bordeaux Mixture.

CABBAGE. For worms and fleas. Ir cabbages are not heading use Ferosene Emulsion for fleas and Copper Sulphate for worms. If heading, use one teaspoonful of saltpeter to one gallon of water and spray the plants.

CHERRY AND PLUM. For rot, fungous diseases, curculio and slug. As buds start, spray with Copper sulphate, remove all diseased branches and burn them. When fruit has set, spray a second tlme, using Bordeaux Mlxture and Paris Green, and as often as it may be needed after that.

CURIRAT AND GOOSEBERRY. For mlldew and worms. As soon as the leaves open or as soon as worms appear, use Bordeaux and Paris Green and repeat at intervals of two weeks as often as needed. Hellebore can be used lnstead of Paris Green and Bordeaux.

PO'TATO. For scab soak seed for one or two hours in a solution of 1 ounce of Corrosive Sublimate (bi-chlorlde of mercury) to 20 gallons of water. When beetles or larvae appear use $1 \mathrm{lb}$. of Paris Green to $100 \mathrm{lbs}$. of Land Plaster. For Blight use Bordeaux Mixture.

ROSE. For red spider or aphis use Kerosene Emulsion; for mildew or black spot use a weak Copper Sulphate Solution; for slug spray Arsenate of Lead or Hellebore.

STRAVBERRy. For rust, use Bordeaux and Paris Green just before blossoms open and a week after blossoms fall, but no more till after crop is gathered.

TOMATO. For rots, blight and worms. Before frults set use Bordeaux and Paris Green; after fruiting use a weak Copper Sulphate Solution.

\section{PEST EXTERMINATORS}

BARTELDES' GOPHER KILLER-Liquid.

It is a quick and positive exterminator for gophers, ground squirrels or prairie dogs that burrow deeply in the ground. It is not as effective for moles or other burrowing ground. It is not as effective for moles or other burrowing for the reason that the gas escapes through the thin layer for the reason that the gas escapes throug
of surrounding earth. Price, $1 \mathrm{qt}$. can, $75 \mathrm{c}$.

\section{POISONED WHEAT.}

For exterminating prairie dogs, gophers, etc. 1 lb. carton, $20 \mathrm{c}$; 5 to $10 \mathrm{lbs}$ at $17 \mathrm{c}$ 100 lbs, at $14 c$ lb.

\section{GOPHERGO.}

A sure death to gophers, squirrels, prairie dogs, rabblts, rats, mice and all other rodents. It is an attractive bait, thoroughly poisoned and guaranteed to do the work. Put up in $25 \mathrm{c}, 50 \mathrm{c}$ and $\$ 1.00$ cans. Directions on each can
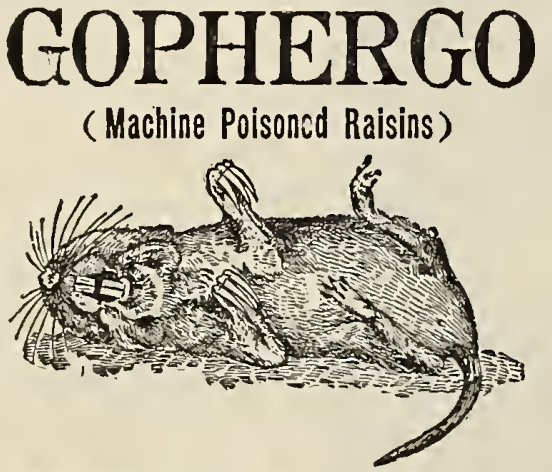

ANT EXTERMINATOR.

A non-poisonous powder which will kill or drive away ants from lawns. Box, $25 \mathrm{c}$.

\section{SULPHATE OR IRON-Powder.}

Will kill dandelions and all weeds having broad and hairy leaves without injury to grass. 4 lbs., $25 \mathrm{c} ; 25 \mathrm{lbs} ., 90 \mathrm{c}$ 50 lhs., $\$ 1.50 ; 100$ lbs., $\$ 2.75$.

STERLINGWORTH LAWN COMPOUND-Powder.

Kills all the weeds having a broad or hairy leaves but not the grass and makes the lawn green and velvety. One pound will dress 100 to 200 square feet. Price, 5 lb. can $60 \mathrm{c} ; 10$ lb. can, $\$ 1.00$.

\section{STERLINGWORTH WEED KILLER-Powder.}

It is a powerful and effective compound. One application will destroy in 12 to 72 hours weeds, grass (including Milk Weed and Witch Grass). Briars, Dandelions, Daisies and all vegetation with which it comes in contact. One pound will make 15 gallons of solution. Price, one pound package, $50 \mathrm{c}$.

\section{FORMULAS TO KILL GRASSHOPPERS.}

No. 1. 100 lbs, of bran, 8 lbs. sugar, 1 lb. saltpeter and 4 lbs. Paris Green. Dissolve the sugar and saltpeter, then add the Paris Green and enough water to moisten the bran well, but not wet enough to destroy its slight adhesiveness; then scatter it all over the field.

No. 2. 1 part Paris Green, 2 parts salt, 40 parts horse dung, by measure, all to be mixed with water till soft, but not sloppy, and scatter over the infested places.

\section{CUT WORM KILLER-POWder.}

This preparation is quick and sure in effect and non-poisonous to domestic animals. 'It is so alluring to Cut Worms that they are irresistibly attracted to it and eat it in preference to any vegetation. Dead Cut-Worms will be seen wherever there are Cut-Worms and Cut-Worm Killer has been used. One pound is sufficient for 175 plants, when in hills, and 150 linear feet of plants when in rows. Price, 1 lb., Sprinkler Top Box, 25c; 5 lb. Tin Can containing Sprinkler Top Bóx, $\$ 1.10$.

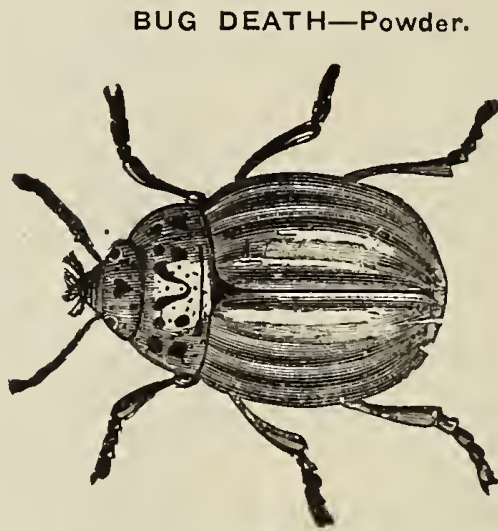

It will kill any bug or worm that attacks or eats the stalk, leaf, vine or blossom of any tree, plant, or vegetable that grows. It is so very fine powdered that it does not wash off except in some such extraordinary case as a cloudburst. It is not injurious to bird or animal life outside of bugs and wormis. It kills or drives away ants without injury to the grass. Also it is very effective to prevent blight on potatoes, cucumbers, melons, tomatoes and other crops. A part of Bug Death mixed with 2 parts of bran and 1 part molasses spread around plants will attract Cut-Worms, which eat the mixture and die. 1 lb., $15 \mathrm{c} ; 3 \mathrm{lbs}$, $40 \mathrm{c} ; 5$ lbs., $60 \mathrm{c} ; 12 \frac{1}{2}$ lbs., $\$ 1.20$.

\section{LAWN SILICATE-Powder.}

It kills weeds in lawns in 24 hours. Economical, easily applied and destroys weeds such as Dandelions, Plantain, Buckhorn, Povertyweed, Chickweed, Burdock, Thistle, etc. etc. It will not harm the grass to any extent though, if dusted too thick, the grass may turn a little brown for a short time after Lawn Silicate has been used; but soon will become greener and more vigorous than before. $5 \mathrm{lb}$. package, $30 \mathrm{c}$. 


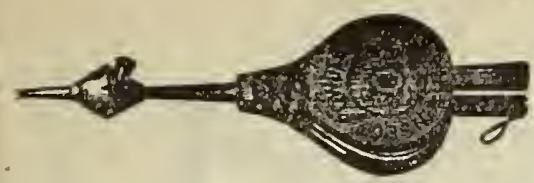

BELLOWS.

For powder. No. 14 holds 4 ozs. Each, $\$ 1.10$. No. 10 holds 8 ozS. Each, $\$ 1.35$.

TIN POWDER DUSTER.

Can be used for sifting on any powder insecticide. Perforated bottom. One-half gallon size, each, 40c.

DICKEY POWDER DUSTER, each, $25 \mathrm{c}$

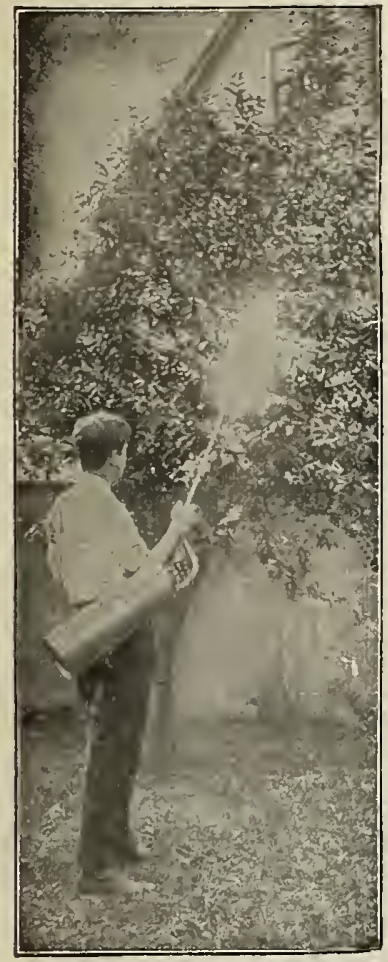

No. 1 Auto-Spray. tank, $\$ 6.75$.
Dusters and Sprayers

If wanted by mail, add postage.

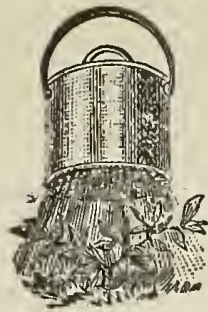

Powder Duster.

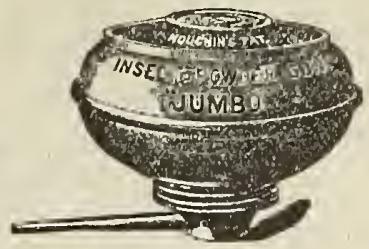

Powder Gun.

POWDER GUNS.

Jumbo Gun is designed for use with our Persian Insect Powder; also the various powder insecticides. Holds ounces, $15 \mathrm{c}$, postpaid.

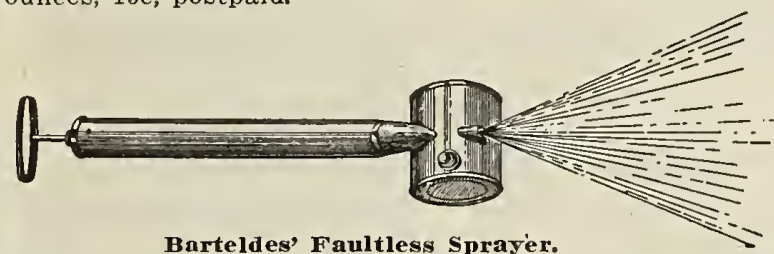
foul ounces. Will outlast several of the cheaper guns.
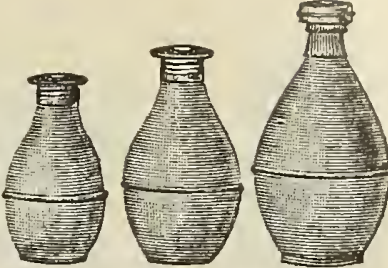

Rubber Plant Sprinklers

SCOLLAY RUBBER PLANT SPRINKLERS.

The very best. When once used you will wonder how you got along without it. For sprinkling plants, applying insecticides, etc., will last a lifetime.

No. 1, large, $\$ 1.00$. No. 2, large, with bent neck, $\$ 1.00$. No. 3 , medium, $75 \mathrm{c}$. No. 4, small, $60 \mathrm{c}$

\section{Special Offer.}

Add to above prices 25 cents and receive an 8 -ounce cake of Sulpho-Tobacco Soap. For 10 cents we will include a 3 -ounce cake. Those taking advantage of this special offer will receive, if "The Window Garden, How to Care for It, and What to Grow

\section{BARTELDES' FAULTLESS SPRAYER.}

The best low priced tin sprayer on the market. It throws a spray as fine as steam, and is very useful for applying Liquid Lice Killer in cracks and crevices about the poultry house, roosts, nest boxes, etc.; also about the and crevices about the poultry house, roosts, nest boxes, etc.; also about the other means of application. For applying insecticides onto rose bushes, shrubs, etc., it is unequaled, and should be in the hands of every gardener, shrubs, etc., it is unequaled, and should be in
fruit grower and poultry keeper. Price, $75 \mathrm{c}$.

\section{AUTO-SPRAY No. 1.}

It may be used where any bucket or Knapsack sprayer can be used, and with much more satisfaction

Eight or ten strokes of plunger in air chamber will compress enough air to discharge the entire contents and make a continuous spray for nine minutes. The "Auto-ISpray" is light and a boy can carry it with ease and cover ten times more area in a day than can be covered with the old style sprayers which require the operator to be constantly pumping in order to do the spraying. The "Auto-Spray" does the work as fast as a man can walk. It will spray every solution that any other pump will handle, including whitewash and cold water paint.

Descriptive circular sent on application. Price: "Auto-Spray" with galvanized iron tank holding 5 gallons, and stop-cock, $\$ 4.50$; with brass

Auto-Pop, which is a patented device for controlling the spray and cleaning the nozzle aperture, each, $\$ 1.00$.

\section{NOVELTY TIN SPRAY PUMP.}

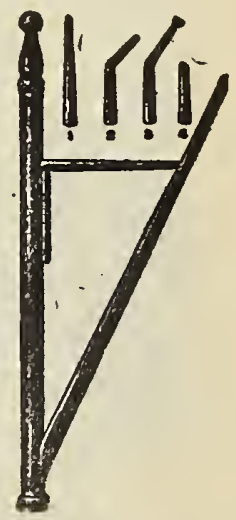

Novelty.

Is used in a bucket. Has four nozzles. Is especially adapted for throwing insecticides on bushes, whitewashing chicken houses, etc., also washing windows, buggies, etc. Price, complete, $\$ 1.25$.

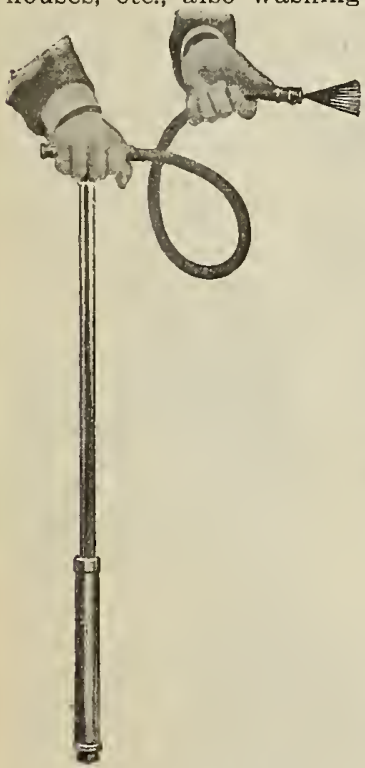

JUNIOR NO. 5 SPRAY PUMP.

Does away entirely with the objectionable foot-rest, clamps, leather suction, packing, etc., etc.

This Pump requires no fastening of any kind, holds itself down and works anywhere and everywhere. All the operator need do is to press the plunger down. It rises of itself, the upward stroke being made by a brass spring forcing the cylinders apart.

The All-brass suction working within a brass eylinder with all Brass Valves, does away entirely with all leather, rubber, or other packing. It is practically impossible for any part to get out of order.

Everything except handle and hose is Solid Brass.

It is the Easiest Working and will do more different kinds of work than any pump ever made. Will pump from a pail barrel, tank, spring or creek. Without fastenings of any kind it stands firmly wherever placed. Weighs only 4 pounds and is Ready for Instant Use Fverywhere.

Farmers with an ordinary amount of Spraying put a barrel on their wagon, set this Pump in and spray their trees as efrectively as ther neimhbor who uses an outfit veighing and costing five times as much.

Will throw two solid contnuous streams, one flat spray and one fine round syray. Has automatic mixer to keep solution stirred, pleases everybody and will last a lifetime.

Price of Pump complete, as showll in cut, $\$ 3.50$.

"KANT-KLOG" SPRAYER.

The "Kant-Klog" Sprayer is a compressed air sprayer fitted with a nozzle for making 2 round and 1 flat spray and two solid streams; has thumb pressure Spring Hose-Cock, carrier strap and safety valve. The sprayer body is made of heavy polished brass or galvanized steel, as desired. Both top and bottom are domeshaped; joined to body under heavy pressure, making a complete

Jr, No. $\mathbf{5}$. double seam. The air pump is made of heavy brass tubing, two inches in diameter.

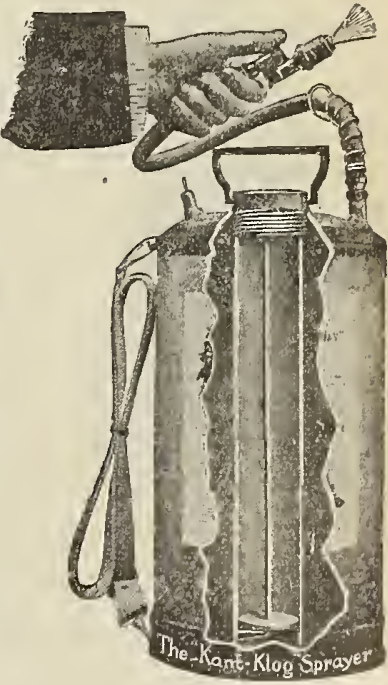

Price with galvanized steel body, $\$ 5.00$; with polished brass, $\$ 6.50$.

Kaut-Klog.

Brass Wlbow for spraying underside of low growing plants, each, 40 trees.

Brass Extension Pipe, 3 feet long, each, $40 \mathrm{c}$. Several can be sclewed together when desired. Used for spraying high 


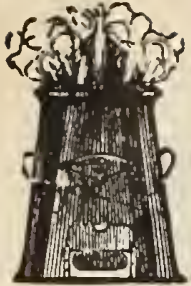

Fumigator.

\section{ATTACHMENTS FOR SPRAYERS.}

Nozzles.

Deming Vermorel with degorger affords a conical discharge. A very popular nozzle. For $1 /$-inch pipe. Price, $75 \mathrm{c}$, postpaid.

Double Vermorel Nozrles. Two nozzles with connecting piece. Price, complete, $\$ 1.75$. Bordeaux for a fan-shaped spray. Will also throw a solid stream. Price, $75 \mathrm{c}$, postpaid. Uuderspray Attachment, made of brass, each, $50 \mathrm{c}$. Extension Brass Plpe, 2 feet long, each, $50 \mathrm{c}$.

RUBBER TUBING.

For use with Spray Pumps. $3 / 8$ and $1 / 2$ inch. $3-p l y, 12 c$ per ft.

\section{EXTENSION RODS.}

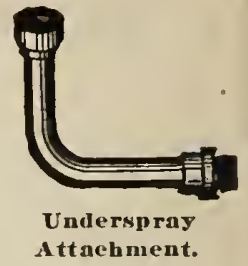

Iron. Fitted ready for use. $4 \mathrm{ft}$. long, $1 / 4$ inch, each, $85 \mathrm{c} ; 6 \mathrm{ft}$. long, $1 / 4$ inch, each, $\$ 1.00 ; 8 \mathrm{ft}, 10 \mathrm{ng}, 1 / 4 \mathrm{inch}$, each, $\$ 1.25$; $10 \mathrm{ft}$. long, $1 / 4$ inch, each, $\$ 1.50$

\section{BRASS SYRINGES}

Well made instruments, suitable for use in applying thin liquid insecticides in greenhouses, etc. Style $B$, 131/2 inches long, $13-16$ inches diameter. Price, $\$ 2.75$.

FUMIGATORS.

Galvanized Iron. Used for fumigating greenhouses, etc. Small size, No. 2, \$2.00. Large size, No. 3, \$2.50.

2 ft. Brass Extension Pipe.

\section{DEMING'S SPRAY PUMPS}

WE CARRY A FULL LINE OF

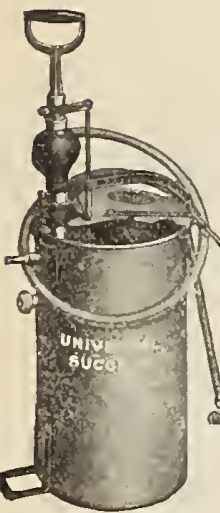

No, 662.

No. 662. Universal Suceess Pump. With various attachments to make it either a Spray Pump, Plumber's Force Pump, whitewasher or a Fire Extinguisher. No. 662 is fitted regularly with a galvanized tank holding five gallons. The galvanized iron will not withstand the action of the Bordeaux Mixture, Lime, Sulphur and Salt Solutions or Ammon-

ical Solution of Copper Carbonate. In case these prepara성 tions are used a brass tank will be furnished. from splashing out. The air chamber, which is also brass, allows a good pressure to be maintained for each of the various purposes.

Price, complete with galvanized iron tank, \$7.00. Price, complete with brass tank, $\$ 9.00$

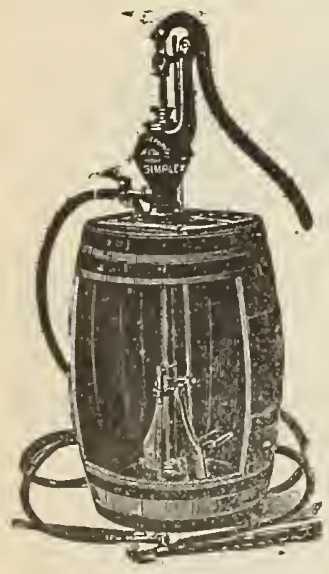

No.

No, 654. The "Priye" Knapsack Greenhouse Sprayer. Is provided with a special attachment for clamping the pump to galvanized iron tank and has a handle by which tank may be carried about after removing the lever and its handle; in this way it can be used similar to a bucket pump. Price, $\$ 9.00$.

No. 675. The "Success" Knapsack Sprayer. Has a 5-gallon copper tank, a brass pump with bronze ball valves and extra wide straps. Price, $\$ 14.00$.

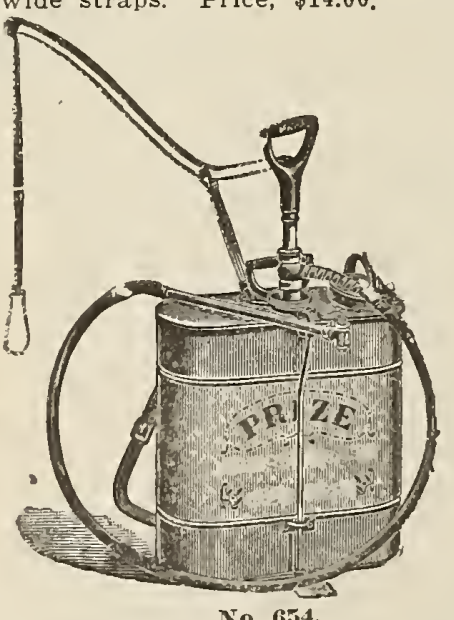

No. 654.
All working pares of pump are brass, including brass ball valves. A sliding cover is prepared to prevent the liquid

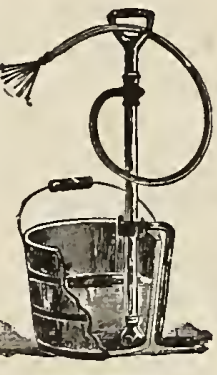

No. 669. "The Prize." Has brass working parts with bronze ball valve and malleable foot rest. Is the best pump for the price that has ever been offered. Is furnished with Acme Nozzle. Price, without bucket, $\$ 3.00$.

No. 689. "Perfect Success." All parts coming in contact with the liquid are brass with indestructible bronze valves. Malleable iron combination foot rest. Has large air chamber and is double acting. throwing a continuous stream. Is provided with Bordeaux Nozzle and four feet of discharge hose. Price, complete, as shown in cut, except bucket, $\$ 5.00$

We can furnish a 7 -foot section hose with couplings and pole-holder to be used in extending the spray to fit either No. 669 or 689 pumps, for $\$ 1.50$.

No. 550. The "Simplex" Barrel Spray Pump. The popular orchard sprayer with mechanical agitator and brass working parts. Cylinder $21 / 2$ inches.

The air chamber is large and insures a constant stream. The agitator agitates. The discharge has a $Y$ connection. Weight about $60 \mathrm{lbs}$.

Pump with outfit "A." Consisting of $121 / 2$ feet $1 / 2$-inch hose, a Bordeaux Nozzle and pole connection, all complete ready for use. Price, $\$ 12.00$.

Barrel not furnished with pump.

\section{No.632. THE CAPTAIN}

BARREL SPRAYER.

The pump is made with $1 \frac{3 / 4}{\text { - }}$ inch Brass Tube Cylinder; has Brass Ball Valves and Valve Seats, and Brass Plunger with improved packing. The Air Chamber is ample in capacity, and is made of $21 / 4$-inch boile tubing. The Discharge Connection is fitted for $1 / 2-i n c h$ hose. It has an improved adjustable clamp for attaching rigidly to the inside of barrel. The Agitator is simple in construction and very efficient.

Weight about 40 lbs

Pump with outfit A, price, $\$ 11.00$.

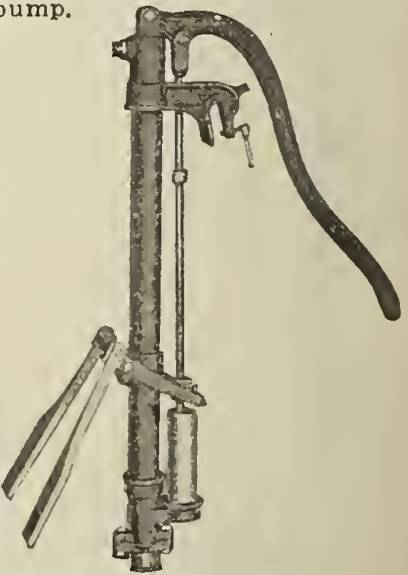

No. 632. 
No. 645. THE CENTURY BARREL PUMP.

This pump sets jow in barrel; the cylinder is submerged and is $21 / 4$ inches in diameter. Base fits $10 \times 10-$ inch hole. The agitator is twin paddle type. Cylinder brass ball valves, cage and seat are easily removed.

Weight about 75 lbs. Price, with outfit A, $\$ 14.25$.

THE SAMPSON DOUBLE ACTING SPRAYER.

For Barrel or Tank,

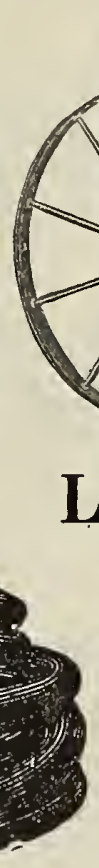

Rubber Hose.

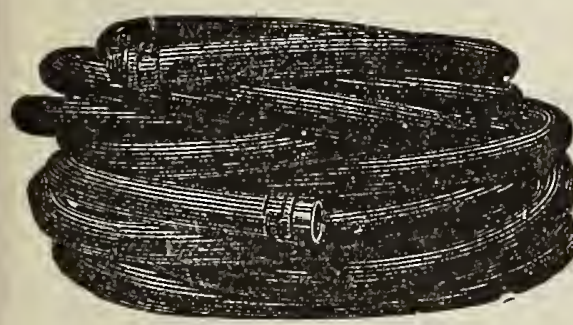

No. 650. BARREL CART.

This cart is very handy, as it dispenses with horse and wagon for spraying orchard or large lon barrel, which can be readily disconnected or attached to it. Price, cart only, $\$ 10.50$.

With each of these Deming Sprayers we give a valuable book free, "Spraying for Profit." Pubmany other styles of the Demine many other sty for special cata logue.
The pump has an extremely large air chamber (18 gallons capacity)

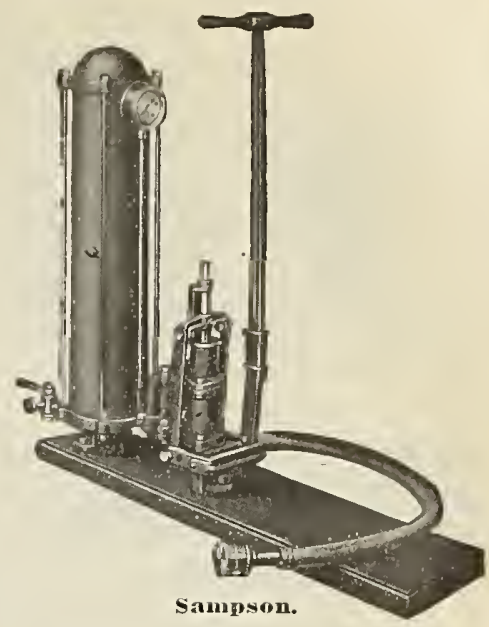

ator to pump and rest alternately. It has a long, well balanced lever, which is a great aid in pumping. The cylinder is brass-lined and all other parts including the ball valves and seats are prass Having a differential plunger, an equal amount of work is done on both strokes making it double-acting is done on both strokes making it double-acting, which decreases the labor and increases the work done. The pump is furnished lined suction hose and strainer. Price, $\$ 35.00$.

\section{LAWN REQUISITES}

RUBBER HOSE. Barteldes' Columbine Grade. 5 ply Sun-resisting - fully guaranteed - fitted with couplings:

\section{Price.}

50 ft., $1 / 2-$ in...$\$ 5.50$

$50 \mathrm{ft} ., 3 / 4-\mathrm{in} . .6 .00$ Corrugated NonKinkable Hose.

The strongest hose made, fitted with couplings, $3 / 4$-inch size. Price, $25 \mathrm{ft}$., $\$ 5.00 ; 50 \mathrm{ft}$., $\$ 9.25$. $1 / 2$-inch size, 25 feet, $\$ 4.25 ; 50$ feet, $\$ 8.00$.

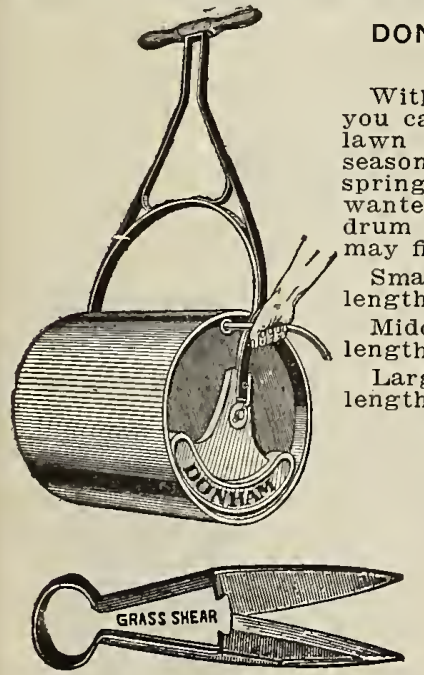

GRASS TRIMMING SHEARS.

For trimming around flower beds, walks, etc. Regular grade, $35 \mathrm{c}$ each. Extra grade, 50c each.
DONHAM WATER BALLAST LAWN ROLLERS.

With this new style of Rollers ou can have any weight roller the land needs, according to pring, when a light. rolling is wanted, you only need to fill the partly, while in summer you Small size diameter 14 inches, 20 inches, $\$ 11.50$. inches, $\$ 14.50$.

18 inches, inches, $\$ 20.50$.

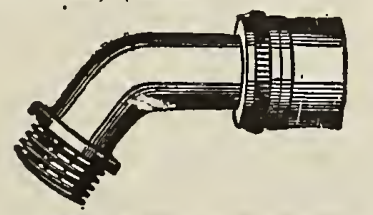

Goose Neck Connection.

GOOSE NECK CONNEC. TION.

Prevents kink and break of hose near ground connection. Made in $3 / 4$-inch size only. Each, $50 \mathrm{c}$.

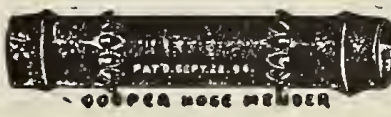

COOPER HOSE MENDER.

'The best "mender" on the market, made of brass, with barbs on each end, which prevents hose from slipping out. Will not rust or wear out. Millions in use. $1 / 2$ or $3 / 4$-inch, each, $10 \mathrm{c}$; dozen, $75 \mathrm{c}$.

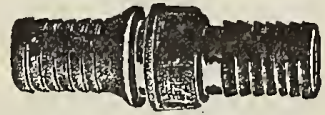

Brass Hose Couplings. BRASS HOSE COUPLINGS.

For $1 / 2$-inch and $3 / 4$-inch hose. Per set, $15 \mathrm{c} ; 2$ for $25 \mathrm{c}$ IRON HOSE MENDERS. $1 / 2$ and $3 / 4$-inch. 6 for $25 \mathrm{c}$.

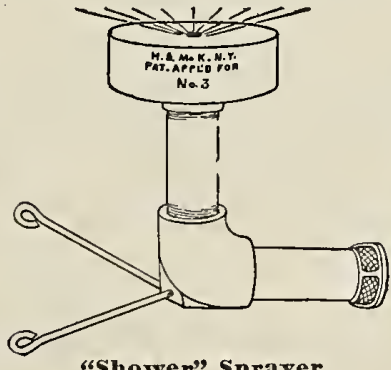

“Shower" Sprayer.

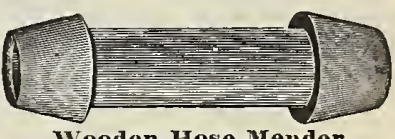

Wooden Hose Mender.

\section{WOODEN HOSE} MENDERS.

(Look like Cooper's.) 1/2inch and $3 / 4$-inch. Per doz. $15 \mathrm{c}$.

PATENT HOSE CLAMP.

1/2-in., each, 5c; doz., 50c $3 / 4$-in., each, $5 \mathrm{c}$; doz., $50 \mathrm{c}$.

\section{CALDWELL BRASS}

WIRE STRAPS.

For 1/2-in., hose, per doz. $15 \mathrm{c} ; 3 / 4-$ in. hose, per doz. 15c; Pliers for same, $25 \mathrm{c}$ each.

\section{SHOWER SPRAYER.}

This is a new sprayer which throws an even gentle spray over an area 25 feet in diam eter; it resembles a natura "shower" more closely than any other sprayer. The nozzle can be used for washing sidewalks, bugoies, etc by simply unscrewing the sprayer. It stands 6 inches high and fit a standard $\%$-inch connection. Holder and nozzle, complete in box, $\$ 2.00$.

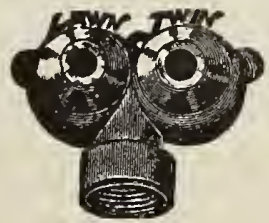

THE LAWN TWIN SPRINKLER,

Is a combination of simplicity, neat ness and effectiveness. The two orifices distribute the water with the utmost freedom and completeness. Its location can be changed with ease, while work ing e changed wire ing, with the aid of wire or cord at Price, each, $35 \mathrm{c}$. 


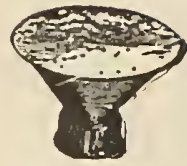

Boston Rose Spray.
COMBINATION SPRINKLER,

This sprinkler will not only sprinkle a full circle, but, by means of a cut off the spray can be regulated so as to cover a fraction of a circle only. This is particularly desirable in sprinkling near the sidewalk. Price, each, 90c.

\section{BOSTON ROSE SPRAY.}

Brass, 3-inch flat face. Fine or coarse for $3 / 4$-inch connection, $60 \mathrm{c}$

\section{GIBB'S NOZZLE.}

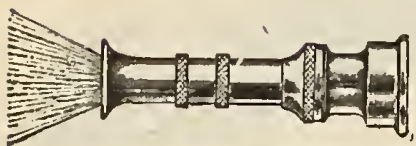

Gibb's Spray Nozzle.

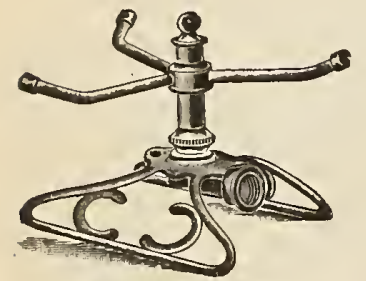

Preston Sprinkler.

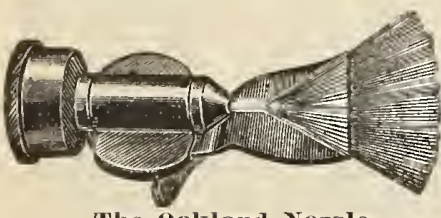

The OakInud Noxzle.

\section{MYSTIC NOZZLE.}

The difference between this nozzle and Gibb's is that it has no way of shutting the stream off. Price, $25 \mathrm{c}$.

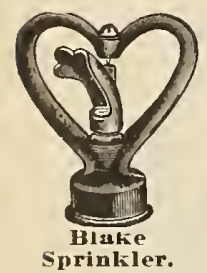

\section{BLAKE SPRINKLER.}

The spoon revolves and spray covers a large area. Each, $25 \mathrm{c}$.

\section{BUSY SPRINKLER.}

This is same as Blake but is mounted on a low base. Each, $65 \mathrm{c}$

\section{RING SPRINKLER.}

The perforations are so arranged as to give a finely divided, well distributed MARQUETTE OR FAN SPRINKLER.

This is made with a spike to stick in the ground, and delivers the spray in fan shaped form. Each, $20 \mathrm{c}$.

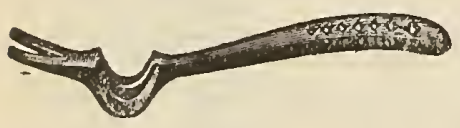

PERFECTION DANDELION PULLER.

Made of best malleable iron. Very light. A sure puller. Price, $40 \mathrm{c}$.

PATENT GIRsS SHEAIR. Made from tempered steel and has a hardwood roller. Price, $\$ 1.50$.

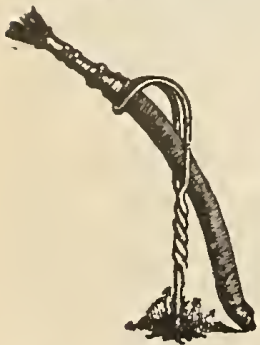

"SNAP" HOSE COUPLINGS.

The handiest coupling on the market. Just push down on the spring lever to disconnect hose. Price, $35 \mathrm{c}$.

SYKES HOSE HOLDER.

Each, $15 \mathrm{c}$.

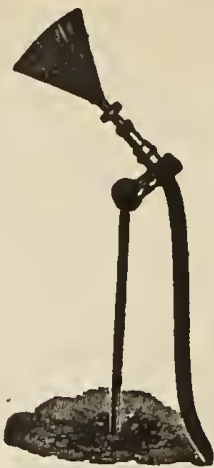

\section{CHICAGO HOSE} HOLDER.

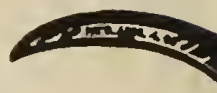

Fitted with ball and socket joints to send spray in any desired dilection. 23 inches high. Price, $80 \mathrm{c}$.

\section{HOSE WASHERS.}

To fit $1 / 2$ and $3 / 4$-inch. Doz., $5 \mathrm{c}$.

\section{LITTLE GIANT GRASS HOOK.}

Is a miniature scythe and cuts like a scythe. Handy for lawn, clipping hedges, Chicago Home Holder.

\section{Price, $50 \mathrm{c}$}

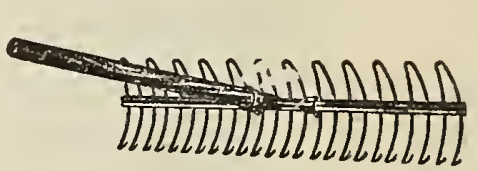

\section{QUEEN CITY LAWN} RAKE.

Is reversible and can be used for grass or leaves, 24 teeth, $201 / 2$ in. long. Each, 50c.

\section{GRASS AND TURF EDGER.}

Very useful when working on lawn walks. Price, $65 \mathrm{c}$.

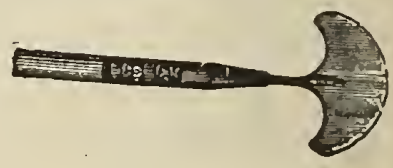

PLANET JR. GRASS EDGER.

Will do either straight or curved edging. Price, $\$ 6.25$.

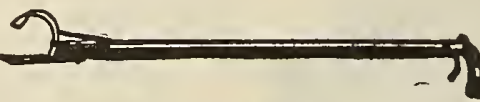

\section{CLIMAX LAWN} WEEDER.

No more backache when weeding with this tool. A simple and easy working device for removing noxious weeds and plants from lawns. Easily operated and does effective work. The full length is 42 inches, enabling the operator to stand erect. Push the chisel under the plant at an angle that will sever the roots. A slight pull on the trigger brings the grab down which securely holds the plant, lifting it out and leaving only a slight mark. Price, $75 \mathrm{c}$.

\section{TROWBRIDGE GRAFTING WAX.}

This is made of standard formula and is furnished in cakes ready for use. $1 / 2 \mathrm{lb}$. cake, $15 \mathrm{c} ; 1 / 2 \mathrm{lb}$. cake, 20c; $1 \mathrm{~b}$. cake, $35 \mathrm{c}$; 5 lbs. at $25 \mathrm{c}$ per $1 \mathrm{~b}$.

\section{TREE PROTECTORS.}

Made of veneer wood. When dampened will blend to fit around the tree. Size $10 \times 18$, price, $\$ 1.00$ per $100 ; \$ 8.00$ per 1,000 ; size $10 \times 22$, price, $\$ 1.15$ per 100 ; $\$ 9.00$ per 1,000 ; size $10 \times 24, \$ 1.25$ per 100 ; $\$ 10.00$ per 1,000 .

\section{WIRE HANGING BASKETS.}

Ten inches, fansy top, each, $25 \mathrm{c} ; 12$ inches, fancy top, each, 30c; 14 inches, fancy top, each, $35 \mathrm{c} ; 16$ inches, fancy top, each, $40 \mathrm{c}$.

SHEET MOSS. For hanging baskets. $1 / 4$ 1b., $15 \mathrm{c} ; 1 / 21 \mathrm{~b} ., 25 \mathrm{c}$; 1b., $40 \mathrm{c}$.

\section{SEED TRYERS.}

Made expressly to use in taking samples of seed and grain from sacks. Made of nickel. Small pocket size, $\$ 1.00$; large, 9 inch, for coffee, beans, etc., $\$ 1.50$.

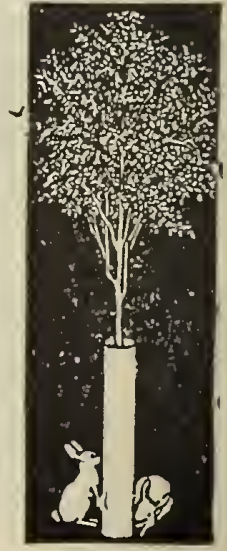




\section{Implement Department}

When Garden Tools are wanted by mail, add postage.

GARDEN AND FIELD HOES.

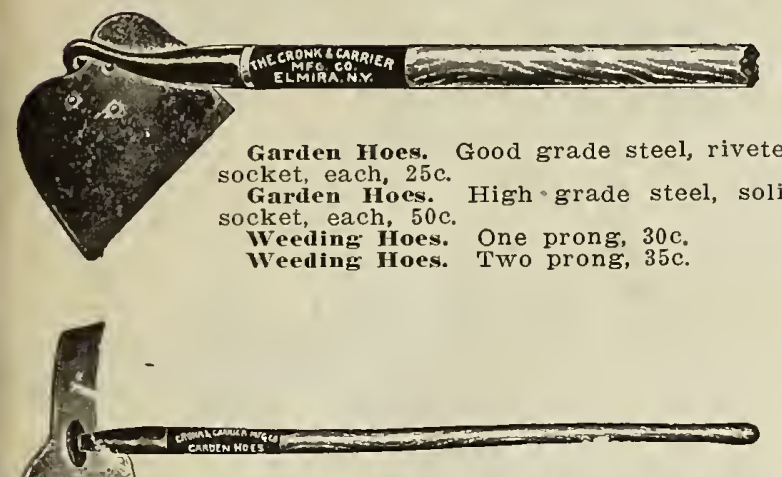

Double Bit Garden Hoe wade $6 \frac{1}{2} \times 2 \frac{1}{8}$ inches. Fach, $50 \mathrm{c}$.

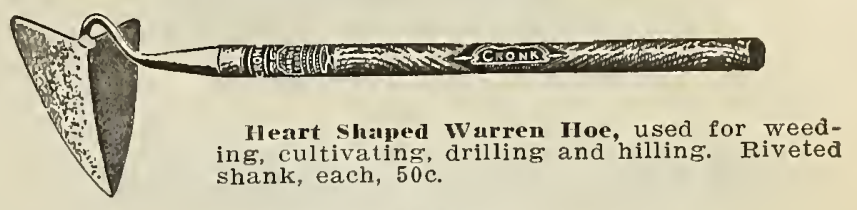

\section{PLANT DIBBER.}

Has wooden handle with solid steel point. Used in making holes for setting out plants. $30 \mathrm{c}$.

Plant Dibber, all iron, price, $30 \mathrm{c}$
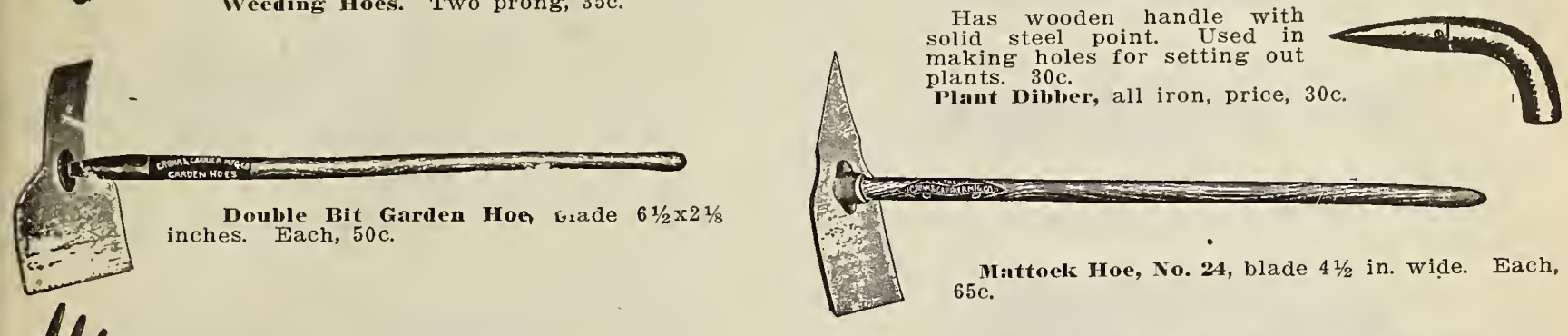
$65 \mathrm{c}$.

Mattoek Hoe, No. 24, blade $4 \frac{1}{2}$ in. wide. Each,
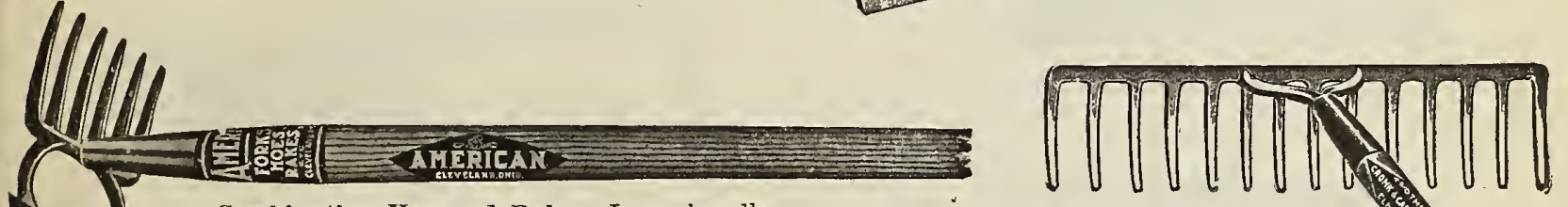

Combination Hoe and Rake. Long handle, blade 6 in. wide. Each, 35c.

\section{GARDEN RAKES.}

"Champion," 14 tooth, each, 45c. "Champion," 16 tooth, each, $50 \mathrm{c}$. "Bow Ideal," 14 tooth, each, 50c. "Bow Ideal," 16 tooth, each, 55c.

SUGAR BEET HOE.

The most popular hand tool in the beet field. Solid shank, 41/4-inch blade, 8-inch handle. Each, 30c.

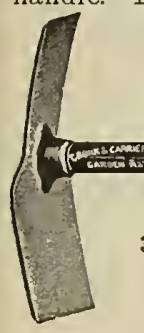

Garden Mattoek No. 13. Blade $1 \frac{1 / 4}{4}$ and 3 inches wide. Each, $60 \mathrm{c}$
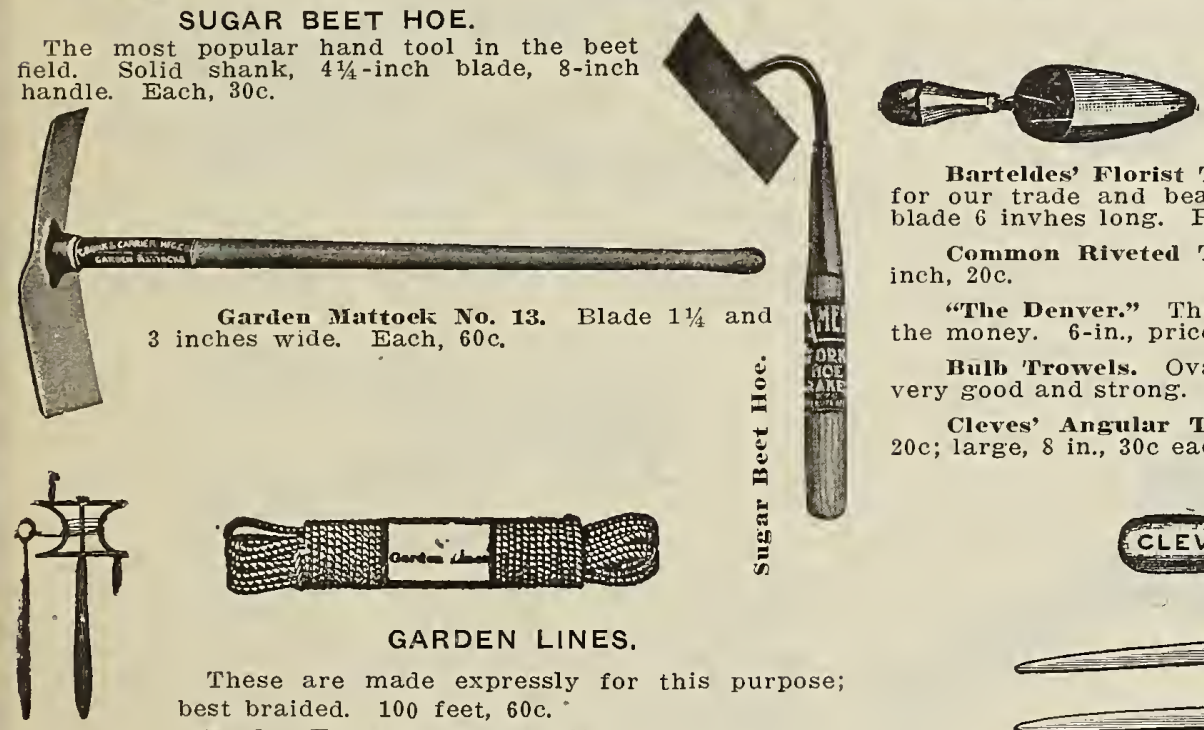

Champion Rake.

TROWELS.

A good trowel is indispensable. Our No. 3090 is 6 inches long, high grade steel. Price, $30 \mathrm{c}$.

Harteldes' Florist Trovel. Made of best steel especially for our trade and bears our name. Shariks extra strong: blade 6 invhes long. Price, $40 \mathrm{c}$.

Common Riveted Trowels. 6-inch, 12c; 7 -inch, 15c; 8inch, $20 \mathrm{c}$.

"The Denver." The strongest trowel on the market for the money. 6-in., price, $20 \mathrm{c}$.

Bulb Trowels. Oval shaped, 6 inches long by $4 \frac{3 / 4}{4}$ wide, very good and strong. Price, 60c.

Cleves, Angular Transplanting Trowels. Small, 5 in., $20 \mathrm{c}$; large, 8 in., $30 \mathrm{c}$ each.

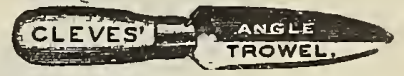

\section{GARDEN LINES.}

These are made expressly for this purpose; best braided. 100 feet, $60 \mathrm{c}$.

Reels. For sanie, per set, $60 \mathrm{c}$.

GARDEN SPADE.

M. C. Pattern, very strong. Each, $\$ 1.00$. HAZELTINE WEEDER.

One of the best. Solid steel, good in general use over the country. Also in general use over the country. Also trees. Each, $25 \mathrm{c}$, postpaid.

LANG'S HAND WEEDER.

One of the best of this class, allowing use of ing. Each, 25c, postpaid.

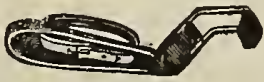

HAND WEEDERS.

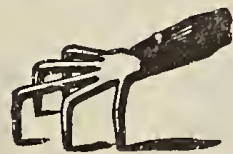

EXCELSIOR WEEDER.

A very useful tool for weeding seed beds, stirring the ground, etc. This is one of the most useful tools in working the garden. No one should be without it. Each, 15c; 3 for $40 \mathrm{c}$; postpaid.

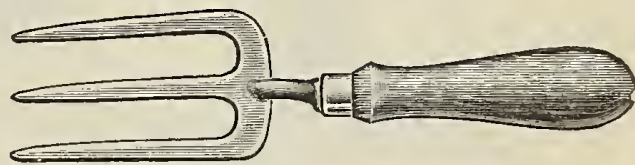

Strawberry Transplauting Fork. Price, $20 \mathrm{c}$.

COMBINATION WEEDER.

Combining as it does both the rake and hoe, it is the most serviceable, durable and perfect weeder on the market. Allows

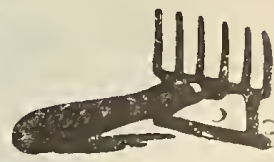
weeding close to

the plants, and is offered at about the same price as other weeders. Each $35 \mathrm{c}$ postpaid. 


\section{KNIVES}

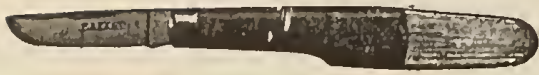

POCKET BUDDING KNIFE.

Polished black horn handle with ivory tip. A very useful knife $75 \mathrm{c}$ each

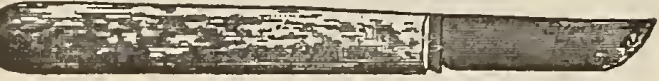

STATIONARY HANDLE BUDDING KNIFE.

Plain, 6 inches long. $25 \mathrm{c}$ each.

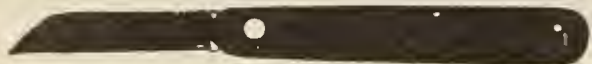

BARTELDES' FLORIST PROPAGATING KNIFE.

Made of very best steel; it is handy, strong, well made and cheap. $75 \mathrm{c}$ each.

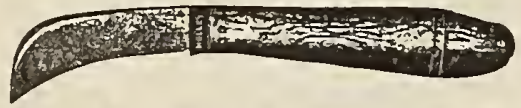

STATIONARY HANDLE PRUNING KNIFE.

High grade steel, $7 \frac{1}{2}$ inches long. $50 \mathrm{c}$ each.

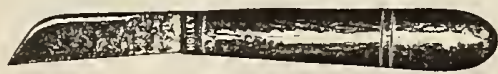

GRAFTING KNIFE.

Wooden handle. Each, 30c.

HENCKEL'S GERMAN PRUNING KNIFE.

Pocket style, made of best material throughout. Small size, each, $65 \mathrm{c}$; medium size, each, $75 \mathrm{c}$.

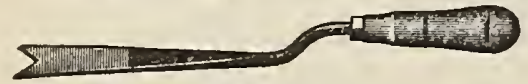

Asparagus Knife.

ASPARAGUS KNIFE.

Made of best steel. Used also to cut Dandelion from lawns. $40 \mathrm{c}$ each.

\section{HUMPHREY'S CONCAVE POTATO KNIFE.}

With the Concave Potato Knife seed potatoes can be cut bet ter, and $\$ 2.00$ to $\$ 3.00$ an acre saved in seed and time by its use. The eyes cut with the knife, have a compact piece and are surrounded by the greatest ainount of tuber. If the same eye had If the same eye had

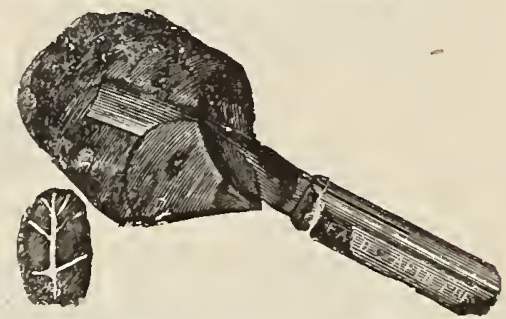

knife the piece would be thin, flat and broad, liable to dry up and decay before germinating. A circular is put in each box with the knife. Price, postpaid, $30 \mathrm{c}$

\section{SAN JOSE TREE PRUNER.}

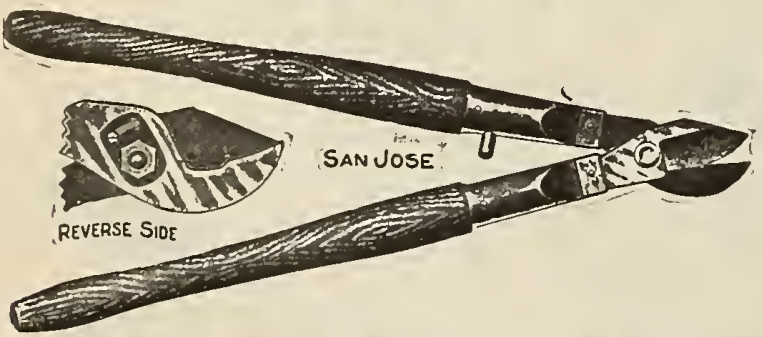

Has long handles, seamless steel ferrules and notched hooks. Length, 26 in. Each, $\$ 1.00$
PRUNING SHEARS.

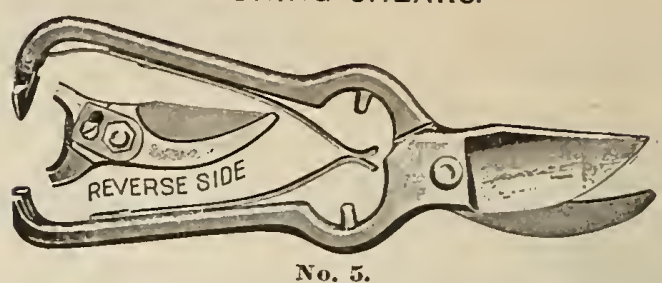

No. 5 has a flat spring, blade with hooks, forged from tool steel, oil tempered and warranted. Length, 9 inches. Fach, $\$ 1.25$.

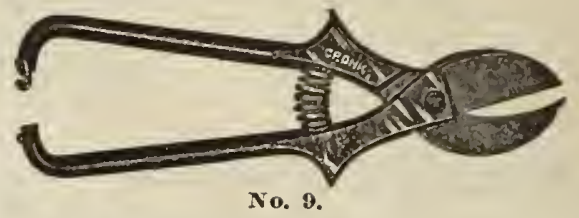

Cronk's No. 9 has solid blades and handles with heavy coil spring; very strong. Length, 9 in. Each, $\$ 1.00$.

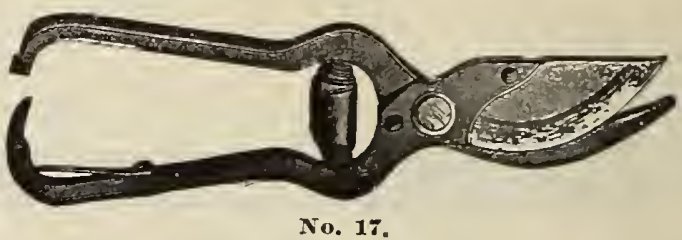

No. 17 has detachable polished tempered steel blade and is 9 inches in length. Each, $50 \mathrm{c}$.

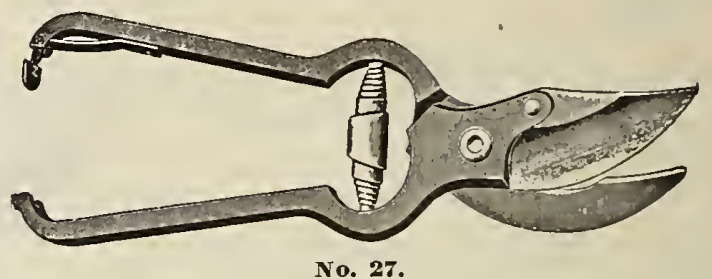

No. 27 has detachable blade of cutlery steel. Notched hook, forged from tool steel and tempered. Length, 9 in Each, \$1.1C.

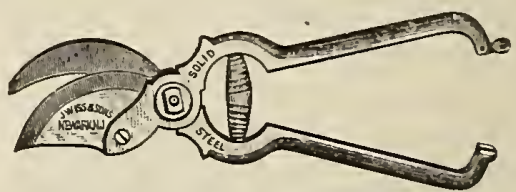

No. 109

Wiss No. 109. Made of the very best steel; very stroug. Each, $\$ 2.00$.

No. 203 Grape Shears. Used for thinning out growing fruits such as grapes, pears, apples, etc. Lencth, $63 \%$ inches: made from high grade steel, with volute spring. Price, 50c.

Henckle's No, 205. Fine imported shears made of best polished steel; has flat springs and a lock nut. Length, 9 in. Each, $\$ 1.50$.

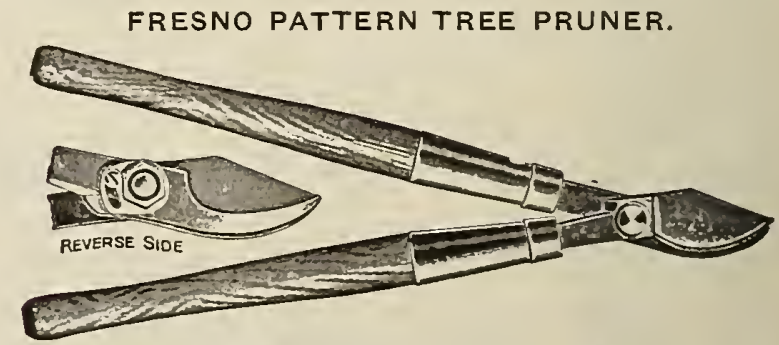

Forged from high grade tool steel. Finely tempered, has solid wrought steel ferrules and a lock nut. It is 26 inches long. Each, $\$ 1.75$. 
HEDGE SHEARS.

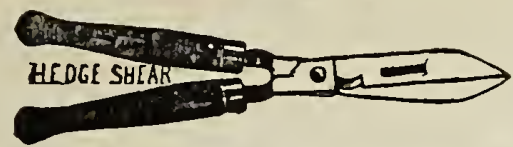

Heavy steel, notched blades, 9 in. long. Each, $\$ 1.65$.

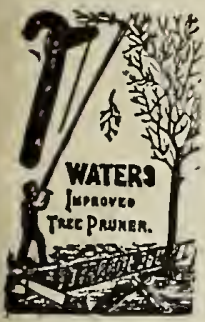

\section{LONG HANDLE TREE PRUNERS.}

Waters Improved Tree Pruner.

A very popular tool for trimming. Our prices are exceptionally low. 8-foot pole, prices are, exch $\$ 1.00 ; 10$-foot pole, complete, each, $\$ 1.15$ : 12 -foot pole, complete, \$1.25. Extra blades, $25 \mathrm{c}$

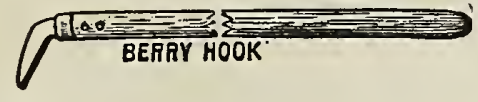

BERRY HOOKS.

Just what is wanted by berry growers to use when cleaning out old growth. Price, 75 c.

\section{ELMIRA PRUNING HOOK AND SAW.}

Has a detachable saw in addition to the pruning hook. 10 -foot pole, $\$ 1.35 ; 12$-fott pole, $\$ 1.50$.

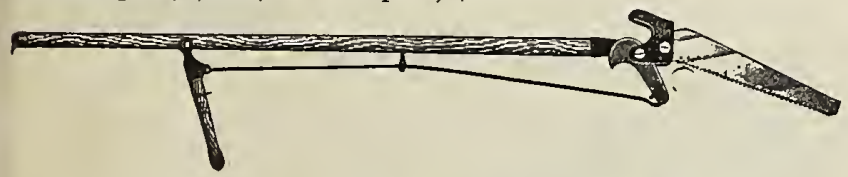

\section{DOUBLE EDGE PRUNING SAW.}

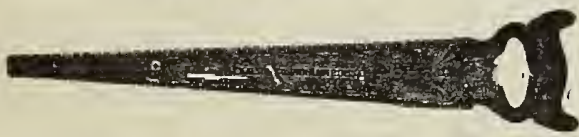

No. 2. Duplex. 16 inches long. Each, $65 \mathrm{c}$.

"PERFECTION" PRUNING SAW.

Made of best steel with adjustable blade, so any branch can be easily removed and close to trunk of tree. Can be used as a hand saw or fastened to any size pole. The best saw on the market. Each, $\$ 1.75$; extra blade, $25 \mathrm{c}$.

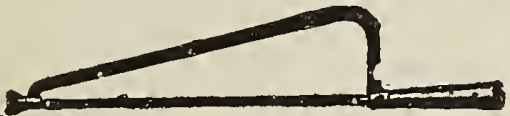

Perfection Pruning Saw With a Short Wooden Handle, each, \$1.75.

\section{CLIMAX FRUIT PICKER.}

The best arrangement we have ever seen for picking apples and pears. It fastens to a pole and has a long bag. Veteran apple men tell us that it is the best contrivance for careful apple pick ing ever introduced.

Price, complete with either 8 or $10-\mathrm{ft}$. pole, $\$ 1.25$; without pole, $\$ 1.00$.
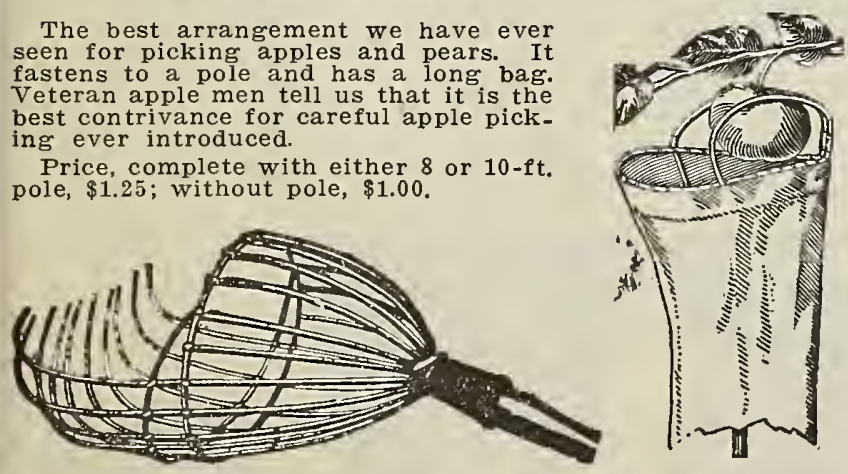

Pennsylvana Fruit Pieker.

Climax Fruit Picker.

THE PENNSYLVANIA FRUIT PICKER.

This illustration speaks for itself. Every apple grower should use them. Furnished with or without a pole with pole, $75 \mathrm{c}$; without pole, $50 \mathrm{c}$
PICKING BAG.

This bag is adjustable as to size of opening and depth so the pickers avoid dropping the fruit into a long deep bag and bruising a considerable percentage of it. The bottom opens up to let fruit escape from bag into box or barrel without being bruised. Price, $\$ 1.40$.

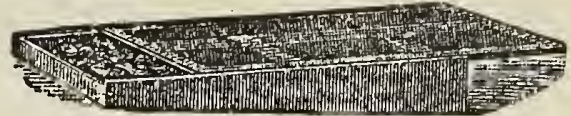

HOT-BED PROTECTING CLOTH.

A waterproof cloth making a grand substitution for glass on hotbeds and cold frames. Protects growing plants in spring and fall from frosts, insects, etc. Promotes hardy and vigorous growth without burning or drawing the plants. No. OO Medium Heavy Grade, $36 \mathrm{in}$. wide, is best for use in Colorado. Price per yard, 16c; 20 yards at $15 \mathrm{c}$ per yard; 50 to 60 yard roll at $14 \mathrm{c}$ per yard. Order early and be ready when wanted.

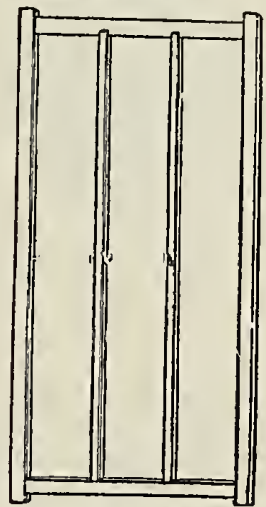

HOT-BED MATS.

Made of Rye Straw. Will not break when wet or dry if bent double. Size, $4 \mathrm{ft}$. 4 inches by $6 \mathrm{ft}$. 6 inches, average weight about 21 pounds. Price, each $\$ 1.25$.

HO'T-BED SASH. Size, 3 feet, 3 In. by 6 feet, for 8 by 10 glass.

Unglazed, each ............\$1.75 Glazed, each ................ 3.75

They will carry better if unglazed, and advise customers to get glass shipped boxed up; adding price of glass to unglazed sash.

Hot-bed Sash.

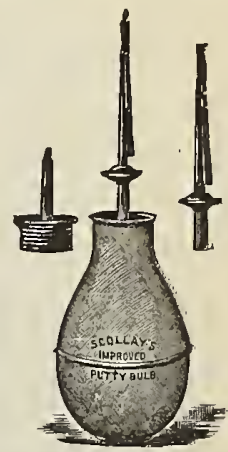

GLAZING PUTTY. In ten to twenty-five pound bladders at $4 \mathrm{c}$ per pound.

MASTICA. For glazing greenhouses. Saves much time and expense. Nothing equals it. $1 / 2$ gal., $85 \mathrm{c}$; gal., $\$ 1.50$.

MASTICA MACHINE. For applying Mastica, \$1.25.

SCOLLAY'S PUTTY BULBS (see cut). For applying liquid putty. $\$ 1.00$ each.

BLACI DIAMOND GLASS CUTTER. Each, $20 \mathrm{c}$.

VAN Reyper or peerless glazing points. No rights or lefts. Holds glass firmly. No. 1 for small, single thick glass. No. 2 for medium double thick glass. No. $21 / 2$ for large, double thick glass and skylight. 1,000 in a box for $70 \mathrm{c}$.

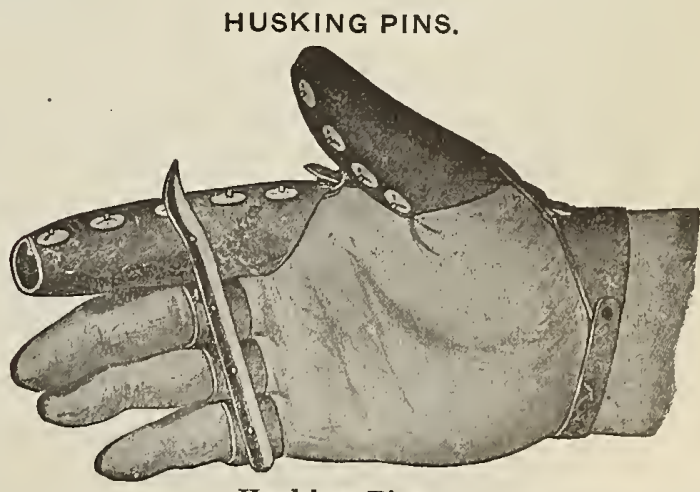

Husking Pins.

Style 7000 Combination Muleskin thumb and finger stall with patent sliding strap adjustment, with a three-compartment pin riveted on a finger stall. Steel three-compartwearing parts on both thumb and finger stall. Price, $25 \mathrm{c}$. Style 200, husking pin only. Price, 15c. 
THERMOMETERS.

We carry a large stock of a general assortment for all purposes. Ask for our special circular of Thermometers. These prices do not include postage except where noted. Ordinarily they carry safely by mail; however, we cannot

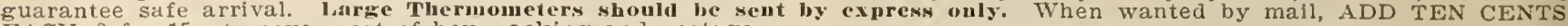
EdCH, 2 for $15 \mathrm{c}$, to cover cost of box, packing and postage.

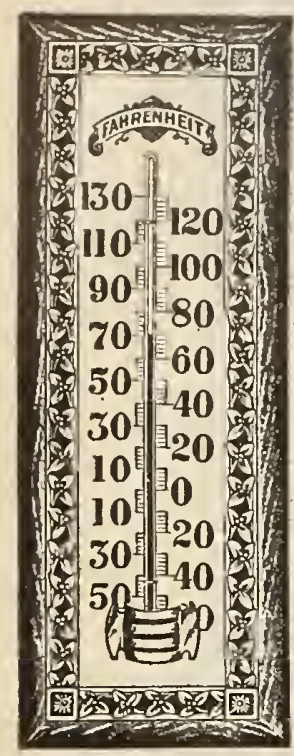

No. 334.

If interested, ask for our pamphlet on Orchard and high grade Thermometers.

Vo. 301. S-lich. Japanued Tin Case. $20 \mathrm{c}$ each.

Vo. 305. 10-inch. Jabanned 'Jin Case with silvered scale. Very reliable for household use $60 \mathrm{c}$ each.

Vo. 314. S-inch. Jajanned'lin Case. A strictly high grade instrument that can be depended upon at all times. Tested, our brand on. $\$ 1.00$ each.

No. 3:34. 10-inrll. Distance IReallng with magnifying tubes. Suitable ll hotbed, greenhouse or house. $25 \mathrm{c}$ each.

No. 410. S-incli. Houselioll. Wood back, especially suited for living

No. 422. I0-ineh Ionschold. Wood back; high grade, with nickel

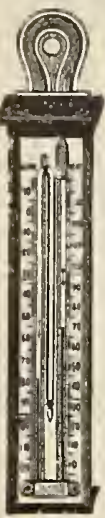

No. 720 .

No. 352. Storm Glass with thermometer and barometer com-

5 c each.

Vo. 720. 10-incll. Self-Reristcrins. Indicates each day the extremes of the temperature. Mounted on imitation Box-wood complete with magnet. $\$ 2.00$ each.

No. 724. 10-inel. Self-Registerlng. Similar instrument to No. 720 with boxwood scale, fitted with a protecting hood. Each, \$2.75.

No. 1017. Hot-bed. A glass tube mounted in a wooden tube with brass pointed bottom. Recommended for use where growing mushrooms, Each, $\$ 1.00$.

No. 20350. Hot-bed. A carefully tested mercury thermometer, well made and very accurate. Each, $\$ 2.00$

No. 900. 8-1nch. All Glass Dairy. For dairymen's It floats. Each, 25c.

No. 901. 9-incli. All Glass Dalry. Hand graduated, with tube enlarged at center, $50 \mathrm{c}$ each.

For Incubator and Brooder Thermometers see price list Poultry Supplies.

\section{FLOWER POTS, SAUCERS AND BOXES}

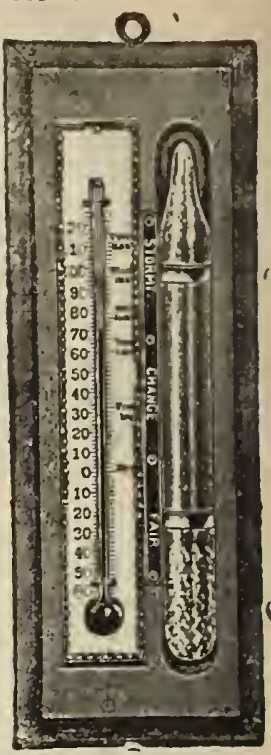

To. 352.

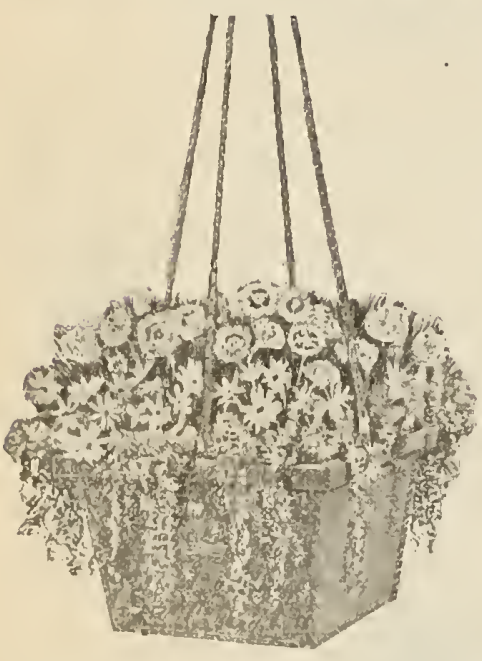

SELF WATERING WINDOW AND PORCH FLOWER BOXES AND HANGING BASKETS. As the name implies, these metal boxes and baskets are provided with a self-watering device which renders attention unnecessary except at intervals of from four to five days. A metal tube in the corner of each box extends from the water reservoir underneath the false bottom upward through the soil to top of box. Inserted in holes in the false bottom are sponges which touch the extreme bottom of reservoir and extend upward through the soil in which the flowers are planted. The water is drawn upward through these sponges in sufficient quantities to maintain a uniform moisture in the soil. These boxes and baskets are made of heavy galvanized iron, neatly painted green, guaranteed not to leak, and provided with eyelets to fasten securely or to hang. On account of our high altitude and dry atmosphere they are provided, especially for our trade, with larger sponges and reservoir than usually furnished.

With each box or basket we will furnish free a booklet containing practical suggestions for window or porch boxes, by Eben E. Rexford. Price List of Window Boxes.

No. $1, \delta$ in. high, $9 \frac{1}{2}$ in. wide, 23 in. long, each... \$1.85 No. 4,8 in. high, $9 \frac{1}{2}$ in. wide, 29 in. Iong, each... 2.30 Price List of Porch Boxes.

No, 21,9 in. high, 12 in. wide, 37 in. long, each....\$3.30 No. 22, 9 in. high, 12 in. wide, 41 in. long, each.... 3.70 Price List Inaging Baskets, including Hooks but no Chain. No. 8,6 in. high, 8 in. square, each..........\$1.25 No, 10,7 in. high, 10 in. square, each........... 1.50 No. $12, \delta$ in. high, 12 in. square, each.......... 1. 15 No. 14, 9 in. high, 14 in. square, each........... 2.00

NEPONSET PAPER FLOWER POTS.

Made of water-proof fabric. Are absolutely unbreakable. The cheapest pot on the market. $21 / 4$. size 1000 in in crate, weight 30 lbs.; per $100,55 \mathrm{c}$; per $1,000, \$ 4.50 ; 4-\mathrm{in}$. size, 500 in crate, weight 26 lbs.; per $100, \$ 1.00 ;$ per $1,000, \$ 8.75 ; 5-i n$. size, 500 in crate, weight 45

BARTELES, Po'T HANGERS, 2 links, 3 strands, each, postpaid, $10 \mathrm{c}$.

\section{PRICE LIST-STANDARD POTS.}

These prices include packing and delivering to railroad in this city.

\begin{tabular}{|c|c|c|}
\hline Inc & \multicolumn{2}{|c|}{ Pots. } \\
\hline 2 & ....\$.15 & $\$ .90$ \\
\hline 21 & $\ldots \ldots .20$ & 1.10 \\
\hline 4 & .30 & 1.5 \\
\hline 5 & .60 & 3.60 \\
\hline 6 & .75 & 5.00 \\
\hline 7 & $\ldots 1.00$ & 6.00 \\
\hline & $\ldots 1.25$ & 8.00 \\
\hline 9 & 1.50 & 11.00 \\
\hline 10 & 2.00 & \\
\hline
\end{tabular}

BULB OR FERN PANS.

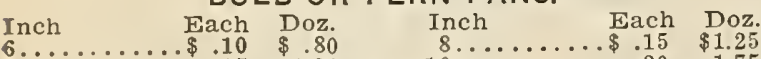

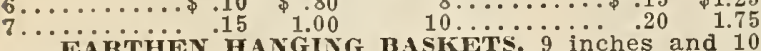

EARTHEN HANGING BASKETS, 9 inches and
EA If you want flower pots per 1,000 ask for latest prices.

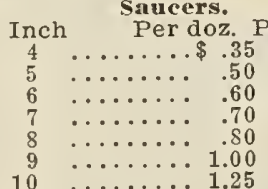

AZ AEA POTS

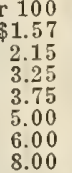

8.00

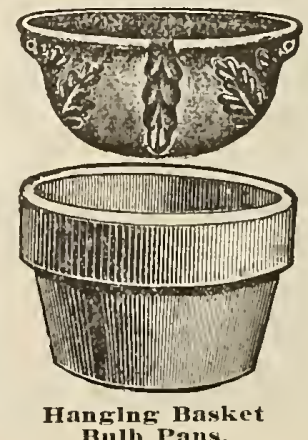

Hanglng: Basket Bulb Pans.
KRAMER'S POT HANGERS.

The neatest, simplest, most convenient and practical device for converting ordinary flower pots into hanging baskets. They fit all standard made pots from 2 to 10 inches across. Single set, $15 \mathrm{c}$; four sets for $50 \mathrm{c}$, postpaid.
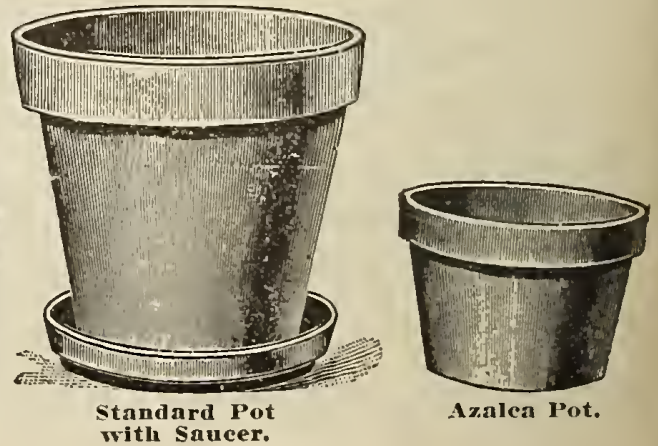

Axalea Pot. 
PLANT AND TREE TUBS.

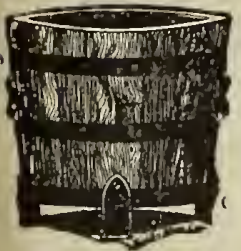

These tubs are made from what is known as Everlasting Cypress. A wood that is durable in resisting decay, yet not exceedingly heavy weight. The manufacturer is proud of the workmanship in finishing them neatly. Are painted green, the castings japanned.

When shipping two or more of a size the feet and bolts are packed inside to facilitate nesting.

CAHOON'S PATENT HAND SEED SOWER.

Fol sowing alfalfa; wheat, oats,

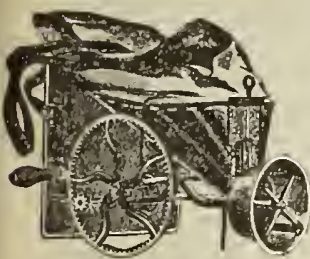
barley, rye, buskwheat, grass seeds, etc. The best machine of the kind in the market. The grain is held in a tight sheet-iron hopper surrounded by a bag which wil hold a bushel of seed. This is suspended by a strap from the operator's neck, and held in position by a strap around the waist. The seed is thrown from $\delta$ to 20 feet on each side of the operator, the heaviest seed being, of course, thrown the greatest distance. Price, $\$ 3.50$.

PREMIER BROADCAST SEED SOWER.

The frame of the machine, which carries all the bearing parts, is made of one piece of metal, thus assuring perfect and permanent alignment, This feature makes the Premier the easiest running machine on the market and prevents it from getting out of order. The seed is fed to the fan wheel through an adjustable slide, in such a manner as to insure even distribution. The slide can be closed instantly. The grain bag is supported by a strap thrown across the shoulders. The Premier will sow any seed that is sown broadcast, such as oats, wheat, rye, barley, flax, millet, clover, timothy, grass seed, etc. Price, $\$ 1.25$.

\section{ROYAL WHEELBARROW CHAIN FEED SEEDERS.}

They run easily and sow evenly in windy weather. The quantity of seed sown is accurately governed by the wheel, which is made of steel, 32 inches high with a tire $1 \frac{1}{4}$ inches wide by $1 / 4$ inch thick. The seeder is instantly thrown out of gear by a lever and the quantity of seed sown is quickly governed by. changing the pin in the index plate.

No. 11. Single Hopper Seeder sows all small seeds, like clover, timothy and alfalfa. With hopper, $14 \mathrm{ft}$ long. Price, $\$ 8.50$. No. 12. Double Hopper Seeder, $14 \mathrm{ft}$. long, like orchard grass, fescue, etc. Price, $\$ 9.00$.

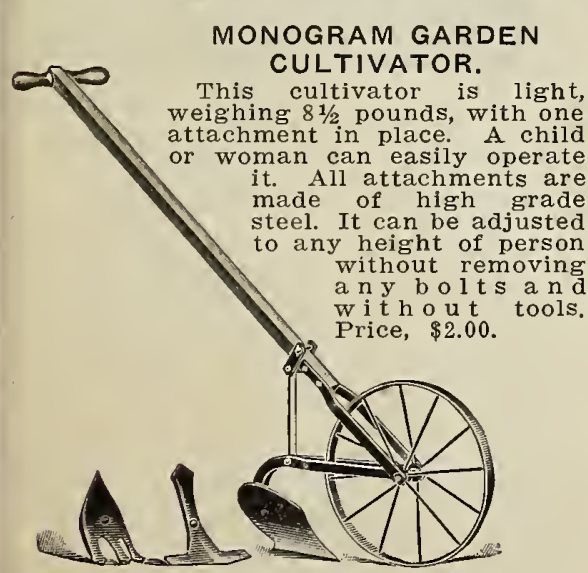

Monogram Cultivator.

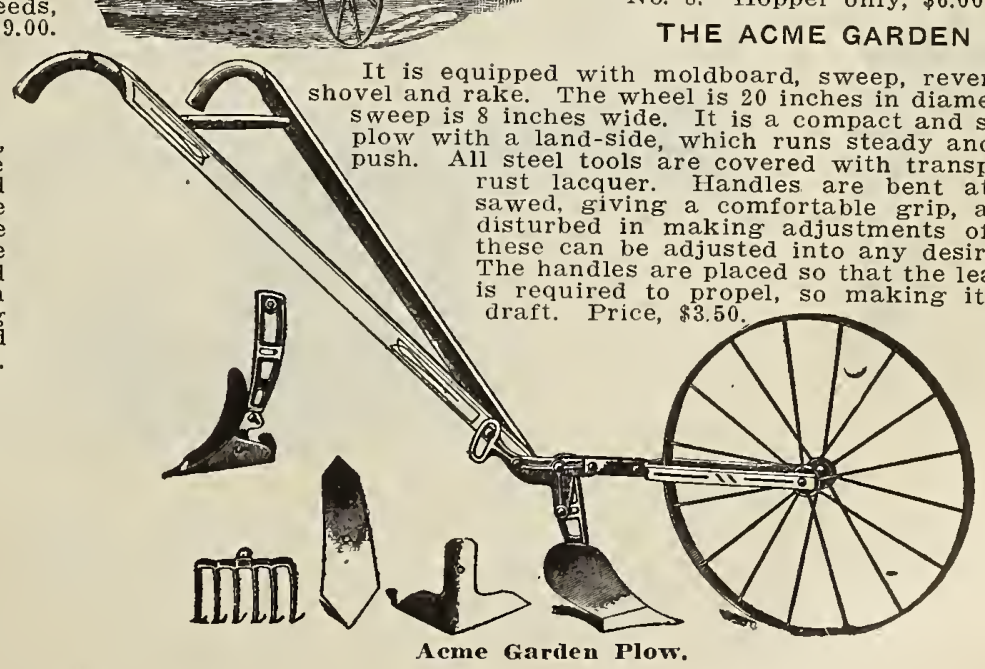

This handy little garden drill is de-

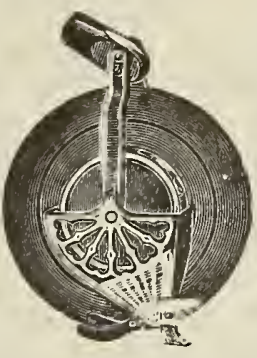
signed only for small plats of ground, hot-beds, etc., and, of course, is not expected to be used for extensive planting, like the large drills. Customers ordering same will please remember this, and that for such a low price a drill of any size could not be offered. However, for the purpse it is intended, it fills the bill all right, and we feel confident our customers will not be disappointed in placing orders for this valuable little drill. You can get close up to the sides of your hot-bed with this drill and save the annoyance of filling in by hand the ends of rows as occurs with other machines. Price, each, $\$ 1.25$.

\section{CYCLONE SEEDER}

It lias its right side concave in shape and rests nicely against the body just above the hip. The crank shaft being above the distributing whe el brings both hands to nearly a level and gives the operator the easiest position possible. It sows evenly all kinds of grass seed, grains and fertilizers. Clover is thrown a width of 18 ft.; timothy, $15 \mathrm{ft}$. alfalfa, $20 \mathrm{ft}$; wheat $25 \mathrm{ft}$; oats, $18 \mathrm{ft}$. millet, $18 \mathrm{ft}$. An operator can sow from 40 to 50 acres per day. Price, $\$ 1.50$

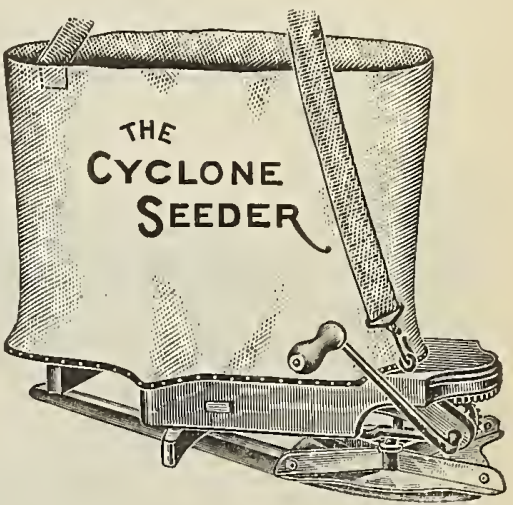

THOMPSON'S WHEELBARROW GRASS SEEDER. For All Kinds of Grass Seed. No. 8. For sowing Brome grass, clover, timothy, millet, alfalfa, etc To, complete, $\$ 10.00$.

o. 8. Hopper only, $\$ 6.00$.

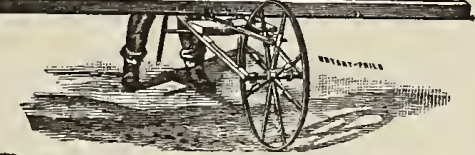

\section{THE ACME GARDEN PLOW.}

r . 


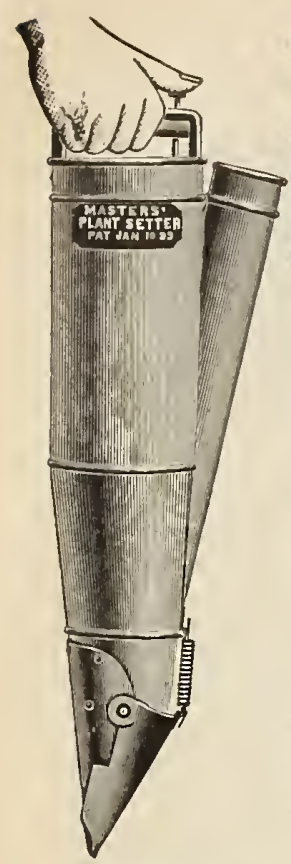

Master Plant Setter.
HAND PLANTERS.

For Planting Corn, Beans and Kafir Corn.

Aeme works in any soil; has a flexible and adjustable iron drop, also an iron seed box and iron channel. The foot is made of polished steel. It is well made, strong, durable, reliable and gives universal satisfaction. Price, $\$ 1.00$.

The Acme Rotary. Price, $\$ 2.00$

"Diamond" Improved Rotary. Has rotary drop. Three seed plates with seven chamber each. Works perfectly. When wanted for planting Kaffir corn please mention in order A disk with special size holes is required. Price, $\$ 1.25$.

\section{EUREKA TUBULAR POTATO PLANTER.}

A very handy tool with jaws of crucible steel, points polished. Galvanized iron taper conveying tube,

\section{Improved} A cme. natural finish. Handle well braced, smooth and comfortable. Planter finished in black Japan. Height, 36 inches, Price, \$1.25.

\section{MASTER PLANT SETTER.}

A man with one of these plant setters can plant more than 3 men can set by hand. Don't wait for showers, but keep the planter going every day, regardless of the weather and by using liquid fertilizer instead of pure water you will produce the best stand of plants ever seen. No stooping, no more backache. Two barrels of water and a setter will insure a perfect stand of plants, rain or no rain. Price, $\$ 4.00$.

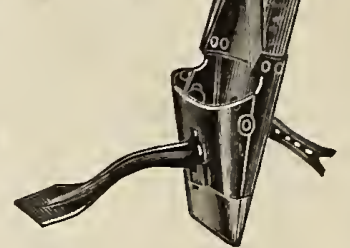

Eureka Potato Planter.

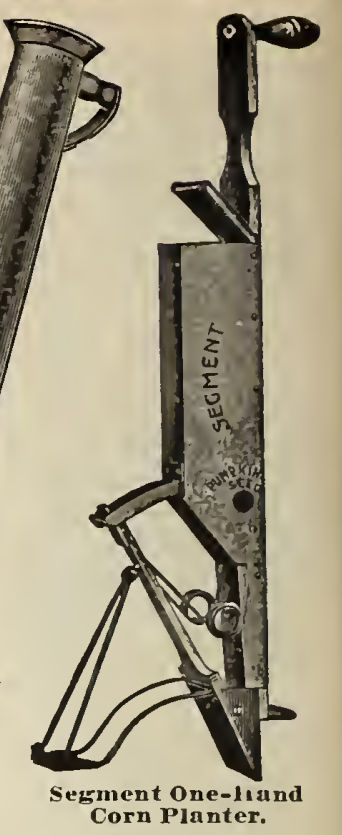

\section{SEGMENT "ONE-HAND" CORN AND BEAN PLANTER.}

Never cracks a Kernel nor Skips a Hill.

The seed pocket can be sufficiently enlarged to perfectly adapt it for planting the largest field beans as well as corn. The seed box and hopper are of galvanized iron. All of the wriking parts are stamped out of sheet steel and are therefore extremely light, strong and accurate. Price, \$1.50.

THE CLIPPER GRAIN AND SEED CLEANER.

Clean your grain thoroughly before taking it to market with a Clipper. You will save the price of a machine in a very short time. We use several in our warehouse and heartily recommend it. Is adaptable for cleaning all classes of

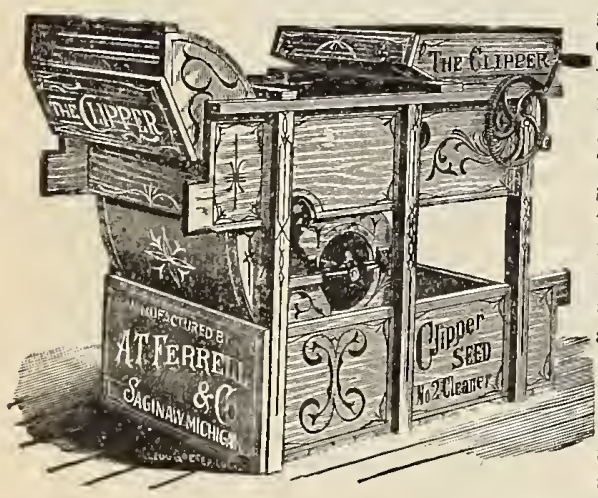
grain or seeds, such as wheat, corn, oats, barley, rye, beans, peas, buckwheat, millet, clover, alfalfa, timothy, fiax, etc., and is suitable for farm or general use. Unlike other mills, the "Clipper" cleans all classes of seed and grain thoroughly in one operation, without any waste, and leaves no tailings to be rehandled. Effectual separation of plantain from clover seed is accomplished, removing all imperfect and foreign seed therefrom, as well as cleaning the perfect seed.

No. 1. Farm size, with 10 screens, complete, $\$ 23.00$. No. 2. Warehouse size, $\$ 33.00$. For larger sizes ask for special catalogue of Clipper Machines.

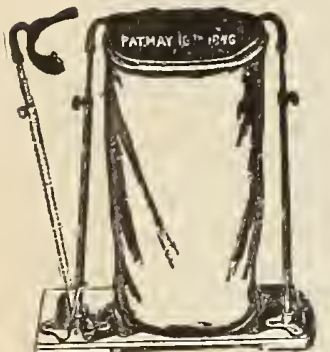

Monher bag Holder.

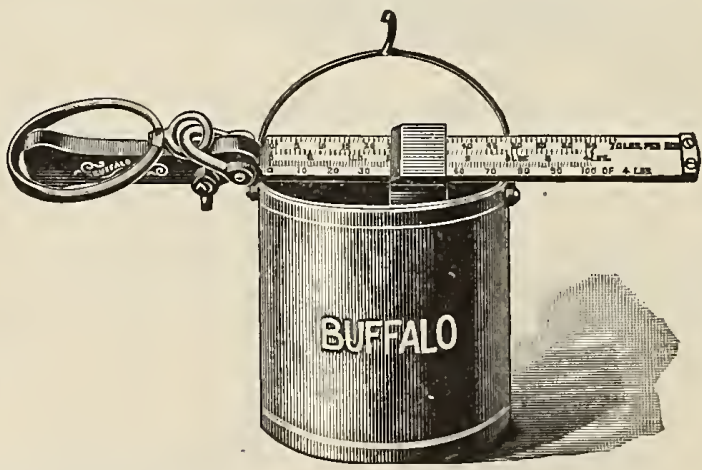

GRAIN SCALE TESTERS.

One quart size, price. Two quart size, price.

\section{REPAIRS AND EXTRAS FOR CLIPPER GRAIN AND SEED CLEANER.}

Screens for No, 1 Mill, wood frame, each, $\$ 1.35$.

Screens for No. 2 Mill, wood frame, each, $\$ 1.50$.

Large cog wheel without crank, each, $\$ 1.25$.

Small $\operatorname{cog}$ wheel for No. 1 or 2 Mili, each, $30 \mathrm{c}$.

Handles for crank, $35 \mathrm{c}$.

Stool for large cog wheel, 50c.

Fan arm casting, No. $107,60 \mathrm{c}$

Fan journal casting, No. 109, $70 \mathrm{c}$

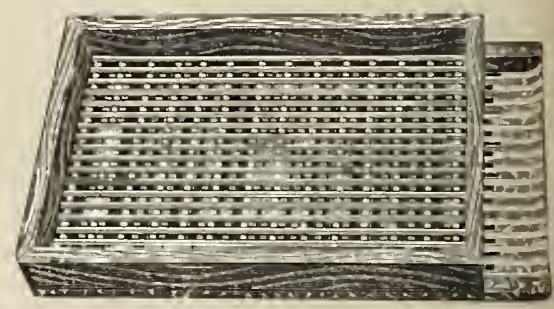

\section{PERFECTION SEED CORN GRADER}

The perfection is admitted by all to be the most simple, practicable, and efficient device ever made for grading seed corn. It is now used by Experiment Stations and thousands of farmers all over the country. It is most RAPID and ACCURATE, grading perfectly 1 bushel in \& minutes.

This Double Screen Grader gets four grades of corn just as it comes from the ear. Viz., 1st, the large, odd shaped kernels; 2nd, the even, perfect kernels; 3 rd, the small kernels; 4 th, the flat kernels that are too thin for seed. Price, $\$ 1.50$.

Holds firmly bags of various lengths. Weight 25 lbs. Price, \$3.75.

$\$ 14.00$

THE MOSHER BAG HOLDER. 


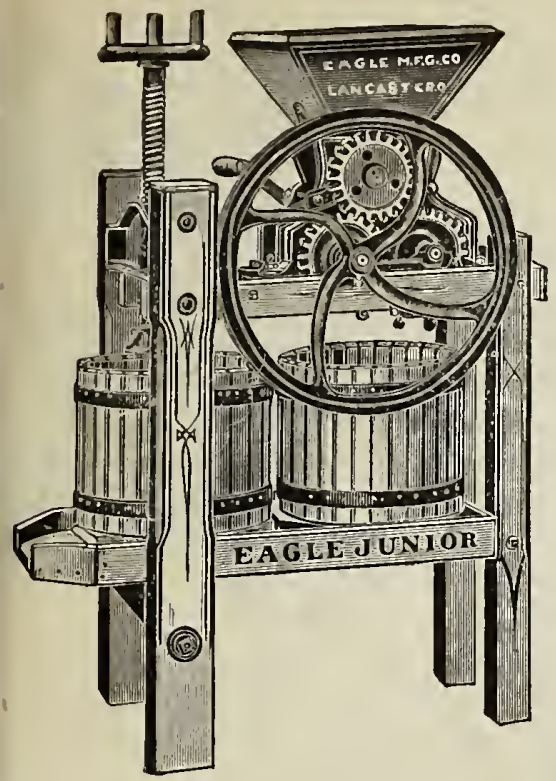

\section{CIDER MILLS}

Our mills have adjustable crusher, large tubs, slats are firmly riveted and run easily. These mills will produce fully 25 per cent more cider from same quantity of apples than any other style of mills. The mills crush the fruit thoroughly and the press extracts every drop available.

\section{Three Sizes:}

Junior, 2 tubs, 1 crank (see cut) Price. .............

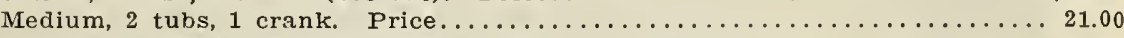
Senior, 2 tubs, 2 cranks. Price..................................... 28.00

\section{BANNER ROOT CUTTERS}

For Cutting All Kinds of Roots for Stock Feeding.

No. 15. Hand and Power, same size and capacity as No. 20 . Weight, 135 lbs. Price, $\$ 14.00$.

No. 16. This machine can be used for hand or power, and it is the only cutter having a balance wheel. It is also supplied with a pulley for belt power, and a crank so it can be used by hand; in fact, it is a small size power cutter, and the best machine for hand and power use. It runs easily by hand. This cutter has the selffeeder and dirt separator.

The Pulley is 12 inches in diameter, with a 3-in. face, and fastens to either end of shaft. It has lugs on bottom of legs so it can be fastened to the floor.

Capacity when run by hand, 30 to 50 bushels per hour. Capacity when run by power, 1 to 3 bushels per minute. Weight, 150 pounds. Price, complete, $\$ 20.00$.

No. 10. Largest Power Cutter; capacity 5 to 7 bushels per minute. Weight, 340 lbs. Price, $\$ 30.00$.

Banner No. 7-The Poultryman's Friend. Just the thing to cut beets, turnips, carrots, etc., for all kinds of poultry.

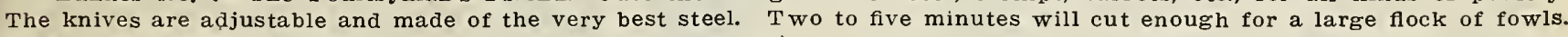
Weight, 50 lbs. Price, $\$ 5.00$

No. 20. It is the most rapid cutter ever invented. It cuts everything in thc root and vegetable line readily into long,

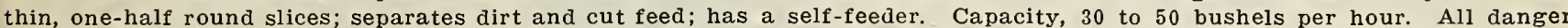
of choking completely obviated by this machine. Weight, 120 lbs. Price, $\$ 12.00$.
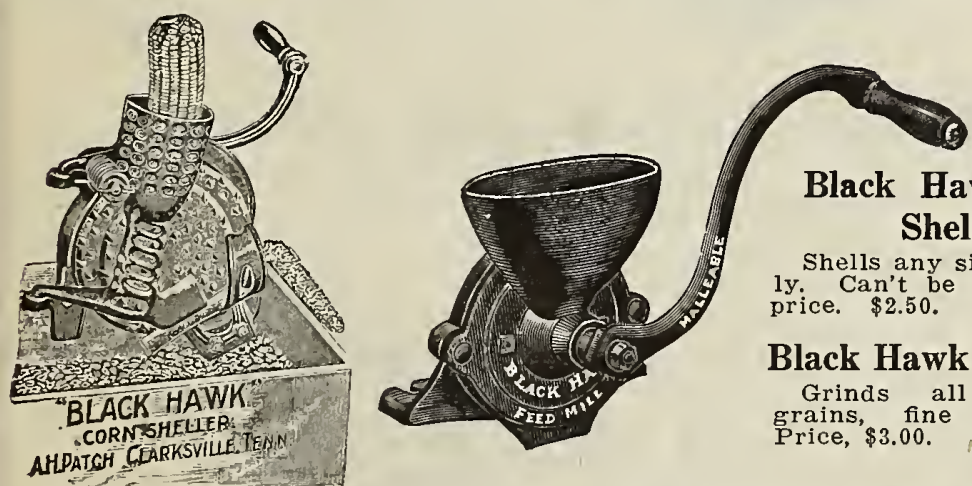

\section{Black Hawk Corn} Sheller

Shells any size thoroughly: Can't be beat for the price. $\$ 2.50$.

Black Hawk Feed Mill Grinds all kinds of grains, fine or coarse.

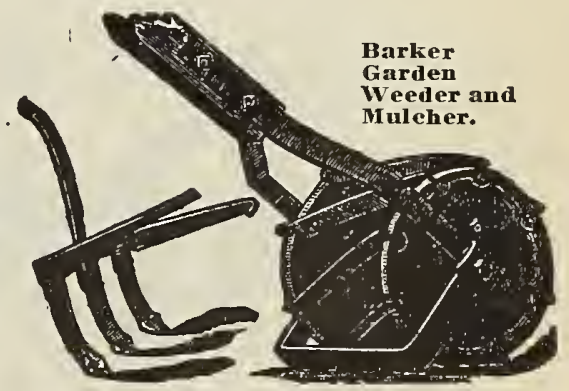

\section{Barker's Garden Weeder}

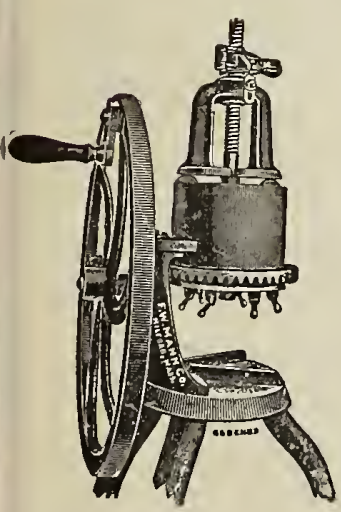

Mann's No. 7 .

The Barker Garden Weeder and Mulcher operates on the plan of a lawn mower The rear blade or knife passes beneath the surface of the soil and the revolving blades pass over it cutting the weeds of the soil and the revolving blades pass over it, cutting the weeds off, and chopping them up so that they soon dry up and die. It will
not work when the weeds are a foot or two high, but it will work successfully in any garden kept the way a garden should be kept. The tool is 8 inches in width and weighs about 15 pounds. Price, $\$ 5.00$

\section{MANN'S BONE CUTTERS.}

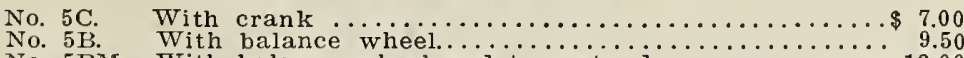

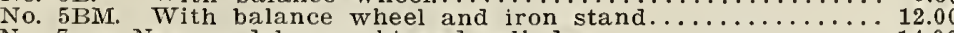

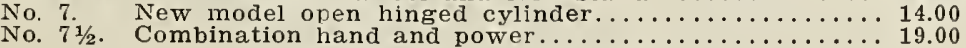

\section{MANN'S CLOVER CUTTER.}

Iade Entirely of Iron and Steel. Cannot Warp or Shrink.

It cuts any kind of hay or clover, either dry or green, very rapidly. Every revolution of the balance wheel produces twelve cuts, Price, complete, $\$ 11.75$; without iron legs, can easily be fastened to a stand or to a table, 9.25 .

We can furnish other sizes of Mann's machines to those who wish them. Ask for special catalogue.

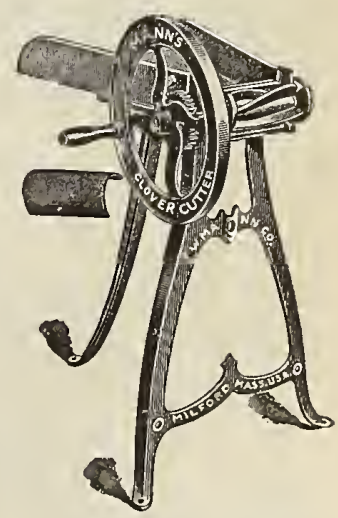

Mann's Clover Cutter.

Barteldes Recleaned Field Seeds are best adapted for Dry Farming. They are not only the best grade that money can buy; but are recleaned by us through the best up-to-date cleaning machines. Buy Barteldes "Columbine" grade. 


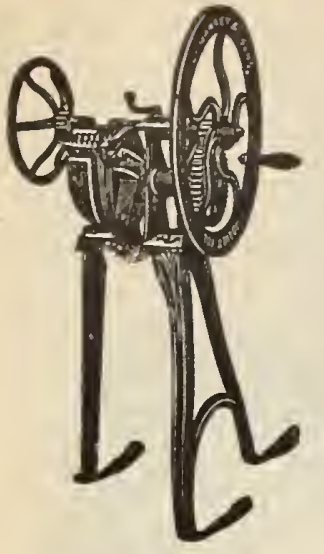

Humphrey's Green Bone Cutter.

\section{HUMPHREY'S CLOVER CUTTER.}

Built by the same people who manufacture the Humphrey Bone cutter. This is sufficlent recommendation to commend it to all. Price, without legs, weighs 85 lbs., $\$ 9.50$; with legs, complete, $\$ 12.00$.

\section{THE HUMPHREY GREEN BONE AND VEGETABLE CUTTER.}

Sold on a positive guarantee to cut more bone in less time anol with less labor than any other bone cutter made.

The Iumphrey Green Bone and Vegetable Cutter is offered our customers with the assurance that it is the best machine of the kind made today. We recommend it only because we feel that it will give perfect satisfaction. It runs so easily, works so rapidly, that it easily ranks first of all bone cutters. We do not feel that we are called upon to point out the advantages of green cut bone, or to dwell upon its value. That is conceded by every poultryman In the "Humphrey" they will find theh machine they have been looking for. It works to perfection. It will pay for itself in a few months' time, at any season of the year. It cuts any bone; also roots, etc.

No, 1 weighs 120 lbs., hand power only, \$13.00. No. 2 power only, \$14.50. No. 2 1/2 weighs 135 lbs., hand and nower, \$16.00.

THE HUMPHREY GRIT CRUSHER.

Hens must be supplied with some form of grit, and there are few places in our country where you do not find glistening granite boulders, flint or hard rock, which can be readily reduced into a satisfactory grit.

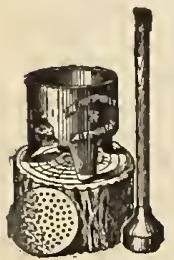
The Hunphrey Grit Crusher is a circular mortar, 9 inches in diameter and 11 inches high, with a removable perforated bottom. Wlth one of them you can break enough grit in half an hour to last your fowls several weeks, and the material costs you nothing. Price, $\$ 4.00$. Weighs $40 \mathrm{lbs}$.

\section{We handle a full line of Humphrey Bone} Cutters, Ask for Catalog.

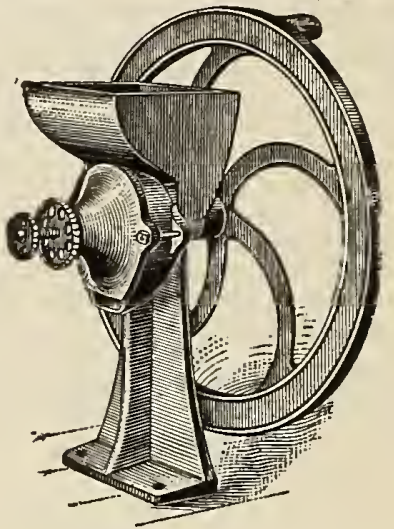

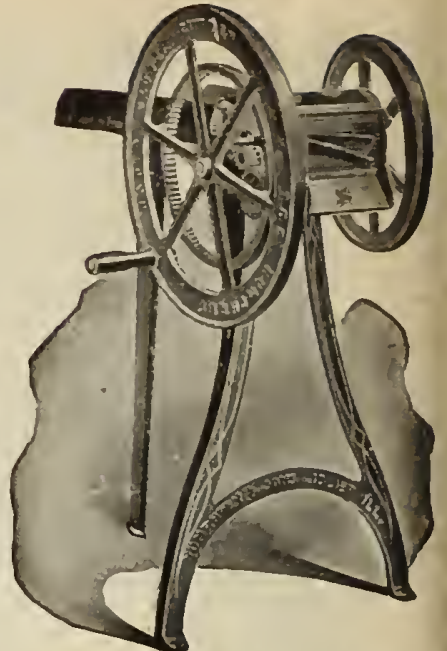

Ifumphres's clover Cutter.

No. 32 HAND GRINDING MILL.

This machine grinds fine or coarse, oats, barley, rye, corn, peas, dry bone, shells, etc., for feeding to poultry. it is a well designed mathroughout and of excellent finlsh: has a 16-inch fly wheel and is light running.

The capacity of this mill is not equalled by any other of the same size. Price. $\$ 5.00$

Shipping weight, 40 pounds. Capacity, 1 or 2 bushels per hour.

No. 35 HAND GRINDING MILL. This mill is similar to No. 32 , but is run either by hand or power. When run by power the capacity is 3 to 4 bushels per hour. Price, $\$ 8.00$. shipping weight, 60 lbs.

\section{PLANET JR. GARDEN AND FARM TOOLS}

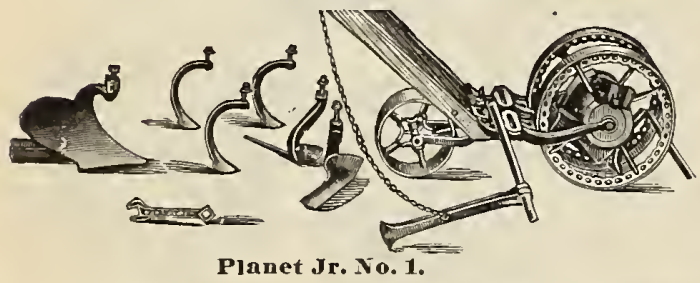

No. 1 COMBINED DRILL SEEDER, WHEEL AND PLOW.

This is a popular combined tool. As a seed sower, it is the same as No. 2 Drill Seeder, but smaller, holding 3 pints. From a drill it is changed to its other uses by removing 2 bolts, when hoes, etc., can be attached. It is an excellent seed sower, a first-class wheel hoe, an excellent furrower, an admirable wheel cultivator, and a rapid and efficient garden plow. Weighs 44 pounds.

Price, with toois as shown, \$9.50; with pair rakes, $\$ 10.25$.

No. 2 DRILL SEEDER.

Similar to No 1 Combined, except the seed hopper is larger, holding three quarts, and machine has no cultivator attachments. Weighs 38 lbs. Price, \$7.50.

No. 3 HILL AND DRILL SEEDER.

It sows evenly in drills, and also drops in hills, at 4, 6, 8. 12 and 24 inches apart. It is thrown out of gear instantly by moving a convenient lever; or the flow of seeds is stopped by pushing down the feed rod. No time is lost; no seed is wasted. It is quickly set to sow different kinds of seed in the exact thickness desired. It covers and rolls down light or heavy, and marks the next row clearly. Holds three quarts. Weighs 46 lbs. Price, \$10.50.

No. 4 IMPROVED COMBINED HILL AND DRILL SEEDER, WHEEL HOE, CULTIVATOR AND PLOW.

This admirable tool combines in a single convenient implement a grand hill-dropping seeder, a perfect drill seeder, a single wheel hoe, a cultivator and a plow. It holds two quarts, and as a seeder is like the No. 3 , sowing in continuous rows, or dropping in hills at five different distances.

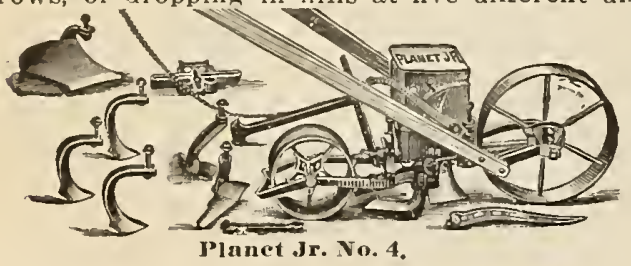

It is useful almost every day of the season, at every stage of garden work. With this one implement the small farmer can do practically all the work in his small crop. Weighs 47 lbs. Price, with tools as shown, $\$ 11.00$; with rake, $\$ 12.25$.

No. 4, Plain Drlll only, no attachments (parts cannot be added except at extra expense.) Weighs 38 lbs, Price, \$9.00.

When ordering be careful to designate whether "Combined" or "Plain." 
PLANET JR. GARDEN AND FARM TOOLS-Continued.

\section{No. 5 HILL AND DRILL SEEDER.}

It is quite identical with No. 3, except its large hopper, capacity 5 quarts, and has drive wheel $161 / 2$ inches in diameter. The machine is built slightly heavier, weighing 51 lbs. Prlee, \$13.00.

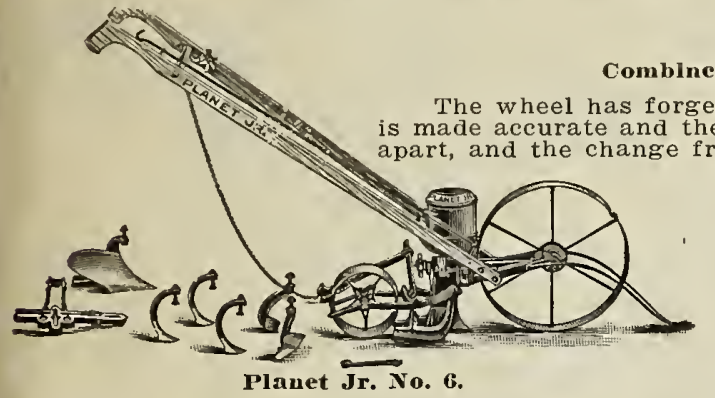

\section{No. 6 PLANET JR.}

omblned Hill and Drll Seeder, Wheel Hoe, Cultivator and Piow.

The wheel has forged steel spokes, is $16 \frac{1}{2}$ inches high, and is most substantial. The feed is made accurate and the hill dropping device is made of steel. It drops $4,6,8,12$ and 24 inches

The wheel can be changed to five different distances and it takes less than a minute to make the change. The index is a new design, easily adjusted by means of an accurate thumb-screw. The cut-off is within easy reach of the thumb and fore-finger of the right hand. The opening plow is narrower than on other drills and the coverers have sufficient opportunity to swing to adjust themselves to all inequalities of the ground. The roller is wide and hollow-faced and has a scraper on its rear to return at once, to their proper place, the seeds and wet soil aahering to it. The handles adjust to a man's or boy's height. Weight, packed, $58 \mathrm{lbs}$. Price of the machine, complete, \$13.50.

This machine can also be furnished as a hill and drill seeder plain. Weight, 50 1bs. Price, \$11.00.

No. 36. The same machine, rigged as a single wheel hoe, cultivator and plow, only. Weight, 33 ibs. Price, \$6.25.

\section{No. 21 COMBINED HILL AND DRILL SEEDER AND FERTILIZER DRILL.}

This Seeder, in addition to planting all kinds of garden seeds in rows, or in hills, 4 , 6 , 8 , 12 or 24 inches apart, will

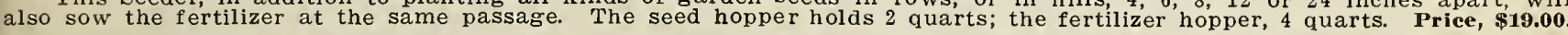

\section{No. 25 COMBINED HILL AND DRILL SEEDER AND DOUBLE WHEEL HOE, PLOW, ETC.}

Thls tool comblnes the most practical features of the No, 4 Drll and No. 12 Double Wheei Hoe.

As a Drill it is almost identical with the "Planet Jr." No. 4 Drill; will sow in drills and hills, $4,6,8,12$ or 24 inches apart, and has the same automatic device for throwing out of gear, and the new combined cut-off and seed index with thumb screw adjustment. It is thoroughly substantial and accurate in sowing all kinds of garden seeds in either hills or in drills.

As a Wheel Hoe it is identical with the "Planet Jr." No. 12 Double Wheel Hoe, the very best machine on the market. The change from Drill to Wheel Hoe takes but a moment, and entire combination is one we can heartily recommend and guarantee satisfactory. Weighs 59 lbs. Price, \$13.50.

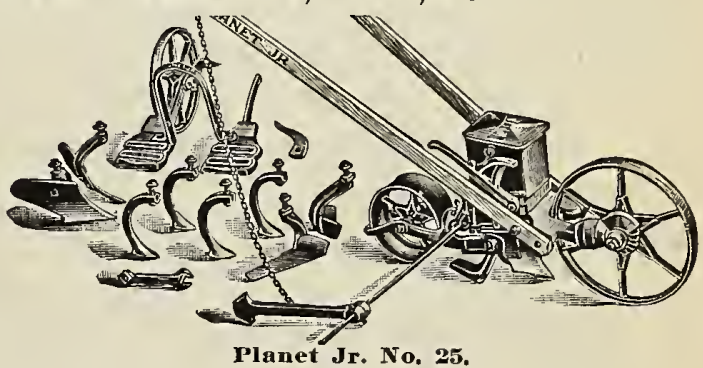

No. 12 DOUBLE WHEEL HOE, CULTIVATOR AND PLOW.

The number of different kinds of work done by this one tool is marvelous, and all are done in the most perfect manner. The teeth are changed with the greatest ease and quickness, without taking the nuts from the standards. The wheels may be set at four different distances apart; the frame at three heights. The handles are adjustable in height to suit man or boy. For rapid and perfect work it's the most money-making tool a farmer can own. Weighs 32 lbs. Price, with toois as shown, $\$ 7.00$.

No. 11 is the No. 12 with addition of Rakes and extra pair short Scuffle Hoes. Weighs 37 lbs. Price, \$9.00.

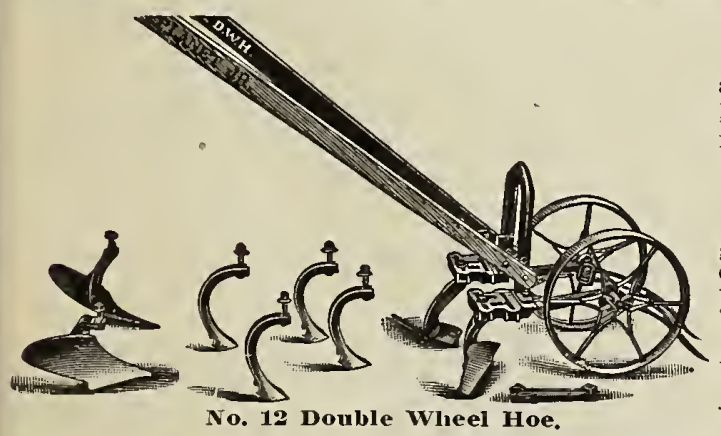

No. 13 DOUBLE WHEEL HOE.

A high arch with only a pair of 6-in. hoes-the most useful tool of any. Unquestionably an onion grower gets more services from this low priced tool, for the ainount invested, than of any tool we can offer. Double Wheel Cultivators are economical of time by working astride the row. Weighs 28 lbs. Price, \$4.75.

\section{SINGLE WHEEL HOE, CULTIVATOR AND PLOW.}

These tools have all the latest improvements offered in "Planet Jr." goods. The handles are adjustable in height. The wheel can readily be changed in height and from one side to the other of frame. The cultivator teeth, hoes, plow, etc. are of high carbon steel, finely finished and vator teeth, hoes, plo

No. 16 has a leaf guard, one 7 -in., one 4-in. rake, three cultivator teeth, two scuffle hoes and one plow. Weighs 29 lbs. Price, \$5.85.

No. 17 has one pair scuffle hoes, 3 cultivator teeth and one plow. Weighs 26 lbs. Price, \$5.00.

No. 171/2. Same as No. 17, except have omitted the plow and added a

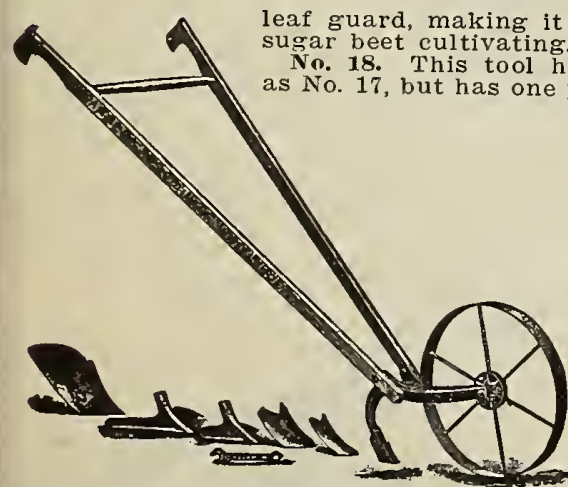
guard, making it an excellent tool for onion and
Weighs 22 lbs. Price, \$4.50. gar beet cultivating. Weighs 22 lbs. Price, \$4.50. as No. 17 but has one pair of 6 -in. hoes only-the tools that are most constantly useful throughout the season. All the other tools Weighs 20 lbs. Price, \$3.50.

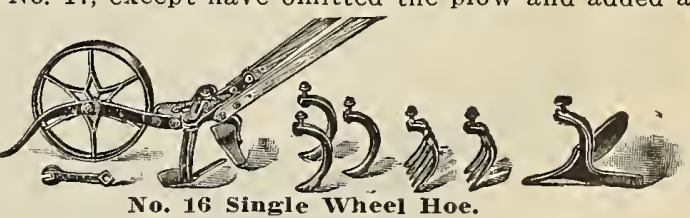

FARMER'S No. 19 WHEEL HOE.

The wheel is high and is made with stiff steel rim and spokes, and a combination steel and malleable iron hub. The wheel arms are steel and the frame of the tool is attached adjustably to the wheel arms, so that the height of the handles may be readily changed to suit man or boy.

The standard is slotted to make regulation of depth easy, and by means of an adjustable malleable filling piece, the same standard is made to carry all the steels that come with the machine.

The parts furnished with this tool are: A large Garden Plow, one 10-in. Sweep, one 6-in. Sweep, one 4-in. Cultivator Tooth, one 2-in. Cultivator Tooth. Weighs only 22 lbs. Price, \$3.75. 


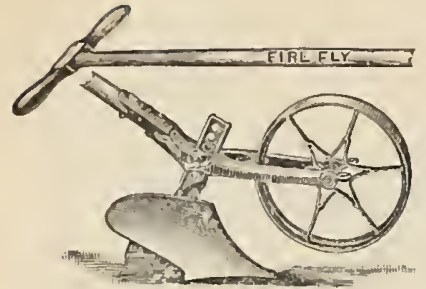

Fire-Fly Garden Plow.

\section{PLANET JR. GARDEN AND FARM TOOLS-Continued.}

No. 38 SINGLE WHEEL DISC HOE, CULTIVATOR AND PLOW.

With tools as shown in illustration. Weight, 29 lbs. Price, $\mathbf{\$ 7 . 0 0}$.

No. 18 $1 / 2$. Same style as No. 38 , less cultivator teeth and plow. Weighs 23 lbs. Prlce, \$4.75.

\section{THE FIRE.FLY GARDEN PLOW.}

This tool is the most useful in small gardens, opening furrows for manure or secd, and covering them quickly. When

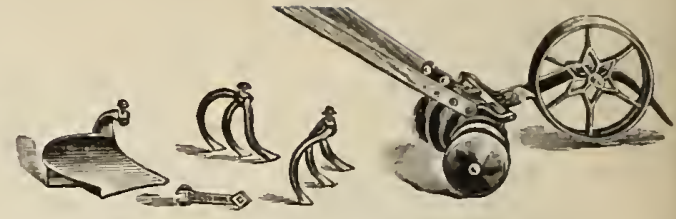

No. 35 Slngle Wheel Dlse Hoe, Cultivator and Plow.

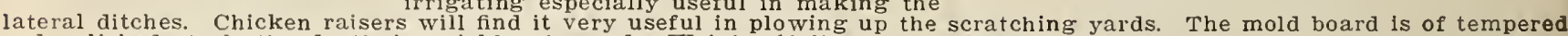
and polished steel; the depth is quickly changed. Weighs 13 lbs. Price, \$2.35.

\section{EXTRAS AND PARTS FOR PLANET JR. HAND TOOLS.}

Double Moldboard Plow, fits Single Wheel Hoes, also No. 1 and No. 4 Combined Drills.......\$1.25

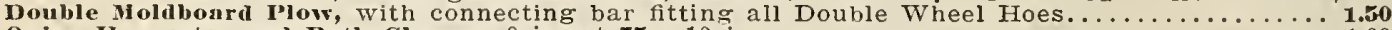

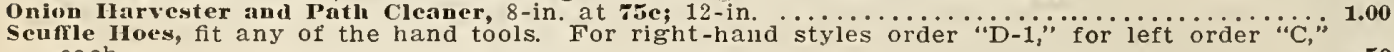

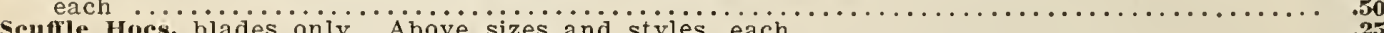

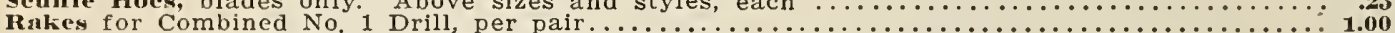

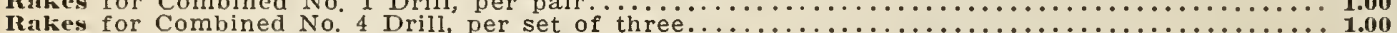

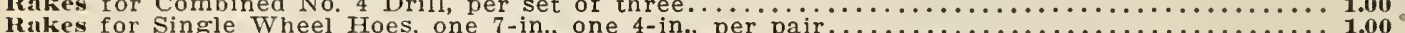

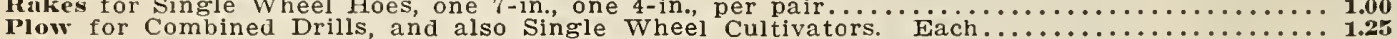

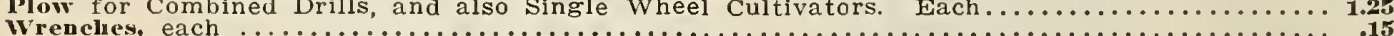

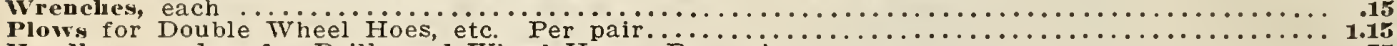

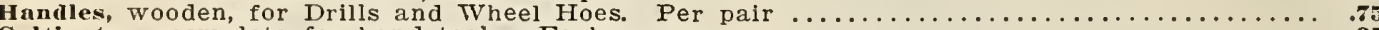

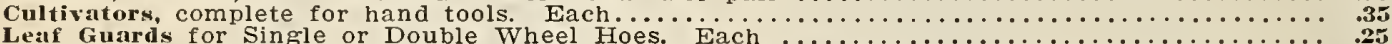

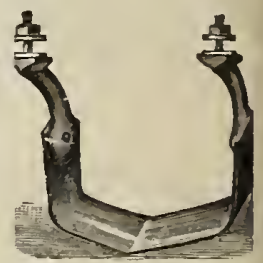

Onion Harvester.

For other parts and extras write us, and if possible designate by "number" stamped on part wanted.

\section{THE PLANET JR. NO. 8 HORSE HOE AND CULTIVATOR.}

Probably no other cultivating machine is so widely known as the "Planet Jr." Combined Horse Hoe and Cultivator, for it is in use throughout the civilized world. It is so strongly built as to withstand incredible strain, yet it is light and easy to handle.

The Frame is long and high, making a tool that will not clog easily.

The standards arc formed up hollow with round throats of stiff steel; they polish quickly and free themselves readily from obstructions; they clasp the frame and strengthen it.

The Depth is under perfect control by means of a new lever wheel and the new patented depth regulator, which are moved instantly in unison by a single lever, making exact work, steadying the machine and relieving the operator.

The Expander. This is an entirely new pattern, superior to all other forms; exceedingly strong, simple, accurate and positive in all positions.

The Reversible Side Iloes, patented, are an important part of the implement. They act as plows for hillers, or as a horse hoe, working so close that an immense amount of hand labor is avoided. Every part is perfected to make the tool acceptable to the farmer, who knows the best is the cheapest. Weighs 82 lbs. Price, \$9.00.

No. 7. Same as illustrated, except no depth regulator. Weighs $77 \mathrm{lbs}$. Price, \$s.50.

No. 1. Same tool without depth regulator, and a plain wheel instead of lever wheel. Weighs 72 1bs. Prlce, \$7.75.

No. Plain Cultivator. Fitted with five cultivator teeth only. With lever spreader and plain wheel. Weighs 64 lbs. Price, \$7.25.

To. 4 Plain Cultivator. Has plain cultivator teeth only, with a stirrup clamp instead of lever spreader and plain wheel. Weighs 57 lbs. Price, \$5.25. No wheel, weighs 49 lbs. Price, \$4.50.

No. 5 Horse Hoc and Cultivator has a lever spreader, but no depth rcgulator and side braces. Has plain wheel. Weighs 69 lbs. I'rice, \$7.75.

\section{PLANET JR. DOUBLE AND SINGLE CELERY HILLERS.}

CELERY HILLERS are now considered indispensable in celery growing. The leaf lifters are adjustable in height, and are especially valuable for first workings. With them some of our best and largest growers hill their celery without any handling. We equip both with lever expanders and leaf lifters. The double hiller only is fitted with lever wheels. The hilling blades are 43 inches long, adjustable in width or height as wanted, the double machine works all rows up to 4 feet apart. The single works all widths, and where market gardeners plant close and first bleach every other
row, it is "just the thing." It is also excellent help for burying the crop. Before hilling, row, it is "just the thing." It is also excellent help for

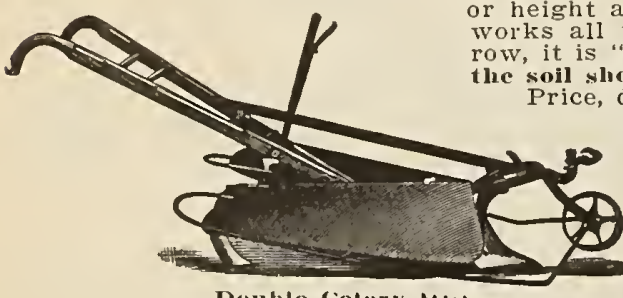

Double celery thise.
"PLANET JR." POTATO DIGGER.

It works well either in green vines or ripe, and does excellent work even when the crop has become very weedy. The tines on the mold board tear the furrow apart and the digging tines complete the work, leaving the potatoes spread on the surface. It is entirely unnecessary to leave every potatoes spread on the sirface. It is entirely unnecessary to leave sicery weight, $123 \mathrm{lbs}$.

"PLANET JR." HILLING ATTACHMENT.

This special Hilling Attachment fits any of our Planet Jr. Horse Hoes, and is very effcctive. Sold either complete, or as an attachment to regular Planet Jr. Horse Hoe.

Price, complete with Horse Hoe, \$9.00. Attachmen alone,

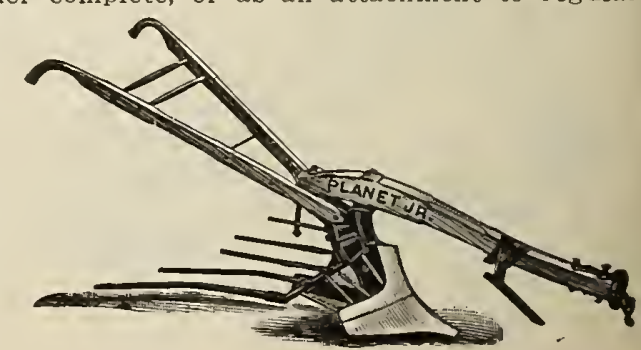




\section{PLANET JR. TWELVE TOOTH HARROW AND CULTIVATOR.}

It has a high frame and the chisel shape teeth can be cut an inch wide each. It may be set with teeth trailing. The foot lever pulverizer is a capital addition for preparing ground for the seed drill or for plant setting. Hand levers regulate both width and depth while in motion; it contracts to 12 inches, and may be further reduced in width by taking off the outside teeth; it expands to 32 inches. It cultivates deep without throwing earth upon the plants, and the smooth, round, throated teeth turn strawberry runners without injuring them.

Price, complete as illustrated (weighs 74 lbs.), $\$ 9.00$.

Same without Pulverizer attachment, \$7.40.

Same without both Wheel and Pulverizer attachment. Plain, $\$ 6.20$.

Strawberry Runner Cutter Attachment is a 10 -in. disc mounted on an out-rigger, and fits above Harrow. Price, \$1.85.

Special 18-in. Sweep wlth Standard, made expressly to fit 12-tooth harrow when pulverizer is taken cff. This combina tion makes sure destruction of all weeds in its path. Price, $\mathbf{\$ 1 . 3 5}$.

\section{No. 3 PLANET JR. FOUR-ROW SUGAR BEET AND BEAN HORSE HOE AND CULTIVATOR.}

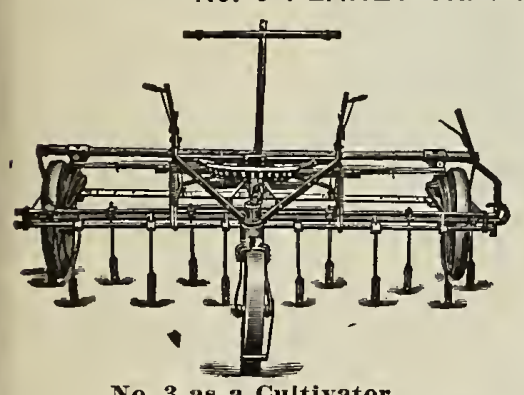

This magnificent tool hoes four rows at once, 18,20 or 22 inches apart, or three rows $24,26,28$ or 30 inches apart, or two rows 36 inches to 42 inches. Two levers, assisted by a powerful spring, control the depth to a nicety or easily lift the tool bars clear. For 1914 we supply a two-wheel seat rig in place of one wheel, for threerow cultivation. Additional price, \$12.50. The patent hoes have a down cut next the row and a plant shield; the curved shape allows the closest hoeing at the surface, while rounding away from the roots. The standard is set over away from the beet tops and the front of the hoe is a leaf guard. The wheels are changeable in width for all rows from 18 inches up.

Price, including thirteen $1 \frac{1 / 4}{4} \times 8$-inch cultivator teeth and five irrigation shovels and standard, four pairs 7 -inch beet hoes, five 5-inch improved sweeps, three 8-inch improved sweeps, \$90.00. Packed weight, 690 lbs. Less cultivator teeth, \$83.00. Less cultivator teeth and irrigation shovels, $\$ 80.00$. Packed weight, $600 \mathrm{lbs}$.

DISCS to use in place of hoes; price, \$3.25 per pair. Very much liked for early work. Can be used also to prepare ground for seeding, four or five on each side of centre.

\section{No. 41 PLANET JR. ORCHARD AND UNIVERSAL CULTIVATOR.}

Price, with two-tooth extensions, \$48.00. Packed weight, $487 \mathrm{lbs}$. With onetooth extensions, \$43.00. Without extensions, \$38.00. Packed weight, 383 lbs.

This is a modern orchard and universal cultivator, built to combine strength, lightness, adjustability and efficiency to the fullest extent in one tool, representing in itself the advantages of our earlier patterns, combined with important improvements.

The steel Wheels are low and entirely enclosed by the frame. Have twelve spokes instead of ten as heretofore.

The Tongue is Steel, hollow and of rectangular section.

The Frame is high carbon steel, compact in form, well braced, heavy and strong.

Without the Extenstions, it cuts 4 feet in width, having seven stiff steel standards, carrying $2 \frac{1 / 2}{2} \times 10$-inch teeth.

With the Extensions, it cuts 6 feet 6 inches, carrying eleven teeth, and the frame can be changed to cut any width from $6 \frac{1}{2}$ down to 4 feet.

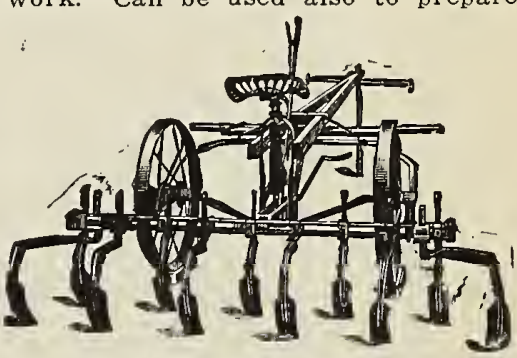

No. 41 orchard Cultivator.

Irrigation Steels, only per set of three, \$2.50.

We supply a set of ten dises and special standards as an extra.

Price, 16-inch, \$4.50 per pair, or \$20.00 per set. This makes a capital disc harrow, light in draft and under perfect control from a comfortable seat.

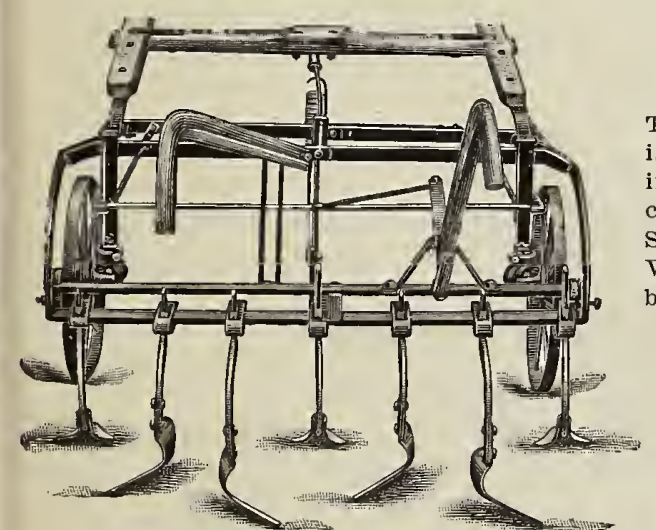

\section{No. 53 PLANET JR. PIVOT WHEEL TWO-ROW HORSE HOE AND CULTIVATOR.}

Packed Weight, 213 lbs.

This new two-row Cultivator is well built, strong and easily adjusted. The hoes do admirable close work and leave the ground level. The steering is done to perfection by the pivot wheel and hand lever. The wheels adjust in width. It works two rows, 16,18 or 20 inches apart. Price, plain, as in cut, \$22.50. With extra set of seven $11 / 4$-inch by 8 -inch Cultivator Teeth and Standards, \$25.00. Irrigation steels with special standards, set of three, \$5.00. We can also furnish a set of seven $13 / 4$-inch teeth with an adjustable leveling bar for $\$ \mathbf{\$ 3 . 0 0}$ extra.

Special circular on application.

EXTRAS AND REPAIRS FOR PLANET JR. HORSE TOOLS. These Prices are F. O. B. Denver.

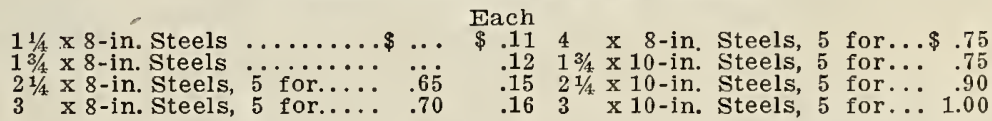

Each

$4 \times 10$-inch Steels, 5 for....\$1.15 6 -inch Side Steels, each.......... 7 -inch Side Steels, each............... 7 -inch Shovel Steels............... 8 -inch Shovel Steels............... Bolts Shovel Steels................

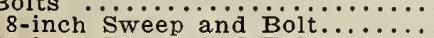
$10-$ inch Sweep and Bolt............. 12-inch Sweep and Bolt........... 15-inch Sweep and Bolt.

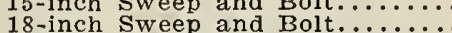

6-inch

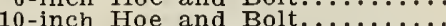

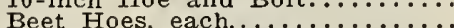

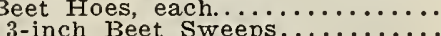

3-inch Beet Sweeps...........

5 -inch Beet Sweeps...........

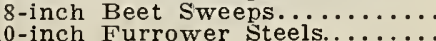

Each

$.55 \quad 15$-inch Furrower Steels.........

.65 20-inch Furrower with wings.

.50
.60 able point $\ldots \ldots \ldots \ldots \ldots \ldots \ldots$

.50

.25

.30

Ridging Steels $\ldots \ldots \ldots$

Hilling Attachment

Roller

Pulverizer.

Pulverizer for $\dot{H}$ arrow, special.
Each \$.17 .18

.22

Each $\$ 1.35$ 2.15 


\section{BEE SUPPLY DEPARTMENT}

when Bee supplies are wanted by mall add postage.

GOOD BOOKS FOR MEE-KEEPERS.

Amatenr Bee-Keever, 80 pages; price, $25 \mathrm{c}$, postpaid.

A. 13. C. of Bee Culture, by A. I. Root; $\$ 2.00$ postpaid; not postpaid, $\$ 1.75$

Iangstroth on thr Ironey Hee, revised by Dadant; $\$ 1.20$, postpaid; not postpaid, $\$ 1.00$.

Advanced Bee Culture, new edition, by Hutchinson; \$1.40, postpaid; not postpald, \$1.25.

Semi-lionthy Magailne-lbee Gleabings. Very helpful and interesting. Send us your subscriptions. $\$ 1.00$ per year.

DOVETAILED HIVE FOR COMB HONEY, $1 \frac{1}{2}$ and 2 STORY.

This hive is furnished either in eight-frame or tenframe size. It consists of a plain box of $\% / 8$-inch No. 1 white

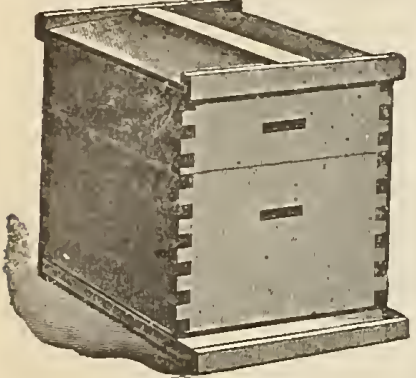
pinc, $137 \% \times 20$ inches outside measure, 93 inches deep, rabbetted $1 / 2 \times 7 / 8$ deep for frames to rest, with hand holes on outside. Eight or ten improved Hoffman frames, and follower board hang in this hive with a bee space above and below.

Folower board is cleated on the ends to prevent warping, and if the cleats are nailed on properly they will form a full bee-space on the side of board going next to the last frame. The bottom board is $14 \times 21$ inches, and is cleated, while the cleat in front is leveled down even with the board. The back cleat forms a bee-space below the frames, leaving an entrance in front with alighting board two inches wide. By this means the hive is not cur to form an entrance. This bottom may be used as a cover in an emergency, or it may be fastened permanently to the hive if desired.

The super is $4 \frac{3}{4}$ inches deep, with slotted sectionholders, sawed slotted separators, follower, and springs. When two supers are included with each hive it is then a two-story hive for comb honey.

All our hives are furnished with Excelsior cover, which is the best hive cover made, unless otherwise ordered.

This cover has a flat surface on the under side, which afiords a proper bee space over the brood frames, yet at the same time it is a sloping cover, and will shed the rain as well as a gable cover (which it really is), and has the advantage of double covers made of thin lumber (which splits up so hadly), as it is made from solid boards 1 inch thick at the center and $5 / 8$ inch at the outer edge. There are only five pieces in this cover, namely: 2 cover boards, 2 cleats and 1 ridge-board.
DANZENBAKER HIVE.

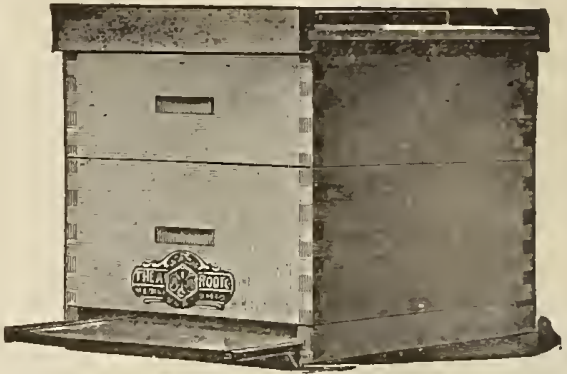

This hive is lightly shallower than the regular Dovetailed Hive but has exactly the same cubic capacity as the eight-frame. The brood-frames are just enough shallower so that the two inches of honey that is usually put above the brood in a regular (ave frame crowded up into the supers, where it

est market price. It is made in 10 -frame size brood-frames are closed-end $7 \%$ inches deep; 17 inches long and each is supported by a pivot in the center inc the lond bars so that it may be readily reversed. The reversing feature makes it possible to get combs built clear out to the end. The frames are closed-end, and stop those chilling air currents across the faces of the combs, a matter of supreme importance in the rearing of brood in the spring. The super takes $4 \times 5 \times 13 \%$ p la in sections. This is 5 , deep super without rabbet in top edge, but wleats to $\mathrm{g}$ e port Danzenport Danzenholders and M fences with end fences with end springs.

It is made $161 / 4$ inches wide to a dmit easily e i g h t Danzen-

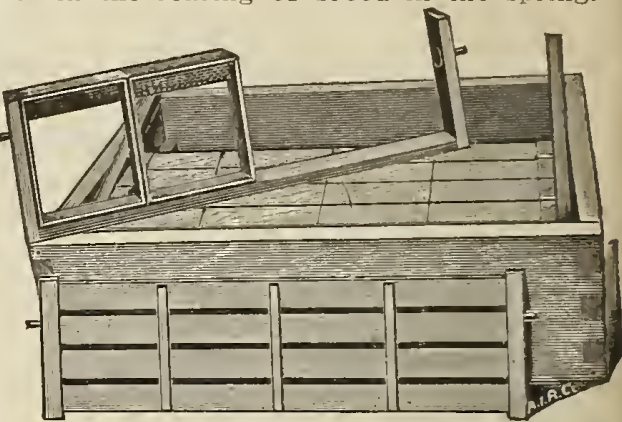

Danzenbaker super. alders and nine $M$ fences with springs.

\section{Prices of Hives for Comb Honey}

The one-story Dovetailed hive includes a cover, bottom and brood chamber, with frames, division board and nails. Any style of super or upper story may be used on this hive.

The one-and-one-half-story hive includes a cover, bottom, broodchamber, complete, and one super with inside fixtures.

The two-story hive includes the same with one more super. Furnished in either eight or ten frame size.

1-story Dov'd hive, no super or upper story, with frames and di-

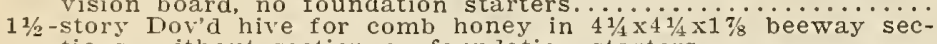
tions, without section or foundation starters.

2 -story Dov'd hive for comb honey in $41 / 4 \times 41 / 4 \times 1 \%$ beeway $\mathrm{sec}$ tions, without section or foundation starters.

$11 / 2-$-story Dov'd hive for comb honey in $4 \frac{14 \times 41 / 4 \times 11 / 2}{1}$ plain sections. without section or foundation starters.

2 -story Dov"d hive for comb honey in $4 \frac{1}{4} \times 41 / 4 \times 1 \frac{1}{2}$ plain sections.

without section or foundation starters.

1-story Danzenbaker hives, used as brood hives, without foundation $11 / 2$-story Danzenbaler hives, without sections or foundation starters

\begin{tabular}{|c|c|c|c|c}
$\begin{array}{c}\text { Designating } \\
\text { Letters and } \\
\text { Numbers for } \\
\text { 8nd 10 frame }\end{array}$ & $\begin{array}{c}\text { Nailed and } \\
\text { Painted } \\
\text { each }\end{array}$ & 1 Hive & 5 Hives & $\begin{array}{c}\text { Weigh t } \\
\text { of 5 }\end{array}$ \\
\cline { 3 - 5 } & & & & \\
\hline AE5- & $\$ 2.40$ & $\$ 1.75$ & $\$ 8.00$ & 100 \\
A E5-10 & 2.55 & 1.90 & 8.90 & 108 \\
AE52S-8 & 3.30 & 2.40 & 10.75 & 135 \\
AE2S-10 & 3.50 & 3.60 & 11.75 & 145 \\
AE522S-8 & 4.00 & 3.10 & 13.50 & 170 \\
AE522S-10 & 4.20 & 3.25 & 14.50 & 182 \\
AE52P-8 & 3.30 & 2.40 & 10.75 & 130 \\
AE52P-10 & 3.50 & 2.60 & 11.25 & 140 \\
AE522P-8 & 4.00 & 3.10 & 13.50 & 165 \\
AE522P-10 & 4.20 & 3.25 & 14.50 & 177 \\
AED5-10 & 2.50 & 1.80 & 8.50 & 100 \\
AED52M-10 & 3.60 & 2.70 & 12.00 & 150 \\
\hline
\end{tabular}

\section{2-Story Dovetailed Hives for Extracted Honey in L. Frames}

This two-story hive includes a cover, bottom, and two bodies which make a brood-cham

and inside fixtures.

Each hive is furnished in either eight or ten frame size.

2 -story Dov'd hive for extracted honey in L frames $(9 \overline{1 / 8})$ in fulldepth upper story; no foundation starters.

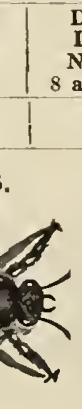

QUEEN BEES.

We can furnish Queen Bees from May 15 th until September 15 th.

Imported Italian Tested Queen from $\$ 3.00$ to $\$ 5.00$ each.

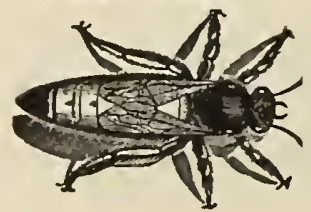

Home Bred Italian Tested Queen, $\$ 2.75$ each. Home Bred Italian Untested Queen, $\$ 1.65$ each. Southern Bred Italian Tested Queen, $\$ 1.75$ each. Southern Bred Italian Untested Queen, $\$ 1.25$ each. 


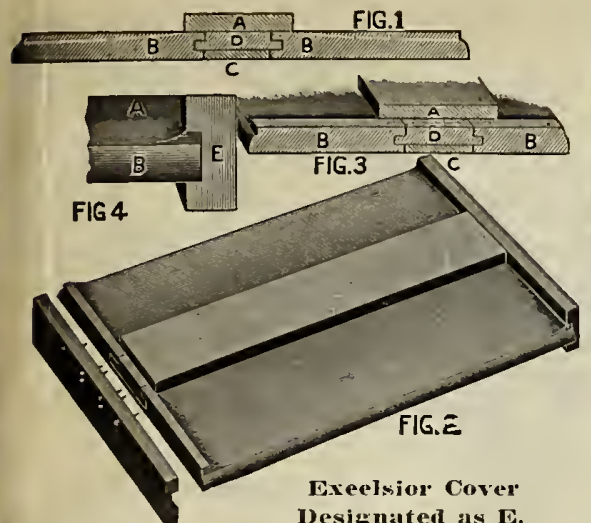

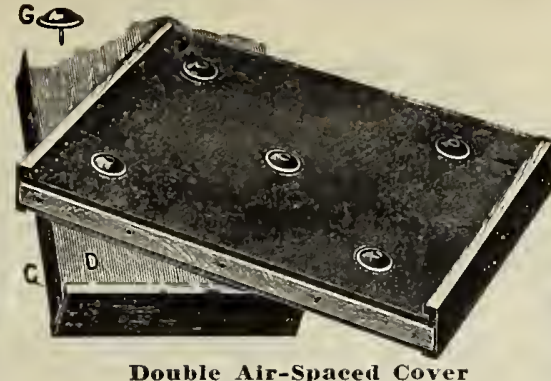

Desiguated as $\mathbf{F}$.

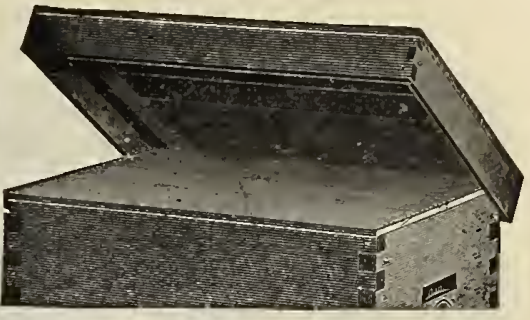

Metal Roofed Cover-Desiznated as $\mathbf{R}$.

\section{Prices of Hive Parts}

\section{Name and Style.}

Supers with section holders, etc., for 8-frame dovetail hives...

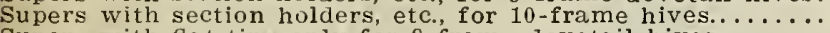

Supers with flat tins only for 8 -frame dovetail hives.

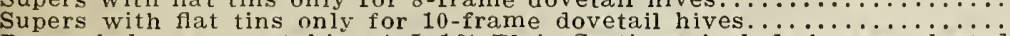

Danzenbaker supers taking $4 \times 5 \times 13 \%$ Plain Sections, include hanger-cleated

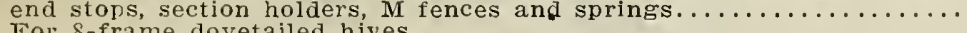

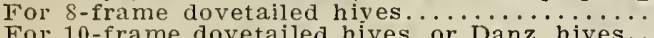

Bodies, with tin rabbets only, 8 -frame.

Bodies, with tin rabbets only, 10-frame.

(n) n

E -Excelsiol covers, complete for 8-frame hives.

E-Excelsior covers, complete for 10 -frame hives. . . . . . . . . . . .

F-Double air-spaced covers, 8 -frame hives.

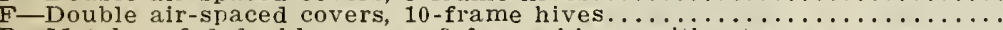

R-Metal-roofed double covers, 8 -frame hives, without super cover...

$\mathrm{R}$-Metal-roofed double covers, 10 -frame hives, without super cover .....
Ex-Colorado Telescope covers, 8 -frame hives, same as $\mathrm{E}$ with addition of Ex-Colorado 'Telescope covers, 8-frame hives, same as E with addition of

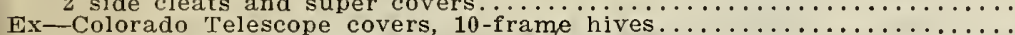

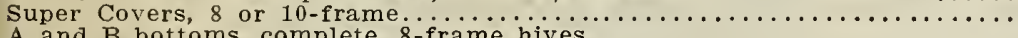

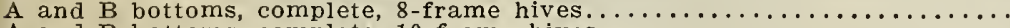

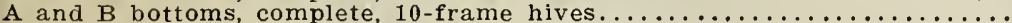

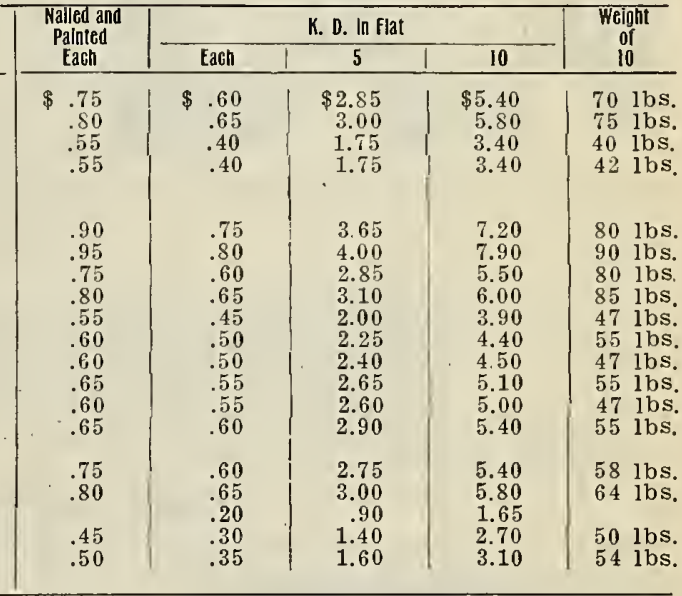

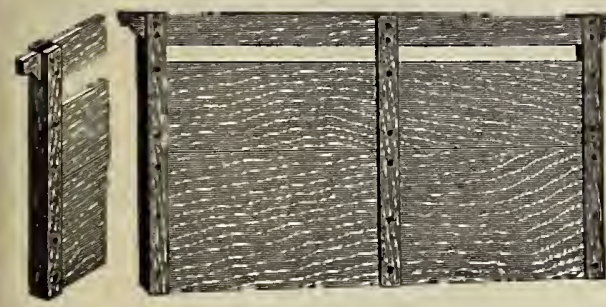

Division Boards.
Plain Division Boards, nailed. Each, 12c; 5 for $50 \mathrm{c} ; 10$ for $95 \mathrm{c}$.

Plain Division Boards, $K$. D. not nailed. 10 for $75 \mathrm{c}$.

Sawed Wood Separators, slotted, $18 \frac{1}{8} \times 4 \frac{1}{2}$ in., 100 for $\$ 1.25$ 500 for $\$ 6.00$.

P-Fences or Cleated Separators for $4 \frac{1}{4}$ plain section, in plain section holders. 100 for $\$ 2.35$.
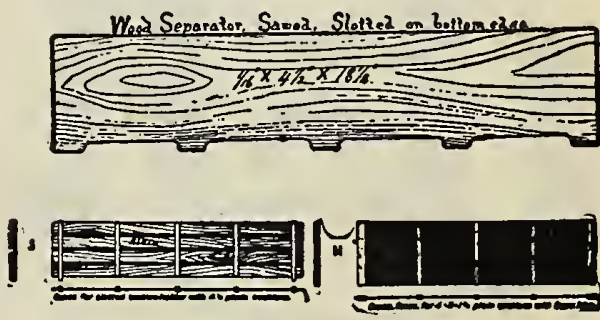

S. d M. Fences.
S- Fences or Clented Separators, used with $41 / 4$ plain sections in slotted section holders. 100 for $\$ 2.35$,
M-Fences or Cleated Separators, used in Danz. super, with $4 \times 5 \times 13 / 8$ plain sections. 100 for $\$ 2.35$.

\section{SECTION HOLDERS.}

Seetion Holder Slats, $1 / 1$ in. thick, $18 \frac{1}{2} \times 1 \frac{7 / 8}{}$ in. wide, 10 for $15 \mathrm{c}$; 100 for $\$ 1.15$ 500 for $\$ 5.50$.

Section Holder Slats, $3 / 8$ in, thick, $181 / 8 \times 17 / 8$ in. wide, 10 for $20 \mathrm{c} ; 100$ for $\$ 1.30$ 500 for $\$ 6.00$ $\$ 11.25$.

Seetion Holders, slotted, $18 \frac{1 / 8}{8} 1 \frac{7 / 8}{}$ in. wide, 10 for $25 \mathrm{c} ; 100$ for $\$ 2.30 ; 500$ for

Danzenbaker Section Holders, 10 for $30 \mathrm{c} ; 100$ for $\$ 2.70 ; 500$ for $\$ 12.50$.

Wedges for Hofiman Frames, 100 for $40 \mathrm{c}$.

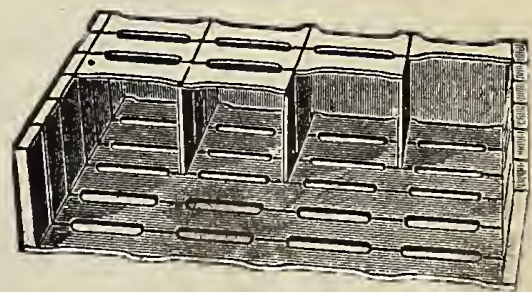

Weed Process Comb Foundation

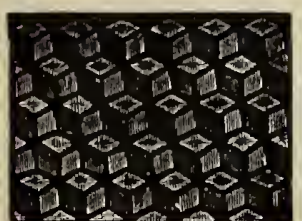

Medium Brood.

\begin{tabular}{|c|c|c|c|}
\hline Quantity. & $\begin{array}{l}\text { Medium } \\
\text { Brood. } \\
51 / 2 \text { to } 6 \\
\text { sq. feet } \\
\text { per lb. }\end{array}$ & $\begin{array}{l}\text { Thin. } \\
10 \text { to } 11 \\
\text { sq. feet } \\
\text { per lb. }\end{array}$ & $\begin{array}{l}\text { Extra } \\
\text { Thin. } \\
12 \text { to } 13 \\
\text { sq. feet } \\
\text { per lb. }\end{array}$ \\
\hline $\begin{array}{l}1,2,5 \text { lb. boxes, per } 1 \mathrm{~b} \ldots \ldots \ldots \ldots \ldots \\
10 \text { ib. boxes, per } 1 \mathrm{~b} \ldots \ldots \ldots \ldots \ldots \ldots \\
25 \text { lb. boxes, per } 1 \mathrm{~b} \ldots \ldots \ldots \ldots \ldots\end{array}$ & $\begin{array}{l}62 \mathrm{c} \\
58 \mathrm{c} \\
56 \mathrm{c}\end{array}$ & $\begin{array}{l}69 c \\
65 c \\
63 c\end{array}$ & $\begin{array}{l}72 c \\
68 c \\
66 c\end{array}$ \\
\hline
\end{tabular}

Write for prices on large quantities

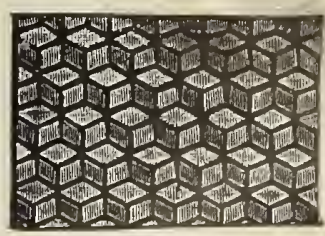

Thin Foundation. 

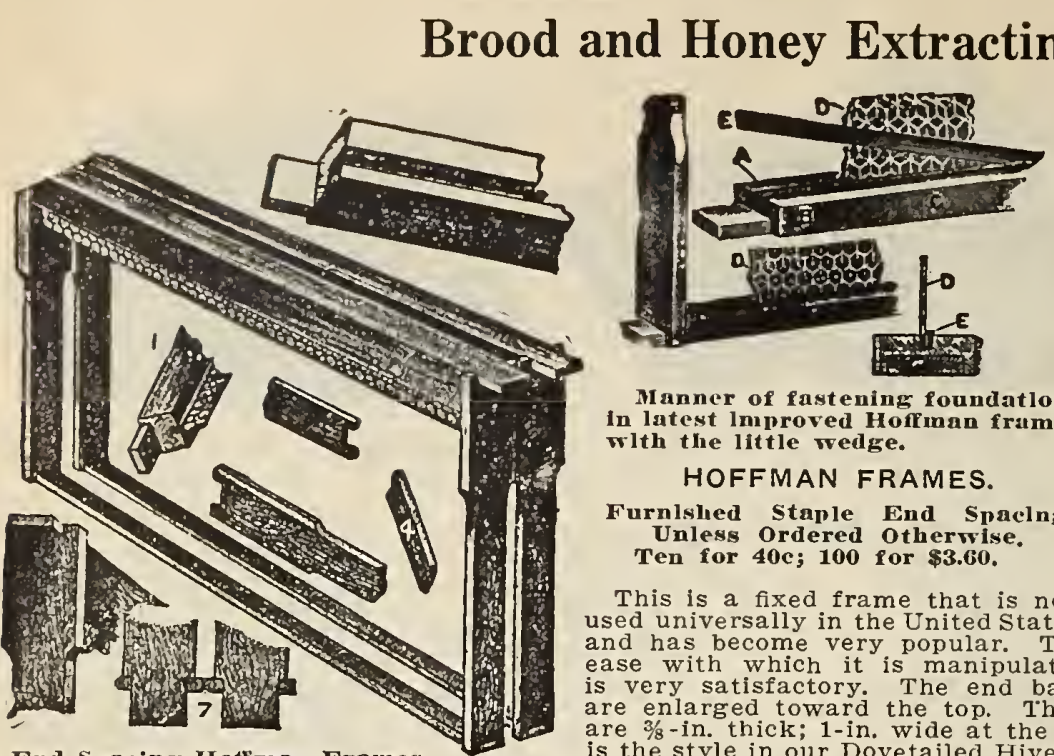

Manner of fastening foundation in latest lmproved Hofman frame wlth the little wedge.

HOFFMAN FRAMES.

Furnished Staple End Spacing Unless Ordered otherwise.
Ten for 40c; 100 por $\$ 3.60$.

This is a fixed frame that is now used universally in the United States, and has become very popular. The ease with which it is manipulated is very satisfactory. The end bars are enlarged toward the top. They Frames

End Spaeing Hotrman Frames.

is $3 / 8$-in. thick; 1 -in. Wide at the narrowest part and $1 \%$-in. at the widest. This of this frame is that it can be hadled inless ordered otherwise. The peculiar merit of this frame is that it can be hadled in lots of two, three or four, all at one time. and the same can be returned to the hive at one operation.

\section{DANZENBAKER CLOSED.END FRAMES.}

Ten for $35 \mathrm{c} ; 100$ for $\$ 3.40$.

This we consider the best of any of the closed-end type of frames ever sold. As it is supported by pivots in each end of the end-bars it is reversible. A comb put in a hive upside down for a day or two during the honey-flow will have the space between the bottom bar (now at the top) and the comb entirely closed up. This secures solid cards of combs
without any pop-holes, or space, between the frame proper and the comb itself.

SHALLOW EXTRACTING FRAMES.

The to $p$-bar is $7 / 8$-inch wide and $3 / 8$-inch thick with single groove; no comb-guide.

Bottom bar is $3 / 4$ wide and $1 / 4$ thick; the end-bars are Hoff man self-spacing style, $3 / 8$ thick by $5 \%$ long, end-spaced with staple same as full-depth Hoffman frames. 10 for $35 \mathrm{c} ; 100$ for $\$ 2.90$.

\section{Basswood One Piece Polished Sections}

Made In two styes: Open top and bottom, and plain or no bee-way. Average weight of 1,000 sections is seventy pounds.
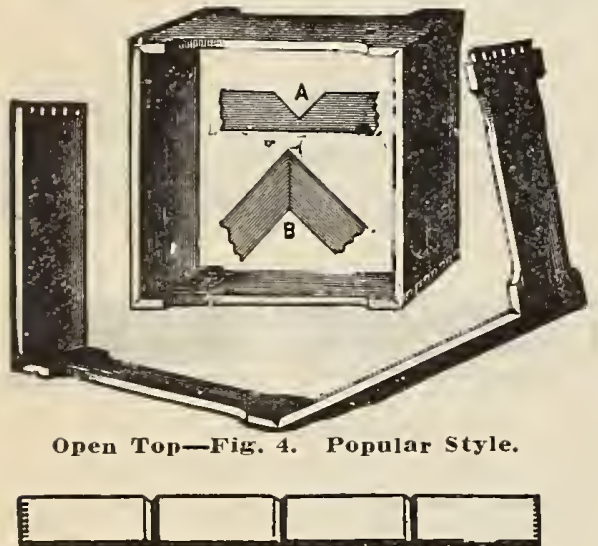

Plain or No Bee-WVay Style
FIRST QUALITY BASSWOOD SECTIONS-NO. 1.

These are to be perfect white sections, all of those with weather stains or black spots on them being culled out. Indeed, they are "snow white." If If you intend to market your honey in the large cities, it will vay you to use the No. 1 white sections.

Unquestionably our sections this year are second to none. We will be very pleased to mail samples on application. SECOND QUALITY SECTIONS-NO. 2.

Second quality sections are those that we do not like to put in the first quality. Understand, they are perfect sections as far as workmanship is concerned, but they have dark streaks or spots on them; or, in other words, they are what are left after the first qualities have been selected out. If you are producing honey for your own use, these will answer all the purposes of a producing honey for

Several of our very successful apiarists in Colorado are using these sections.

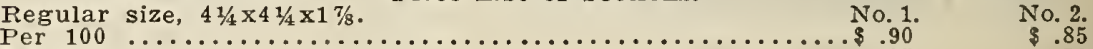

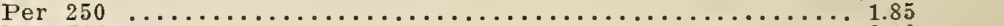

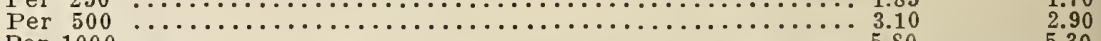

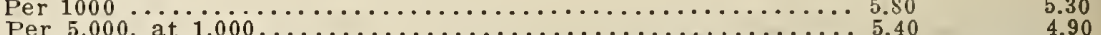

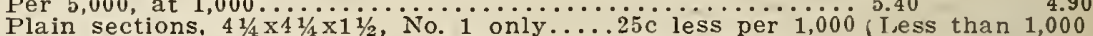
Plain sections, $4 \times 5 \times 1 \%$, No. 1 only.........25c less per 1,000 lots same prices Ask for special prices on large quantities.

\section{Tin and Wire Parts, Hammers and Paints}

T Tins for 8-frame hive supers, $\$ 1.15$ per 100 .

T Ting for 10 -frame hive supers, $\$ 1.35$ per 100.

Flat Wins for section holder rest, 8-frame, $60 \mathrm{c}$ per 100 ; for 10 -frame, $75 \mathrm{c}$ per 100.

Tin Rabbets for frame rests, 8-frame hives, $\$ 1.15$ per 100 ; 10 -irame hives, $\$ 1.35$ per 100

Bent Staples for $T$ tins, per $1 \mathrm{~b} ., 40 \mathrm{c}$.

Fnd Spacing Staples, per 1b., $20 \mathrm{c}$

Hive tSaples, $1 \frac{1}{2}$ in. wide, are used to fasten the bottom, roof or supers to hive fasten the bottom, roof or supers to hive driver or chisel and used again. Per lb., $20 \mathrm{c}$.

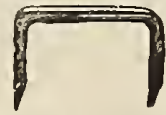

Bee Staple.

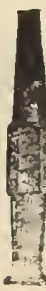

Wire, Briglit Tinned, No. 30, for frames. For lb. spool, $30 \mathrm{c}$; $1 / 2$ lb. spool, $20 \mathrm{c}$

super Flat Springs, to hold the section holders tight together. Price per $100,75 \mathrm{c}$; per 1,000

Magnetic IIamner-Common.

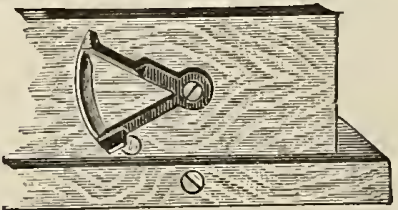

VAN DEUSEN HIVE CLAMP. These are very conventent for fastening loose bottoms when you want to move hives. They may also be used to hold the cover on, or two bodies together. Price, $35 \mathrm{c}$ for 10 pairs, including two for 10 pairs, including

COATED WIRE NAILS FOR HIVES, ETC

Prices subject to market changes. Price Per

Size.

$1-$ in., very fine and $\operatorname{slim} \ldots \ldots \ldots \ldots \ldots \ldots \ldots .20 \quad \$ 1.50$

$2 d$, regular, fine, for nailing frames........... .15

$3 \mathrm{~d}, 11 \mathrm{~s}$ in. long, for nailing cases........... 10 .

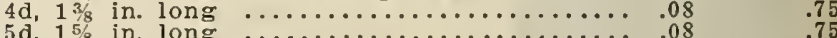

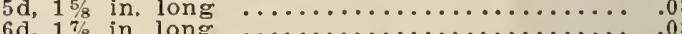

7d, $21 / 8$ in. long, for nailing hives.............

Magnetie Hammers, common. Price, $15 \mathrm{c}$.

Magnetie Hammers, Savage, best quality, $25 \mathrm{c}$

Paint for Bee Hives. Qt., 50c; $1 / 2$ gal., $80 \mathrm{c}$; gal., $\$ 1.50$

Paint Brushes, 3-inch, good article. Price, $45 \mathrm{c}$. 


\section{Foundation Fasteners and Section Presses} PARKER'S FOUNDATION FASTENER.

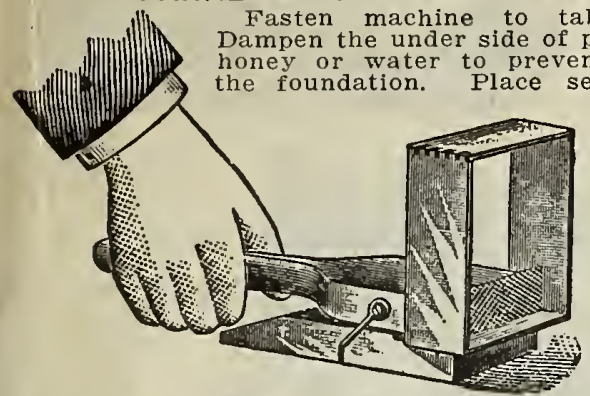

with screws. of point of lever with its sticking to section in position foundation just under the edge of lever; press lever down on foundation by lifting handle, turn foundation up against end of lever and
slide lever off of foundation by

lifting on handle and Arawing it backward, which fastens the foundation to section. Price, $35 \mathrm{c}$.

DAISY FOUNDATION FASTENER

This is probably the best machine for its price for putting starters into sections. It is easily operated and with a little practice a girl or boy will put starters in from 400 to 500 sections per hour. Complete directions are sent with each machine.

Price, with lamp, \$1.25; without lamp, $\$ 1.00$.

RAUCHFUSS COMBINED SECTION PRESS AND FOUNDATION FASTENER.

Simplicity, efficiency, accuracy and urability are its chief characteristics, and is guaranteed to give satisfaction. Fitted for $41 / 4 \times 4^{1} / 4$ sections, with lamp all ready to fasten to table or bench. Price, complete with lamp, $\$ 3.00$.
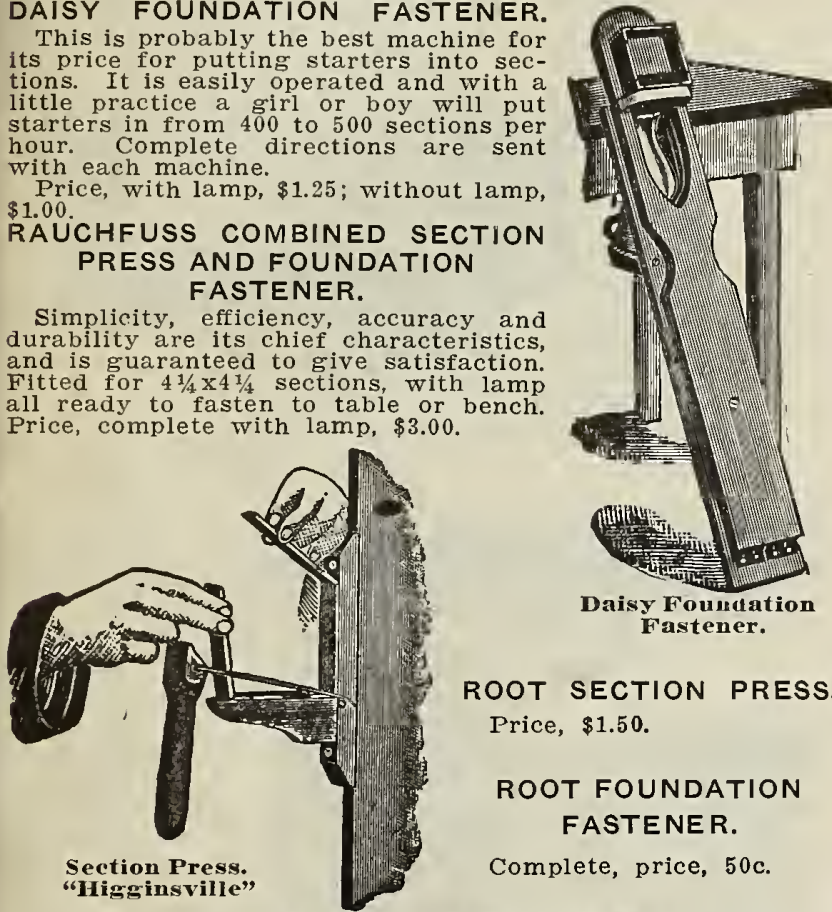

ROOT SECTION PRESS. Price, $\$ 1.50$.

\section{ROOT FOUNDATION}

FASTENER.

Complete, price, 50c.

"HIGGINSVILLE" SECTION PRESS.

This machine is a marvel in its way for a low priced Section Press.

All you have to do is to screw it fast to a bench or some upright and it is ready for using. Price, 50c each.

\section{VAN DEUSEN WAX TUBE FASTENER.}

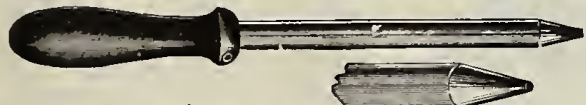

It is simply a tin tube about half an inch in diameter six inches long, tapering and at the apex a small hole. On one side, near the handle is prickled another small hole which may be opened or closed with the thumb. When the tube is stood up in a cup of hot wax the air will escape from the upper hole and the wax flow in at the other small hole at the bottom. The thumb is closed over the upper one, the instrument is drawn out of the wax, and the point is then slowly drawn along the edge of the foundation in contact with the top-bar, leaving a finc stream of hot wax to cement it. Price, $25 \mathrm{c}$ each.

\section{CARLIN'S FOUNDATION CUTTER.}

These are very convenient for cutting a great number of pieces. cutting a great number of pieces, should be kept hot by occasionally immersing in hot water. Price, tin wheel, 15c; steel wheel, $25 \mathrm{c}$.
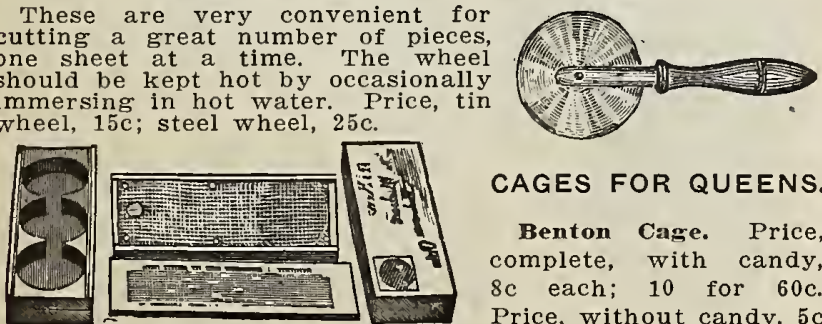

CAGES FOR QUEENS.

Benton Cage. Price, complete, with candy, $8 \mathrm{c}$ each; 10 for $60 \mathrm{c}$ Price, without candy, $5 c$ Benton Cage.

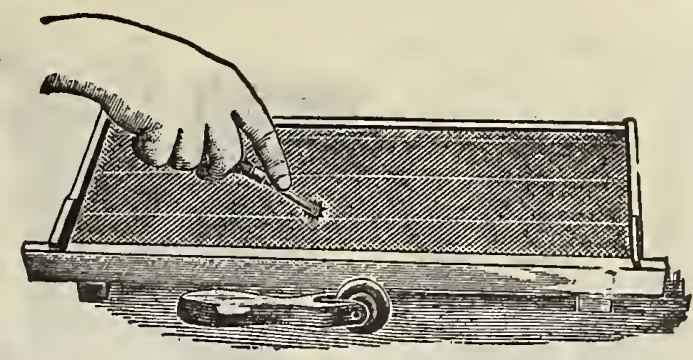

SPUR WHEEL WIRE IMBEDDER.

This imbedder has metal wheel with teeth so arranged that by running along the wire the wire is pressed into the foundation. Price, $25 \mathrm{c}$

\section{DAISY FOUNDATION ROLLER.}

Is also illustrated in above cut. Used to press the foundation to the frame. Price, 15c.

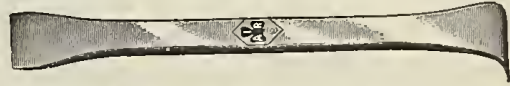

NICKELED-STEEL HIVE-TOOL.

A new :pring-steel nickel-plated hive-tool, which is both a scraper and a pry. The end which is turned down at right angles, or the hoe-end, fits nicely up into the palm of

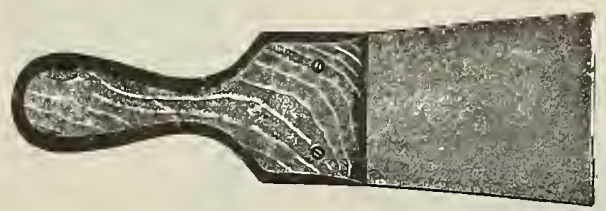
the hand when tools is used as $\begin{array}{ll}\text { a pry } & \text { or a } \\ \text { scraper. Price, }\end{array}$ $40 \mathrm{c}$ :

HIVE

SCRAPERS.

Each, 25c.

MILLER'S QUEEN CATCHER AND INTRODUCING CAGE.

Any one who is afraid to catch the queen by the wings can slip this cage right over her, and she will crawl up, and then the plug can be inserted.

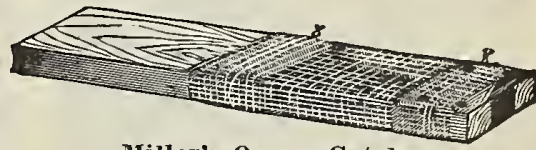

dised advantageously not only for introducing

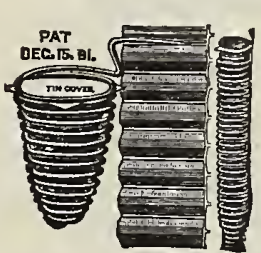
thick it can be slipped down between the combs or slid in at the entrance. WEST QUEEN-CELL PROTECTOR.

These are to prevent bees from gnawing into and tearing down cells given them at certain times of the year. Price, 5c each; 10 for $40 \mathrm{c}$.

Spiral Cage to hold the virgin queens after she hatches, till she can be disposed of; each, $10 \mathrm{c} ; 10$ for $70 \mathrm{c}$

PERFORATED ZINC QUEEN EXCLUDERS OR HONEY BOARDS.

These are used to exclude the queen from the upper story. Our zinc is perforated with round corners, size, 17-100 of an inch, the best size and style.

Each Per 10 Zinc, size $12 \times 191 / 8$, for 8 -frame hives....... $14 \times 191 / 80$, for 10 -frame hives....... Wood bound zinc honey boards, nailed, for .20

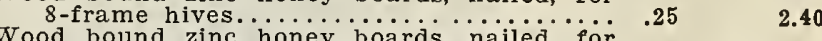

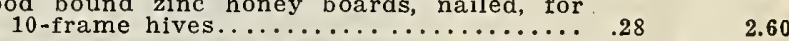

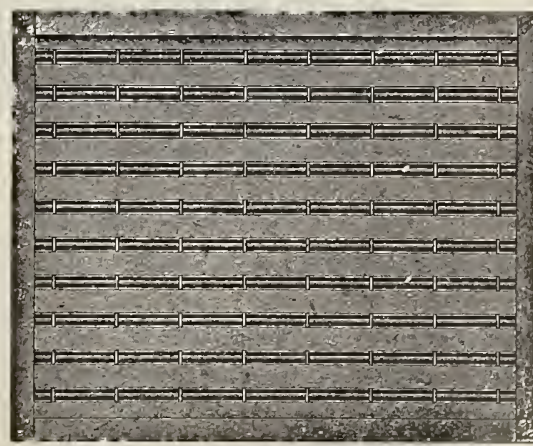

Wood and Wire Honey-Board.
W O O D A N D W I R E HONEY BOARD. This is made just like the wood-bound zine board, except that the wire strips are substituted for the zinc.

Eig h t-frame wood and wire honey-board, $137 / 8$ x20; each, 85c; per $10, \$ 3.10$.

Ten-frame wood and wire honeyboard, $16 \times 20$, each,
$40 \mathrm{c}$; per 10 , $\$ 3.65$. 

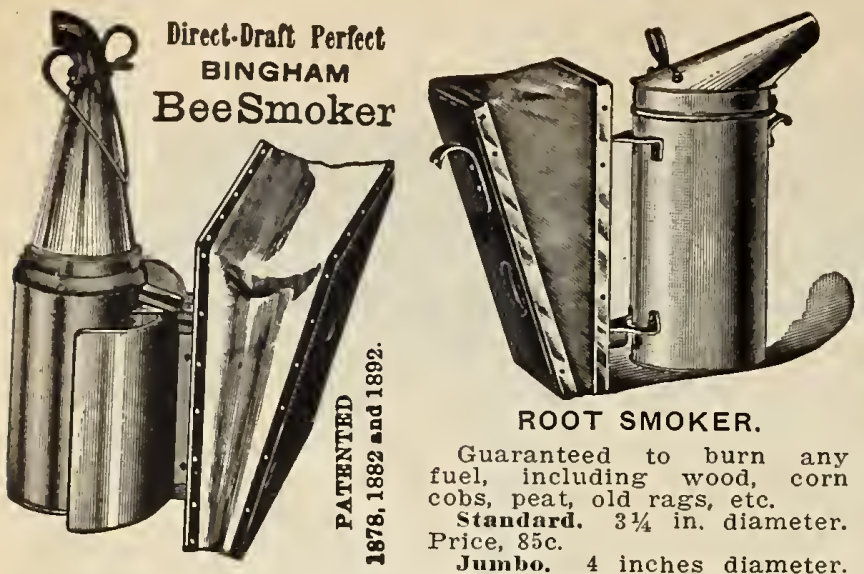

Guaranteed to burn any fuel, including wood, corn Standard. $3_{1 / 4}^{1 / 4}$ in. diameter. Price, 85c. 4 inches diameter. Price, $\$ 1.25$.

DIRECT-DRAFT PERFECT BINGHAM BEE SMOKER. The direct draft assures constant smoke. They are well made. Have wide shields and wire handles to cone.

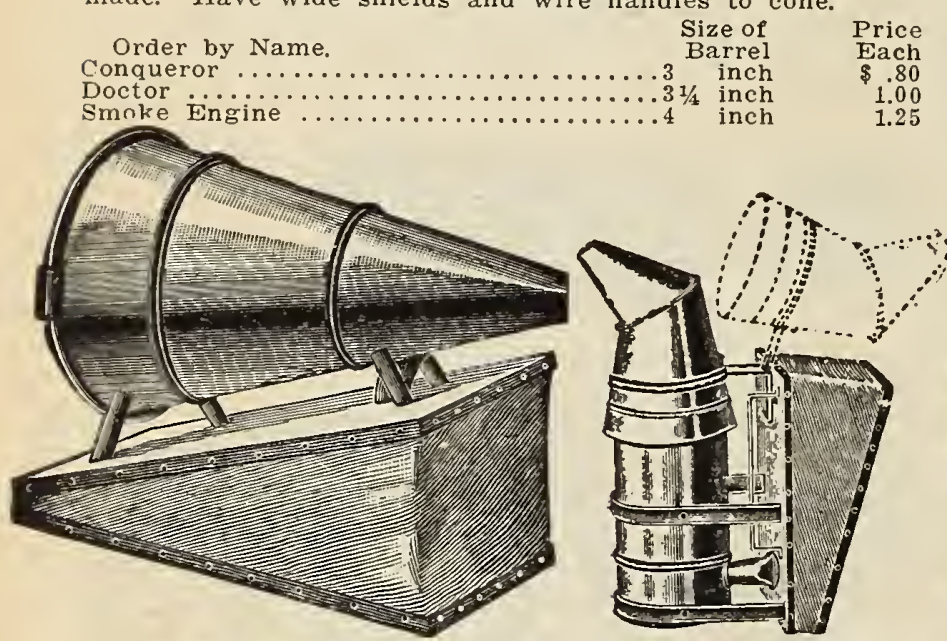

Clark's smoker.

HIGGINSVILLE SMOKER.

CLARK'S SMOKER.

This is the most commonly used smoker on the market. Is cold in a small apiary. Price $55 \mathrm{c}$.

\section{DANZENBAKER TWENTIETH-CENTURY} a hot blast, with a $31 / 4$-inch fire box. The nozzle throws back to believe it as good as any smoker made and a truly high class article. Will outlast many higher priced ones. Price, $75 \mathrm{c}$.

\section{SMOKER.

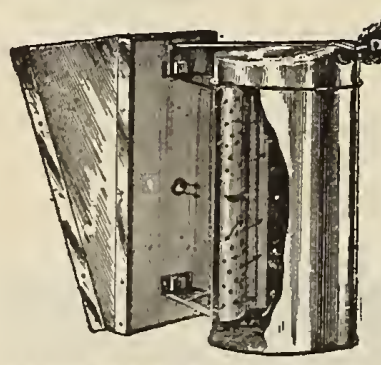

This is a hot and cold blast smoker combined, having a vertical grate instead of one located in the bottom of the cup. as in other smokers. Like the Root smoker, it has no valve to get out of order. Price, $\$ 1.00$.

PORTER'S BEE ESCAPES.

Thls escape is far superior to all others.
Bee escapes greatly facilitate the removing of honey from hives and supers. The escape is fastened to a board, after making a suitable hole in same. One escape to a

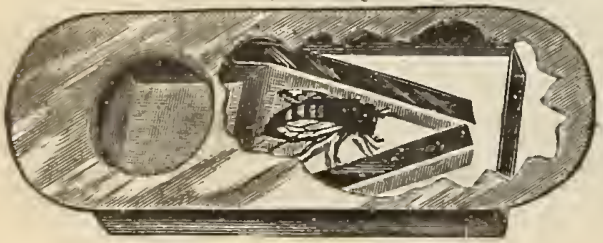
are sent with each one. Price, per dozen postp a i d. Escapes mounted with rims, for 8 or 10 frame hives. for $\$ 1.50$, not

\section{PORTER'S}

ESCAPES FOR BEE HOUSES.

Price, 25c each; $\$ 2.75$ per dozen, postpaid.
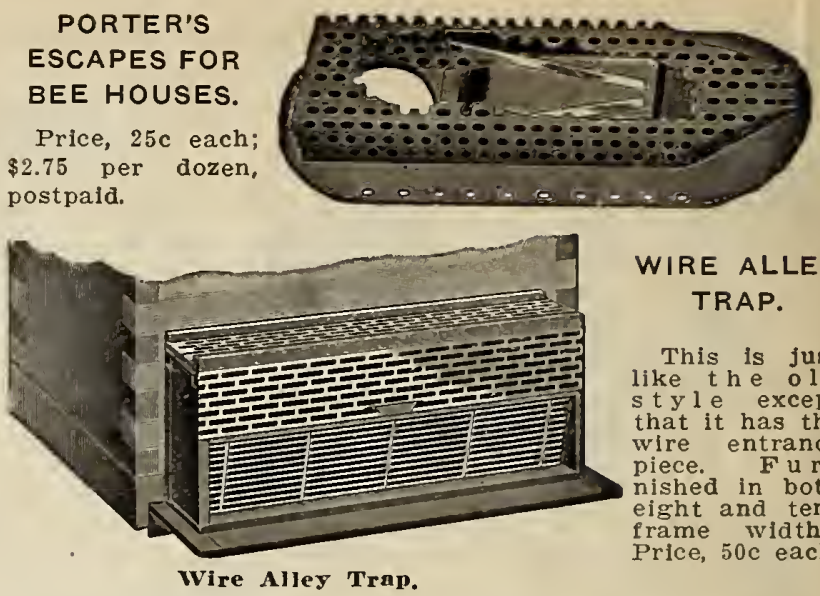

WIRE ALLEY TRAP.

This is just like the old style except that it has the wire entrance pished in both eight and tenframe widths. Price, $50 \mathrm{c}$ each.

\section{BEE ENTRANCE GUARDS. \\ Vire Entrance- Euard. Made with wood top and ends, with wire front, $20 \mathrm{c}$ each; 10 for $\$ 1.80$. \\ Zine Eutranee- suard. Made of each: 10 for $\$ 1.20$.}

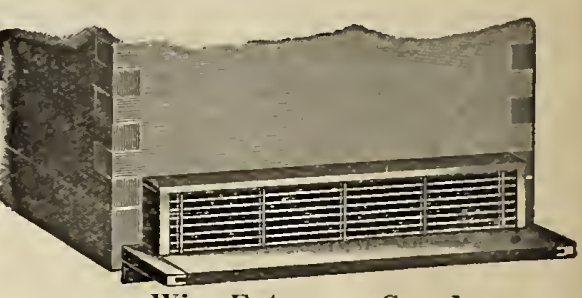

ALLEY'S COMBINED DRONE AND QUEEN TRAP.

Directions for use on each trap; price, $50 \mathrm{c}$ each.

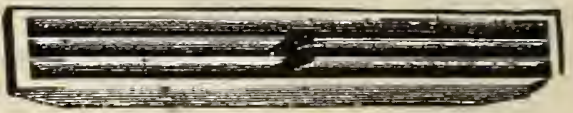

S I M P L I C I T Y BEE F E E D E R. Price, $10 \mathrm{c}$ each: DIVISION BOARD FEEDER.

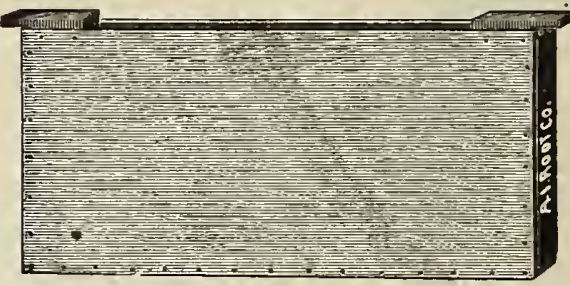

Has the $\mathrm{sa} \mathrm{m} \theta$ outside dimensions as an ordinary brood frame, and can be used in the can be used in the brood chamber the same way. To feed, all that is necessary is to opening on the top bar. Price, nailed $35 \mathrm{c}$ each; in flat, $25 \mathrm{c}$.

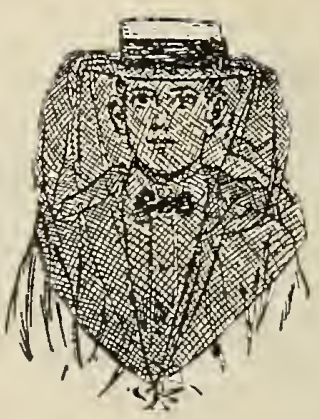

BEE VEILS.

Globe Bee Veil.

The veil weighs only 5 ounces. Price, \$1, postpaia.

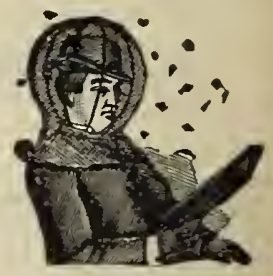

Globe Veil.

Bee Veil No, 1. Cotton tulle, with silk tulle face, $60 \mathrm{c}$ each, postpaid. No. 2. Cotton tulle throughout:
$50 \mathrm{c}$ each, postpaid.

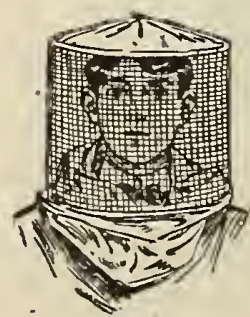

ALEXANDER BEE-VEIL.

This is one of the best and strongest bee-veils that we sell. The portion around the face and head consists of a wire cloth made especially to order for this purpose, with eight meshes to the inch. and offers very little obstruction to the eye. The top consists of muslin gathered at the center and the bottom is of the same material made in the form of a skirt that slips loosely around the shoulders. Price, 75c; postpaid.

Alexunder Vell.
BEE-HATS. Flexible rim, fit any 


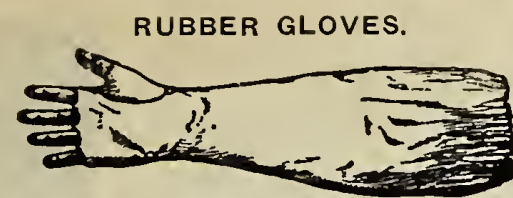

They are useful in handling very cross bees, and are a perfect protection for the hands. In ordering be sure to give the number of the size you want, and remember that in rubber you nees two sizes larger than you wear in kid.

Ladie's' Gauntlets, sizes 6, 7, 8; per pair, \$1.65.

Gent's Gauntlets, sizes 10, 11, 12; per pair, $\$ 1.75$; sizes $13,14,15$, per pair, $\$ 2.10$

CANVAS GLOVES. $50 \mathrm{c}$ per pair.

We have these in two sizes only, large for men and small for ladies. You cannot use a tight-fitting glove while working with bees in warm weather.

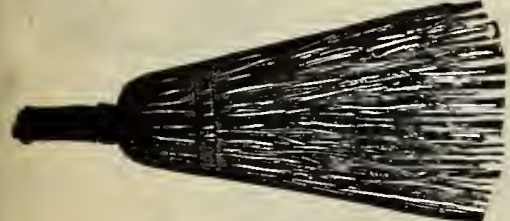

COGGSHALL'S BEE B R U S H (see cut). Price, 15c.

GE R M A N B E E BRUSH. Made of genuine horsehair bristles, either black or white. Coggshall's Bee Brush. Black, 25c; white, $30 \mathrm{c}$.

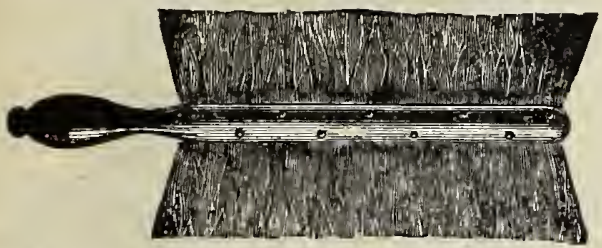

THE-DIXIE BEE BRUSH. A double brush with sof and pliable fibres in a strong wood handle, long enough to reach across an ordinary Langstroth frame. Price, $15 \mathrm{c}$.

\section{MANUM'S \\ SWARM}

CATCHER. this article is the on the market.

Its great feature is that it will stand alone basket where the bees are flying the thickest, by placing the legs at angles with the main (see cut)

Swarms can be successfully handled 20 feet in the air.

the air. $\$ 1.50$.

Price, with out pole, $\$ 1.10$.
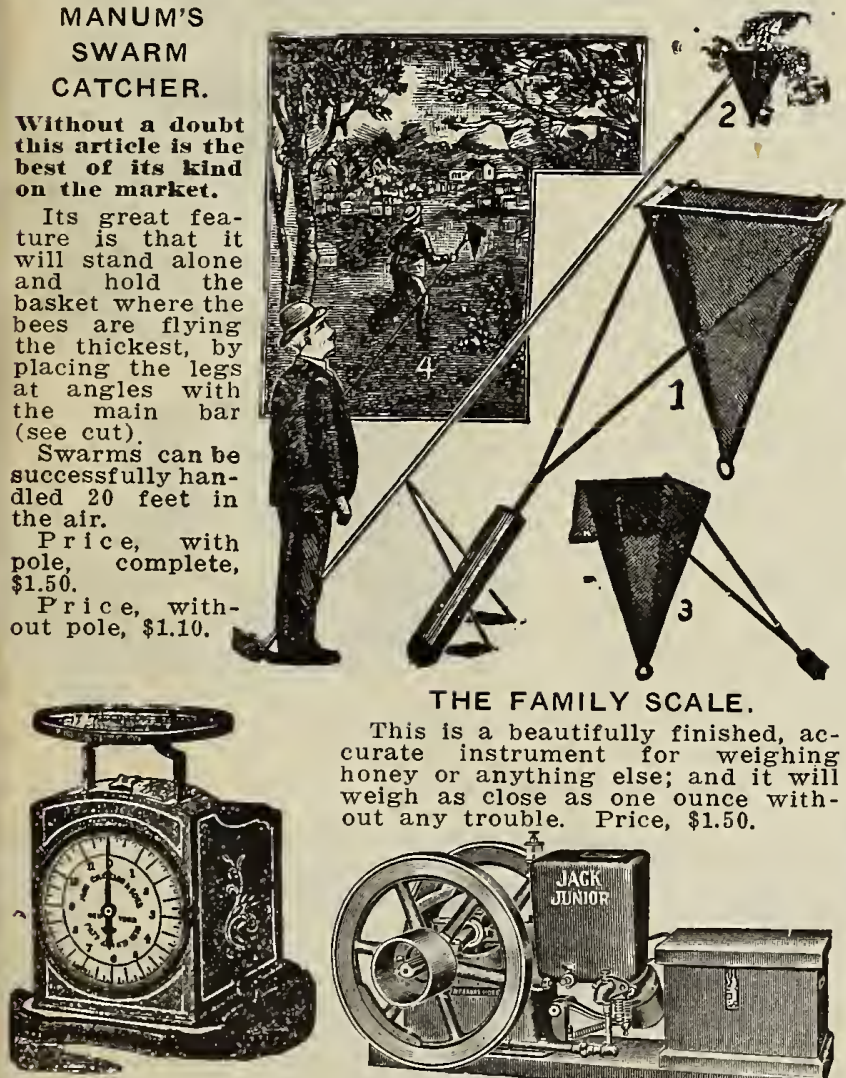

THE FAMILY SCALE.

This is a beautifully finished, accurate instrument for weighing honey or anything else; and it will weigh as close as one ounce without any trouble. Price, $\$ 1.50$.
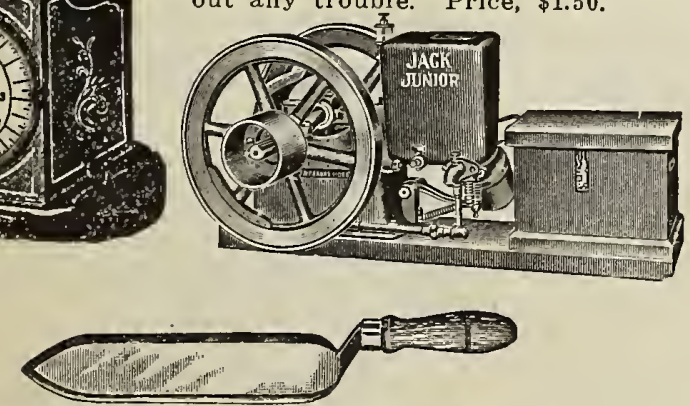

BINGHAM HONEY KNIFE. Price, $75 \mathrm{c}$. without a doubt best of its kind

e, with

\section{NOVICE HONEY KNIFE. Price, $80 \mathrm{c}$}

\section{No. 5B. NOVICE TWO-FRAME (NON-REVERSIBLE EXTRACTOR.}

For Langstroth or Hoffman frames standing on end, or any other frame not over $9 \frac{1 / 2}{\mathrm{in}}$. deep or $18 \frac{1 / 4}{\mathrm{l}} \mathrm{long}$, top-bar 20 in. (wt. 45 lbs.)

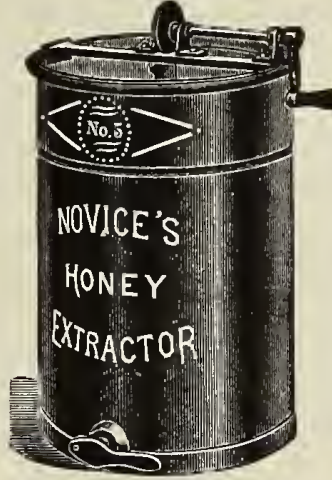

It is intended for the use of those who have only a small number of colonies, and who desire a good, well-built, serviceable machine at a moderate cost. While not reversible many think the combs can be handled almost as quickly. Price, $\$ 11.50$.

NOVICE FOUR-FRAME (NON-REVERSIBLE) EXTRACTOR.

No. $54 \mathrm{~B}-F o u r-f r a m e$ Novice for Langstroth or regular Hoffman frames, comb-pockets $9 \% / 8$ in. wide: can 20 in. diameter; weight, $80 \mathrm{lbs}$. $\$ 16.25$.

The machine has ball-bearings, top and bottom, and our latest style of gear with slip-gear lever.

No. 15. COWAN RAPID RE. VERSIBLE EXTRACTOR.

This for many years has been one of our leaders. While it is not automatic in revers. ing, yet the combs can be turned the other side to by putting one hand down into the can of the machine, catching one basket and then the other, drawing them to the other side while the reel revolves slowly.

Holds two frames; weighs 70 lbs. Price, $\$ 14.75$.

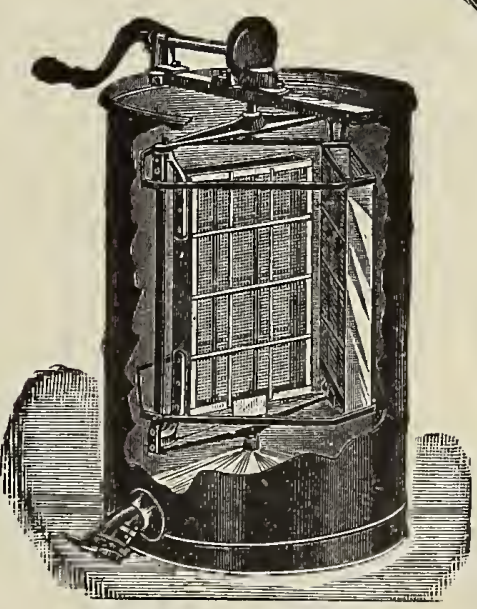

Root Automatic Extractor.

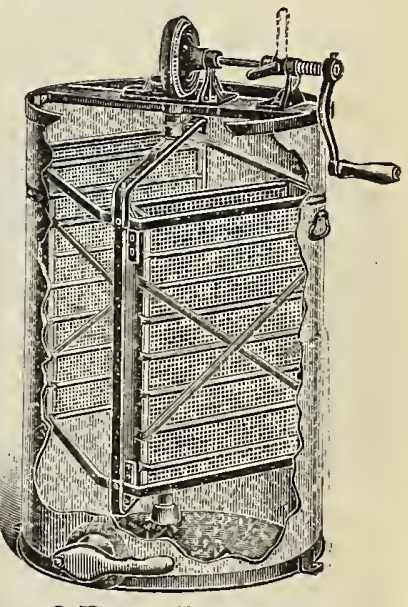

2-Frame Reversible Cowan.

THE ROOT AUTO. MATIC REVERSIBLE EXTRACTOR.

This we consider by all odds to be our best machine. It has all the latest attachments, ano is capable of heavy work. The automatic reversing feature has stood the test of hard usage for a number of years in some of the largest apiaries in the world. It is simple and positive in its action, the entire mechanism being placed on top of the reel and out of the honey. No. $25 \mathrm{~B}$ - Four-frame Root Automatic. 29 ins. in diameter( weight 180 ibs.), $\$ 32.00$.

\section{GASOLINE ENGINE FOR DRIVING HONEY EXTRACTOR} - "JACK JR."

Where a large amount of extracting is to be done, and especially if help is high-priced, we strongly advise the use of a gasoline engine for runnin, we strongly advise the use power engine, floor space $46 \times 29$ inches, capacity of horsepower engine, floor space $46 \times 29$ inches, capacity of tank, 1
gallon; weight, 440 lbs. Price, $\$ 65.00$. 


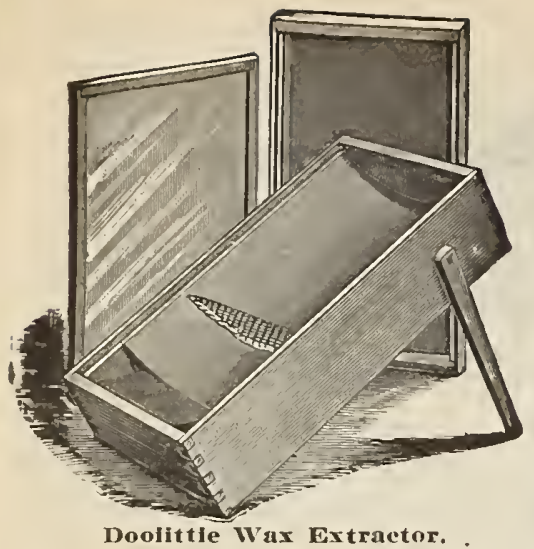

Doolitie Wax Extractor.
DOOLITTLE WAX EXTRACTOR.

Once of the Most Paying Things, Considering First Cost, is a Good Solar Wax Extractor.

There is not "millions in it," but there is many a dollar"s worth of wax that can be saved in a season, even in a small apiary, by having a solar wax extractor setting handy where you can drop in little pieces of comb as they accumulate, and you have no idea how much will accumulate, until some day you look into the wax extractor, and behold! there is a beautiful cake of clear, transparent wax in the extractor pan. "A dollar saved is a dollar earned," and a Solar Wax Extractor will earn this dollar for you.

Doolittle Solar Fixtractor, weighs $30 \mathrm{lbs}$., \$4.75.

\section{DADANT'S UNCAPPING CAN.}

This Is Indispensabie to tile Apiarist Who Has Much lioney to Extract.

The uncapping is done over it and the cappings fall on the screen below and are drained. It not only saves a great deal of honey, but also the white wax cappings, and it keeps things neat and clean. This machine is also invaiuable for making Sugar Syrup by the percolator plan for feeding. Spread over the wire cloth a thickness of muslin; over this distribute evenly a layer of cotton batting about an inch thick, and over the whole another thickness of muslin. Now pour in sugar and water in equal proporfior feeding. Weighs 60 lbs price, $\$ 9.50$.

ROOT GERMAN STEAM WAX PRESS AND UNCAPPING CAN. Weighs $75 \mathrm{lbs}$. Price, \$13.50.

\section{ROUND TAPERING HONEY PAILS.}

Can be shipped and stored nested.

No. 3. Holds $4 \mathrm{lbs}$. honey; per doz., 80c; per $100, \$ 5.00$.

No. 5. Holds 7 lbs, honey; per doz., $\$ 1.00$; per $100, \$ 7.00$.

No. 10 . Holds $14 \mathrm{lbs}$. honey; per doz., $\$ 1.50$; per $100, \$ 10.00$

1 qt. Friction Top Tin Pails, per doz., $90 \mathrm{c}$; per $100, \$ 5.25$.

1 gal. Friction Top Tin Pails, per doz., $\$ 1.65$; per $100, \$ 11.00$

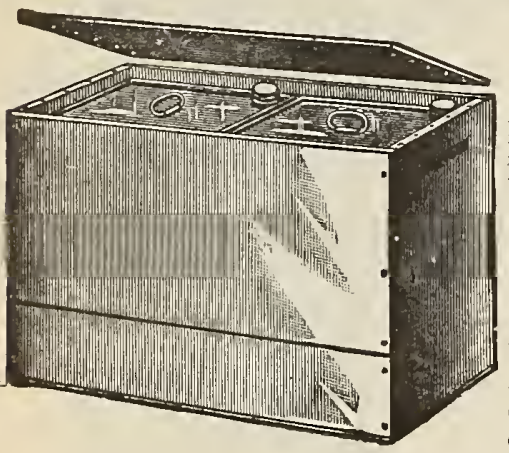

SQUARE HONEY CANS.

Hoids 60 ilus.-5 gailons, with screw eaps.

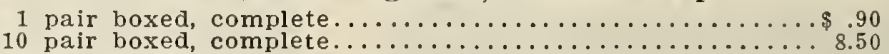

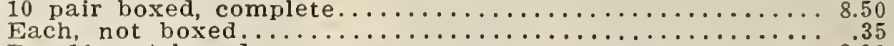

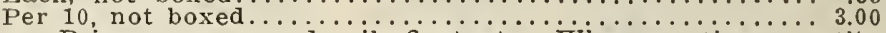
Prices on cans and pails fluctuate. When wanting quantity ask for prices.

Cонв BUCKeTs. For five $L$ frames, $\$ 1.35$.

\section{SHIPPING CASES FOR COMB HONEY.}

Comb honey put up in a nice, clean, attractive crate will bring more than when packed in an unattractive shape. Most of our crates are made of snow white basswood, except the bottoms and back, which are not visible when set on a counter. They are simply beautiful to look at, and when filled with nice comb honey they are doubly beautiful.

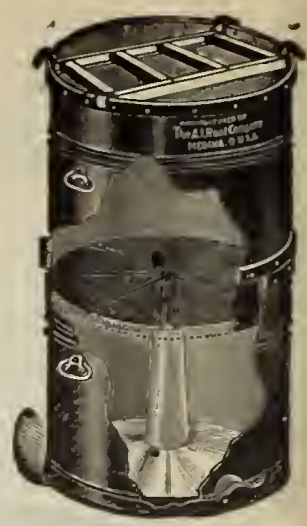

Datant's Uncepping Can.

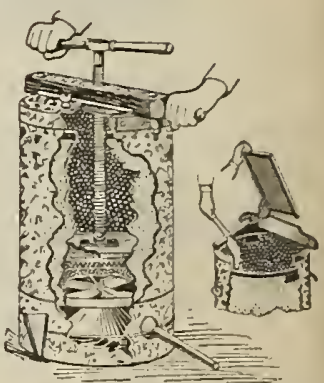

German Steam Wax Press.

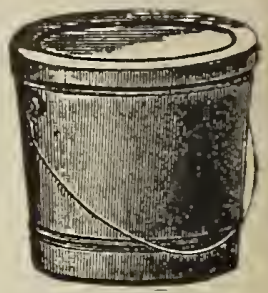

The 24-1b. double-tier case is almost universally used in Colorado, as it is the one which finds most favor with western dealers in honey. It was adopted as the standard package by the members of the Colorado State Bee Keepers' Association several years ago.

It certainly is the most attractive package, as one-fourth of all the honey contained is exposed to view.
One sheet of paper should be placed in the bottom of the case, and the other over the top inside.

Price List of Shipping Cases with Glass, Nails and Paper, Complcte. Original Crates are 50 eases each.

Each Per 10 Per 50 Per 100 24-1b. Double Tier, $21 / 2$ in. glass.................

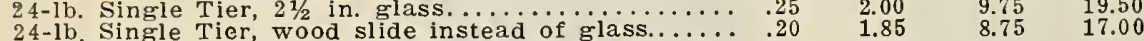

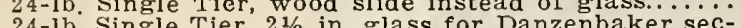
24-lb. Single Tier, $2 \frac{1}{2}$ in. glass for Danzenbaker sec$\begin{array}{rlrrr}\text { tions } \ldots \ldots \ldots \ldots \ldots \ldots \ldots \ldots \ldots \ldots \ldots \ldots \ldots \ldots \ldots \ldots \ldots \ldots & .25 & 2.15 & 10.00 & 19.25 \\ 12-1 b . \text { Single Tier, } 2 \text { in. glass for Regular sections... } & .20 & 1.75 & 8.25 & 16.00\end{array}$

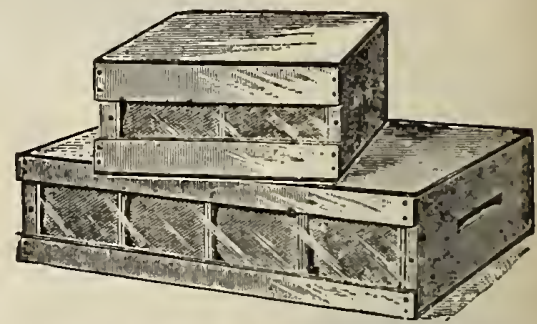

Single Tier Shipping Case.

\section{CARTONS FOR COMB HONEY.}

We sell two forms of cartons-one known as the folding, in which the section is completely inclosed; the other is the Danzenbaker with open sides. These latter are cheaper, and much handier to put the sections in, and can be used in ordinary shipping-cases, while

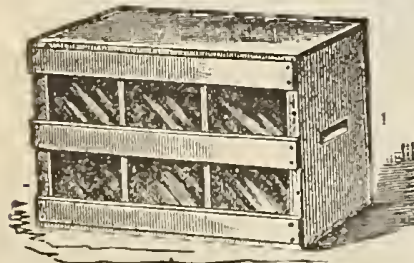

Double Tier Sinipping Case. the folding carton requires a special case. To hold the Danzenbaker in place it is advisable to slip a rubber band over it. These we furnish when ordered. It necessarily has no printing at the sides, but has on all the other panels.

Both styles of cartons are furnished for our regular sizes fections- $41 / 4 \times 41 / 1 \times 17 / 8$ and $1 \frac{1 / 2}{\text {; }}$ also $4 \times 5 \times 1 \frac{3}{8}$. Other sizes are furnished in large quantity on special order.

We would advise any honey-producer who sells any honey locally to purchase a quantity of the folding cartons. They the honey home without danger; and moreover they tend to the honey home without danger; and moreover they tend to

\section{Priee List of Cartons.}

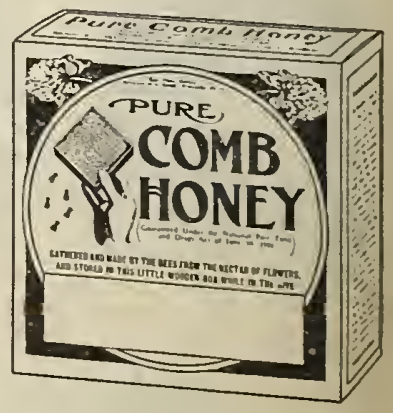

Danz. cartons, plain, no printing, $55 \mathrm{c}$ per $100 ; 500, \$ 2.40 ; 1.000, \$ 4.40$. Weight of $100,41 \mathrm{bs}$.

Danz. cartons, regular sizes, printed two colors, without name and address, $70 \mathrm{c}$ per $100 ; 500, \$ 3.20 ; 1,000, \$ 5.90$ Folding cartons, regular sizes, plain; $100,65 \mathrm{c} ; 500, \$ 2.90 ; 1,000, \$ 5.40$. Weight of $100,5 \mathrm{z} / 2 \mathrm{bs}$.

Folding cartons, printed, as specified above, no name or address, $100,80 \mathrm{c} ; 500, \$ 3.70 ; 1,000, \$ 6.90$. 


\section{Poultry Department}

when loultry Supplies are wanted by mall add postage.

\section{Genuine Standard Cyphers Incubators}

\section{FIRE-PROOFED-INSURABLE.}

These Incubators are built strictly in compliance with the dovetailed specifications adopted by the National Board of Fire Underwriters and bear the official Label of the Associated Fire Insurance Companies doing business in North America.

MADE IN FOUR SIZES.

No. 0, 70 Hen Eggs, 56 Duck Eggs........... \$15.75

No. 1,144 Hen Eggs, 112 Duck Eggs............. 23.50
No, 2, 244 Hen Eggs, 200 Duck Eggs.............\$34.00

No. 3, 390 Hen Eggs, 300 Duck Eggs.............. 40.00

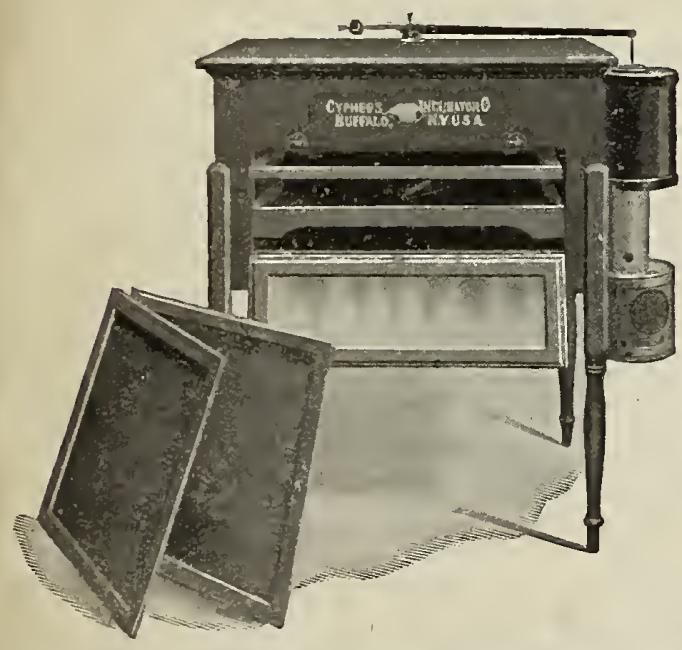

No. 1 Standard Cyphers Incubator, Fire-Proofed, Insurable, 144-egrs eapacity. Showing, "split" lower diaphragm removed, egg tray and npper diapliragun partly drawn out.

It is conclusively demonstrated that by the use of these improved machines our customers are able to obtain larger average hatches of strong, vigorous and healthy chicks and ducklings than have ever before been reported in the history of the industry.

The No. 0 and No. 1 size incubators are not equipped with the nursery drawers, for the reason that they are not required in these smaller size machines, and the drop-bottom is omitted for the same reason. These two smaller-sized machines contain all other improvements, including the new metal-cap, banded heaters, the latest-improved thermostats, the removable top diaphragms, the inclined egg trays, and the split lower diaphragms. Furthermore, the hatching and nursery apartments of each of these machines have been deepened one inch, as compared with the earlier styles, thus securing a larger volume of air in the incubating chamber and a greater depth in the nusery section.

The No. 2 and No. 3 Standard Cyphers Incubators are equipped with what we call a drop-bottom. The bottom panel of each machine consists of a substantial frame, enclosing a hinged bottom that can be let down any distance until it reaches the floor. By this means the entire under surface of the lower felt diaphragm is exposed, thus materially increasing the ventilation of the hatching chamber and nursery apartment, especially the latter.

The No. 2, 244-egg capacity, and the No. 3, 390-egg capacity, latest pattern Standard Cyphers Incubators are furnished with two nursery drawers. The drawers occupy the nursery space underneath the egg trays and are reached through solid wooden doors, located below the glass-panel door that opens into the upper portion of the hatching chamber where the egg trays are situated.

The No. 3 size Incubators are supplied with extra ventilating tubes, by means of which these large machines may be used with maximum results for hatching both hen eggs and duck eggs. In other words, they are combination hen-egg and duck-egg incubators.

All these Standard Cyphers Incubators are warranted as follows:

First-To require no supplied moisture, under normal conditions, thus solving and disposing of the troublesome "moisture question."
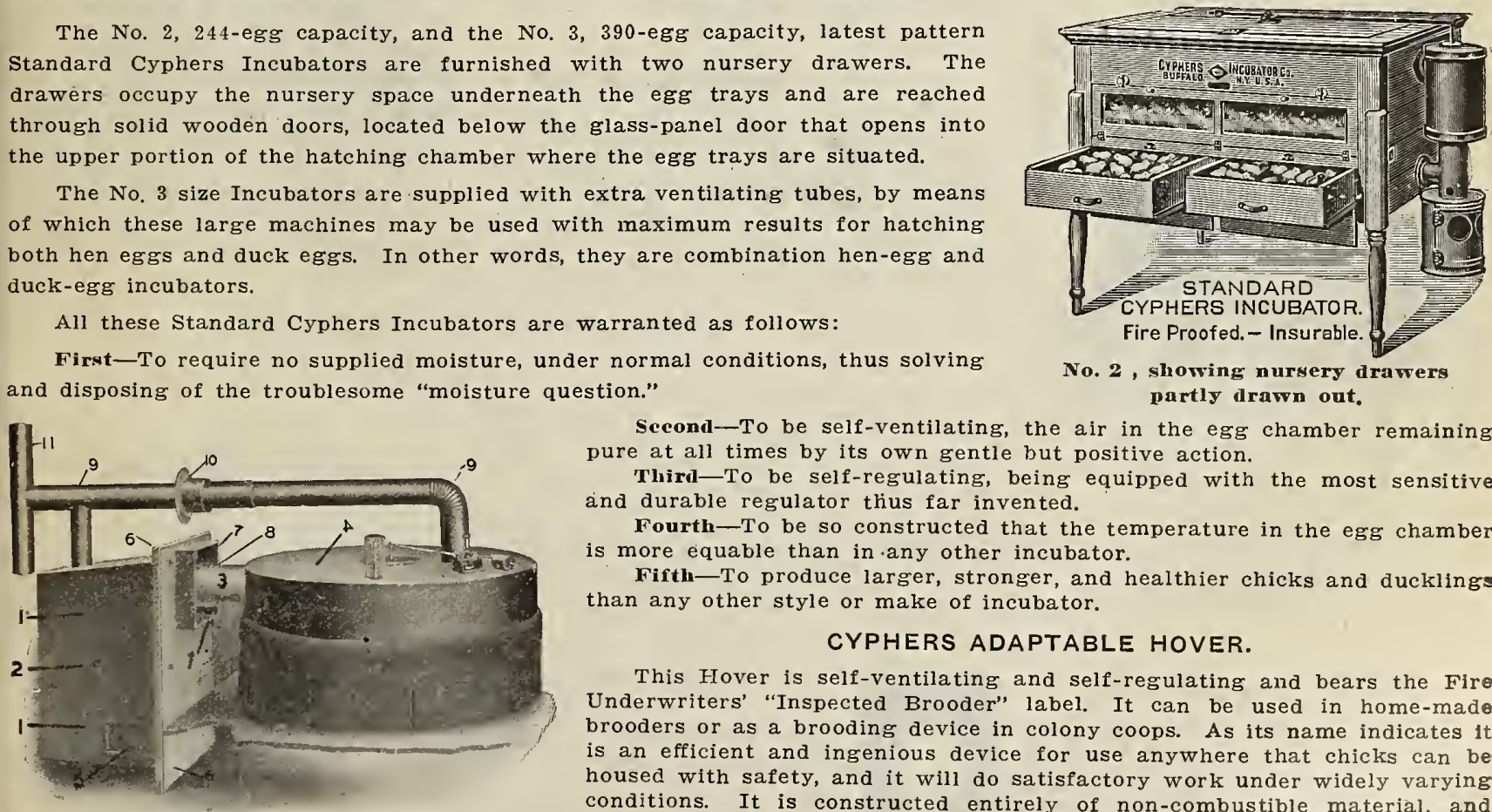

Second-To be self-ventilating, the air in the egg chamber remaining pure at all times by its own gentle but positive action.

Third-To be self-regulating, being equipped with the most sensitive and durable regulator thus far invented.

Fourth-To be so constructed that the temperature in the egg chamber is more equable than in any other incubator.

Fifth-To produce larger, stronger, and healthier chicks and ducklings than any other style or make of incubator.

\section{CYPHERS ADAPTABLE HOVER.}

This Hover is self-ventilating and self-regulating and bears the Fire Underwriters' "Inspected Brooder" label. It can be used in home-mado brooders or as a brooding device in colony coops. As its name indicates it is an efficient and ingenious device for use anywhere that chicks can be housed with safety, and it will do satisfactory work under widely varying conditions. It is constructed entirely of non-combustible material, and could be operated, without danger of fire, if placed in a kindling wood box

Cyphers Adaptable Hover. 


\title{
Cyphers Combination Brooders and Colony Houses
}

\author{
FIRE-PROOFED-INSURABLE. \\ STYLE A OUTDOOR BROODER.
}

Is recommended for use of poultry raisers who feel that they do not wish to invest in the larger sized and more costly three-apartment outdoor brooders. The Style A is equipped with the Cyphers Fire-Proof Brooder Heater and Standard Adaptable Hover, and bears the Fire Underwriters "Inspected Brooder" label. It employs top heat exclusively, thus giving the chicks free use of all space underneath the hover. It is self-ventilating and self-regulating.

By the use of the double-frame door we secure several advantages, including the following: A large door opening

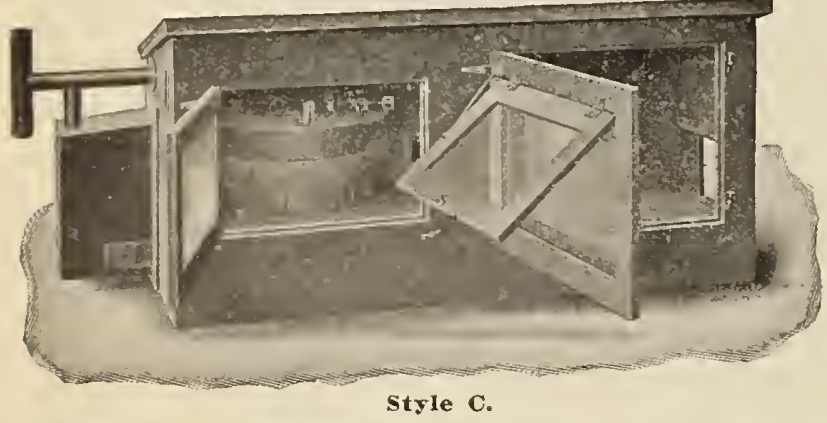

to one side, out of the way for cleaning purposes; 2 door. the sill of which is on a level with the floor of the exercising room, which facilitates cleaning, a convenient means for obtaining ample ventilation, while at the same time preventing cats, rats and other enemies of chicks from gaining access to the brooder; a protection against rain beating in when the inner door is hooked open for purposes of ventilation.

Dimensions: Floor space, $32 \times 32$ inches; height, 32 inches in front, 24 inches at rear. Capacity (normal), seventy-five newly-hatched chicks; hover space for twice that number.

Price, Style A Outdoor Brooder, $\$ 13.50$.

\section{STYLE B QUTDOOR BROODER.}

It possesses all the valuable features found in our Style $A$, and is twice as large. Style B Brooder has three apartments, and for that reason is recommended especially to all poultry raisers. The construction of the chick doors in the rartition which separates the hover and exercising apartis most unusual and advantageous. An opening or chick is most unusual and advantageous. An opening or chick door is located at either end of the partition, close to the floor, which leaves the center board on a line between the outdoor chick exit and the space underneath the hover, thus hover. This construction also does away with four corners in these brooders, thereby practically eliminating the danger of swall chicks losing their way to the hover. IWaoh of these

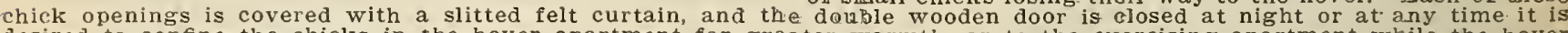

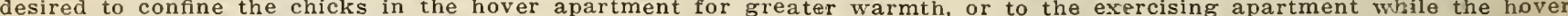
apartment is being cleaned and aired.

Dimensions: Floor space, $32 \times 62$ inches; height, 32 inches in front, 24 inches in rear. Capacity (normal $)_{\text {. }}$ one hundred newly-hatched chicks; can accommdate one hundred and fifty ehicks.

Price, Style B, $\$ 18.00$.

\section{STYLE C OUTDOOR BROODER.}

The Cyphers Style C Brooder is equipped with the Cyphers Fire-Proof Heater and Standard Adaptable. for is insurable, each brooder bearing the "Inspected Brooder" label of the Underwriters Laboratories.

This three-apartment brooder is double insulated, and so is doubly valuable during the winter months and in early spring.

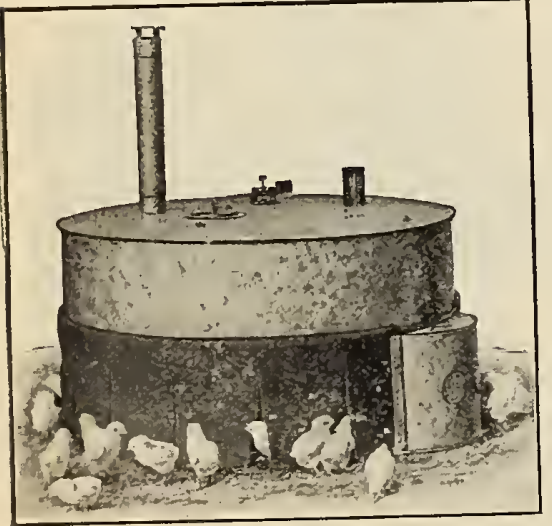

Dimensions: Floor space, $32 \times 62$ inches; height, 32 inches in front 24 inches at rear. Capacity (normal), one hundred newly-hatched chicks;. can accommodate one hundred and fifty chicks.

Price, Style C, $\$ 20.00$.

\section{CYPHERS .PORTABLE BROODING HOVER.}

This hover is self-regulating, self-ventilating, all metal, proctically indetructiol It is constructed throughout of metal. except the brooding curtain, and, witb reasonable care, with list a life-time. except the brooding curtain, and, with reasonable care, wh last a life-time. There is nothing about it to wear out or give out, except tbat once a month or such matter a new wick will be needed. The lamp has a seamless britom and therefor cannot spring a leak. It holds 2 quarts of oil and will last 48 to 96 hours, depending on the time of the year, or the temperature of tb.e place in which the hover is operated. The hover will comfortably accomnodate 80 newlyhatched chicks, or 50 from 3 to 6 weeks old. Price, \& $\$ 75$

\section{INTERNATIONAL SANITARY' HOVER.}

This hover can be picked up and carried around with ease and used anywhere. It gives equally good results in a hen house, barn, cow stall, piano or dry goods box. It is circular in shape, is made of metal throughout, and fire. proof. The hover sets on floor just as a mother hen does. The lamp can be lifted out through the top and the operator does not need to hen does. The lamp can lamp getting into lineel in the dust. There is no possibilty of gases and fumed out. looked at and dropped the air breathed by the chicks. The thermometer can During the winter months this hover back without moving the hover (see illustration. Dill hold 12 quarts of oats which. when can be used for sprouting grain for green feed. It will hold 500 laying hens for $\$$ days. sprouted, will

\section{PORCELAIN NEST EGGS.}

The "Opal brand are the best made. They are clean cut and uniform. Worth They are clean cut and uniform. With these there is no danger of getting stale eggs mixed with the fresh ones, nor the hens acquiring the habit of egg eating. for $10 \mathrm{c} ; 6$ for $15 \mathrm{c} ; 12$ for $30 \mathrm{c}$. We can supply in gross lots at special prices.

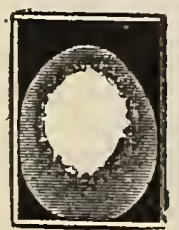

\section{LIME NEST EGGS,}

These nest eggs are the best imitation of hen eggs and are unbreakable. Each, 5c; per doz., 35c.

For Medicated Nest Eggs, see page 104

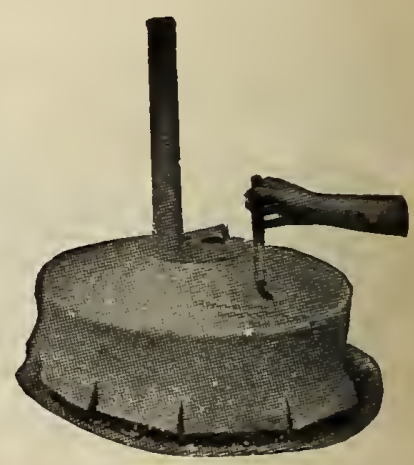

International Snnitary Horer. 


\section{ESSEX-MODEL “MIDDLE-PRICE” INCUBATORS}

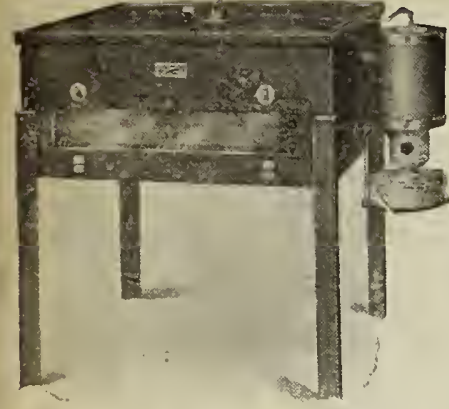

Hiddle-I'rice Incubator. Complete. No extras to buy.

MISSION FINISH-LATEST STYLE MADE.

This is a line of Middle-Price Incubators for those earnest poultry keepers who want tilating principlecgS?5; e9..9petaoin etaoin shrdlu cmfwryp etaoin shrdlu mfwyp vbgkqjvb a reliable hatcher, but not expensive. In the Middle-Price Incubators the heating and ventilating principle of the Standard Model Incubator is in a great part retained. The double cases are of pine with ample packing or insulating material between them; nicely finished in Mission Style and in every way are a dependable hatcher. Compare these prices with those of any other make of HIGH GRADE MACHINES that holds as many egrs, and you will find that these cost less by one-half. 'They are positively the greatest values offered in Incubators of these sizes.

\section{ESSEX-MODEL MIDDLE-PRICE INCUBATORS.}

Prices and Sizes.

No. A. Holds 70 eggs; shipping weight $50 \mathrm{lbs}$. Price.................. $\ldots .50$

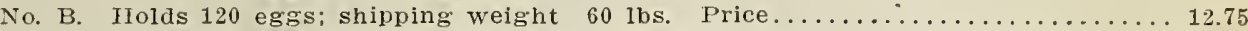

No. C. Holds 200 eggs; shipping weight 100 lbs. Price......................... 17.00

Call at our store and examine these machines. See how easily they work

\section{ESSEX-MODEL “NEW HOMESTEAD” INCUBATOR}

\section{THE BEST OF LOW-PRICED MACHINES.}

The NEW HOMESTEAD HATCHER. For the first time we are able to offer breeders an opportunity to secure a high class hot water Incubator at a price that during past years has been asked for cheaply constructed, made-to-sell machines. Constructed of first-class material with a handsome Rosewood finish, a heating equipment made wholly of copper and an egg capacity equal to much higher-priced machines, the NEW HOMESTEAD HATCHER has become at once the most popular hot water machine ever offered. Made on correct hatching principles that insure high hatching quality. Poultry keepers will take no chance in buying this wonderful little machine.

A special feature in this machine is the double glass in the top through. which the eggs and chicks may be seen. The thermometer is also in full view.

The BEST of LOW-PRICED machines. One size only, 70 eggs, shipping weight 25 lbs. Price, $\$ 7.50$.

\section{ESSEX-MODEL COLONY BROODER---Styles A and B}

The Essex-Model Brooders are known wherever poultry is raised by reason of their splendid combination of light, heat, ventilation and floor space. Their superiority-over all others is readily seen. In these Brooders the fresh outside air is first heated; then introduced and spread throughout the hover without creating a draft. The absence of oil fumes is secured by air tight heating parts, and in all of the Essex-Model Brooders the hover can be readily raised for cleaning purposes. The advantages named place the Essex Model Brooders in a class by themselves, as the most economical, most practical and highest quality Brooder made. The Essex-Model A and B Outdoor Colony Brooders and Roost Coops are

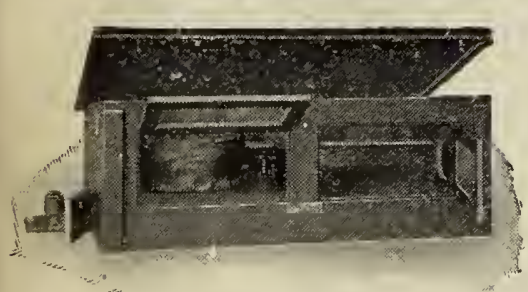

Colony Brooder-Style B. similar in appearance and construction, the difference between the two Brooders being as follows:

Model A Brooder, price, $\$ 11.50$. Contains two apartments and is $281 / 4 \times 471 / 2$ inches in size. It has a supplementary cover or diaphragm that may be used for indoor purposes or outdoors in fine weather when the roof is raised, thereby affording superior ventilation. Shipping weight, $95 \mathrm{lbs}$.

Model B Brooder, price, \$14.25. Contains three apartments, two of them similar to the Model $A$ and an additional exercising apartment separated by a wooden partition. This Brooder is $34 \frac{1}{2} \times 581 / 4$ inches in size. It has a wire screen for the window of the nursery chamber. Shipping weight, 140 pounds.

Both of these Brooders have a triple roof including the outer enameled iron one and are practically indestructible.

\section{ESSEX-MODEL NEW HOMESTEAD BROODER}

This is a low-priced Brooder substantially constructed, and is considerably in advance of the kind usually sold at the price we ask for it. It can be used either indoor or outdoors. It is $21 \times 341 / 2$ inches and has a chick capacity nearly equal to brooders that are sold for double the money. It is equipped with our superior heavy galvanized iron lamp

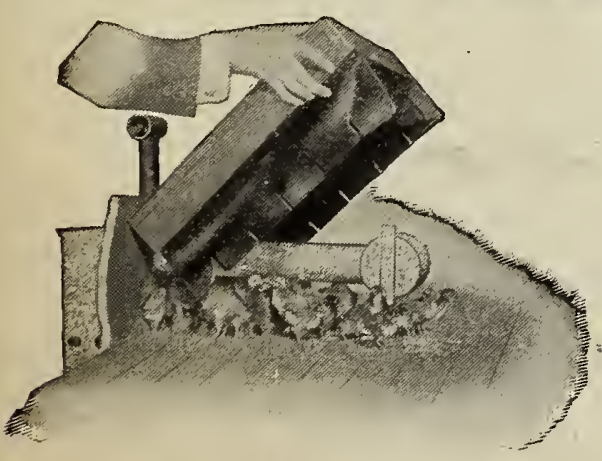

Portable Hover. and chimney, metal heating parts, tested thermometer, and is complete in every way. Capacity, 50 chicks. Price, $\$ 5.75$. Shipping weight, $40 \mathrm{lbs}$.

\section{ESSEX-MODEL PORTABLE HOVER}

An especially attractive and practical brooding outfit for those who wish to bulld their own brooders or for attaching to a small colony house or coop, or for use in a brooder house. No other hover possesses as many practical advantages. It may be easily raised for cleaning purposes or to examine the chicks beneath it without detaching it from the brooder-one of our latest improvements not possessed by any other similar hover.

Price, complete, $\$ 6.75$. Shipping weight, 25 lbs.

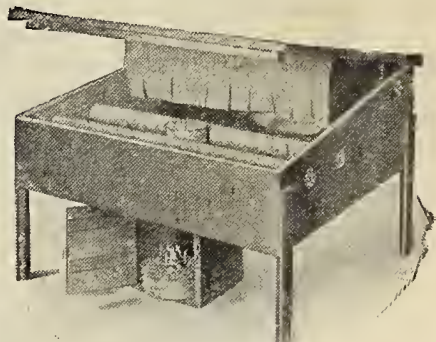

New Homesteud Brooder. 


\section{The W.-K. Chicken Coop}

This Galvanlzed Iron Coop won't rust, and will last a llfetime.

It is Rat, Weasel, Mink and Skunk proof; and Mites cannot live in an iron house.

It is dry and won't absorb moisture.

It is easily cleaned and is perfectly sanitary.

It is put together in grooves and slldes, and is held solld simply by two small bolts, which may be removed and the coop taken apart in a few seconds. The bottom simply slides in and may be removed and cleaned without llfting the coop, disturbing the chickens or soiling your clothes.

The openings are closed by two doors; one solid and one for ventilation. In the solid door is a small opening for young chicks-a door within a door-and it's all slmpliclty simplified. Wlth the screen door a circulation is secured through the ventllators that makes hot nights cool, while the ventllators are perfectly rain-proof. One side of the coop opens like a lld and turns the coop into a model nest; while the lld only partially raised makes a double ventilation when needed.

This coop is about $18 \times 24 \mathrm{ln}$. and $17 \mathrm{ln}$. high, givlng plenty of room for a hen and 25 chicks, 'till old enough to shift for themselves. Price, \$2.00.
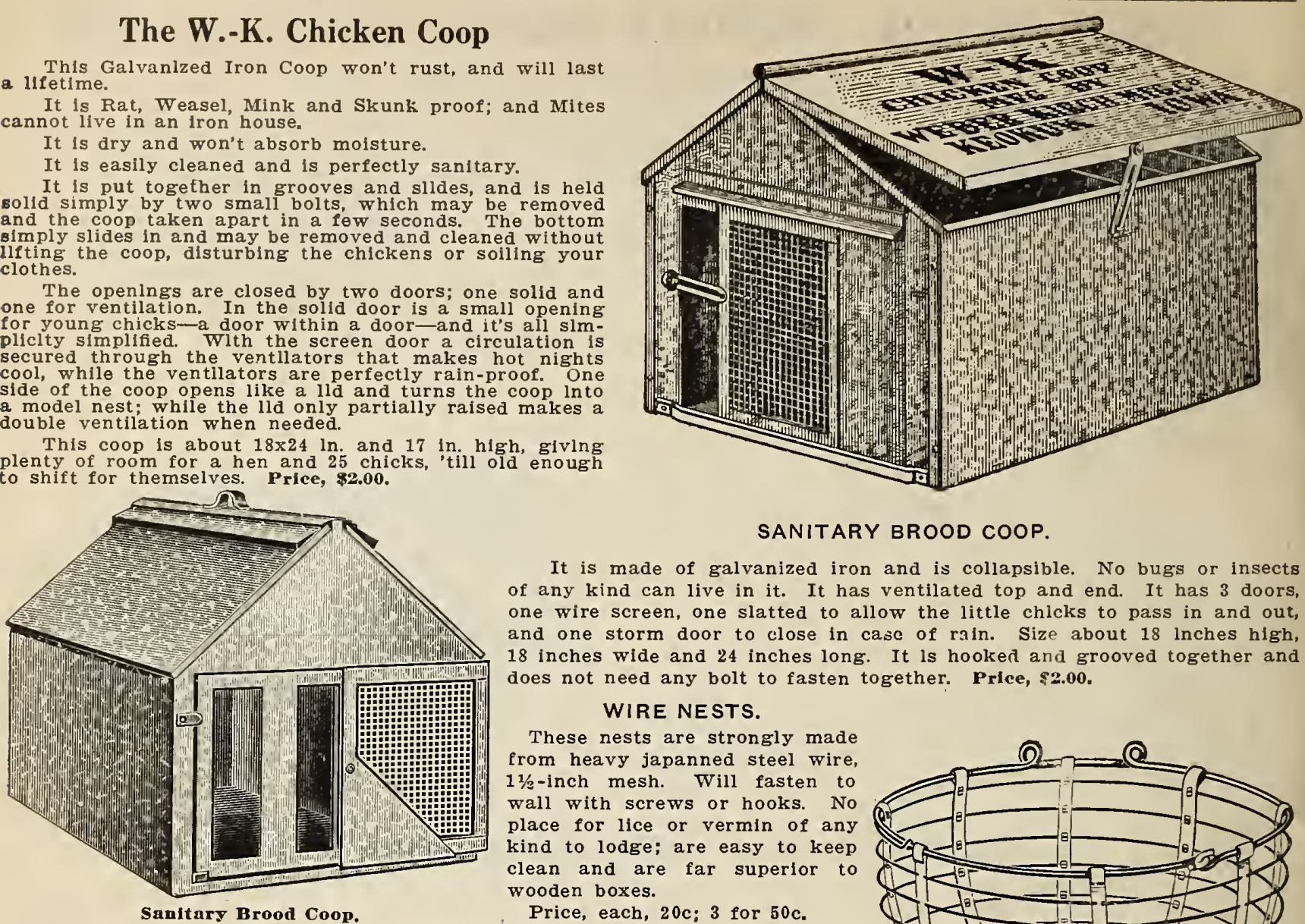

\section{SANITARY BROOD COOP.}

It is made of galvanized iron and is collapsible. No bugs or insects of any kind can live in it. It has ventilated top and end. It has 3 doors, one wire screen, one slatted to allow the little chlcks to pass in and out, and one storm door to close in casc of rain. Size about 18 lnches high, 18 inches wide and 24 inches long. It is hooked and grooved together and does not need any bolt to fasten together. Price, $\$ 2.00$.

\section{WIRE NESTS.}

These nests are strongly made from heavy japanned steel wire, $11 / 2-$ inch mesh. Will fasten to wall with screws or hooks. No place for lice or vermin of any kind to lodge; are easy to keep clean and are far superior to wooden boxes.

Price, each, 20c; 3 for 50c.

OAKE'S HYDRO-SAFETY LAMP.

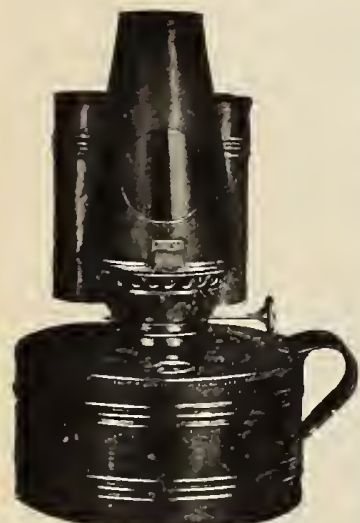

This lamp has been on the market for several years; is well advertised; is well liked and in common use. The Oakes' Hydro-Safety Lamp is made for incubator and brooder use excluslvely, and its construction in every part is such as to combine absolute safety with ecenomy of oil, a constant even heat and a great convenience in use.

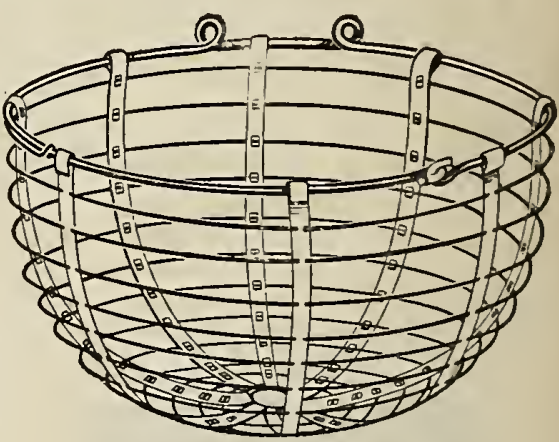

Wire Nest.

\section{PRICES:}

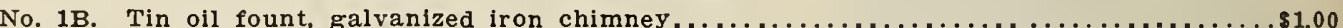

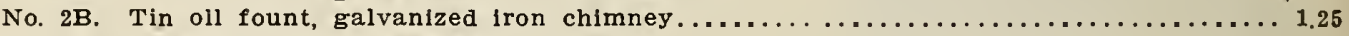

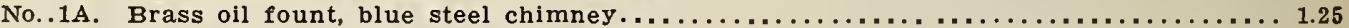

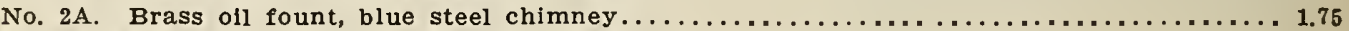

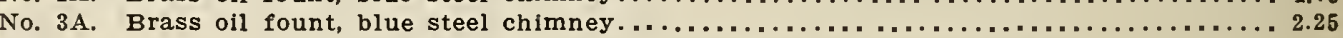

\section{INCUBATOR AND BROODER LAMPS AND PARTS.}

Essex-Model, small size, for Nos. 0, 1, A and B Incubators. Price, without chimney.......8 80 Essex-Model, large size, for Nos. 2, 3 and C Incubators. Price, without chimney......... 1.00 Essex-Model Brooder Lamp for Portable Hover and 1911 Brooders. Price, with chimpney.. 1.25 Oake's Hydro-safety Lamp. Essex-Model Lamp, complete for Portable Hover and Model B Brooder. Price.............. 1.00

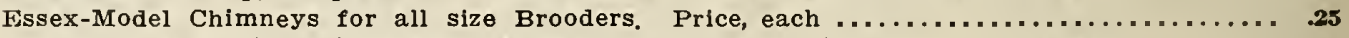
Cyphers Incubator lamp bowls for No. 0 and No. 1 Incubators, 75c each; for No. 2 and No. 3 incubators, each.......... 1.00 Barteldes' Incubator lamp bowls for No. 0, 35c; No. 1 incubators, 50c; for No. 2 and No. 3 incubators, each........... .60

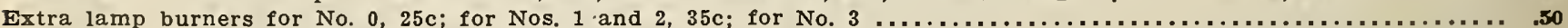

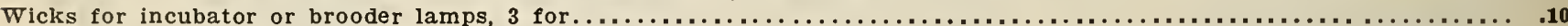

PILLING ANGULAR KILLING KNIFE.

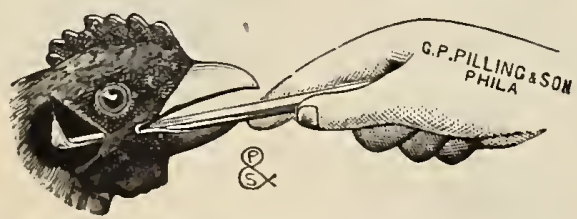

By simply turning the wrist the jugular vein and spinal cord are cut, thereby bleeding the fowl, allowing the feathers to be removed without using water. 50 cents, postpald.

\section{FRENCH POULTRY KILLING KNIFE.}

\section{(0)14)}

Every poultry raiser should have one Kllling Knife. These are made of finely tempered instrument steel, with nickled handle; will last a lifetime. Sent postpald on recelpt of $50 \mathrm{c}$.

PLAIN BRUSSELS HAIR GAPE WORM EXTRACTOR. 10 c each, postpald.

PHILADELPHIA GAPE WORM EXTRACTOR. Price, postpald, 25c. 


\section{Thoroughbred Poultry and Eggs for Hatching}

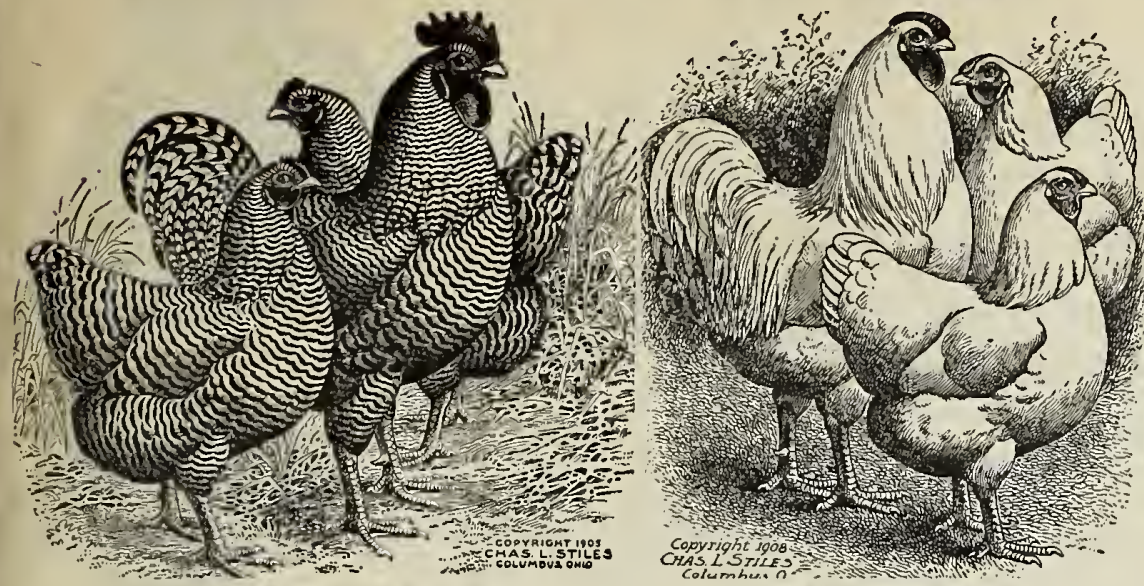

Barred Plymouth Rock.

White Wyandotte.

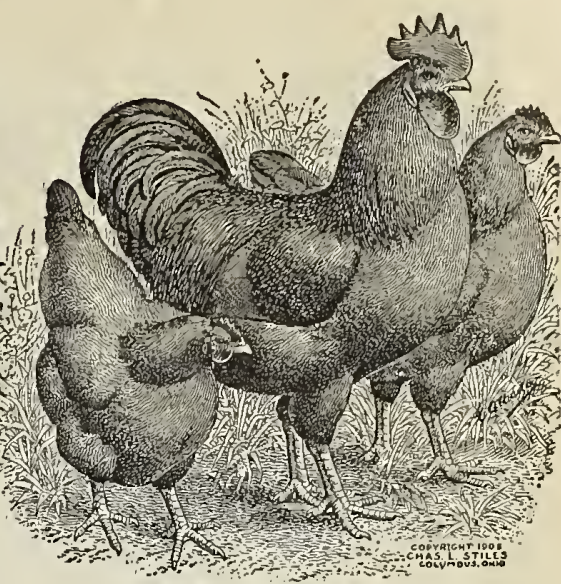

Rhode Island Red.

\begin{tabular}{|c|c|c|c|c|c|c|c|c|c|}
\hline$\because$ & & [ale & & & Prio. & & Doz. & $\begin{array}{r}\text { Eggs } \\
\text { Per 1 } \\
\text { Setting }\end{array}$ & $\begin{array}{c}\text { Eggs } \\
\text { Per } 2 \\
\text { Settings }\end{array}$ \\
\hline 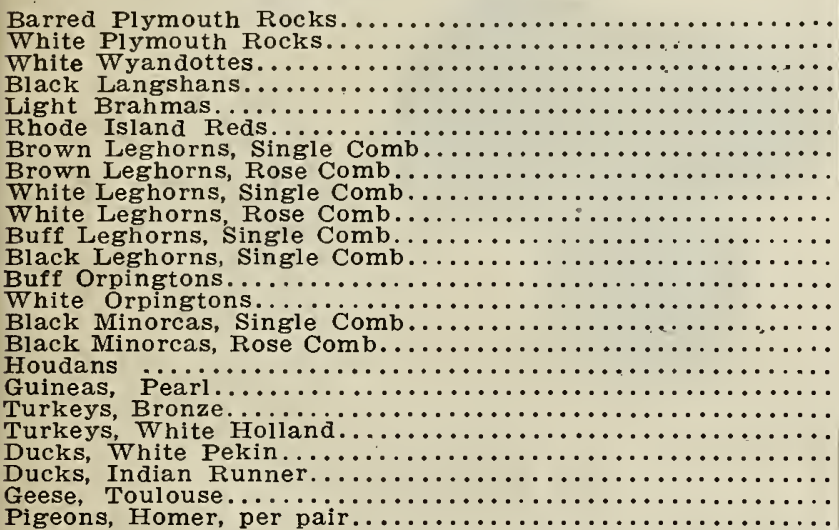 & $\begin{array}{r}3.00 \\
4.00 \\
4.00 \\
5.00 \\
4.00 \\
3.00 \\
2.50 \\
3.50 \\
2.50 \\
3.50 \\
4.00 \\
5.00 \\
4.00 \\
5.00 \\
4.00 \\
5.00 \\
4.00 \\
2.00 \\
7.00 \\
7.00 \\
2.50 \\
3.00 \\
5.00 \\
1.50\end{array}$ & $\begin{array}{l}\text { to } \\
\text { to } \\
\text { to } \\
\text { to } \\
\text { to } \\
\text { to } \\
\text { to } \\
\text { to } \\
\text { to } \\
\text { to } \\
\text { to } \\
\text { to } \\
\text { to } \\
\text { to } \\
10 \\
\text { to } \\
\text { to } \\
\text { to } \\
\text { to } \\
\text { to } \\
\text { to } \\
\text { to } \\
\text { to } \\
\text { to }\end{array}$ & $\begin{array}{r}\$ 12.00 \\
12.00 \\
10.00 \\
15.00 \\
10.00 \\
10.00 \\
6.00 \\
8.00 \\
6.00 \\
8.00 \\
10.00 \\
10.00 \\
10.00 \\
10.00 \\
8.00 \\
10.00 \\
10.00 \\
3.00 \\
12.00 \\
12.00 \\
5.00 \\
5.00 \\
7.00 \\
2.00\end{array}$ & $\begin{array}{r}\$ 6.00 \\
6.00 \\
6.00 \\
8.00 \\
7.00 \\
6.00 \\
6.00 \\
7.00 \\
6.00 \\
7.00 \\
8.00 \\
8.00 \\
8.00 \\
12.00 \\
8.00 \\
8.00 \\
8.00 \\
4.00 \\
15.00 \\
15.00 \\
8.00 \\
8.00 \\
15.00\end{array}$ & $\begin{array}{l}\text { to } \\
\text { to } \\
\text { to } \\
\text { to } \\
\text { to } \\
\text { to } \\
\text { to } \\
\text { to } \\
\text { to } \\
\text { to } \\
\text { to } \\
\text { to } \\
\text { to } \\
\text { to } \\
\text { to } \\
\text { to } \\
\text { to } \\
\text { to } \\
\text { to } \\
\text { to } \\
\text { to } \\
\text { to } \\
\text { to }\end{array}$ & $\begin{array}{r}\$ 15.00 \\
15.00 \\
12.00 \\
15.00 \\
12.00 \\
12.00 \\
10.00 \\
10.00 \\
10.00 \\
10.00 \\
12.00 \\
12.00 \\
12.00 \\
25.00 \\
12.00 \\
12.00 \\
12.00 \\
6.00 \\
20.00 \\
20.00 \\
12.00 \\
12.00 \\
20.00\end{array}$ & 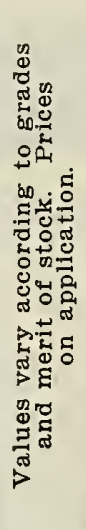 & $\begin{array}{r}\$ 3.00 \\
3.00 \\
3.00 \\
3.00 \\
3.00 \\
3.00 \\
2.50 \\
2.50 \\
2.50 \\
2.50 \\
3.00 \\
3.00 \\
3.00 \\
4.00 \\
3.00 \\
3.00 \\
3.00 \\
2.00 \\
3.00 \\
3.50 \\
2.50 \\
2.50 \\
50 \mathrm{c}\end{array}$ & $\begin{array}{r}\$ 4.50 \\
4.50 \\
4.50 \\
4.50 \\
4.50 \\
4.50 \\
4.00 \\
4.00 \\
4.00 \\
4.00 \\
4.50 \\
4.50 \\
4.50 \\
6.50 \\
4.50 \\
4.50 \\
4.50 \\
3.25 \\
4.50 \\
6.00 \\
4.25 \\
4.25 \\
\operatorname{ch} .\end{array}$ \\
\hline
\end{tabular}

We do not keep these fowls on hand; thus, it is impossible to fill orders as promptly as we desire. Nearly all of our breeders are located in the country, therefore, when we receive your order it is necessary to write a letter and it is usually a day before the breeder receives it, and another day before he can deliver the birds to us. Thus, it can easily be seen that it takes three days before we can fill your order.

In very cold weather it is sometimes necessary to hold the birds for a day or so until the weather moderates, as it is dangerous to move valuable birds of the large comb breeds-such as Minorcas and Leghorns-in severe weather, on account of the danger of freezing their combs.

We are particularly careful about shipping birds. Our shipping coops are light but very substantially made and have a slatted top, allowing plenty of air, and taking a cheaper express rate than the canvas coops. Provision is made for feed and water.

During the breeding season, or from February 1st to May 1st, we try to have on hand a display of good cockerels at our store, but outside of this period it is impossible to do this, as the birds which are kept confined are bound to become weakened and sickly in time. The price of these birds depends much on the merit of each particular specimen; therefore, it is difficult to give exact prices in the catalogue.

In writing for birds be sure to state whether you wish utility or show birds.

We are always glad to make quotations, so do not hesitate to inquire.

We advertise sll kinds of eggs for hatching, but please remember that we do not guarantee them. about $85 \%$ fertile, but on account of the amount of handling which they are bound to receive in our hands and in transit, wo have found it necessary to withdraw any guarantee whatever. We regret very much that we find it necessary to do we have found it necessary to withdraw any guarantee whatever. We

Turkeys and Ducks do not usually start laying in this locality much before March 15 th, and as the first eggs are never the best, we think the first of April is plenty early.

Orders for one and two settings are packed in Anderson egg boxes. Each egg has a compartnent, and is carefully protected by layers of corrugated paper. Larger lots are packed in baskets.

Eggs should go via express. We send a notice by mail the same day that the express shipment is made, advising customer of same. No goods sent C. O. D.

\section{A FEW THINGS TO REMEMBER IF YOU WANT YOUR CHICKENS TO DO WELL:}

Do not keep a hen more than two years unless exceptionally good. thus, if you want them to lay in October, November and December, when eggs are bringing a good price, hatch your chicks in March, April and the beginning of May.

Every year or so introduce new blood into your flock, either by getting a male bird or a setting of eggs. Fowls too much inbred lose vigor.

Build your houses so as to have plenty of sunshine and fresh air, but be sure that there is no draught and that the roof is not leaky. Most of the diseases come from draught, dampness and foul air.

Feed your chickens enough to keep the body warm and have a little more for laying. Nature requires more feed in winter to keep the body warm, and hens cannot lay eggs until this want is first provided for, then the surplus feed goes to make egg.s

Do not expect your hens to lay much if you feed grain alone. They must have, to do their best, vegetables or alfalfa meal, meat, ground bone, oyster shell and grit. in addition to grain

Keep the house clean and free from mites and lice and the chickens will amply repay you for your work.

Don't feed the chicks wet food.

Don't keep your brooder too warm.

Don't feed little chicks more than they will eat up clean.

Don't take chicks out of incubator too soon.

Don't forget to feed mash 3 or 4 times a week.

Don't expect fertile eggs from an over-fat hen times.

Don't forget to keep charcoal before your fowls at all 


\section{EGG TESTERS}

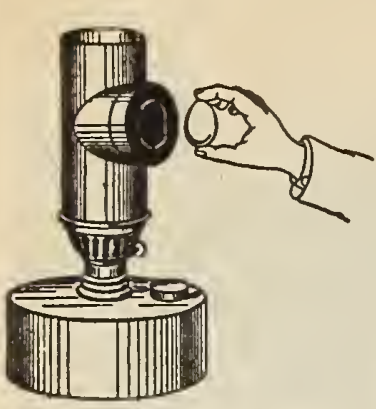

X-Rny Egg Tester.

\section{X-RAY EGG TESTER.}

This is one of the best and cheapest small sized egg testers on the market. It will fit any ordinary house lamp, and will show this egg tester meets all requirements. Price, $25 \mathrm{c}$.

\section{THE “PRACTICAL” EGG TESTER.}

The standard tester in use on large eastern duck and broller farms, and one that embodies the best ideas to date. This tester is equipped with an extra strong reflector, also a good No. 3 lamp, and will last a lifetime with proper car. No better made or more practical tester has ever been placed on the market. Price, $\$ 1.60$.

\section{THE DAVIS RAPID EGG TESTER.}

Consists of a hard wood, handsomely finished box, $6 \frac{1}{2} \times 6 \times 3$ inches, lined with asbestos and covered with black felt cloth. It is operated by placing an ordinary light globe within the tester and attaching the cord on the tester to the socket. The eggs are placed within the beveled-edge slots on top of the tester and the light shows whether they are good or bad. Can be used in broad daylight with perfect results.

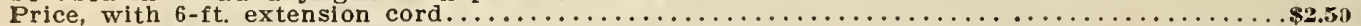

\section{HIGH GRADE TESTED THERMOMETERS.}

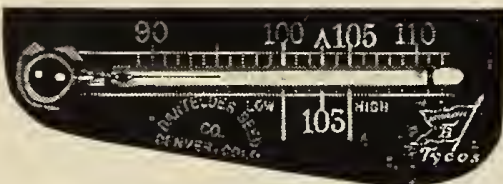

Essex-Model Incubator Thermoneter. An accurate, guaranteed thermometer. Glass tube is made to magnify the mercury. Price, each, 60c, postpaid; $50 \mathrm{c}$ each, not postpaid.

Essex Thermometer Wires. Made to hang thermometer in the ego chamber to save space. Price, each, 10c.

Certifled Thermometer with scale also etched on the glass tube, with certificate, $\$ 1.50 ; 2$ for $\$ 2.50$, postpaid.

Incubator Thermometer, round corners, tube set at an angle, $75 \mathrm{c} ; 2$ for $\$ 1.25$, postpaid.

Brooder Thermometer with magnifying lens front, postpaid, $75 \mathrm{c}$.

Brooder Thermometer, flat, 35c, postpaid. paid.

iSpecial Thermometer for Cypher's Brooders, 45c, post-

\section{TYCOS HYGRO.}

METER.

The. use of an incubator hygrometer effectively lessens the percentage of chicks dying in the shell, dying in the shell, improper moisture improper moisture conditions. The illus-
tration shows the
correct position of the instrument in use taking the place of one egg in the egg tray, thus showing the conditions actually surrounding the eggs. Price, $\$ 1.50$, by mail, \$1.65. Extra wicks for same, each, 10c; per doz., $\$ 1.00$, postpaid.
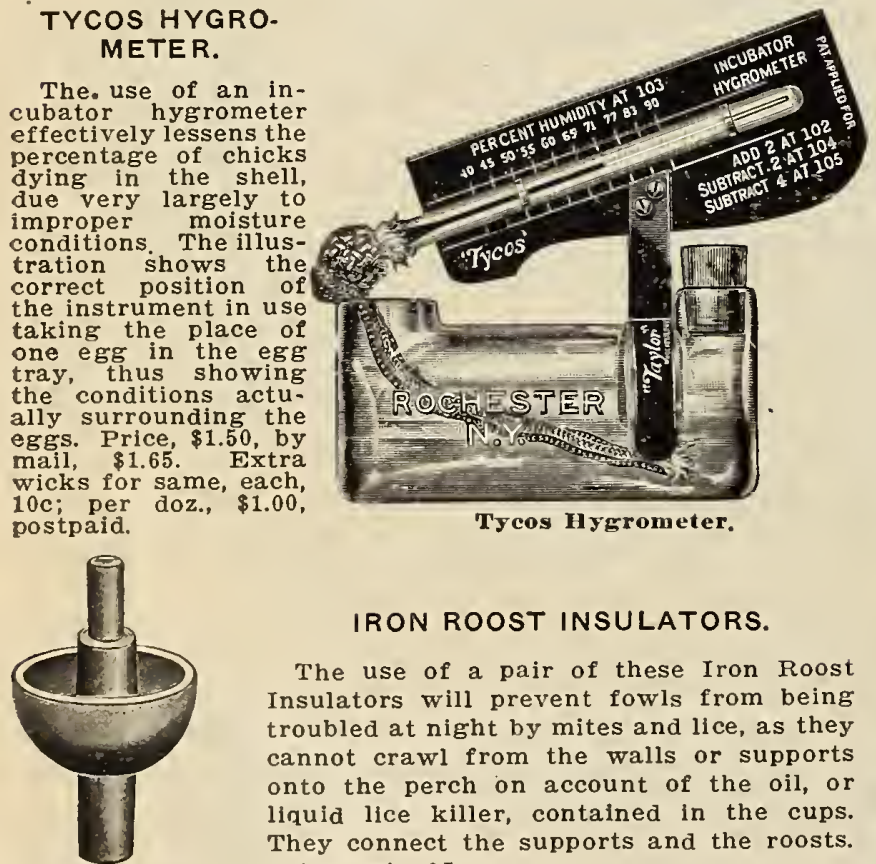

Iron Roost

IRON ROOST INSULATORS.

The use of a pair of these Iron Roost Insulators will prevent fowls from being troubled at night by mites and lice, as they cannot crawl from the walls or supports onto the perch on account of the oil, or liquid lice killer, contained in the cups. They connect the supports and the roosts. Price, pair, $25 \mathrm{c}$.

Insuiator.

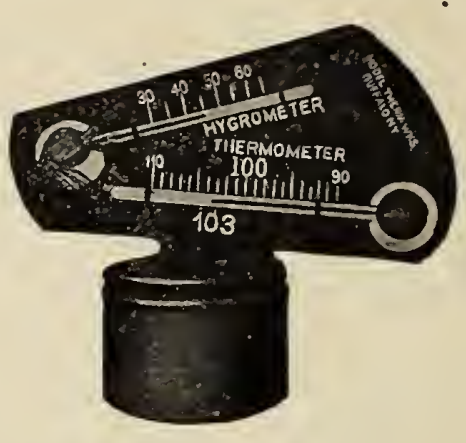

ESSEX-MODEL “READ EASY" HYGRO. METER.

It enables the operator to decide just how nuch moisture is in the n: xchine when the temlerature is at or near the incubating point. It is very simple and is arranged to read as easy as a thermometer. Price, each, $\$ 1.25$.

ESSEX-MODEL COMBINATION THERMOMETER AND HYGROMETER.

Saves space in the incubator by mounting the thermometer and the hygrometer on one stand. Price, each, \$1.75.

\section{CAPONIZING INSTRUMENTS.}

They are made by expert surgical instrument manufacturers and are first-class in every respect. With each set of instruments we send a booklet containing full directions for using the instruments and caring for the capons. Book alone is $10 \mathrm{c}$.

\section{PHILADELPHIA CAPONIZ- ING SETS.}

Philadelphia Caponizing Sets.

Complete set, in plain pasteboard box, postpaid, $\$ 2.50$.

Complete set, velvet case, postpaid, $\$ 2.75$

Farmer's Caponizing Set in velvet case, postpaid, $\$ 3.00$.

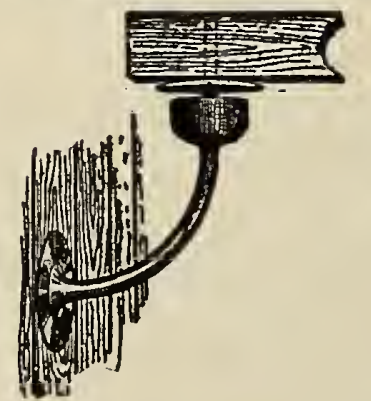

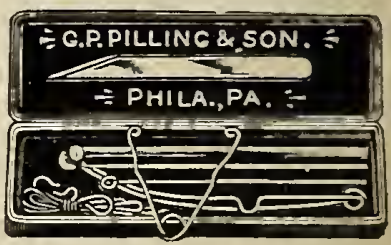

\section{LICE PROOF PERCH} SUPPORTS.
When the little cup is filled with coal oil, Barteldes' Lice Killer, or any of the numerous liquid insecticides or disinfectants, it is impossible for lice to pass from the walls of the building to the roost, or from the roost to the building: hence hens can roost in perfect roost in perfect peace at night, and in a short time your fowls will be free from the plague, the lice dying for want of nourishment. Price, sample pair, $35 \mathrm{c}$;
doz., $\$ 3.50$. Wolcott, Colo.

THE BARTELDES SEED CO.

Dear Sirs:-Chickens arrived $O . K$. and are doing nicely. Am well pleased with them. Arrived on 15 th of March. MRS A L DUNNINGTON. 


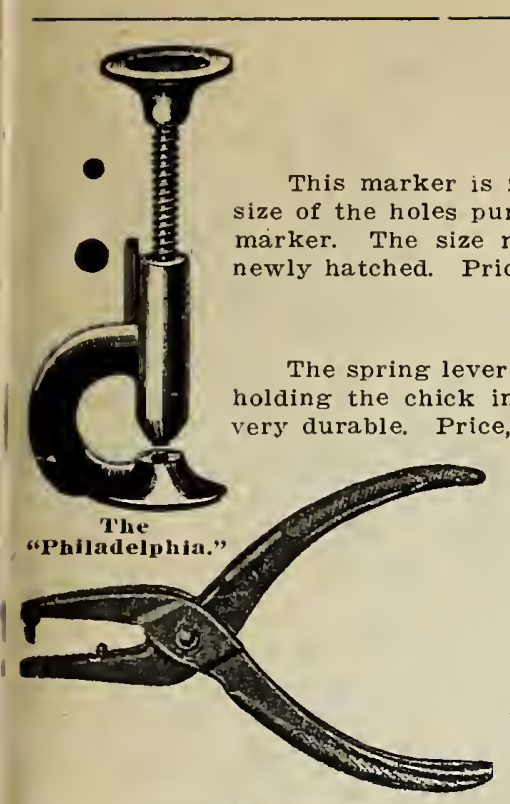

Model Toe Marker.

\section{CLIMAX OR "STAY-ON" LEG BANDS.}

These rings are made of spring brass and so bent that the tag acts as a clasp, holding them securely in place. Tags are aluminum. Mention size wanted when ordering.

Price, 12 for $20 \mathrm{c} ; 25$ for $35 \mathrm{c} ; 50$ for $60 \mathrm{c} ; 100$ for $\$ 1.00$, postpaid.

\section{PIGEON BANDS.}

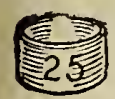

Made from aluminum tubing. Are put on safely when birds are young. Are very light

Price, 12 for $20 \mathrm{c}$; 25 for $40 \mathrm{c}$; 50 for $75 \mathrm{c} ; 100$ for $\$ 1.35$, postpaid.

\section{OPEN PIGEON BANDS.}

Made from flat aluminum. Price, 12 for $15 \mathrm{c} ; 25$ for $30 \mathrm{c}$; 50 for $50 \mathrm{c} ; 100$ for $80 \mathrm{c}$, postpaid.

\section{ROUND ALUMINUM WIRE BANDS.}

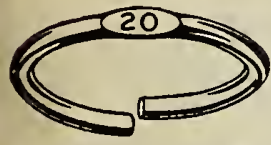

Made of wire aluminum, flattened where the number is placed. Sample free for the asking. The most satisfactory leg band on the market. Are used by a majority of the largest breeders in the west. Made in 4 sizes:

Round Alumlnum. No. 1, extra large; No. 2, large; No. 3, medium; No. 4, small

Price, 12 for $20 \mathrm{c} ; 25$ for $40 \mathrm{c}$; 50 for $75 \mathrm{c} ; 100$ for $\$ 1.35$, postpaid.

All bands are numbered unless otherwise ordered.

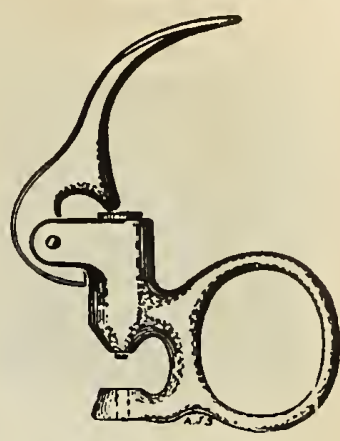

The "Acme."

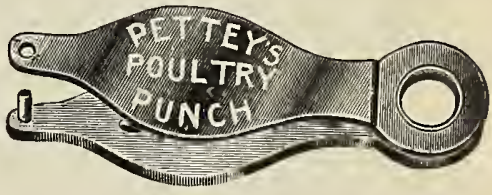

\section{Leg Bands}

gOP Ponltry show secretaries and others buying Leg Bands in large quantitles will do well to write us,

\section{WOOD'S REVOLVING EGG CABINETS.}

Eggs intended for hatching should be turned daily. Wood's Revolving Egg Cabinets are a practical device for doing this work and meet a widespread need among poultrymen who save eggs for hatching.

\section{PRICES.}

150 -egg size, weight $30 \mathrm{lbs} \ldots \ldots \ldots \ldots \ldots \ldots \ldots \ldots \ldots \ldots+25$

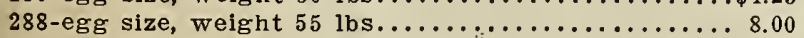

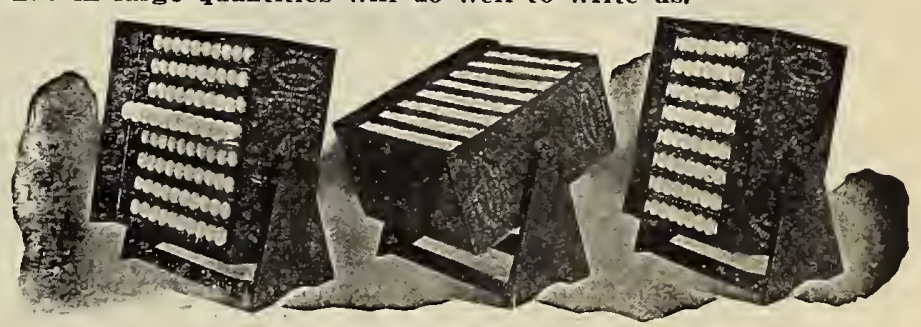

\section{ELATERITE RE-INFORCED ROOFING.}

This is made of solid body, tough, pliable and durable, Elaterite Cement, re-inforced with one layer of heavy imported India burlap, backed with highly compressed saturated wool felt. Top surface is mica. It is water, steam, acid and fire proof. No coal tar is used in its make-up. Put up in rolls 40 feet long and 32 inches wide, complete with nails and

$4 \mathrm{X}$ grade, medium, weighs about 55 lbs., price, $\$ 3.75$ per roll. $5 \mathrm{X}$ grade, heavy, weighs about 651 bs., price, $\$ 4.00$ per roll.

INDIA RUBBER ROOFING.

Just the thing for that chicken house. Put up in rolls 40 feet long and 32 inches wide, enough to cover 100 square leet, 1 ply, light, weighs about 35 lbs., price, $\$ 1.70$ per roll. 2 ply, medium, weighs about 451 bs., price, $\$ 2.00$ per roll. 3 ply heavy, weighs about 55 lbs., $\$ 2.35$ per roll. 


\section{Drinking Fountains}

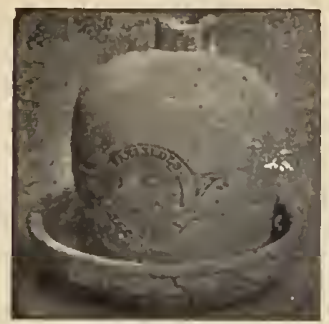

\section{BARTELDES' TWO.PIECE EARTHEN DRINKING FOUNTAIN.}

These stoneware drinking fountains keep the water cool and clean, and chicks from getting wet or drowned. Made with open bottom for convenience of cleaning, and inverted into a pan. Price, 2-qt. size, 35c; gal. size, $50 \mathrm{c}$.

THE "COLORADO" FOUNTAIN. One Piece.

Half gallon, each $25 \mathrm{c}$; one gallon, each $11 / 2$ quarts, fits inside brooder, each $25 \mathrm{c}$.

THE "SANITARY" FOUNTAIN.

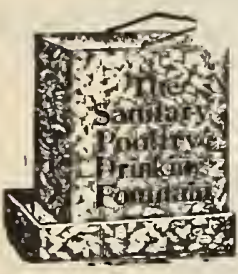
A square, galvanized fountain in two parts. A slight pull on the projecting part of the bottom removes it broom, both parts are easily and thoroughly cleaned. It is filled instantly. It can be hung up out of the dirt on an ordinary nail or hook.

Price, 1 gallon size, 60c; 2 gallon size,

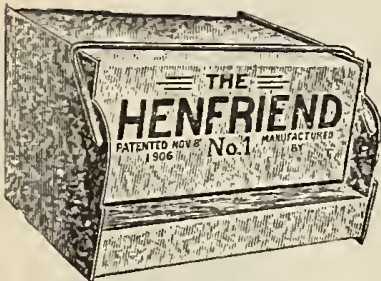

HENFRIEND DRINKING FOUNTAIN.

Can be used also as a feed box. Size No. $1,60 c$; size No. 2, 50c; size No. $3,35 \mathrm{c}$
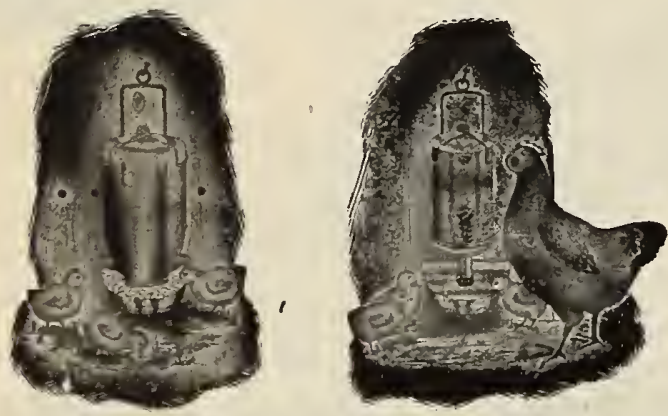

DAVIS FOOD AND WATER FOUNTAIN.

One of the most handy fixtures for poultrymen. Can be filled with water or feed. It consists of an iron frame, into which any kind of bottle or mason jar is inverted, and can be hung anywhere. See illustrations. Price, frame only, 25c.

\section{"BON-MAX" DRINKING PANS.}

This inexpensive drinking fountain pan consists of a mason jar lid welded to a steel pan. Any pint, quart or half gallon mason jar will fit. Price of pan, each, $10 \mathrm{c}$.

\section{MODEL WALL FOUNTAIN.}

This fountain is made of galvanized iron and is plattened on the back so it can be hung on the wall of the poultry house to prevent litter from getting in the water. It has a good sized square opening, making it easy to clęan and permitting a free flow of water. It will last a lifetime.

Price, 1 qt. size, 50c; 1 gal. size, $75 \mathrm{c} ; 2$ gal. size, $\$ 1.00$.

\section{TARRED PAPER.}

Cover your chicken houses with tarred paper to keep dampness out and to prevent draughts. Can be furnished in rolls, ranging from 40 to 60 pounds, and 32 inches wide. Price, $2 \frac{1 / 2}{\mathrm{c}}$ per pound.

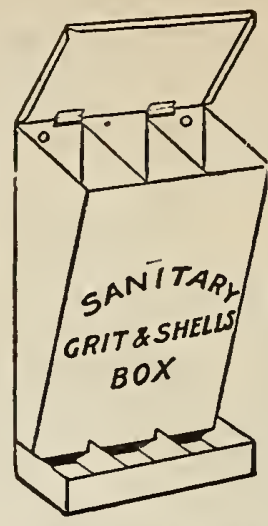

SANITARY SELF-FEEDING BOXES FOR POULTRY.

This box is manufactured from the best galvanized fron. It can be hung up against the wall at any height desired. It is a first-class article, is practically indestructible and will last a lifetime. No. 0, 1 pint to a bin, 3 compartments, price, $40 \mathrm{c}$. No, 1,2 quarts to a bin, 3 compartments, price, 75c. No. 2, 2 large compartments, price, $\$ 1.00$. $\$ 2.25$

PERRLeSS hoppers. 8-qt., $\$ 1.15 ; 16$-qt., $\$ 1.65 ; 32$-qt.,
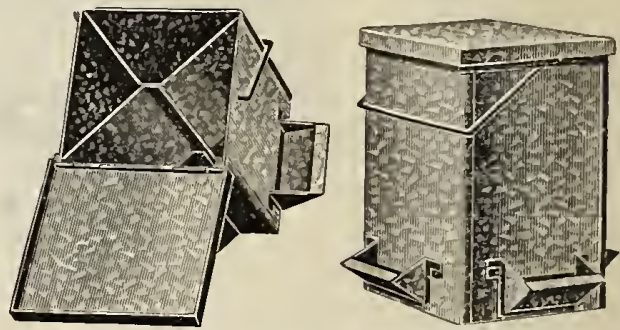

Four in One Sanitary Feeder.

FOUR IN ONE SANITARY FEEDER.

Made of galvanized iron and collapsible. It has 4 compartments which can be used for 4 kinds of grit or feed. Size $71 / 4 \times 71 / 4 \times 11$ inches. Being collapsible they are shipped knocked down; are put together in one minute. Each, $85 \mathrm{c}$.

N. W. AUTOMATIC FEEDER AND FOUNTAIN.

Will feed water, grit, shell, grain, etc. Any size mason Jar fits the pans. Made in 2 sizes. No. 5 , each, $15 \mathrm{c}$; No. 6 , each, $20 \mathrm{c}$.

\section{BOSTON FEED HOPPERS.}

Chick size, price............................ $\$$. 1.00 Hen size, price $\ldots \ldots \ldots \ldots \ldots \ldots \ldots \ldots \ldots \ldots \ldots \ldots, 1.00$

Hopper for shell, grit, etc..................

BARTELDES' GALVANIZED FEED TROUGH.

No. 1. Size, 12 inches long, in 1,2 or 3 compartments, price, $25 \mathrm{c}$.

No. 2. Size, 30 inches long. width 7 inches, depth 4 inches, price, $\$ 1.00$.

\section{PIGEON NAPPIES.}

7 -in. diameter, 2 for $25 \mathrm{c} ; 12$ for $\$ 1.40$.

9-in. diameter, $15 \mathrm{c}$ each; 12 for

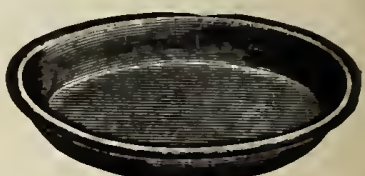

Pigeon Noppy.

MODEL CANFIELD DRINKING CUPS.

These cups are made of sheet iron, heavily enameled, and hold half a pint each. They are indispensible for waterand hold half a pint each. They are indispensible for watering and feeding birds cooped in exhibition cages. The back front of cage. Have large flat bottoms to prevent tipping if set in cage.

if set in cage.
Price, each, 15c; by mall, 20c.

\section{GALVANIZED POULTRY NETTING.}

The best and cheapest fence to put around a chicken yard. Sold in full rolls of 150 lineal feet, any size from 3 to 6 feet high. 2 -inch meshes. Price, $60 \mathrm{c}$ per 100 square to 6 feet high; 2-inch meshes. Price, $60 \mathrm{c}$ per 100 square feet. Rabbit wire, 1-inch mesh
Price, $\$ 1.60$ per 100 square feet. 


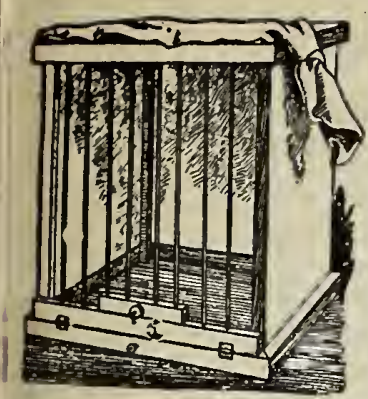

\section{BARTELDES' EXHIBITION COÓPS.}

The Popular Show Coops.

It is strong and can be sent long distances with safety to itself and contents. The iron bars are $1 / 4$-inch iron; the ends, top and back of heavy canvas. Wood part painted blue. A curtain drops over front. The narrow door at bottom admits of cleaning out litter, etc. Shipped to customers litter, D. Can be put together quickly.

No. 4 , for pair, $24 \times 30 \times 30$ in., each, $\$ 2.40$

No. 2, for pen, $24 \times 42 \times 30$ in. each $\$ 3.25$.

No. 1, same dimensions as No. 2 , but has 2 compartments. Each, $\$ 3.40$

\section{Eggs Boxes and Carriers}

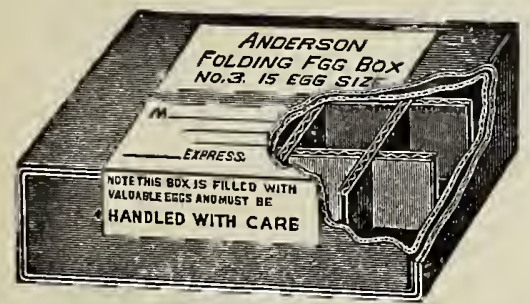

EGG SHIPPING BOXES.

The Anderson.

It's made of corrugated paper and is a most excellent shipping box. Is supplied knocked down.

No. 3 , holds 15 eggs, $15 \mathrm{c}$ each; $\$ 1.50$ dozen.

No. 4, holds 30 eggs, $20 \mathrm{c}$ each; $\$ 2.25$ dozen.

No. 5, holds 50 eggs, 30 c each; $\$ 3.00$ dozen.

\section{PAPER EGG BOXES.}

Just the thing for use in delivering eggs for family egg trade. You will get a premium over market when you deliver good stock in these boxes.

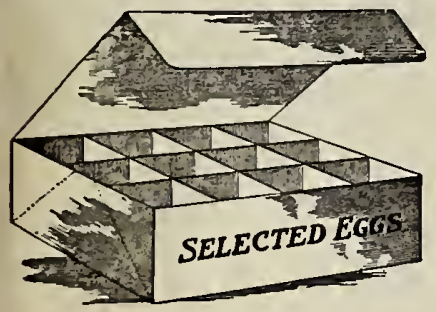

Erie. One dozen size, arranged like cut, $3 \times 4$. Single dozen, $15 \mathrm{c} ; 100$ for $\$ 1.00$; 1,000 for $\$ 8.00$.

Sewanee. One dozen size, long shaped, $2 \times 6$, extra heavy paper. Single dozen, $20 \mathrm{c} ; 100$ for $\$ 1.35 ; 1,000$ for $\$ 10.00$

\section{FARMER'S FRIEND EGG CARrier.}

The most complete egg carrier on the market holds twelve dozen eggs. It is equipped with an adjustable cover and a patent combination lifter and fastener. Just the thing for the farmer and poultryman.

Price, complete, 75c.

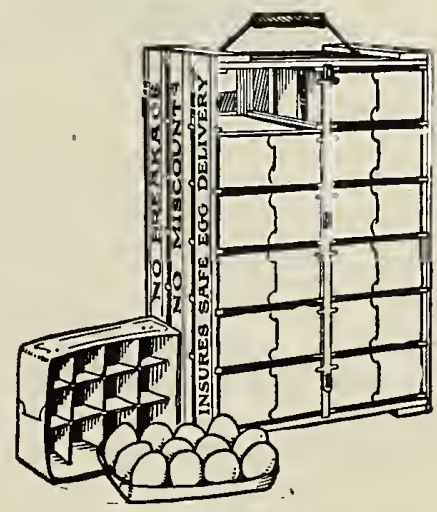

Modern Egg Crate.

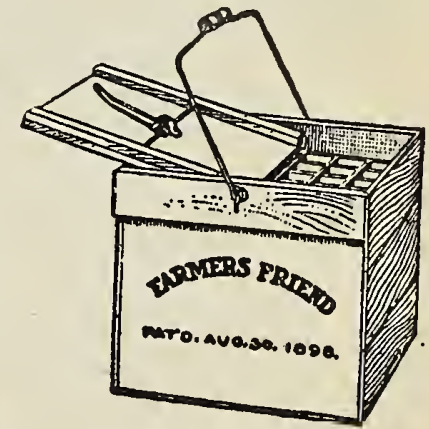

HUMPTY DUMPTY EGG CARRIER, SLATTED CRATES.

This carrier can be folded flat when not in use. Six dozen size, $35 \mathrm{c}$ each; 12 dozen size, $50 \mathrm{c}$ each.

\section{MODERN EGG CRATES.}

These crates are light in weight, well balanced, and strong enough to withstand any use The frame work is made of white wood and is made of white wood and the individual carriers are constructed of the toughest kind of jute board with assuring perfect safety for eggs.

Size No. 4, holds 4 dozen eggs. . . . . . . . .

Size No. 8 , holds 8 dozen eggs....................... Size No. 12, holds 12 dozen eggs.................... 1.75

\section{Egg and Meat Preservers}

\section{WATER GLASS EGG PRESERVER.}

It is a simple matter to preserve eggs with Water Glass Egg Preserver. The pure heavy Water Glass is simply diluted one part to ten of boiled water, the eggs paced in an earthen jar or barrel and covered with the solution. If you are preserving your eggs as fast as they are laid, make a solution first and put the eggs in it as they are gathered.

When strictly fresh eggs have been put into Water Glass Egg. Preserver they have invariably, at the end of market eggs supposed to be fresh.

On gallon of Water Glass Egg Preserver will preserve nearly 100 dozen eggs. Price, gallon, $\$ 1.50$; quart, $40 \mathrm{c}$; pint, 25c.o Cannot be mailed.

\section{SMOKE EXTRACT.}

This is a liquified hickory smoke, and is used for smoking hams and bacon. It is applied with a brush, and gives exactly the same results as if deposited on the meat by the old method of smoking. Try a bottle of it on some of your

hams or bacon, and you will never go back to the old method of smoking.

Price, small bottle, 35c; large bottle, 75c. Cannot be malled.

THE BARTELDES SEED CO.

Sirs: Some years ago I had a great deal of trouble raising my baby chicks. Indigestion of different forms. I was leeding this, that and the other feed. I finally tried your prepaired chick food and deveston of different forms. I was satisfactory $I$ have never ceased to recommend it to all poultry raisers. Wishing you success in maintaining the high standard of your foods, I remain. 


\section{Barteldes' Best Line}

\section{Condition Powders, Lice Killers and Remedies}

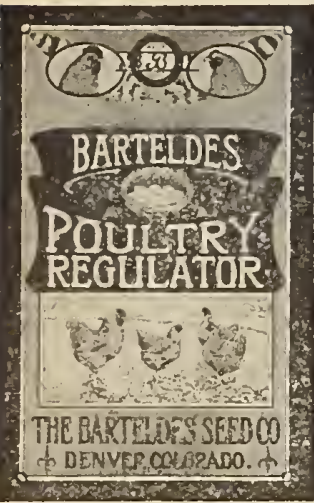

\section{BARTELDES' POULTRY REGULATOR.}

Is a compound of vegetable extracts, herbs, roots, etc., so proportioned that they act gently on the fowls' internal organs, relieve and remove any irregularities that exist and tone up the system. It is the best condition powder on the market; try it. Small size package, 25c; uarge size package, $50 \mathrm{c}$.

\section{BARTELDES' LIQUID LICE KILLER.}

A wholesale lice and vermin destroyer. Saves expenses and labor. No dipping, no dusting, no greasing, easily applied. Does not injure or mar the plumage. 1 -quart can, $35 \mathrm{c}$; $1 / 2$-gallon can, 60c; 1-gallon can $\$ 1.00$.

\section{BARTELDES' BRONCHITIS REMEDY:}

This is one of the best remedies for Bronchitis. As this disease is caused by colds, keep the fowls out of damp quarters, sudden changes of temperature, etc. Price, per pkg. $50 \mathrm{c}$, postpaid.

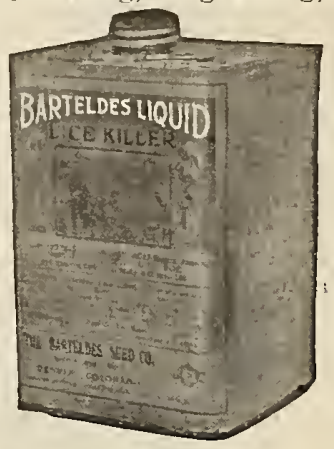

\section{BARTELDES' ANIMAL REGULATOR.}

It is not only one of the best regulators but also a stimulating tonic. It consists of pure medicinal roots, barks and herbs, carefully mixed in the exact proportions to gently act on the bowels, liver and digestive organs of farm animals, and to purify the blood. It insures a perfect digestion. The worst run-down animal can be given Barteldes' Animal Regulator according to directions printed on each package and an improvement will be noticed in a very short time.

Small size carton, 25c; large size carton, 50c; 9-1b. sack, $\$ 1.00 ; 14-1 \mathrm{~b}$. sack, $\$ 1.50$.

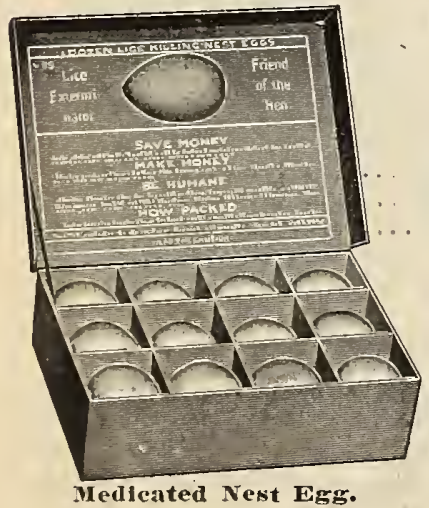

BARTELDES' MEDICATED NEST EGG.

Lice destroyer and nest egg combined. It is a sure death to all lice and mites affecting poultry. When in use it slowpoultristes away uiving off fumes fatal to all insect vermin. $5 \mathrm{c}$ each; $50 \mathrm{c}$ per dozen.

\section{BARTELDES' LIMBERNECK} REMEDY.

Limberneck is caused by eat. ing decayed animal matter, and is fatal if not treated at once. This remedy is one of the most effective ever put on the market, and will do the the market, and will do the per pkg., $50 \mathrm{c}$, postpaid.

\section{BARTELDES' MICROZONE-Liquid.}

This up-to-date remedy will cure roup, sore eyes, sore mouth, sore breast, back or shoulder, cracked heels, wounds, sores or cuts, saddle galls and canker. Used in drinking water for roup, or a-teaspooniful is mixed with one pint of warm water and applied with a clean rag on sores. Bottle, 50c. Tablets, concentrated; dissolves easily; 50c, postpaid.

\section{BARTELDES' WHITE DIARRHOEA REMEDY.}

White Diarrhoea is often times not serious in itself, but will lead to something worse. It ought to be treated immediately with Barteldes' White Diarrhoea Remedy. Price, per bottle, $50 \mathrm{c}$; cannot be malled.
BARTELDES' INSECT POWDER.

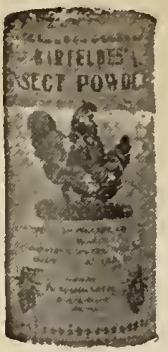

Will kill insects on poultry, live stock and plants; exterminates chiggers, moths, ants, roaches, fleas, lice, etc. Can with perforated top, $25 \mathrm{c}$.

\section{BARTELDES' COLUMBINE GRADE PARROT FOOD.}

Is a mixed food which will keep Polly in good health. Put up in packages. Price, $15 \mathrm{c}$

BARTELDES' CHOLERA CURE. and other digestive surest and most effective cure for ing water. Price, 50c, postpaid.

\section{BARTELDES' ROUP CURE.}

Cures Roup and Cures it Quick.

This preparation is a powder and has made some wondr ful cures. It is very effective and quick acting. Will cure the most stubborn cases. Used in drinking water. It is put up in two sizes; $50 \mathrm{c}$ and $\$ 1.00$, postpaid.

\section{BARTELDES' SCALY LEG AND HEAD LICE SALVE.}

Used on young chicks and for scaly legs. Small size can, $10 \mathrm{c}$; large size can, $25 \mathrm{c}$, postpaid

\section{BARTELDES' NO.FLY-Liquid.}

Will keep flies off your cows and horses. $1 / 2$ gallon, $60 \mathrm{c}$; gallon, $\$ 1.00$

\section{PERSIAN INSECT POWDER.}

The grade we handle is strictly pure. Don't be deceived by any low priced, adulterated article. $1 / 4 \mathrm{lb} ., 20 \mathrm{c} ; 1 / 2 \mathrm{lb} ., 35 \mathrm{c}$; $1 \mathrm{lb} ., 50 \mathrm{c}$.

\section{AVENARIUS CARBOLINEUM-Liquid,}

The famous German Wood Preserver and Insecticlde. Paint or spray your chicken houses, hog pens, stables, sheds, etc., with Avenarius Carbolineum to permanently destroy all kinds of vermin and preserve your building from rot and decay. Prices, qt. can, 50c; gal., $\$ 1.50$. For large quantity, ask for prices.

CHLOROLEUM-Similar to Creolio-Liquid.

Chloroleum disinfects, kills lice and mites, cures and prevents cholera and roup in poultry. Effectual and economical. 6-oz. bottle, $25 \mathrm{c}$; pint bottle, $40 \mathrm{c}$; q t. can, $60 \mathrm{c}$; $1 / 2$ gal., $90 \mathrm{c}$; galion, $\$ 1.50$.

LIME AND SULPHUR SOLUTION-Liquid.

Extensively used for spraying poultry houses to kill lice and mites. For full description see page 71 .

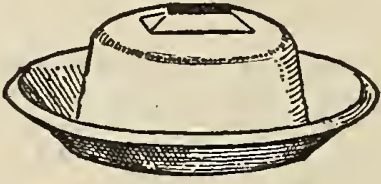

PURE SULPHUR FUMIGAT. ING CANDLES.

Our Pure Sulphur Fumigating Candles are equal to any Fumigating Candles on the market.

They are easy to light, easy to extinguish, safe to use, and produce a deadly vapor to all infectious diseases, disease germs and insect life. Price, each, 10c; per dozen, $\$ 1.00$; by mail, each, $5 \mathrm{c}$ extra.

\section{FLOUR OF SULPHUR.}

Good to remedy canker mouth, etc. Also to burn as disinfectant. $1 \mathrm{lb}, 10 \mathrm{c} ; 4 \mathrm{lbs}, 30 \mathrm{c} ; 10 \mathrm{lbs}, 50 \mathrm{c}$.

\section{TOBACCO DUST.}

Ground very fine. Drives away lice and vermin. $1 \mathrm{lb}$., $10 \mathrm{c} ; 5$ lbs., 40c; 25 lbs., $\$ 1.50 ; 100$ lbs., $\$ 4.80$.

\section{OCULUM.}

A scientific remedy and preventative for cholera, roup and white diarrhoea; also cure for gapes, diarrhoea in sheep, salves, solts and kidney worm in hogs. All of these diseases are caused by germs, and the only way to cure the disease is to kill the germ; the surest and safest remedy on the market is Oculum.

Innoculate your fowls and prevent these diseases. Oculum is very easy to apply. Directions and dropper with each bottle. Prices, $10 \mathrm{c} ; 50 \mathrm{c}$ and $\$ 1.00$. 


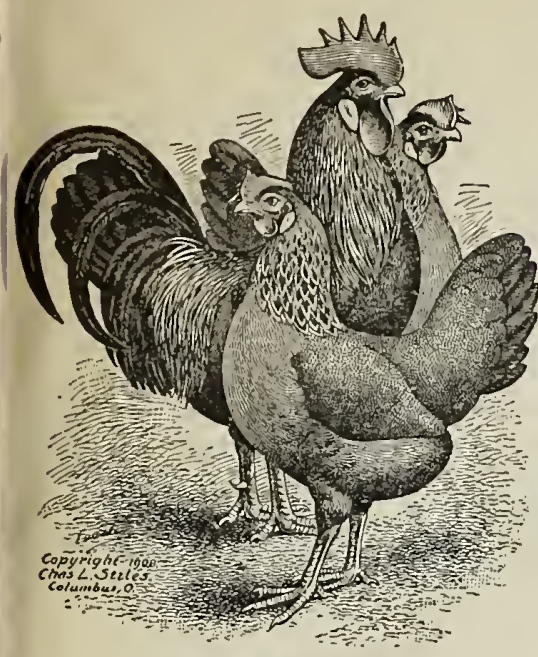

Brown Leghorn.

BARTELDES' CHICK FEED (HOYT'S). The Best Balanced Dry Foods for Chicks.

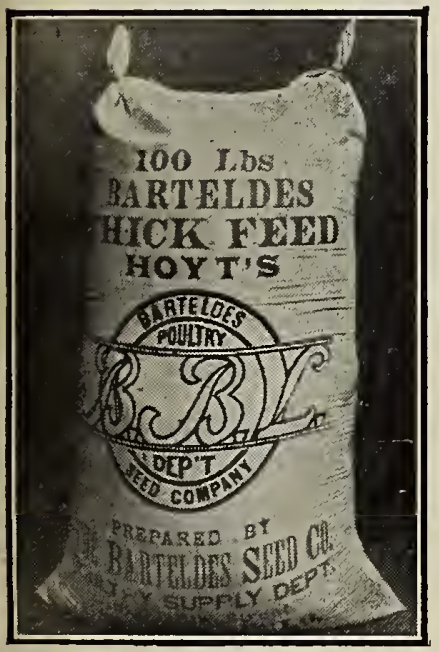
This is our own formula; beware of imitations. In Barteldes' Chick Feed we know we have a food far superior to any other chick feed on the market. It is made from the best of seed grain; in fact, every grain that is put in this food would grow if planted. It is a perfect chick food. It contains all the necessary ingredients that a chick needs. It will prevent bowel trouble and all other chick complaints. It is used by most every poultry raiser in Colorado. We have never had a single complaint against it; every. one pronounces it a wonderflil food. Put up in our own printed sacks.

Price: 6-1b. pkg., 25c; 14-1b. sack, $50 \mathrm{c}$; $30-1 \mathrm{~b}$. sack, 90c; 50-1b. sack, $\$ 1.50$; 100 -1b. sack, $\$ 2.75$.

DENVER CHICK FEED.

A good mixed chick feed, similar to Barteldes' Chick Feed, but not quite as complete in ingredients. $7 \mathrm{lbs}$. for $25 \mathrm{c} ; 17 \mathrm{lbs}$. for $50 \mathrm{c} ; 35 \mathrm{lbs}$. for $\$ 1.00 ; 100 \mathrm{lbs}$. for $\$ 2.25$.

\section{BARTELDES' DEVELOPING FOOD.}

Has no equal for growing chicks. A mixture of small grains, beef scraps, charcoal and other ingredients for the quick growth of poultry.. Should be given as soon as chicks get too large to be fed Barteldes' Chick Feed. Price: $7 \mathrm{lbs}$. for $25 \mathrm{c} ; 17 \mathrm{lbs}$., $50 \mathrm{c}$; $50 \mathrm{lbs} ., \$ 1.25 ; 100 \mathrm{lbs}$., $\$ 2.35$.

\section{BARTELDES' FATTENING FOOD.}

A fowl to be worthy of the highest market price must be "finished," that is, it must have a liberal quantity of fat and meat on its frame, and that is easily obtained by using Barteldes' Fattening Food. Price, 50-lb. sack, $\$ 1.25 ; 100-1 b$. sack, $\$ 2.25$.

\section{DENVER LAYING FOOD.}

A Carefuly Balanced Mash Food for Eggs and Feather Making.

As we have had many years' experience in Colorado, we ieel that we are familiar with the needs and requirements of our Western poultry breeders, and, in offering this Mash, we know we are offering a high grade article that gives favorable results. A trial will convince the most skeptical that this food is an egg producer.

Price, 50 lbs., $\$ 1.00 ; 100 \mathrm{lbs} ., \$ 1.75$.

\section{POULTRY FOODS}

Ask for Latest Price List Sent Free

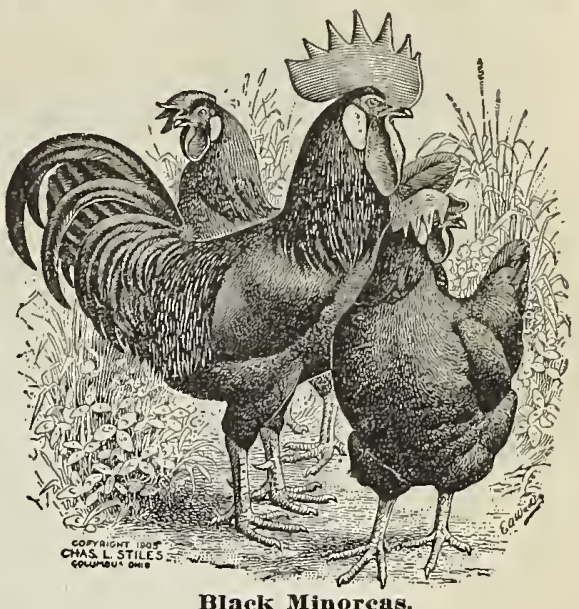

BIack Minoreas.
BARTELDES' MIXED HEN FEED.

This is a balanced food of mixed grains for laying hens. It contains grit, shell, bone, dried meat, sunflower and mixed grains of different kinds in suitable proportions, to promote egg yield. The variety of grains, shell, grit, dried meat, etc., being of different size induces fowls to scratch more, and as exercise is necessary to promote indigestion, they will be kept strong and vigorous.

Price fluctuates. Present price, 50 lbs., \$1.10; 100 lbs., $\$ 1$. A0. Ask for quotations on large quantities.

\section{BARTELDES' MIXED PIGEON FEED.}

Specially prepared for pigeons and squabs, contains red wheat, Kaffir corn, cracked corn, buckwheat, many other suitable grains and shell. Price, $7 \mathrm{lbs}, 25 \mathrm{c} ; 50$ lbs., $\$ 1.25$; $100 \mathrm{lbs}$., $\$ 2.25$.

\section{ALFALFA CLOVER MEAL.}

This is alfalfa hay reduced to a meal containing the entire product-stalks, leaves and blossoms. It is a grand green food for winter. It furnishes protein, lime and other mineral salts. Fowls relish it immensely. Feeding clover insures an increase of fertile eggs. It likewise adds lustre to the plumage. In original sacks of $100 \mathrm{lbs}$. at $\$ 1.40$ per $100 \mathrm{lbs}$. Less sack lots at $2 \mathrm{c}$ per $\mathrm{lb}$

\section{MILLET SEED.}

Let your fowls "work for their living" by scratching in litter for millet seed. It is a good food for the growing chicks. Price, $8 \mathrm{lbs}$. for $25 \mathrm{c}$; 25 lbs. for $65 \mathrm{c}$.

\section{CRUSHED OYSTER SHELL.}

This is a most important article for the poultry yard, and should be supplied to the fowls liberally.

Our shell is of superior quality, as all parts of the egg shell are contained in them; whereas a good portion of the shell offered is nothing more than the refuse of the fertilizer works and not fit to offer a decent hen.

5 -1b. package.$\ldots \ldots \ldots \ldots \$ .15$ 12-lb. package $\ldots \ldots \ldots \ldots \cdots \cdots, \quad .25$ 30 -lb. sack $. \ldots \ldots \ldots \ldots \ldots \ldots, .40$

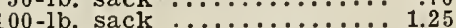
Ask for price on large quantities.

Crushed Clam Shell-Same price as Oyster Shell.

WT Kaffir Corn, Wheat, Corn, whole and cracked, Barley, whole and ground, small White Peas, at market prices. Remember, when you buy these Grain Foods from us you get full weight.

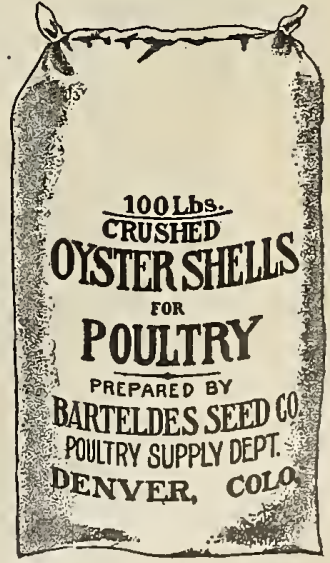




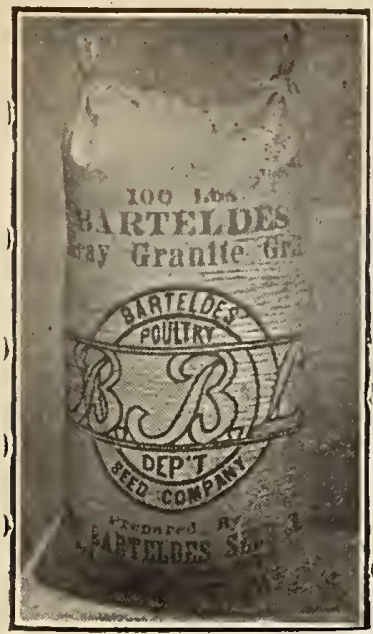

GRAY GRANITE GRIT.

It is made from crushed rocks found in the Rocky Mountalns and of such composition that the expanslon and contraction of the gizzard breaks it into small pleces, which keeps continually sharp until the last and smallest. 5 lbs., 15c; 12 lbs., 25c; 30 lbs., $40 \mathrm{c}$; 50 lbs., 70c; $100-1 \mathrm{~b}$. sack, $\$ 1.15 ; 300$ lbs., $\$ 3.00$.

\section{MEAT AND BONE MEAL.}

Is a well balanced mixture of fine ground bone and meat meal. Admirably adapted for building up and fattenlng brollers. Prices: $13 \mathrm{lbs}$., 50c; 25-lb. sack, 85c; 50-lb. sack, $\$ 1.15 ; 300$ lbs., $\$ 3.00$.

DRIED MEAT, BONE AND BLOOD.

Similar to above, with addition of blood. Price: $13 \mathrm{lbs}$. $50 \mathrm{c} ; 25$ lbs., $85 \mathrm{c} ; 50$ lbs., $\$ 1.60 ; 100-1 \mathrm{~b}$. sack, $\$ 3.00$.

\section{MEAT MEAL.}

Meat Meal is a concentrated food, containing 60 to 65 per cent. protein. In the meat meal we sell there is absolutely no adulteration, and the analysis will be found uniform throughout. A great flesh producer. 13 lbs., 50c;25 lbs., $85 \mathrm{c} ; 50$ lbs., $\$ 1.60 ; 100-1 \mathrm{~b}$. sack, $\$ 3.00$.

\section{GREEN CUT BONE-Granulated.}

Made from soluble bones, dried but not cooked, retaining all the marrow and oil in the bones. Price: 7 lbs., $25 \mathrm{c}$; 15 lbs., $50 \mathrm{c} ; 25$ lbs., $75 \mathrm{c}$; 50 lbs., $\$ 1.25 ; 100 \mathrm{lbs}$., $\$ 2.25$.

GRANULATED BONE No. 1-Coarse, Strictly Pure.

Consists of ground beef bone, thoroughly dried and free from grease. Rich in phosphate of lime, which is so neces sary for making good egg shells and for building up the frame of the chicken. Should be placed in liberal quantities in a clean, dry place, accessible to the chickens at all times.

Price: 10 lbs., 50c; $25-1 b$. sack, $\$ 1.00 ; 50-1 b$. sack, $\$ 1.75$ $100-1 b$. sack, $\$ 3.25$.

GRANULATED BONE No. 2-Second Grade.

Made from good bones, though not selected. Price: 10 lbs., $35 \mathrm{c} ; 25-1 \mathrm{~b}$. sack, 70c;50-1b. sack, $\$ 1.30 ; 100-1 \mathrm{~b}$. sack, $\$ 2.50$.

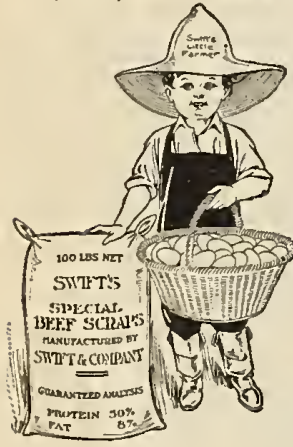

SWIFT'S HIGH PROTEIN BEEF SCRAPS.

A very superior grade of meat scraps prepared in a meal suitabe for feeding in mash or with other soft foods. Contains fully 50 per cent protein and 8 per cent fat. Every pound contains as much feeding material as 10 lbs, of fresh meat. Is bound to give good results.

Price: 4 lbs. for $25 \mathrm{c} ; 25 \mathrm{lbs}$. for $\$ 1.25$; $50^{*}$ lbs., $\$ 2.15 ; 100$ lbs., $\$ 4.00$
COLORADO HIGH PROTEIN BEEF SCRAPS.

Practically the same as Swift's, but manufactured in Denver. 4 lbs., 25c; 10 lbs., 50c; 25 lbs., \$1.25; 50 lbs., $\$ 2.10$; 100 lbs., \$3.85.

BONE MEAL No. 1-Fine, Strictly Pure.

Is the same as the coarse, but ground finer for the smaller chicks, and is a great frame builder. It can be mixed with the mash in limited quantities. Price: $10 \mathrm{lbs}$. $50 \mathrm{c} ; 25-1 \mathrm{~b}$. sack, $\$ 1 . \mathrm{c} 0 ; 50-1 \mathrm{~b}$. sack, $\$ 1.75 ; 100-1 \mathrm{~b}$. sack, $\$ 3.25$.

\section{ARMOUR'S BLOOD MEAL-Deodorized.}

Conceded to be one of the greatest egg producers on earth. It is a great chick grower. If you want winter eggs, blood meal will bring them. One of the cheapest foods there is: One $1 \mathrm{~b}$. is equal to $16 \mathrm{lbs}$. of fresh meat. As to the advantage gained by feeding blood meal to young chicks, ducks and turkeys, we can say there is positively nothing better for them. One heaping teaspoonful a day fed in a mash for a dozen hens will make an increase of eggs that will be surprising. Price: $3 \mathrm{lbs} ., 25 \mathrm{c} ; 10 \mathrm{lb}$. bag, $70 \mathrm{c} ; 25 \mathrm{lbs}$., $\$ 1.65$; $50-1 \mathrm{~b} . \mathrm{keg}, \$ 2.75 ; 100-\mathrm{b}$. keg, $\$ 5.00$.

\section{BLOOD MEAL, COLORADO MADE.}

Manufactured by our own Denver Packing Company, practically the same as Armour's but not fully deodorized. Price: 4 lbs., 25c; 10 lbs., 50c; 25 lbs., $\$ 1.15 ; 50$ lbs., $\$ 2.15$; $100 \mathrm{lbs} ., \$ 4.00$.

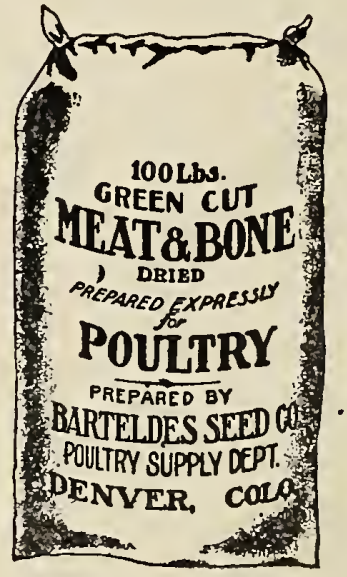

\section{GREEN CUT MEAT AND BONE-Dried.}

This is a Western product and a most excellent food, having all the elements necessary to make healthful growth. The meat is sufficienty evaporated to prevent becoming rancid. Keeps well. Should be placed in liberal quantities in a clean, dry place, easily accessible to the chickens at all times. Price, 7 lbs., 25c; 15 lbs., 50c; 25 lbs., $75 \mathrm{c}$; 50 lbs., $\$ 1.25 ; 100-1 \mathrm{~b}$. sack, $\$ 2.25$.

\section{RED PEPPER COMPOUND} FOR POULTRY.

This can be mixed with soft food and fed to advantage. Price, per lb., $25 \mathrm{c}$; $5 \mathrm{lbs}$. for $\$ 1.00 ; 25 \mathrm{lbs}$., $\$ 4.50$.

CHARCOAL.

Pure charcoal is an excellent aid in arresting bowel complaints, and is both simple and harmless. A corrector of bowel troubles where the hens have not had a variety.

Granulated. Suitable size for grown fowls; can be kept in open dish ready to be eaten as wanted. 2-1b. carton with directions, 25c; 10 lbs., 60c; $25 \mathrm{lbs}$. $\$ 1.00 ; 100$ lbs., $\$ 3.00$,

Powdered. Suitable for chicks' feed in soft food. Price same as above.

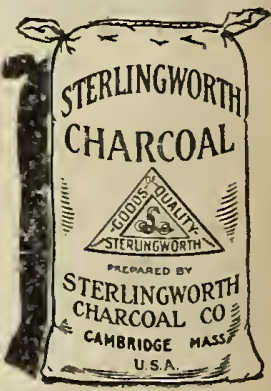

\section{CONKEY'S REMEDIES}

We handle a full line of Conkey's remedies and Tonics for poultry and stock. If interested ask for special circular sent free.

Conkey's Roup Cure, $25 \mathrm{c}, 50 \mathrm{c}$ and $\$ 1.00$ packages.

Conkey's Bronchitis Cure, 50c package.

Conkey's Cholera Cure, $25 \mathrm{c}$ and $50 \mathrm{c}$ packages.

Conkey's Gape Cure, 50c package.

Conkey's Chicken Pox Cure, 50c package.

Conkey's Limberneck Cure, 50c package.

Conkey's Scaly Leg Cure, 50c package.

Conkey's Rheumatic Cure, 50c package.

Conkey's Poultry Worm Cure, 50c package.

Conkey's White Diarrhoea Cure, 25c and $50 \mathrm{c}$ packages.
Conkey's Poultry Tonic, $25 \mathrm{c}$ package.

Conkey's Lice Powder, $10 \mathrm{c}, 25 \mathrm{c}$ and $50 \mathrm{c}$ packages.

Conkey's Lice Killer, $35 \mathrm{c} ; 60 \mathrm{c}$ and $\$ 1.00$ cans.

Conkey's Laying Tonic, $25 \mathrm{c}, 50 \mathrm{c}$ and $\$ 1.00$ packages.

Conkey's Horse Tonic, $\$ 1.00$ package.

Conkey's Healing Powder, $25 \mathrm{c}$ and $50 \mathrm{c}$ packages.

Conkey's Colic Remedy, 50c and $\$ 1.00$ packages.

Conkey's Hoof Remedy, $50 \mathrm{c}$ and $75 \mathrm{c}$ packages.

Conkey's Bag Ointment, $25 \mathrm{c}$ and $50 \mathrm{c}$ packages.

Conkey's Stock Tonic, $25 \mathrm{c}, 50 \mathrm{c}$ and $\$ 1.00$ packages. 


\section{THERE IS ONLY ONE BEST}

\section{SATISFACTION OR YOUR MONEY BACK}

Guaranteed Animal and Poultry Regulators and Remedies

PRATTS POULTRY REGULATOR.

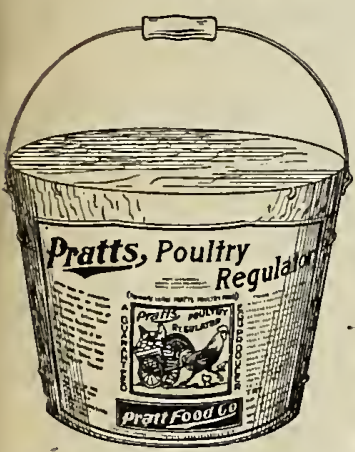

This is the original Poultry Regulator of America, in use by the most successful poultry-raisers everywhere.

It is entirely different from Pratts Animal Regulator.

It is a perfect digestive and tonic suited to the constitution of poultry.

It is a guaranteed egg producer, and when regularly used hens lay throughout the year.

It prevents chicken cholera, gapes, roup, rheumatism, expels worms, prevents leg weakness, egg eating. It also greatly im-

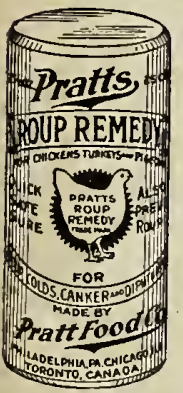
proves turkeys, geese, ducks, pigeons and guineas-making them grow bigger and quicker, $100-1 \mathrm{~b}$. bags, $\$ 9.00 ; 25-1 \mathrm{~b}$. pails at $\$ 2.50$. $25 \mathrm{c}, 50 \mathrm{c}$ and $\$ 1.00$ packages.

\section{PRATTS ROUP REMEDY. \\ (Pills or Powder.)}

A scientific preparation guaranteed to prevent and cure roup, colds, canker, catarrh and diphtheria. Pratts Roup Pills for individual treatment of advanced cases, will cure. One trial as a preventive will convince you that you need this valuable remedy. $25 \mathrm{c}, 50 \mathrm{c}$ and $\$ 1.00 \mathrm{a}$ box.

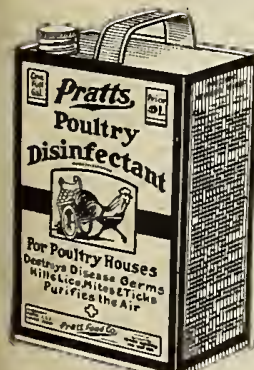

\section{PRATTS POULTRY DISINFECTANT AND LICE KILLER.}

If poultry keepers would regularly spray the chicken houses, roosts, dropping boards and utensils with Pratts Poultry Disinfectant, most all their troubles would vanish. Guaranteed as a disinfectant and destroyer of lice, mites and vermin of all kinds. Put up in 1 qt., 2 qt., and 1 -gal. cans. 1 qt. can, $35 \mathrm{c} ; 2$ qt. can, $60 \mathrm{c} ; 1$ gal. can, $\$ 1.00$.

\section{PRATTS LICE KILLER.}

(Powdered Form.)

It quickly and thoroughly kills all lice on little chicks, big chicks, setting nens, and incubator chicks. It rids horses, cattle, hogs, dogs and cats of lice, and destroys ticks on sheep. It destroys insects and bugs on vines, plants and flowers. A valuable deodorizer and disinfectant, for all poultry houses, barns, stables and dwellings. Drives out moths from closets, furniture, carpets and clothing. $25 \mathrm{c}$ and $50 \mathrm{c}$.

Pratts Cholera Remedy, 25c and 50c a box.

Pratts Head Lice Ointment, 25c a box.

\section{PRATTS HEALING OINTMENT.}

(Fol Man and Beast.)

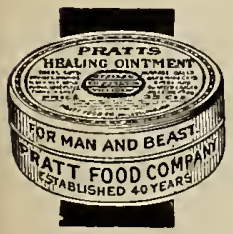

This is a humane preparation for the quick cure of all sores, cuts, scratches, grease wounds, burns, scalds, corns, harness and saddle galls, barb-wire fence cuts, itching, eczema and eruptions. Heals naturally, permanently and leaves no dangerous scabs. Excellent for human use, too. $25 \mathrm{c}$ and $50 \mathrm{c}$.
PRATTS BABY CHICK FOOD.

This is one of the greatest Money Savers and greatest Chick Savers ever placed on the market. Every man, woman or child who raises little chicks, turkeys, ducks and geese should try at least one package of Pratts Baby Chick Food. It is a scientific food ration to be fed for the first three weeks. If you want real success with your hatches, if you want to save all the baby chicks, if you want them to grow fast-get Pratts Baby Chick Food on our recommendation for your first trial, after that you will never be without it

Put up as follows: 1-lb. package, 25c 3-lb. package, $50 \mathrm{c} ; 14-\mathrm{lb}$. bags, $\$ 1.00 ; 50-\mathrm{lb}$. package, $\$ 3.00 ; 100-1 b$. bags, $\$ 5.75$.

PRATTS WHITE DIARRHOEA REMEDY.

This remedy will positively save many dollars worth of little chicks to poultry raisers. It has taken us nearly three years to find a remedy for White Diarrhoea and we are so sure that we have it in this article that we are authorized to refund the purchase price in case it fails. 25c and $50 \mathrm{c}$ a box. Mailed, postpaid, on receipt of price.

\section{PRATTS ANIMAL REGULATOR}

This is the original and pioneer Stock Regulator of America. It keeps horses well and strong, improves their wind, and makes their coat sleek and glossy.

Cows give more and richer milk, the percentage of butter fat being increased, and their calves are strong and healthy. Steers fatten in half the time.

Hogs are raised and fattened quickly and kept free from disease. Sheep are kept healthy, and their meat and wool improved by its use. Test it on our guaran tee to do the work or money refunded.

$25 \mathrm{c}, 50 \mathrm{c}$ and $\$ 1.00$ packages. $12-1 \mathrm{~b}$. pails,
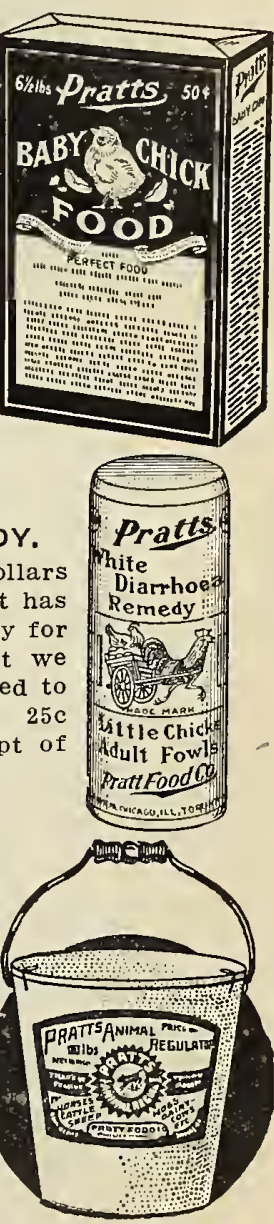

$\$ 1.75 ; 25-1 b$. pails, $\$ 3.00 ; 100-1 b$, sacks, $\$ 9.00$

\section{PRATTS DIP AND DISINFECTANT} Has received the $U$. S. Government rating for sheep scab (1 part Dip to 70 parts water). Cures sheep of ticks, foot-rot and other diseases; cures cattle of mange, ringworm, scabies, screw worms; cures horses of mange, ticks, lice, ringworm, thrush, galls, cuts, Wounds; cures hogs of mange, lice, eczema, fly and maggots; cures dogs of fleas, lice and mange. $\$ 1.00$ a gallon; $35 \mathrm{c}$ a quart.

Pratts Healing Powder, $25 \mathrm{c}$ a box:

Pratts Veterinary Colic Cure, $50 \mathrm{c}$ and $\$ 1.00$ a bottle

Pratts Worm Powder, 50c and $\$ 1.00 \mathrm{a}$ box.

Pratts Distemper and Pink Eye Remedy, 50c a bottle.

Pratts Liniment (for Man or Beast), 25c, 50c and $\$ 1.00$ a bottle.

\section{PRATTS BRONCHITIS REMEDY.}

Bronchitis in poultry is fatal in a few days unless promptly checked with Pratts Bronchitis Remedy. This remedy is sure, safe and quick and will save your birds. $25 \mathrm{c}$ and $50 \mathrm{c}$ boxes. Mailed, postpaid, on receipt of price.

\section{PRATTS CONDITION TABLETS.}

A "bracer" for overworked, run-down poultry. Keeps show birds in the pink of condition; puts flesh on thin birds; prevents colds, roup and liver troubles. We guarantee this Remedy to satisfy you or refund purchase price. $25 \mathrm{c}$ and $50 \mathrm{c}$ a box. Mailed, postpaid, on receipt of price. 


\section{CONCENTRATED STOCK FOODS}

BLATCHFORD'S CALF MEAL.

A Perfect Milk Substitute, will raise calves at from one-third to one-quarter the expense of feeding milk.

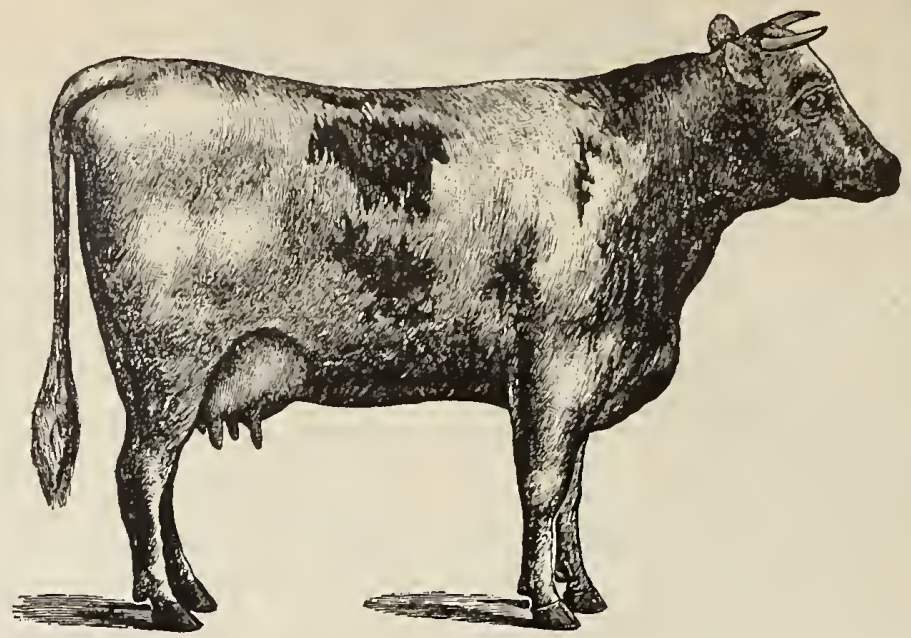

100 Pounds Gorund Oif Cake contains $27 \mathrm{lbs}$. of digestible protein.

100 Pounds Corn, Oats or Barley contain 9 lbs. of digestible protein.

\section{Blatchford's Calf Meal}

This calf meal is a perfect substitute for milk as it contains all the elements necessary for bodily growth in the correct proportions. It pushes pigs, colts, lambs, calves, etc., forward better and quicker than any other food; also prevents scouring. One pound of calf meal mixed with one gallon of skim milk will make a gallon of perfect food, equal in feeding value to one gallon of whole milk, at one-half the cost. After the calf is 3 or 4 weeks old water can be used instead of skim milk with equal good results. The gruel should be fed at a temperature of 90 to 100 degrees. When the gruel is made of whole milk the proportions should be: 1 pint calf meal, 2 quarts whole milk and 2 quarts water. It is also a good plan to have a little calf meal dry in a box stall where the calves can get it. Fed dry in this way it has been found a cure for the most obstinate cases of "scouring." Price, 25 -1b. bag, $\$ 1.00 ; 50-1 b$. bag, $\$ 2.00 ; 100-1 b$. bag, $\$ 3.50$.

\section{Oil Cake Meal}

OIL CAKE MEAL is the most valuable and useful by-product of the farm. It is not only cery rich in protein but is a safe and palatable food. When fed judiciously there is no class of animals kept on the farm to which it may not be fed with profit for a shorter or longer period. It is much relished by all classes of domestic animals, and is, to some extent, an appetizer as well as a food. Being mildly laxative it exercises a salutary influence on the digestive organs. There is no kind of concentrated foods or grain with which it cannot be combined. To all kinds of growing animals it may be fed with much benefit in the winter, along with grain and other meal. It may form as much as $10 \%$ of the concentrated feed. It is also very helpful for cattle that are finished on pasture.

As a food for wilch cows Oil Cake Meal, to a certain limit, is most satisfactory; though it should not exceed 3 to $31 / 2$ pounds daily. It not only increases the quantity of milk; but will also increase the amount of butter fat. Repeated experiments have proven that butter made from the milk of oil cake fed cows is easily digested even by a weak stomach, while butter made from ordinary fed cows is hard to digest. The amount of digestive protein in oil cake meal compared with other grain foods is from $2 \frac{1}{2}$ to 3 times larger.

OIL CAKE MEAL or GROUND OIL CAKE, as it is very often called, is the by-product of flax seed after the oil has been extracted. It contains 27.3 protein and 48.5 carbohydrate per 100 pounds. The nutritive ratio is $1: 1.7$.

In fattening all kinds of animals for the market a certain amount of Oil Cake Meal or Flax Seed Meal should be fed the last 3 or 4 weeks of the fattening period, as their use will not only add weight, but improve greatly the general appearance.

To pounltrymen it is likewise of value in keeping fowls in good health. Price fluctuates. Present price: 8 lbs. for $25 \mathrm{c} ; 25 \mathrm{lbs}$. for $70 \mathrm{c} ; 50 \mathrm{lbs}$. for $\$ 1.30 ; 100 \mathrm{lbs}$. for $\$ 2.50$.

\section{Flax Seed Meal}

FLAX SEED MEAL is made from whole flax seed, ground fine, and contains per 100 pounds 8.1 water; 4.7 ash; 21.6 protein; 7.3 crude fibre; 27,9 nitrogen extract, and 30.4 ether extract. Being richer than Oil Cake Meal it requires less to mix with other foods to obtain equal results.

A little fed occasionally to poultry is very beneficial. One tablespoonful in a mash to each dozen fowls, daily, is a great help during the moulting season. Present price: 1 lb., 10c; 3 lbs., 25c; 10 lbs., $80 \mathrm{c} ; 251 \mathrm{bs} ., \$ 1.75 ; 50 \mathrm{lbs} ., \$ 3.25$.

Barteldes "Western Seeds" have been in use in this Western country for 35 years and have proven to be best adapted either for irrigation or dry farming. 


\section{Dog Cakes, Remedies, Bird Foods, Etc.}

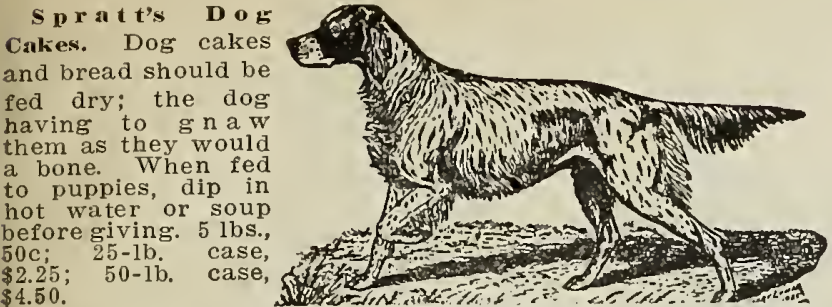

sipratt's I'upwy Cakes. 21/2-1b. net cartons, 25c; 5-1b. net cartons, 50c; 25-1b. box, $\$ 2.40$.

spratt's 'Terrier Cakes. About $2 \frac{1}{2}-1 \mathrm{~b}$. cartons, $25 \mathrm{c}$.

Spratt's Anti-Vonit Remedy. Bottle, 50c.

Spratt's Constipation Tablets. Pkg., $50 \mathrm{c}$.

Spratt's Íidney Tablets. Pkg., $50 \mathrm{c}$.

Spratt's Diarrhoca Tablets. Pkg., $50 \mathrm{c}$.

Dog Soap with directions how to use. Pkg., 25c.

Pouliry Soap with directions how to use it. Pkg., 25c.

Malted Kitten Food in tins. Price, $25 \mathrm{c}$.

Cat Food. 12 -ounce cartons, $10 c ; 2 \frac{1}{2}-1 b$. cartons, $25 c$.

Barteldes' Fish Food. Per package, $10 \mathrm{c}$.

Barteldes' Columbiue Grade Parrot Food. Per pkg., 15c.

Bitter Iron 'Tonie and Sons Restorer. Liquid. Creates

appetite and restores lost song. 2-oz. bottle, $25 \mathrm{c}$ each.
MeAllister's Moeking Bird Food. Strictly pure and high grade. Per bottle, $25 \mathrm{c}$.

Bird Food Manna. Song restorer and prevents disease. Each caged bird needs it. In round balls ready to fasten to wire of cage. $15 \mathrm{c}$ each, prepaid.

salt Cat aids digestion, invigorates and promotes good health: brick, $15 \mathrm{c}$.

\section{BIRD SEED.}

Canary reeleaned. $1 \mathrm{lb}$. for $10 \mathrm{c}$. Henu, Russian, ehoice. $1 \mathrm{lb}$. for $10 \mathrm{c} ; 3$ lbs. for $25 \mathrm{c}$.

Rape, ehoice. 1 lb, for $10 \mathrm{c} ; 3$ lbs, for $25 \mathrm{c}$

Larger lots at market prices.

Bird saud. Pure and sifted, $21 / 4-1 \mathrm{~b}$. package, $10 \mathrm{c}$.

Cuttle Bone. A piece should be in every cage. 2 oz., $10 \mathrm{c} ; 1$ lb.,

BARTELDES' HOOF PACKING.

Used to pack the underside of the hoof when it is too low, or when inflamed; also to prevent cracking. It is a white rock, easily dissolved into a thick paste, which soon hardens. It does not crack easily and keeps its pliability hardens. It does not crack easily alld keeps its pliability

Bitter Liek Bricks. A new way to give conditioner to horses and cattle. Put up in bricks shaped so cattle can lick easily. One brick, about $2 \frac{1}{4}$ lbs., $25 \mathrm{c}$; dozen, $\$ 2.50$.

Holder for same, $20 \mathrm{c}$ each.

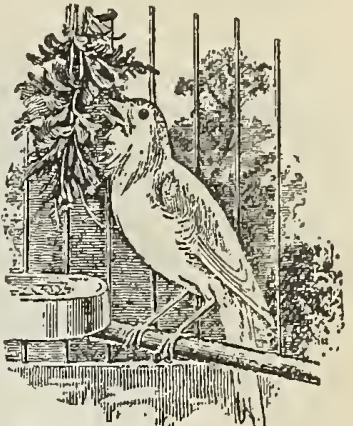

\section{Good Books for Poultry and Pet Stock Fanciers}

The Poultry Manual. A guide to successful poultry

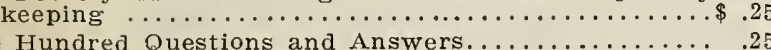

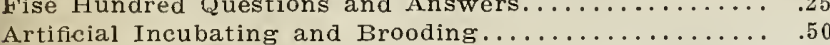

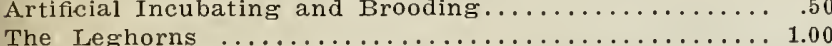

The Plymouth Rocks (160 pages)............... 1.00

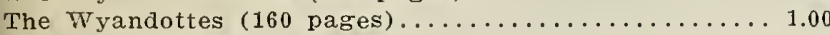

Egrs and Ego Farms.........................50

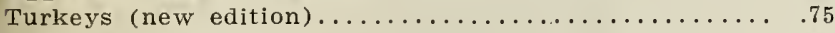

The Bantam Fowl....................... .50

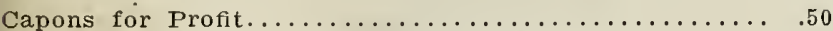

American Standard of Perfection, latest edition..... 2.00

Successful Poultry Keeping.................. 1.00

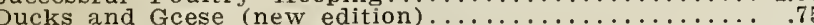

Poultry Houses and Fixtures.

Rhode Island Reds.................

How to Build Poultry Houses

Minorcas, Every Comb and Color, by Northup........ .50

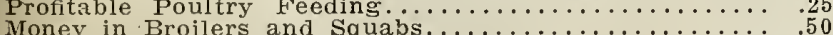




\section{Raffia and Reeds}

\section{INDIAN BASKETS.}

How to make these baskets is now taught in nearly all schools and kindergartens, and is also practiced in many homes as a pastime or as a source of revenue. Thesc baskets are madc of linfia in both natural and dyed colors. Wie are headquarters for this and can furnish it in any quantity and in many different colors.

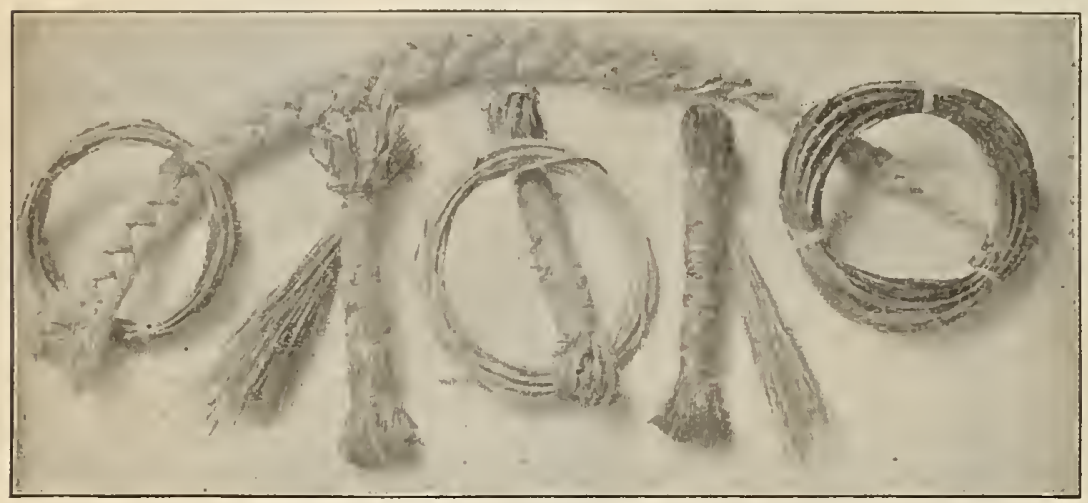

RAFFIA.

COLOKED. When ordering mention number.

Per small bunch, 5c; 2 ozs., 10c; per 1/4 lb. of one color, $20 \mathrm{c}$; per $1 / 21 \mathrm{lb}$. of one color, $35 \mathrm{c}$; per $1 \mathrm{~b}$. of one color, $65 \mathrm{c}$.

No. 1, Dark Red. No. 8, Jet Black.

No. 2, Dark Green. No. 9, Old Gold.

No. 3, Olive Green. No.10, Yellow.

No. 4, Pink. No. 11, Indian Red.

No. 5, Navy Blue. No.12, Purple.

No. 5, Navy Blue. No. 12, Purple. Yellow. No. 6, Seal Brown. No. 13, Canary, Yellow.
No. 7 , Orange.

NATURAL.-1st Grade. Per 3 oz. bunch, $10 \mathrm{c}$; per 1/2 1b., $20 \mathrm{c}$; per $1 \mathrm{lb} ., 30 \mathrm{c}$. In original skeins of $1 \frac{1 / 2}{2}$ to $3 \mathrm{lbs}$, each at $25 \mathrm{c}$ per 1b. 5-1b. lots or more at $20 \mathrm{c}$ a $1 \mathrm{~b}$.

\section{RATTAN REEDS.}

When Raffia is wanted by mail, add postage. showing all our colors on a cald. Large lots to teachers and professional weavers at special prices.

\section{BOOKS ON RAFFIA WORK (Postpaid).} Basket, Mraking-How to Do It............... .25 Indian Basket Weaving, with Illustrations.......... 1.00 Designs for Bead $W^{T}$ ork, price................ .25
These are the Imported Reeds-nothing better. Thelr usefulness in the work with Raffia is very prominent. We now carry a stock in sizes from No. 1, the smallest, to No. 6. No. $1,0 z ., 10 \mathrm{c} ; 1 / 1 \mathrm{lb}, 35 \mathrm{c} ; 1 \mathrm{~b}, 21.25$. No. $4,1 / 4 \mathrm{~b}, 125 \mathrm{c} ; 1 \mathrm{~b} ., 85 \mathrm{c}$. If by mail, add postage.

\section{NEEDLES.}

No. 21, $1 \frac{1}{2}$ inch long: No. 18, $1 \frac{3 / 4}{4}$ inch long; No. 17,2 inches lons. Six needles for $5 c$. A package of 25 one size for $15 \mathrm{c}$. We can furnish needles blunt or sharp point.

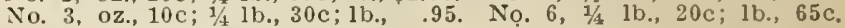

\section{House Decorations}

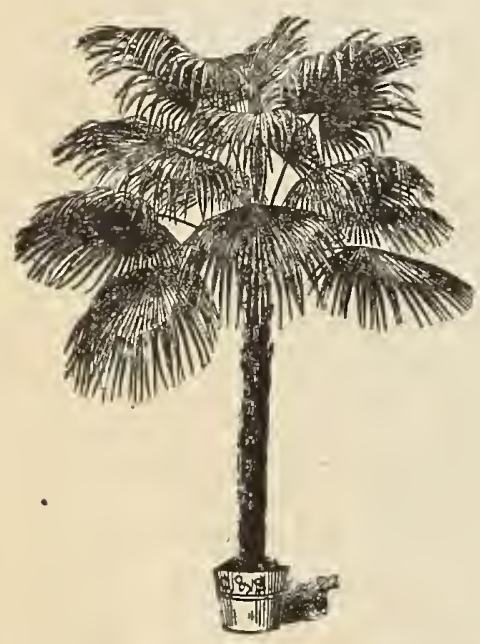

\section{Artificial Palms}

Made of Nothing but Perfeet Leaves.

These plants are especially recommended for use in house decorating, for hallways in reception rooms, on pedestals, hotels, public buildings, etc.

\section{CHAMAEROPS-Fan Palms.}

In 4 -in pots, 18 in high, 5 Each In 4 -in. pots, $18 \mathrm{in.}$ high, 5- 6 leaves. $\$ 1.00$ In 5 -in. pots, 24 in. high, 6 二 7 leaves 1.25 In 6 -in. pots, 36 in. high, 7 二 8 leaves. 1.75 In 7 -in. pots, 44 in. high, 8 - 10 leaves. 2.25 In 8 -in. pots, $56 \mathrm{in.} \mathrm{high,} 10$ - 12 leaves. 4.00

LARGER FAN PALMS, in Neat Square Boxes.

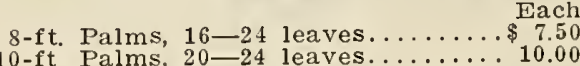
Largel than 10 feet made to order.

\section{PALM LEAVES}

16-18 inches long Fan Palm Leaves. Per doz. $20-22$ inches long Fan Palm Leaves. $\$ 2.50$

\section{CYCAS REVOLUTA-Sago Palm.}

In 6-in pots 6 Each In 7 -in. pots, 7 leaves, 36 in high... 3.00 In 8 -in. pots, 8 leaves, 44 in high ... 4.00 In 10 -in. pots, 10 leaves, $54-60$ in. high 6.00 PREPARED CYCAS LEAVES.

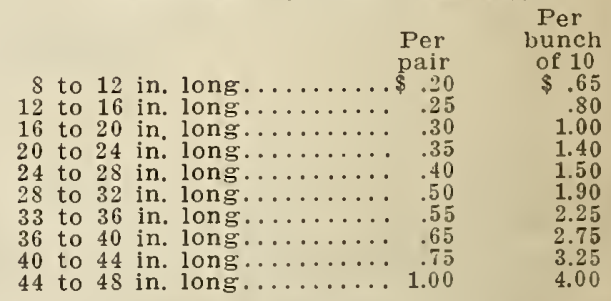

We have a speeial department for Florists' supplies, and issue a 32-page price list for same. If interested, write us.

\section{CHILI CON CARNE AND HOT TAMALE INGREDIENTS}

Dealers and others using quantity, will do well to ask us for prices for large lots.

$\begin{array}{rr}\text { Per } & \text { Per } 101 \mathrm{~b} \\ 1 \mathrm{~b} . & 10 \mathrm{ts} \\ 45 \mathrm{c} & \$ 3.80 \\ 40 \mathrm{c} & 3.75 \\ 90 \mathrm{c} & 8.50\end{array}$

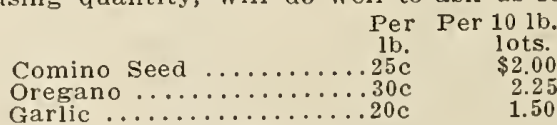

Per Per $10 \mathrm{lb}$.
lb.

Mexican Beans ...........10 $10 \mathrm{c} \quad \$ .70$

Corn Husks ...............

\section{FLAVORING SEEDS}

Te carry a full line of seeds expressly for use in flavoring pickles, soups; also baking, etc. Per Per. Per Per

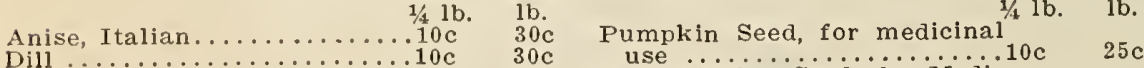
Caraway, clean and fresh...10c Coriander, bleached........10 $30 \mathrm{c}$
$20 \mathrm{c}$ Water Melon Seed, for MediPoppy, Blue..................10 $\quad 25 \mathrm{c}$ $\begin{aligned} \text { Per } & \text { Per } \\ 1 / 4 \text { lb. } & 1 \mathrm{~b} \text {. }\end{aligned}$ Mustard, Yellow............ $20 \mathrm{c}$

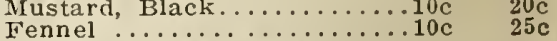
Fennel .................... If tamale ingredients and flavoring seeds are wanted by mail, add postage.

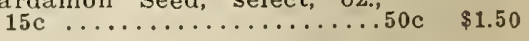




\section{Foreign Names of Vegetables and Herbs}

ENGLISH.

Asparagus

Beans

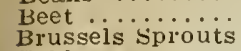

Cabbage

Caraway

Carrot ....

Celery

Corn saiad.

Cress, Gardeil

Cress, Water

Cucumber.

Egg Plan
Endive

Garlic

Garlic Räish

Kale Radis

Kohl Rabi.

Letluce

Melon, ivate

Mushroom

Nasturtium

Okra

Onion

Parsnip

Peas.

Pepper

Pumpkin

Radish

Rhubar

Spinach

Squash

Tomato

Turnip …

\author{
FRENCH.
}

Artichaut

Asperge

Haricots

Chou de Bruxelles.

Chou ponme

Cumin des pres.

Carotte

Chou-fleus.

Celeri

Mais

Clesson alenois

Cresson de fontaine.

Concombre

Aubergine

Chicoree, Endive.

Ail

Raifort sauvage

Chou vert.

Chou-rave
Poireau

Poirea

Melon

Melon deau

Champignol

Capucine

Ognon

Persil

Panais

Pois.

Potiron

Patiro

Rhubarbe

Salsifis

Epinar

Pomme d'Aimour

Navet

Absinthe
SPANISH.

Alcachofa

Espariago

Frijoles

Coleo de Bruselas.

Col repollo

Alcaravea

Coliflor

Apio

Machä valerianili.

Miaiz

Berro de Fuente

Pepino

Eerengena

Escarola, Endibia

Ajo

Rabano picant
Breton, Berza

Breton,
Colinabo

Puerro

Lechuga

Sandia

Seta

Capuchina

Quimbomb

Cebolla

Chirivia

Guisante

Pimiento

Rabano

Rabano

Salsifi blanco

Espinaca

Tomate

Ajenjo
ITALIAN.

Articiocea

Sparagio

Barbabietola

Cavolo di Brusselle.

Cavolo cappuccio

Carvi

Cavolofiore

Sedano

Mais

Agretto

Nasturzio aquatico

Petronciano

Indivia

Aglio

Cavolo verde
Cavolo rapa.

Porro

Popone

Melone d'aqua.

Fungo pratajolo

Ocra

Cipolio

Preztinaca

Pisello...

Peperone

Ravanelio

Rabarbaro

Sassefrica

Zucca

Pomo d’oro

Assenzio

\section{GENERAL INDEX}

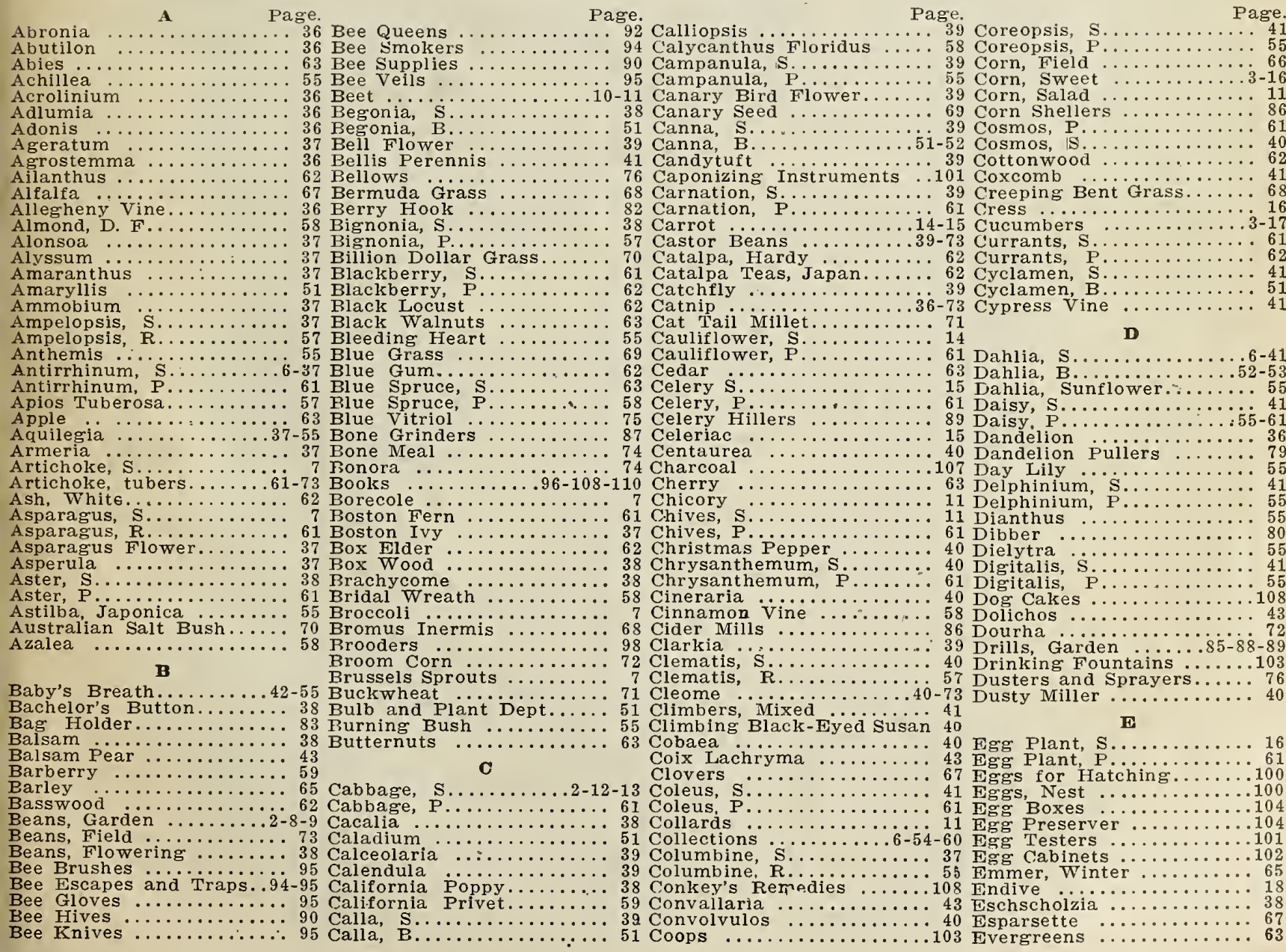




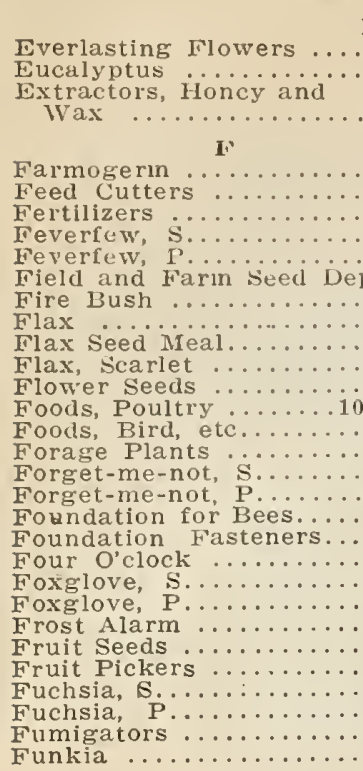

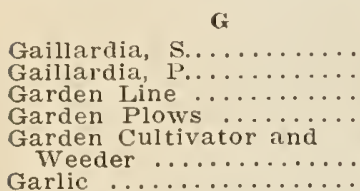

Gasoline Engines

Geranium, S.
Geranium,

Gilia

Giadiolus

Glazing Tüols

Globe Amaranth

Gloxinia, S

Glycine Sinensis

Godetia

Golden Elder

Golden Glow

Gooseberry, S.

Gourds

Graders, Corn

Grafting Wax

Grain cieaner.....

Grain Scale Testers

Grape Shears

Grass Hook

Grass Shears

Grass Seed Mixtures.

Grass Seeders

Grit

Gumbo

Gypsophila $\dot{\mathrm{S}}$.

Gypsophila, P..

\section{H}

Hammer, Magnetic

Hanging Baskets

Hanging Basket plants

Hardy Plants, Climbing.

Hardy Shrubs

Hawthorn

Heaters, Orchard

Hedge Plants

Helichrysum

Helianthus, S.

Heliotrope, S

Hemp

Hibiscus, $P$.

Hickory Nuts

Hoes, Hand

Hoes, Wheel

Hollyhock, S.

Honey Locst

Honey Plants

Honeysuckle

Hose, Rubber

Hose, Couplers

Hose Menders

Hose Washers

Hose Holders
Page.

2 Hot-bed Mats

Page.

louse Protecting Cloth. 83 Osage Orange ...

llouse Decorations ......110 Oxalis, $\mathbf{S}$.
Husking Pins ..........

Hovers $\ldots \ldots \ldots \ldots \ldots \ldots \ldots$ y9 Oyster shell

7t Hyacinth Beans

74 Hygrometers

42 Ice Plant

43 Dx-Eyed Dais

101

6i Immortelles

59 Implements

63 Insecticides

106 Insecticides
43 Insect Powder plant.

36 Ipomoea

$\begin{array}{ll}107 & \text { Iry, } \\ 108 & \text { Iry, }\end{array}$

69 Iris

42

61 Japanese Fern Ball.

43 Paeonies ...

110 Paint

80 Palm, $\mathrm{P}$.

75 Pansy, $\mathrm{P}$

43 Parsley

43 Parsnip

43 Passiflora

61 Paw Paw

Peanuts

Pear

53 Pearl Millet

43 Peas, Garden

40 Peas, Field

59 Pepper, S.

72 Pepper, P.

43 Persimmon

68 Petunia, S

Phlox, S. .

$\mathbf{P}$

42 Japanse marning

41 Japan Quince

82 Job's Tears ...

82 Johnson

61 I

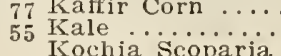

Kochia Scoparia

Kohl R
Knives

55 Kudzu Vine

84 Lagurus Ovatus

.86-88 Lantana

18 Larkspur

95 Lawn Requisites

42 Lawn Rollers.

42 Leek

54 Leg Bands

83 Lentils

42 Lice Irillers

42 Lilac, S..

54 Lilac, Pardy

42 Lilies, Hardy $\ldots . .$.

58 Lily of the Valley, pips

57 Linum

61 Lobelia, P.

42 Love-in-a-mist

86 Lupins

64 II

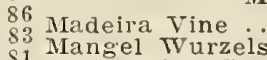

\$1 Margel Wurzels

67 Marguerite, S.

i9 Marigold

68 Marvel of Peru.

85 Meadow Fescue

23 Meat Meal

44 Melon, Musk

4 Mesembryanthemum

Mexican Burning Bush. Mignonette

Phlox,
71-72 Phlox, P.
Picea ...

73 Picea

18 Pine

81 Pinks, 's.

$\ldots \ldots \ldots \ldots \ldots \ldots \ldots$

4 Scabiosa

63 Schizanthus

44 Sea Plnk

54 Sensitive Plant

41 Sections, Bee Hive.

Seedcrs

seed rryers

56 Shallu

96 slipping Cases, Honey.

mall Fruits

46 Snilax, S.

23 smoke Extract

26 snapdragon, s.

44 snapdragon, $\mathrm{P}$

63 Snowball, $\mathrm{P}$.

72 Soft Maple

70 Spade, Garden

73 Speltz

71 spirea

-2s spray Pumps

61 sprinkling Nozzles

63 spruce

44 squash

61 Stocks, 10 weeks, S.

45 stocks, 10 weeks, P.

56-61 Stokesia Cyranea

63 Strawberry Shrub

46 Strawberry, S

46 Stipa Pennata.

61 Sugar Maple

Planet Jr., Tools.......... 87 summer Bedding Plants.

Planters

85-86 Summer Bulbs

44 Plant Foods ............ 74 , Sunflower, Fancy

-55 Pop Corn .............. 66 Swan River Dais

78 Poppy, P

-46 Swarm Catcher

79 Portulaca $\ldots . . \ldots \ldots \ldots \ldots .45$ Sweet Clover

18 Porch and Window Boxes. 84 Sweet Peas

102 Potatoes ..............28 28 Sweet Sultan

73 Potatoes. Sweet .........29-61 sweet Williams, $\mathrm{S}$

105 Pot, Flower

105 Pot, Flower

59 Poultry Supplies

89 Sweet Williams, P

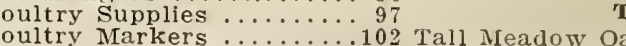

43 Poultry Netting ............104 Tamarix Africana

54 Pratt's Animal Regulators. 109 Tarragon,

43 Primrose .............. 47 Tarragon, $\vec{R}$.

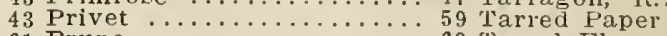

61 Prune

43 Pruing Saws

71 Pruning Shears

55 Pumpkin

63 Tassel Flower

82 Teosinte

81 Thermometers

29 Thunbergia

58

Pyrethrum, s.

11

47 Tigridia

3 Nuince, S....

Q

Timothy

Tomato, s

44

$\mathbf{R}$

Tree Seeds Protectors

Tree Pruners

............

107 Ragged Sailor

4-20-21 Rakes, Garden

-22 Rakes, Lawn
43 Rape, Dwf. Essex.

47 Trowels

so Trumpet

79 Tubs, Plant

43 Raspberry, S

44 Raspberry, $P$

61 Tuberose

Rattan Reeds ................ v

93 Millet Mäize

79 Milo Maizulus

61 Minulus ..

57 Mock Orang

58 Momordica Charantia

82 Montbretia

82 Moon Flower

59 Morning Glory

42 Moss
42 Moss

55 Mourning Bride

61 Mushroom Spawn

69 Mystard

58 Nasturtiums

63 Nemophila.

80 Nests-Wire

88 Nigella

55 Nuts

${ }_{73}$ Nappies...$\cdots$

58 Oats
-61 Oculum

72 Red Pepper, Poultry

43 Red Top ..............

61 Regulators, Animal .........

58 Remedies, Poultry, etc.....105 Verbena,

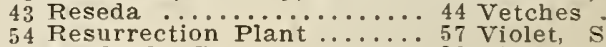

54 Resurrection Plant ...... 57 Violet, $\mathrm{S}$.

44 Rhubarb, ${ }_{40}$ Rhubabrb, P................. 61

110 Ricinus

44 Roofing Material .........103 Wallfower

44 Roost Brackets ...........102 Weeders

23 Root Cutters ........... 86 Wheat ${ }_{4}$.

44 Rose, named P..........

Rose of Sharon............5 5 \&hip-Poor-Tiil

$\mathbf{N}$

Rose of Sharon

44 Ruhher Plants

$\ldots \ldots \ldots \ldots .57$ wild Flower Garden....... 5

44 Rutaba Mulberry .......6.6. Wild Rice $\ldots \ldots \ldots \ldots \ldots 71$

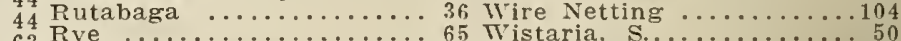

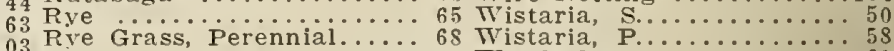

Wonderberry

Woodbine ................ $37-5$

54 Sage, $\mathrm{S}$ 36

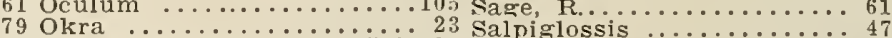

79 Onions

79 Onion sets

23 Salpiglossis

Harvester $\ldots \ldots \ldots \ldots .26$ Salvia, $\mathbf{S}$.

89 Salvla, $\mathbf{P} \ldots \ldots \ldots \ldots \ldots \ldots \ldots 47$

5 Zinnia 


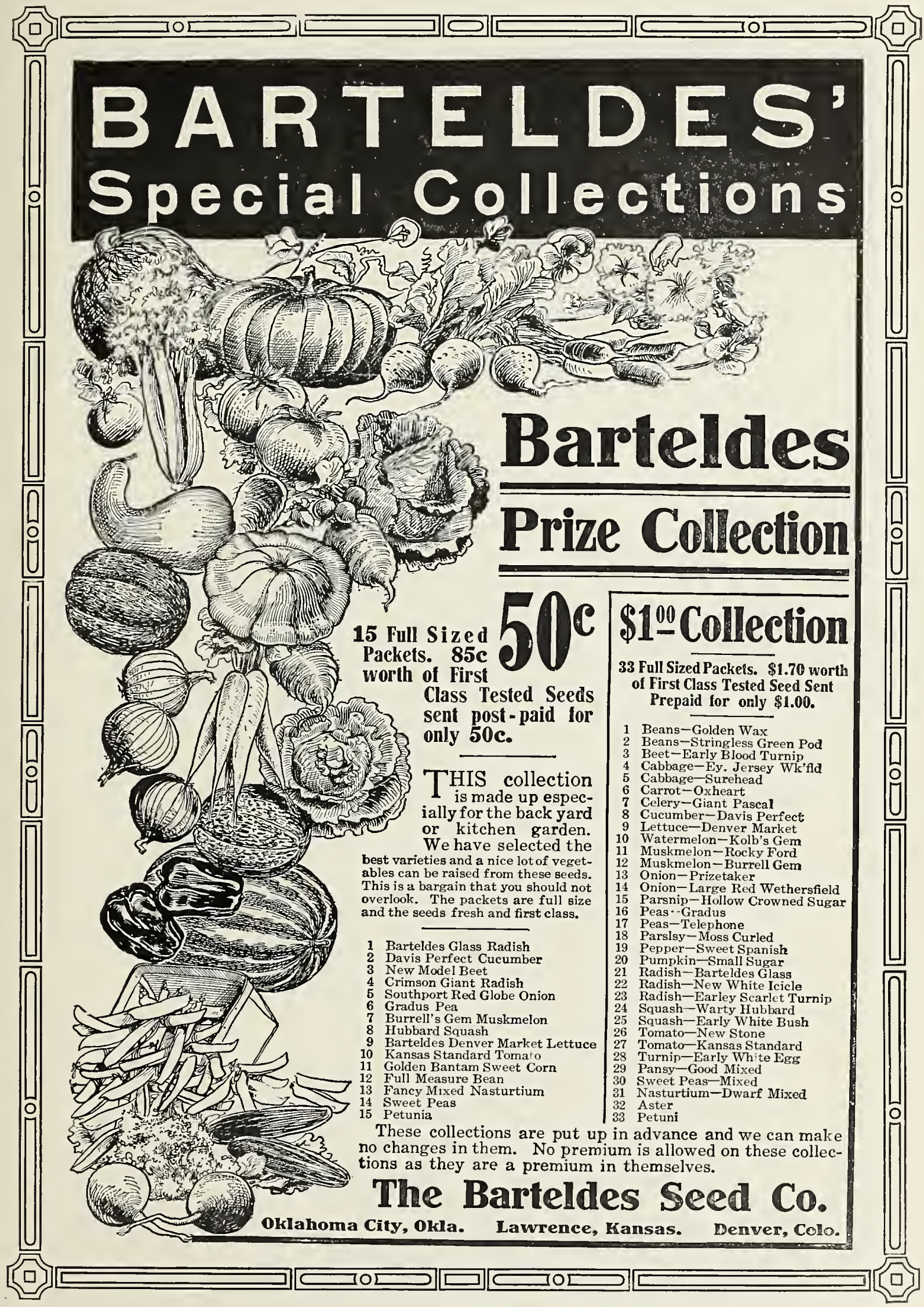




$$
\text { FETERITA } 0\}^{39}
$$

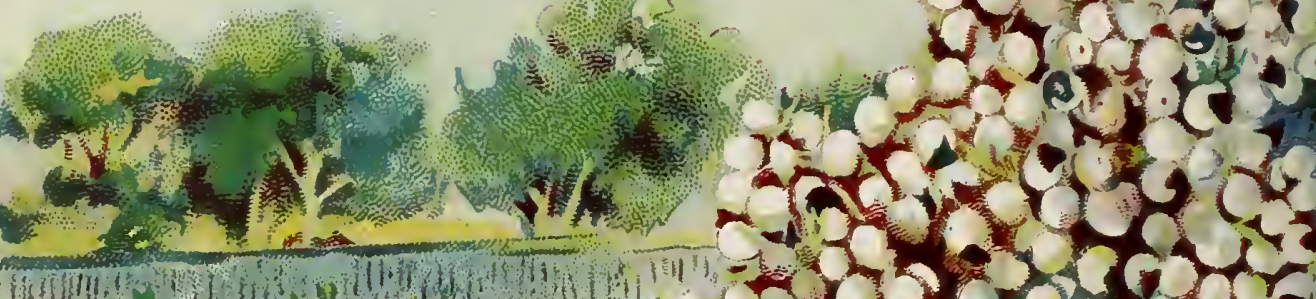

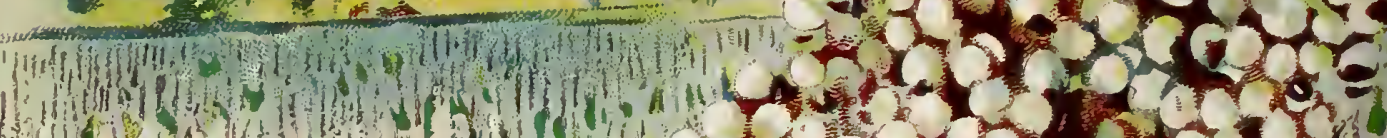

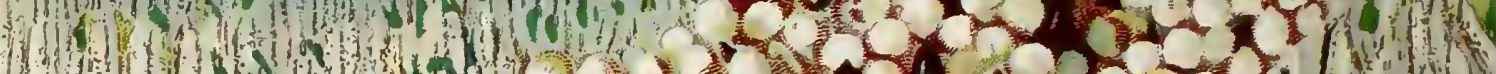
II 1 II i) 1 .

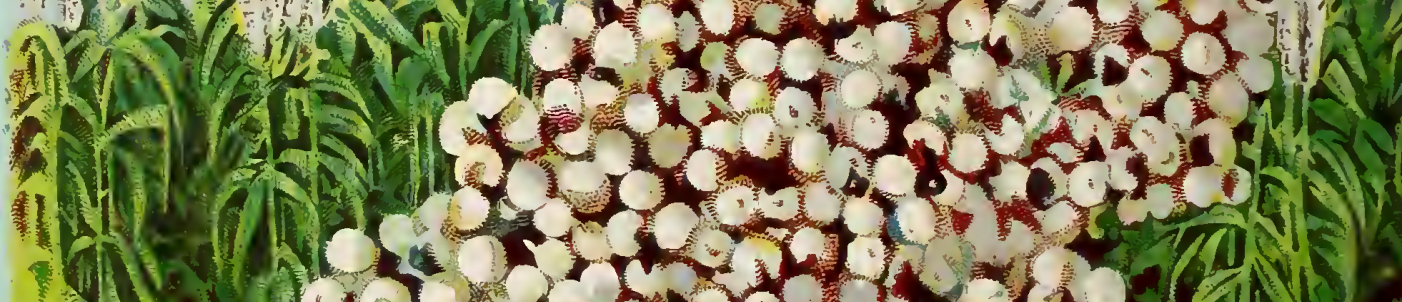

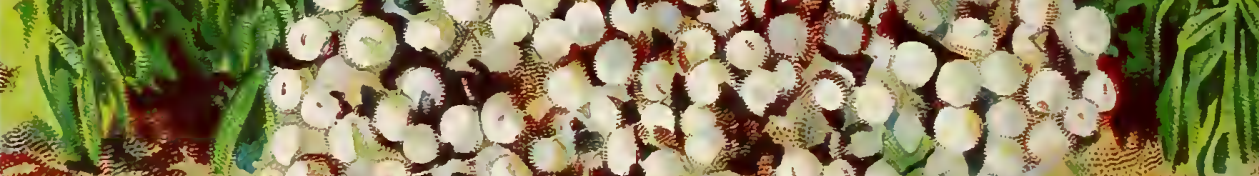

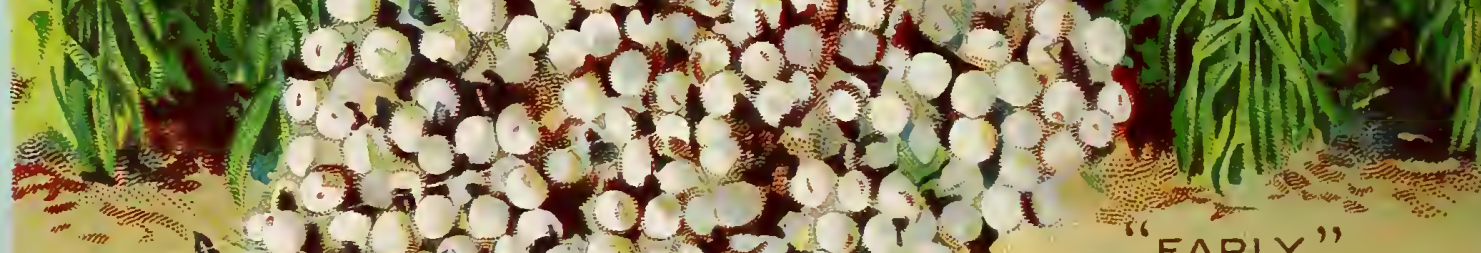

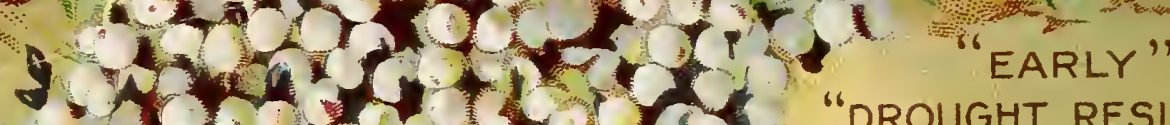
10.10 "DROUGHT RESISTING"

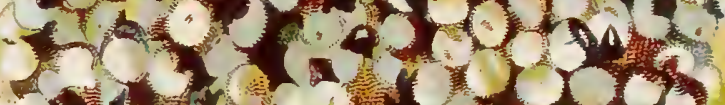

"BIG YIELDER"

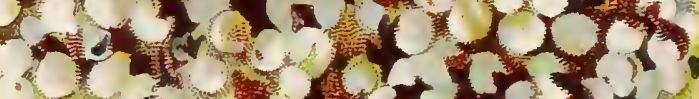

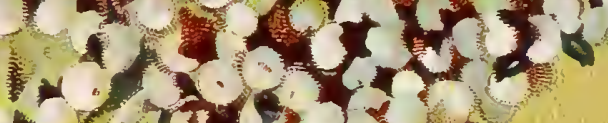

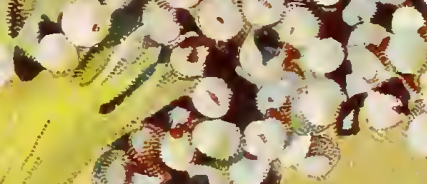
$\lim ^{2} \operatorname{lit}^{7}$

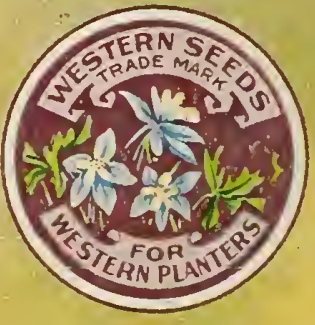

\section{THE BARTELDES SEED CO., COLORADO SEEd hOUSE, DENVER, COLORADO.}

